\section{2) Wiadomości (3) Lekarskie \\ Czasopismo Polskiego Towarzystwa Lekarskiego}

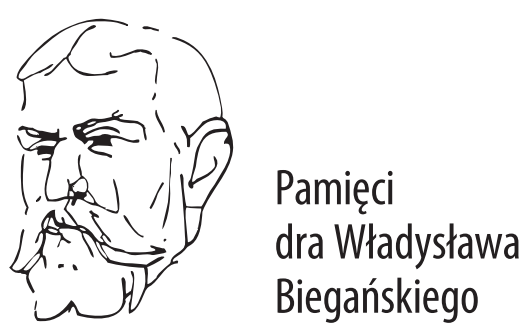

Rok założenia 1928

TOM LXXII, 2019, Nr2, luty

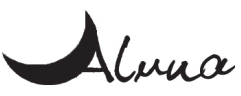

Aluna Publishing 
Wiadomości Lekarskie is abstracted and indexed in: PubMed/Medline, EBSCO, SCOPUS, Index Copernicus, Polish Medical Library (GBL), Polish Ministry of Science and Higher Education.

Copyright: @ ALUNA Publishing.

Articles published on-line and available in open access are published under Creative Common Attribution-Non Commercial-No Derivatives 4.0 International (CC BY-NC-ND 4.0) allowing to download articles and share them with others as long as they credit the authors and the publisher, but without permission to change them in any way or use them commercially.

\section{Zasady prenumeraty miesięcznika Wiadomości Lekarskie na rok 2019}

Zamówienia na prenumeratę przyjmuje Wydawnictwo Aluna:

- e-mailem: prenumerata@wydawnictwo-aluna.pl - listownie na adres:

Wydawnictwo Aluna

ul. Z.M. Przesmyckiego 29, 05-510 Konstancin-Jeziorna

Prosimy o dokonywanie wpłat na numer rachunku Wydawnictwa: Credit Agricole Bank Polska S. A.: 82194010763010740700000000

Cena prenumeraty dwunastu kolejnych numerów: 240 zł/rok (w tym 5\% VAT)

Cena prenumeraty zagranicznej: 120 euro/rok.

Cena pojedynczego numeru - $30 \mathrm{zł}$ (w tym 5\% VAT) + koszt przesyłki.

Przed dokonaniem wpłaty prosimy o złożenie zamówienia. 


\section{4) Wiadomości . Lekarskie}

Editor in-Chief

Prof. Władysław Pierzchała

Deputy Editor in-Chief:

Prof. Aleksander Sieroń

Statistical Editor

Dr Lesia Rudenko
Polskie Towarzystwo Lekarskie:

Prof. Waldemar Kostewicz - President PTL

Prof. Jerzy Woy-Wojciechowski - Honorary President PTL

Prof. Tadeusz Petelenz

\section{International Editorial Board - in-Chief:}

Marek Rudnicki

Chicago, USA

\section{International Editorial Board - Members:}

Kris Bankiewicz
Christopher Bara
Krzysztof Bielecki
Zana Bumbuliene
Ryszarda Chazan
Stanislav Czudek
Jacek Dubiel
Zbigniew Gasior
Andrzej Gładysz
Nataliya Gutorova
Marek Hartleb
Roman Jaeschke
Andrzej Jakubowiak
Oleksandr Katrushov
Peter Konturek
Jerzy Korewicki
Jan Kotarski

Kris Bankiewicz

Zana Bumbuliene

Ryszarda Chazan

$\begin{aligned} \text { San Francisco, USA } & \text { George Krol } \\ \text { Hannover, Germany } & \text { Krzysztof Łabuzek } \\ \text { Warsaw, Poland } & \text { Henryk Majchrzak } \\ \text { Vilnius, Lithuania } & \text { Ewa Małecka-Tendera } \\ \text { Warsaw, Poland } & \text { Stella Nowicki } \\ \text { Ostrava, Czech Republic } & \text { Alfred Patyk } \\ \text { Cracow, Poland } & \text { Palmira Petrova } \\ \text { Katowice, Poland } & \text { Krystyna Pierzchała } \\ \text { Wroclaw, Poland } & \text { Tadeusz Płusa } \\ \text { Kharkiv, Ukraine } & \text { Waldemar Priebe } \\ \text { Katowice, Poland } & \text { Maria Siemionow } \\ \text { Hamilton, Canada } & \text { Vladyslav Smiianov } \\ \text { Chicago, USA } & \text { Tomasz Szczepański } \\ \text { Poltava, Ukraine } & \text { Andrzej Witek } \\ \text { Saalfeld, Germany } & \text { Zbigniew Wszolek } \\ \text { Warsaw, Poland } & \text { Vyacheslav Zhdan } \\ \text { Lublin, Poland } & \text { Jan Zejda }\end{aligned}$

San Francisco, USA George Krol

New York, USA

Katowice, Poland

Katowice, Poland

Katowice, Poland

Memphis, USA

Gottingen, Germany

Yakutsk, Russia

Katowice, Poland

Warsaw, Poland

Houston, USA

Chicago, USA

Sumy, Ukraine

Katowice, Poland

Katowice, Poland

Jacksonville, USA

Poltava, Ukraine

Katowice, Poland
Managing Editor:

Agnieszka Rosa

International Editor:

Lesia Rudenko

I.rudenko@wydawnictwo-aluna.pl

Distribution and Subscriptions:

BartoszGuterman prenumerata@wydawnictwo-aluna.pl
Graphic design / production:

Grzegorz Sztank

www.red-studio.eu
Publisher:

ALUNA Publishing

ul. Przesmyckiego 29, 05-510 Konstancin - Jeziorna www.aluna.waw.pl www.wiadomoscilekarskie.pl www.medlist.org 


\section{REGULAMIN PRZYJMOWANIA I OGŁASZANIA PRAC W WIADOMOŚCIACH LEKARSKICH}

1. Miesięcznik Wiadomości Lekarskie jest czasopismem Polskiego Towarzystwa Lekarskiego, ma charakter naukowo-edukacyjny. Zamieszczane są w nim prace oryginalne, kliniczne i doświadczalne oraz poglądowe w języku polskim lub angielskim oraz innych językach (za zgodą redakcji).

2. Publikacja pracy w Wiadomościach Lekarskich jest płatna. Od stycznia 2017 roku koszt opublikowania artykułu wynosi 1000 zł plus 23\%VAT. Jeżeli pierwszym autorem pracy jest członek Rady Naukowej czasopisma lub zespołu recenzentów - za druk nie pracy nie pobieramy opłaty, jeśli zaś jest kolejnym współautorem - opłata wynosi 500 zł plus 23\%VAT. Wydawca wystawia faktury. Opłatę należy uiścić po otrzymaniu pozytywnej recenzji, przed opublikowaniem pracy. Z opłaty za publikację zwolnieni są członkowie Polskiego Towarzystwa Lekarskiego z udokumentowaną opłatą za składki członkowskie za ostatnie 3 lata.

3. Prace zapisane w formacie DOC (z wyłączeniem rycin, które powinny stanowić osobne pliki) należy przesłać pocztą elektroniczną na adres redakcji: Agnieszka Rosa-amarosa@wp.pl.

4. Objętość prac oryginalnych - łącznie z rycinami i piśmiennictwem - nie może przekraczać 21600 znaków (12 stron maszynopisu), prac poglądowych - do 36000 znaków (20 stron).

5. Strona tytułowa powinna zawierać:

- tytuł w języku angielskim i polskim,

- pełne imiona i nazwiska autorów,

- afiliację autorów,

6. Praca oryginalna powinna mieć następującą strukturę: wstęp, cel pracy, materiał i metody, wyniki, dyskusja i wnioski, które nie mogą być streszczeniem pracy. Przy zastosowaniu skrótów konieczne jest podanie pełnego brzmienia terminu przy pierwszym użyciu. W pracach doświadczalnych, w których wykonano badania na ludziach lub zwierzętach, a także w badaniach klinicznych, należy umieścić informację o uzyskaniu zgody komisji etyki badań naukowych.

7. Streszczenia zarówno w języku polskim, jak i angielskim powinny zawierać 200250 stów. Streszczenia prac oryginalnych, klinicznych i doświadczalnych powinny posiadać następującą strukturę: cel, materiał i metody, wyniki wnioski. Nie należy używać skrótów w tytule ani w streszczeniu.

8. Słowa kluczowe (3-6) należy podawać w języku angielskim i polskim, zgodnie z katalogami MeSH (Medical Subject Headings Index Medicus http://www.nim. nih.gov.mesh/MBrower.html). Słowa kluczowe nie mogą być powtórzeniem tytułu pracy.

9. Materiał ilustracyjny - ryciny, wykresy, rysunki, fotografie, slajdy - powinien być opisany cyframi arabskimi i zapisany jako pliki JPG, TIFF lub EPS o rozdzielczości 300 DPI (nie w plikach tekstowych). Ich opisy należy przesłać w osobnym pliku. W tekście muszą znajdować się odniesienia do wszystkich rycin (w nawisach okrągłych).

10. Tabele - ich tytuły (nad tabelą) i treść - powinny być zapisane w programie Microsoft Word, ponumerowane cyframi rzymskimi. Wszystkie stopki dotyczące tabeli powinny znajdować się poniżej tekstu tabeli. W tekście pracy należy umieścić odniesienia do wszystkich tabel (w nawiasach okrągłych).

11. W wykazie piśmiennictwa ułożonym według kolejności cytowania należy uwzględnić wyłącznie te prace, na które autor powołuje się w tekście. W pracach oryginalnych nie powinno być więcej niż 30 pozycji, a w poglądowych nie więcej niż 40 pozycji. Każda pozycja powinna zawierać: nazwiska wszystkich autorów, pierwsze litery imion, tytuł pracy, skrót tytułu czasopisma (wg Index Medicus), rok, numer, stronę początkową i końcową. Przy pozycjach książkowych należy podać: nazwisko autora (autorów), pierwszą literę imienia, tytuł rozdziału, tytuł książki, wydawnictwo, miejsce i rok wydania. Dopuszcza się cytowanie stron internetowych z podaniem adresu URL i daty użycia artykułu oraz o ile to możliwe nazwisk autorów. Każda pozycja piśmiennictwa powinna mieć odwo- łanie w tekście pracy umieszczone w nawiasie kwadratowym, np. [1], [3-6]. Pozycje zapisuje się w sposób zaprezentowany w Załączniku nr 1 do niniejszego regulaminu.

12. Po piśmiennictwie należy podaćadres do korespondencji, nazwisko i imię pierwszego autora, adres, numer telefonu oraz adres e-mail.

13. Do pracy należy dołączyć oświadczenie podpisane przez wszystkich autorów określające udział poszzzególnych autorów w przygotowaniu pracy (np. koncepcja i projekt pracy, zbieranie danych i ich analiza, odpowiedzialność za analizę statystyczną, napisanie artykułu, krytyczna recenzja itd.), a także oświadczenie, że biorą oni odpowiedzialność za treść. Ponadto należy zaznaczyć, że praca nie była publikowana ani zgłaszana do druku w innym czasopiśmie.

14. Jednocześnie autorzy powinni podać do wiadomości wszelkie inne informacje mogące wskazywać na istnienie konfliktu interesów, takie jak:

- zależności finansowe (zatrudnienie, płatna ekspertyza, doradztwo, posiadanie akcji, honoraria),

- zależności osobiste,

- współzawodnictwo akademickie i inne mogące mieć wpływ na stronę merytoryczną pracy,

- sponsorowanie całości lub części badań na etapie projektowania, zbierania, analizy i interpretacji danych lub pisanie raportu.

Konflikt interesów ma miejsce wtedy, gdy przynajmniej jeden z autorów ma powiązania lub zależności finansowe z przemysłem bezpośrednie lub za pośrednictwem najblizszej rodziny. Jeśli praca dotyczy badań nad produktami częściowo lub całkowicie sponsorowanymi przez firmy, autorzy mają obowiązek ujawnić ten fakt w załączonym oświadczeniu.

15. Każda praca podlega weryfikacji w systemie antyplagiatowym (zapora ghostwriting).

16. Redakcja przestrzega zasad zawartych w Deklaracji Helsińskiej, a także w Interdisciplinary and Guidlines for the Use of Animals In Research, Testing and Education, wydanych przez New York Academy nof Sciencees' Adhoc Resarch. Wszystkie prace odnoszące się do zwierząt lub ludzi muszą być zgodne z zasadami etyki określanymi przez Komisję Etyczną.

17. Czasopismo recenzowane jest w trybie podwójnej, ślepej recenzji. Nadesłane prace są oceniane przez dwóch niezależnych recenzentów, a następnie kwalifikowane do druku przez Redaktora Naczelnego. Recenzje mają charakter anonimowy. Krytyczne recenzje autorzy otrzymują wraz z prośbą o poprawienie pracy lub z decyzją o niezakwalifikowaniu jej do druku. Procedura recenzowania artykułów jest zgodna z zaleceniami Ministerstwa Nauki i Szkolnictwa Wyższego zawartymi w opracowaniu "Dobre praktyki w procedurach recenzyjnych w nauce" (Warszawa 2011) i szczegółowo została opisana na stronie http://www.nauka. gov.pl/g2/oryginal/2014_02/307f933b1a75d6705a4406d5452d6dbf.pdf

18. Redakcja zastrzega sobie prawo redagowania nadesłanych tekstów (dokonywania skrótów i poprawek). Prace są wysyłane do akceptacji autorów. Poprawki autorskie należy przesłać w terminie 3 dni od daty wysłania wiadomości e-mail (pocztą elektroniczną). Brak odpowiedzi w podanym terminie jest równoznaczny z akceptacją przez autora nadesłanego materiału

19. Przyjęcie pracy do druku oznacza przejęcie praw autorskich przez Redakcję Wiadomości Lekarskich.

20. Autorzy otrzymują nieodpłatnie plik PDF wydania, w którym znajduje się ich praca, a na życzenie - egzemplarz drukowany. Plik elektroniczny przeznaczony jest do indywidualnego użytku autora, bez prawa do rozpowszechniania bez zgody redakcji.

21. Prace przygotowane niezgodnie z regulaminem zostaną zwrócone autorom do poprawienia.

22. Redakcja nie odpowiada za treść zamieszzzanych reklam. 


\section{SPISTREŚCI}

PRACE ORYGINALNE / ORIGINAL ARTICLES

Tetyana Pertseva, Tetyana Kireieieva, Mariia Krykhtina, Kseniia Bielosludtseva, Kateryna Dyagovets

DIAGNOSTIC ROLE OF SYSTEMIC INFLAMMATION, BLOOD COAGULATION AND PADUA PREDICTION SCORE IN LUNG THROMBOSIS

RISK ESTIMATION IN HOSPITALIZED PATIENTS WITH COMMUNITY-ACQUIRED PNEUMONIA

DIAGNOSTYCZNA ROLA MARKERÓW UKŁADOWEGO STANU ZAPALNEGO, ZABURZEŃ UKLADU KRZEPNIECIA KRWI ORAZ SKALI PADEWSKIEJ W OCENIE RYZYKA

WYSTAPIENIA ZATORU PŁUCNEGO U PACJENTÓW HOSPITALIZOWANYCH Z POWODU ZEWNATTRZSZPITALNEGO ZAPALENIA PłUC

Aidyn G. Salmanov, Volodymyr 0. Shkorbotun, Yaroslav V. Shkorbotun

ANTIMICROBIAL RESISTANCE OF STAPHYLOCOCCUS AUREUS CAUSING OF SURGICAL SITE INFECTIONS IN EAR, NOSE AND THROAT SURGERY

ANTYBIOTYKOOPORNOŚĆ STAPHYLOCOCCUS AUREUS STANOWIACEGO CZYNIK ETIOLOGICZNYZAKAŻEŃ POLA OPERACYJNEGO W PRZYPADKU OPERACJI USZU,

NOSA I GARDLA

Ulyana B. Mykhaylyshyn

PSYCHOLOGICAL FEATURES OF MOTIVATIONAL SPHERE OF DRUG ADDICTS

CECHY PSYCHOLOGICZNE SFERY MOTYWACYJNEJ UZALEŻNIENIA OD NARKOTYKÓW

Tetiana Litovchenko, Valeriia Grymailo, Oksana Tondiy, Vartanush Florikian, Olena Zavalna, Anna Voitiuk

THE PECULIARITIES OF THE HEART RATEVARIABILITY AND ELECTROENCEPHALOGRAM CHANGES IN PATIENTS WITH EPILEPSY AND CARDIOVASCULAR PATHOLOGY

CHARAKTERYSTYKA ZMIENNOŚCI RYTMU SERCA I ZMIIAN W ELEKTROENCEFALOGRAMIE U PACJENTÓW Z PADACZKA I CHOROBA UKLADU SERCOWO-NACZYNIOWEGO

Dmytro 0. Mykytenkov, Tetiana S. Gruzieva

MODERN MODEL OF GENETIC MONITORING AS A PROMISING TOOL FOR REDUCING INCIDENCE OF GENETIC PATHOLOGIES IN UKRAINE

NOWOCZESNY MODEL MONITORINGU GENETYCZNEGO JAKO OBIECUJĄCE NARZEDZIE REDUKCJI WYSTĘPOWANIA WAD GENETYCZNYCH NA UKRAINIE

Viacheslav M. Husiev, Daria S. Khapchenkova

INFLUENCE OFTHE TRANSFERRED SYPHILITIC INFECTION ON THE COURSE OF PREGNANCY, CHILDBIRTH AND THE STATE OF NEWBORNS

WPŁYW PRZENOSZONEJ DROGA P.ŁCIOWA INFEKCJI KILA NA PRZEBIEG CIAŻY, PORODU ORAZ STAN OGÓLNY NOWORODKÓW

Pavlo G. Kravchun, Olga I. Kadykova, Dmitry G. Molotyagin

CHANGES IN PENTRAXIN-3 LEVEL AND ITS INTERACTION WITH METABOLIC INDICES IN PATIENTS WITH CORONARY ARTERY DISEASE AND TYPE 2 DIABETES MELLITUS

ZMIANY STEZŻENIA PENTRAKSYNY 3 I JEJ INTERAKCJE ZE WSKAŹNIKAMI METABOLICZNYMI U PACJENTÓW Z CHOROBĄ WIEŃCOWĄ ORAZ CUKRZYCA TYPU 2

Andriy R. Stasyshyn, Mykola A. Bychkov, Solomiia V. Bychkova

A NEW METHOD OF DIAGNOSIS OF THE HIATAL HERNIA ASSOCIATED WITH GASTROESOPHAGEAL REFLUX DISEASE

NOWA METODA DIAGNOSTYKI PRZEPUKLINY ROZWORU PRZEEYKOWEGO WSPÓŁWYSTEPUJACEJ Z REFLUKSEM ŻOŁADKOWO-PRZELYKOWYM

Mykola I. Lytvynenko, Olha I.Zalyubovska, Volodymyr 0. Korobchanski, Tetiana I. Tiupka, Viktor V. Zlenko, Yuliia N. Avidzba

ANALYSIS OF THE STATE OF NITRATE POLLUTION OF AOUIFER OF KHARKIV REGION ACCORDING TO LABORATORY TESTS

ANALIZA STANU ZANIECZYSZCZENIA AZOTANAMI WARSTW WODONOŚNYCH W OBWODZIE CHARKOWSKIM NA PODSTAWIE WYNIKÓW BADAŃ LABORATORYJNYCH

Kyryll V. Makolinets, Vasyl I. Makolinets, Dmytro V. Morozenko, Kateryna V. Gliebova, Svitlana I. Danylchenko

BIOCHEMICAL MARKERS OF CONNECTIVE TISSUE METABOLISM IN RATS'BLOOD SERUM WITH EXPERIMENTAL KNEE OSTEOARTHRITIS AND THEIR DYNAMICS DURING CONSERVATIVE TREATMENT BIOCHEMICZNE MARKERY METABOLIZMU TKANKI ŁACZNEJ W SUROWICY KRWI SZCZURÓW W EKSPERYMENTALNYM MODELU CHOROBY ZWYRODNIENIOWEJ STAWU KOLANOWEGO I ICH ZMIANY W TRAKCIE LECZENIA ZACHOWAWCZEGO

Ivan G. Savka

FORENSIC MORPHOLOGICAL SIGNS CHARACTERIZING STABILITY OF THE FEMUR, TIBIA AND FIBULA DURING EFFECT OF EXTERNAL DESTRUCTIVE LOAD

MORFOLOGICZNE OBJAWY WYKORZYSTYWANE W KRYMINALISTYCE CHARAKTERYZUJACE STABILNOŚĆ KOŚCI UDOWEJ, KOŚCI STRZALKOWEJ ORAZ KOŚCI PISZCZELOWEJ W

TRAKCIE DZIALANIA ZEWNĘTRZNEJ SILY NISZCZACEJ

Serhii H. Ubohov, ViktorV. Trokhymchuk, Violetta I. Todorova, Volodymyr A. Zahoriy PROCESS MODEL OF THE PHARMACEUTICAL INTEGRATED MANAGEMENT SYSTEM

MODELOWANIE PROCESÓW FARMACEUTYCZNEGO ZINTEGROWANEGO SYSTEMU ZARZADZANIA

Paweł Podsiadło, Adam Nogalski, Sylweriusz Kosiński, Tomasz Sanak, Kinga Sałapa, Robert Gałązkowski, Tomasz Darocha

IS AN EMERGENCY DEPARTMENT A SAFER PLACE FOR HYPOTHERMICVICTIMS THAN AN AMBULANCE? A COMPARISON OF THE KNOWLEDGE OF MEDICAL PERSONNEL CONCERNING HYPOTHERMIA CZY ODDZIAL RATUNKOWY JEST BEZPIECZNIEJSZYM MIEJSCEM DLA PACJENTA W HIPOTERMIII NIŻ KARETKA? PORÓWNANIE WIEDZY PERSONELU MEDYCZNEGO

NATEMAT HIPOTERMII

Yuriy Yu. Yarov

RHEOLOGICAL, IMMUNOLOGICAL AND MICROBIOLOGICAL PARAMETER DYNAMICS AFTER DENTAL IMPLANTATION

ZMIANA PARAMTERÓW REOLOGICZNYCH, IMMUNOLOGICZNYCH ORAZ MIKROBIOLOGICZNYCH POZALOŻENIU IMPLANTU STOMATOLOGICZNEGO 
Larysa Ya. Fedoniuk, Stepan S. Podobivskyi, Alexandr M. Kamyshnyi, Anna S. Saturska, Vira 0. Khavtur, Olga M. Marchuk, Oksana M. Zahrychuk, Olga B. Furka, Valentyna M. Cherniashova MORPHOLOGICAL AND PHYSIOLOGICAL, BIOLOGICAL AND EPIDEMIOLOGICAL FEATURES OF ACARIANA OF THE GENUS IXODES (LATREILLE, 1795)

- HUMAN ECTOPARASITES IN BIOGEOCENOSES OF TERNOPIL REGION

MORFOLOGICZNE, FIZJOLOGICZNE, BIOLOGICZNE ORAZ EPIDEMIOLOGICZNE CECHY ROZTOCZY Z RZĘDU KLESZCZY (LATREILLE, 1795)

- LUDZKICH EKTOPASOŻYTÓW W BIOGEOCENOZIE W OBWODZIE TARNOPOLSKIM

Svitlana M. Chuhray, Viktoria E. Lavrynenko, Rostyslav F. Kaminsky, Iryna V. Dzevulska, Olexandr V. Malikov, Olexandr I. Kovalchuk, Liudmyla M. Sokurenko

MORPHOFUNCTIONAL STATUS OF CARDIO-VASCULAR SYSTEM OF RATS WITH CONGENITAL HYPOTHYREOSIS

STATUS MORFO LOGICZNO-CZYNNOŚCIOWY UKŁADU SERCOWO-NACZYNIOWEGO SZCZURÓW Z WRODZONĄ NIEDOCZYNNOŚCIĄ TARCZYCY

Svitlana B. Semenenko, Svitlana Y. Karatieieva, Oksana V. Bakun, Ksenia V. Slobodian, Oksana I. Yurkiv

PECULIAIRITIES OF THE FUNCTIONING CIRCADIAN ORGANIZATION THE ION-REGULATING FUNCTION OF KIDNEY UNDER THE CONDITION

OF PINEAL GLAND HYPERFUNCTION OF THE INFLUENCE NITROGEN MONOXIDE SYNTHESIS BLOCKADE

CHARAKTERYSTYKA OKOLODOBOWEJ FUNKCJI REGULACJI WODNO-ELEKTROLITOWEJ NEREK W WARUNKACH NADCZYNNOŚCI SZYSZYNKI

IZAHAMOWANIA SYNTEZY TLENKU AZOTU

Patrycja Zielińska, Inga Janik, Martyna Maciejewska, Olimpia Sipak

PRÓBA OCENY WIEDZY KOBIET NA TEMAT CIĘCIA CESARSKIEGO W BADANIU ANKIETOWYM

AN ATTEMPT TO ASSESS WOMEN'S KNOWLEDGE ABOUT CAESAREAN SECTION IN THE QUESTIONNAIRE SURVEY

Petro P. Hanynets, Natalia A. Sinienko, Ozar P. Mintser

QUANTITATIVE ASSESSMENTS OF THE QUALITY OF MEDICAL CARE FOR PATIENTS IN CONDITIONS OF PRIVATE-STATE PARTNERSHIP

ILOŚCIOWA OCENA JAKOŚCI OPIEKI MEDYCZNEJ PACJENTÓW LECZONYCH W PLACÓWKACH FUNKCJONUJĄCYCH W RAMACH PARTNERSTWA PUBLICZNO-PRYWATNEGO

Tomasz Tittinger, Rafał Słoniak, Damian Szzzepański, Tadeusz Szymon Gaździk, Małgorzata Kulesa-Mrowiecka, Łukasz Kikowski

LATERAL INSTABILITY OF THE KNEE JOINT AND DISORDER OF THE ANKLE JOINT EXTENSION DISORDER IN MEN

NIESTABILNOŚĆ BOCZNA STAWU KOLANOWEGO A ZABURZZENIE WYPROSTU STAWU SKOKOWEGO U MĘŻCZYZN

PRACE POGLADOWE / REVIEW ARTICLES

Vladyslav A. Smiianov, Halyna S. Zaitseva, Victorya A. Kurganskaya, Anatoly G. Dyachenko, Volodymyr P. Zbarazhskyi, Yevhen V. Smiianov, Olha A. Pilipec VACCINATION COVERAGE RATES AND THE INCIDENCE OFVACCINE PREVENTABLE DISEASES AMONG CHILDREN IN SUMY REGION OF UKRAINE ODSETEK WYSZCZEPIENIA POPULACJI A WYSTĘPOWANIE CHORÓB ZAKAŹNYCH, KTÓRYM MOŻNA ZAPOBIEC DZIĘI SZCZEPIENIOM U DZIECI W OBWODZIE SUMSKIM NA UKRAINIE

Vitalii M. Pashkov, Maryna V. Trotska

NATURAL ENVIRONMENT AS COMPONENT OF PUBLIC HEALTH: SOME ASPECTS OF ITS LEGAL REGULATION

ŚRODOWISKO NATURALNE JAKO ELEMENT ZDROWIA PUBLICZNEGO: WYBRANE ASPEKTY REGULACJI PRAWNYCH

Anna M. Antonenko, Olena P. Vavinevych, Maria M. Korshun, Sergii T. Omelchuk

HYGIENIC ASSESSMENT OF THE EFFECTS OF PESTICIDES APPLICATION ON CHILDREN POPULATION MORBIDITYWITH THYROID GLAND DISEASES

SANITARNA OCENA WPLYWU EKSPOZYCJI NA PESTYCYDY NA CHOROBOWOŚĆ W POPULACJI DZIECI Z CHOROBAMI TARCZYCY

Larysa 0 . Herasymenko

POSTNATAL PERIOD PSYCHOLOGICAL ASPECTS

PSYCHOLOGICZNE ASPEKTY OKRESU POLOGU

Oleksandr Sarkanich, Olena Shevtsova, Ozar Mintser

ENSURING THE CONTINUITY OF MEDICAL CARE AT THE STAGE OF PATIENTS REHABILITATION

ZAPEWNIENIE CIĄGLOŚCI OPIEKI MEDYCZNEJ U CHORYCH PODDAWANYCH REHABILITACJI

Anatolii T. Komziuk, Dmytro M. Velichko, Volodymyr S. Goshovskyi, Valentyna A. Goshovska, Olena V. Klymenko

THE RIGHTS OF SURGEONS WHILEWORKING WITH HIV-INFECTED PATIENTS IN UKRAINE

PRAWA LEKARZY CHIRURGÓW LECZACYCH PACJENTÓW Z WIRUSEM HIV NA UKRAINIE

Piotr Feusette, Joanna Płonka, Jarosław Bugajski, Agata Duszańska, Beata Łabuz-Roszak, Marek Gierlotka

NIEWYDOLNOŚĆ SERCA - PROBLEM MEDYCZNY, EKONOMICZNY I SPOŁECZNY

HEART FAILURE - MEDICAL, ECONOMIC AND SOCIAL PROBLEM

OPISY PRZYPADKU / CASE REPORTS

Pavel A. Dyachenko

HIV/AIDS IN THE GUISE OF A DEMYELINATING DISEASE

ZAKAŻENIE HIV/AIDS OBJAWIIAJĄCE SIĘ POD POSTACIĄ CHOROBY DEMIELINIZACYJNEJ

Aleksandra Kaszyńska, Tadeusz M. Zielonka, Katarzyna Życińska

KASZEL U PACJENTA ZZAPALENIEM DRÓG Ż́́ŁCIOWYCHW PRZEBIEGU CHOROBY CAROLIEGO. OPIS PRZYPADKU

A COUGH IN A PATIENT WITH CHOLANGITIS IN THE COURSE OF CAROLI'S DISEASE. CASE REPORT

Oleh A. Loskutov, Andrii 0. Zhezher, Yevhen M. Sulimenko

CLINICAL CASE OF SUCCESSFUL MANAGEMENT OF ACUTE MYOCARDIAL INFARCTION DURING PREGNANCY

SKUTECZNE LECZENIE OSTREGO ZAWAŁU SERCA U KOBIETY W CIĄŻYY

Dawid Gajda, Michał Dyaczyński

ZESPÓŁ OGILVIEGO - OPIS PRZYPADKU

OGILVIE SYNDROME - CASE REPORT 
PRACA ORYGINALNA

ORIGINAL ARTICLE

\title{
DIAGNOSTIC ROLE OF SYSTEMIC INFLAMMATION, BLOOD COAGULATION AND PADUA PREDICTION SCORE IN LUNG THROMBOSIS RISK ESTIMATION IN HOSPITALIZED PATIENTS WITH COMMUNITY-ACQUIRED PNEUMONIA
}

\author{
DIAGNOSTYCZNA ROLA MARKERÓW UKŁADOWEGO STANU \\ ZAPALNEGO, ZABURZEŃ UKŁADU KRZEPNIĘCIA KRWI ORAZ \\ SKALI PADEWSKIEJ W OCENIE RYZYKA WYSTĄPIENIA ZATORU \\ PŁUCNEGO U PACJENTÓW HOSPITALIZOWANYCH Z POWODU \\ ZEWNĄTRZSZPITALNEGO ZAPALENIA PŁUC
}

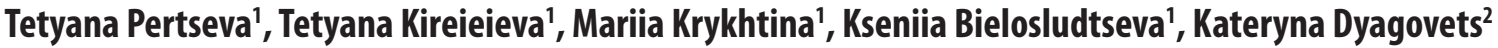 \\ 'DEPARTMENT OF INTERNAL MEDICINE 1, STATE INSTITUTION“DNIPROPETROVSK MEDICAL ACADEMY OF MINISTRY OF HEALTH OF UKRAINE,' DNIPRO, UKRAINE \\ 2DEPARTMENT OF HISTOLOGY, STATE INSTITUTION “DNIPROPETROVSK MEDICAL ACADEMY OF MINISTRY OF HEALTH OF UKRAINE”, DNIPRO, UKRAINE
}

\begin{abstract}
Introduction: Some coagulation and thrombotic disorders during severe CAP could lead to some intravascular disorders and even be the reason of lethal end in hospitalized patients with CAP. But this fact hadn't been established to the end yet.

The aim was to study the intravascular changes in patients with severe CAP and to estimate the role of parameters of systemic inflammation (procalcitonin (PCT), C-reactive protein (CRP)), blood coagulation test (fibrinogen, D-dimer, heparin time, prothrombin time) and risk of thrombosis in patients with moderate and severe (AP.

Materials and methods: The main group was 63 patients with moderate to severe CAP. The mean age was 54.0 [37.0-63.0] years old, men - 46 (73.0\%)). Depending on the severity all patients of the main group were divided into 2 subgroups: subgroup 1 - 36 patients with moderate CAP (the mean age was 51.0 [32.5-62.5] years old, men - 29 (80.5\%)), subgroup 2 - 27 patients with severe CAP (the mean age was 56.0 [46.0-68.0] years old, men - 17 (63.0\%). Subgroups had no significant difference according to age $(p=0,348)$ and $\operatorname{sex}(\mathrm{p}=0,237)$. Received results were compared with values in control group. The control group was 10 healthy people (the mean age was $52.0[35.6-62.0]$ years old, men $-5(50.0 \%)$ ). Results and conclusions: Patients with severe CAP had significantly higher levels of PCT, CRP, D-dimer, prothrombin time, heparin index and the lowest level of heparin time. This fact shows the highest risk of thrombosis in patients with severe CAP on the background of severe systemic inflammation. The mean level of scores by Padua scale in patients with severe CAP was 5.0 [5.0-6.0] scores, which was significantly higher than in patients with moderate CAP, who had 1.0 [1.0-2.0] scores.

On autopsy of 5 died patients with severe CAP we found thrombosis of lung vessels which differ from embolism or post-mortem blood clots. These changes maybe reflect systemic thrombosis at patients with severe CAP and could be the reasons of increased mortality in this category of patients.
\end{abstract}

KEY WORDS: CAP, thrombosis, Padua scale, inflammation, markers

Wiad Lek 2019, 72, 2, 149-153

\section{INTRODUCTION}

Community-acquired pneumonia (CAP) is one of the most common causes of mortality among other infectious diseases all over the world. The mortality rate of patients with CAP depends on the severity of the disease and comorbidity [1]. To improve the outcomes in the management of CAP there has recently been a significant attention paid to evidence-based scoring systems and biological markers. They can objectively help to predict the severity, to justify hospital or ICU admission [2]. The role of inflammatory markers had already established rather good. But researchers believe that some coagulation and thrombotic disorders during severe
CAP could lead to some intravascular disorders and even be the reason of lethal end in hospitalized patients with CAP $[3,4,5]$. But this fact hadn't been established to the end yet.

\section{THE AIM}

That's why the aim was to study the intravascular changes in patients with severe CAP and to estimate the role of parameters of systemic inflammation (procalcitonin (PCT), C-reactive protein (CRP)), blood coagulation test (fibrinogen, D-dimer, heparin time, prothrombin time) and risk of thrombosis in patients with moderate and severe CAP. 
Tetyana Pertseva et al.

Table I. Levels of systemic inflammation parameters in patients with moderate to severe CAP, Me [25-75\%]

\begin{tabular}{|c|c|c|c|c|}
\hline \multirow{2}{*}{ Parameter } & \multicolumn{2}{|c|}{ Main group } & \multirow{2}{*}{ Control group } & \multirow{2}{*}{$\mathbf{p}$} \\
\hline & subgroup 1 & subgroup 2 & & \\
\hline $\begin{array}{l}\text { CRP, } \\
\mathrm{mg} / \mathrm{l}\end{array}$ & $\begin{array}{c}136.9 \\
{[95,9-192,0]}\end{array}$ & $\begin{array}{c}223.8 \\
{[187,8-324,6]}\end{array}$ & $\begin{array}{c}4.5 \\
{[3,4-5,5]}\end{array}$ & $\begin{array}{l}P_{c-s 1}=0.000 \\
P_{c-s 2}=0.000 \\
P_{s 1-s 2}=0.000\end{array}$ \\
\hline $\begin{array}{c}\mathrm{PCT} \\
\mathrm{mcg} / \mathrm{ml}\end{array}$ & $\begin{array}{c}1.5 \\
{[0,7-2,4]}\end{array}$ & $\begin{array}{c}0.7 \\
{[0,6-12,0]}\end{array}$ & $\begin{array}{c}0.01 \\
{[0,04-0,09]}\end{array}$ & $\begin{array}{l}P_{c-s 1}=0.045 \\
P_{c-s 2}=0.007 \\
P_{s 1-s 2}=0.846\end{array}$ \\
\hline $\begin{array}{c}\text { Fibrinogen, } \\
\mathrm{mcg} / \mathrm{ml}\end{array}$ & $\begin{array}{c}2.9 \\
{[2,4-3,1]}\end{array}$ & $\begin{array}{c}9.2 \\
{[5,8-13,3]}\end{array}$ & $\begin{array}{c}2.7 \\
{[2,4-3,0]}\end{array}$ & $\begin{array}{l}P_{c-s 1}=0.648 \\
P_{c-s 2}=0.000 \\
P_{s 1-52}=0.001\end{array}$ \\
\hline
\end{tabular}

$P_{c-51}$ - between control group and subgroup 1;

$P_{c-s 2}^{c-s 1}$ - between control group and subgroup 2;

$P_{s 1-52}^{c-s 2}$ - between subgroup 1 and subgroup 2 .

Table II. Levels of blood coagulation test parameters and D-dimer in patients with moderate to severe CAP, Me [25-75\%]

\begin{tabular}{|c|c|c|c|c|}
\hline \multirow{2}{*}{ Parameter } & \multicolumn{2}{|c|}{ Main group } & \multirow{2}{*}{ Control group } & \multirow{2}{*}{$\mathbf{p}$} \\
\hline & subgroup 1 & subgroup 2 & & \\
\hline $\begin{array}{l}\text { D-dimer, } \\
\mathrm{ng} / \mathrm{ml}\end{array}$ & $\begin{array}{c}1382.7 \\
{[989,4-2940,0]}\end{array}$ & $\begin{array}{c}1802.1 \\
{[1389,6-5325,3]}\end{array}$ & $\begin{array}{c}264.0 \\
{[254,0-294,0]}\end{array}$ & $\begin{array}{l}P_{c-s 1}=0.000 \\
P_{c-s 2}=0.001 \\
P_{s 1-52}=0.679\end{array}$ \\
\hline $\begin{array}{l}\text { Heparin time, } \\
\text { seconds }\end{array}$ & $\begin{array}{c}40.0 \\
{[37,0-40,0]}\end{array}$ & $\begin{array}{c}23.0 \\
{[21,0-39,5]}\end{array}$ & $\begin{array}{c}56.0 \\
{[55,0-57,0]}\end{array}$ & $\begin{array}{l}P_{c-s 1}=0.000 \\
P_{c-s 2}=0.000 \\
P_{s 1-s 2}=0.007\end{array}$ \\
\hline $\begin{array}{l}\text { Heparin index } \\
\%\end{array}$ & $\begin{array}{c}140.0 \\
{[122,0-142,0]}\end{array}$ & $\begin{array}{c}132.0 \\
{[122,0-140,0]}\end{array}$ & $\begin{array}{c}105.0 \\
{[98,0-112,0]}\end{array}$ & $\begin{array}{l}P_{c-s 1}=0.000 \\
P_{c-s 2}=0.007 \\
P_{s 1-52}=0.557\end{array}$ \\
\hline $\begin{array}{l}\text { Prothrombin time, } \\
\text { seconds }\end{array}$ & $\begin{array}{c}18.0 \\
{[16,0-20,0]}\end{array}$ & $\begin{array}{c}22.0 \\
{[20,0-25,0]}\end{array}$ & $\begin{array}{c}13.0 \\
{[12,0-14,0]}\end{array}$ & $\begin{array}{l}P_{c-s 1}=0,000 \\
P_{c-s 2}=0,000 \\
P_{s 1-s 2}=0,000\end{array}$ \\
\hline $\begin{array}{l}\text { Prothrombin index, } \\
\%\end{array}$ & $\begin{array}{c}82.0 \\
{[72,0-90,0]}\end{array}$ & $\begin{array}{c}86.0 \\
{[76,0-90,0]}\end{array}$ & $\begin{array}{c}100.0 \\
{[98,0-108,0]}\end{array}$ & $\begin{array}{l}P_{c-s 1}=0.000 \\
P_{c-s 2}=0.000 \\
P_{s 1-52}=0.692\end{array}$ \\
\hline $\begin{array}{l}\text { Recalcification time, } \\
\text { seconds }\end{array}$ & $\begin{array}{c}100.0 \\
{[92,0-104,0]}\end{array}$ & $\begin{array}{c}92.5 \\
{[74,5-102,0]}\end{array}$ & $\begin{array}{c}61.0 \\
{[55,0-66,0]}\end{array}$ & $\begin{array}{l}P_{c-s 1}=0.000 \\
P_{c-s 2}=0.000 \\
P_{s 1-s 2}=0.105\end{array}$ \\
\hline
\end{tabular}

$P_{c-s 1}$ - between control group and subgroup 1 ;

$P^{c-51}$ - between control group and subgroup 2;

$P_{s 1-52}^{c-s 2}$ - between subgroup 1 and subgroup 2 .

\section{MATERIALS AND METHODS}

The main group was 63 patients with moderate to severe CAP. The mean age was 54.0 [37.0-63.0] years old, men - $46(73.0 \%))$. Depending on the severity all patients of the main group were divided into 2 subgroups: subgroup 1 - 36 patients with moderate CAP (the mean age was 51.0 [32.5-62.5] years old, men - $29(80.5 \%)$ ), subgroup 2 - 27 patients with severe CAP (the mean age was 56.0 [46.0-68.0] years old, men - 17 (63.0\%). Subgroups had no significant difference according to age $(\mathrm{p}=0,348)$ and $\operatorname{sex}(\mathrm{p}=0,237)$.

The formulation of diagnosis CAP and assessment of its severity were determined according to the international guidelines [6] and SMRT-CO scale [7].
General clinical analysis, blood coagulation test, determination of systemic inflammation biomarkers (PCT and CRP) were performed after hospitalization before starting of antibacterial treatment.

Blood coagulation test was done routinely including such parameters as recalcification test, heparin time, heparin index, prothrombin time and ptothrombin index.

The determination of serum PCT levels was by immunochemical electrochemiluminescence method, D-dimer and CRP levels were estimated by immunoturbodimetric method $[8,9]$.

Received results were compared with values in control group. The control group was 10 healthy people (the mean age was 52.0 [35.6-62.0] years old, men - $5(50.0 \%))$. 


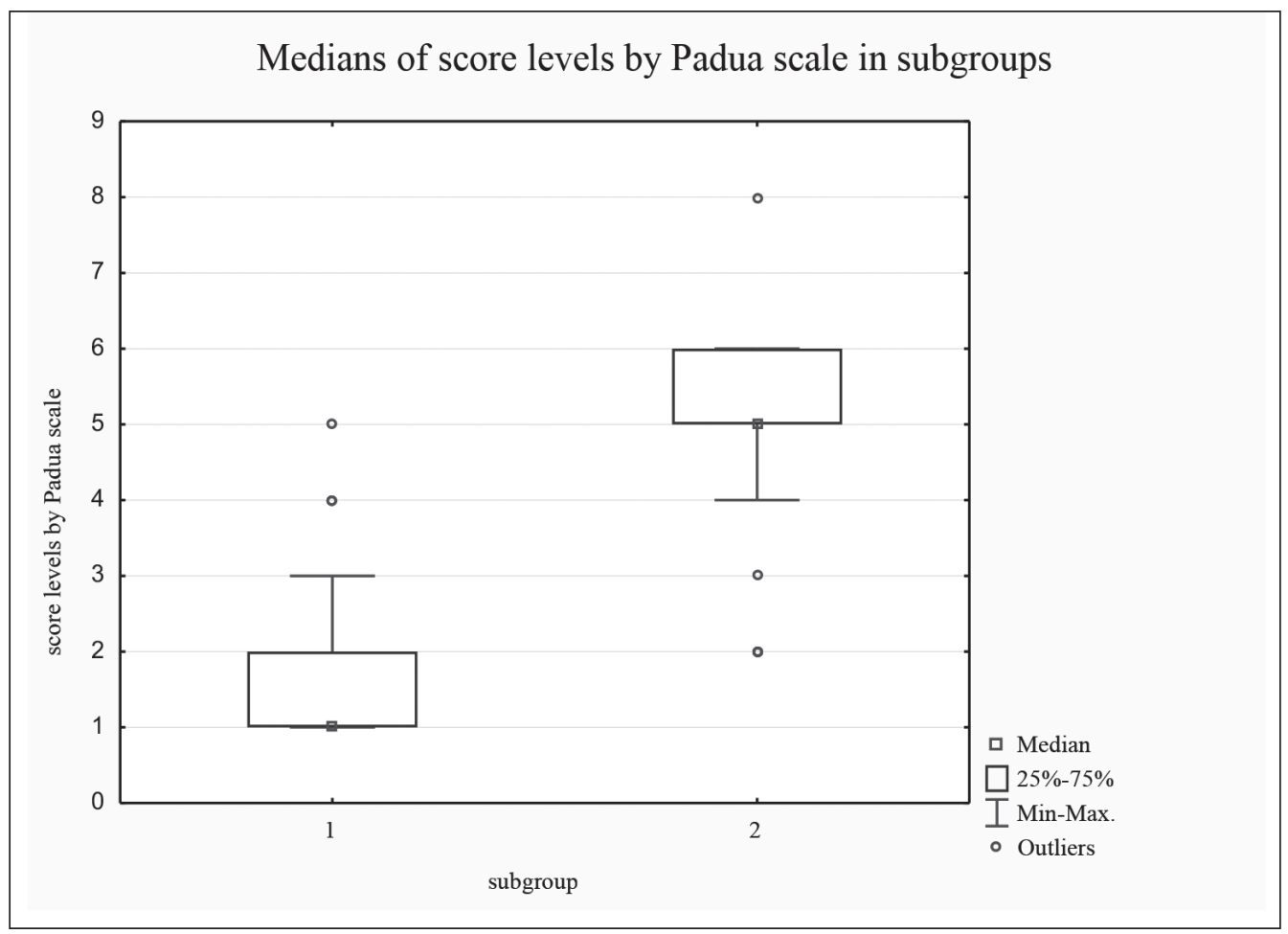

Fig. 1. Medians of score levels by Padua scale in subgroups

Table III. Relationships between Padua scale and other parameters

\begin{tabular}{ccc}
\hline Parameter & $\mathbf{R}$ & $\mathbf{P}$ \\
\hline SMRT-CO & 0,751 & 0,000 \\
\hline CRP & 0,389 & 0,002 \\
\hline PCT & 0,490 & 0,263 \\
\hline Fibrinogen & 0,689 & 0,000 \\
\hline D-dimer & 0,393 & 0,146 \\
\hline Heparin time & $-0,356$ & 0,017 \\
\hline Heparin index & $-0,233$ & 0,197 \\
\hline Prothrombin time & 0,534 & 0,000 \\
\hline Prothrombin index & 0,037 & 0,803 \\
\hline Recalcification time & $-0,144$ & 0,354
\end{tabular}

The risk of thrombosis was estimated with the help of Padua Prediction Score for risk of lung thrombosis [10].

At died patients we observed autopsy data including electronic microscope investigations.

Statistical processing of the results in research was carried out using the methods of biometric analysis, implemented in software packages EXCEL-2003 (№ 74017-641-947520157075) and STATISTICA 6.0 (№ 31415926535897) [11].

\section{RESULTS AND DISCUSSION}

Analyzing the data of main group patients we detect that during hospitalization everybody has clinical symptoms of CAP combining with mono- or bilateral lung infiltration on chest X-ray.

The severity according to the SMRT-CO scale of patients in subgroup 1 was $0.0[0.0-1.0]$ scores, in sub- group $2-3.0[3.0-5.0]$ scores $(p=0.000)$, which proved the right distribution of patient among subgroups.

During investigation of systemic inflammatory markers we found that in both subgroup 1 and subgroup 2 the mean levels of CRP and PCT were higher than in control group (table I). Detailed analysis showed that patients with severe CAP had significantly higher levels of these parameters.

During investigation of blood coagulation test and D-dimer we found that in both subgroup 1 and subgroup 2 the mean levels of D-dimer and prothrombin time were higher than in control group, the mean level of heparin time was lower than in control croup (table II). Detailed analysis showed that patients with severe CAP had significantly higher levels of D-dimer, prothrombin time, heparin index and the lowest level of heparin time. This fact shows the highest risk of thrombosis in patients with severe CAP. 
A

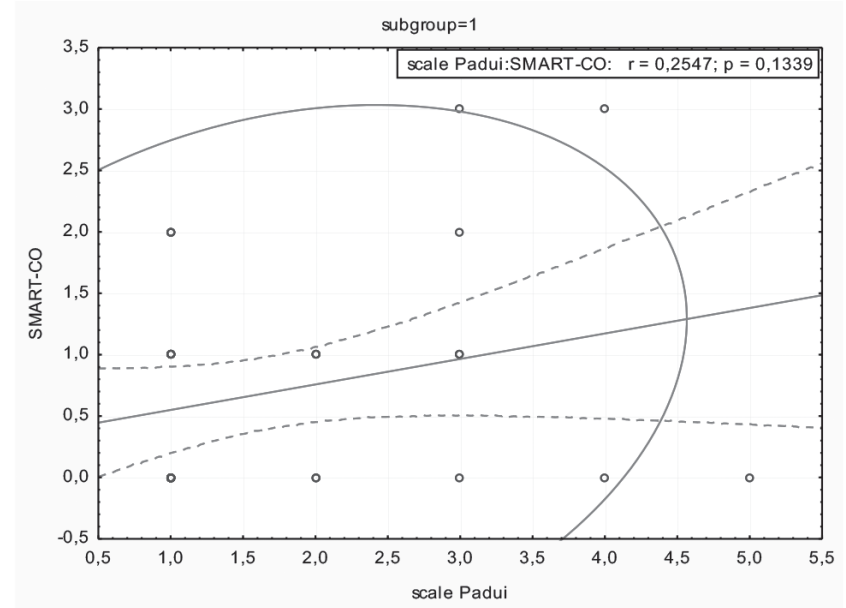

B

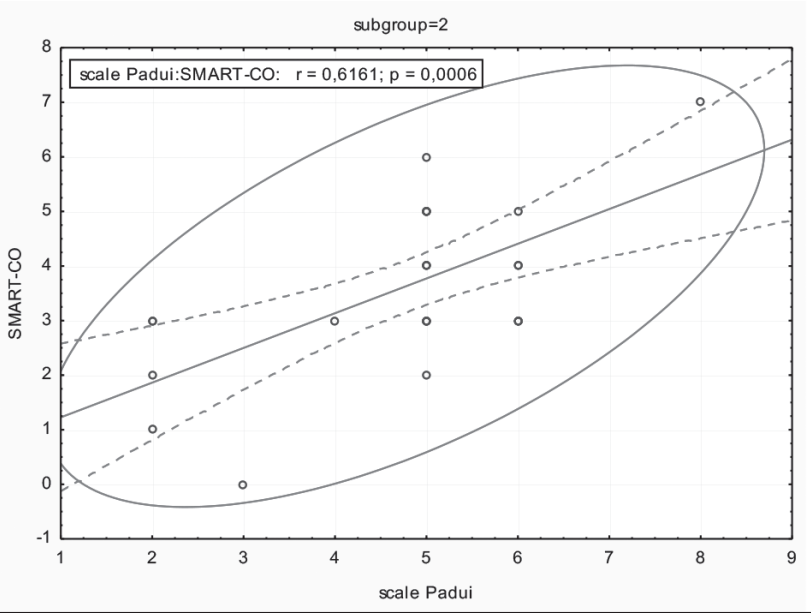

Fig. 2. Correlation of score levels by Padua scale and SMRT-CO scale in hospitalized patients with CAP: subgroup 1 (A), subgroup 2 (B).

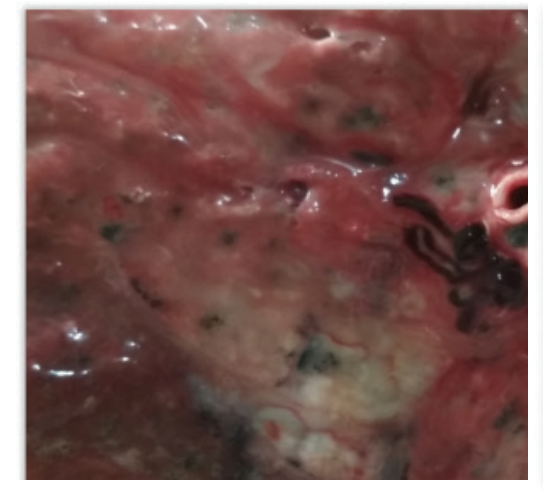

A

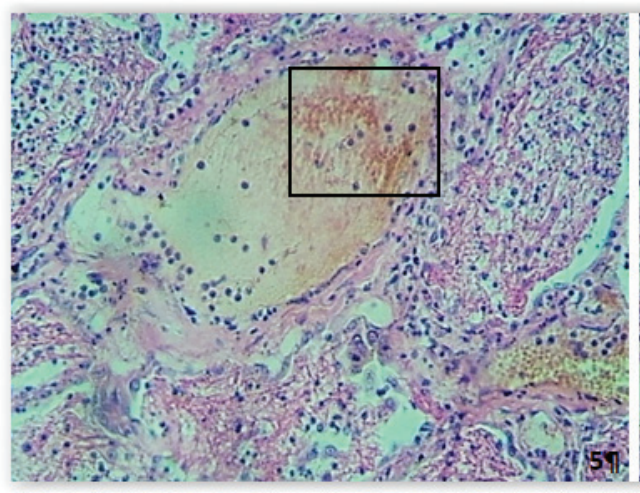

B

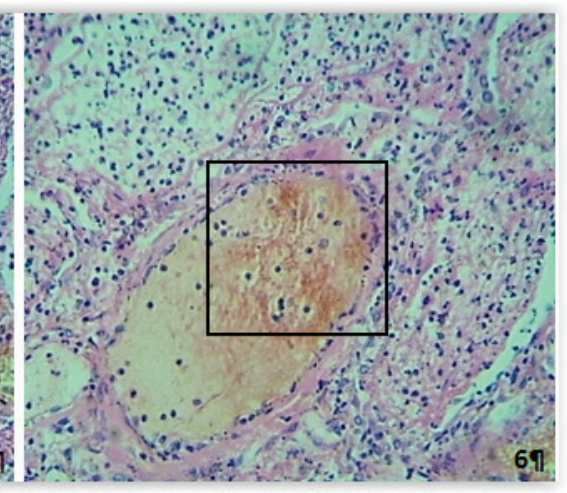

69

Fig.3. Macro- and microscopically data of lung autopsy died from CAP

The mean level of scores by Padua scale in patients with severe CAP was 5.0 [5.0-6.0] scores, which was significantly higher than in patients with moderate CAP, who had 1.0 [1.0-2.0] scores ( $\mathrm{p}=0.000)$ (Fig.1).

Besides thelevel of Padua scale score correlated significantly with SMRT-CO score, CRP, fibrinogen, heparin time and prothrombin time (Table III, Fig. 2), which demonstrates its relationships with CAP severity by both vital and inflammatory parameters.

During treatment all patients received antibacterial treatment according to standards depending on the severity of disease, mucolytic, oxygenation, symptomatic treatment. Besides, patients with severe CAP received anticoagulants in prophylactic doses.

Unfortunately despite treatment $5(8 \%)$ patients with severe CAP died. On autopsy of we found such pathomorphological signs: macroscopically - thrombosis of small or large branches of the pulmonary artery on the background of expressed purulent-destructive changes (Fig. 3A), microscopically - wall clots, partly with obturating growth, necrosis of surrounding tissues, lymphohystioid and neutrophil infiltration; the organization of the thrombus with the recanalization of the vessels (Fig. 3B).
So we defined that died patients with CAP have thrombosis of lung vessels which differ from embolism or post-mortem blood clots. These changes maybe reflect systemic thrombosis at patients with severe CAP and could be the reasons of increased mortality in this category of patients.

\section{CONCLUSIONS}

1. Died patients with severe CAP are characterized by lung vessels thrombosis, which could be the reason of high lethality of patients with this disease.

2. Severe CAP is characterized by very high risk of thrombosis by Padua scale, which was confirmed on autopsy. Padua scale could be used in hospitalized patients with CAP for predicting the risk of thrombosis.

3. Increased levels of CRP and PCT are correlated with high risk of lung vessels thrombosis and show the direct connection between systemic inflammation and thrombotic disorders in patients with moderate to severe CAP. 
4. Decreased heparin time and increased prothrombin time could be the predictors of thrombotic complications in patients with moderate to severe CAP.

\section{REFERENCES}

1. Torres A, Peetermans WE, Viegi G, Blasi F. Risk factors for communityacquired pneumonia in adults in Europe: a literature review. Thorax 2013; 68: 1057-65.

2. Vail GM, Xie YJ, Haney DJ, Barnes (J. Biomarkers of thrombosis, fibrinolysis, and inflammation in patients with severe sepsis due to community-acquired pneumonia with and without Streptococcus pneumoniae. Infection 2009; 37:358-64.

3. Violi F, Cangemi $R$, Calvieri C. Pneumonia, thrombosis and vascular disease. J Thromb Haemost 2014; 12: 1391-400.

4. Clayton TC, Gaskin M, Meade TW. Recent respiratory infection and risk of venous thromboembolism: case-control study through a general practice database. Int J Epidemiol 2011; 40:819-27.

5. Ribeiro DD, Lijfering WM, van Hylckama Vlieg A, Rosendaal FR, Cannegieter SC. Pneumonia and risk of venous thrombosis: results from the MEGA study. J Thromb Haemost 2012; 10:1179-82.

6. Niederman MS, Luna CM. Community-acquired pneumonia guidelines: a global perspective. Semin Respir Crit Care Med 2012;33(3):298-310.
7. Charles P. GP. and others. SMART-COP: A Tool for Predicting the Need for Intensive Respiratory or Vasopressor Support in Community-Acquired Pneumonia. Clinical Infectious Diseases 2008, 47 (3):375-84.

8. Hedlund J, Hansson L 0 . Procalcitonin and C-reactive protein levels in community-acquired pneumonia: correlation with etiology and prognosis. Infection 2000; 28:68-73.

9. Gosselin RC, Owings JT, Utter GH. A new method for measuring D-dimer using immunoturbidometry: a study of 255 patients with suspected pulmonary embolism and deep vein thrombosis. Blood Coagul Fibrinolysis 2000; 11(8):715-21.

10. Barbar S, Noventa F, Rossetto V, Ferrari A. A risk assessment model for the identification of hospitalized medical patients at risk for venous thromboembolism: the Padua Prediction Score. J Thromb Haemost 2010; 8(11):2450-7.

11. Hollander M., Wolfe D.A., Chicken E. (2014). Nonparametric Statistical Methods, John Wiley \& Sons.

\section{Authors' contributions:}

According to the order of the Authorship.

Conflict of interest:

The Authors declare no conflict of interest.

\section{CORRESPONDING AUTHOR Mariia Krykhtina}

Department of internal medicine 1 , State Institution "Dnepropetrovsk Medical Academy of the Ministry of Health of Ukraine" Street 9, V. Vernadskogo, 49044, Dnipro, Ukraine e-mail:mariakryhtina@gmail.com

Received: 10.09 .2018

Accepted: 12.01 .2019 
PRACA ORYGINALNA

ORIGINAL ARTICLE

\title{
ANTIMICROBIAL RESISTANCE OF STAPHYLOCOCCUS AUREUS CAUSING OF SURGICAL SITE INFECTIONS IN EAR, NOSE AND THROAT SURGERY
}

\author{
ANTYBIOTYKOOPORNOŚĆ STAPHYLOCOCCUS AUREUS \\ STANOWIAZCEGO CZYNIK ETIOLOGICZNY ZAKAŻEŃ POLA \\ OPERACYJNEGO W PRZYPADKU OPERACJI USZU, NOSA I GARDŁA
}

\author{
Aidyn G. Salmanov, Volodymyr O. Shkorbotun, Yaroslav V. Shkorbotun \\ SHUPYK NATIONAL MEDICAL ACADEMY OF POSTGRADUATE EDUCATION, KYIV, UKRAINE
}

\begin{abstract}
Introduction: Staphylococcus aureus is one of the major pathogens that causes of surgical site infection (SSI). Scant information is available on the occurrence and antimicrobial susceptibility of S. aureus in patients with SSI in Ear, Nose and Throat (ENT) surgery.

The aim: To assess the activity of antimicrobials against S.aureus, isolated from patients with SSI by the ENT departments of Kyiv hospitals.

Materials and methods: A total of 516 S. aureus isolates from of patients with SSI in ENT surgery. Antimicrobial susceptibility of S. aureus were determined, using automated microbiology analyzer. Some antimicrobial susceptibility test used Kirby - Bauer antibiotic testing. Interpretative criteria were those suggested by the Clinical and Laboratory Standards Institute (CLS).

Results: The most active antibiotics found in the study were linezolid and tigecycline, showing growth inhibition of $100 \%$ strains tested. Susceptibility to the other antimicrobials was also on a high level: $98,4 \%$ of strains were found susceptible to nitrofurantoin, $98.1 \%$ - to trimethoprim/sulphamethoxazole, $97.6 \%$ - to fusidic acid, $97.1 \%$ - to mupirocin, $95.9 \%$ - to teicoplanin, $94.7 \%$ - to vancomycin and fosfomicin, $90.6 \%$ - to moxifloxacin, $89.1 \%$ - to tobramycin, $87.3 \%$ - to gentamycin. Susceptibility to rifampicin (85.5\%), cefoxitin (84.6\%), levofloxacin (84.3\%), erythromycin (82.6\%), tetracycline (76.3\%), and clindamycin (75.4\%) was observed to be some lower. Resistance to oxacyllin S. aureus (MRSA) came up to $21.1 \%$.

Conclusions: S. aureus in ENT departments to be a serious therapeutic and epidemiologic problem. The constant monitoring of antimicrobials resistance in every hospital is required. Antibiotics application tactics should be determined in accordance with the local data of resistance to them.
\end{abstract}

KEY WORDS: ENT, SSI, S.aureus, MRSA, antimicrobial resistance

Wiad Lek 2019, 72, 2, 154-158

\section{INTRODUCTION}

Despite major advances in infection control interventions, healthcare-associated infections remain a major public health problem and patient safety threat worldwide $[1,2]$. Surgical site infections (SSI) are the most common type of nosocomial infection among surgical patients. [3-7].

Staphylococcus aureus is a major pathogen that causes of surgical site infection $[5,6,8-10]$. Worldwide, the increasing resistance of this pathogen to various antibiotics complicates treatment of $S$ aureus infections [8-10]. $S$. aureus has been recognized as an epidemiologically important pathogen [9]. Despite anti -biotic therapy, staphylococcal infections occur frequently in hospitalized patients and have severe consequences $[9,10]$. About 35$40 \%$ of patients undergoing surgery acquire at least one nosocomial S. aureus infection [5], leading to increased morbidity, mortality, hospital stay, and costs [11]. Development of resistance to commonly used antimicrobials limited treatment options against infections due to this pathogen $[5,9]$.

S. aureus is both a commensal bacterium and a human pathogen. Approximately $30 \%$ of the human population is colonized with S. aureus [12]. Nasal carriage of S. aureus among hospital personnel is a common cause of hospital acquired infections $[12,13]$. It is estimated that $20-30 \%$ of individuals are persistent carriers of S. aureus, around $30 \%$ are intermittent carriers, and 40-50\% are non carriers [14].

Nasal carriage of $S$. aureus among hospital personnel is a common cause of hospital acquired infections [1214]. Approximately $5 \%$ of colonised healthcare workers (HCWs) develop clinical infections [15] and symptomatic methicillin - resistant S. aureus (MRSA) infections among HCWs have been described in several case reports [16]. Emergence of drug resistant strains especially MRSA is a serious problem in hospital environment. Nasal carriage among HCWs is the main source for the transmission 
of MRSA and most S. aureus among patients within and between wards [13].

It has been shown that overall epidemiology and clinical manifestations of $S$. aureus vary significantly among different countries [10] and different regions of the same country [5,8]. In Ukraine, the potential public health threat due to antimicrobial resistance is high because of the fact that antimicrobial agents can easily be purchased without prescription, lack of coordinated routine surveillance of antimicrobial resistance, poor laboratory capacity, and poor infection control mechanisms by health facilities contributing to the emergence and spread of antimicrobial resistance.

Knowledge on the antimicrobial susceptibility status of circulating pathogens in a given health facility is important for better management of infectious pathogens particularly where routine culture and sensitivity testing is not practiced. Recent study at 12 Ukrainian hospitals, showed isolation rate of S. aureus from $27.6 \%$ of clinical specimens, of which over $29.1 \%$ of the isolates were MRSA [6]. Scant information is available on the occurrence and antimicrobial susceptibility of $S$. aureus in patients with surgical site infection in ENT departments in Ukraine.

\section{THE AIM}

The objective of the current study was to assess the activity of antimicrobials of S. aureus among patients with SSI in ENT departments in Kyiv hospitals, Ukraine.

\section{MATERIALS AND METHODS}

\section{STUDY POPULATION}

Over a 36 month period (January 2014 to December 2016), this retrospective study was performed in ENT departments of 3 Kyiv hospitals that are similar in terms of medical equipment, laboratory facilities and number of surgeries performed. The patients' age ranged from 19 to 74 . All patients undergoing ENT surgery with SSI were included in the database.

\section{ETHICS}

According to Ukrainian law, as this retrospective study did not modify the laboratory or clinical practices of the physicians, no informed consent and no approval of an Ethics Committee were required.

\section{DATA COLLECTION}

In order to determine of SSIs cases in the participating hospitals, passive search (through records from medical officers) and active identification (through epidemiological diagnostics) were used. In each hospital, the microbiologist and the attending physician collected the data in an electronic case report form. Case identification was triggered by the microbiologist after a positive culture S.aureus. After verification, microbiological and clinical data were recorded on the case report form. Information from the other types of medical doc- uments was also considered. The information was collected using tables for the standard criteria of SSIs diagnostics that were developed by the Centers for Disease Control and Prevention (Atlanta, USA) [17] and adopted for use in Ukraine.

\section{ANTIMICROBIAL SUSCEPTIBILITY TESTING} The intraoperative specimens were collected in sterile containers using all aseptic precautions. The identification and antimicrobial susceptibility of the S.aureus were determined, using automated microbiology analyzer Vitek 2 Compact (BioMerieux, France). Some antimicrobial susceptibility test used Kirby - Bauer antibiotic testing. In general, susceptibility of staphylococci strains to the following antibiotics was analyzed: benzylpenicillin, oxacyllin, cefoxitin, gentamycin, tobramycin, levofloxacin, moxifloxacin, erythromycin, clindamycin, linezolid, teicoplanin, vancomycin, tetracycline, tigecycline, fosfomicin, nitrofurantoin, fusidic acid, mupirocin, rifampicin, and trimethoprim/sulphamethoxazole. Interpretative criteria were those suggested by the Clinical and Laboratory Standards Institute (CLSI) [18].

\section{DEFINITIONS}

The investigation was based on the standard definition of an SSIs as purulent discharge from a surgical wound and the identification of microorganisms in the liquid at the surgical site. SSI was defined as an infection absent upon admission that became evident $48 \mathrm{~h}$ or more after admission in patients hospitalized for a reason other than SSI [17]. Only patients with post-operative infections were considered as SSI cases.

\section{STATISTICAL ANALYSIS}

The analysis of statistical data was performed using Microsoft Excel for Windows. The primary end point was the epidemiology of the S.aureus isolated in SSI samples and their resistance to antibiotics. Values of $\mathrm{p}<0.05$ were considered statistically significant.

\section{RESULTS}

Over the studied period, 586 patients ( $52.8 \%$ female, $56 \pm 20$ years, range $19-74$ years) with microbiologically proven SSI were included. There was no statistically significant difference in occurrence of $S$. aureus among different age group and sex. As a result of studying of staphylococci tested strains susceptibility to antibiotics it was established, that based on antimicrobial susceptibility analysis, the most active antibiotics found in the study were linezolid and tigecycline, showing growth inhibition of $100 \%$ strains tested (Table I).

Susceptibility to the other antimicrobials was also on a high level: $98,4 \%$ of strains were found susceptible to nitrofurantoin, $98.1 \%$ - to trimethoprim/sulphamethoxazole, $97.6 \%$ - to fusidic acid, $97.1 \%$ - to mupirocin, $95.9 \%$ - to teicoplanin, $94.7 \%$ - to vancomycin and fosfomicin, $90.6 \%$ - to moxifloxacin. Susceptibility to tobramycin (89.1\%), gentamycin $(87.3 \%)$, rifampicin (85.5\%), cefoxitin (84.6\%), levofloxacin (84.3\%), 
Aidyn G. Salmanov et al.

Table I. The activity of antimicrobials against S.aureus, isolated from patients with SSI by the ENT departments of Kyiv hospitals, Ukraine ( $n=586)$.

\begin{tabular}{|c|c|c|c|}
\hline \multirow{2}{*}{ Antibiotic } & \multicolumn{3}{|c|}{ Division by susceptibility, \% } \\
\hline & $\mathbf{S}$ & $\mathbf{R}$ & $\mathbf{R}(95 \% \mathrm{CI})$ \\
\hline Cefoxitin & 84.6 & 15.4 & $12.5-18.3$ \\
\hline Benzylpenicillin & 21.3 & 78.7 & $75.4-82.0$ \\
\hline Oxacyllin & 78.8 & 21.2 & $17.9-24.5$ \\
\hline Gentamycin & 87,3 & 12.7 & $10.0-15.4$ \\
\hline Tobramycin & 89.1 & 10.9 & $8.4-13.4$ \\
\hline Levofloxacin & 84.3 & 15.7 & $12.8-18.6$ \\
\hline Moxifloxacin & 90.6 & 9.4 & $7.0-11.8$ \\
\hline Erythromycin & 82.6 & 17.4 & $14.3-20.5$ \\
\hline Clindamycin & 75.4 & 24.6 & $21.1-28.1$ \\
\hline Linezolid & 100.0 & 0 & 0 \\
\hline Teicoplanin & 95.9 & 4,1 & $2.5-5.7$ \\
\hline Vancomycin & 94.7 & 5,3 & $3.5-7.1$ \\
\hline Tetracycline & 76.3 & 23,7 & $20.2-27.2$ \\
\hline Tigecycline & 100.0 & 0 & 0 \\
\hline Fosfomicin & 94.7 & 5,3 & $3.5-7.1$ \\
\hline Nitrofurantoin & 98.4 & 1,6 & $0.6-2.6$ \\
\hline Fusidic acid & 97.6 & 2,4 & $1.2-3.6$ \\
\hline Mupirocin & 97.1 & 2,9 & $1.5-4.3$ \\
\hline Rifampicin & 85.5 & 14,5 & $11.6-17.4$ \\
\hline Trimethoprim / sulphamethoxazole & 98.1 & 1,9 & $0.7-3.1$ \\
\hline
\end{tabular}

Note: $S$ - Susceptible; R - Resistant

Table II. Susceptibility of oxacyllin-resistant S.aureus (MRSA) to antibiotics in the ENT departments of Kyiv hospitals, Ukraine $(n=124)$

\begin{tabular}{cccc}
\hline \multirow{2}{*}{ Antibiotic } & \multicolumn{2}{c}{ Susceptibility, $\%$} & Susceptible \\
\cline { 2 - 4 } & Resistant & Moderately resistant & 26,3 \\
\hline Cefoxitin & 73,7 & 0 & 68,4 \\
\hline Gentamycin & 31,6 & 0 & 73,7 \\
\hline Tobramycin & 26,3 & 0 & 73,7 \\
\hline Levofloxacin & 10,5 & 15,8 & 84,2 \\
\hline Moxifloxacin & 10,5 & 63,2 \\
\hline Erythromycin & 56,8 & 42,1 \\
\hline Clindamycin & 57,9 & 0 & 100,0 \\
\hline Linezolid & 0 & 0 & 89,5 \\
\hline Teicoplanin & 0 & 84,2 \\
\hline Vancomycin & 10,5 & 0 & 63,2 \\
\hline Tetracycline & 15,8 & 100,0 \\
\hline Tigecycline & 36,8 & 0 & 73,7 \\
\hline Fosfomicin & 0 & 0 & 94,7 \\
\hline Nitrofurantoin & 26,3 & 0 & 89,4 \\
\hline Fusidic acid & 5,3 & 0 & 97,1 \\
\hline Mupirocin & 5,3 & 0 & 42,1 \\
\hline Rifampicin & 2.9 & 5,3 & 94,7 \\
\hline Trimethoprim/sulphamethoxazole & 42,1 & 0 & \\
\hline
\end{tabular}


erythromycin (82.6\%), tetracycline (76.3\%), and clindamycin (75.4\%) was observed to be some lower. Resistance to oxacyllin S.aureus (MRSA) came up to $21.1 \%$.

Analysis of the profiles for strains resistant to 6 and more classes of antibiotics demonstrated, that all the $S$. aureus strains were resistant to oxacyllin (MRSA), suggesting previously shown evidences on multiple antimicrobial resistance among staphylococci, resistant to oxacyllin. Oxacyllin-resistant strains were found not to have identical susceptibility to cefoxitin, and therefore, different mechanisms of resistance to oxacyllin were presumed. Thus, oxacyllin-resistant strains were also resistant to cefoxitin.

Research of MRSA prevalence in ENT departments shown, that $11 \%$ of staphylococci strains, isolated from patients having SSI, had multiple resistance to antibiotics. Further, $35.7 \%$ of MRSA strains were resistant only to the group of beta-lactamic antibiotics, while the rest - also to the other classes of antibiotics.

It should be highlighted, that when isolating MRSA, particular attention should be paid to the choice of antibiotic, prescribed for treatment. Having analyzed MRSA resistance levels to antibiotics, our data allowed us to determine the antibiotics, that can be chosen for treatment of staphylococcal infections (Table II).

MRSA resistance levels, in comparison with resistance of all analyzed S.aureus strains in general, were higher, and therefore, the list of antibiotics to be effective used for MRSA treatment, had more limitations. Except of linezolid and tigecycline, that no strain demonstrated resistance to, MRSA indicated quite high levels of susceptibility to mupirocin (97.1\%), nitrofurantoin and trimethoprim/ sulphamethoxazole (both 94,7\%), fusidic acid $(89,4 \%)$. These antibiotics could be the preparations of choice for the treatment of MRSA-caused infections.

It is important to specifically note low levels of MRSA susceptibility to glycopeptide antibiotics, vancomycin and teicoplanin (vancomycin - 15,8\%, and teicoplanin - 10,5 $\%)$, that no strain quite recently demonstrated resistance to, and that were typically chosen for treatment of infections, caused by MRSA. Isolation of such strains suggested, that staphylococci have acquired resistance to vancomycin, and that it is greatly important to find new antibiotics, active against MRSA.

\section{DISCUSSION}

In this study presents the first data on the activity of antimicrobials against S.aureus, isolated from patients with SSI in ENT departments in Ukraine. The current study revealed high rate of resistance to most of the antimicrobials by strains of S. aureus isolated from patients with SSI in ENT departments. Interestingly, benzylpenicillin, which is currently not used for treatment of staphylococcal infections anymore, was shown to be ineffective in $75.4 \%$ of strains, which still suggests the usefulness of this antibiotic for patient treatment, based on the individual antibiogram data.

At first glance, taking into account the fact, that levels of antimicrobial resistance of tested strains of $S$. aureus did not exceed $24.6 \%$, it seems quite easy to choose any of the above-mentioned antibiotics (excepting benzylpenicillin) to treat staphylococcal infections. However, analysis of antimicrobial resistance profiles revealed that some strains were resistant to 9-13 antibiotics, belonging to 6-10 classes of antimicrobials. This considerably limits the choice of antibiotics useful for treatment of infections, despite of low levels of resistance among staphylococci in general.

Resistance to oxacyllin S.aureus (MRSA) came up to 21.1\%. $35.7 \%$ of MRSA strains were found to be resistant only to beta-lactamic antibiotics: penicillin, cefoxitin, and oxacyllin. Such an MRSA phenotype is specific for non-nosocomial strains of S. aureus, or for strains, resistant due to modified penicillin-binded proteins (not PBP2a) [19]. Other strains, except of anti-beta-lactam resistance, were resistant to other classes of antibiotics, and such a phenotype is considered to be specific for nosocomial MRSA [20].

MRSA strains are highly prevalent in Ukrainian surgical hospitals, those strains account for approximately $50 \%$ of all S. aureus isolates recovered from health care infections [5-7, 20,21]. In Europe, the proportion of MRSA isolates in infected patients varied in 2015 from less than $0 \%$ to more than $57.2 \%$, with a pooled mean rate of around $16.8 \%$ [10]. In the United States, the proportion of MRSA strains approached almost $60 \%$ in 2003, with an average rate of resistance over the period 1998-2002 of around $50 \%$ [22]. In 2007, a Mediterranean study found that the highest proportions of MRSA were reported by Egypt (52 $\%)$, Cyprus (55 \%), Algeria (45 \%), Malta (50 \%) and Jordan (56\%), in comparison to other Mediterranean countries such as Lebanon (12\%), Tunisia (18\%) and Morocco (19\%) [23].

According to the global experience, the implementation of infection control system is the most efficient remedy, directed on prevention of MRSA spreading in healthcare facilities. This may explain, to some extent, such a huge difference in MRSA prevalence in various countries. To combat the spreading of strains, resistant to antibiotics, one should have, first of all, reliable data about the status of this problem (antimicrobial resistance) in each region, hospital, and even in every department. Implementation of standardized methods to receive this information, as well as introduction of efficient sanitary and hygienic approaches to control and decrease the prevalence of problematic microorganisms is of great importance, and should be based on the close cooperation between experts, both microbiologists, clinicians, and epidemiologists.

\section{STUDY LIMITATIONS}

According to the results of our study, the prevalence of MRSA by ENT departments was $21.1 \%$. However, the information provided may not reflect, in our opinion, the real MRSA prevalence in the country due to impact of several factors, the most important of which was small selection of strains. An antimicrobial resistance study should preferably be performed on large cohorts. The consequence of a small population size is the low probability of detecting an important effect, since the analysis is underpowered. The present surveillance was conducted only in 3 hospitals, and the results cannot be generalized to all Ukrainian hospital settings. 


\section{CONCLUSIONS}

$S$. aureus in the ENT departments is a serious therapeutic and epidemiological problem. The constant monitoring of antimicrobials resistance in every hospital is required. Antibiotics application tactics should be determined in accordance with the local data of resistance to them.

\section{REFERENCES}

1. World Health Organization. Report on the burden of endemic health careassociated infection worldwide. WHO Document Production Services, Geneva[Switzerland]; 2011. Available from: http://apps.who.int/iris/ bitstream/10665/80135/1/9789241501507_eng.pdf.

2. Pittet D, Allegranzi B, Storr J, Bagheri Nejad S, Dziekan G, Leotsakos A et al. Infection control as a major World Health Organization priority for developing countries. JHosp Infect. 2008; 68: 285-292.

3. Magill SS, Hellinger W, Cohen J, Kay R, Bailey C, Boland B, et al. Prevalence of healthcare-associated infections in acute care hospitals in Jacksonville, Florida. Infection Control Hospital Epidemiology, 2012 Mar; 33 (3):283-91. doi:10.1086/664048.

4. European Centre for Disease Prevention and Control. Pointprevalence survey of healthcare-associated infections and antimicrobial use in European acute care hospitals.Stockholm: ECDC; 2013. Available from: https://ecdc.europa.eu/sites/portal/files/media/en/publications/ Publications/healthcare-associated-infections-antimicrobial-use-PPS. pdf Accessed January 11, 2018.

5. Salmanov AG. Antimicrobial resistance and healthcare-associated infections in Ukraine. Epidemiological report of the multicenter study (2010 - 2014). Kyiv:AgrarMediaGroup, 2015:452 p. [In Ukrainian].

6. Salmanov AG, Vdovychenko YuP, Nychytailo MYu, Andriuschenko DV, Verner OM. Incidence of Surgical Site Infections and Antimicrobial Resistance their Pathogens in Ukraine. International Journal of Antibiotics and Probiotics. 2018 Mar; 2 (1):18-29. doi: https://doi.org/10.31405/ijap.2-1.18.02.

7. Salmanov A. Surgical site infections and antibiotic resistance of causal agents in the hospitals of Kiev, Ukraine. EpiNorth. 2009;10(3):120-7.

8. Salmanov AG, Usenko AYu. Antibiotic resistance of nosocomial strains of Staphylococcus aureus in surgical stationaries of Ukraine: results of multicenter investigation (2015-2016). Klinicheskaia Khirurgiia, 85(5), 5-9. https://doi. org/10.26779/2522-1396.2018.05.05. [In Russian]

9. WHO publishes list of bacteria for which new antibiotics are urgently needed. 7Feb.2017.Geneva-WH0.Official site. Availablefrom:http://www.who.int/ mediacentre/news/releases/2017/bacteria-antibiotics-needed/en/.

10. European Centre for Disease Prevention and Control. Antimicrobial resistance surveillance in Europe 2015.Annual Report of the European Antimicrobial ResistanceSurveillanceNetwork (EARS-Net).Stockholm:ECDC;2017. Available from: https://ecdc.europa.eu/sites/portal/files/media/en/publications/ Publications/antimicrobial-resistance-europe-2015.pdf

11. Kock R, Becker K, Cookson B, van Gemert-Pijnen JE, Harbarth S, Kluytmans J, et al. Methicillin - resistant Staphylococcus aureus (MRSA): burden of disease and control challenges in Europe. Euro Surveill. 2010; 15(41):19688. Available from:http://www.eurosurveillance.org/content/10.2807/ese.15.41.19688-en.

12. Wertheim HF, Melles DC, Vos MC, van Leeuwen W, van Belkum A, Verbrugh HA, Nouwen JL. The role of nasal carriage in Staphylococcus aureus infections. Lancet Infect Dis. 2005;5(12):751-62

13. Salmanov AG, Verner OM, Shelkova NG, Nicolska Ol, Blahodatny VM, Slepova LF. Prevalence of Nasal Carriage of Staphylococcus aureus and its Antibiotic Susceptibility among Healthcare Workers (HCWs) in Ukraine. International Journal of Antibiotics and Probiotics. 2018 Mar; 2 (1):30-41. doi: https://doi. org/10.31405/ijap.2-1.18.03.
14. Espinosa-Gongora C, Dahl J, Elvstrom A, van Wamel WJ, Guardabassi L. Individual predisposition to Staphylococcus aureus colonization in pigs on the basis of quantification, carriage dynamics, and serological profiles. Appl Environ Microbiol. 2015 Feb;81(4):1251-6.

15. Albrich WC, Harbarth S. Health-care workers: source, vector, or victim of MRSA? LancetInfectDis. 2008May;14:289-301.doi: 10.1016/S1473-3099(08)70097-5.

16. Haamann F, Dulon M, Nienhaus A. MRSA as an occupational disease: a case series. Int Arch Occup Environ Health. 2011 Mar;14:259-266. doi: 10.1007/ s00420-010-0610-7

17. Horan TC, Gaynes RP, Martone WJ, Jarvis WR, EmoriTG. CDC definitions of nosocomial surgical siteinfections, 1992: a modification of CDC definitions ofsurgical wound infections. Am J InfectControl HospEpidemiol. 1992;13:606-8.

18. Clinical and Laboratory Standards Institute. Performance Standards for Antimicrobial Susceptibility Testing: Eighteenth Informational Supplement M100-S18. Wayne, PA, USA: CLSI; 2008.

19. Stapleton PD, Taylor PW. Methicillin resistance in Staphylococcus aureus: mechanisms and modulation. Science Progress. 2002;85,1:57-72.

20. Salmanov AG, Verner OM. Prevalence of methicillin-resistant Staphylococcus aureus (MRSA) in Kyiv Surgical Hospital (Ukraine). International Journal of Antibiotics and Probiotics. 2017 Dec; 1 (2): 73-83.

21. Salmanov AG, Marievsky VF. Antibiotic resistance of nosocomial strains of Staphylococcus aureus inthe Ukraine: the results of multicenter study. NovostiKhirurgii. 2013 Jul-Aug;21(4):78-83 [In Ukrainian].

22. NNIS. National Nosocomial Infections Surveillance(NNIS) System Report, data summary from January1992 through June 2004, issued October 2004. Am J Infect Control. 2004; 14:470-485.

23. Borg MA, de Kraker M, Scicluna E, van de Sande-BruinsmaN, Tiemersma E, Monen J, Grundmann H. Prevalenceof methicillin-resistant Staphylococcus aureus (MRSA) ininvasive isolates from southern and eastern Mediterranean countries. J Antimicrob Chemother. 2007 Dec;60(6):1310-5.

The work is carried out within the framework of the planned initiative research work of the Shupyk National Medical Academy of Postgraduate Education, Kyiv, Ukraine.

Acknowledgment: The authors wish to express their grateful acknowledgement to all the microbiologists, physicians and nurses who contributed to this study.

Authors' contributions:

According to the order of the Authorship

Conflict of interest:

The Authors declare no conflict of interest

\author{
CORRESPONDING AUTHOR \\ Aidyn Salmanov \\ Shupyk National Medical Academy \\ of Postgraduate Education, \\ St. Dorohozhytska 9 \\ 04112, Kyiv, Ukraine \\ tel. +380667997631 \\ e-mail:mozsago@gmail.com
}

Received: 08.11 .2018

Accepted: 22.01.2019 
PRACA ORYGINALNA

ORIGINAL ARTICLE

\title{
PSYCHOLOGICAL FEATURES OF MOTIVATIONAL SPHERE OF DRUG ADDICTS
}

\section{CECHY PSYCHOLOGICZNE SFERY MOTYWACYJNEJ UZALEŻNIENIA OD NARKOTYKÓW}

\author{
Ulyana B. Mykhaylyshyn \\ DEPARTMENT OF PSYCHOLOGY, STATE UNIVERSITY «UZHHOROD NATIONAL UNIVERSITY», UZHHOROD, UKRAINE
}

\begin{abstract}
Introduction: The article considers the psychological features of motivational sphere of drug addicts. The article presents the results of the empirical study of the specifics of motivational sphere of drug addicts with the subsequent statistical analysis.

The aim of this study is to identify psychological characteristics of motivational sphere of drug addicts.

Materials and methods: The research has been conducted at Transcarpathian Oblast Narcological Dispensary (Uzhhorod, Ukraine). The experiment involved 30 drug addicts of different age and sexes. In order to diagnose the motivational sphere of drug addicts, the following methods have been used: Diagnostics of motivation to avoid failure by T. Ehlers; Measuring the motivation to success by T. Ehlers; Diagnostics of risk attitude by G. Schubert.

Results: It has been found that the determining factors of motivation for drug abuse are: social and psychological conditions of life, factors of group influence, direct psychophysiological influence of drugs, daring illusory satisfaction. It has been determined that young people with unstable spiritual needs and lack of stable positive interests are the category who is the most inclined to drug abuse.

Conclusions: The data of statistical, quantitative and qualitative analysis has been obtained allowing concluding that the development of destructive motivation affects the inclination to using the narcotic substances.
\end{abstract}

KEY WORDS: motivational sphere, drug addiction, psychoactive substances, addictive behaviour, motivation for success, predisposition to risk, motivation of affiliation, drug abuse, motivation of behaviour

Wiad Lek 2019, 72, 2, 159-164

\section{INTRODUCTION}

The complicated social and economic situation, which is observed in Ukraine, preconditions the negative tendencies, the growth of drug abuse cases including, which deforms the human motivational sphere. The spread of such dangerous phenomena among the young people poses a threat to the health of the nation. In this regard, the implementation of measures aimed at preventing the further growth of drug addiction, as well as the development of effective strategies to overcome addictions is extremely relevant.

Often, the help to patients with drug addiction is limited to detoxification and relief from the state of physical dependence. With this approach, specialists do not pay enough attention to the fact that the main causes of drug abuse are of psychological character, and the formation of dependence is accompanied in a patient with the emergence of strong mental trauma, which deforms the motivational sphere, changes other substructures of an individual, adversely affects all spheres of his/her mental life.

That is why the motivational sphere of drug addicts is relevant for the research.

\section{ANALYSIS OF RECENT RESEARCHES AND PUBLICATIONS}

Despite long history of researching the drug addicts personality, the motivation and psychological readiness to drugs abuse, sex-age characteristics of drug addicts, it is necessary to note the study of causes, that contribute to the formation of purpose of drug abuse, and the study of motivational sphere of drug addicts is insufficient [1, p. 80].

Among the numerous studies devoted to the motivation of drug abuse, we note the study of T. I. Petrakov and team, which emphasizes that psychological readiness for the use of psychoactive substances is determined by personal beliefs, pressure of groups and authority, conformism, demonstrative protest against the opinions of the others, the desire for self-affirmation, removing of emotional stress [2, p. 45].

P. D. Shabanov, author of the manual on narcology, points out that imitation is the motive for the first use of narcotic substances, as well as the desire to look like adults, to be independent in decision-making. However, it is not so easy to determine what motives and risk factors are the key once to shape the need for use of narcotic drugs. The un- 
conscious about its harm is considered to be an important factor that determines the first time drugs using [3, p. 98].

According to the study of A. Y. Taras, "youth with unstable spiritual needs and the lack of stable positive interests is the most inclined to drug abuse» [4, p. 56].

N. G. Naydonova et al. also considers the combination of a number of features of personality as psychological factors in the formation of models of drug-addictive behaviour [5, p. 170]. They include: the lack of formation of higher emotions, limited interest, the lack of purpose for work and other socially useful activities, low internal control, the desire to artificially change own condition caused by mental imbalance, a sense of inner tension, pathological aspirations for self-affirmation or hedonistic tendencies, emotional-volitional imbalance, violation of psychological adaptive mechanisms, motivational sphere and other substructures..

In the foreign literature, the so-called confrontation of generations is often mentioned as the dominant motive for addictive behaviour in young people - a protest against the spiritual values of parents and society as a whole. From the neo-Freudian point of view, the predominant nowadays consumption culture, the desire to consume happiness as a commodity are the main motives of addictive behaviour. A certain role in the spread of drugs is played by myths in relation to their effects that are spreading in a society [2, p. 67].

When psychic dependence is formed, the main motivation is the desire - the need to somehow change the mental state. And with physical dependence - the main motive for drug abuse is the fear of abstinence [6, p. 350].

Consequently, the study of motivational sphere includes a number of social and psychological factors that influence the personality and the formation of this dependence.

\section{THE AIM}

The purpose of this study is to identify psychological characteristics of motivational sphere of drug addicts.

\section{MATERIALS AND METHODS}

The research has been conducted at Transcarpathian Oblast Narcological Dispensary (Uzhhorod, Ukraine). The experiment involved 30 drug addicts of different age and sexes. In order to diagnose the motivational sphere of drug addicts, the following methods have been used:

1. Diagnostics of motivation to avoid failure by T. Ehlers. 2. Measuring the motivation to success by T. Ehlers.

3. Diagnostics of risk attitude by G. Schubert.

This psychodiagnostic set of techniques makes it possible to identify, describe and reliably assess the psychological peculiarities of respondents. The complex is an adequate tool for researching the motivational sphere of drug addicts.

\section{RESULTS AND DISCUSSION}

Having applied the method of T. Ehlers on diagnostics of motivation to avoid failure, the following results are obtained: 6 respondents (20\%) have a high level of moti- vation to avoid failures; 16 respondents (53\%) - average; 8 respondents (27\%) - low level (Figure 1).

Motivation to avoid failure involves the following specificity of human behaviour: passivity, fear of mistakes and failure, avoidance of responsible decisions, fear of risk. Motivation to avoid failure belongs to the negative sphere. With this type of motivation, a person seeks to avoid condemnation and punishment first and foremost. Expectation of unpleasant consequences determines the activity.

The distribution of rates of failure avoiding is as following: - low level of motivation to avoid failure -8 respondents; - average level of motivation to avoid failure - 16 respondents;

- high level of motivation to avoid failure -6 respondents. Indicators for each member of the sample are presented graphically (Figure 2).

The minimum indicator of motivation to avoid failure is 2 points, and the maximum is 22 points

The domination of average level of failure avoiding indicates the tendency to change the motivation to avoid failure into the motivation to success.

Low level of failure avoiding indicates the orientation on success and readiness to overcome problems that arise on the way of its achievement.

People with high level of protection, that is, with fear of accidents, are more likely to find themselves in such troubles than those, who possess high level of motivation to success.

Having applied the method of T. Ehlers on measuring the motivation to success, the following results are obtained: $5(17 \%)$ respondents possess high level of motivation to success, 13 (43\%) - average level, 11 (37\%) - low level, 1 (3\%) very high level (Figure 3 ).

Motivation to success is the strategy of human behaviour, when an individual is focused on activity, result achievement, is not afraid of mistakes, takes different actions, andis capable to risk.

High level of motivation to success is characterised by a deep awareness of dependence of own professional success on self-cognition, self-control and self-improvement. Needs associated with personal growth are clearly identified: to master the level of skill and competence, to provide material comfort for oneself, to develop own strengths and abilitie. These individuals are characterised by the power of will, self-control and responsibility for own actions, which inevitably increases their success in solving of cognitive and professional tasks.

The average level of motivation to success is characterised by the sufficient formation of all components of motivation. Individuals of this type are usually active, initiative. They consciously seek to master knowledge and skills, are able to work organised and make efforts to achieve the desired result.

Low level of motivation for success is characterised by the fact that personal professional qualities are weak and they cannot always be detected, most likely, the motive is characterised through the awareness of «it is needed». It is usually associated with the outer side of the process, focused on formal success, achievement of an estimated result. 

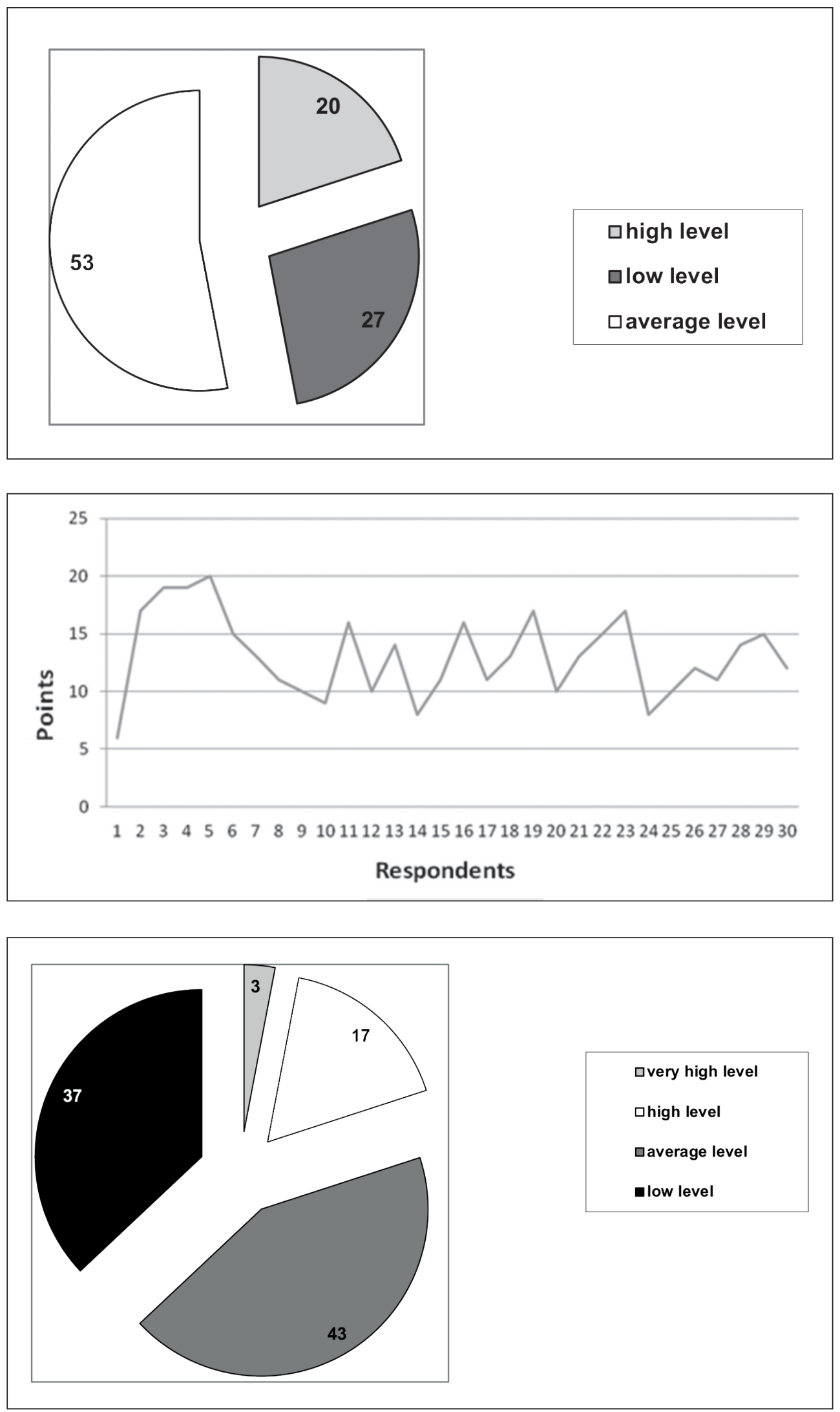

Figure 1. Graphic presentation of the research results based on the method of T. Ehlers on diagnostics of motivation to avoid failure

Figure 2. Motivation to avoid failure by technique of T. Ehlers

Figure 3. Graphic presentation of the research results on the method of T. Ehlers on measuring the motivation to success
Motivation to success has a positive character. With this motivation, human actions are aimed at achieving constructive, positive results. People motivated by success, set the main positive goal, the achievement of which is regarded as success. They are characterised by expectation of success, they are confident in it. Their work causes positive emotions.

We have carried out a mathematical and statistical analysis of the techniques by T. Ehlers on avoiding failure and achieving success. 

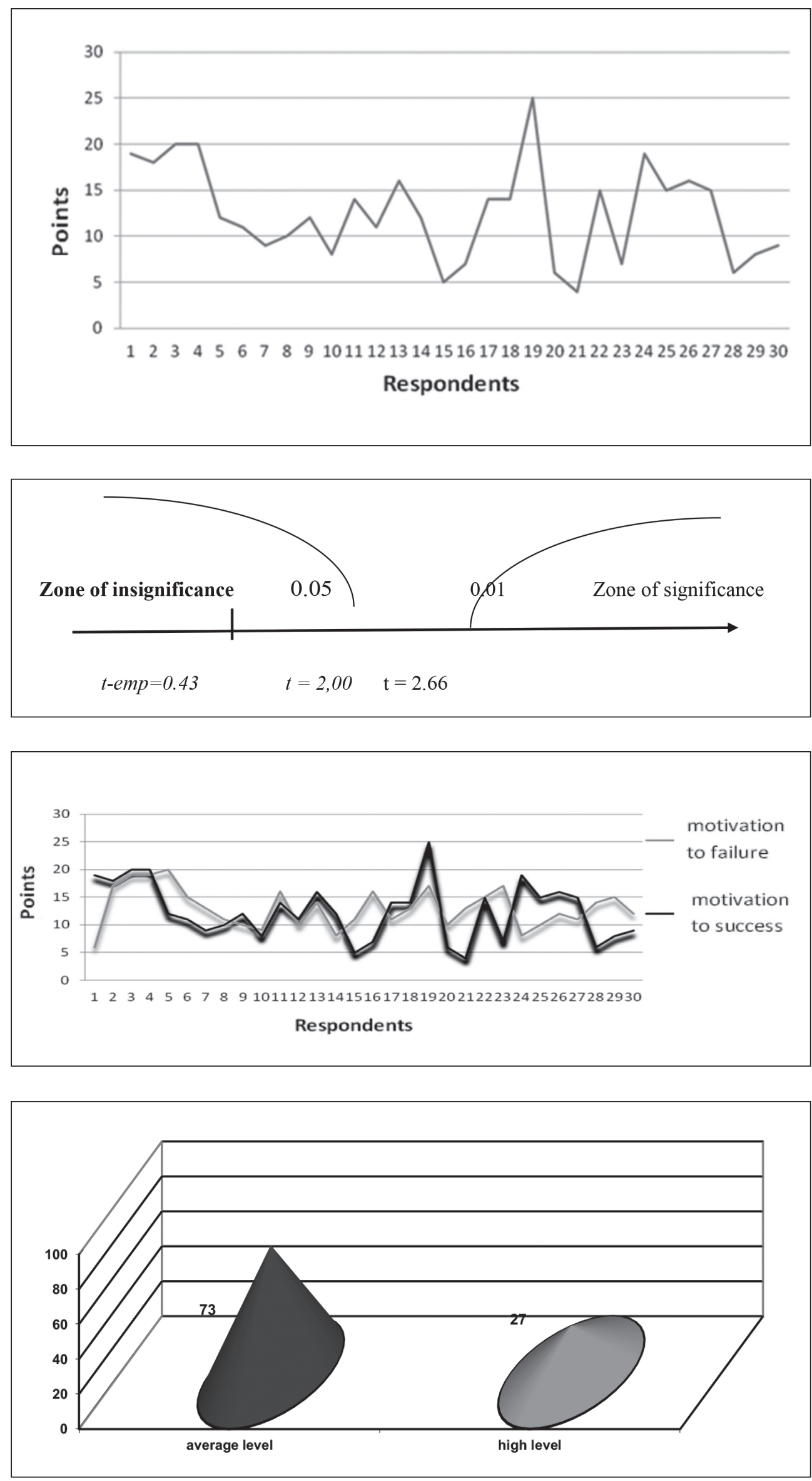

Figure 4. Motivation to success by T. Ehlers

Figure 5. Axis of significance

Figure 6. Correlation of techniques on motivation to avoid failure and motivation to success

Figure 7. Graphic presentation of the research results on the method of $G$. Schubert on diagnostics of risk attitude. 
In the process of research, we have used the parametric criterion - $t$ criterion of Student.

Sequence of analysis:

1. We issue the null and the alternative hypothesis:

$H_{0}$ : The average value of indicator of motivation to avoid failure is not significantly different from the average value of indicator motivation to success.

$H_{1}$ : The average value of indicator of motivation to avoid failure differs from the average value of indicator of motivation to success.

2. Checking of assumptions: the distribution of the studied parameters is normal, linked sampling, the scopes of samples are the same.

3. Calculation of the empirical value of t-emp is provided .

4. Critical value of tcr is indicated .

5. Decision making: since $t$-emp $<t c r$, that is, $0.43<2.00$. The null hypothesis is accepted at the level of significance 0.05 . We build the axis of significance (Figure 5).

Consequently, at the level of significance of 0.05 there is no reason to assert that the average value of the indicators is not significantly different. Therefore, the method of motivation to avoid failure by T. Ehlers does not differ in its indicators from the values of method of motivation to success by T. Ehlers. Therefore, the $H_{0}$ hypothesis is accepted, and $H_{1}$ is rejected.

Mathematical analysis of the research has confirmed that in the given techniques by T. Ehlers, the average indicator of motivation to avoid failure (53\%) and the average value of motivation to success $(43 \%)$ predominate.

To fix the general indicators, we analyse graphic presentations of motivation to success and motivation to avoid failure (Figure 6).

Thus, with the help of correlation of techniques by T. Ehlers on motivation to avoid failure and motivation to success, one can see the dominance of the average tendencies in two techniques.

Having applied the method of diagnostics of risk attitude by G. Schubert, the following results are obtained: 22 (73\%) of drug addicts show average readiness for risk, 8 (27\%) - high level, low level has not been detected ( Figure 7).

The study on the given method has demonstrated that average level of predisposition to risk has been found in 22 respondents. This suggests that the respondents in this study are inclined to risk only when it is strictly necessary. High level of predisposition to risk has been found in 8 respondents, which means the presence of risk in different situations, regardless of significance. Low level of predisposition to risk has not been detected.

For statistical calculation of technique on diagnostics of risk attitude by G. Schubert, we have used the method of testing the hypotheses on numerical values of parameters by comparing the dispersion of F-criterion (Fisher's criterion), where statistics have the form $[6, \mathrm{p} .210]$ :

Femp $=S_{1}^{2} / S_{2}^{2}$,

Where $S_{1}^{\frac{1}{2}}$ and $S_{2}{ }^{2}$ are dispersions

Sequence of analysis:

1. We issue the null and the alternative hypothesis:

$\mathrm{H}_{0}$ : the dispersions do not differ from each other;
$H_{1}:$ the dispersions differ from each other

2. Checking of assumptions: the distribution of the studied parameters is normal, linked sampling, the measurements are made on interval scale.

3. Selecting the statistical criterion. The situation corresponds to the model of two-sided F-criterion (Fisher's criterion): Femp $=S_{1}{ }^{2} / S_{2}{ }^{2}$.

4. The results of calculating the F-emp.The sample dispersions $S_{1}{ }^{2}=66.26, S_{2}{ }^{2}=31.69$. Hence the value of the empirical criterion is $66.26 / 31.69=2.09$.

5. Defining of critical value of criterion F. For two-sided model at the level of significance $a$, two critical values Fcr for points $(a / 2)$ and $(1-a / 2)$ of $F$-distribution with the number of degrees of freedom $d f_{1}$ and $d f_{2}$ are set.

For $a=0.05$ we get $F_{0,025}=2.98$ and $F_{0,975}=0.34$; for $a=0.01$ the critical values are $F_{0,005}=4.30$ and $F_{0,995}=0.23$.

6. Decision making. Since the value Femp=2.09 is not in any critical zone $(0.34<2.09<2.98)$, the null hypothesis $H_{0}$ is accepted.

Even at the significance level of 0.05 there is no reason to assert that dispersion values differ from one another. Thus, according to statistical calculations, the predisposition to risk does not differ.

\section{CONCLUSIONS}

Theoretical and methodological analysis of approaches to the study of psychological features of motivational sphere of drug addicts has shown that when using narcotic substance, the motivational sphere of an individual is deformed, all substructures of an individual change, that is, narcotic dependence leads to a number of psychological and personality changes of an individual, gradually destroying the motivational sphere of an individual and personality in general.

The data of statistical, quantitative and qualitative analysis has been obtained allowing concluding that the development of destructive motivation affects the inclination to using the narcotic substances.

Prospective directions of further scientific researches may be the issues of deepening of theoretical and experimental data on the issue under consideration. The development of corrective programme aimed at overcoming of pathological motivation towards the use of psychoactive substances, improving the motivational sphere of drug addicts is urgent.

\section{REFERENCES}

1. Aymedov, K.V. (2001). Doslidzhennya motyvatsiyi zlovzhyvannya psykhoaktyvnymy rechovyny [Research on the motivation of substance abuse].5Mizhnarodnyymedychnyykonhresstudentivimolodykhvchenykh [5th International Medical Congress of Students and Young Scientists]. Ternopil.

2. Blagov, L. N. (1994). Affektivnyy erasstroystva pri opiynoy narkomanii [Affective disorders in opiate addiction] (Unpublished Doctoral Dissertation). Ministry of Health. Russian State Scientific centre on Narcology, Moscow.

3. Rean, A.A. (2001). Praktychna psykhodiahnostyka osobystosti [Practical Psychodiagnostics of Personality]. St.Petersburg.

4. Fromm, E. (2006). Anatomiya lyudskoyi destruktyvnosti [Anatomy of Human Destruction]. Moscow: AST. 
5. Horban, A.Ye.,Milyutina, O.L., Kovtun, T.V., \&Voronovska, V.I. (1998). Novyy kompleksny ymetod terapiyi khvorykh opiynoyi narkomaniyeyu [A new comprehensive method of treatment for patients with opioid addiction]. Moscow.

6. Kochunas, R. (2005). Psykholohichne konsultuvannya. Hrupova psykhoterapiya [Psychological counseling. Group psychotherapy]. Moscow: Akademichnyy proekt; Haudeamus.

\section{Conflict of interest:}

The Author declare no conflict of interest.

\author{
CORRESPONDING AUTHOR \\ Ulyana B. Mykhaylyshyn \\ Department of Psychology, \\ State University «Uzhhorod National University», \\ 14 Universytetska St., 88000 Uzhhorod, Ukraine \\ tel: +380506991399 \\ e-mail:myb69@ukr.net
}

Received: 01.12.2018

Accepted: 31.01 .2019

\section{Międzynarodowa Konferencja Medical Science Pulse - Opole 23-24 maja 2019r.}

Tematyka VI Międzynarodowej Konferencji Medical Science Pulse koncentruje się na problematyce komercjalizacji prac badawczo-rozwojowych oraz innowacyjnych projektów w obszarze szeroko rozumianej opieki zdrowotnej, w tym aspektów prowadzenia badań i ich upowszechniania w środowisku gospodarczym, zagadnień prawnych oraz dotyczących własności intelektualnej. Program konferencji obejmuje: obrady plenarne z wykładami naukowymi zaproszonych gości, debatę naukową na bazie prezentowanych referatów, prezentacje projektów badawczych w ramach modułu Master Class (sesja plakatowa) oraz specjalistyczne warsztaty dla młodych naukowców i studentów. Niezwykle wysoki poziom merytoryczny, goście z Europy i USA, panele szkoleniowe, dyskusje i debaty - te cechy wyróżniają naszą Konferencję w skali krajowych propozycji.

Uczestnicy otrzymają certyfikaty wraz z punktami edukacyjnymi.

\section{MASTER CLASS ORAZ SESJA e-PLAKATOWA}

Zapraszamy do aktywnego udziału w VI Międzynarodowej Konferencji Medical Science Pulse i zaprezentowania swoich prac w ramach Master Class/Sesji e-Plakatowej. Ekspozycja e-plakatów przewidziana jest przez cały czas trwania Konferencji, omówienie zgłoszonych e-plakatów - w drugim dniu Konferencji. Autorzy pięciu najlepszych streszczeń zostaną zakwalifikowani do prezentacji

ustnej podczas Master Class (pierwszy dzień Konferencji), która będzie współprowadzona przez Wykładowców Konferencji. Streszczenia należy zgłaszać do 31 marca 2019 roku na adres: k.szwamel@interia.pl. Strona konferencji: http://e-event24.pl/6th_MSP_Conference/

\section{6th International Medical Science Pulse Conference - Opole - Poland, May 23-24, 2019}

The main themes of the 6th International Medical Science PulseConference are commercialization of research and development initiatives and innovativeness of projects in the broadly understood area of healthcare, including aspects of conducting research and its dissemination in the economic environment, legal issues and other matters related to intellectual property. The conference program includes: plenary sessions with lectures by invited speakers, academic debates on the presented speeches, presenting research projects within the framework of the Master Class module (poster session) as well as specialist seminars for young scientists and students. This high-level conference also features guests from Europe and the USA, training panels, discussions and debates - which distinguishes our conference from many other national meetings. Participants will receive certificates along with educational points.

\section{MASTER CLASS AND e-POSTER SESSION}

We cordially invite you to actively participate in 6th International MEDICAL SCIENCE PULSE Conference and present your work within the framework of a Master Class/e-Poster Session. The exhibition of e-posters is scheduled to take place throughout the Conference, and discussing of the submitted e-posters - on the second day of the Conference. Authors of the five best abstracts will qualify for an oral presentation during the Master Class Session (first day of the Conference), which is co-hosted by Conference Lecturers. Abstracts should be submitted by March 31, 2019 to the following address: k.szwamel@interia.pl. The conference website: http://e-event24.pl/6th_MSP_Conference/ 
PRACA ORYGINALNA

ORIGINAL ARTICLE

\title{
THE PECULIARITIES OF THE HEART RATE VARIABILITY AND ELECTROENCEPHALOGRAM CHANGES IN PATIENTS WITH EPILEPSY AND CARDIOVASCULAR PATHOLOGY
}

\section{CHARAKTERYSTYKA ZMIENNOŚCI RYTMU SERCA I ZMIAN W ELEKTROENCEFALOGRAMIE U PACJENTÓW Z PADACZKĄ I CHOROBĄ UKŁADU SERCOWO-NACZYNIOWEGO}

\author{
Tetiana Litovchenko ${ }^{1}$, Valeriia Grymailo ${ }^{2}$, Oksana Tondiy' ${ }^{1}$, Vartanush Florikian' ${ }^{1}$, Olena Zavalna ${ }^{1}$, Anna Voitiuk ${ }^{1}$ \\ 'DEPARTMENT OF NEUROLOGY AND CHILD NEUROLOGY, KHARKIV MEDICAL ACADEMY OF POST-GRADUATE EDUCATION, KHARKIV, UKRAINE \\ 2KHARKIV RAILWAY CLINICAL HOSPITAL №1 OF BRANCH OF «HC» JSC «UKRZALLZNYTSIA», KHARKIV, UKRAINE
}

\begin{abstract}
Introduction: Epidemiological studies have shown that the risk of myocardial infarction and stroke is significantly higher in patients with epilepsy compared with people not suffering from epilepsy.

The aim of the study was to study the parameters of HRV and EEG in patients with epilepsy to identify risk factors for cardiovascular pathology.

Materials and methods: We observed 50 patients with epilepsy without cardiovascular pathology (group 1) and 56 patients with epilepsy and cardiovascular pathology (group 2). All patients underwent clinical neurological examination, EEG, HRV and ECG assessment.

Results: There was a significant decrease in the HRV power in both groups of patients compared with general population data $(\mathrm{p}<0.02)$. Also in patients of the 2nd group, TP and the power of HRV in the LF, $\mathrm{HF}$ ranges were significantly decreased $(\mathrm{p}<0.001)$. Unstrained autonomic balance was detected in $40 \%$ in the 1 st group and in $6 \%$ of patients in the $2 n d$ group $(p<0.001)$. Each patient had as higher $L F / H F$ ratio as less time to next seizure left ( $r s=0.72 ; p<0.05)$. There was no correlation of the heart rate (ECG) and the time to the next seizure ( $r s=0.12 ; p<0.05$ ). A correlation of the LF / HF ratio with $\beta$ rhythm (EEG) was revealed for patients in both groups (for group 1: rs $=0.48$; for group 2: $r s=0.52 ; \mathrm{p}<0.02$ ). When evaluating HRV in both groups, depending on the taken AEDs, it was found that the average values of TP, VLF, LF, HF, SDNN were significantly lower in patients receiving carbamazepine when compared with patients receiving other AEDs $(p<0.001)$.

Conclusions: The factors of increased cardiovascular risk were: tense autonomic balance with a tendency to sympathicotonia, signs of a decrease in parasympathetic activity, a decrease in the TP, an increase in the representation of the EEG $\beta$-rhythm. The magnitude of the change in the frequency of the a rhythm in response to hyperventilation as well as the magnitude of the change in TP in orthostasis can serve as indicators of the adaptation reserve in patients with epilepsy. The development of an acute vascular event may increase the frequency of seizures and the presence of paroxysmal EEG phenomena. HRV is more informative to determine the oncoming of the seizure, than the routine ECG. Levetiracetam and lamotrigine have a more favorable effect on the autonomic balance of the heart than carbamazepine and valproic acid.
\end{abstract}

KEY WORDS: epilepsy, HRV, EEG, cardiac disorders

\section{INTRODUCTION}

Epidemiological studies have shown that the risk of myocardial infarction and stroke (both ischemic and hemorrhagic) in patients with epilepsy is higher than in people who are not suffering from epilepsy. Cleary et al. found that patients who develop epileptic seizures after 60 years have an increased risk of stroke $[1,2,3]$.

Another study presents data on increasing the risk of stroke in young patients with epilepsy, which according to the authors is because of both long-term course of epilepsy (seizures since childhood) and long-term use of AEDs. It has been shown that carbamazepine, phenytoin, phenobarbital and valproic acid can adversely affect risk factors for cardiovascular and cerebrovascular diseases [4].

The reason for the increased risk of cardiovascular and cerebrovascular diseases in patients with epilepsy is considered to be dyslipidemia, an increase in the thickness of the intima media complex, an increase in the level of markers of systemic inflammation and oxidative stress, homocysteine and a high level of C-reactive protein in blood plasma, which increases the activity of the blood coagulation system and the risk of atherosclerosis. The above changes according to the authors correlate with the duration of administration and dose taken AEDs (carbamazepine, valproates, phenobarbital). However, carbamazepine and valproic acid remain the 
most commonly used AEDs in most countries due to their effectiveness and availability $[2,4]$.

Several studies have been conducted on risk factors for vascular disease in patients with epilepsy. However, the effect of AEDs on patients with established cardiovascular diseases has not been studied, and no methods have been developed to detect diseases of the cardiovascular system at the preclinical stage in patients with epilepsy [5].

\section{THE AIM}

The aim of the work was to study changes in the parameters of HRV and EEG, as well as their correlation in patients with epilepsy and cardiovascular pathology in comparison with patients with epilepsy without cardiovascular pathology in order to identify cardiac risk factors in patients with epilepsy.

\section{MATERIALS AND METHODS}

One of the methods of early detection of imbalance in the cardiovascular system is to evaluate heart rate variability.

HRV parameters reflect the autonomic balance of the body and functional reserves of its management mechanisms. For the purpose of quantitative assessment of autonomic regulation of heart rhythm using the estimation of HRV indices [5,5].

Spectral analysis of HRV was used, which allowed to quantify the influence of various regulatory systems on the heart function in patients with epilepsy.

We observed the first group is the 50 patients suffering from epilepsy without cardiovascular pathology (CVP) at the age of 18-40 years and the second group is the 56 patients suffering from epilepsy and CVP at the age of 38-65 years. The number of patients of both sexes was comparable in each group. The disease's duration was on average of $9.7 \pm 0,58$ years in the 1 st group $15,3 \pm 0,72$ years in the 2st group. The duration of intake of AEDs has averaged $7.4 \pm 0,95$ years in the 1 st group and 11,32 $\pm 0,86$ years in the 2st group.

All patients underwent clinical and neurological examination, standard electrocardiographic examination (ECG), electroencephalographic examination (EEG), study of heart rate variability (HRV).

The obtained data were processed by methods of variation and correlation statistics using computer software. The probability of discrepancies was determined using Student's criterion $(\mathrm{t})$, and differences between the indicators, which have a distribution other than normal, were determined with the help of the Manna-Whitney test. The results were processed using Microsoft Excel 2010 (Microsoft Corporation) and Statistica 10.0 for Windows. Correlation analysis was performed by calculating the Spearman correlation coefficient $(r)$. Differences were considered statistically significant at $\mathrm{p} \leq 0.05$.

\section{RESULTS AND DISCUSSION}

All patients received AEDs monotherapy in a stable medium-therapeutic dosage: valproates from 10 to $20 \mathrm{mg} / \mathrm{kg} /$ day, carbamazepine from 10 to $20 \mathrm{mg} / \mathrm{kg} /$ day, lamotrigine from 1.5 to $3.5 \mathrm{mg} / \mathrm{kg} /$ day, levetiracetam from 12 to 20 $\mathrm{mg} / \mathrm{kg} /$ day.

Cardiac pathology in patients of the second group was represented by hypertension (HT) I, II, III stages are 29 (57\%) patients, coronary heart disease (CHD): stable angina stress II A, II B functional classes are $6(13 \%)$ patients, a combination of HT and CHD are $15(30 \%)$ patients.

It is known that low HRV rates may indicate a disturbance of autonomic control of cardiac activity. It is shown that in patients with heart failure, as well as those who have had myocardial infarction, there is a persistent decrease in HRV. Signs of increased tone sympathetic autonomic nervous system observed in patients with hypertension [7]. In addition, there was an increased risk of fatal arrhythmias in patients with signs of increased sympathetic or decreased parasympathetic activity. It is assumed that autonomic cardiac dysfunction is important in the development of SUDEP [8].

The studies in patients with epilepsy showed signs of parasympathetic insufficiency and a tendency to increase sympathetic activity $[9,10]$. In the calculation and analysis of the relation LF/HF signs of sympathicotonia ( $\mathrm{LF} / \mathrm{HF}$ greater than or equal to 3 ) was observed in 2 patients of the 1 st group and 3 patients of the 2 nd group. The difference between the groups is unreliable ( $p>0.05$ ), which forced to consider the power balance of the HRV spectrum in different ranges in more detail. It is known that the power ratio of the HRV spectrum in the range LF, HF, VLF reflects the autonomic balance of regulation of cardiac activity, which is considered to be unstrained if $\mathrm{HF}>\mathrm{VLF}>\mathrm{LF}$ (parasympathetic variant) or $\mathrm{LF}>\mathrm{HF}>\mathrm{VLF}$ (sympathicotonic variant) provided a sufficient value of TP (more than $2000 \mathrm{~ms}^{2}$ ). In persons under chronic stress, the autonomic balance in most cases looks like VLF $>\mathrm{LF}>\mathrm{HF}$ or $\mathrm{LF}>\mathrm{VLF}>\mathrm{HF}$, which reflects the activation of the sympathetic link of the VNS, the transition of the autonomic regulation to the suprasegmental level, i.e. excessive tension of adaptive mechanisms to ensure the activity of the body, its adaptation to changes in the conditions of functioning [11].

Intense autonomic balance was observed in $48 \%$ of patients of the 1 st group and in $56 \%$ of patients of the 2 nd group. The difference is again unreliable $(p>0.05)$. However, the unstrained balance was observed in $40 \%$ of patients of group 1 and only in $6 \%$ of patients of group $2(\mathrm{p}<0.001)$. In addition, the number of patients whose HRV power prevailed in the VLF range was significantly higher among patients of group 2 (70\% in the second group, $42 \%$ in group $1, \mathrm{p}<0.05)$. Patients of the first group, in which there was a predominance of the power spectrum of HRV in the VLF range, marked ECG changes (incomplete blockade feet beam Guisa, the reduction of repolarization, slowing intraventricular conduction and vnutriepreserdnaya, strengthening of potentials of the left ventricle) in contrast to patients, whose power spectrum was dominated in the range of $\mathrm{LF}$ and $\mathrm{HF}>\mathrm{HF}$.

There was a decrease in HRV output in patients with epilepsy $[12,13]$. When determining the HRV spectrum power, the examined patients showed a significant decrease in the total HRV power in both groups compared 
to the general population data $(\mathrm{p}<0.02)$. There were also significantly lower rates of TP in patients of the second group compared to the first $(\mathrm{p}<0.001)$. In addition, the significantly lower were indicators of the power spectrum of the HRV in the LF, HF range in the 2nd group $(p<0.001)$. A similar trend was observed for VLF, but the differences are not statistically significant $(\mathrm{p}>0.05)$ (Table 1).

Changing the total power of HRV during the orthostatic test displays the adaptive capacity of the body to meet changing needs during the change of mode of operation. The greater the difference, the greater the" adaptive reserve "of the organism [13]. The difference in TP at rest and in orthostasis was significantly higher on average in group 1 patients $(p<0.001)$. In addition, it is known that the transition from a horizontal to a vertical position in the normal $\mathrm{TP}$ is reduced mainly due to a decrease in parasympathetic activity. The increase in TP in the orthostatic test may indicate an overstrain of compensatory mechanisms for ensuring activity [12]. The number of patients whose TP decreased in orthostasis compared to rest was significantly higher in group 1 patients $(\mathrm{p}<0.05)$. And back - the number of participants whose TP was growing in orthostasis is higher for the patients of the 2nd group ( $\mathrm{p}<0.05)$.

It is considering that HRV changes could be a predictor of development of cardiovascular pathology and mortality from diseases of cardiovascular system [14], the obtained data demonstrate that patients with epilepsy have the increased risk of development of cardiovascular diseases owing to autonomic cardiac dysfunction. HRV can be applied to assessment of risk of development of cardiovascular pathology in patients with epilepsy.

It was noted that the closer the next seizure, the greater the ratio of LF/HF in patients of both groups (1-st groop $\mathrm{rs}=-0,37 ; \mathrm{p}<0,05 ; 2$-nd groop $\mathrm{rs}=-0,43 ; \mathrm{p}<0,05)$, which did not correlate $(1$-st groop $r s=0.15 ; 2$-nd groop $r s=0.17)$ with the change in the mean heart rate (according to ECG), possibly due to the short period of routine ECG recording (Fig.1). Thus, HRV is more informative for determining the seizure oncoming than a routine ECG.

When evaluated HRV in both groups, depending on the taken AEDs, it was found that the average values of TP, VLF, LF, HF, SDNN were significantly lower in patients receiving carbamazepine when compared with patients receiving other AEDs $(p<0.001)$. It was also noted that the power in the HF range in group 1 patients was comparable in patients receiving carbamazepine and valproates, but this index was significantly higher in patients receiving lamotrigine and levetiracetam $(\mathrm{p}<0.02)$. A similar trend was observed in patients of the second group, but the differences were unreliable ( $p>0.05$ ), probably due to a larger number of $p a-$ tients with intense autonomic balance among patients of the second group. Given that the decrease in parasympathetic activity is one of the predictors of cardiovascular disease, it can be assumed that levetiracetam and lamotrigine have a more favorable effect on the autonomic balance of the heart.

In addition, among the patients of the second group, there was a subgroup of patients with epilepsy who had experienced an acute vascular event (AVE), which, however, was not the cause of epilepsy (23 patients). These patients were compared with other patients of the 2 nd group (33 patients) for the same period of time. The appearance of paroxysmal EEG phenomena was observed in 10 (44\%) patients from those who had experienced AVE and in 3 (9\%) patients without AVE ( $\mathrm{p}<0.05)$. Generalization of paroxysmal activity in patients with focal paroxysmal activity and an increase in its amplitude was observed in $11(48 \%)$ patients from those who had AVE and $5(15 \%)$ patients without AVE $(\mathrm{p}<0.05)$. Also among the patients of this subgroup, an increase in the frequency of epileptic seizures after AVE was observed: the average frequency of seizures in the subgroup before AVE was $4.6 \pm 0.33$ per month; after AVE - $8.2 \pm 0.87$ per month $(\mathrm{p}<0.05)$.

We also studied the relationship of cardiovascular and nervous systems in the first and second groups according to HRV, ECG and EEG. It was found that the heart rate is inversely proportional to the total power of $\mathrm{HRV}$ (TR) $(\mathrm{rs}=-0,65 ; \mathrm{p}<0,02)$. This can be explained by the fact that the main contribution to heart rate variability is made by the parasympathetic component, and an increase in parasympathetic tone leads to a decrease in heart rate. It was also noted that TR is directly proportional to SDNN, probably due to the fact that SDNN is one of the main indicators of parasympathetic activity. Interestingly, the value of SDNN in turn correlated with the frequency of rhythm $\alpha$ in hyperventilation ( $r s=0.58 ; \mathrm{p}<0.001)$ and was significantly lower in patients of the second group $(p<0.001)$. In addition, there was a correlation between the ratio of LF/ $\mathrm{HF}$ and the representation of $\beta \mathrm{EEG}$ rhythm in patients of both groups (for group 1: $r s=0.48$; for group 2 : $r s=0.52 ; p<0.02$ ).

The value of rhythm a frequency change in response to hyperventilation within 2 minutes was significantly less in patients of the second group $(\mathrm{p}<0.02)$. This can be explained by a decrease in the elasticity of the vascular wall, in particular arterioles, brain, their rigidity in patients of the second group. In addition, the value of rhythm a frequency change in response to hyperventilation correlated with the value of TP change in orthostasis compared to rest ( $\mathrm{rs}=$ $0.43 ; \mathrm{p}<0.02$ ). Thus, both of these parameters can serve as indicators of adaptive reserve in patients with epilepsy (the value of the change in the frequency of rhythm $\alpha$ in response to hyperventilation, the value of TP changes in orthostasis compared to rest).

Despite the fact that the most used antiepileptic drugs such as carbamazepine and valproic acid have normotymic properties, in a large number of patients with epilepsy revealed a tense autonomic balance with a tendency to sympathicotony, which is not only a predictor of cardiac disorders, but can also contribute to the development of seizures and even be one of the factors of evaluation of the patient with epilepsy without seizures to continue antiepileptic therapy. Despite the fact that the number of patients with tense autonomic balance did not differ significantly in both groups, the unstrained balance was observed only in some patients of the second group (6\%), unlike the first, which may indicate that cardiovascular disease also violates the autonomic regulation of cardiac activity.

Patients with epilepsy who have a tense autonomic 
balance with a tendency to sympathicotony may have an increased risk of developing cardiac pathology, although the effect of cardiovascular disease on the course of epilepsy remains a debatable issue. In such patients, it may be appropriate to use additional methods of correction of autonomic disorders, such as physical therapy, reducing stress - psychological support, the inclusion in therapy of drugs with vegetostabilizing properties.

\section{CONCLUSIONS}

1. The factors of increased cardiovascular risk were: tense autonomic balance with a tendency to sympathicotonia, signs of a decrease in parasympathetic activity, a decrease in the TP, an increase in the representation of the EEG $\beta$-rhythm. The magnitude of the change in the frequency of the a rhythm in response to hyperventilation as well as the magnitude of the change in TP in orthostasis can serve as indicators of the adaptation reserve in patients with epilepsy.

2. The development of an acute vascular event may increase the frequency of seizures and the presence of paroxysmal EEG phenomena

3. Levetiracetam and lamotrigine have a more favorable effect on the autonomic balance of the heart than carbamazepine and valproic acid.

4. HRV, namely the increase in the ratio of LH/HF is more informative to determine the oncoming seizure than the routine ECG.

\section{REFERENCES}

1. Katherine S. Eggleston, Bryan D. Olin, Robert S. Fisher. Ictal tachycardia: The head-heart connection. Seizure - European Journal of Epilepsy Volume 23, Issue 7, Pages 496-505, August 2014

2. Fatar M, Akin I, Borggrefe M, Platten M, Alonso A. Interaction between heart and brain in sudden cardiac death. Herz. 2017 Apr;42(2):171-175. doi: 10.1007/s00059-017-4547-4.

3. Chang CS, Liao CH, Lin CC, Lane HY, Sung FC, Kao CH. Patients with epilepsy are at an increased risk of subsequent stroke: A populationbased cohort study. Seizure. 2014 May; 23(5):377-81. PMID: 24630806. DOI: 10.1016/j.seizure.2014.02.007
4. Park KJ, Sharma G, Kennedy JD, Seyal M. Potentially high-risk cardiac arrhythmias with focal to bilateral tonic-clonic seizures and generalized tonicclonicseizures are associated with the duration of periictal hypoxemia. Epilepsia. 2017 Dec;58(12):2164-2171. doi: 10.1111/epi.13934. Epub 2017 Nov 3

5. Baysal-Kirac L, Serbest NG, Şahin E et al. Analysis of heart rate variability and risk factors for SUDEP in patients with drug-resistant epilepsy. Epilepsy Behav. 2017 Jun;71(Pt A):60-64. doi: 10.1016/j. yebeh.2017.04.018. Epub 2017 May 23.

6. Cygankiewicz I1, Zareba W. Heart rate variability. Handb Clin Neurol. 2013;117:379-93. doi: 10.1016/B978-0-444-53491-0.00031-6.

7. Ryvlin P, Nashef L, Lhatoo SD, Bateman LM, Bird J, Bleasel A, et al. Incidence and mechanisms of cardiorespiratory arrests in epilepsy monitoring units (MORTEMUS): a retrospective study. The Lancet Neurology. 2013 0ct; 12(10): 966-77. PMID: 24012372. DOI: 10.1016/ S1474-4422(13)70214-X

8. MyersKA, Bello-EspinosaLE,Symonds JD etall. Heartratevariabilityin epilepsy: A potential biomarker of sudden unexpected death in epilepsy risk. Epilepsia. 2018 Jul;59(7):1372-1380. doi: 10.1111/epi.14438. Epub 2018 Jun 6.

9. Mańka-Gaca I, Łabuz-Roszak B, Machowska-Majchrzak A, Kalarus Z, Średniawa B, Pierzchała K. Interictal heart rate in patients with epilepsy. Wiad Lek. 2016; 69(3 pt 2): 443-8. PMID: 28478403

10. Billeci L, Marino D, Insana L, Vatti G, Varanini M. Patient-specific seizure prediction based on heartratevariability and recurrence quantification analysis. PLoSOne. 2018Sep 25;13(9):e0204339. doi: 10.1371/journal.pone.0204339.

11. Behbahani S. A review of significant research on epileptic seizure detection and prediction using heart rate variability. Turk Kardiyol Dern Ars. 2018 Jul;46(5):414-421. doi: 10.5543/tkda.2018.64928.

12. Mańka-Gaca I, Łabuz-Roszak B, Machowska-Majchrzak A. Interictal heart rate in patients with epilepsy. Wiad Lek. 2016;69(3 pt 2):443-448.

13. Galli A, Lombardi $F$ Heart rate variability regression and risk of sudden unexpected death in epilepsy. Med Hypotheses. 2017 Feb;99:49-52. doi: 10.1016/j.mehy.2016.11.016. Epub 2016 Nov 25

14. MoridaniMK, FarhadiH. Heartratevariability as abiomarkerfor epilepsyseizure prediction. Bratisl Lek Listy. 2017;118(1):3-8. doi: 10.4149/BLL_2017_001.

\section{Authors' contributions:}

According to the order of the Authorship.

\section{Conflict of interest:}

The Authors declare no conflict of interest.

\section{CORRESPONDING AUTHOR Valeriia Grymailo}

5 Balakirev lane, 61103 Kharkiv, Ukraine

tel: +380637160022

e-mail: lelia.grim@gmail.com

Received: 15.09 .2018

Accepted: 10.01.2019 
PRACA ORYGINALNA

ORIGINAL ARTICLE

\title{
MODERN MODEL OF GENETIC MONITORING AS A PROMISING TOOL FOR REDUCING INCIDENCE OF GENETIC PATHOLOGIES IN UKRAINE
}

\author{
NOWOCZESNY MODEL MONITORINGU GENETYCZNEGO JAKO \\ OBIECUJĄCE NARZĘDZIE REDUKCJI WYSTĘPOWANIA WAD \\ GENETYCZNYCH NA UKRAINIE
}

\author{
Dmytro 0. Mykytenko ${ }^{1,2}$, Tetiana S. Gruzieva ${ }^{1}$ \\ 'BOGOMOLETS NATIONAL MEDICAL UNIVERSITY, KYIV, UKRAINE \\ ${ }^{2}$ CLINIC OF REPRODUCTIVE MEDICINE «NADIYA», KYIV, UKRAINE
}

\begin{abstract}
Introduction: The medical and social substantiation of an optimized system of genetic monitoring in Ukraine for providing of quality medical care with economic substantiation should be developed for quality medical care and justification of budget expenditures and the economic evaluation of the effectiveness of treatment and prevention measures. The aim is to develop a modern model for the genetic monitoring and provide substantiation of the measures for the prevention of hereditary transmission of genetic defects and birth of children with congenital defects.

Materials and methods: The following research methods have been employed: systematic approach and analysis technique; bibliographic and semantic method; method of conceptual modeling.

Conclusions: The model of genetic monitoring with the modern concepts of healthcare reform in Ukraine has been developed taking into account the priorities of the state health policy, modern internationally recognized and recommended by WHO.
\end{abstract}

KEY WORDS: genetic monitoring, model, genetic pathologies, genetic load

\section{INTRODUCTION}

Prolonged period of unfavorable socio-economic and political climate in Ukraine, stagnation of economy and deterioration of environment resulted in the exacerbation of the country's demographic crisis and aggravation of the general situation in healthcare system. Although WHO data indicate a weak tendency towards the stabilization of the situation over the last years (crude mortality rate fell from 16.66 per 1000 persons in 2005 to 14.76 in 2014, total fertility rate increased from 1.1 in 2001 to 1.5 in 2013, life expectancy at birth grew from 67.3 in 2005 to 71.44 in 2014), mid-year population is still decreasing at a rate of $0.7 \pm 0.3 \%$ year starting from 1994 , the number of born living, that increased between 2001 and 2008 from 7.71 to 11.8 per 1000 persons, is nearly stable, the share of over-65 population demonstrates intermittent growth from $11.3 \%$ in 1986 to $15.47 \%$ in 2014 [1]. These data give no promise that a demographic problem could be solved in mid-term perspective.

Also, a slight intermittent tendency to the increase in the number of children with birth defects, from 22.21 in 2004 to 23.16 in 2013 per 1000 liveborn children, along with reduced probability of dying in the first five years of life from 21.83 in 1981 to 9.46 in 2014 per 1000 liveborn children (2.3-fold), and reduction in infant death from 16.23 in 1981 to 7.85 in 2014 per 1000 liveborn children (2.07-fold) [1] are indicative of the following: a) improved quality of medical care and provision of a chance at survival for those children who would have not had this chance otherwise; $b$ ) withdrawal of a number of pathological conditions from the influence of natural selection, which will promote the gradual accumulation of the relevant pathologies and necessitates the introduction of an effective system of genetically-predisposed pathologies monitoring in order to counteract further increase in genetic load. Infertility is one of the manifestations of genetic load, since diseases with a genetic component are characterized by impaired fertility and increased risk of birth defects [2]. According to WHO, the share of sterile marriages is $15-20 \%$.

Thus, there is an urgent need in the introduction of an effective genetic pathologies monitoring system in order to prevent further increase of genetic load in Ukraine. However, in view of the permanent reforming of the healthcare system, the latest vectors of which have been approved by the law of Ukraine "On State Financial Guarantees of Public Health Care" dated 19.10.2017, and set-aside resolution of the issues related to thefinancing of secondary and tertiary levels of medical care, it is extremely important to develop the model that could be integrated into the healthcare system at any stage of its reforming. 


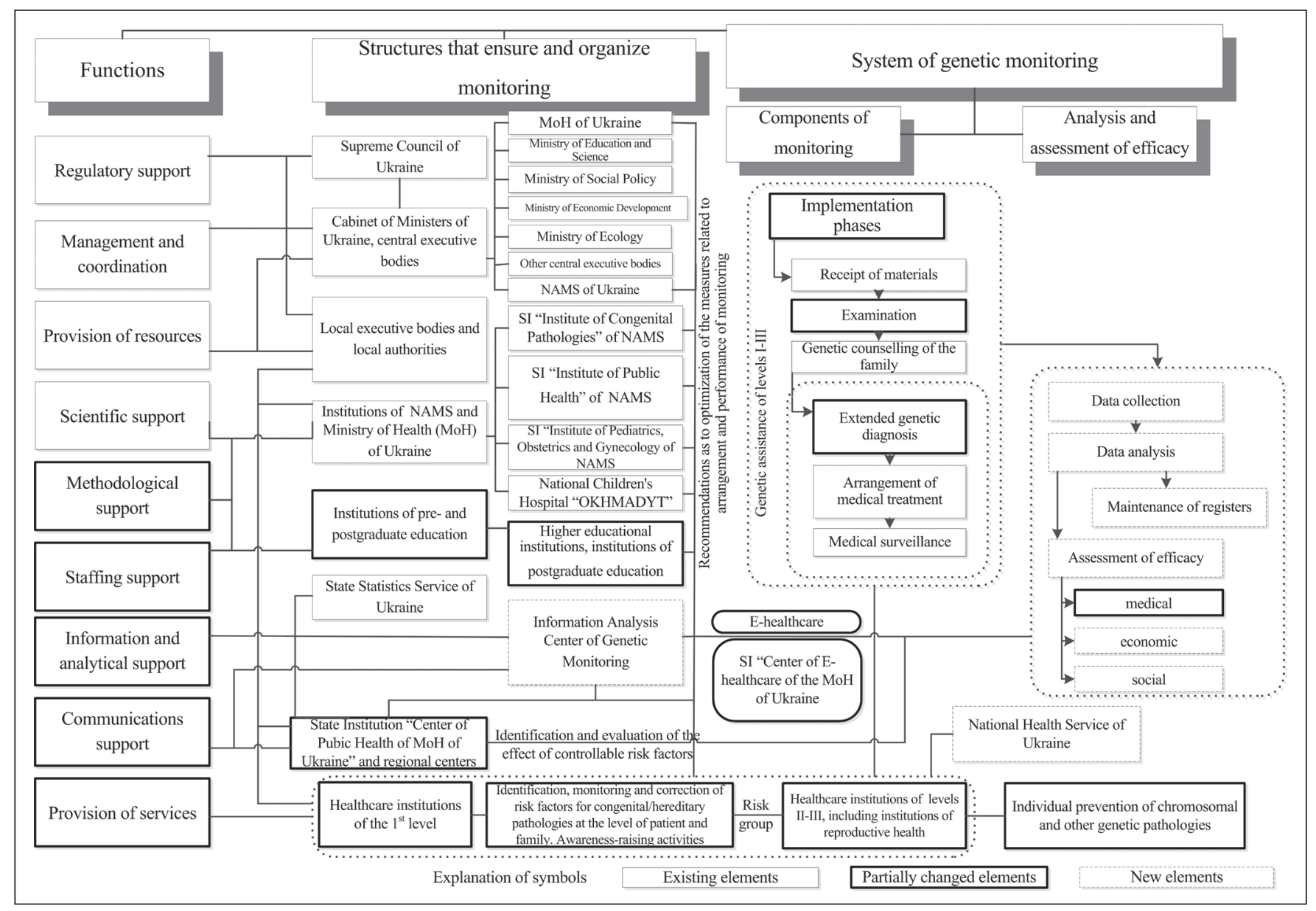

Fig. 1. Modern structural and functional model of genetic monitoring system in Ukraine

\section{THE AIM}

The objective of this research is to develop a modern model for the monitoring of genetic pathologies and provide scientific substantiation of the measures aimed at prevention of hereditary transmission of genetic defects and birth of children with congenital defects.

\section{MATERIALS AND METHODS}

Data from scientific literature and statistical reports by WHO have been used as information basis for this research.

The following research methods have been employed:

- systematic approach and analysis technique was used at all stages of research in order to address specified tasks;

- bibliographic and semantic method was used to study and analyze data from scientific literature with regard to the problem under investigation;

- method of conceptual modeling was employed to develop the model of genetic monitoring system.

\section{RESULTS AND DISCUSSION}

It has been established that the rate of congenital malformations in Ukraine exceeds the average rate seen in Europe, which is characteristic of the countries with low living standards. Since the in- fertility and congenital abnormalities have multifactorial etiology, their control should focus on the internal (genetic predisposition) and external controllable factors [3,4]. To achieve a productive goal, the provisions of Art. 29 of the Law of Ukraine "Fundamentals of Healthcare Legislation of Ukraine" on the organization of the genetic monitoring should be fulfilled. However, as seen from the analysis of legal frameworks and the current state of medical genetic service, there are problems in the provision of genetic counseling services (GCS) to the population of Ukraine. Given the urgency of the issues of genetically-predetermined pathologies control, rising incidence of such conditions, problems associated with regulatory support and provision of resources for medical genetic service, and the need for improvement of its operation, the optimized system of genetic monitoring and its functional and structural model have been substantiated (Fig. 1,2).

Priorities of the state health policy, current internationally recognized and recommended by WHO strategies of genetic monitoring, and existing problems and needs identified in the previous research have been used as a basis for the formation of optimized model of genetic monitoring $[5 ; 6]$.

It has been determined that optimized genetic monitoring system aims at prevention, timely identification and correction of genetically predetermined pathologies, provision of high quality and accessible GCS, reduction of genetic load, and prevention of resulting medical, social and economic losses. 


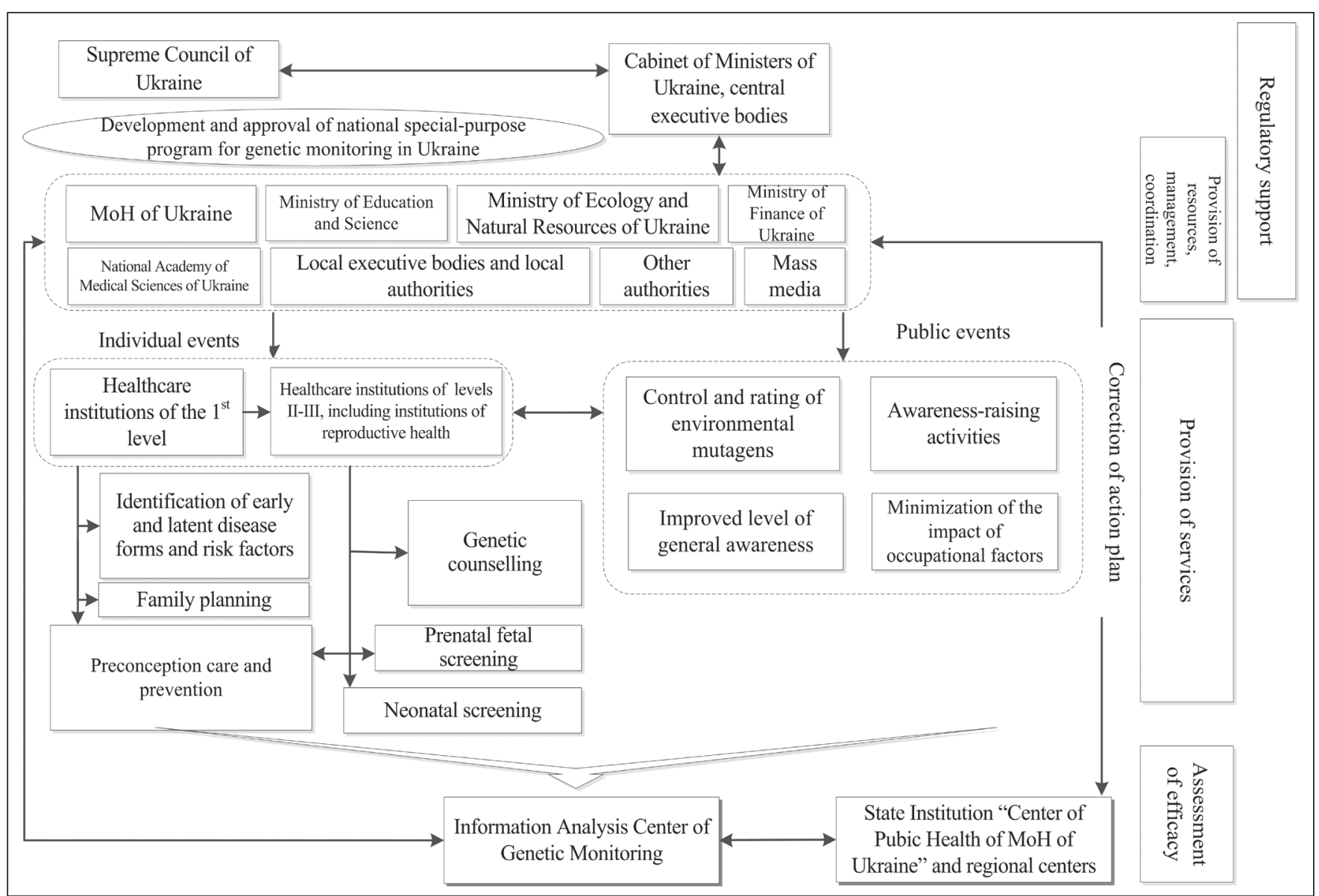

Fig. 2. Conceptual diagram of comprehensive interagency system of prevention of chromosomal and other genetic pathologies in the population

Planning and monitoring of chromosomal and other genetic pathologies, analysis of data obtained from research and surveys, management decisions, provision of services, assurance and assessment of their availability and quality, evaluation of medical, social and economic efficiency are considered to be the main areas of activity of genetic monitoring system.

The proposed model consists of numerous structural components and their inherent functions, including organizational and managerial, coordination, scientific, educational, methodological, communicative, research and information, regulatory and resource support. Each structural component is responsible for the implementation of the functions established under the system of genetic monitoring, with extensive cross- and intra-sectoral relations.

This model includes institutions and organizations involved in the performance of genetic monitoring, their functions, components of the system of provision and organization of work; it establishes the stages for monitoring of genetic disorders and introduces a new analytical framework in charge of the collection, processing and analysis of information, evaluation of performance indicators and development of recommendations aimed at improvement of genetic pathologies prevention.

The feature of this model is that it includes existing elements of genetic counseling system, partially modified elements and qualitatively new ones. (Fig. 3).
The existing elements incorporated in the developed model without changes of their functions include those in charge of regulatory, resource and scientific support, management and coordination, in particular the Supreme Council of Ukraine, Cabinet of Ministers of Ukraine, central executive bodies, the main of which are $\mathrm{MoH}$ of Ukraine, Ministry of Education and Science of Ukraine, Ministry of Social Policy of Ukraine, Ministry of Economic Development and Trade of Ukraine, Ministry of Ecology and Natural Resources of Ukraine, State Statistics Service of Ukraine and local executive bodies and local authorities. The function of scientific support is performed by the institutions and organizations of the $\mathrm{MoH}$ and NAMS of Ukraine with such relevant agencies as the State Institution "Institute of Congenital Pathologies" of NAMS of Ukraine and State Institution "O. M. Marzeiev Institute of Public Health" of NAMS of Ukraine; the function of communications support is performed by relevant institutions and mass media.

A qualitatively new element to be implemented is Information Analysis Center of Genetic Monitoring which establishment under the MoH of Ukraine is deemed appropriate. The main tasks of the Center should be the collection, processing, analysis of data obtained during the genetic monitoring, followed by assessment of the main criteria of its effectiveness: indicators of medical, economic and social efficiency. According to the WHO concept, three groups of indicators are used to characterize the quality of medical care: indicators of structure, process and final results of provided care. 


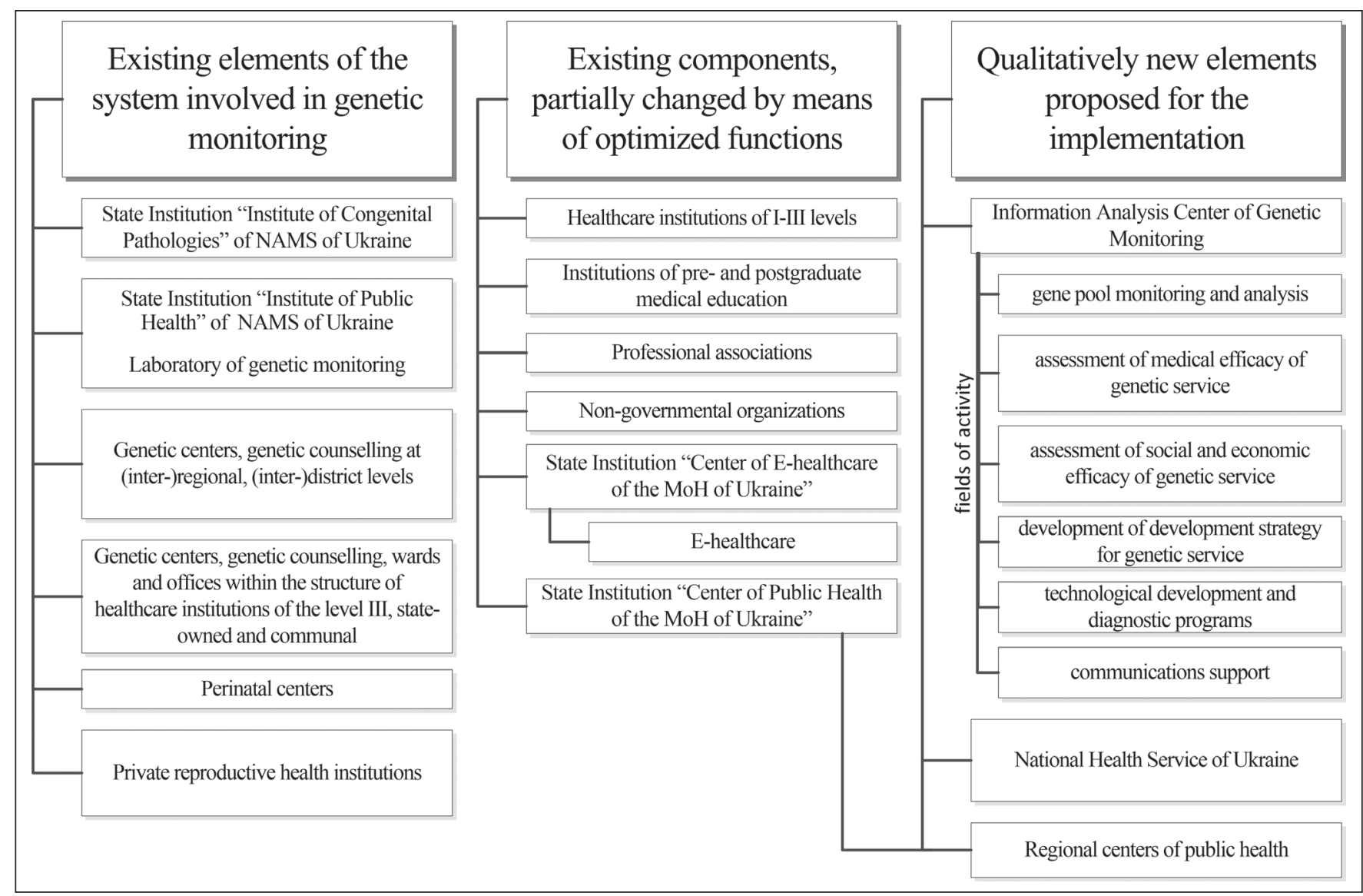

Fig. 3. Main elements of implementation of modern model of genetic monitoring system

The clinical efficacy of the monitoring of genetic disorders will involve the reduction in reproductive losses and child mortality, improved diagnosis, modification of the structure of congenital pathologies in newborns in favor of less-disabling diseases.

Social efficiency can be estimated by the reduced share of genetic diseases in the disability causes and reduced overall level of childhood disability, increased satisfaction of the population with the quality of medical care.

In contrast to the existing system of genetic monitoring, the new model involves assessment of the economic efficacy of the measures taken. According to the calculations made in the study, the medical outcome of the previous 5-year genetic monitoring program that took place in Kyiv was $8.1 \%$ reduction of reproductive losses among registered pregnancies. The economic efficacy forecast for the implementation of genetic monitoring program at the national level has been calculated using the extrapolation method. Based on the previously calculated reproductive fetal losses and economic equivalent of the cost of living (in the form of profit of the state budget resulting from person's activities) $[2 ; 7 ; 8 ; 9]$, the expected reduction in the number of reproductive losses with the implementation of genetic monitoring program has been evaluated as $3477.2 \pm 160.5$ cases per year, the cumulative profit of the state budget - UAH 21603.2 \pm 997.1 million or USD $1716.4 \pm 79.2$ million, taking into account the purchasing parity.
Optimization of other components of the model is logically related to the organization of a new information analysis link and modification of methodical approaches to neonatal screening. Introduction of such changes requires improved system of provision of resources for genetic monitoring. Firstly, proper staffing and improvement of pre- and postgraduate training of specialists in population genetics, public health, laboratory diagnostics, professional topic-specific development of physicians of healthcare institutions of I-II levels, primarily general practitioners-family physicians, obstetricians-gynecologists and pediatricians.

To ensure the functioning of the information analysis center, scientific and methodological support of its operation within the organizational hierarchy should be provided. The best is to put the feedback and efficacy assessment unit under the control of the Ministry of Health are of Ukraine in order to receive, process, save and analyze the reporting information of health departments of local authorities and bodies of local self government developed on the basis of reports of healthcare institutions. This unit should be responsible for the evaluation of medical, social and economic efficacy of the measures that have been taken and involves the use of modern information and application systems. Analytical results will serve as the basis for improvement of the structure, organization, provision of resources for the process of genetic disorders monitoring. 
According to the proposed model of genetic monitoring system, the major role in the identification of risk factors of genetic pathologies in patients (as per art. 2.2 of the Guidelines on the organization of provision of medical and genetic assistance, approved by the Order of the $\mathrm{MoH}$ of Ukraine dated 31.12.2003 No. 641/84) is assigned to the primary care physicians of "first medical contact" (general practitioners-family physicians, pediatricians, primary care doctors, obstetrician-gynecologists) that subsequently refer patients to medico genetic institutions of respective region. The above requires modification of occupational characteristics of positions in the corresponding specialties. The programs of individual prevention of hereditary transmission of genetic abnormalities should be developed with the involvement of experts in reproductive genetics, obstetricians-gynecologists, taking into account the possibilities of preimplantation and prenatal diagnosis. The prophylaxis of chromosomal and other genetic pathologies at the level of population should be performed on the basis of interagency interaction and under coordination of information analysis center of genetic monitoring.

Thus, the proposed model of genetic monitoring, unlike the existing one, is based on the cross-sectoral approach, includes modern information analysis center with wide range of functions, including evaluation of medical, social and economic efficacy of the measures taken with due consideration to the opinions of service providers and users, powerful system of e-healthcare on the basis of eHealth, involves the cooperation with the State Institution "Center of Public Health of the MoH of Ukraine", its regional branches, local executive bodies and local authorities, training of specialists in public health and population genetics, expansion of preventive functions of primary healthcare institutions with regard to initial genetic counseling, enhancement of communication relations and has a clear focus on prevention.

Improvement of genetic pathologies prevention as a strategic direction of healthcare activities will give the opportunity to reduce the load of genetic diseases and decrease significant costs incurred by the citizens and the state as a whole, achieve improvement of public health and sustainable use of resources under the conditions of competing priorities. The outlined goals are extremely important as the healthcare faces numerous challenges and threats and is subject to significant resource constraints. Under such conditions, the prevention of genetic pathologies is not only a social but also an economic necessity, and requires strict state and public control.

Based on the research findings, the following priority measures aimed at improvement of genetic monitoring have been identified, which need to be implemented within the framework of the proposed functional and structural model:

- extension of the list of conditions that are subject to additional reporting and analysis within genetic monitoring in order to assess the state of the population's gene pool, along with registration of cases of primary sterility, spon- taneous abortions (especially during the first trimester of gestation, when the share of lethal mutations, primary genomic and chromosomal, is over 50\%), perinatal death, multiple pregnancies, birth of children with congenital abnormalities, and evaluation of the weight and growth of newborns and their sex distribution;

- establishment of national registers of reproductive losses, congenital and hereditary pathologies, infertile couples and results of screening of germ cells donors for the genetic pathologies;

- extension of genetic monitoring to include pregnant women, newborns, adolescents $\leq 17$ years of age;

- supplementing the screening programs for pregnant women at high risk with tests for chromosomal abnormalities and fetal malformations by introducing reimbursement of expenses associated with the performance of non-invasive tests for chromosomal abnormalities of the fetus using the blood of pregnant woman and invasive types of genetic diagnosis;

- establishment of the system for reimbursement of the costs associated with embryos PGD to the carriers of genetic pathologies, which proved to be effective for the individual prevention of the inheritance of genetic mutations (genomic, chromosomal, gene);

- vesting of primary healthcare centers' physicians (general practitioners-family physicians, obstetricians-gynecologists, pediatricians, and primary care doctors) with the functions of identification of risk factors and possible manifestations of chromosomal or other genetic pathologies;

- transition from neonatal screening methods based on immuno-fluorescence analysis for 4 diseases to the methods of mass spectrometry covering over 30 medical conditions and characterized by lower cost of examination; - enhancement of the preventive focus of genetic monitoring measures and provision of medical and genetic services, implementation of the preventive health promotion strategy of the WHO, which envisages modification of people's physical activity, dietary habits, restriction of influence and prevention of negative effects of external factors in the development of multifactorial pathologies, enabling some individuals and communities to control the factors that shape the health;

- development of legal framework of healthcare system and settlement of issues of genetic monitoring application in the context of government reform and enhancement of local administrations;

- improvement of training degree of physicians in medical genetics, provision of access to scientific electronic databases and information resources;

- creation of common medical and information area, formation of e-health system, which will expand the opportunities for the establishment of proposed registers. The development and implementation of the special-purpose state medical and social genetic monitoring program in Ukraine for 2019-2023 is an important component of improving the provision of genetic counseling services to the population. 


\section{CONCLUSIONS}

This research addresses a very important applied research task concerned with substantiation of improvement of genetic pathologies prevention by implementation of modern functional and structural model of genetic monitoring system in Ukraine in the context of socio-economic transformations and resource constraints. The model, unlike the existing one, is based on the cross-sectoral approach, includes modern information analysis center with wide range of functions, including evaluation of medical, social and economic efficacy with due consideration to the opinions of service providers and users, powerful system of e-healthcare on the basis of eHealth, involves the cooperation with the State Institution "Center of Public Health of the MoH of Ukraine", its regional branches, local executive bodies and local authorities, training of specialists in public health and population genetics, expansion of preventive functions of primary healthcare institutions with regard to initial genetic counseling, enhancement of communication relations and has a clear focus on prevention. Implementation of genetic monitoring program has potential medical effect amounting to $3477.2 \pm 160.5$ prevented cases of reproductive losses, and economic effect of UAH 21603.2 \pm 997.1 million or USD 1716.4 \pm 79.2 million of state budget profit per 1 year of implementation as a national special-purpose program.

A set of actions aimed at improvement of genetic pathologies prevention has been developed, including the measures at the national, sectoral and regional levels to be implemented by the scientific institutions of the National Academy of Medical Sciences of Ukraine, institutions of pre- and postgraduate education of the MoH of Ukraine and Ministry of Education and Science of Ukraine, practical healthcare institutions, in particular, extension of the list of genetic conditions that are subject to reporting, application of genetic monitoring to adolescents $\leq 17$ years of age, reimbursement of the costs associated with genetic testing for some categories of patients within the framework of the system of compulsory (state) social health insurance, modification of the approaches to neonatal screening, improved involvement and degree of training for physicians of primary care setting, and etc.

\section{REFERENCES}

1. European Health Information Gateway "Health for All". 2014. http:// data.euro.who.int/hfadb/shell_ru.html.

2. Mykytenko D0, Pylyp LYa, Lynchak OV et al. Genetic Load in the Population of Ukraine: Reproductive Losses. Current problems of obstetrics and gynecology, clinical immunology and medical genetics. 2012; 24: 472-487.

3. Global action plan for the prevention and control of noncommunicable diseases 2013-2020. WHO. Geneva, Switzerland. 2013. p. 55.

4. Gruzieva TS, DufynetcVA. Prevention of Non-communicable Deseases sa Public Health Priority in Ukraine. Cyril-Methodius Days of Social Services: proceedings of the international expert - scientific conference. Trnava, Slovakia, 05-06.02.2015. Budapest, Hungary: HERALDIKA KIADÓ. 2015. p. 260-274.

5. Mykytenko D. 0. Optimization of the organizational structure of the system for genetic pathologies monitoring as guarantee of population's reproductive health preservation. Ukraine: Health of Nation. 2017;1(42): 75-82.
6. Mykytenko D. O. Substantiation of ways to improve provision of genetic counselling services to the population based on sociological surveys . Ukraine: Health of Nation. 2017;2(43): 67-74.

7. Mykytenko D0, Lynchak OV, Tymchenko OI. Genetic Load in the Populations of Ukraine: congenital and hereditary pathology. Woman's Health: Journal of Research and Practice. 2012,10(76):17-21.

8. Mykytenko D0, Tymchenko Ol, Lynchak OV. Genetically Dependent Reproductive Losses: economic aspect. Hygiene of populated places. 2012,60:342-346.

9. Tymchenko Ol, Lynchak OV, Protsiuk OV et al. Gene pool and health: natural and artificial selection in the population of Ukraine. Kyiv, State Institution "0.M. Marzeiev Institute of Hygiene and Medical Ecology NAMSU", Medinform»; 2015, p. 163.

The scientific work was carried out within the framework of scientific research projects of the SI "Institute of Hygiene and Medical Ecology named after A. M. Marseev, NAMS of Ukraine" and State Program "Health of the Nation". Themes of projects: "Estimation of the possible impact of habitat on radioactive contaminated and "clean" territories on the state of the population gene pool” (ДП 20.10, № 0110U001465), 'Influence of selection processes on population reproduction in Ukraine’ (AMH.Ф.07.12, № 0112U001052). Theme of project of SI "National Scientific Center for Radiation Medicine, NAMS of Ukraine": "Investigation of the factors of female and male infertility in the remote period after the accident at the Chernobyl Nuclear Power Plant" (510, № 0111U000755). Theme of project of International Scientific and Technical University named after academician Yuriy Bugay: "Formation, increase and rational use of strategic potential of Ukraine” (№0111U009268).

\section{Authors' contributions:}

According to the order of the Authorship.

\section{Conflict of interest:}

The Authors declare no conflict of interest.

\section{CORRESPONDING AUTHOR Dmytro Mykytenko}

Clinic of reproductive medicine NADIYA

Maksyma Kryvonosa str. 19a, office 220

Kyiv 03037, Ukraine

tel:+380445922178

e-mail: mikitenko@ukr.net

Received: 18.09 .2018

Accepted: 05.01.2019 
PRACA ORYGINALNA

ORIGINAL ARTICLE

\title{
INFLUENCE OF THE TRANSFERRED SYPHILITIC INFECTION ON THE COURSE OF PREGNANCY, CHILDBIRTH AND THE STATE OF NEWBORNS
}

\author{
WP.tYW PRZENOSZONEJ DROGĄ PŁCIOWĄ INFEKCJI KIŁĄ NA \\ PRZEBIEG CIAZŻY, PORODU ORAZ STAN OGÓLNY NOWORODKÓW
}

\author{
Viacheslav M. Husiev, Daria S. Khapchenkova \\ DONETSK NATIONAL MEDICAL UNIVERSITY, LIMAN, UKRAINE
}

\begin{abstract}
Introduction: The article presents information about the peculiarities of the course of pregnancy and childbirth in women with a syphilitic infection in the anamnesis. The peculiarities of the state of newborn babies born from mothers who have suffered syphilis are described. To date, the incidence of syphilis in Ukraine has a clear tendency to decline, but still remains quite high. The maximum incidence of syphilis is observed in women aged 15-20 years. The combination of pregnancy and syphilitic infection in an anamnesis is an unfavorable factor in regard to high risk of perinatal complications, the frequency of which does not tend to decrease.

The aim - study the features of the course of pregnancy and childbirth in women with a syphilitic infection in the anamnesis, the evaluation of the state of newborns. Materials and methods: A prospective examination of 57 healthy women and their newborns (control group) and 60 pregnant women with a history of syphilitic infection (the main group) had been conducted. All pregnant women had undergone ultrasound examination, including feto- and placentometry, an estimate of the amount of amniotic fluid. The effect of the transferred syphilis on the state of the newborn had been assessed in accordance with the results of the clinical examination of an anthropometric data, including an Apgar score.

Results: It is stated that the incidence of latent $(41,66 \%)$ and forms with a prolonged course $(20,00 \%)$ of syphilitic infection. The threat of premature childbirth was almost 3,5 times higher than in women with syphilis, cases of an anemia in pregnant women - 2 times, hypertensive disorders of pregnant women were 2,4 times more common in women of the main group, fetal development retardation syndrome 6,4 times, while a greater percentage of this disorder was recorded among women in the main group who were ill with latent forms and suffered secondary recurrent syphilis (35\%). In $20 \%$ of the cases, pregnancy in women with syphilis has been completed by the cesarean section, an abnormality of the contractile capacity of the uterus was significantly higher $-23,33 \%$. The adaptive capacity of the newborns in the main group has been significantly lower, compared to the control group.

Conclusions: Syphilitic infection in the anamnesis complicates the course of pregnancy with numerous pathological conditions. Syphilitic infection, borne before pregnancy, affects not only the course of pregnancy, but also the course of childbirth and the postpartum period. The pathological conditions in infants are due to a decrease in resistance to birth stress, early depletion of adaptive resources of newborns under the influence of a syphilitic infection of the mother. In children who have experienced chronic intrauterine hypoxia, the risk of hemorrhagic syndrome is significantly higher due to increased permeability of the vascular wall. Such children have a tendency to develop neurological disorders and respiratory system lesions.
\end{abstract}

KEY WORDS: syphilis, pregnancy, children

Wiad Lek 2019, 72, 2, 175-180

\section{INTRODUCTION}

To date, the incidence of syphilis in Ukraine has a clear tendency to decline, but still remains quite high $[1,2,3]$. It is worth noting that the problem of syphilis is far from the optimal solution not only in our country. In 2000 91,5 new cases were registered per 100 thousand of population, whereas in 2007 this indicator decreased to 29,9 , in 2009, it amounted to - 20,0, in 2011. - 17,4, in 2012. - 13,6 cases. The incidence of syphilis in Ukraine is characterized by a gradual decline (in 2014 - 3,674 cases (8,6 per 100000 population), in 2015 - 3228 cases (7,6 per 100000 population).

The maximum incidence of syphilis is observed in women aged 15-20 years. [1-3]. The established frequency of syphilis in the population among pregnant women ranges from $0,2 \%$ in developed and up to $13 \%$ in developing countries [1-8].

According to available data, hidden and late forms predominate in the structure of the incidence of syphilis in Ukraine, as well as in the countries of the near and far abroad: from 20 to $40 \%$. According to the literature, in the group of patients with latent syphilis, persons with early forms predominate - from 57 to $95,7 \%$, late syphilis is recorded in 9,8-13,6\%, and in unspecified patients - in $6,4-13,1 \%$ of patients [1-9].

The combination of pregnancy and syphilitic infection is an extremely unfavorable factor in view of high perinatal complications, the frequency of which does not tend to decrease. 
Table I. Distribution of women according to the forms of the transferred syphilis

\begin{tabular}{ccc}
\hline \multirow{2}{*}{ The form of syphilitic infection } & \multicolumn{2}{c}{ Main Group, $\mathbf{n}=\mathbf{6 0}$} \\
\cline { 2 - 3 } & Abs. & \% \\
\hline Primary seropositive & 6 & 10,00 \\
\hline Secondary recent & 4 & 6,66 \\
\hline Secondary recurrent & 12 & 20,00 \\
\hline Latent early & 25 & 41,66 \\
\hline Seroresistance & 8 & 13,33 \\
\hline Discharged & 5 & 8,33 \\
\hline
\end{tabular}

The urgency of studying this problem is also due to the lack of dynamic observation of the physical and mental development of children born to women who had syphilis [10-12].

According to numerous authors $[11,13-16]$, pregnancy after syphilis is complicated with preeclampsia, polyhydramnios, premature births, anemia [14, 16, 17-19]. Postponed syphilitic infection is likely to cause a decrease in the energy resources of the uterus, which is one of the reasons for the secondary weakness of labor and inferiority of the period of expulsion in some pregnant women. There is also a premature discharge of the amniotic fluid, atonic bleeding, premature detachment of the normally located placenta [14, 15, 16-19].

A frequent complication in children born to mothers who have had syphilis in an anamnesis is the pathology of the central nervous system. Due to the cerebral dysfunction, children aged 6-13 years are diagnosed with psychopathic, cerebroasthenic and convulsive conditions, schizophrenia, oligophrenia, mental retardation syndrome, accompanied by symptoms of peripheral nervous system lesions in the form of asymmetry of nervous regulation $[12,17,20-21]$. In this case, the revealed disorders are associated with the lesion of the chromosome apparatus of the reproductive cells (gameto-, blasto- and embryopathies). Such conditions are called parasyphilitic and are manifested by various defects of physical, neurological, mental and intellectual development in the catamnesis [12, 15, 22, 23].

\section{THE AIM}

In view of the foregoing, it is important to study the features of the course of pregnancy and childbirth in women with a syphilitic infection in the anamnesis, the evaluation of the state of newborns, which served the purpose of our study.

\section{MATERIALS AND METHODS}

Design studies, distribution groups. A prospective examination of 57 healthy women and their newborns (control group) and 60 pregnant women with a history of syphilitic infection (the main group) was conducted. All pregnant women underwent ultrasound examination, including feto-and placentometry, an estimate of the amount of amniotic fluid. The state of the newborns was assessed by the results of a clinical examination, including an Apgar score, anthropometric data. Also, the features of the early neonatal period (weight loss and recovery, the complications of the adaptation period and pathological symptoms in newborns) were also determined.

\section{STATISTICAL ANALYSIS}

Statistical processing of materials was carried out using variational statistical methods using the standard package of MS Office 365 Excel Windows'10'Home application programs. For quantitative characteristics, after calculating the descriptive statistical parameters within each sample, a check was made on the nature of the distribution. In the case of a normal distribution of similar characteristics in the samples, the Student's test was used to compare them. In the absence of a normal Gaussian distribution in bound sets of quantitative traits (and also with rank characteristics), the comparison was made using non-parametric Fisher criteria. Mismatches between comparable values were considered statistically significant at a significance level of $\mathrm{p}<0,05$.

\section{RESULTS AND DISCUSSION}

According to the data, there is a tendency to increase the frequency of latent $(41,66 \%)$ and long-term $(20,00 \%)$ forms of syphilitic infection among the pregnant women of the study group (Table I).

It should be noted that the overwhelming majority of women who had a syphilitic infection before pregnancy were housewives $-56,67 \%$ of cases compared to the control group $-21,05 \%(p<0,05)$. It is pertinent to note that this indicator also includes unemployed women. A relatively high percentage of women with syphilis in the anamnesis accounted for workers in industrial enterprises - 23,33\%, employees accounted for $16,67 \%$, compared with the control group $7,02 \%$ and $61,40 \%$, respectively $(p<0,05)$.

\section{COMPLICATIONS OF PREGNANCY INTHE STUDY GROUPS}

The most common complications of pregnancy were anemia - $49(81,67 \%)$ in pregnant women of the main group and $23(40,60 \%)$ in the control group, with anemia of mild degree detected in $41(68,33 \%)$ and $21(36,84 \%)$ women, the average degree - in $8(13,33 \%)$ and $2(3,51 \%)$ cases respectively $(p<0,05)$. The threat of termination of pregnancy occurred in 33 (55,00\%) women who had syphilis, and 10 women in the control group (17,55\%, p 


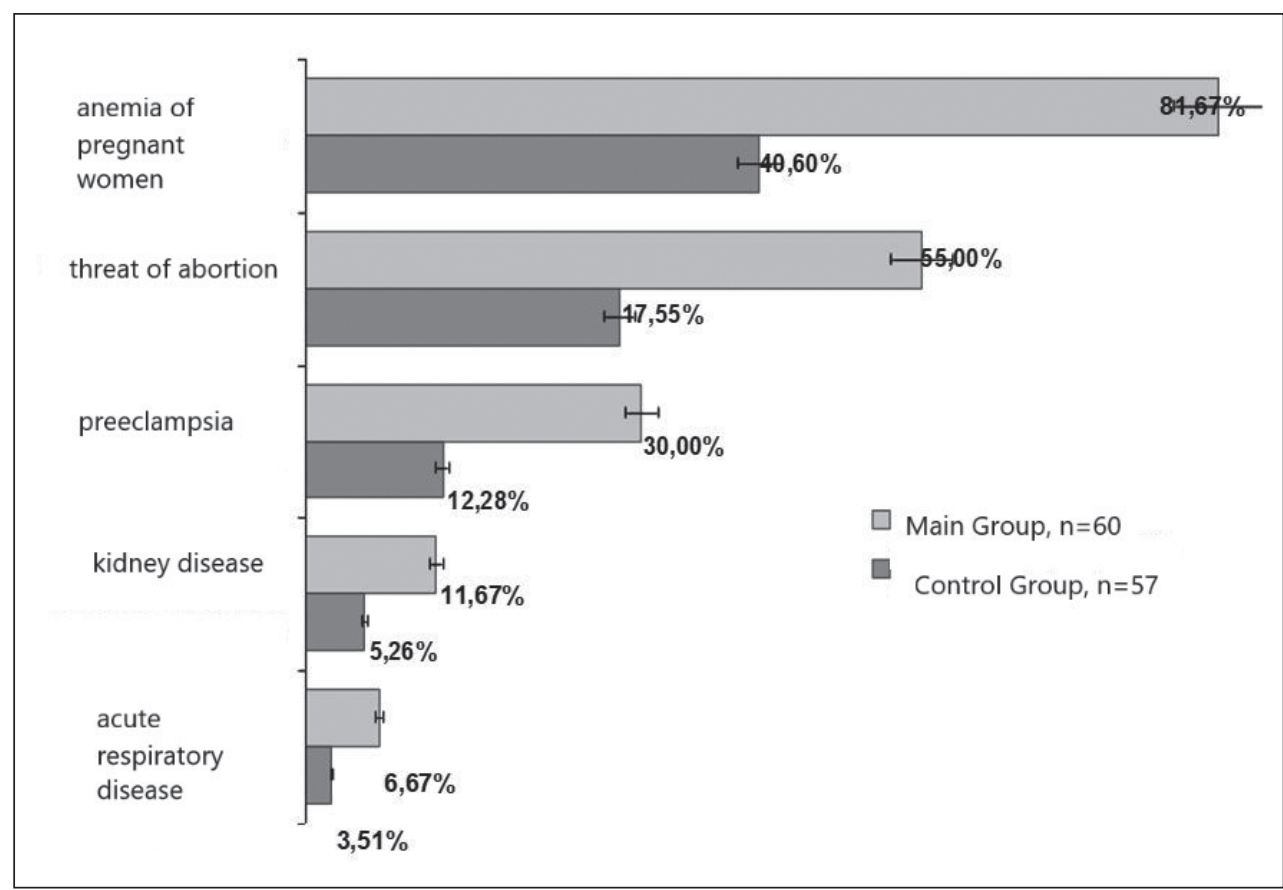

Fig.1. Frequency of complications of pregnancy in patients of the examined groups
$<0,05)$. A significant part was the threat of termination of pregnancy up to 12 weeks - $17(28,33 \%)$ in women in the main group and $8(14,04 \%)$ in the control group $(p>0.05)$, the risk of premature birth was diagnosed in $16(26,67 \%)$ and $2(3,51 \%)$, respectively $(\mathrm{p}<0,05)$. Preeclampsia, as a complication of pregnancy, was more common among women in the main group and amounted to 18 (30,00\%), whereas in the control group these indicators were 7 $(12,28 \%)(\mathrm{p}<0,05)$. The early gestosis accounted for 5 $(8,33 \%)$ and $3(5,26 \%)$ cases $(p>0,05)$, mild preeclampsia was diagnosed in the pregnant group in 13 cases $(21,67 \%)$, in the control group $-4(7,02 \%)(\mathrm{p}<0,05)$. Preeclampsia of moderate degree was diagnosed in one patient of the main group $(1,67 \%)$, due to the deterioration of the condition of a woman with severe preeclampsia, she was delivered in an urgent order.

\section{RESULTS OF FETOMETRY}

The intrauterine growth retardation syndrome was diagnosed in antenatal fetometry in 27 pregnant women of the main group $(45,00 \%)$, whereas in the control group this index was 4 cases $(7,02 \%, \mathrm{p}<0,05)$. The first stage of Fetal growth restriction (FGR) was detected in 13 cases $(21,67 \%)$ in the group of women who were ill with syphilis, whereas in the control group this indicator was diagnosed in 4 cases $(7,02 \%, p<0,05)$. Second-degree Fetal growth restriction (FGR) occurred in the main group in 12 cases $(20,00 \%)$, the third degree $-2(3,33 \%)$, respectively.

Statistics of patients with polyhydramnios showed the following distribution: moderate polyhydramnios occurred in women who had syphilis in $7(11,67 \%)$ cases, in women in the control group - $5(8,77 \%)$ cases. The marked polyhydramnios in $12(20,00 \%)$ and $2(3,51 \%)$, respectively $(\mathrm{p}<0,05)$.
The malignancy, which was considered as a marker of intrauterine hypoxia and placental dysfunction, was detected in patients of the main group in 18 cases (30,00\%), in 13 cases $(21,67 \%)$ moderate malnutrition, expressed malic acid was recorded in 5 cases $(8,33 \%)$ in the main group. In patients of the control group, moderate malnutrition was detected in 4 cases $(7,02 \%, \mathrm{p}<0,05)$.

\section{FEATURES OF THE COURSE OF LABOR AND THE POSTPARTUM PERIOD}

Syphilitic infection, borne before pregnancy, affects not only the course of pregnancy, but also the course of childbirth and the postpartum period. The most common was premature discharge of amniotic fluid, which was observed in 25,00\% (15 cases) of pregnant women who had syphilis, whereas in women with a physiological pregnancy this percentage was below $10,53 \%$ ( 6 cases, $\mathrm{p}<0,05)$. Premature births were found in the 1 st case of women in the main group $(1,67 \%)$. Due to worsening of the condition of the pregnant women against a background of pre-eclampsia, a premature delivery was performed - a caesarean section, in the control group there were no such cases.

In 14 cases $(23,33 \%)$, the birth was complicated by abnormalities of uterine contractile activity in the pregnant women of the main group, whereas this complication was observed only in 4 cases $(7,02 \%)$ of the pregnant control group ( $p<0,05)$. Bleeding during the III stage of labour was observed in 4 patients $(6,67 \%)$ of the main group, in the control group this complication was not observed ( $p$ $<0,05)$. When the placenta was examined in the postpartum period, 10 cases $(16,67 \%)$ of the women of the main group were found to have defects, which led to a manual revision of the uterine cavity and the removal of placental defects. In women of the control group, this pathology was observed in 3 cases $(5,26 \%, p<0,05)$. Birth injuries occurred in 8 women of the main group $(13,33 \%)$ and in 5 cases of the 


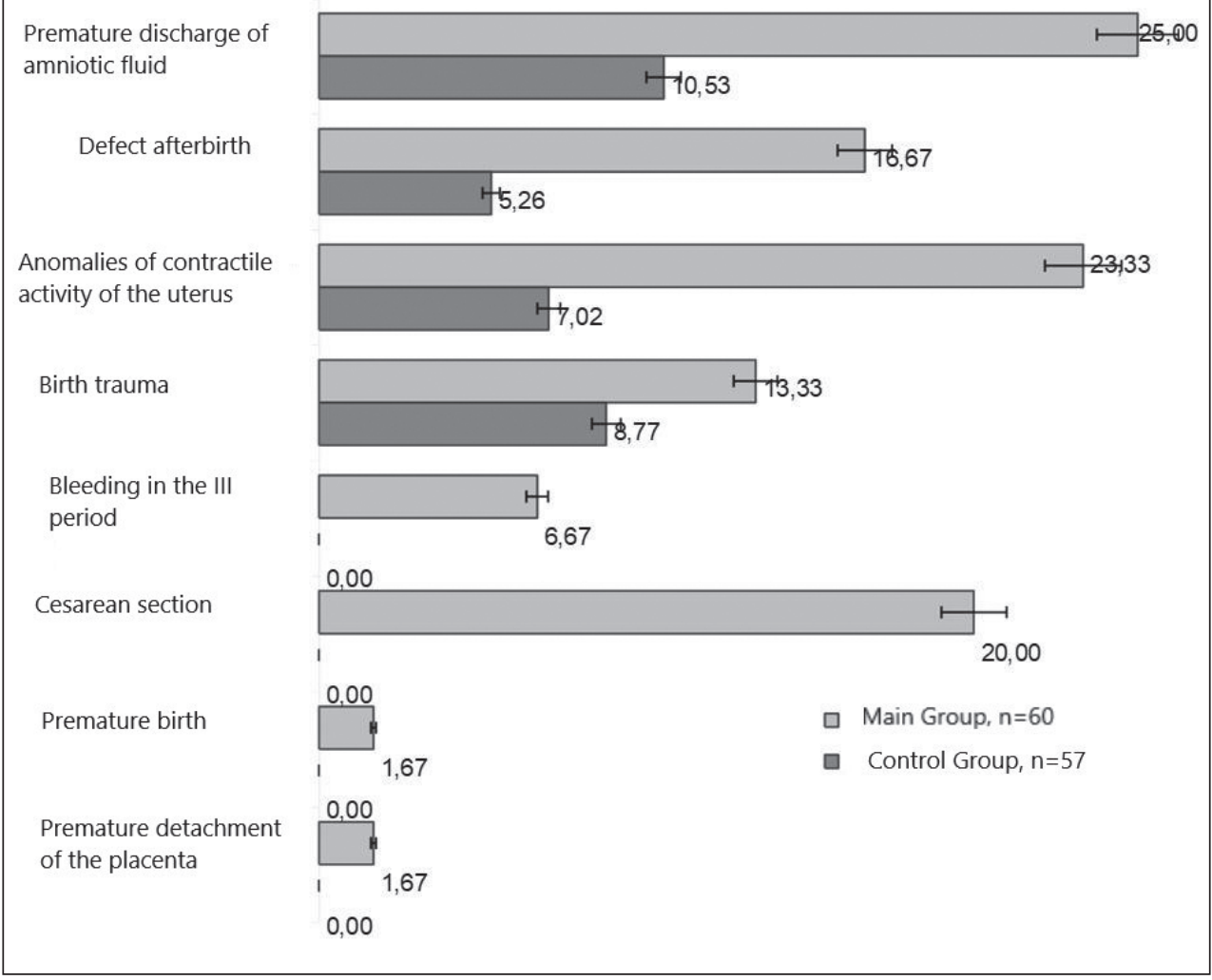

Fig. 2. The nature of obstetric complications in the patients of the examined groups.

control group $(8,77 \%, \mathrm{p}<0,05)$. As a result of the analysis it was found that in 6 patients of the main group $(10,00 \%)$ the postnatal period was complicated by the subinvolution of the uterus, in the 1 st $(1,67 \%)$ - endometritis. In the control group, only the first patient was diagnosed with a lochiometer $(1,75 \%, \mathrm{p}<0,05)$.

\section{CONDITION OF NEWBORNS}

Children with symptoms of congenital syphilis were not recorded. When assessing the state of newborns and the course of the early postnatal period, the following was noted: the Apgar score of newborns in the main group was significantly lower than in the control group $(6,69 \pm 0,18$ and 8,25 $\pm 0,12$ points in the first minute and 7, 67 $\pm 0,12$ and 9,19 $\pm 0,11$ points in the fifth minute, respectively ( $p$ $<0,05)$ ). Low Apgar scores were set due to a decrease in muscle tone in 13 newborns - 21,67\% and reflex excitability -16 newborns $-26,67 \%$, due to the pallor of the skin - $15(25,00 \%)$, respectively. The average body mass index of newborns in the main group is significantly lower than in the control group $(3062,00 \pm 36,8$ and $3497,72 \pm 51,23$ g, p <0,05) (Table II).

Anthropometric measurements revealed that the average circumference of the head and shoulders of the newborn in the main group was significantly lower than that in the control group, and amounted to 33,28 $\pm 0,42$ and 35,53 \pm $0,15 \mathrm{~cm}$ and $33,75 \pm 0,4$ and $34,82 \pm 0,17 \mathrm{~cm}$, respectively $(\mathrm{p}<0,05)$. Physiological weight loss in newborns as a percentage of women in the main group was $4,75 \pm 0,28 \mathrm{~g}$, in newborns in the control group $-4,26 \pm 0,24 \mathrm{~g}$, respectively.

\section{THE COURSE OF POSTNATAL ADAPTATION}

The disturbance of early postnatal adaptation of newborns, manifested by a combination of pathological symptoms, is twice as high in women who have had syphilis. Hemorrhagic syndrome occurred in $7(11,67 \%)$ of newborns, from mothers who had syphilis, in the control group this pathology occurred in $3(5,26 \%, \mathrm{p}<0,05)$ cases; neurological disorders - in $6(10,00 \%)$ of the newborns of the main group, $2(3,51 \%, \mathrm{p}<0,05)$ - control group; respiratory distress syndrome was observed in newborns of only the main group in 3 cases $(5,00 \%, \mathrm{p}<0,05)$.

Syphilitic infection in the anamnesis complicates the course of pregnancy with numerous pathological conditions. In women with syphilitic infection, pregnancy was accompanied by complications, among which a fairly high percentage accounted for Fetal Growth Retardation, malnutrition and polyhydramnios, anemia of pregnant women, the threat of premature birth, preeclampsia. Reduction of the number of amniotic fluid, according to L.G. Sichinawi et al. [24], is an unfavorable prognostic sign in terms of perinatal losses. Syphilitic infection, borne before pregnancy, affects not only the course of pregnancy, but also the course childbirth and the postpartum period. In the opinion of a number of authors $[17,20]$, the transferred syphilitic infection may affect the energy capabilities of the neuromuscular apparatus of the uterus, which leads to an increase in the duration of the most energy-intensive phases of the birth act and the frequency of primary and secondary weakness of labor, its discoordination.

The pathological conditions of infants are due to a decrease in resistance to birth stress, early depletion of adap- 
Table II. Indicators of anthropometry in newborns in both groups $(M \pm m)$

\begin{tabular}{ccc}
\hline Indicators & Main Group, $\mathbf{n}=\mathbf{6 0}$ & Control Group, $\mathbf{n}=\mathbf{5 7}$ \\
\hline Body weight, $\mathbf{g}$ & $3062,00 \pm 36,80^{*}$ & $3497,72 \pm 51,23$ \\
\hline Height, $\mathrm{cm}$ & $51,32 \pm 0,35^{*}$ & $53,98 \pm 0,26$ \\
\hline Head circumference, $\mathrm{cm}$ & $33,28 \pm 0,42^{*}$ & $35,53 \pm 0,15$ \\
\hline Shoulder circumference, $\mathrm{cm}$ & $33,75 \pm 0,40^{*}$ & $34,82 \pm 0,17$ \\
\hline
\end{tabular}

Note. * - probably the difference in the relevant indicators between comparable groups $(p<0.05)$.

tive resources of newborns under the influence of a syphilitic infection of the mother. According to the literature [25], the risk of haemorrhagic syndrome in children who underwent chronic intrauterine hypoxia is significantly higher due to increased permeability of the vascular wall. Such children have a tendency to develop neurological disorders and respiratory system lesions.

\section{CONCLUSIONS}

1. The threat of premature birth was almost 3.5 times higher than in women with syphilis, anemia of pregnant women - 2 times, gestosis of pregnant women was 2,4 times more common in women of the main group, NWFP in 6.4 times, while a greater percentage of this disorder was registered among the women of the main group who were ill with latent forms and suffered secondary recurrent syphilis $-35,00 \%$.

2. In $20,00 \%$ of cases, the pregnancy in women with syphilis was completed by cesarean section, the abnormality of the contractile capacity of the uterus in women of the main group was significantly more frequent $-23,33 \%$.

3. The adaptive capabilities of the newborns in the main group had a significantly lower Apgar score than the control group.

\section{REFERENCES}

1. Volkoslavsky V.N. Quasi-periodicity in dynamics of incidence of syphilis and the main directions of the organization of fight against STD in Ukraine. Theses of reports of a scientific and practical conference. Odessa, 2003: 25-26 (in Russian)

2. Indicators treatment-and-prophylactic help to patients with skin and venereal diseases in Ukraine. Center of medical statistics of MOZ of Ukraine. To.; 1993-2007: 56. (in Ukrainian)

3. Scherbakova Y.V. Incidence of syphilis in Ukraine. In prince: Scherbakova Y.V. Clinical immunology. Allergology. Infektologiya. 2009; (1): 27-30. (in Russian)

4. Renton A. Epidemiology, control and surveillance of syphilis and gonorrhea in the Russian Federation. Renton A., Ward H., Meheus A. Report of a WHO mission to Russia to carry out a situation analysis. Geneva, 2005: 73-74

5. Indicators of the treatment-and-prophylactic help to patients with skin and venereal diseases in Ukraine. M.V. Centre responsible for release of Smart guys of medical statistics of MOZ Ukraini-K.: 2009:110. (in Ukrainian)
6. Mavrov G.I. Infections, sexually transmitted, and problem of sexual and reproductive health of the nation. Mavrov G.I., Nagorny A. E., Chinov G.P. Clinical immunology. Allergology. Infektologiya. 2010; (1): 5-14. (in Russian)

7. Volkoslavskaya V.N. Dynamics of incidence of pathology of skin and infections, sexually transmitted population of Ukraine in recent years (2000-2010) Volkoslavskaya V.N., Gutnev A.L. Topical issues of a dermatovenereology and cosmetology: materials $\mathrm{YI}$ of a congress of dermatovenerologists of Republic of Belarus, Vitebsk, 24-25 нояб. 2011 Mr. Opubl. ARS physician. 2011; (15): 23-24. (in Russian)

8. Volkoslavskaya V.N., Gutnev A.L. About incidence of infections, sexually transmitted in Ukraine. Clinical immunology. Allergology. Infektologiya. 2011; (1): 10-12. (in Russian)

9. Duarte G. Syphilis and pregnancy...the story continues! Duarte G., Rev. Bras. Ginecol. Obstet. 2012; 34, (2): 49-51

10. Daoud M. Syphilis in pregnancy. Daoud M, Duca E, Petrescu Z. Rev. Med. Chir. Soc. Med. Nat. lasi. 2011; 115, (4): 1097-1101

11. A risk model for congenital syphilis infants born tom others with syphilis treated in gestation: a prospective cohort study. Liu J.B., Hong F.C., Pan P. [et al.]. Sex. Transm. Infect. 2010; 86 (4): 292-296

12. Rasskazov N.I. Post-syphilitic violations at the pregnant woman, a fruit and the newborn. In the book Rasskazov N.I., Shvarev E. G., L.A. Bakhmutova L. A. Infections, sexually transmitted. 1999; (3): 33-36. (in Russian)

13. Kokina 0.A., Guryeva V. A., Yevtushenko N.V., Nemtseva T.V. Features of a current and the result of pregnancy depending on volume and timeliness of therapy of syphilis. Magazine of obstetrics and female diseases. 2011; 60 (4): 48-54. (in Russian)

14. Ostroukhova T. N. The result of childbirth at women, serorezistivny on syphilis during pregnancy and/or childbirth. Ostroukhova T. N. of STD. 2002; (3): 25-29 (in Russian)

15. Nascimento M.I.,CunhaAde A.,Guimarães E.V.[et al.] Pregnancies complicated by maternalsy philisand fetal death. Rev.Bras.Ginecol. Obstet. 2012; 34, (2): 56-62

16. Kokhanevich E.V., Kaminsky V., Dudka S.V., Bulda O.V. Some features of a course of pregnancy and childbirth at women with syphilis in the anamnesis. Collection of scientific works. Associations of obstetriciansgynecologists of Ukraine. Kiev, 2001: 337-340 (in Ukrainian)

17. Patselya M.V. A syphilitic infection and its consequences at pregnant women of Patsel M. Reproductive health of the woman. 2007; 1 (30): 222-224. (in Ukrainian)]

18. Mayansky A.N. Infectious relationship in the mother fruit system (a part I). Mayansky A.N. Questions of diagnostics in pediatrics. 2009; 1(4): 12-19. (in Russian)

19. ParkerJr. C.R. The effects of syphilis on endo crine function of the fetoplacental unit. ParkerJr. C.R., Wendel G.D. Am. J .Obst. Gynec. 2007; 159 (6): 1327-1331. 
20. Astakhov V. M. Features of a course of pregnancy, childbirth and the postnatal period of women with the mixed infection of a genital path in the anamnesis In the books Astakhov V.M., Bilim G. V., Bilim A.V. Pediatriya, obstetrics and gynecology. 2001, (3). the 85-89p.(in Ukrainian)

21. Amaral E. Syphilis during pregnancy and fetal death: back to the future. Amaral E. Rev. Bras. Ginecol. Obstet. 2012; 34 (2): 52-55

22. Saraceni V. Coverage by the Family Health Strategy and diagnosis of syphilisin pregnancy and congenital syphilis. Saraceni V., Miranda A.E. Cad. Saude Publica. 2012; 28 (3): 490-496

23. Vestergaard T. Syphilis during pregnancy. Vestergaard T., Ibsen H. H. Ugeskr. Laeger. 2012; 174(20): 1369-1370.

24. Sichinava L.G. Mnogoplodiye. Modern approaches to tactics of conducting pregnancy and childbirth. Sichinava L.G., Panina 0.B. Questions of gynecology, obstetrics and perineanatologiya. 2003; 2 (3): 56-62.213 (in Russian)

25. Rasskazov N.I. Early congenital syphilis in the neonatal period: clinical features and diagnostic problems. Rasskazov N.I., Altukhov S.A., Elantseva G.H. Ros. magazine of skin. and veins Bol. 1999, (4): 33-36.218 (in Russian)

\section{Authors' contributions:}

According to the order of the Authorship.

\section{Conflict of interest:}

The Authors declare no conflict of interest.

\section{CORRESPONDING AUTHOR} Daria S. Khapchenkova

Department of Human Anatomy № 1,

Donetsk National Medical University

Privokzalnaya Street, 27, Liman, 84404, Ukraine

tel: +38 (050) 9281337

e-mail:xapcha86@gmail.com

Received: 19.09 .2018

Accepted: 24.01.2019 
PRACA ORYGINALNA

ORIGINAL ARTICLE

\title{
CHANGES IN PENTRAXIN-3 LEVEL AND ITS INTERACTION WITH METABOLIC INDICES IN PATIENTS WITH CORONARY ARTERY DISEASE AND TYPE 2 DIABETES MELLITUS
}

\section{ZMIANY STEZŻENIA PENTRAKSYNY 3 II JEJ INTERAKCJE ZE WSKAŹNIKAMI METABOLICZNYMI U PACJENTÓW Z CHOROBĄ WIEŃCOWĄ ORAZ CUKRZYCĄTYPU 2}

\author{
Pavlo G. Kravchun, Olga I. Kadykova, Dmitry G. Molotyagin \\ KHARKIV NATIONAL MEDICAL UNIVERSITY, KHARKIV, UKRAINE
}

\begin{abstract}
Introduction: Recently great attention is paid to studying of coronary artery disease (CAD) pathogenesis against the background of the diabetes mellitus (DM). First of all, the question of an inflammatory component role in development of atherosclerosis in patients with DM 2 types is studied. One of new perspective markers of immune inflammation is pentraxin-3 (PTX-3).

The aim of the study was to evaluate the nature of changes in the level of pentraxin- 3 in patients with coronary artery disease, depending on the presence of type 2 diabetes mellitus and to investigate the nature of the relationship with metabolic parameters.

Materials and methods: Comprehensive examination of 110 patients with CAD was conducted. Patients were divided into groups depending on presence of type $2 \mathrm{DM}$ : to the first group $(n=75)$ entered patients with CAD and type $2 D M$, the group of comparison was made by 35 patients with CAD without type $2 D M$. 25 almost healthy persons entered into control group.

Results: As a result of a research it is established the reliable increase in PTX-3 level in all patients with CAD in comparison with group of control for $65.40 \%$. And in the conditions of the combined current of CAD and type 2 DM, PTX-3 level is for $80.14 \%$ higher, than in persons of control group. Also interrelation between PTX-3 and indicators of dcarbohydrate and lipidic exchanges were defines. According to the carried-out correlation analysis there was revealed existence of direct integral probable connections between PTX-3 level and levels of glucose $(r=0.41 ; p<0,05)$, insulin $(r=0.36 ; p<0,05)$, index of HOMA $(r=0.89 ; p<0,05)$, TG level $(r=0.74 ; p<0,05)$ and the return with the HDL $(r=-0.54 ; p<0,05)$.

Conclusions: In patients with CAD with the accompanying type 2 DM it is established higher PTX-3 level, than in patients without type 2 DM and control group that demonstrates autoimune link activation. In the examined patients PTX-3 level increase was associated with violation of lipid and carbohydrate exchanges.
\end{abstract}

KEY WORDS: coronary artery disease, type 2 diabetes mellitus, metabolic violations, pentraxin-3

Wiad Lek 2019, 72, 2, 181-185

\section{INTRODUCTION}

Coronary artery disease (CAD) is one of the most common causes of mortality in developed countries, stipulating the attention paid to the study of the pathogenesis of ischemic heart disease. In Ukraine, the prevalence and incidence of CAD increases annually and comprises $53.8 \%$ of the circulatory system diseases. Mortality from ischemic heart disease is about 650 per 100 thousand of population [1].

A major risk factor for CAD is diabetes mellitus (DM), which became one of the leading medical and social problems of modern society, due to high morbidity and its prevalence, frequent development of chronic micro- and macrovascular complications [2, 3].

CAD develops 2-4 times more often in patients with type 2 diabetes than in patients of the same age without diabetes [4]. Cardiovascular diseases is the main reason for disability and mortality of patients with diabetes, and these diseases are to a considerable extent preconditioned by CAD [5]. It should be noted that 3 of 4 patients with DM die from causes associated with atherosclerosis, and in most cases (75\%) from CAD.

The prevalence of DM in Ukraine is 3041.6 per 100 thousand of population, and the primary morbidity is 272.0 per 100 thousand of population [4]. And this is a medical and social problem in terms of cardiovascular morbidity, which requires the improvement of diagnostic approaches and determines the relevance of the study.

Generalized or chronic inflammation is one of the pathogenic mechanisms of atherosclerosis. This is confirmed by recent clinical and experimental data obtained by determination of inflammation markers (C-reactive protein (CRP), proinflammatory cytokines, such as interleukin-1, 


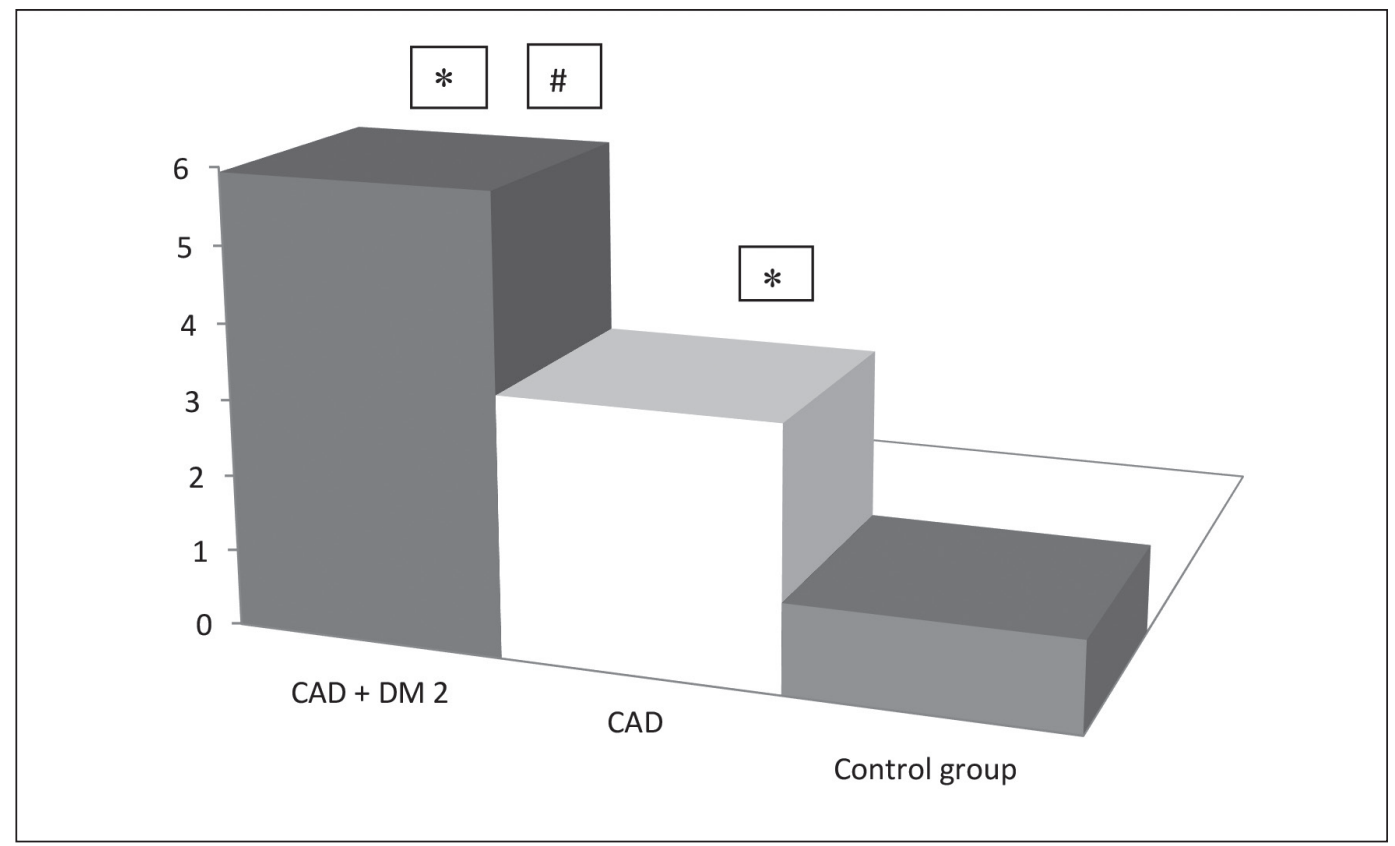

Fig. 1. The character of changes in the level of pentraxin-3 depending on the presence of type 2 diabetes in patients with ischemic heart disease.

Note: ${ }^{*} p<0.05$

when compared to the control group; $\# p<0.05$ when compared to the comparison group.

interleukin-6 (IL-6), interleukin-12, tumor necrosis factor- $\alpha$ (TNF- $\alpha$ ), serum amyloid A, haptoglobin, fibrinogen) [6-12]. First of all, the role of inflammatory component in the development of atherosclerosis in patients with type 2 diabetes is being studied.

One of the new markers of immune inflammation is pentraxin-3, overexpressed in endothelial and smooth muscle cells, monocytes and macrophages, which are components of the vascular wall and atherosclerotic plaque [12-15].

Pentraxin-3 (PTX-3), also known as TNF-inducible gene 14 protein, is related to pentraxin super-family, which includes classical short pentraxins CRP and serum amyloid P component, long pentraxin PTX-4, and a group of neuronal pentraxins. Its role in atherosclerosis has not yet been clarified. However, some scientific studies indicate an increased secretion of PTX-3 in patients with CAD $[16,17]$. Other researchers reported that its increased expression was associated with acute coronary syndrome, and high plasma levels of PTX-3 were predictors of adverse clinical outcomes in patients with heart failure $[18,19]$. However, the pathogenic role of PTX-3 in the development of CAD in patients with type 2 diabetes has not yet been studied, which requires further research in this direction.

\section{THE AIM}

The purpose of the study was to evaluate the nature of changes in the level of pentraxin-3 in patients with coronary artery disease, depending on the presence of type 2 diabetes mellitus and to investigate the nature of the relationship with metabolic parameters.

\section{MATERIALS AND METHODS}

The study involved comprehensive examination of 110 patients with $\mathrm{CAD}$, who were treated at the Department of
Cardiology of the Municipal Non-Profit Enterprise "City Clinical Hospital No.27" of Kharkiv City Administration, which is the basic medical institution of Academician L.T. Malaya Department of Internal Medicine No.2, Clinical Immunology and Allergology of Kharkiv National Medical University of the Ministry of Health of Ukraine. The patients were divided into groups depending on the presence of type 2 diabetes: the first group $(n=75)$ included patients with CAD and type 2 diabetes, the comparison group comprised 35 patients with $\mathrm{CAD}$ without diabetes. The control group included 25 practically healthy persons. The study did not include patients with severe concomitant disorders of the respiratory and digestive organs, kidneys and cancer.

The diagnosis was made in accordance with the effective orders of the Ministry of Health of Ukraine.

All the patients underwent general clinical and instrumental examination.

In order to control carbohydrate metabolism, glucose levels were determined by glucose oxidant method, the content of glycosylated hemoglobin $\left(\mathrm{HbA}_{1 \mathrm{c}}\right)$ in whole blood was determined by photometric reaction with thiobarbituric acid using commercial test system produced by the company Reagent (Ukraine) in accordance with the attached instruction. The concentration of insulin was determined by the immunoassay method using the commercial test system Insulin ELISA Kit produced by the company DRG (Germany). The HOMA Index (Homeostasis Model Assessment) was calculated using the formula: insulin $(\mathrm{mU} / \mathrm{ml}) \times$ fasting glucose $(\mathrm{mmol} / \mathrm{l}) / 22.5$

In HOMA index $>2.77$ the patients were considered insulin-resistant.

Biochemical study included determination of total cholesterol (TC) and high density lipoprotein (HDL) by peroxidase method using Cholesterol Liquicolor reagent kit produced by company Human (Germany) in heparin-stabilized blood serum. Triglycerides (TG) were 
Table I. Metabolic indices in patients with coronary artery disease and type 2 diabetes mellitus $(M \pm m)$

\begin{tabular}{|c|c|c|c|}
\hline Indices & $\begin{array}{c}\text { CAD + Type } 2 \text { DM } \\
(n=75)\end{array}$ & $\begin{array}{c}\text { CAD } \\
(n=35)\end{array}$ & $\mathbf{p}$ \\
\hline Insulin, mcU/ml & $27.16 \pm 0.48$ & $8.32 \pm 0.21$ & $\mathrm{p}<0.05$ \\
\hline Fasting blood glucose & $7.19 \pm 0.31$ & $4.37 \pm 0.08$ & $\mathrm{p}<0.05$ \\
\hline $\mathrm{HbA} 1 \mathrm{c}, \%$ & $10.42 \pm 0.28$ & $4.68 \pm 0.25$ & $\mathrm{p}<0.05$ \\
\hline HOMA, U & $8.87 \pm 0.71$ & $1.67 \pm 0.25$ & $\mathrm{p}<0.05$ \\
\hline $\mathrm{TC}, \mathrm{mmol} / \mathrm{l}$ & $5.43 \pm 0.09$ & $5.41 \pm 0.06$ & $\mathrm{p}>0.05$ \\
\hline $\mathrm{TG}, \mathrm{mmol} / \mathrm{l}$ & $1.81 \pm 0.07$ & $1.58 \pm 0.04$ & $\mathrm{p}<0.05$ \\
\hline $\begin{array}{l}\text { HDL cholesterol, } \\
\mathrm{mmol} / \mathrm{l}\end{array}$ & $0.91 \pm 0.02$ & $1.51 \pm 0.03$ & $\mathrm{p}<0.05$ \\
\hline $\begin{array}{l}\text { LDL cholesterol, } \\
\mathrm{mmol} / \mathrm{l}\end{array}$ & $3.09 \pm 0.07$ & $2.67 \pm 0.06$ & $\mathrm{p}>0.05$ \\
\hline $\begin{array}{l}\text { VLD cholesterol, } \\
\mathrm{mmol} / \mathrm{l}\end{array}$ & $1.57 \pm 0.03$ & $1.14 \pm 0.02$ & $\mathrm{p}>0.05$ \\
\hline $\mathrm{Al}$ & $3.34 \pm 0.09$ & $3.27 \pm 0.04$ & $\mathrm{p}>0.05$ \\
\hline $\mathrm{BMI}, \mathrm{kg} / \mathrm{m}^{2}$ & $24.18 \pm 0.14$ & $24.36 \pm 0.41$ & $\mathrm{p}>0.05$ \\
\hline
\end{tabular}

Table II. Relationship between pentraxin-3 and metabolic parameters in patients with coronary artery disease and type 2 diabetes mellitus (rcrit $=0.34$ )

\begin{tabular}{ccc}
\hline & PTX-3 & $\mathbf{p}$ \\
\hline Glucose & 0.41 & $\mathrm{p}<0.05$ \\
\hline Insulin & 0.36 & $\mathrm{p}<0.05$ \\
\hline HOMA & 0.89 & $\mathrm{p}<0.05$ \\
\hline HbA1c & 0.28 & $\mathrm{p}>0.05$ \\
\hline TC & 0.26 & $\mathrm{p}>0.05$ \\
\hline TG & 0.74 & $\mathrm{p}<0.05$ \\
\hline HDL cholesterol & -0.54 & $\mathrm{p}<0.05$ \\
\hline LDL cholesterol & 0.18 & $\mathrm{p}>0.05$ \\
\hline VLDL cholesterol & 0.20 & $\mathrm{p}>0.05$ \\
\hline AF & 0.11 & $\mathrm{p}>0.05$
\end{tabular}

determined by enzymatic colorimetric method using Triglycerides GPO reagent kit produced by company Human (Germany). Atherogenicity factor (AF) was calculated by A.M. Klimov's formula: $\mathrm{AF}=(\mathrm{TC}-\mathrm{HDL}) / \mathrm{HDL}$; very low density lipoprotein $(\mathrm{VLDL})=\mathrm{TG} / 2.2 \times 0.45,(\mathrm{mmol} / \mathrm{l})$; low density lipoprotein $(\mathrm{LDL})=\mathrm{TC}-(\mathrm{VLDL}+\mathrm{HDL})$, (mmol/l). Obesity was characterized by the body mass index (BMI) (the Kettle Index), which was calculated by the formula:

weight $(\mathrm{kg}) /$ height $\left(\mathrm{m}^{2}\right)$

Pentraxin- 3 concentration was determined by the immunoassay method using the commercial test system Human pentraxin 3 (PTX3) Elisa Kit produced by SUNLONG BIOTECH (China) in accordance with the attached instruction.

Statistical data was processed using Statistica software, version 6.0. The differences between the groups in the distribution close to normal were evaluated by Pearson's criterion. The differences were considered statistically significant at $\mathrm{p}<0.05$.

\section{RESULTS AND DISCUSSION}

Our study showed a statistically significant increase in PTX-3 level in all patients with CAD as compared to the control group (Fig. 1). Thus, PTX-3 level in the control group was $1.18 \pm 0.54 \mathrm{ng} / \mathrm{ml}$, which was $65.40 \%$ less than in patients with CAD, where the value of this index was $3.41 \pm 0.68 \mathrm{ng} / \mathrm{ml}(\mathrm{p}<0.05)$.

In patients with a concomitant course of CAD and DM 2, the PTX-3 level was $80.14 \%$ higher than that of the control group and was $5.94 \pm 0.57 \mathrm{ng} / \mathrm{ml}(\mathrm{p}<0.05)$.

Comparative analysis demonstrated a statistically significant increase in PTX-3 level by $57.41 \%$ in patients with CAD, subject to the presence of type 2 diabetes, which indicated an activation of PTX-3 inflammatory marker, which can be considered a predictor of the concomitant course.

The findings of the study are in agreement with the results obtained by other researchers. Haibo L. [20] performed examination of 596 patients ( 467 men, 129 women, mean age 
$65.9 \pm 8.1$ years), showing that PTX -3 could be considered an inflammatory predictor of CAD. The level of PTX-3 in patients with CAD was $3.12 \pm 0.63 \mathrm{ng} / \mathrm{ml}$, which was higher than in the control group.

The Cardiovascular Health Study (CHS) conducted by the National Heart, Lung, and Blood Institute involved examination of 5888 men and women aged 65. PTX-3 was associated with cardiovascular disease and mortality, and its concentration was higher in patients with stable angina pectoris $(\mathrm{p}<0.001)$, as well as in patients with myocardial infarction $(p=0.005)$ and ischemic stroke $(p \leq 0.001)$, than in the control group [21].

In our opinion, taking into account the association of type 2 diabetes with changes in the lipid and carbohydrate profile, which leads to an increase in the incidence of cardiovascular complications in patients with CAD [22], it was expedient to study the features of lipid and carbohydrate metabolism in patients with CAD in the presence of concomitant type 2 diabetes.

In groups of patients with CAD with concomitant type 2 diabetes, fasting glucose level reached $7.19 \pm 0.31$ $\mathrm{mmol} / \mathrm{l}$, and in the group of patients with CAD without diabetes it comprised $4.37 \pm 0.08 \mathrm{mmol} / \mathrm{l}(\mathrm{p}<0.05)$. The level of fasting insulin was $27.16 \pm 0.48 \mathrm{mcU} / \mathrm{ml}$ in first group patients and was significantly higher than the level of fasting insulin in second group patients, namely $8.32 \pm 0.21 \mathrm{mcU} / \mathrm{ml}(\mathrm{p}<0.05)$. First group patients were found to have higher values of glycosylated hemoglobin than in the second group, $10.42 \pm 0.28 \%$ and $4.68 \pm 0.25 \%$ respectively $(\mathrm{p}<0.05)$. Determination of the HOMA index showed its significant increase in patients of the first group $(8.87 \pm 0.71)$ as compared to the second group $(1.67 \pm 0.25)(\mathrm{p}<0.05)$ (Table 1$)$.

Assessment of lipid profiles revealed an increase in the level of LDL cholesterol ( $3.09 \pm 0.07 \mathrm{mmol} / \mathrm{l}$ as compared to $2.67 \pm 0.06 \mathrm{mmol} / \mathrm{l}), \mathrm{VLDL}$ cholesterol $(1.57 \pm 0.03 \mathrm{mmol} / \mathrm{l}$ as compared to $1.14 \pm 0.02 \mathrm{mmol} / \mathrm{l})(\mathrm{p}>0.05)$; an increase in TG level $(1.81 \pm 0.07 \mathrm{mmol} / \mathrm{l}$ versus $1.58 \pm 0.04 \mathrm{mmol} / \mathrm{l}$, respectively), and a decrease in HDL cholesterol ( $0.91 \pm 0.02$ $\mathrm{mmol} / \mathrm{l}$ compared to $1.51 \pm 0.03 \mathrm{mmol} / \mathrm{l}$, respectively) $(\mathrm{p}<0.05)$ in patients with CAD and type 2 diabetes as compared to patients without diabetes (Table I).

Taking into account the association of chronic inflammation markers with metabolic parameters in patients with CAD and type 2 diabetes, we identified a relationship between PTX-3 and carbohydrate and lipid metabolism indices in our patients.

Correlation analysis showed the presence of direct integral potential links between the level of PTX-3 and glucose levels $(\mathrm{r}=0.41 ; \mathrm{p}<0.05)$, insulin $(\mathrm{r}=0.36 ; \mathrm{p}<0.05)$, HOMA index $(r=0.89 ; \mathrm{p}<0.05)$, the level of TG $(r=0.74 ; \mathrm{p}<0.05)$ and reverse with HDL cholesterol $(r=-0.54 ; p<0.05)$ (Table II).

In the multiethnic study of the University of Vermont Medical College including 2383 patients an increase in PTX-3 was positively associated with age $(\mathrm{p}<0.045)$, obesity $(\mathrm{p}<0.045)$, insulin levels $(\mathrm{p}<0.045)$, systolic blood pressure $(\mathrm{p}<0.045), \mathrm{CRP}(\mathrm{p}<0,045)$ and the thickness of carotid intima-media $(\mathrm{p}<0.045)[23]$.
The data obtained in different populations are of different nature, but today we can consider PTX-3 as a new marker that will be used to improve diagnostic efficiency in patients with CAD and type 2 diabetes.

\section{CONCLUSIONS}

1. Patients with CAD were found to have a higher level of PTX$3(5.94 \pm 0.57 \mathrm{ng} / \mathrm{ml})$ than patients without type 2 diabetes $(3.41 \pm 0.68 \mathrm{ng} / \mathrm{ml})$ and control group $(1.18 \pm 0.54 \mathrm{ng} / \mathrm{ml})$, indicating activation of the immune-inflammatory link.

2. Metabolic disorders in patients with CAD and type 2 diabetes are manifested by hyperinsulinemia, hyperglycemia, hypertriglyceridemia, increased insulin resistance and decreased LDL cholesterol levels.

3. In the examined patients, an increase in the level of PTX-3 was associated with an increase in triglycerides, glucose, insulin, HOMA index, and a decrease in HDL cholesterol.

\section{REFERENCES}

1. Kovalenko V.M., Dorogoy A.P. Sercevo-sudinny khvorobi: medichnosocialne znachennya ta strategiya rozvitku cardiologii v Ukraini [Cardiovascular diseases: medical and social significance and strategy of cardiology development in Ukraine]. Ukrainian Cardiology Journal. 2016; 3: 5-14. (In Ukrainian).

2. Pogrebnyak 0.0. Vpliv simvastatinu i corurginu na klinichniy perebig ishemichnoi khvorobi sercya, masu tila ta kharakter rozpodilu jirovoi tkanini u khvorih na cukroviy diabet 2 tipu [Effect of simvastatin and corurgin on the clinical course of coronary heart disease, body weight and the distribution of fatty tissue in patients with type 2 diabetes mellitus]. Zaporozhye Medical Journal 2013; 3(78):57-59. (In Ukrainian).

3. Kravchun N.A. Osoblyvosti formuvannya sercevo-sudynnyh uskladnen' cukrovogo diabetu 2 tipu u khvorih z riznimi proyavami metabolichnogo sindromu ta ih pharmacologichna corecciya [Features of formation of cardiovascular complications of type 2 diabetes in patients with various manifestations of metabolic syndrome and their pharmacological correction]. Diss. ... doc. med. sciences. 14.01.14. Kharkiv, 2007. 323 p. (In Ukrainian).

4. Citowskiy M.N. Statistichniy, klinichniy ta morphologichniy aspect vplivu cukrovogo diabetu na stan sercevo-sudinnoi systemi [Statistical, clinical and morphological aspects of the influence of diabetes mellitus on the state of the cardiovascular system]. Scientific Herald of Uzhgorod University, series «Medicine» 2017; 1(55): 168-177. (In Ukrainian).

5. Illyash M.G., Bazyka 0.E., Dovganich N.V. et al. Arterialna hypertensiya ta cukroviy diabet: suchasni aspecti licuvannya [Arterial hypertension and diabetes mellitus: modern aspects of treatment]. Practitioner 2016; 5(2): 5-9. (In Ukrainian).

6. Hajsadeghi S., Chitsazan M., Chitsazan M. et al. Changes of High Sensitivity C-Reactive Protein During Clopidogrel Therapy in Patients Undergoing Percutaneous Coronary Intervention. Res Cardiovasc Med 2015; 5(1): e28997, http://dx.doi.org/10.5812/ cardiovascmed.28997.

7. Poredos P., Spirkoska A., Lezaic L., Mijovski M.B. and Jezovnik M.K. Patients with an Inflamed Atherosclerotic Plaque have Increased Levels of Circulating Inflammatory Markers. J Atheroscler Thromb 2017; 24(1): 39-46, http://dx.doi.org/10.5551/jat.34884. 
8. Xiong G.L., Prybol K., Boyle S.H. et al. Inflammation markers and Major Depressive Disorder in Patients with Chronic Heart Failure: Results from the Sertraline Against Depression and Heart Disease in Chronic Heart Failure (SADHART-CHF) study. Psychosom Med 2015; 77(7): 808-815, http://dx.doi.org/10.1097/PSY.0000000000000216.

9. TalebS. Inflammation in atherosclerosis L'inflammation dansl'athérosclérose. Archives of Cardiovascular Diseases 2016; 109(12): 708-715.

10. Solomon S., Pasarin L., Ursarescu I. The effect of non-surgical therapy on C reactive protein and IL-6 serum levels in patients with periodontal disease and atherosclerosis. Int J Clin Exp Med 2016; 9(2): 4411-4417.

11. Ammirati E., Moroni F., Norata G.D., M. Magnoni, and P.G. Camici. Markers of Inflammation Associated with Plaque Progression and Instability in Patients with Carotid Atherosclerosis. Mediators of Inflammation 2015; Article ID 718329, 15 pages, http://dx.doi.org/10.1155/2015/718329.

12. Shindo A., Tanemura H., Yata K., Hamada K. Inflammatory Biomarkers in Atherosclerosis: Pentraxin 3 Can Become a Novel Marker of Plaque Vulnerability. PLoS One 2014; 9(6): e100045, http://dx.doi. org/10.1371/journal.pone.0100045.

13. Zhou Q., Chai X.-P., Fang Z.-F., Hu X.-Q. and Tang L. Association of Plasma Pentraxin-3 Levels on Admission with In-hospital Mortality in Patients with Acute Type A Aortic Dissection. Chin Med J (Engl) 2016; 129(21): 2589-2595, http://dx.doi.org/10.4103/0366-6999.192785.

14. Chodkowski A., Nabrdalik K., Kwiendacz H., Gumprecht J. Association of pentraxin 3 with atherosclerotic cardiovascular diseases - general knowledge in 2018. Clinical Diabetology 2018; 7(4): 203-206, http:// dx.doi.org/10.5603/DK.2018.0015.

15. Agilli M., Aydin F.N., Cayci T., Kurt Y.G. Pentraxin 3 (PTX3) plasma levels and carotid intima media thickness progression in the general population: A methodological approach. Nutrition, Metabolism \& Cardiovascular Diseases 2014; 24(12): e38-e39, https://doi. org/10.1016/j.numecd.2014.08.011.

16. Fornai F., Carrizzo A., Forte M. The inflammatory protein Pentraxin 3 in cardiovascular disease. Immun Ageing 2016; 13(1): 25, http://dx.doi.org/10.1186/s12979-016-0080-1.

17. Liu H., Guan S., Fang W. Associations between pentraxin 3 and severity of coronary artery disease. BMJ Open 2015; 5(4): e007123, http://dx.doi. org/10.1136/bmjopen-2014-007123.
18. Akgul 0., Baycan 0.F., Bulut U., Somuncu M.U. Long-term prognostic value of elevated pentraxin 3 in patients undergoing primary angioplasty for ST-elevation myocardial infarction. Coron Artery Dis 2015; 26(7): 592-7, http://dx.doi.org/10.1097/MCA.0000000000000280.

19. George M., Shanmugam E., Srivatsan V. Value of pentraxin-3 and galectin-3 in acute coronary syndrome: a short-term prospective cohort study. Ther Adv Cardiovasc Dis 2015; 9(5): 275-84, http://dx.doi. org/10.1177/1753944715578405.

20. Haibo L., Xiaofang G., Chunming W. et al. Prognostic value of plasma pentraxin-3 levels in patients with stable coronary artery disease after drug-eluting stent implantation. Mediators Inflamm 2014; 2014: 963096.

21. Jenny N.S., Arnold A.M., Kuller L.H. Associations of Pentraxin 3 with Cardiovascular Disease and All Cause Death: The Cardiovascular Health Study. Arterioscler Thromb Vasc Biol 2009; 29(4): 594-599, http:// dx.doi.org/10.1161/ATVBAHA.108.178947.

22. Parhofer K.G. Interaction between Glucose and Lipid Metabolism: More than Diabetic Dyslipidemia. Diabetes Metab J 2015; 39(5): 353-362, http://dx.doi.org/[10.4093/dmj.2015.39.5.353].

23. Jenny N.S., Blumenthal R.S., Kronmal R.A. Associations of pentraxin 3 with cardiovascular disease: the Multi-Ethnic Study of Atherosclerosis. JThromb Haemost 2014; 12(6): 999-1005, http://dx.doi.org/10.1111/ jth. 12557.

The work is performed within research of Department of Internal Medicine №2, Clinical Immunology and Allergology named by L.T. Malaya of the Kharkiv National Medical University "Coronary artery disease in the conditions of a polymorbydity: pathogenetic aspects of development, current, diagnostics and improvement of the treatment" (№0118U000929), the term of performance is 2017-2019.

\section{Authors' contributions:}

According to the order of the Authorship.

\section{Conflict of interest:}

The Authors declare no conflict of interest.

\section{CORRESPONDING AUTHOR Olga Kadykova}

Nauky, 4, 61022 Kharkiv, Ukraine

tel: +380508115557

e-mail: kadykova.olga1985@gmail.com

Received: 28.08.2018

Accepted: 10.01 .2019 
PRACA ORYGINALNA

ORIGINAL ARTICLE

\title{
A NEW METHOD OF DIAGNOSIS OF THE HIATAL HERNIA ASSOCIATED WITH GASTROESOPHAGEAL REFLUX DISEASE
}

\author{
NOWA METODA DIAGNOSTYKI PRZEPUKLINY ROZWORU \\ PRZEŁYKOWEGO WSPÓŁWYSTĘPUJĄCEJ Z REFLUKSEM \\ ŻOŁĄDKOWO-PRZEŁYKOWYM
}

\author{
Andriy R. Stasyshyn', Mykola A. Bychkov' ${ }^{2}$, Solomiia V. Bychkova ${ }^{3}$ \\ 'DEPARTMENT OF SURGERY AND ENDOSCOPY, FACULTY OF POSTGRADUATE EDUCATION, DANYLO HALYTSKY LVIV NATIONAL MEDICAL UNIVERSITY, \\ LVIV, UKRAINE \\ ${ }^{2} 1^{\text {ST }}$ DEPARTMENT OF THERAPY AND MEDICAL DIAGNOSTICS OF THE FACULTY OF POSTGRADUATE EDUCATION, DANYLO HALYTSKY LVIV NATIONAL \\ MEDICAL UNIVERSITY, LVIV, UKRAINE \\ ${ }^{3}$ DEPARTMENT OF PHYSIOLOGY OF HUMANS AND ANIMALS OF IVAN FRANKO NATIONAL UNIVERSITY OF LVIV, LVIV, UKRAINE
}

\begin{abstract}
Introduction: Gastroesophageal reflux disease (GERD) is one of the most common gastroduodenal diseases. The relationship between the hiatal hernia and the GERD is established. It is advisable to develop an accessible non-invasive diagnostic method for this combined pathology.

The aim of the research was to estimate measuring of calcium in patients' saliva samples as simple non-invasive diagnostic method of GERD associated with the hiatal hernia. Materials and methods: The samples of saliva were obtained from 37 patients with hiatal hernia associated with GERD and 22 healthy volunteers. The content of calcium in saliva was measured using calcium-sensitive dye Arsenazo III by photometrical method at a wavelength of 590-650 nm.

Results: It has been established that in the saliva of patients with hiatal hernia, the calcium content was increased by $100.9 \%$ compared to the control group. Such a significant increase in the level of calcium in the saliva of patients with hiatal hernia may be due to the fact that the development of this pathology is a disorder of calcium homeostasis. Conclusions: It has been found that the calcium content in the saliva of patients with hiatal hernia exceeded the norm almost twice. Thus, the determination of calcium content in saliva can be used as a simple non-invasive diagnostic marker of hiatal hernia associated with GERD.
\end{abstract}

KEY WORDS: hiatal hernia; gastroesophageal reflux disease; diagnostics

Wiad Lek 2019, 72, 2, 186-188

\section{INTRODUCTION}

The problem of hiatal hernia, combined with gastroesophageal reflux disease today is considered as one of the challenging issues, as evidenced by the large number of publications, both domestic and foreign $[1,2,3,4]$. Probably the difficulty in diagnosing hiatal hernia and GERD can be explained by frequent atypical course of the disease, the presence of concomitant pathology and the absence of a "gold standard" of surveys.

The main reason for the hiatal hernia combined with GERD is a disorder in the functioning of the anti-reflux barrier, which includes: the lower esophageal sphincter, the abdominal segment of the esophagus, the esophageal hiatus, the gastrophrenic ligament, and the cardiac notch. With the severe GERD course acid damage to the esophagus leads to a decrease in its contractility and tone of the lower esophageal sphincter (LES), they do not restore after cicatrization of erosion under the influence of pharmacological therapy. Sliding hiatal hernia causes incontinence of the phrenicoesophageal apparatus and increases the diameter of the esophageal hiatus. In this case, the cardiac section of the stomach is shifted to the chest cavity through the esophageal hiatus. The mixed type hiatal hernia occurs more often than the typical paraesophageal hernia. In this case, there is a general atonia of the phrenoesophageal membrane in conjunction with its local disruprion, for this reason not only esophagogastric junction slips up through the esophageal opening, but also to a greater or lesser extent part of the stomach [2].

At present, postoperative lethality after hiatal hernia open repair surgery remains high enough $-25 \%$ [5]. The failure of the esophagogastric junction is $55-70 \%$ of the total number of complications, and the mortality from the esophagogastric bleeding is $22-34 \%$ [6]. Large and giant hiatal hernias are associated with GERD in 50-90\% and constitute a high risk of complications, such as esophagogastric ulceration and bleeding (2-10\%), metaplasia (5-20\%) and esophageal adenocarcinoma (0.5-6\%), stricture (7-25\%), perforation (0-4\%), compression of the mediastinum [7].

According to the algorithm recommended by the American Gastroenterological Association in 2008 and 2013, 
in the presence of typical GERD symptoms, endoscopy of the upper digestive tract cannot be mandatory [8]. The "golden standard" of diagnostics for a long time has been considered a daily esophageal $\mathrm{pH}$ monitoring [9]. However, the high cost, invasiveness, inconvenience during the examination which cannot be completely eliminated even if Bravo radio capsule is used, substantiate the feasibility of finding new diagnostic techniques.

The search for new morphological signs of damage to the esophageal mucosa by the gastric material continues. First, this will allow the non-erosive GERD to be distinguished from functional heartburn, and second, to control the effectiveness of therapy, including the use of proton pump inhibitors (PPIs) [9]. An electron microscopic evaluation of the esophagus mucosal biopsy material can be recommended as the primary method for detecting early esophageal changes [10]. The method has a significant advantage in controlling treatment with PPI compared to $\mathrm{pH}$-metric technique due to the possibility of direct evaluation of the lesion. However, the obstacle to widespread introduction into clinical practice is the cost of examination and the lack of special equipment in health care facilities.

Recently, much attention has been paid to the study of preepithelial defense of the esophagus mucosa from the aggressive content of reflux material. Preepithelial defense includes saliva and secretion of esophageal submucosal glands, which first come in contact with aggressive factors. Saliva plays an important role in ensuring the effective chemical clearance of the esophagus, maintaining the homeostasis of the viscoelastic gel layer of the esophageal mucosa. There is also a reflexive relationship between receptor apparatus of the esophageal mucosa and efferent nerve fibers of the salivary glands, which can be broken in the presence of GERD [11]. Previous studies have shown a statistically significant decrease in the level of ionized calcium in saliva in patients with GERD compared to healthy individuals [12]. Consequently, it is important to study the content of specific components of saliva in patients with hiatal hernia and GERD.

\section{THE AIM}

The aim of the research is to determine significance and give estimate to the non-invasive method of diagnostics of hiatal hernia associated with GERD.

\section{MATERIALS AND METHODS}

There were analysed the results of the diagnostics method of hiatal hernia associated with GERD in 37 patients who were undergoing inpatient treatment in the clinic of surgery and endoscopy of the Faculty of Postgraduate Education during 2017-2018 including 18 men and 19 women. Patients' age ranged from 23 to 71 years (the average age was $47 \pm 4.9)$. The content of calcium in saliva was measured using Arsenazo III calcium-sensitive dye photometrically at a wavelength of 590-650 $\mathrm{nm}$.

Normal values of calcium levels in human saliva are found in 22 healthy volunteers.

\section{RESULTS AND DISCUSSION}

It is known that calcium is an important electrolyte, which promotes trophic support of submucosal layer of the esophagus, stimulates the secretion of mucus and bicarbonates by superficial epithelial cells. It was shown that $\mathrm{Ca}^{2+}$ influxes through L-type $\mathrm{Ca}^{2+}$ channels have been demonstrated to play an important role in the maintenance of the lower esophagus sphincter tone $[13,14]$. Thus the reduced concentration of $\mathrm{Ca}^{2+}$ leads to disorder of the motor functions. Our previous results showed that the concentration of calcium in saliva as well as in gastric juice of patients with GERD was statistically significantly decreased [15, 16]. But it is still unknown the concentration level of this electrolyte in the saliva of the patients with combined pathology: GERD associated with hiatal hernia.

When performing esophagogastroduodenoscopy, radiographic examination of the gastro-intestinal canal with barium sulfate, computer diagnostics of the organs of the abdominal cavity, hiatus hernia was diagnosed in 37 patients, GERD in 34 patients, which amounts 91.9\%; esophagogastric bleeding in 9 patients $(24.3 \%)$; stomach ulcer and duodenal ulcer in 3 patients $(8.1 \%)$; gallstone disease in 4 patients $(10.8 \%)$; obesity in 2 patients $(5.4 \%)$. In four patients, several pathologies were detected at once.

In the saliva of the patients with hiatal hernia calcium was between 0.4 to 5.9 and the average was $2.17 \mathrm{mmol} / \mathrm{l}$. In the control group, content of calcium ranged between 0.57 to 1.72 and the average was $1.08 \mathrm{mmol} / \mathrm{l}$. Therefore it has been found that in the saliva of the patients with hiatal hernia calcium content increased compared to the control group by $100.9 \%(\mathrm{p}<0.001)$, i.e. calcium was higher almost twice than the norm. Probably, such a substantial increase in the level of calcium in saliva of patients with hiatus hernia may be due to the fact that the development of this pathology involve disorder of calcium homeostasis, but for confirmation of this hypothesis further research is needed.

Previously it was shown the concentration of calcium was statistically significantly reduced in patients with GERD [15]. Besides it was revealed the increasing the ratio of free calcium saliva and gastric juice in patients with GERD. This ratio increases with the progression of the disease, which may indicate on deep motility disorders of gastro-esophageal connection [16].

The obtained data is opposite to our previous results obtained on saliva of patients with GERD $[15,16]$. This may indicate a profound intensification of the pathology process in patients with combined pathology.

\section{CONCLUSIONS}

1. It has been found that in the saliva of patients with hiatal hernia associated with GERD, calcium content was increased in comparison with the control group by $100.9 \%(\mathrm{p}<0.001)$.

2. Thus, estimation of calcium content in saliva can be used as a simple non-invasive diagnostic marker of hiatal hernia associated with GERD. 


\section{REFERENCES}

1. Bychkov M.A.,Stasyshyn A.R. Analiz rezul'tativ videolaparoskopichnykh antyreflyuksnykh operatsiy u patsiyentiv z hastroezofaheal'noyu reflyuksnoyu khvoroboyu [Analysis of the results of video-laparoscopic antireflux operations in patients with gastroesophageal reflux disease]. Actual problems of modern medicine. Bulletin of the Ukrainian Medical Stomatological Academy. 2013; 13 (4): 4-6. (In Ukrainian).

2. Gubergits N.B., Lukashevich G.M., Golubova 0.A. Gryzhi pishchevodnogo otverstviya diafragmy: sovremennyye predstavleniya o patogeneze i lechenii [Hernia of the esophageal cavity of the diaphragm: contemporary ideas about pathogenesis and treatment]. Modern gastroenterology. 2012; 3 (65): 105-113. (In Russian).

3. Matviychuk B.0., Guraevsky A.A., Stasyshyn A.R. et al. Khirurhichni aspekty likuvannya khvorykh iz hryzhamy stravokhidnoho otvoru diafrahmy ta hastroezofaheal'noyu reflyuksnoyu khvoroboyu [Surgical aspects of treatment of patients with hernia of the diaphragmatic esophagus and gastroesophageal reflux disease]. Achievements in Biology and Medicine. 2015; 1: 90-93. (In Ukrainian).

4. Kohn G.P., Price R.R., DeMeester S.R. et al. The guidelines for the management of hiatal hernia. Practice / Clinical Guidelines published by the Society of American Gastrointestinal and Endoscopic 1 (25) 2015 93 Surgeons (SAGES). Surgical endoscopy. 2013; 27 (12): 4409-4428.

5. Tovkach Yu.V. Suchasni tekhnolohiyi v khirurhichnomu likuvanni hastroezofaheal'noyi reflyuksnoyi khvoroby [Modern technologies in surgical treatment of gastroesophageal reflux disease]. Clinical and Experimental Pathology. 2013; 1 (43): 194-196. (In Ukrainian).

6. Reva V.B. Topohrafo-anatomichne obgruntuvannya plastyky diafrahmy z pryvodu diafrahmal'nykh hryzh [Topographic and anatomical substantiation of diaphragm plastics for diaphragmatic hernias]. Clinical anatomy and operative surgery. 2003; 2(1): 41-45. (In Ukrainian).

7. Stefanidis D., Hope W.W., Kohn G.P. Guidelines for surgical treatment of gastroesophageal reflux disease. Surg. Endosc. 2010; 24 (11):2647-2669.

8. ChernyavskyV.V. Ratsional'noye vedeniye patsiyentovs gastroezofageal'noy reflyuksnoy bolezn'yu i perspektivy izlecheniya [Rational management of patients with gastroesophageal reflux disease and cure prospects]. Modern gastroenterology. 2014; 5(79): 101-106. (In Russian).

9. ShipulinV.P., ChernyavskyV.V., KupchikL.M. Retsidivy gastroezofageal'noy reflyuksnoy bolezni: vozmozhnyye puti resheniya problem [Relapse of gastroesophageal reflux disease: possible solutions to problems]. Modern gastroenterology. 2011; 4(60): 107-111. (In Russian).

10. Bychkov M.A., Bychkova S.V., Shvydkiy Y.B. Ul'trastrukturni zminy slyzovoyi obolonky stravokhodu u patsiyentiv, yaki tryvalo zastosovuyut' nesteroyidni protyzapal'ni preparaty [Ultrastructural changes in the esophageal mucosa in patients who continued to use non-steroidal anti-inflammatory drugs]. Ukr. medical journal. 2011; 4(84): 114-115. (In Ukrainian).
11. Dorofeev A.E., Afanasyev M.V., Rassokhina 0.A. Nekotoryye mekhanizmy ezofagoprotektsii u bol'nykh gastroezofageal'noy reflyuksnoy bolezn'yu i ikh korrektsiya [Some mechanisms of esophagoprotection in patients with gastroesophageal reflux disease and their correction]. Modern gastroenterology. 2011; 1(57): 78-83. (In Russian).

12. Bychkov M.A., Bychkova S.V., Bychkov Y.A. Osoblyvosti vmistu kal'tsiyu u slyni khvorykh na hastroezofaheal'nu reflyuksnu khvorobu [Features of the calcium content in the saliva of patients with gastroesophageal reflux disease]. Modern gastroenterology. 2013; 6(74): 38-42. (In Ukrainian).

13. Takahara Akira, Nozaki Shuhei, Ishiguro Akane et al. Selectivity of Ca2+ channel blockers for dilator actions on the isolated lower esophageal sphincter and aorta from rats. Journal of Pharmacological Sciences. 2018; 137(1): 98-100.

14. Asaoka Daisuke, Nagahara Akihito, Hojo Mariko et al. Association of medications for lifestyle-related diseases with reflux esophagitis. Ther Clin Risk Manag. 2016; 12: 1507-1515.

15. Bychkov M.A. Osoblyvosti vmistu kal'tsiyu u shlunkovomu soku u khvorykh na hastroezofaheal'nu reflyuksnu khvorobu [Gastric juice calcium content in patients with gastroesophageal reflux disease]. Lik Sprava. 2014; 11:142-6. (In Ukrainian).

16. Bychkov M.A., Yakhnitska M.M. Osoblyvosti obminu kal'tsiyu slyny u patsiyentiv z hastroezofaheal'noyu reflyuksnoyu khvoroboyu [Features of exchange of calcium saliva in patients with gastroesophageal reflux disease]. Wiad Lek. 2018; 71 (3 pt 1): 561-563. (In Ukrainian).

\section{Authors' contributions:}

According to the order of the Authorship.

Conflict of interest:

The Authors declare no conflict of interest.

\section{CORRESPONDING AUTHOR Andriy Stasyshyn}

Department of Surgery and Endoscopy

Faculty of Postgraduate Education

Danylo Halytsky Lviv National Medical University

9, Mykolaychuka Str., 79059, Lviv, Ukraine

tel: +380637208429

e-mail: astasyshyn@i.ua

Received: 23.09 .2018

Accepted: 18.01.2019 
PRACA ORYGINALNA

ORIGINAL ARTICLE

\title{
ANALYSIS OF THE STATE OF NITRATE POLLUTION OF AQUIFER OF KHARKIV REGION ACCORDING TO LABORATORY TESTS
}

\section{ANALIZA STANU ZANIECZYSZCZENIA AZOTANAMI WARSTW WODONOŚNYCH W OBWODZIE CHARKOWSKIM NA PODSTAWIE WYNIKÓW BADAŃ LABORATORYJNYCH}

\author{
Mykola I. Lytvynenko, Olha I. Zalyubovska, Volodymyr O. Korobchanski, Tetiana I. Tiupka, Viktor V. Zlenko, Yuliia N. Avidzba \\ KHARKIV NATIONAL MEDICAL UNIVERSITY, KHARKIV, UKRAINE
}

\begin{abstract}
ABSRACT
Introbuction: The scientific-methodical substantiation of measures on supplying the population with drinking water of guaranteed quality is one of the main factors of sanitary and epidemiological welfare of the population of the region.

The aim: The aim of this work is the analysis of the state of nitrate pollution of sources of drinking water supply in Kharkiv region

Materials and methods: Studies of drinking water were conducted and evaluated according to the requirements of current standards

Results: In recent years in the area there has been a tendency of deterioration of the quality of drinking water from decentralized water supply facilities (wells and capping sources) Conclusions: The percentage of drinking water samples with exceeding the established standards on sanitary-chemical indicators of the objects of centralized water supply in recent years is on the average $15 \%$, and it is $30 \%$ for the facilities of decentralized water supply.
\end{abstract}

KEY WORDS: drinking water, laboratory tests, water nitrate methemoglobinemia

Wiad Lek 2019, 72, 2, 189-192

\section{INTRODUCTION}

The scientific-methodical substantiation of measures on supplying the population with drinking water of guaranteed quality is one of the main factors of sanitary and epidemiological welfare of the population of the region. The problem of providing the population with quality drinking water in Kharkiv region is urgent and sharp enough. $[4,7,8]$

The surface water resources of Kharkiv region are represented by rivers (867), lakes (583), reservoirs (56), rates (2538) and the Dnipro-Donbas channel. One of the peculiarities of water resources is that the rivers, which serve as the main sources of water supply, are also used as sewage receivers. Centralized water supply is provided to only $24 \%$ of rural settlements (the rest is $76 \%$, which is 1286 rural settlements which receive drinking water from decentralized sources). [5]

In the vast majority, not the whole territory of the settlement of rural is provided with centralized water supply, but only its central part.

The residents of the area use water for drinking from more than 5,000 wells of public use and from more than 40 thousand individual wells. The water taken from the considerable part of them does not meet the regulatory requirements for sanitary-chemical indicators. [6]

In our scientific work the laboratory tests of water on sanitary-chemical indicators from sources of centralized and decentralized drinking water supply have been conducted and the data of laboratory researches of the experts of the state sanitary and epidemiological service and Kharkiv regional laboratory center of the $\mathrm{MOH}$ of Ukraine for the past ten years for the analysis of pollution of aquifer of Kharkiv region with nitrates has been analyzed. The purpose of the article is the analysis of the state of nitrate pollution of the sources of drinking water supply in Kharkiv region for the scientific substantiation of measures to prevent the outbreak of water-nitrate methemoglobinemia.

The first who described the cases of water-nitrate methemoglobinemia in the 50s of the previous century were American scientists, doctors S.Comley and K.Walton. At that time, 278 cases were registered, 39 of which were fatal.

In recent years, according to the literature in various countries around the world, more than 1000 cases have been registered, more than 100 of which have been fatal. For example, in the Czech Republic - 115 cases. According to the Water Framework Directive EU, 2000, the water monitoring for nitrate is required in the community [1].

Nitrates are not methemoglobinemia makers, but by doing the digestive tract with water, under the influence of the intestinal microflora, they are restored into nitrite. The latest enter the bloodstream and block hemoglobin through the formation of methemoglobin $(\mathrm{MtHb})$, which is not capable of entering into the reversible reaction with oxygen and 
carrying it. If the amount of methemoglobin exceeds 50\% of the total amount of hemoglobin, the organism may die from hypoxia of the central nervous system. In all the above cases with the sick infants, the adults remained healthy. It turned out that in their blood methemoglobin does not accumulate due to the destruction of red blood cells methemoglobinemia, so there is a rapid recovery of hemoglobin. The kids, especially of the first year of life, were noticed to have a shortage of methemoglobin reductase, which leads to the accumulation of methemoglobin. That is why, the younger the child, the more severe the disease. [2,3]

\section{THE AIM}

The aim of this work is the analysis of the state of nitrate pollution of sources of drinking water supply in Kharkiv region.

Analysis of the sanitary and epidemic situation that has developed in the region shows that the use of drinking water from centralized and non-centralized sources of water supply can be a risk factor for public health. Microbial, in particular viral, pollution of drinking water can cause an outbreak of viral hepatitis A, for which the water factor of transmission of viral infection is decisive. Non-compliance of drinking water quality with regulatory requirements for sanitary and chemical indicators is one of the reasons for the spread of diseases of non-infectious etiology: water-nitrate methemoglobinemia (excess water nitrates), urolithiasis and cholelithiasis (excess water mineral salts), cardiovascular disease (hard water), diseases of the gastrointestinal tract (excess water sulfates), etc.

The article analyzes the morbidity of the population of Kharkiv region by water-nitrate methemoglobinemia. The discrepancy between the drinking water quality and the regulatory requirements for sanitary-chemical indicators is one of the reasons for the distribution of water and nitrate methemoglobinemia (the excess of nitrates in water).

\section{MATERIALS AND METHODS}

Studies of drinking water were conducted and evaluated according to the requirements of DSTU 4808:2007 "Sources of centralized drinking water supply. Hygienic and ecological requirements to water quality and rules of selection", DSanPin 2.2.4-171-10 "Hygienic requirements to drinking water intended for human consumption", the sanitary rules and standards of surface water protection from pollution" (SanPiN4630-88), State sanitary rules of planning and development of human settlements, approved by the order of the Ministry of Health of Ukraine dated June 19, 1996 No. 173, GOST 17.1.5.02-80 "Protection of nature. Hydrosphere Hygienic requirements for zones of recreation of water objects " an information sheet on scientific (scientific and technical) products intended for practical application in the field of healthcare "Method of assessment of the degree of medical and ecological stress in the area of the location of the water recreational zone" No. 76 - 2016

\section{RESULTS AND DISCUSSION}

It has been established, that for the last 10 years in drinking water from objects of centralized water supply, the standards for the sanitary-chemical indicators have been exceeded at the level of $15 \%$.

It has been determined that the excess of nitrate content in drinking water from centralized sources of water supply is almost not detected (less than 1\%).

In recent years in the area there has been a tendency of deterioration of the quality of drinking water from decentralized water supply facilities (wells and capping sources) as according to sanitary and chemical indicators (exceeding the standards from $38,0 \%$ to $45,0 \%$ ).

High concentrations of nitrates have been detected in $30 \%$ of samples taken from drinking water sources of decentralized water supply.

The own research has found that the most polluted nitrates are public wells located on the territory of small settlements (towns and villages of urban type) in the water of which according to the laboratory studies the excess content of nitrates was 3-5 times.

Along with nitrate pollution of water wells established exceeding the established standards of iron up to 1015 times, suspended solids and chromaticity up to 10 times, sulfates -2 times.

In addition, it was determined that the levels of bacterial contamination of water of these objects also tend to increase.

These wells are in poor sanitary conditions. The water from these wells is practically not used by the population for drinking purposes. But there is a risk of ingress of contaminated water to groundwater in individual wells of inhabitants of the region.

The main reasons for the poor quality of water are the composition of natural waters, their lack of protection from pollution, stagnation due to insufficient analysis of spring water, the penetration of pollution with surface runoff, a significant anthropogenic load on the territory of settlements, as well as unauthorized and chaotic arrangement of sources of non-centralized water supply.

The general disadvantages in the operation of wells include poor technical condition, lack of annual cleaning and disinfection.

One of the probable causes of pollution of the aquifer is non-compliance and lack of sanitary protection zones of sources of centralized drinking water supply.

Due to the high content of nitrates in well water in the districts of the region, the cases of poisoning by nitrates (water-nitrate methemoglobinemia) among the children under the age of 3 years are constantly recorded. 40 cases of poisoning of children by nitrates were registered in the region from 2006 to 2017. The water for feeding these children was taken from the individual wells and the wells for public use, where the content of nitrates exceeded the statutory rate in 3-8 times (Fig. 1).

As indicated in the graph, the number of cases of poisoning with nitrates in the Kharkiv region tends to decrease. In order to prevent water-nitrate methemoglobinemia in children, the Department of Health of the Kharkiv Regional 


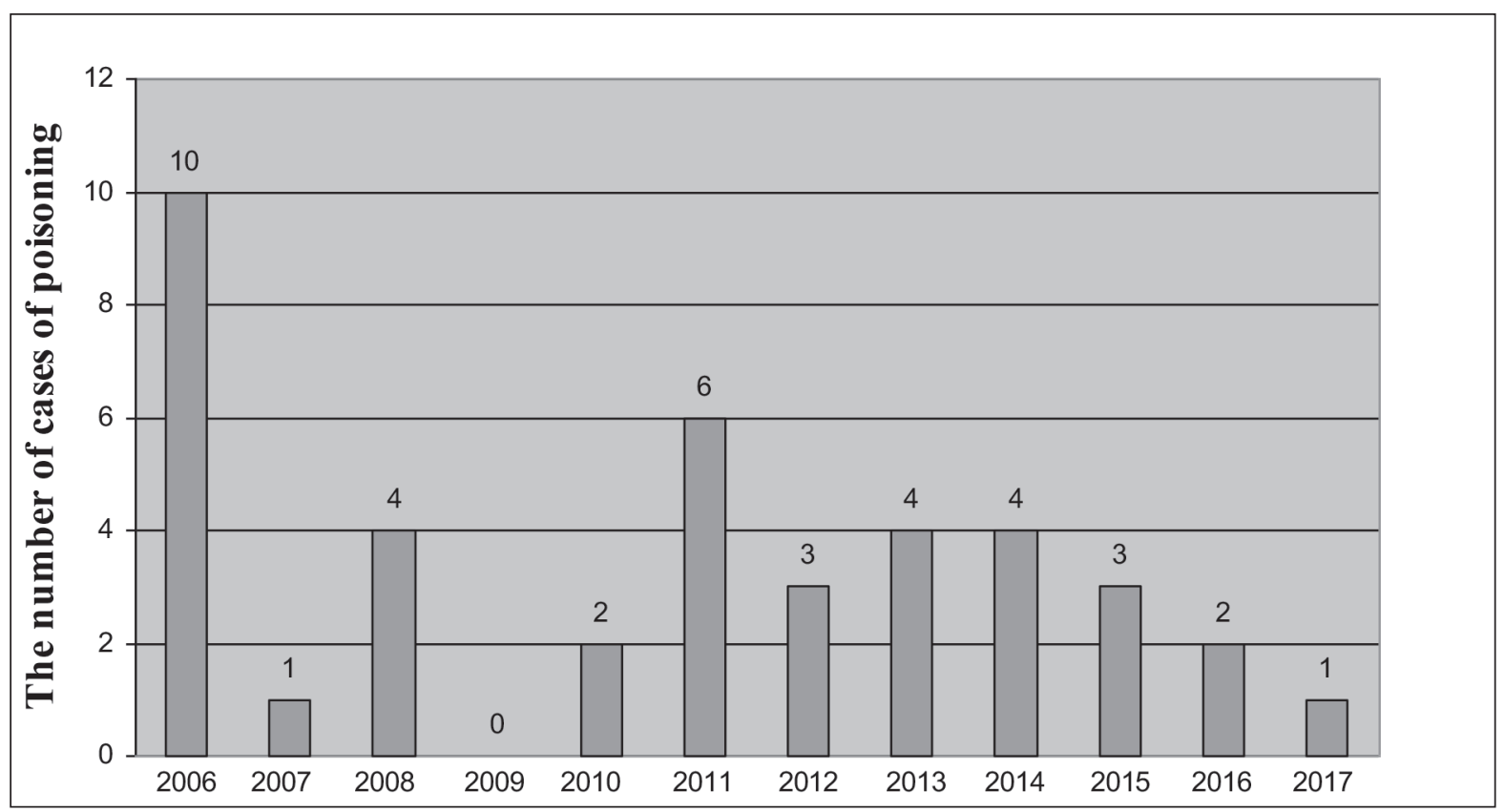

Fig. 1. Cases of nitrate poisoning (water-nitrate methempglobinemia) among the children under the age of 3 years in Kharkiv region for the period $2006-2017$.

State Administration issued an appropriate order in which the chief doctors of the central district and city hospitals provide for the systematic carrying out of women's consultations by medical doctors, general outpatient clinics - family medicine for explanatory work on the inadmissibility of using water from the wells and cupolas for the preparation of baby food; offer pregnant women in the third trimester of pregnancy drinking water from individual and public wells beforehand to study its nitrogen content.

\section{CONCLUSIONS}

1. The percentage of drinking water samples on sanitary-chemical indicators of the objects of centralized water supply in recent years is on the average $15 \%$, and it is $40 \%$ for the facilities of decentralized water supply.

2. It has been found that in drinking water taken from centralized sources of water supply, the excess of nitrate content is almost not detected (less than 1\%), and high concentrations of nitrates are detected in $40 \%$ of samples taken from the sources of decentralized water supply.

3. 40 cases of poisoning of children by nitrates have been registered in the region for the last 12 years.

4. The unsatisfactory technical conditions, the lack of annual cleaning and disinfection should be classified as some of general disadvantages in the operation of wells.

5. To prevent the occurrence of diseases of children under the age of 3 years on the water-nitrate methemoglobinemia, the scientists of Kharkiv national medical university constantly provide recommendations concerning the non-use of water from wells and natural sources for infant feeding, as well as the need to implement continuous monitoring of the water sources of decentralized drinking water supply.
6. In order to improve the sanitary and ecological state of surface reservoirs, the scientists of Kharkiv national medical university have developed and implemented a set of preventive measures, the main of which are:

- conducting a thorough analysis of the causes of deterioration or improvement of the quality of water of open water bodies by the scientists;

- scientific substantiation of proposals for the implementation of measures to stop discharges of insufficiently cleaned and untreated sewage into the reservoir, disinfection of waste water (special attention is paid to the treatment facilities located in rural settlements);

- continuous monitoring of pollution levels of surface water bodies by organoleptic, physic-chemical, microbiological indicators, as well as on salts of heavy metals, pesticides, strontium and cesium;

- to ensure work with the media on informing the state of surface water and drinking water.

7. The implementation of the above recommendations in Kharkiv region will help to reduce the incidence of water-nitrate methemoglobinemia and improve the quality of drinking water in the region.

\section{REFERENCES}

1. http://zakon.rada.gov.ua/laws/show/994_962

2. Goncharuk E. Communal hygiene. Health, 2006;792.

3. Datsenko I. Preventive medicine. Health, 2004;792.

4. Rybalova 0., H. Korobkova, A. Kozlovska Analysis of the ecological state of the river Siversky Donets in the boundaries of Kharkiv region. Collection of scientific articles of the IX International Scientific and Practical Conference Ecological safety: Problems and Solutions. Kharkiv, 2013;1:25-27.

5. Report on the state of the environment in Kharkiv region for 2016. State Department of Environmental Protection in Kharkiv region, 2017;354. 
6. Ecological atlas of the Kharkiv region State administration. State administration of environmental protection in the Kharkiv region, 2005;80.

7. Lytvynenko M. Ecological and hygienic substantiation of optimization of the regional system of recreational use of reservoirs: author's abstract. dis for obtaining sciences. Degree Candidate medical Sciences: special 14.02.01 «Hygiene and professional pathology», Kharkiv, 2016;25.

8. Scherban M, Lytvynenko M., HarnikV. Comparative analysis of the status of recreational reservoirs of Kharkiv region by the results of sanitary and environmental studies. Odesa Medical Journal, 2015;6:62-66

\section{Authors' contributions:}

According to the order of the Authorship

\section{Conflict of interest:}

The Authors declare no conflict of interest.

\section{CORRESPONDING AUTHOR}

Mykola I. lytvynenko

Kharkiv national medical university

4 Nauky Avenue, Kharkiv, Ukrain

Tel.: +38096-215-11-48.

E-mail:kkld1@ukr.net

Received: 10.11 .2018

Accepted: 31.01 .2019 
PRACA ORYGINALNA

ORIGINAL ARTICLE

\title{
BIOCHEMICAL MARKERS OF CONNECTIVE TISSUE METABOLISM IN RATS' BLOOD SERUM WITH EXPERIMENTAL KNEE OSTEOARTHRITIS AND THEIR DYNAMICS DURING CONSERVATIVE TREATMENT
}

\author{
BIOCHEMICZNE MARKERY METABOLIZMU TKANKI ŁACZNEJ \\ W SUROWICY KRWI SZCZURÓW W EKSPERYMENTALNYM \\ MODELU CHOROBY ZWYRODNIENIOWEJ STAWU KOLANOWEGO \\ I ICH ZMIANY W TRAKCIE LECZENIA ZACHOWAWCZEGO
}

\author{
Kyrylo V. Makolinets', Vasyl I. Makolinets' ${ }^{2}$, Dmytro V. Morozenko ${ }^{1,2}$, Kateryna V. Gliebova'2, Svitlana I. Danylchenko ${ }^{3}$ \\ 'SYTENKO INSTITUTE SPINE AND JOINT PATHOLOGY, KHARKIV, UKRAINE \\ ${ }^{2}$ NATIONAL UNIVERSITY OF PHARMACY, KHARKIV, UKRAINE \\ ${ }_{3}^{3}$ PETRO MOHYLA BLACK SEA NATIONAL UNIVERSITY, MYKOLAIV, UKRAINE
}

\begin{abstract}
Introduction: There are many methods for diagnosis and treatment of knee joints osteoarthritis in modern orthopedics. The infrared radiation is one of the most popular and effective methods though it needs experimental substantiation on rats.

The aim: Experimental definition of the effectiveness of the proposed method of conservative treatment of knee joints osteoarthritis using sodium diclofenac, glucosamine hydrochloride and infrared laser radiation, on the basis of biochemical markers of connective tissue metabolism in rats.

Materials and methods: Experimental studies were performed on 40 white male rats. A part of rats received infrared laser radiation in addition to diclofenac sodium and glucosamine hydrochloride. Results: Using a complex of infrared laser radiation and glucosamine hydrochloride and diclofenac sodium in conservative treatment of rats with experimentally induced knee joints osteoarthritis rats after 24 days of treatment. Treatment with the above-mentioned scheme resulted in a significant reduction in the content of glycoproteins (28.5\%), chondroitin sulfates (26.1\%), alkaline phosphatase activity (32.3\%), and I and II fractions of glycosaminoglycans, namely chondroitin-6- (28.7\%) and chondroitin-4-sulfate (40.3\%). Moreover, these indicators of the studied markers approached the level of intact animals.

Conclusions: Changes in biochemical markers of connective tissue in rats during experimental knee joints osteoarthritis indicated a higher efficiency of the treatment regimen with the use of low-intensity infrared laser radiation compared with exclusively drug therapy.
\end{abstract}

KEY WORDS: knee osteoarthritis, rats, laser therapy, glucosamine hydrochloride, sodium diclofenac

Wiad Lek 2019, 72, 2, 193-197

\section{INTRODUCTION}

The modern approach to the integrated therapy of knee osteoarthritis is grounded on the recommendations of EULAR [1], built on the principles of evidence-based medicine. All approaches to the treatment of patients with knee joints osteoarthritis were divided into 4 groups: pharmacological, non-pharmacological, intra-articular and surgical. The pharmacological agents most commonly used to treat osteoarthritis of the knee joints are nonsteroidal anti-inflammatory drugs. They have the ability to reduce pain and show a pronounced anti-inflammatory effect [2]. In clinical practice, more and more clinicians are using drugs based on glucosamine hydrochloride. Its bioavailability is about $90 \%$. It has pronounced chondroprotective properties, moderate anti-inflammatory effect, and prevents the progression of degenerative processes in the joint [3].
In recent years, the attention of specialists is also attracted by the possibility of using laser therapy in the treatment of patients with knee joints osteoarthritis with severe articular syndrome. The use of laser radiation in the treatment of knee osteoarthritis provides significant anti-inflammatory and analgesic effects, accelerates blood circulation in the irradiation zone, activates metabolic processes, enhances phagocytosis, improves immunobiological reactivity of the organism and microcirculation in the synovial membrane, has an immunomodulatory effect, reduces the phenomenon of osteoporosis, and slows down the progression of bone destruction [4]. This is accompanied by changes in such biochemical markers of blood as glycoproteins and proteoglycans which reflect the state of joints connective tissue. The catabolism of these markers varies depending on the course of inflammatory and reparative processes in 
joints osteoarthritis. Thus, a rational combination of local effects and general therapeutic measures is required in the regenerative treatment of patients with osteoarthritis. In this case, the effectiveness of complex conservative treatment does not depend only on the correct choice of laser irradiation parameters, which are mainly aimed at reducing the intensity of inflammation and the elimination of pain syndrome [5].

\section{THE AIM}

The aim of the study was to experimentally define the effectiveness of the proposed method of conservative treatment of knee joints osteoarthritis using sodium diclofenac, glucosamine hydrochloride and infrared laser radiation, on the basis of biochemical markers of connective tissue metabolism in rats.

\section{MATERIALS AND METHODS}

Experimental studies were performed on 40 white male rats aged 6 months with body weight from 250 to 300 $\mathrm{g}$ of the population of the experimental and biological clinic of Sytenko Institute of Spine and Joint Pathology. Animals were kept in accordance with sanitary norms on the standard diet [6]. Experiments on rats were performed within regulations of the European Convention for the Protection of Vertebrate Animals used for experimental and other purposes [7]. Euthanasia of animals was carried out by decapitation due to the need of blood selection for the research. The research plan are approved by the Bioethics Committee of "Sytenko Institute of Spine and Joint Pathology”, Protocols № 81 of December 20, 2010.

Knee joints osteoarthritis was modeled by intramuscular administration of dexamethasone at a dose of $7 \mathrm{mg} / \mathrm{kg}$, once a week during 3 weeks. The treatment started 3 days after the last injection of dexamethasone. Experimental group consisted of 5 rats whose biochemical blood tests results had been initially evaluated after 3 weeks of knee joints osteoarthritis. A control group had 5 intact rats. Group I $(n=10)$ comprised rats with simulated knee joints osteoarthritis without further treatment. They were observed on the $10^{\text {th }}$ and $24^{\text {th }}$ days. Group II animals $(\mathrm{n}=$ 10) were treated by administering diclofenac sodium ( $8 \mathrm{mg}$ / $\mathrm{kg}$ ) and glucosamine hydrochloride (50 mg / $\mathrm{kg}$ ) orally. Drugs were injected per os with a probe. The volume of the solution was $0.5 \mathrm{ml} / 100 \mathrm{~g}$ of a rat weight. Group III animals $(n=10)$ received infrared laser irradiation at a dose of $0.3 \mathrm{~J}$ followed by oral administration of diclofenac sodium $(8 \mathrm{mg} / \mathrm{kg})$ and glucosamine hydrochloride (50 $\mathrm{mg} / \mathrm{kg})$.

Laser therapy was performed on the caudal surface of the right wool-free knee joint using the Mustang apparatus: wavelength $0.89 \mu \mathrm{m}$, pulsed power 7-8 $\mathrm{W}$, pulse frequency $3000 \mathrm{~Hz}$, the session duration was 3 minutes 42 seconds. Laser sessions were performed daily during 10 days (10 sessions). To evaluate the treatment efficacy of the proposed schemes we carried out a biochemical study of rats' blood treated with different regimens on the $10^{\text {th }}$ and $24^{\text {th }}$ days of treatment. The content of glycoproteins in blood serum of rats was determined by the method modified by O. P. Stenberg and Ya. N. Dotsenko; chondroitin sulfates were determined by the Nemeth-Csoka method in the modification of L. I. Slutskii; glycosaminoglycans (hereinafter - GAG) and their fractions were checked by M. P. Stern with co-authors; alkaline phosphatase activity was measured by the kinetic method $[8,9]$. Statistical data analysis was carried out using software packages Microsoft Excel XP and Statsoft Statistica 10.0. Comparison of patient groups was performed according to the Student's parametric criterion and Wilcoxon's non-parametric criterion [10].

\section{RESULTS AND DISCUSSION}

On the $24^{\text {th }}$ day of the recovery period, after the simulating knee joints osteoarthritis, we detected an increase in the content of the connective tissue metabolism markers (glycoproteins, chondroitin sulfates) and the change in the ratio of GAG fractions in blood serum of rats. It is known that virtually all GAG cartilage matrices, except for hyaluronan, are sulfated. They are chondroitin sulfate and keratan sulfate. The total concentration of GAG in the matrix of articular cartilage reaches $10 \mathrm{~g} / 100 \mathrm{~g}$ of dry matter, which during the development of inflammatory-destructive processes in the cartilage of the knee joints can lead to increasing of their concentration in blood serum. The concentration of glycoproteins in blood serum of rats with experimental knee joints osteoarthritis increased by $37.0 \%$ compared to the indicator in the intact group of animals. In our opinion, this is due to the inflammatory process in the capsule of the affected joints. Cartilage tissue of the joints is rich in glycoproteins, which, in case of osteoarthritis, causes an increase in their expression by chondrocytes. These include fibronectin, tenascine-C, clusterin, proteoglycan-binding protein and other glycoproteins involved in cartilage catabolism in inflammatory-degradation processes in the joints during inflammation. The destruction of cartilaginous tissue was confirmed by increase in the total chondroitin sulfates concentration by $32.9 \%$, as well as GAG fraction I increase by $32.2 \%$, GAG fraction II (chondroitin-6 and chondroitin-4-sulfates) increase by $79.8 \%$, which are the parts of the cartilage and bone tissue of the affected joints (Table I).

The obtained data show that the above-mentioned biochemical parameters fully reflect the processes occurring in the tissues of the affected joint. This is the reason for using the above-mentioned biochemical markers for laboratory control of the effectiveness of treatment.

In the dynamics of treatment after 10 days of therapy, the content of glycoproteins decreased by $11.5 \%$ in the group of rats treated without laser radiation and by $23.7 \%$ in the blood of rats treated with laser therapy compared to the group of animals without medical treatment. It was also found that the content of blood serum glycoproteins in rats treated with diclofenac, glucosamine hydrochloride in combination with laser therapy was lower by $13.8 \%$ 
BIOCHEMICAL MARKERS OF CONNECTIVE TISSUE METABOLISM IN RATS' BLOOD SERUM WITH EXPERIMENTAL KNEE...

Table I. Biochemical markers of connective tissue metabolism in rat's blood serum on 24 day after modeling of knee osteoarthritis

\begin{tabular}{ccc}
\hline Biochemical markers & Intact group, $\mathbf{n = 5}$ & Experimental group, $\mathbf{n}=\mathbf{5}$ \\
\hline Glycoproteins, $\mathrm{g} / \mathrm{l}$ & $0.94 \pm 0.03$ & $1.37 \pm 0.01^{* * *}$ \\
\hline Chondroitin sulfates, g/l & $0.316 \pm 0.019$ & $0.420 \pm 0.019^{*}$ \\
\hline Total GAG, $\mathrm{g} / \mathrm{I}$ & $0.252 \pm 0.006$ & $0.369 \pm 0.012^{* * *}$ \\
\hline I fraction GAG, $\mathrm{g} / \mathrm{l}$ & $0.152 \pm 0,003$ & $0.201 \pm 0.005^{* *}$ \\
\hline II fraction GAG, $\mathrm{g} / \mathrm{I}$ & $0.084 \pm 0.003$ & $0.151 \pm 0.010^{* *}$ \\
\hline III fraction GAG, g/l & $0.016 \pm 0.009$ & $0.017 \pm 0.004$ \\
\hline Alkaline phosphatase, U/L & $25.1 \pm 0.65$ & $36.7 \pm 0.40^{* * *}$
\end{tabular}

Notes: ${ }^{*}-p<0.05 ;^{* *}-p<0.01 ;{ }^{* * *}-p<0.001$ in comparison with the intact group

Table II. Dynamics of biochemical markers of connective tissue metabolism in rat's blood serum with modeling of knee osteoarthritis after 10 days of treatment (Me, $25 \%-75 \%)$

\begin{tabular}{|c|c|c|c|}
\hline \multirow[b]{2}{*}{ Biochemical markers } & \multicolumn{3}{|c|}{ Dynamic of biochemical markers } \\
\hline & $\begin{array}{c}\text { Group I } \\
\text { Recovery without treatment, } \\
n=5\end{array}$ & $\begin{array}{c}\text { Group II } \\
\text { Treatment without laser, } \\
n=5\end{array}$ & $\begin{array}{l}\text { Group III } \\
\text { Laser treatment, } \\
n=5\end{array}$ \\
\hline Glycoproteins, g/l & $\begin{array}{c}1.39 \\
1.38-1.42\end{array}$ & $\begin{array}{c}1.23 * \\
1.20-1.25\end{array}$ & $\begin{array}{l}1.06 * * \Delta \Delta \\
1.02-1.09\end{array}$ \\
\hline Chondroitin sulfates, g/l & $\begin{array}{c}0.435 \\
0.423-0.441\end{array}$ & $\begin{array}{c}0.398^{*} \\
0.395-0.401\end{array}$ & $\begin{array}{c}0.341 * * * \Delta \\
0.326-0.345\end{array}$ \\
\hline Total GAG, g/l & $\begin{array}{c}0.358 \\
0.336-0,363\end{array}$ & $\begin{array}{c}0.284^{*} \\
0.252-0.306\end{array}$ & $\begin{array}{c}0.271^{* *} \\
0.246-0.271\end{array}$ \\
\hline I fraction GAG, g/l & $\begin{array}{c}0.198 \\
0.194-0.203\end{array}$ & $\begin{array}{c}0.152 \\
0.143-0,174\end{array}$ & $\begin{array}{c}0.158^{*} \\
0.153-0.164\end{array}$ \\
\hline II fraction GAG, g/l & $\begin{array}{c}0.142 \\
0.142-0.143\end{array}$ & $\begin{array}{c}0.103^{*} \\
0.102-0.118\end{array}$ & $\begin{array}{c}0.094^{*} \\
0.088-0.109\end{array}$ \\
\hline III fraction GAG, g/l & $\begin{array}{c}0.014 \\
0.013-0.022\end{array}$ & $\begin{array}{c}0.018 \\
0.012-0.018\end{array}$ & $\begin{array}{c}0.016 \\
0.016-0.017\end{array}$ \\
\hline Alkaline phosphatase, $\mathrm{U} / \mathrm{L}$ & $\begin{array}{c}36.50 \\
34.70-38.00\end{array}$ & $\begin{array}{c}33.40 \\
31.50-35.30\end{array}$ & $\begin{array}{c}25.30^{* *} \\
24.60-27.60\end{array}$ \\
\hline
\end{tabular}

Notes: ${ }^{*}-p<0.05 ;^{* *}-p<0.01 ;{ }^{* * *}-p<0.001$ in comparison with the I group; $\triangle-p<0.05 ; \triangle \triangle-p<0.01$ in comparison with the II and III groups

compared with the group of animals treated with drugs only. This is evidently due to the use of low-intensity laser radiation, which positively affects the tissues of the affected joints in knee osteoarthritis, further reducing the intensity of inflammation in the synovial membranes, edema, and promoting the regeneration of articular cartilage. Reduced catabolism of proteoglycans of articular cartilage caused a positive dynamics of chondroitin sulfate content in rats' blood with experimental knee joints osteoarthritis. In the group of animals treated without laser therapy, the content of total chondroitin sulfates was reduced by only $8.5 \%$ compared with the group without treatment. In the third group of animals after additional application of laser therapy, the decrease in the content of total chondroitin sulfates was $21.6 \%$, which confirms the higher efficiency treatment regimens using laser therapy (Table II).

Moreover, rats treated with diclofenac and glucosamine hydrochloride with using laser therapy showed positive dynamics in the content of GAG fractions in blood serum. Lower values of I and II GAG fractions (chondroitin- 6 and chondroitin-4-sulfate) were noted in this group of rats on the $10^{\text {th }}$ day immediately after treatment, compared to the group II animals treated without laser therapy. There was also a decrease in serum alkaline phosphatase activity in the group of rats treated with low-intensity laser radiation. Perhaps it was due to bone isoenzymes, indicating a slowing down of destructive processes in the subchondral bone of the joints in osteoarthritis. The content of total calcium in all animal groups remained unchanged compared to intact animals.

A study of connective tissue biochemical markers in blood serum of rats was carried out after 24 days of the medical treatment course to assess the long-term results of rats' treatment by different methods of therapy. In the blood serum of rats treated with a combination of laser therapy and medical preparations, there was a significant decrease in the content of glycoproteins (28.5\%), chondroitin sulfates (26.1\%), alkaline phosphatase activity (32.3\%), and I and II GAG fractions (chondroitin-6 (28.7\%) and chondroitin-4-sulfate (40.3\%)) 24 days after the treatment (Table III). 
Kyrylo V. Makolinets et al.

Table III. Dynamics of biochemical markers of connective tissue metabolism in rat's blood serum with modeling of knee osteoarthritis after 24 days of treatment $(\mathrm{Me}, 25 \%-75 \%)$

\begin{tabular}{|c|c|c|c|}
\hline \multirow[b]{2}{*}{ Biochemical markers } & \multicolumn{3}{|c|}{ Dynamic of biochemical markers } \\
\hline & $\begin{array}{c}\text { Group I } \\
\text { Recovery without treatment, } \\
\mathrm{n}=5\end{array}$ & $\begin{array}{c}\text { Group II } \\
\text { Treatment without laser, } \\
\mathrm{n}=5\end{array}$ & $\begin{array}{c}\text { Group III } \\
\text { Laser treatment, } \\
n=5\end{array}$ \\
\hline Glycoproteins, g/l & $\begin{array}{c}1.37 \\
1.36-1.41 \\
\end{array}$ & $\begin{array}{c}1.12^{*} \\
1.07-1.25 \\
\end{array}$ & $\begin{array}{c}0.98 * * \\
1.02-1.09 \\
\end{array}$ \\
\hline Chondroitin sulfates, g/l & $\begin{array}{c}0.452 \\
0.435-0.462\end{array}$ & $\begin{array}{c}0.364 * \\
0,352-0,387\end{array}$ & $\begin{array}{c}0.334^{* * *} \\
0.321-0.343\end{array}$ \\
\hline Total GAG, g/l & $\begin{array}{c}0.364 \\
0.342-0.373\end{array}$ & $\begin{array}{c}0.267 * \\
0.252-0.286\end{array}$ & $\begin{array}{c}0.246 * * \\
0,238-0,267\end{array}$ \\
\hline I fraction GAG, g/l & $\begin{array}{c}0.202 \\
0.197-0.206\end{array}$ & $\begin{array}{c}0.152 \\
0.137-0.151\end{array}$ & $\begin{array}{c}0.144 * \\
0.153-0.164\end{array}$ \\
\hline II fraction GAG, g/l & $\begin{array}{c}0.144 \\
0.140-0.152\end{array}$ & $\begin{array}{c}0.098 * \\
0.095-0.106\end{array}$ & $\begin{array}{c}0.086 * \\
0.088-0.109\end{array}$ \\
\hline III fraction GAG, $\mathrm{g} / \mathrm{l}$ & $\begin{array}{c}0.018 \\
0.014-0.024\end{array}$ & $\begin{array}{c}0.017 \\
0.013-0,019\end{array}$ & $\begin{array}{c}0.016 \\
0.016-0.017\end{array}$ \\
\hline Alkaline phosphatase, $\mathrm{U} / \mathrm{L}$ & $\begin{array}{c}36,80 \\
35.50-38,00\end{array}$ & $\begin{array}{c}29.40 \\
28.20-30.10\end{array}$ & $\begin{array}{c}24.9 * * \\
24.3-28.00\end{array}$ \\
\hline
\end{tabular}

Notes: ${ }^{*}-p<0.05 ;^{* *}-p<0.01 ;{ }^{* * *}-p<0.001$ in comparison with the I group

We also noted that group III animals had approximately the same values of biochemical markers as intact animals, which is due to the greater effectiveness of the therapeutic technique with the use of the above-mentioned complex in comparison with using only drugs.

In our opinion, the reason for such positive changes is precisely the action of laser beams, which contribute to the increase of local reactivity around the articular tissues, contribute to the reduction of the inflammatory process in the synovial membranes, and also create favorable conditions for the regeneration of articular cartilage.

It is known that in the development of knee joint inflammation, the positive effect of laser irradiation can slow down the progression of the disease, reduce the duration of patients' recovery with the early stages of knee joints osteoarthritis, and lead to a decrease in the biochemical markers of proteoglycans catabolism in cartilage tissue. Thus, during the analysis of the results of biochemical studies of connective tissue markers in the blood of experimental animals, it was found out that the decrease in the activity of the inflammatory processes and the destruction of the cartilage tissue of the affected joints more actively occurred in the group of rats where the course of laser therapy and drugs was applied.

\section{CONCLUSIONS}

Thus, changes in biochemical markers of connective tissue status in rats during experimental knee joints osteoarthritis indicated a higher efficiency of the treatment regimen with the use of low-intensity infrared laser radiation compared with drug only therapy. We used the infrared laser radiation complex and glucosamine hydrochloride and sodium diclofenac in conservative treatment of rats with experimentally induced knee joints osteoarthritis after 24 days of treatment according to the above-mentioned scheme. As a result, we observed a significant decrease in the content of glycoproteins (28.5\%), chondroitin sulfates (26.1\%), alkaline phosphatase activity (32.3\%), as well as II GAG fractions, namely chondroitin-6 (28.7\%) and chondroitin-4-sulfate (40.3\%) and I. Moreover, the studied markers indicators approached the level of the same indicators in the intact animals.

The obtained results of the experimental study on rats showed that the use of laser therapy in the early stages of knee joints osteoarthritis can significantly improve the clinical condition of patients, and be effective in the treatment of knee joints osteoarthritis on early stages.

\section{REFERENCES}

1. Jordan KM, Arden NK, Doherty M, Bannwarth B, Bijlsma JW, Dieppe $P$, et al. EULAR Recommendation 2003: UN evidence laxer approach to the management of knee osteoarthritis: report of a Talk Force of the Standing Committee bur international Clinical Studies Includiry Therapeutic Trials (ESCISIT). Annals Rheumatology. 2003; 62(12): $1145-55$.

2. Niempoog S, Siriarchavatana P, Kajsongkram T. The efficacy of Plygersic gel for use in the treatment of osteoarthritis of the knee. J Med Assoc Thai. 2012; 10: 113-9.

3. Korzh MO, Khvisyuk OM, Dyedukh NV, y dr. Osteoartroz. Konservatyvna terapiya [0steoarthritis Conservative therapy]. Kharkov: Zolotye stranytsy; 2007.424 p. (In Ukrainian)

4. Vasil'yeva LV, Latysheva MN. Primeneniye magnitolazeroterapiya v kompleksnom lechenii bol'nykh osteoartrozom [The use of magnetic laser therapy in the complex treatment of patients with osteoarthrosis]. Vestnik novykh meditsinskikh tekhnologiy. 2010; 2 (17): 169-70. (In Russian) 
5. Alghadir A, Omar MT, Al-Askar AB, Al-Muteri NK. Effect of low-level laser therapy in patients with chronic knee osteoarthritis: a single-blinded randomized clinical study. Lasers Med Sci. 2014; 29(2); 749-55.

6. Kozhem'yakin YM, Khromov OS, Filonenko SO. Naukovo-praktychni rekomendatsiyi z Utrymannya laboratornykh tvaryn ta roboty z nymy. Derzhavnyy farmakolohichniy tsentr MOZ Ukrayiny [Scientific and practical recommendations for the maintenance of laboratory animals and work with them. State Pharmacological Center of the Ministry of Health of Ukraine]. Kyiv; 2002. 155 p. (In Ukrainian)

7. European convention for the protection of vertebrate animals used for experimental and other scientific purpose: Council of Europe 18.03.1986. Strasbourg; $1986.52 \mathrm{p}$.

8. Morozenko DV, Leont'yeva FS. Metody doslidzhennya markeriv metabolizmu spoluchnoyi tkanyny u klinichniy ta eksperimental'niy medytsyny [Methods of studying the markers of connective tissue metabolism in clinical and experimental medicine]. Molodyy vchenyy. 2016; 2 (29); 168-72. (In Ukrainian)
9. Goryachkovskiy AM. Klinicheskaya biokhimiya v laboratornoy diagnostika [Clinical biochemistry in laboratory diagnostics]. Odessa: Ekologiya, 2005; 616. (In Russian).

10. Glants S. Mediko-biologicheskaya statistika [Biomedical statistics]. Per. s angl. M: Praktika; 1998. 459 p. (In Russian)

The research is a fragment of the scientific work of the Sytenko Institute of Spine and Joint Pathology for 2008-2010 "To study the influence of the complex application of low-intensity infrared laser radiation and medical preparations on the course of osteoarthritis" (State registration number 0108U000391)

\section{Authors' contributions:}

According to the order of the Authorship.

Conflict of interest:

The Authors declare no conflict of interest.

\section{CORRESPONDING AUTHOR Dmytro V. Morozenko}

Sytenko Institute of Spine and Joint Pathology 80 Pushkinskaya Street, 61000, Kharkov, Ukraine tel: +38(067)7225748

e-mail:d.moroz.vet@gmail.com

Received: 18.09 .2018

Accepted: 11.01 .2019 
PRACA ORYGINALNA

ORIGINAL ARTICLE

\title{
FORENSIC MORPHOLOGICAL SIGNS CHARACTERIZING STABILITY OF THE FEMUR, TIBIA AND FIBULA DURING EFFECT OF EXTERNAL DESTRUCTIVE LOAD
}

\section{MORFOLOGICZNE OBJAWY WYKORZYSTYWANE W KRYMINALISTYCE CHARAKTERYZUJĄCE STABILNOŚĆ KOŚCI UDOWEJ, KOŚCI STRZAŁKOWEJ ORAZ KOŚCI PISZCZELOWEJ W TRAKCIE DZIAŁANIA ZEWNĘTRZNEJ SIŁY NISZCZĄCEJ}

\author{
Ivan G. Savka \\ HIGHER STATE EDUCATIONAL ESTABLISHMENT «BUKOVINIAN STATE MEDICAL UNIVERSITY», CHERNIVTSI, UKRAINE
}

\begin{abstract}
Introduction: Fractures of the lower limb bones very often become the subject of forensic expertise when experts have to determine the mechanisms of fracture formation, make retrospective restoration of conditions of their occurrence, solve the issues concerning the possibility of their formation under certain conditions.

The aim of study is directed to investigation of morphological signs facilitating solidity of the osseous tissue of the lower limb long tubular bones, and therefore, promoting biochemical processes of their destruction in case of external traumatic impact.

Materials and methods: Expert investigations included 128 injuries of the long tubular bones of the lower limb: femoral bone -40 cases, tibia -46 , fibula -42 . Fractures of every bone were assessed by the three thirds: proximal, middle and distal. All the 29 macroscopic and 8 microscopic morphological signs of the osseous tissue were examined. Control studies were carried out on 576 specimens of the femoral bone, tibia and fibula (192 specimens of each), removed from dead males and females aged from 24 to 70 . Results: The most valuable morphological signs forming "modulus of stability" are: length of plastic deformity zones from the site of stretching and compression, deviation angle of sphenoid cracks together with the character of traumatic injury impact. An important value in this respect belongs to the square of the medullar canal, length of the biggest sphenoid crack, number of longitudinal cracks and shape of the medullar canal from the site of compression, total mineral content and the height of the biggest crest in the rupture zone. Conclusions: "Modulus of stability" of the osseous tissue of the long tubular bones of the lower limb most accurately reflects interaction of traumatic mechanical impact with the bone structures during their injuries that should be considered in forensic practice in the process of making expertise.
\end{abstract}

KEY WORDS: stability, morphological signs, osseous tissue, tubular bones, lower limb

Wiad Lek 2019, 72, 2, 198-200

\section{INTRODUCTION}

Fractures of the lower limb bones occur twice as many as fractures of the upper limb bones. They often become the subject of forensic expertise when experts have to determine the mechanisms of fracture formation, make retrospective restoration of conditions of their occurrence, solve the issues concerning the possibility of their formation under certain conditions, etc.

At the present stage of development of forensic science and practice determination of the mechanisms of fracture formation includes a comprehensive approach concerning this issue with investigation of physical properties of the osseous tissue, analysis of the regularities of deformities and destruction considering structural and geometric peculiarities of bones [1-3].

Nowadays forensic medicine experiences the lack of a clear algorithm concerning the effect of structural-functional peculiarities of certain portions of the lower limb long bones and regularities of mechanogenesis and morphogenesis of their fractures. At the same time, modern forensic practice requires a detailed study of the main structural components of the long tubular bones influencing on their stability in case of their destruction $[4,5]$.

\section{THE AIM}

The study aims at investigation of morphological signs facilitating solidity of the osseous tissue of the lower limb long tubular bones, and therefore, promoting biochemical processes of their destruction in case of external traumatic impact.

\section{MATERIALS AND METHODS}

Our expert investigations included injuries of the long tubular bones of the lower limb: femoral bone -40 cases, tibia -46 , fibula -42 . Fractures of every bone were assessed by the three thirds: proximal, middle and distal.

Metric macroscopic measurements were made by means of a caliper - directly on the bone and by means of applied 


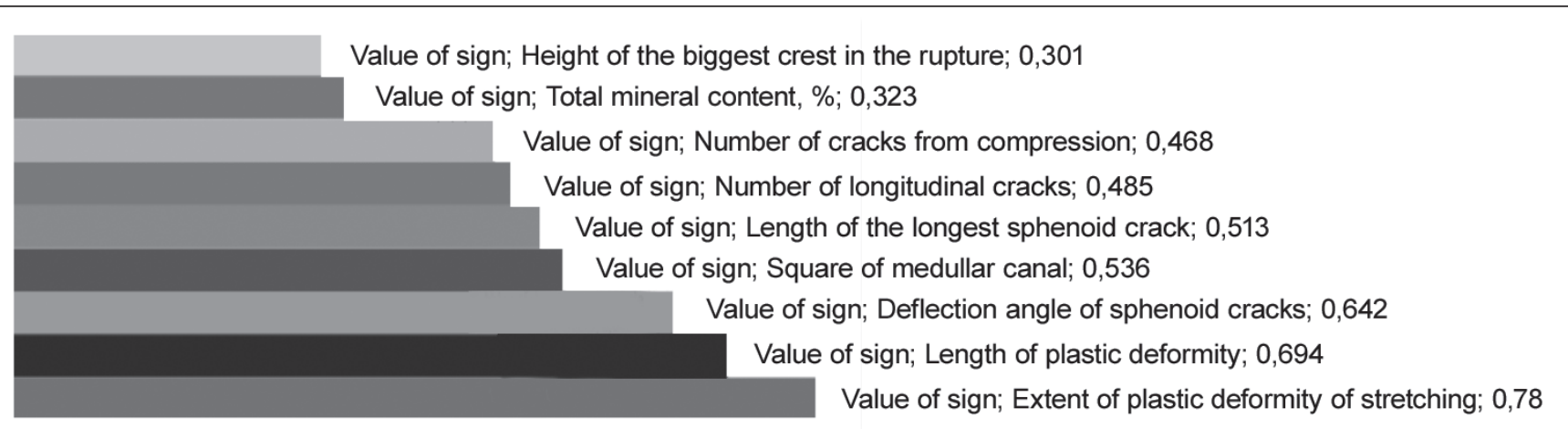

Fig. 1. A number of forensic morphological signs of "modulus of stability" of the lower limb long tubular bones and their value.

computer programs including the functions of taking linear sizes and distance between separate elements - on a digital image of a destructed bone.

Totally 29 parameters were obtained characterizing structural-functional peculiarities of the examined bone in the place of destruction, area and square of its fracture: bone circumference; longitudinal bone diameter; transverse bone diameter; longitudinal diameter of the medullar canal; transverse diameter of the medullar canal; medullar parameter in thelongitudinal direction (correlation of longitudinal diameters of the medullar canal and bone); medullar parameter in the transverse direction (correlation of transverse diameters of the medullar canal and bone); the compact substance thickness in the anterior bone sectors; the compact substance thickness in the posterior bone sectors; the compact substance thickness in the median bone sectors; the compact substance thickness in the lateral bone sectors; discontinuity coefficient concerning the bone diameter; discontinuity coefficient concerning the compact substance thickness; extent of a plastic deformity area from the side of rupture; the number of teeth in the area of rupture; the number of treelike fissures from the side of sprain; the number of longitudinal fissures from the side of sprain; the number of fissures from the medullar canal from the side of sprain; rupture area coefficient concerning the bone diameter; rupture area coefficient concerning the compact substance thickness; extent of a plastic deformity area from the side of compression; the height of the biggest crest in the rupture area; the number of $V$-shaped fissures passing from the final portions of the cone-shaped depressions in the rupture area; the number of $\mathrm{V}$-shaped fissures passing from the lateral portions of the cone-shaped depressions in the rupture area; the length of the longest V-shaped fissure; deviation angle of V-shaped fissures; the number of fissures from the medullar canal from the side of compression; the number of X-, V-shape fissures from the side of compression; the number of longitudinal fissures from the side of compression.

Examination of morphological signs of the osseous tissue on the micro-level was conducted on 576 specimens of the femoral bone, tibia and fibula (192 specimens of each), removed from dead males and females aged from 24 to 70 (the control group). $156(81,2 \%)$ specimens of every bone were taken from men and $36(18,8 \%)$ - from women. The biggest number of the examined specimens were taken from the individuals 36 60 years of age $-144(75,0 \%)$ from every bone; 24 (12,5\%) from the femoral bone, tibia and fibula were taken from the individuals 22-35 years of age and 61-74 years.
General volume of every specimen $V_{1}$ was determined by means of centrifuge tubes with marks, their mass before and after their filling with fluid (ortoxylene), centrifugation, drying, processing of the organic substance in the muffle furnace, obtaining appropriate masses $\mathrm{m} \mathrm{i} \mathrm{m}^{1}$.

The data received were processed by means of a number of physical formulas, therefore obtaining a number of volumetric-massive parameters: the volume of pores of the hard matrix and water, the volume of organic and mineral content, density of organic and mineral content of every specimen, total density and the content of mineral mass in them. The square of the medullar canal in the proximal, middle and distal portions of the femoral bone, tibia and fibula with accuracy to $0,01 \mathrm{~cm}$ was calculated as well.

In the process of the comparative analysis and generalization of the findings obtained with calculation of such statistical indices as arithmetic mean, mean arithmetic error, meansquare deviation, quartile and confidence interval with the use of frequency analysis, single-factor and multi-factor analyses of variance, the interrelations between the main characteristics of fractures and morphological structural signs of different portions of the lower limb long bones were determined.

\section{RESULTS AND DISCUSSION}

The part of the bone due to the effect of external impact is accompanied by deformity of the osseous tissue with formation of fractures, stratification, flexion and micro-crakcs. Splits and crests with dentate surface and a number of cracks in the bone are formed in the direction of force vector action.

The effect of physical forces causing bone fractures included four main groups: blunt injuries with flexion deformity, twisting, compression and effect along the axis of the limb.

Determined regularities of structural disorders of the lower limb long tubular bones in case of their injuries enabled to distribute structural-functional peculiarities of their structure and separate morphological signs of bone fractures.

All the 29 morphological parameters of fracture area and 8 volumetric-massive parameters of structural peculiarities of the examined bones were grouped into separate factors (modules).

Among others the factor is distinguished that is the most valuable and rather completely reflects interrelation of 
traumatic mechanical impact with bone structures and its injuries. The most complete and integral its characteristics will be grouping together interrelated forensic-morphological signs under the name "modulus of stability" of the bone (Fig. 1).

This factor sufficiently describes interrelation of traumatic mechanical force with bone structures and its injuries associated with "modulus of stability" of the bone. Length of plastic deformity zones from the site of stretching and compression is the most important sign in it. Deflection angle of sphenoid cracks consisting factor 3 occupies a leading position together with the character of traumatic force action. An important value in this respect belongs to the square of the medullar canal, length of the biggest sphenoid crack, number of longitudinal cracks and shape of the medullar canal from the site of compression, total mineral content and the height of the biggest crest in the rupture zone.

Thus, long bones of the lower limbs exclusively rationally meet structural requirements of the human body. Possessing a minimal weight due to their hollow tubular structure they ensure high stability to axial forces of compression [6].

Next parameters of the bones as circumference, thickness of the compact osseous substance, size of the medullary canal, mineral and organic content play an important role in the formation of firmness and stability to the influence of mechanical environmental factors [7-8].

Trauma is associated with the formation of a number of cracks of different types. Splits and crests with dentate surface are formed in the direction of force vector action. In general, the frequency of crack formation and their number depended on the circumstances and severity of the trauma itself. At the same time, different types of cracks demonstrated their maximal values according to their amount reflecting the mechanics of fracture.

In addition to mechanical effect of physical force on the bone, formation of cracks is considerably affected by physical-chemical features of the bone itself, its content and geometric shape [9-10].

The prospects of future studies consists of further comprehensive examination of interrelations between the main structural components of the osseous tissue and regularities of formation of morphological signs in case of fractures of various bones of the human skeleton. Detection of morphological signs of long tubular bones fractures enables to identify the character of the injury and find the mechanism of its occurrence in forensic-medical practice.

\section{CONCLUSIONS}

1. Proximal, median and distal thirds of the femur, tibia and fibula of the lower limb possess a considerable number of morphological peculiarities reflecting their stability.

2. "Modulus of stability" of the osseous tissue of the long tubular bones of the lower limb reflects interrelation of a traumatic mechanical impact with bone structure in case of injury that should be considered in forensic practice in the process of determining the mechanisms of their destruction.

\section{REFERENCES}

1. ColeJH,Van derMeulen MC. Wholebonemechanics and bonequality. Clinical Orthopaedics and Related Research. 2011; 469: 8: 2139-2149.

2. Leng H, Dong XN, Wang X. Progressive post-yield behavior of human cortical bone in compression for middle-aged and elderly groups. Journal of Biomechanics. 2009; 42:491-497.

3. Donnelly E. Methods for Assessing Bone Quality: A Review. Clinical Orthopaedics and Related Research. 2011; 469: 8: 2128-2138.

4. Kreider JM, Goldstein SA. Trabecular bone mechanical properties in patients with fragility fractures. Clinical Orthopaedics and Related Research. 2009 Aug; 467(8): 1955-1963.

5. Sroga GE, Karim L, Colón W, Vashishth D. Biochemical characterization of major bone-matrix proteins using nanoscale-size bone samples and proteomics methodology. Molecular Cellular Proteomics. 2011; 10: 9: 110.

6. Savka I.G. Macroarchitectonic peculiarities of long bones in the lower extremity. Georgian Med News. 2017; 1 (262): 98-101.

7. Eleftheriou K.I., Rawal J.S., James L.E. et al. Bone structure and geometry in young men: the influence of smoking, alcohol intake and physical activity. Bone. 2013; 52(1): 17-26.

8. Bruce Martin R. Determinants of the mechanical properties of bones. Journal of Biomechanics. 1991; 24 (1): 79-88.

9. Jaffar M., Murlimanju B.V., Saralaya V.V. et al. Bone morphometry. Bratisl. Lek. Listy. 2012; 113(11): 673-5.

10. Webster S.S. The past, present, and future of bone morphometry: its contribution to an improved understanding of bone biology. J. Bone Miner. Metab. 2005; 23:1-10.

The study is the part of research of the department of Forensic Medicine and Medical Jurisprudence of Higher State Educational Establishment «Bukovinian State Medical University»: "Expert diagnostics of changes in biological tissues and human environments by morphological and laboratory indicators in solving urgent issues of forensic science and practice" (state registration number in Ukraine 0118U001191).

\section{Conflict of interest:}

The Author declare no conflict of interest.

\section{CORRESPONDING AUTHOR}

\section{Ivan G. Savka}

65a, Heroiyv Maydanu str., flat 50, 58029 Chernivtsi, Ukraine

tel: +38-095-567-33-99

e-mail:savka.ivan@bsmu.edu.ua

Received: 23.09.2018

Accepted: 12.01.2019 
PRACA ORYGINALNA

ORIGINAL ARTICLE

\title{
PROCESS MODEL OF THE PHARMACEUTICAL INTEGRATED MANAGEMENT SYSTEM
}

\section{MODELOWANIE PROCESÓW FARMACEUTYCZNEGO ZINTEGROWANEGO SYSTEMU ZARZĄDZANIA}

\author{
Serhii H. Ubohov, Viktor V. Trokhymchuk, Violetta I. Todorova, Volodymyr A. Zahoriy \\ SHUPYK NATIONAL MEDICAL ACADEMY OF POSTGRADUATE EDUCATION, KYIV, UKRAINE
}

\begin{abstract}
Introduction: One of the innovative trends in the modern development of the pharmaceutical sector is the introduction of integrated management systems (IMS) at the enterprises for the production and distribution of medicines.

The aim: to substantiate and develop a process model and approaches to the regulation and documentation, performance evaluation and improvement of the IMS within the pharmaceutical institution (PI) and hospital pharmaceutical service (HPS).

Materials and methods: research materials used: international standards, regulations and guidelines of the Ministry of Health of Ukraine, scientific publications, information of Pl and hospitals, placed on official websites and collected in the process of direct observation. Research methods are: systemic-review, generalization, observation, documentary, structural-logical and graphic modeling.

Results: Based on the requirements of good practices and international standards in the field of management of quality, ecology, occupational health and safety, social responsibility, a typical process model of the IMS of PI and HPS (pharmaceutical integrated management system - PIMS) has been substantiated and developed. The content of each process of a typical PIMS model is described and structured. The expected results (outputs) of the PIMS processes are determined. The approaches to the regulation and documentation of the PIMS processes in the conditions of functioning of the four-level documented information system are substantiated. A matrix of responsibility and authority of the staff of PI and hospitals within the PIMS is developed. The structurally hierarchical model of the performance evaluation and improvement of the PIMS has been designed and described. Conclusions: The results are the basis for the establishing, regulating and documenting of the PIMS and the development of a system for its performance evaluation and continual improvement.
\end{abstract}

KEY WORDS: medicines, pharmaceutical institution, hospital pharmaceutical services, integrated management system, process model

Wiad Lek 2019, 72, 2, 201-208

\section{INTRODUCTION}

One of the innovative trends in the modern development of the pharmaceutical sector is the introduction of integrated management systems (IMS) at the enterprises for the production and distribution of medicines. Over the past ten years, a number of studies have been carried out by scientists to substantiate the benefits and principles of the implementation IMS of pharmaceutical companies based on good practices $(\mathrm{GxP})$ and international standards in the field of management of quality, ecology, occupational health and safety, as well as social responsibility $[1,2]$. As part of this research direction, the staff of the Shupyk National Medical Academy of Postgraduate Education was substantiated the scientific and practical approaches to the formation of the IMS in pharmaceutical institutions (PI), which carry out wholesale, retail sales and extemporal manufacturing of medicines [3]. The next stage is the development of IMS process models for their implementation in different types of PI, as well as in hospital pharmaceutical services (HPS), which determined the relevance and aim of this work.

\section{THE AIM}

The research aim is to substantiate and develop a process model and approaches to the regulation and documentation, performance evaluation and improvement of the IMS within the pharmaceutical institution and hospital pharmaceutical service.

\section{MATERIALS AND METHODS}

Research materials used: international standards, regulations and guidelines of the Ministry of Health of Ukraine, scientific publications, information on PI and hospitals (Ternopil, Zaporizhya, Dnipro, Chernihiv regions), posted on official websites and collected in the process of direct observation. Research methods are: systemic-review, generalization, observation, documentary, structural-logical and graphic modeling.

\section{RESULTS AND DISCUSSION}

In the previous work, we developed a structural and logical model for the implementation of the IMS in PI, as well as 


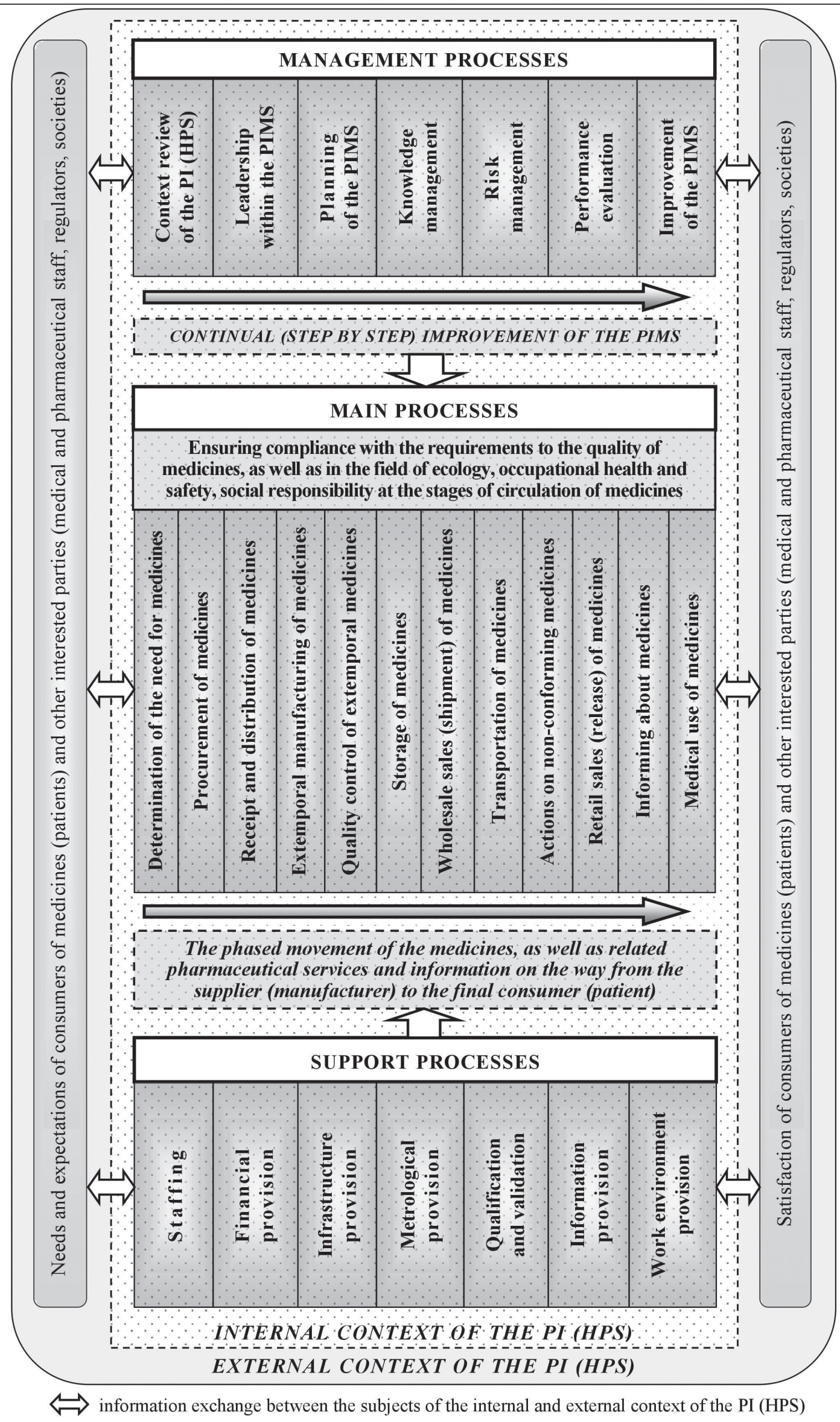

Fig. 1. Typical process model of the pharmaceutical integrated management system. 


\begin{tabular}{|c|c|c|}
\hline I level & $\begin{array}{c}\text { BASIC } \\
\text { DOCUMENTS }\end{array}$ & $\begin{array}{l}\text { Policy within the PIMS } \\
\text { Objectives within the PIMS } \\
\text { Manual for the PIMS }\end{array}$ \\
\hline II level & $\begin{array}{l}\text { REGULATORY } \\
\text { DOCUMENTS }\end{array}$ & $\begin{array}{c}\text { Process regulations } \\
\text { (Process diagram, Technological process card) } \\
\text { Risk management regulatory documents }\end{array}$ \\
\hline III level & $\begin{array}{l}\text { INSTRUCTIONAL- } \\
\text { METHODICAL } \\
\text { DOCUMENTS }\end{array}$ & $\begin{array}{l}\text { Standard operating procedures (SOP) } \\
\text { Technological instructions } \\
\text { Work instructions }\end{array}$ \\
\hline IV level & $\begin{array}{l}\text { WORKING } \\
\text { (PRIMARY) } \\
\text { DOCUMENTS }\end{array}$ & $\begin{array}{l}\text { Protocols (records) } \\
\text { Registers, Acts } \\
\text { Plans, Reports, etc. }\end{array}$ \\
\hline
\end{tabular}

Fig. 2. Documented information system of the pharmaceutical integrated management system. the integration and identification of potential spheres of synergy of structural elements and requirements of the GxP (GDP/GSP/GPP/GVP) and international standards (ISO 9001, ISO 14001, OHSAS 18001, SA 8000), based on which the IMS is built [3]. The results of these studies became the basis for the development of a typical process model of the IMS of PI (pharmaceutical integrated management system - PIMS) (Fig. 1). This model was developed as a unified one and therefore it can be used for the formation of the PIMS in different types of PI (pharmaceutical warehouses, retail and production pharmacies), as well as in pharmaceutical services of hospitals (secondary and tertiary levels of medical care), which includes pharmaceutical subdivisions (pharmacy, warehouse of medicines, department of clinical pharmacists, etc.). The importance of formation the PIMS in HPS confirms our analysis of the information of those domestic hospitals, with a Quality Management System (QMS) already in place, which showed that the QMS is short of covering the processes of circulation of medicines in hospitals. Therefore, the integration of the PIMS into the general QMS or IMS of hospital will contribute to the improvement of the pharmaceutical component of the hospital activity.

The objective of the PIMS model developed is to satisfy the interests of consumers of medicines (patients) and other interested parties (medical and pharmaceutical staff, regulators, society). The realization of this objective is achieved through the implementation of three categories of processes: management processes, main processes and support processes. The management processes of the PIMS include: context review of the PI (HPS), leadership within the PIMS, planning of the PIMS, knowledge management, risk management, performance evaluation and improvement of the PIMS. The support processes of the PIMS include: staffing, provision of financial resources and infrastructure, metrological provision, equipment qualification and processes validation, information provision, work environment provision (physical, social, psychological, etc.). The group of main processes of the PIMS includes activities to ensure compliance with the requirements of legislation, GxP, normative documents (Pharmacopoeia, Quality Control Methods, Protocols of the pharmacist, etc.) on the quality of medicines and related pharmaceutical services, as well as international standards in the field of management of quality, ecology, occupational health and safety, social responsibility at the following stages of circulation of medicines: determination of the need for medicines, procurement of medicines, receipt and internal distribution of medicines, extemporal manufacturing of medicines in pharmacies, quality control of extemporal medicines, storage of medicines, wholesale sales (shipment) of medicines, transportation of medicines, actions on non-conforming medicines (low-quality, falsified, unregistered, forbidden for circulation, expired), retail sales (release) of medicines to patients and medical staff, informing patients and medical staff about medicines, medical use of medicines (in outpatient or inpatient settings). It is important to note here that the main processes of a typical model of the PIMS, which are uncharacteristic for a PI of the corresponding type or HPS, are not included in the process structure of the PIMS implemented in a particular institution. For example, the PIMS of pharmaceutical warehouse does not include the processes of manufacturing and retail sales of medicines, to the PIMS of pharmacy - the processes of wholesale sales of medicines, etc. In the event that it is necessary to add a new process (for example, an outsourcing process) to the group of main processes of the PIMS, then this typical model is open for extension. Another important point is that, in the presented model of the PIMS, the management of the aspects of ecology, occupational health and safety, social responsibility is not highlighted in separate processes. This is due to the interprocess character of these aspects in the context of the peculiarities of pharmaceutical activity, in particular regarding the management of the movement of medicines on the way from the supplier (manufacturer) to the final consumer (patient). Therefore, these aspects "permeate" both the main processes and the processes of management and support of the PIMS.

An important requirement of $\mathrm{GxP}$ and international 
Table I. Matrix of responsibility and authority of the staff of pharmaceutical institutions and hospitals within the pharmaceutical integrated management system

\begin{tabular}{|c|c|c|c|c|c|c|c|c|c|c|c|c|c|c|}
\hline \multirow[b]{2}{*}{$\begin{array}{l}\text { Names } \\
\text { of the PIMS } \\
\text { processes }\end{array}$} & \multirow[b]{2}{*}{$\begin{array}{l}\text { Expected results (outputs) } \\
\text { of the PIMS processes }\end{array}$} & \multicolumn{13}{|c|}{$\begin{array}{l}\text { The posts and levels of responsibility and authority of the staff } \\
\text { of pharmaceutical institutions and hospitals* }\end{array}$} \\
\hline & & 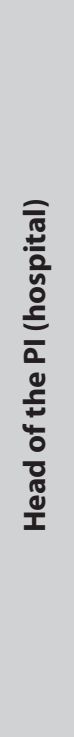 & 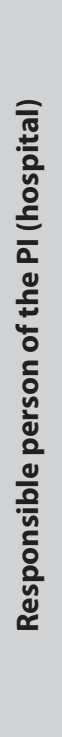 & 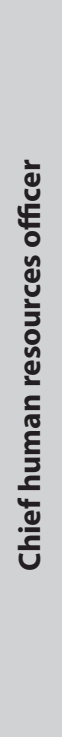 & 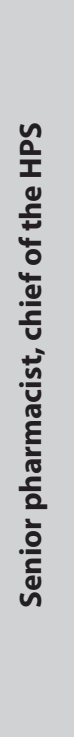 & 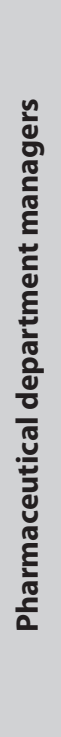 & 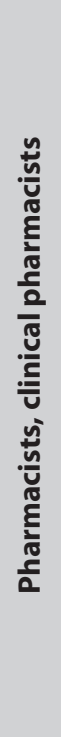 & 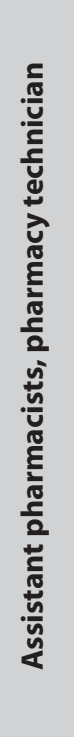 & 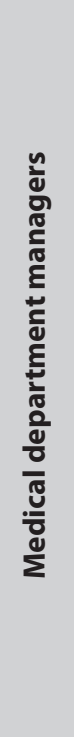 & 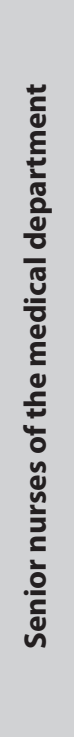 & 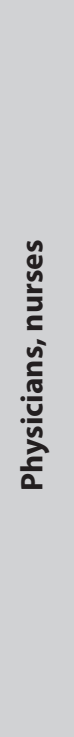 & 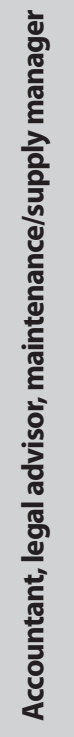 & 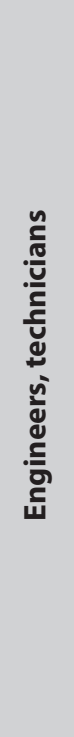 & 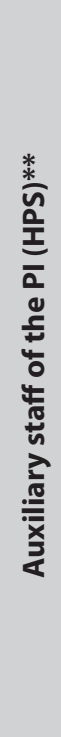 \\
\hline 1 & 2 & 3 & 4 & 5 & 6 & 7 & 8 & 9 & 10 & 11 & 12 & 13 & 14 & 15 \\
\hline \multicolumn{15}{|c|}{ MANAGEMENT PROCESSES } \\
\hline $\begin{array}{l}\text { Context review of } \\
\text { the PI (HPS) }\end{array}$ & $\begin{array}{l}\text { Understanding of the context } \\
\text { (environment) of PI (HPS) }\end{array}$ & M & $\mathrm{R}$ & I & $P$ & $P$ & 1 & 1 & 1 & 1 & 1 & I & I & I \\
\hline $\begin{array}{l}\text { Leadership within } \\
\text { the PIMS }\end{array}$ & $\begin{array}{c}\text { Effective and efficient implementation } \\
\text { of vision, policy and obligation within } \\
\text { the PIMS }\end{array}$ & M & $\mathrm{R}$ & $\mathrm{P}$ & $P$ & $P$ & 1 & I & $P$ & $P$ & I & 1 & 1 & I \\
\hline $\begin{array}{l}\text { Planning of the } \\
\text { PIMS }\end{array}$ & $\begin{array}{l}\text { Established objectives of the PIMS, } \\
\text { planned actions and performance } \\
\text { indicators for their achievement }\end{array}$ & M & $\mathrm{R}$ & $P$ & $P$ & $P$ & I & 1 & 1 & I & 1 & 1 & 1 & I \\
\hline $\begin{array}{c}\text { Knowledge } \\
\text { management }\end{array}$ & $\begin{array}{l}\text { Effective and efficient knowledge } \\
\text { management within the PIMS }\end{array}$ & M & $\mathrm{R}$ & $P$ & $P$ & $\mathrm{P}$ & I & I & $\mathrm{P}$ & $P$ & 1 & 1 & I & I \\
\hline Risk management & $\begin{array}{l}\text { Effective and efficient elimination } \\
\text { (reduction) of potential risks in the PI (HPS) }\end{array}$ & M & $\mathrm{R}$ & 1 & $P$ & $\mathrm{P}$ & I & I & $P$ & $P$ & I & 1 & I & I \\
\hline $\begin{array}{l}\text { Performance } \\
\text { evaluation of the } \\
\text { PIMS }\end{array}$ & $\begin{array}{c}\text { Effective and efficient monitoring, review } \\
\text { (analysis) and performance evaluation of } \\
\text { the PIMS }\end{array}$ & M & $\mathrm{R}$ & I & $P$ & $P$ & 1 & I & 1 & 1 & I & 1 & I & I \\
\hline $\begin{array}{l}\text { Improvement of } \\
\text { the PIMS }\end{array}$ & $\begin{array}{l}\text { Effective and efficient corrective and } \\
\text { preventive actions to eliminate non- } \\
\text { conformities, continual (step-by-step) } \\
\text { improvement of the PIMS }\end{array}$ & M & $\mathrm{R}$ & I & $P$ & $\mathrm{P}$ & I & I & $P$ & $P$ & I & I & I & I \\
\hline \multicolumn{15}{|c|}{ MAIN PROCESSES } \\
\hline $\begin{array}{l}\text { Determination } \\
\text { of the need for } \\
\text { medicines }\end{array}$ & $\begin{array}{l}\text { List and planned volume of procurement } \\
\text { of medicines are determined according to } \\
\text { the established requirements***}\end{array}$ & M & y & I & $P$ & $\mathrm{R}$ & $\mathrm{P}$ & I & $P$ & $P$ & $P$ & 1 & 1 & I \\
\hline $\begin{array}{l}\text { Procurement of } \\
\text { medicines }\end{array}$ & $\begin{array}{l}\text { Good quality medicines purchased } \\
\text { in accordance with the established } \\
\text { requirements }\end{array}$ & M & $\mathrm{R}$ & I & $P$ & I & I & I & 1 & 1 & 1 & $P$ & I & I \\
\hline $\begin{array}{l}\text { Receipt and } \\
\text { internal distribution } \\
\text { of medicines }\end{array}$ & $\begin{array}{c}\text { Good quality medicines accepted and } \\
\text { distributed in accordance with the } \\
\text { established requirements }\end{array}$ & M & $\mathrm{R}$ & I & $P$ & $P$ & $P$ & 1 & $\mathrm{P}$ & $P$ & I & I & I & $P$ \\
\hline $\begin{array}{l}\text { Extemporal } \\
\text { manufacturing } \\
\text { of medicines in } \\
\text { pharmacies }\end{array}$ & $\begin{array}{l}\text { Good quality medicines manufactured } \\
\text { (made) in pharmacies in accordance with } \\
\text { the established requirements }\end{array}$ & M & $P$ & I & $P$ & $\mathrm{R}$ & $\mathrm{P}$ & $P$ & 1 & I & I & 1 & 1 & $P$ \\
\hline
\end{tabular}




\begin{tabular}{|c|c|c|c|c|c|c|c|c|c|c|c|c|c|c|}
\hline $\begin{array}{l}\text { Quality control } \\
\text { of extemporal } \\
\text { medicines }\end{array}$ & $\begin{array}{l}\text { Extemporal medicines that have passed } \\
\text { quality control in accordance with the } \\
\text { established requirements }\end{array}$ & $M$ & $\mathrm{R}$ & I & $P$ & $P$ & I & I & 1 & I & I & 1 & I & I \\
\hline $\begin{array}{l}\text { Storage of } \\
\text { medicines }\end{array}$ & $\begin{array}{l}\text { Good quality medicines stored in the } \\
\text { PI (hospitals) in accordance with the } \\
\text { established requirements }\end{array}$ & $M$ & $P$ & I & $P$ & $\mathrm{R}$ & $P$ & I & $P$ & $\mathrm{P}$ & $P$ & 1 & I & I \\
\hline $\begin{array}{l}\text { Wholesale sales } \\
\text { (shipment) of } \\
\text { medicines }\end{array}$ & $\begin{array}{l}\text { Good quality medicines sold (shipped) } \\
\text { to recipients (pharmacies, hospitals) in } \\
\text { accordance with established requirements }\end{array}$ & $M$ & $P$ & I & $P$ & $\mathrm{R}$ & $\mathrm{P}$ & $P$ & 1 & I & I & I & I & $\mathrm{P}$ \\
\hline $\begin{array}{c}\text { Transportation of } \\
\text { medicines }\end{array}$ & $\begin{array}{l}\text { Good quality medicines transported in } \\
\text { accordance with established requirements }\end{array}$ & $M$ & $P$ & I & $P$ & $\mathrm{R}$ & $\mathrm{P}$ & $P$ & I & I & I & I & $P$ & $P$ \\
\hline $\begin{array}{l}\text { Actions on non- } \\
\text { conforming } \\
\text { medicines }\end{array}$ & $\begin{array}{l}\text { Non-conformity quality medicines } \\
\text { withdrawn from circulation and } \\
\text { transferred for utilization or disposal in } \\
\text { accordance with established requirements }\end{array}$ & $\mathrm{M}$ & $\mathrm{R}$ & I & $P$ & $P$ & I & I & $P$ & $\mathrm{P}$ & I & I & I & I \\
\hline $\begin{array}{l}\text { Retail sales } \\
\text { (release) of } \\
\text { medicines to } \\
\text { patients and } \\
\text { medical staff }\end{array}$ & $\begin{array}{l}\text { Good quality medicines sold (released) } \\
\text { to consumers (patients, medical staff) in } \\
\text { accordance with established requirements }\end{array}$ & $M$ & $P$ & I & $P$ & $\mathrm{R}$ & $P$ & $P$ & I & I & I & I & I & I \\
\hline $\begin{array}{l}\text { Informing patients } \\
\text { and medical staff } \\
\text { about medicines }\end{array}$ & $\begin{array}{l}\text { Good information about the medicines } \\
\text { provided to patients and medical staff in } \\
\text { accordance with established requirements }\end{array}$ & $M$ & P & I & $P$ & $\mathrm{R}$ & $P$ & $P$ & $P$ & I & $P$ & I & I & I \\
\hline $\begin{array}{l}\text { Medical use of } \\
\text { medicines (in } \\
\text { outpatient or } \\
\text { inpatient settings) }\end{array}$ & $\begin{array}{l}\text { Good quality medicines used for medical } \\
\text { purposes in accordance with established } \\
\text { requirements }\end{array}$ & $M$ & $\mathrm{R}$ & I & $P$ & $\mathrm{P}$ & $P$ & I & $P$ & $P$ & $P$ & I & I & I \\
\hline \multicolumn{15}{|c|}{ SUPPORT PROCESSES } \\
\hline Staffing & $\begin{array}{l}\text { Good staffing and training to provide of } \\
\text { the PIMS functioning }\end{array}$ & M & $P$ & $\mathrm{R}$ & $P$ & $P$ & 1 & 1 & $P$ & 1 & I & 1 & 1 & I \\
\hline Financial provision & $\begin{array}{l}\text { Good financial provision of the PIMS } \\
\text { functioning }\end{array}$ & M & $P$ & 1 & $P$ & $P$ & I & I & $P$ & $P$ & I & $\mathrm{R}$ & I & I \\
\hline $\begin{array}{l}\text { Infrastructure } \\
\text { provision }\end{array}$ & $\begin{array}{c}\text { Good infrastructure provision (premises, } \\
\text { equipment, vehicles, communication } \\
\text { technologies, etc.) for the functioning of } \\
\text { the PIMS }\end{array}$ & M & $P$ & I & $P$ & $P$ & I & I & $P$ & $\mathrm{P}$ & I & $\mathrm{R}$ & $P$ & I \\
\hline $\begin{array}{l}\text { Metrological } \\
\text { provision }\end{array}$ & $\begin{array}{l}\text { Provision with suitable monitoring and } \\
\text { measurement tools necessary for the } \\
\text { functioning of the PIMS }\end{array}$ & M & $P$ & I & $P$ & $P$ & I & 1 & $P$ & $\mathrm{P}$ & I & $\mathrm{R}$ & $P$ & I \\
\hline $\begin{array}{l}\text { Qualification and } \\
\text { validation }\end{array}$ & $\begin{array}{l}\text { Effective and efficient procedures for the } \\
\text { equipment qualification and validation of } \\
\text { the PIMS processes }\end{array}$ & M & $\mathrm{R}$ & I & $\mathrm{P}$ & $P$ & I & I & 1 & I & I & $P$ & $\mathrm{P}$ & I \\
\hline $\begin{array}{l}\text { Information } \\
\text { provision }\end{array}$ & $\begin{array}{l}\text { Good documentary and information } \\
\text { provision of the PIMS functioning }\end{array}$ & M & $\mathrm{R}$ & 1 & $\mathrm{P}$ & $P$ & 1 & I & $\mathrm{P}$ & $\mathrm{P}$ & I & $\mathrm{P}$ & $P$ & I \\
\hline $\begin{array}{l}\text { Work environment } \\
\text { provision }\end{array}$ & $\begin{array}{c}\text { Good working conditions (physical, social, } \\
\text { psychological) for the efficient functioning } \\
\text { of the PIMS }\end{array}$ & $M$ & P & $\mathrm{P}$ & $P$ & $\mathrm{R}$ & I & I & $P$ & $\mathrm{P}$ & I & $P$ & I & I \\
\hline
\end{tabular}

Notes:

*Levels of responsibility and authority: $M$ - process manager; $R$ - responsible for the functioning of the process; $P$ - process participant; $I$ - person informed about the process.

**The auxiliary personnel include: packers, sanitary cleaners, cleaners, loaders, driver forwarders, etc.

***The requirements of legislation, good practices and normative documents (Pharmacopoeia, Quality Control Methods, Protocols of the pharmacist, etc.) on the quality of medicines and related pharmaceutical services, as well as international standards in the field of quality, ecology, occupational health and safety, social responsibility. 
standards is the good documentation of the corresponding management system. Therefore, at the second stage of research, we have substantiated approaches to the regulation and documentation of the PIMS processes. Based on the study of the requirements of the aforementioned normative documents, the analysis of scientific literary sources and own observations, we propose to introduce, within the PIMS, a four-level documented information system, which includes: basic, regulatory, instructional-methodical and working (primary) documents (Fig. 2) [4, 5].

All of the basic documents of the PIMS (documented information of the first level) shown in Figure 2 can be merged into a single document, namely the Manual for the PIMS, the main sections of which should be: policy and objectives of the PI (hospital) within the PIMS; scope of the PIMS; description of structure of the PI (HPS); list and description of the PIMS processes, indicating the interconnections and interactions of these processes and the personnel responsible for their execution (using graphic charts and tables) [5]. In the context of the above-mentioned we described and structured the content of each process of a typical model of the PIMS, where the structural elements of the processes can be considered as separate subprocesses (procedures). After the development of the basic documents, the regulation and documentation of each individual process (subprocess) of the PIMS should be carried out. This is done by developing regulatory and instructional-methodical documents (documented information of the second and third levels), namely: process regulations and specific instructions describing the algorithms for performing certain types of work (operations) within the PIMS processes (standard operating procedures, work and technological instructions, etc.) $[4,5]$. Obligatory components of the process regulations should be a process diagram and technological process card (TPC). Process diagram is a graphical model that shows the sequence of operations and interconnections between different participants in the process. One of the most convenient and effective modern tools for constructing process diagrams is the methodology of modeling IDEF0 and IDEF3 [6, 7]. TPC is a document that contains brief information on the consistent description of operations, terms and conditions for their execution, the responsible executors and other process participants, the names and format of the input and output documentation, the results of operations and facilities to ensure their execution. Each concrete institution (PI, hospital) approves the form of the TPC, which is most consistent with the content and specificity of its activities. The regulatory documents should also include such risk management documents as risk classifier, risk profile passport and risk register [8]. The PIMS working documentation (documented information of the fourth level) includes a wide range of primary documents (protocols, records, registers, acts, plans, reports, etc.), which include information on planned and executed operations (actions), monitoring and measurement results, detected non-conformities (defects), etc. The system of primary documentation of each type of institution (PI, hospital) has its own peculiarities. At the same time, the unification of the types and forms of primary documentation and the transition to electronic document circulation (internal and external) will contribute to improving the efficiency of the PIMS.

Taking into account the leading role of personnel in the implementation and maintaining of the PIMS, at the next stage of our research we have developed a matrix of responsibility and authority of the staff of PI and hospitals within the PIMS and identified the expected results (outputs) of the PIMS processes (table I). Within the PIMS, a four-level system of responsibility and authority is offered: process manager (first level); responsible for the functioning of the process (second level); process participant (third level); person informed about the process (fourth level). This system covers all main groups of posts that are in the PI and hospitals, namely: top management staff (head of the PI (hospital), Responsible person, chief human resources officer, chief of the HPS, legal advisor); pharmaceutical staff (senior pharmacist, pharmaceutical department managers, pharmacists, clinical pharmacists, assistant pharmacists, pharmacy technician); medical staff (medical department managers, physicians, senior nurses, nurses); economic and technical staff (accountant, maintenance and supply manager, engineers, technicians, etc.); auxiliary staff (packers, sanitary cleaners, cleaners, loaders, driver forwarders, etc.). The management of the PI (hospital) should provide a clear definition, inclusion in job descriptions and informing all employee of their functions, responsibilities and authority within the PIMS. This approach is fully in line with one of the basic principles of quality management enshrined in the ISO 9001 standard, which implies "the engagement of all personnel" [9].

At the last stage of this work, we designed the structurally hierarchical model of the performance evaluation and improvement of the PIMS, which is an important part of the general management process within the PIMS (Fig. 3). The model, depicted in the form of a "pyramid", contains a hierarchical list of concrete actions to performance evaluation and improvement of the PIMS, with a clear periodicity of these actions. At the bottom of the "pyramid" there is a constant monitoring and measurement of the functional characteristics of main processes of the PIMS and the quality of medicines and pharmaceutical services. This is done daily in the current mode. Here it is recommended to adhere to the following principle: one person performed an operation (work) - another (who has the appropriate authority and is independent in administrative terms from the first one) has checked the correctness (quality) of its execution [10]. The next step in the "pyramid" is the periodic monitoring of the functional characteristics of the management and maintenance processes of the PIMS, which is recommended to be conducted on a monthly basis. The results of monitoring and measurement, as well as the results of their analysis and evaluation, are documented in the protocols (records) of the established form. The following in the hierarchy of actions on performance evaluation of the PIMS include 


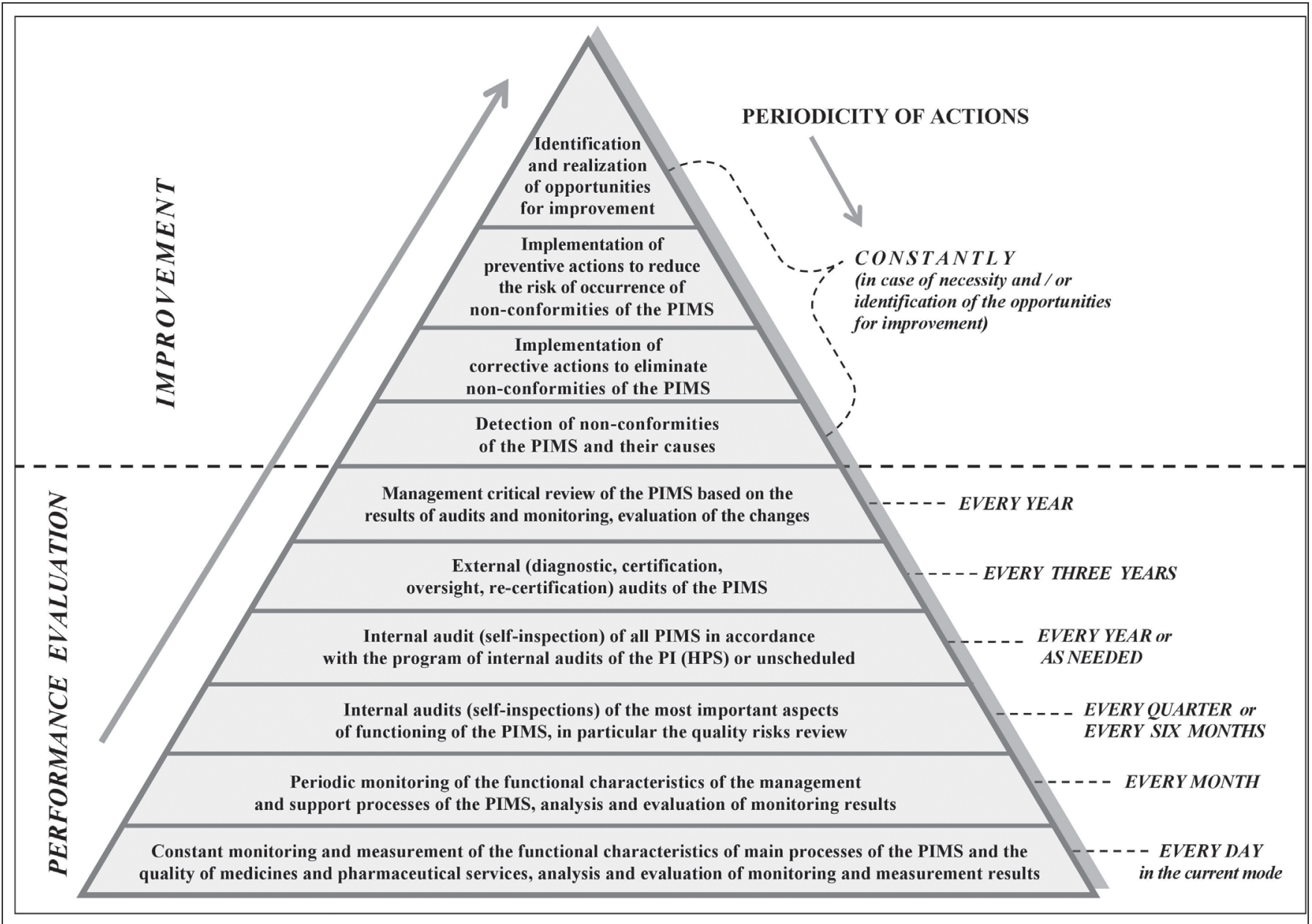

Fig. 3. Structural hierarchical model of performance evaluation and improvement of the pharmaceutical integrated management system.

the planned internal audits (self-inspections) conducted in PI (HPS) in accordance with the approved program (schedule) of internal audits. The most important aspects of the functioning of the PIMS, in particular the quality risks review, are recommended to be audited quarterly or every six months, and audit of all PIMS - at least once a year. If necessary (in case of receipt of complaints, claims, detection of non-conformities, etc.) unscheduled audits may be conducted. It is advisable to involve external experts in conducting diagnostic audits of the PIMS at least once every three years. In this case, the requirements of $\mathrm{GxP}$ for outsourcing should be respected [10]. External audits also include certification (primary), oversight and recertification audits carried out by certifying organizations. Based on the results of audits and monitoring, the management of the PI (hospital) conducts a critical reviews of the performance of the PIMS every year, as well as an evaluation of the changes (proposed, implemented). And only after that, there is a transition to the peak of the "pyramid", where there are actions to improve the PIMS, namely: detection of non-conformities and their causes, implementation of corrective and preventive actions (CAPA), identification and realization of opportunities for improvement. These actions are performed continuously whenever necessary and/or as the opportunities for improving the PIMS are identified. The arrow shown in Figure 3 is directed to the top of the "pyramid". This symbolizes the desire of the PIMS to continual improvement. The structurally hierarchical model of the performance evaluation and improvement of the PIMS, together with its description, as well as the general process model of the PIMS and the matrix of responsibilities and authority, should be included in one of the sections or annexes of the Manual for the PIMS.

\section{CONCLUSIONS}

Based on the requirements of $\mathrm{GxP}$ and international standards in the field of management of quality, ecology, occupational health and safety, social responsibility, a typical process model of the PIMS has been substantiated and developed. The content of each process of a typical PIMS model is described and structured. The expected results (outputs) of the PIMS processes are determined.

The approaches to the regulation and documentation of the PIMS processes in the conditions of functioning of the four-level documented information system are substantiated. A matrix of responsibility and authority of the staff of PI and hospitals within the PIMS is developed. The structurally hierarchical model of the performance evaluation and improvement of the PIMS has been designed and described. 
Thus, the above results are the basis for the establishing, regulating and documenting of the PIMS and the development of a system for its performance evaluation and continual improvement. A promising direction for further research is the development of models for concrete processes of the PIMS, as well as the identification of indicators, criteria and methods for the evaluation of their performance.

\section{REFERENCES}

1. Kaidalova A.V., Kovalenko S.M., Pidpruzhnykov Yu.V., Chystiakov 0.H. Vyznachennia etapiv rozrobky ta vprovadzhennia system yakosti na farmatsevtychnomu pidpryiemstvi vidpovidno do vymoh ISO ta GMP [Determine the phases of development and implementation of quality systems in the pharmaceutical enterprise in accordance with ISO and GMP requirement]. Visnyk farmatsii. 2008; 4:65-67.

2. Svitlychna K.S., Posylkina 0.V. Pobudova intehrovanoi systemy menedzhmentu na farmatsevtychnykh pidpryiemstvakh [Construction of an integrated management system at pharmaceutical enterprises]. Farmakom. 2010; 3:88-96.

3. Trokhymchuk V.V., Ubohov S.H. Naukovo-praktychni pidkhody do formuvannia intehrovanykh system upravlinnia na optovykh ta rozdribnykh farmatsevtychnykh pidpryiemstvakh [Scientific and practical approaches to the formation of integrated management systems at the wholesale and retail pharmaceutical enterprises]. Liky Ukrainy Plius. 2018; 2(35):29-33.

4. Suchasna kontseptsiia zabezpechennia yakosti likarskykh zasobiv: kolektyvna monohrafiia [Contemporary concept of quality assurance of medicines: collective monograph]. Vinnytsia: Nilan-LTD; 2018.

5. Kotvitska A.A., Lebedynets V.O. Rehlamentatsiia I dokumentuvannia systemy upravlinnia yakistiu pidpryiemstva z vyrobnytstva likarskykh zasobiv: metod. rek. [Regulation and documentation of the quality management system of the enterprise for the production of medicines: method. rec.]. Kharkiv: NTMT; 2015.

6. Vetiutneva N.O., Ubohov S.H., Zahorii H.V., Pylypenko H.H., Fedorova L.0. Funktsionalna model provedennia vkhidnoho kontroliu yakosti likarskykh zasobiv v aptechnykh zakladakh. Chastyna I [Functional model of incoming quality control of medicines in pharmaceutical institutions. Part I]. Zbirnyk naukovykh prats spivrobitnykiv NMAPO imeni P. L. Shupyka. 2015; 5(24):276-288.
7. Kotvitska A.A., Lebedynets V.0. Modeliuvannia systemy upravlinnia yakistiu ta reformuvannia orhanizatsiinoi struktury pidpryiemstva z vyrobnytstva likarskykh zasobiv: metod. rek. [Modeling the quality management system and reforming the organizational structure of the enterprise for the production of medicines: method. rec.]. Kharkiv: NTMT; 2015.

8. Trokhymchuk V.V., Hudz N.la., Ubohov S.H., Zahorii V.A. Upravlinnia ryzykamy dlia yakosti v aptechnykh zakladakh: metod. rek. [Quality risks management of in pharmaceutical institutions: method. rec.]. Kyiv: Ratibor; 2018.

9. Quality management systems. Requirements: IS0 9001:2015 [download: 01.08.2018]; https://www.iso.org/obp/ui/\#iso:std:iso:9001:ed-5:v1:en.

10. Podpruzhnykov Yu.V., Nemchenko A.S., Andriukova L.N., Humeniuk N.Y. Systemi kachestva y nadlezhashchye praktyky v farmatsyy: uchebnoe posobye [Quality Systems and Good Practices in Pharmacy: tutorial]. Kyiv: SIC GROUP UKRAINE; 2017.

\section{Authors' contributions:}

According to the order of the Authorship.

\section{Conflict of interest:}

The Authors declare no conflict of interest.

\section{CORRESPONDING AUTHOR}

\section{Serhii H. Ubohov}

Department of quality control and standardization of medicines of the Shupyk National Medical Academy of Postgraduate Education 9 Dorohozhytska Str., 04112 Kyiv, Ukraine tel: +380672317656 e-mail: ubogov@ukr.net ; kaf-kontryak@ukr.net

Received: 20.11.2018

Accepted: 30.01.2019 
PRACA ORYGINALNA

ORIGINAL ARTICLE

\title{
IS AN EMERGENCY DEPARTMENT A SAFER PLACE FOR HYPOTHERMIC VICTIMS THAN AN AMBULANCE? A COMPARISON OF THE KNOWLEDGE OF MEDICAL PERSONNEL CONCERNING HYPOTHERMIA
}

\section{CZY ODDZIAŁ RATUNKOWY JEST BEZPIECZNIEJSZYM MIEJSCEM DLA PACJENTA W HIPOTERMII NIŻ KARETKA? PORÓWNANIE WIEDZY PERSONELU MEDYCZNEGO NA TEMAT HIPOTERMII}

\author{
Paweł Podsiadło ${ }^{1,2}$, Adam Nogalski ${ }^{3}$, Sylweriusz Kosiński ${ }^{4,5}$, Tomasz Sanak ${ }^{6}$, Kinga Sałapa ${ }^{7}$, Robert Gałązkowski ${ }^{2,8}$, \\ Tomasz Darocha ${ }^{2,9}$ \\ 'DEPARTMENT OF EMERGENCY MEDICINE, JAN KOCHANOWSKI UNIVERSITY, KIELCE, POLAND \\ ${ }^{2}$ POLISH MEDICAL AIR RESCUE, WARSAW, POLAND \\ ${ }^{3}$ DEPARTMENT OF TRAUMATOLOGY AND EMERGENCY MEDICINE, MEDICAL UNIVERSITY, LUBLIN, POLAND \\ ${ }^{4}$ DEPARTMENT OF ANAESTHESIOLOGY AND INTENSIVE CARE, PULMONARY HOSPITAL, ZAKOPANE, POLAND \\ ${ }^{5}$ FACULTY OF HEALTH SCIENCES, JAGIELLONIAN UNIVERSITY MEDICAL COLLEGE, KRAKÓW, POLAND \\ ${ }^{6}$ DEPARTMENT OF DISASTER MEDICINE AND EMERGENCY CARE, JAGIELLONIAN UNIVERSITY MEDICAL COLLEGE, KRAKOW, POLAND. \\ 'DEPARTMENT OF BIOINFORMATICS AND TELEMEDICINE, JAGIELLONIAN UNIVERSITY MEDICAL COLLEGE, KRAKÓW, POLAND \\ ${ }^{8}$ DEPARTMENT OF EMERGENCY MEDICAL SERVICES, MEDICAL UNIVERSITY OF WARSAW, WARSAW, POLAND \\ ${ }^{9}$ DEPARTMENT OF ANAESTHESIOLOGY AND INTENSIVE CARE, MEDICAL UNIVERSITY OF SILESIA, KATOWICE, POLAND
}

\begin{abstract}
Introduction: Improper initial management of a victim in severe hypothermia is associated with a risk of cardiac arrest. At the same time, an uncontrolled drop in core body temperature in trauma victims is an independent risk factor for mortality. Medical personnel require a thorough understanding of the pathophysiology and treatment of hypothermia. Gaps in this understanding can lead to serious complications for patients.

The aim: To compare knowledge concerning hypothermia between medical personnel working in emergency departments (ED) and emergency medical services (EMS).

Materials and methods: A total of 5,362 participants were included in the study. In this study, EMS and ED personnel were encouraged to participate in an e-learning course on hypothermia. Subsequently, the scores of a pre-test, lesson tests and post-test completed by participants of this course were compared.

Results: Pre-test scores were significantly higher among personnel working in EMS compared with those working in EDs. Nurses employed in EDs had significantly more failures in completing the course than EMS nurses. The most difficult topics for all practitioners were post-traumatic hypothermia and hypothermia-related clotting disorders. Conclusions: EMS personnel have a higher level of knowledge of hypothermia than ED personnel. Moreover, an e-learning course is an effective tool for improving medical personnel's knowledge of hypothermia.
\end{abstract}

KEY WORDS: e-learning; hypothermia; medical education; emergency department; emergency medical systems

\section{STRESZCZENIE}

Wstęp: Niewłásiwe postępowaniezpacjentami w głębokiej hipotermii wiąże sięzryzykiem zatrzymania krążenia. Wśród pacjentów, którzy doznali urazów, obniżenie temperatury głębokiej ciała stanowi niezależny czynnik ryzyka zgonu. Tak więcznajomość patofizjologii hipotermii oraz zasad postępowania wśród personelu medycznego ma kluczowe znaczenie dla uniknięcia powikłań. Cel pracy: Porównanie wiedzy na temat hipotermii personelu oddziałów ratunkowych (ED) i pracowników zespołów ratownictwa medycznego (EMS).

Materiał i metody: Do badania włączono 5362 uczestników szkolenia. Personel medyczny pracujący zarówno w ED, jak i w EMS, został zaproszony do udziału w szkoleniu e-learningowym dotyczącym hipotermii. Porównano wyniki testu wstępnego, testów kończących poszzzególne lekcje oraz testu końcowego, uzyskane przez obie grupy personelu. Wyniki: Wyniki testu wstępnego były istotnie wyższe wśród personelu EMS niż wśród personelu ED. Pielęgniarki zatrudnione w ED miały istotnie więcej niepowodzeń w zaliczeniu kursu niż pielęgniarki EMS. Dla wszystkich uczestnicy najtrudniejsza do przyswojenia okazała się wiedza z zakresu hipotermii pourazowej izależnych od wychłodzenia zaburzeń krzepnięcia. Wnioski: Personel EMS dysponuje wyższym poziomem wiedzy o hipotermii niż personel ED. Szkolenie za pomocą e-learningu okazało się skutecznym narzędziem poszerzenia tej wiedzy.

SŁOWA KLUCZOWE: e-learning; hipotermia; kształcenie medyczne; oddział ratunkowy; zespół ratownictwa medycznego 


\section{INTRODUCTION}

Reported deaths due to hypothermia number around 1,500 annually in the United States and around 125 annually in Poland $[1,2]$. However, the real incidence of hypothermia remains unknown. Core body temperature is not routinely measured in patients who are admitted to hospitals. For this reason, hypothermia is less commonly recognized, while the actual number of cases could be significantly higher.

Cardiac arrest is the most dangerous complication of hypothermia. Ventricular Fibrillation (VF) may be precipitated by excessive movement while handling the patient, along with endotracheal intubation, aggressive ventilation, rapid core temperature declines (afterdrop), and unnecessary chest compressions $[1,3,4]$. Additionally, the heart becomes unresponsive to electrical defibrillation and drugs [5]. Although hypothermic cardiac arrest occurs most often below a core body temperature (Tc) of $28^{\circ} \mathrm{C}$, it begins to be a risk below $32^{\circ} \mathrm{C}$. It can occur in both the prehospital and hospital settings. Cardiac arrest associated with treatment or transport is called rescue collapse [1]. Debaty et al. showed that half of the patients in severe hypothermia who were found alive sustained rescue collapse. Therefore, the initial assessment is a high risk period for the hypothermic patient [6]. An appropriate level of understanding of these risks by first responders and other providers is a crucial component of patient survival.

Another important cold injury is post-traumatic hypothermia. It, along with acidosis and coagulopathy, comprises what is known as the triad of death in trauma patients. Hypothermia alone is also an independent risk factor of mortality in patients with traumatic injuries [7]. A very large study ( $\mathrm{n}=700,304)$ found the overall mortality in patients with post-traumatic hypothermia to be $25.5 \%$, compared with only $3 \%$ in normothermic patients [8]. Thus, an awareness of this risk factor coupled with the appropriate use of thermal insulation and prophylaxis against hypothermia can play an important role in reducing mortality.

According to the Utstein Formula presented by The International Liaison Committee on Resuscitation, the effective education of medical personnel is an indispensable element in the Chain of Survival [9]. Our study presents the degree of effectiveness of hypothermia education and can provide useful insights into improving a healthcare system's capability to manage these vulnerable patients.

The aim of this study was to compare knowledge about the initial phase of care of hypothermic patients between emergency medicine departments personnel and ambulance personnel. An additional goal was to assess the effectiveness of an e-learning course for improving one's competency regarding hypothermia.

\section{MATERIAL AND METHODS}

\section{DESIGN}

A total of 5,677 medical practitioners participated in the online hypothermia course, including personnel from emergency departments and emergency medical services.
The study was based on test results that assessed the initial knowledge of both ED and EMS groups, as well as their understanding of material covered in an online hypothermia course. Further, we evaluated any increase in knowledge as a result of this course. The course was implemented through an e-learning platform composed of an entry exam (pre-test), lesson topics on hypothermia followed by corresponding lesson tests, and a concluding final exam (post-test). The pre-test and post-test were composed of the same 15 questions. Participants were not informed of the correct answers after any test, with the achieved score only being shown. The course was accepted by the National Consultant of Emergency Medicine who approved it for Emergency Medical Staff curriculum. Personnel from EDs and EMS were invited to take part in the course. Information about the course was mailed in poster form and in a written recommendation to participate signed by the National Consultant of Emergency Medicine. While the course had tailored modules for EMS and ED personnel, the pre-test, post-test, and five lesson tests were identical. The pre-test was not timed although the post-test had a ten minute time limit for completion. A passing score was 75\% on the post-test and for each lessons' practice test. Data were collected from December, 2015 to February, 2017.

\section{PARTICIPANTS}

Participants self-registered through an online platform, chose the appropriate learning module (ED or EMS), and specified their profession (physician, nurse, paramedic), age, and years of practice (seniority). The study only included individuals who registered as ED or EMS staff, submitted personal identifying information, completed a pre-test, all lesson tests, and a post-test. Individuals that did not provide demographic information, did not belong to one of the listed occupational groups, or who did not complete the entire course were excluded from the study. To limit the level of bias, each participant could be registered in only one module. The number of participants was not limited.

\section{STATISTICAL ANALYSES}

The results of the pre-test, the first attempts to pass each lesson test, and the final test were analyzed. Differences between the ED group and the EMS group in the occupational subgroups (physicians, nurses and paramedics) were compared. The proportion of correct pre- and post-test responses was reported using mean values with a standard deviation, minimum and maximum values, and due to a skewed distribution of the results, a median and interquartile range (IQR). The Mann-Whitney test was used to compare the median results between each occupational group in the ED with the corresponding occupational group in EMS. Non-parametric methods, instead of the parametric two-factor ANOVA analysis for repeated measurements, were applied because of the lack of normality of distributions of the examined features in individual groups. The non-parametric Mann-Whitney 
Table I. Demographic characteristics of emergency departments and emergency medical services included in the study

\begin{tabular}{|c|c|c|c|c|}
\hline & & Physicians & Nurses & Paramedics \\
\hline \multicolumn{5}{|c|}{ ED } \\
\hline \multicolumn{2}{|c|}{$\mathrm{n}$} & 88 & 130 & 249 \\
\hline \multirow{2}{*}{ Sex n (\%) } & Women & $35(39.8)$ & $120(92.3)$ & $126(50.6)$ \\
\hline & Men & $53(60.2)$ & $10(7.7)$ & $123(49.4)$ \\
\hline \multicolumn{2}{|c|}{ Age (median [IQR]) } & $33[28,42]$ & $43[32,48]$ & $28[25,32]$ \\
\hline \multicolumn{2}{|c|}{$\begin{array}{l}\text { Lenght of service (median } \\
\text { [IQR]) }\end{array}$} & $6[2,18]$ & $21[10,28]$ & $4[2,7]$ \\
\hline \multicolumn{5}{|c|}{ EMS } \\
\hline \multicolumn{2}{|c|}{$\mathrm{n}$} & 171 & 503 & 4221 \\
\hline \multirow{2}{*}{ Sex n (\%) } & Women & $36(21.1)$ & $392(77.9)$ & $519(12.3)$ \\
\hline & Men & $135(78.9)$ & $111(22.1)$ & $3702(87.7)$ \\
\hline \multicolumn{2}{|c|}{ Age (median [IQR]) } & $44[37,50]$ & $45[41,52]$ & $34[29,44]$ \\
\hline \multicolumn{2}{|c|}{$\begin{array}{l}\text { Lenght of service (median } \\
\text { [IQR]) }\end{array}$} & $18[10,25]$ & $25[20,31]$ & $10[5,16]$ \\
\hline \multicolumn{2}{|c|}{$\mathrm{p}$ (ED-EMS) } & $<0.001$ & $<0.001$ & $<0.001$ \\
\hline
\end{tabular}

test was also used to compare age or seniority between groups of medical personnel. The analysis of the relationship between the two quantitative features was based on the Spearman rank correlation coefficient. Additionally, the Shapiro-Wilk test was used to check the compliance of the empirical distribution of the examined variable with the theoretical normal distribution. Categorized data were presented using frequency and percentages. The relationship between two qualitative features was based on the chi-square independence test.

The results were considered statistically significant if the calculated p-value did not exceed the significance level $\alpha=0.05$. In addition, $R$ software was used for statistical calculations, available at www.r-project.org.

\section{ETHICS}

The consent of the bioethical commission was not deemed necessary since the study does not rely on data from patients' medical records.

\section{RESULTS}

\section{DEMOGRAPHIC CHARACTERISTICS}

There were 315 individuals that did not complete their training and were excluded from the study. Of the 5,362 practitioners included in this study, 467 (8.7\%) were employed by emergency departments and 4,895 (91.3\%) by emergency medical services. The ED group consisted of $18.8 \%$ physicians $(n=88), 27.8 \%$ nurses $(n=130)$, and $53.3 \%$ paramedics $(n=249)$. In the EMS group, $3.4 \%$ were physicians $(n=171), 10.3 \%$ nurses $(n=503)$, and $86.2 \%$ paramedics $(n=4221)$. There were significant differences in age and seniority between the two groups which are summarized in Table I.
Correlation analysis did not reveal a statistically significant relationship between pre-test results and age $(R=0.01, p=0.907)$, or between pre-test results and seniority $(\mathrm{R}=0.01, \mathrm{p}=0.802)$ in the ED group. In the EMS group, however, there was a significant correlation between pre-test results and age $(\mathrm{R}=0.15, \mathrm{p}<0.001)$ and between pre-test results and seniority $(\mathrm{R}=0.14, \mathrm{p}<0.001)$. However, it should be emphasized that this is a very weak relationship and is probably due to the very large number of EMS participants.

\section{INITIAL KNOWLEDGE AND LEARNING RESULTS}

The median of the pre-test results of the ED physicians was significantly lower from the median pre-test results of EMS physicians $(\mathrm{p}=0.038)$. This trend was also present for nurses $(\mathrm{p}<0.001)$ and paramedics $(\mathrm{p}=0.002)$. A summary of these results is shown in Figure 1.

Subsequently, the knowledge gained was assessed by comparing pre-test results with the first attempt at the final test (post-test) among the ED and EMS personnel. In all of the groups there was a statistically significant increase in the number of correct responses in the post-test, compared with the pre-test $(p<0.001)$. EMS nurses scored significantly better on their post-test than ED nurses $(p=0.008)$. The median of the post-test results among physicians employed in EDs and EMS was not significantly different $(\mathrm{p}=0.870)$. Similarly, the median of the post-test results was not significantly different among paramedics from EDs and EMS $(\mathrm{p}=0.096)$.

Among ED staff, 94 (20.1\%) participants did not score the minimum points $(12 / 15)$ needed to pass the course. The percentage of participants who did not pass was similar in the EMS group and amounted to $18.2 \%(n=890)$. There was no significant difference between the passing rates of physicians and paramedics working in an ED or EMS, while there was a statistically significant difference among nurses. Thus, 30.8\% of nurses working in an ED and $15.1 \%$ of those working in EMS did not pass the post-test $(\mathrm{p}<0.001)$ - Figure 2 . 


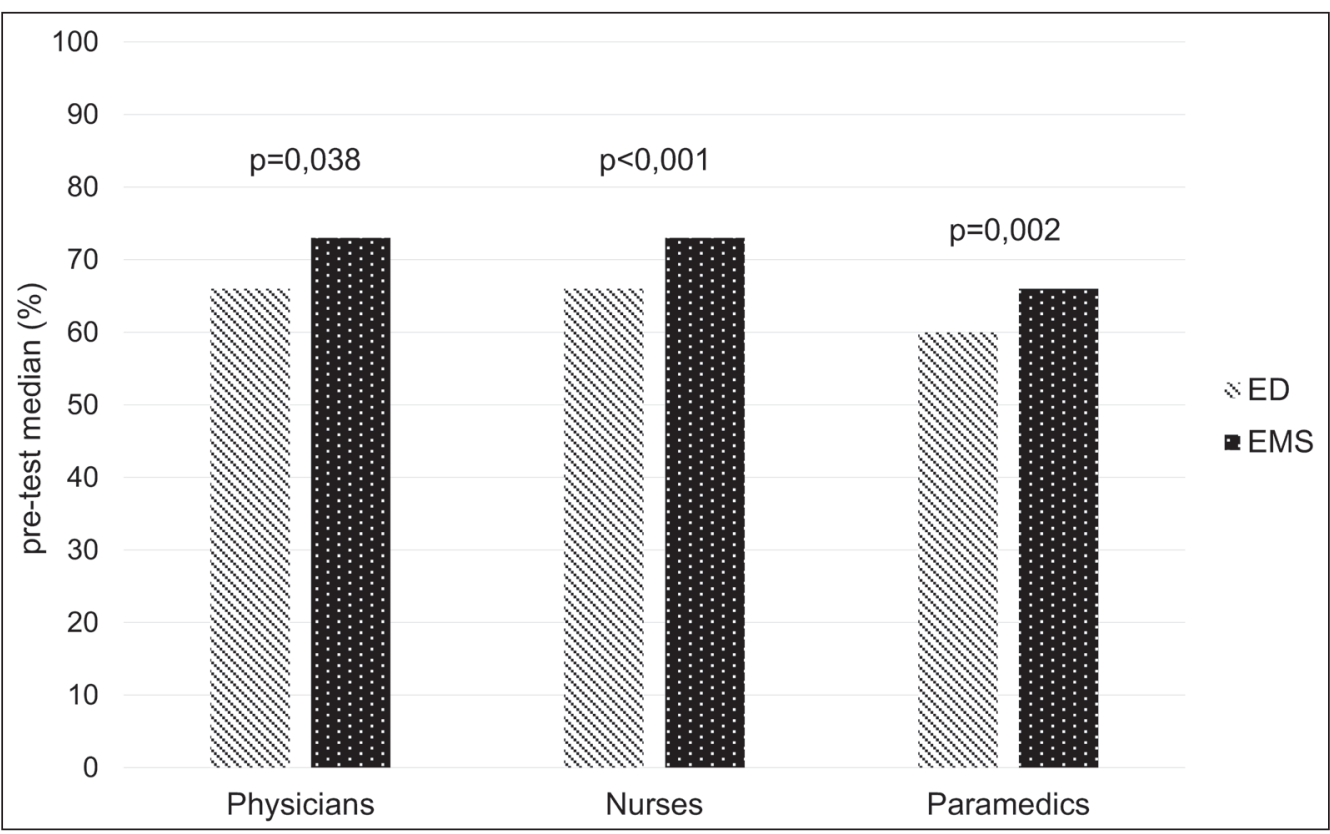

Fig. 1. Comparison of pre-test results of ED and EMS personnel in occupational groups.

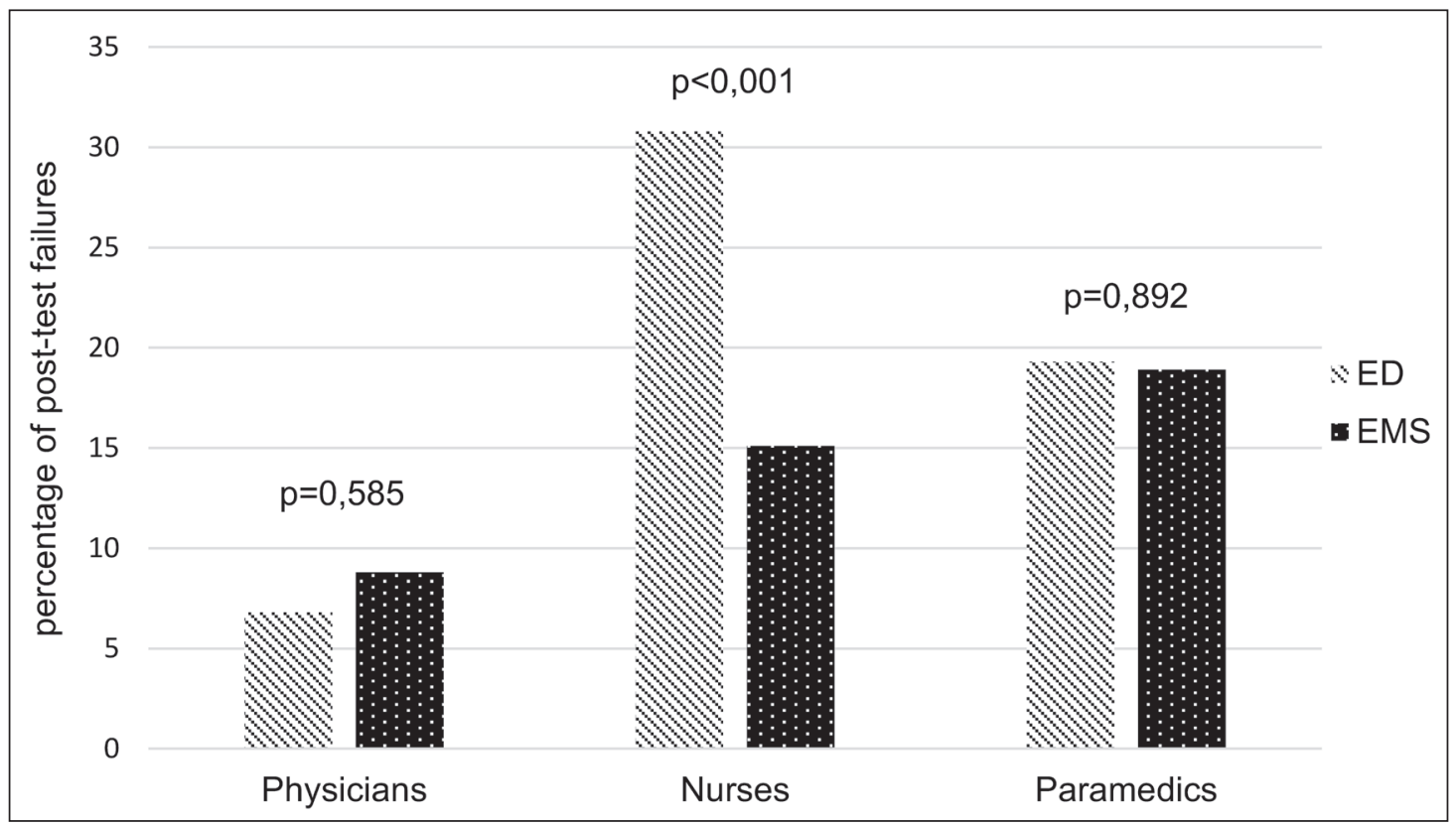

Fig. 2. The percentage of first attempt failed post-tests among occupational groups.

\section{LESSON TESTS}

The scores of five lesson tests were compared. The percentage of correct answers was lower in the ED group - Figure 3. Comparing the distribution of responses to the lesson tests among occupations (physicians, nurses and paramedics) showed a statistically significant difference for the clotting disorders lesson among all occupational groups; avalanche, ECG, and temperature measurement lessons among nurses; and ECG and temperature measurement lessons among paramedics (Tab. II).

As lesson modules on post-traumatic hypothermia differed for the ED and EMS groups, they cannot be directly compared. However, both groups scored poorly in these lesson tests.

\section{DISCUSSION}

Our study showed that the initial level of knowledge concerning hypothermia was significantly higher for all occupational groups working in EMS. The results of the pre-tests and most of the lesson tests in the EMS group were better across all EMS occupations compared with the ED group. These differences are statistically significant.

Regarding these data, one may pose the question whether a hospital is always a safe place for hypothermic patients. In their survey of hypothermia knowledge, Ireland et al. found trauma center staff to have significant gaps in understanding, similar to those uncovered by our study. Coagulation disorders were particularly misunderstood - only $27 \%$ of 
Table II. Comparison of lesson test results from selected lessons (presented as medians [IQR])

\begin{tabular}{|c|c|c|c|c|}
\hline & & Physicians & Nurses & Paramedics \\
\hline \multirow{3}{*}{ Avalanches } & ED & $100[100,100]$ & $100[75,100]$ & $100[75,100]$ \\
\hline & EMS & $100[100,100]$ & $100[100,100]$ & $100[100,100]$ \\
\hline & $\mathrm{p}$ & 0.219 & $<0.001$ & 0.222 \\
\hline \multirow{3}{*}{ ECG } & $\mathrm{ED}$ & $75[75,100]$ & $75[50,100]$ & $75[50,100]$ \\
\hline & EMS & $75[75,100]$ & $75[75,100]$ & $75[75,100]$ \\
\hline & $\mathrm{p}$ & 0.332 & $<0.001$ & 0.004 \\
\hline \multirow{3}{*}{ Thermal insulation } & ED & $100[100,100]$ & $100[75,100]$ & $100[75,100]$ \\
\hline & EMS & $100[75,100]$ & $100[75,100]$ & $100[75,100]$ \\
\hline & $\mathrm{p}$ & 0.175 & 0.058 & 0.083 \\
\hline \multirow{3}{*}{ Clotting disorders } & ED & $75[50,75]$ & $75[50,75]$ & $75[50,75]$ \\
\hline & EMS & $75[50,100]$ & $75[75,100]$ & $75[50,100]$ \\
\hline & $\mathrm{p}$ & 0.042 & $<0.001$ & 0.003 \\
\hline \multirow{3}{*}{$\begin{array}{l}\text { Temperature } \\
\text { measurement }\end{array}$} & ED & $100[75,100]$ & $75[75,100]$ & $75[75,100]$ \\
\hline & EMS & $100[75,100]$ & $100[75,100]$ & $100[75,100]$ \\
\hline & $\mathrm{p}$ & 0.211 & $<0.001$ & 0.001 \\
\hline
\end{tabular}

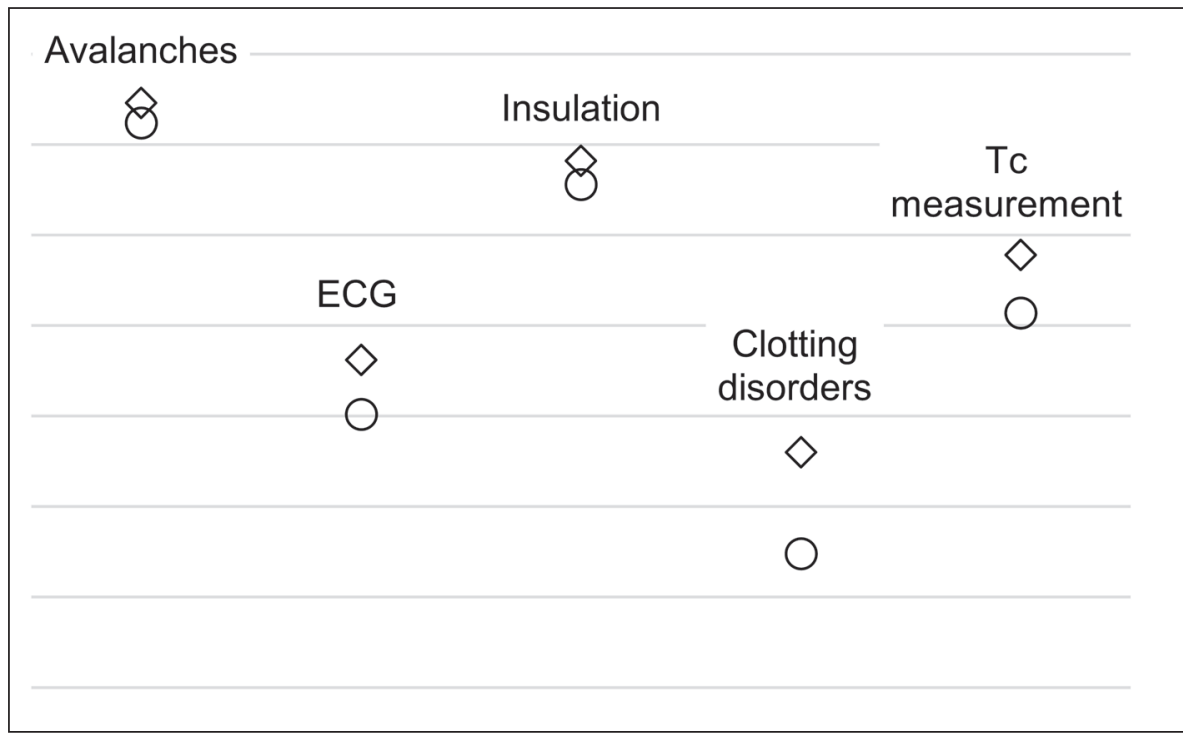

Fig. 3. Percentage of correct answers on lesson tests from individual lessons in the ED and EMS groups.

practitioners were able to identify coagulopathy as a pathology caused by hypothermia. Among those surveyed, other pathophysiological aspects of hypothermia were also poorly known: over $1 / 3(36.4 \%)$ of respondents were unable to identify the temperature below which hypothermia is diagnosed, while $1 / 3$ were unable to identify the most important mechanism of heat loss. Disturbingly, only $16 \%$ of respondents identified the esophagus as a possible location to measure core temperature. It must be mentioned that more than half of the physicians had had lengthy careers and held senior positions and that $1 / 3$ of nurses had completed postgraduate training [10]. Similar results were obtained by Kosiński et al. in a survey on the treatment of patients with hypothermia in EDs. Relatively few patients had a correctly measured core temperature while no patients in cardiac arrest with deep hypothermia were transported to a facility equipped for extracorporeal life support [11]. In light of our results, EMS personnel appear to be better prepared to manage hypothermic patients. Two factors likely contribute to this trend. Firstly, the comparison of demographic data (Tab. I) shows that EMS personnel have significantly more work experience in their respective fields (physicians $18 v s .6$, nurses 25 vs. 21, paramedics 10 vs. 4 years). Secondly, as EMS personnel cannot easily receive help from more experienced colleagues at the scene, this may stimulate them to acquire more knowledge concerning initial patient management [12]. The data support this assumption, showing a correlation between years of service and the results of the pre-tests for the EMS group. However, this correlation is not seen in the ED personnel group. 
Differences in the practitioners working in EDs compared with those in EMS are most pronounced among nurses. This is particularly clear in the analysis of first attempt failures on the post-test. Twice as many ED nurses failed the post-test on their first attempt compared to EMS nurses ( $30.8 \%$ vs $15.1 \%, \mathrm{p}<0.001$ respectively). The scores in the pre-test and individual lesson tests were also higher among the EMS nurses compared with ED nurses. The lower median age in ED staff also points to an overall less experienced population compared with EMS staff. Personnel working in EDs also often train in other specialties in order to work in other hospital departments, thereby further decreasing their time spent on training emergency medicine specifically. We can also assume that medical practitioners with longer careers in emergency medicine (EMS personnel) tend to be those that are the best suited to the profession and, as such, tend to be more effective in their roles. Two studies performed by Aiken et al. highlight the impact of nurses' educational levels on hospital mortality. Thus, the improvement of hospital staff knowledge may lead to an increase in the quality of care $[13,14]$.

Poor tests results may be a consequence of first-time exposure to a subject, while learning material for the first time is less effective than review $[15,16]$. This phenomenon seems to be particularly present for the clotting disorders and post-traumatic hypothermia sections of our online course. The importance of post-traumatic hypothermia and hypothermic coagulopathy is underappreciated not only in Poland but also in other countries with cold climates. This can be seen in the paucity of hypothermia-specific equipment present in Scandinavian ambulances. A study of the equipment carried by the Norwegian emergency services showed that only $12 \%$ of ambulances have thermometers designed for core temperature measurement, and only $14 \%$ have equipment for the active warming of a patient [17].

Our study proved that an e-learning course is an effective teaching tool regarding hypothermia. The increase in theoretical knowledge ranges from 14.5 to 23.1 percentage points (pp) across all occupational groups in both the ED and EMS groups. This corresponds to the results of other studies evaluating e-learning as a medium for education among medical staff. Yao et al. obtained an increase in knowledge of $10.8 \mathrm{pp}$ in the training of medical staff to diagnose gastric cancer. Nesterowicz observed a $16 \mathrm{pp}$ increase in pharmacy course, while Nicastro and Morgulis described a 28 and 29 pp increase respectively in the fields of gastroenterology and hematology [18-21].

\section{LIMITATIONS OF THE STUDY}

The most significant limitation of the study is the disproportionate number of EMS participants compared with ED participants. The relatively small number of ED representatives limits the generalizability of our results. It is likely that individuals who decided to participate in the course are more interested in increasing their knowledge. Therefore, this may induce a selection bias. In addition, since the selection of the ED or EMS modules was used to identify each practitioner's primary workplace, it is difficult to determine the percentage of medical practitioners who work in both an ED and EMS.

\section{CONCLUSIONS}

EMS personnel participating in the training showed a higher level of knowledge concerning hypothermia than hospital ED staff. The biggest differences were seen among nurses. Additional training courses dedicated to ED nurses may be beneficial. All participants of the course displayed poor knowledge of post-traumatic hypothermia and its related coagulopathy. Since these disorders are associated with increased mortality, it seems to be reasonable to emphasize these topics in educational process. Indeed, an e-learning platform is an effective tool for improving emergency medical personnel's understanding of hypothermia.

\section{REFERENCES}

1. Brown DJA, Brugger H, Boyd J et al. Accidental Hypothermia. N Engl J Med. 2012;367:1930-1938.

2. Central Statistical Office of Poland. Demographic Base. 2015.

3. Paal P, Gordon L, Strapazzon G et al. Accidental hypothermia-an update : The content of this review is endorsed by the International Commission for Mountain Emergency Medicine (ICAR MEDCOM). Scand J Trauma Resusc Emerg Med. 2016;24:111.

4. Zafren K, Giesbrecht GG, Danzl DF et al. Wilderness Medical Society Practice Guidelines for the Out-of-Hospital Evaluation and Treatment of Accidental Hypothermia. Wilderness Environ Med. 2014;25:425-445.

5. Mallet ML. Pathophysiology of accidental hypothermia. QJM. 2002;95:775-785.

6. Debaty G, Moustapha I, Bouzat P et al. Outcome after severe accidental hypothermia in the French Alps: A 10-year review. Resuscitation. 2015;93:118-123.

7. ShafiS, Elliott AC, Gentilello L. Is Hypothermia Simply a Marker of Shock and Injury Severity or an Independent Risk Factor for Mortality in Trauma Patients? Analysis of a Large National Trauma Registry. JTrauma Inj Infect Crit Care. 2005;59:1081-1085.

8. Martin RS, Kilgo PD, Miller PR et al. Injury-associated hypothermia: An analysis of the 2004 National Trauma Data Bank. Shock. 2005;24:114-118.

9. Søreide $E$, Morrison L, Hillman $K$ et al. The formula for survival in resuscitation. Resuscitation. 2013;84:1487-1493.

10. Ireland S, Murdoch K, Ormrod P et al. Nursing and medical staff knowledge regarding the monitoring and management of accidental or exposure hypothermia in adult major trauma patients. Int J Nurs Pract. 2006;12:308-318.

11. Kosiński S, Darocha T, Gałązkowski R et al. Accidental hypothermia in Poland - estimation of prevalence, diagnostic methods and treatment. Scand J Trauma Resusc Emerg Med. 2015;23:1-6.

12. Hörberg A, Jirwe M, Kalén S et al. We need support! A Delphi study about desirable support during the first year in the emergency medical service. Scand J Trauma Resusc Emerg Med. 2017;25:1-11.

13. Aiken LH, Sloane DM, Bruyneel $L$ et al. Nurse staffing and education and hospital mortality in nine European countries: a retrospective observational study. Lancet. 2014;383:1824-30.

14. Aiken LH, Clarke SP, Cheung RB et al. Educational levels of hospital nurses and surgical patient mortality. JAMA. 2003;290:1617-1623. 
15. Ally M. Foundations of educational theory for online learning. In: Anderson T, ed. Theory Pract Online Learn. 2nd ed. Alberta: Athabasca University Press; 2008. p. 15-44.

16. Thorne CJ, Lockey AS, Kimani PK et al. e-Learning in Advanced Life SupportWhatfactors influenceassessment outcome? Resuscitation. 2017;114:83-91.

17. Karlsen AM, Thomassen $\emptyset$, Vikenes BH et al. Equipment to prevent, diagnose, and treat hypothermia: A survey of Norwegian pre-hospital services. Scand J Trauma Resusc Emerg Med. 2013;21:63.

18. Yao K, Uedo N, Muto M et al. Development of an E-learning System for the Endoscopic Diagnosis of Early Gastric Cancer: An International Multicenter Randomized Controlled Trial. EBioMedicine. 2016;9:140-147.

19. Nesterowicz K, Librowski T, Edelbring S. Validating e-learning in continuing pharmacy education: User acceptance and knowledge change. BMC Med Educ. 2014;14.

20. Nicastro E, Lo Vecchio A, Liguoro I et al. The Impact of E-Learning on Adherence to Guidelines for Acute Gastroenteritis: A Single-Arm Intervention Study. PLoS One. 2015;10:e0132213.

21. Morgulis $Y$, Kumar RK, Lindeman R et al. Impact on learning of an e-learning module on leukaemia: a randomised controlled trial. BMC Med Educ. 2012;12:36.

\section{Conflicts of interest:}

The authors declare that they have no competing interests. Ethics approval:

Not required since the study does not rely on patients' data. Funding:

This research did not receive any specific grant from funding agencies in the public, commercial, or not-for-profit sectors.

\section{CORRESPONDING AUTHOR \\ Tomasz Darocha}

Department of Anaesthesiology and Intensive Care,

Medical University of Silesia

Medykow 14, 40-752 Katowice, Poland

tel. 502664128

e-mail: tomekdarocha@wp.pl

Received: 23.11.2018

Accepted: 11.02 .2019 
PRACA ORYGINALNA

ORIGINAL ARTICLE

\title{
RHEOLOGICAL, IMMUNOLOGICAL AND MICROBIOLOGICAL PARAMETER DYNAMICS AFTER DENTAL IMPLANTATION
}

\section{ZMIANA PARAMTERÓW REOLOGICZNYCH, IMMUNOLOGICZNYCH ORAZ MIKROBIOLOGICZNYCH PO ZAŁOŻENIU IMPLANTU STOMATOLOGICZNEGO}

\author{
Yuriy Yu. Yarov \\ DONETSK NATIONAL MEDICAL UNIVERSITY, KRAMATORSK, UKRAINE
}

\begin{abstract}
Introduction: It has been proven that the oral hygiene is determined by the quantitative and qualitative composition of the bacterial biofilm, by the local immunity, and the rheological properties of the oral fluid.

The aim of this study was to observe the dynamics of these parameters in the short term postoperative period after dental implantation in patients with a different state of periodontal tissues, depending on maintenance therapy.

Materials and methods: 124healthy people, aged 18 to 34, were examined. Depending on thefollow-up maintenancetherapy after dental implantation, patients were divided into two equal study groups: patients of the main group received the proposed differentiated maintenance therapy, the volume and multiplicity of which were determined by the initial oral hygiene state; patients of the control group underwent traditional treatment. Patients with healthy periodontium comprised a comparison group. Using the digital drop shape, the viscosity coefficientb ${ }_{2}$ was determined. Identification of the biofilm's microorganisms was carried out with aerobicand anaerobic cultivation techniques. The presence of immunoglobulin SIgA in the oral liquid was determined by Manchinis radial immunodiffusion method. Results: In the main group, the viscosity coefficient $b_{2}$ and the content of SIgA immunoglobulin in the oral fluid were significantly higher than in the control group ( $\left.p<0.05\right)$. The proposed maintenance therapy led to the restoration of the species domination of the probiotic microflora, proportional to the healthy periodontium both in the frequency of selection, and the level of insemination. The indicated dynamics of these parameters leads to a probable decrease of the Green-Vermillion $\mathrm{HI}(\mathrm{p}<0,05)$.

Conclusions: Proposed maintenance therapy leads to a probable improvement of the oral hygiene state based on Green-Vermillion Hl, caused by the normalization of the surfactant properties of the oral liquid, biofilm's ratio of microbial associations, and local oral hygiene.
\end{abstract}

KEY WORDS: oral hygiene, dental implants, maintenance therapy

\section{INTRODUCTION}

The hygienic state of the oral cavity significantly influences the healing processes in postoperative wounds after dental implantation, and in the future it also influences the osteointegration of the implant [1-3]. Multiple experimental and clinical studies prove that oral hygiene is largely determined by the quantitative and qualitative composition of the bacterial biofilm, by the local immunity, and the rheological properties of the oral fluid [4-6]. Therefore, identification of abnormalities in these indicators after dental implantation is of practical interest, since it allows for their adjustment with appropriate targeted medical therapy [7]. This is important to maintain a satisfactory oral hygiene at a stable level, as a main component of preventing complications after dental implantation. As more and more people make choices in favor of dental implants each year, the number of patients with complications is expectedly on the rise, with the most common of complications being periimplantitis $[8,9]$. The prevalence of this complication reaches $12-43 \%$ for the majority of implantation systems [10]. The requirement of successful implantation surgery in the immediate and long-term implant functioning becomes even more urgent in patients with inflammatory diseases of periodontal tissues [11].

\section{THE AIM}

Aim of this study was to observe the dynamics of these parameters in the short term postoperative period after dental implantation in patients with a different state of periodontal tissues, depending on maintenance therapy.

\section{MATERIALS AND METHODS}

A total of 124 somatically healthy people (54 men and 70 women) aged 18 to 34 years old were examined, among them: 25 persons with healthy periodontium, 35 patients with chronic catarrhal gingivitis (CCG), 30 patients with 
generalized periodontitis (GP) of the I degree, 34 patients with GP of the II degree of severity. Subsequently, all patients underwent a prescribed dental implant surgery. CCG and GP were diagnosed on the basis of data from clinical examination, radiography, periodontal indexes and tests in accordance with the International Classification of Diseases ICD-10. Oral hygiene state was determined using the total hygienic index of Green-Vermillion (OHI-S) (Green, Vermillion, 1960). Oral fluid was taken for rheological and immunological tests; a dental biofilm was taken by standard method for microbiological testing; for microbiological - a biofilm tooth extraction according to the standard method. Rheological test included using the digital drop shape analyzer, with which the viscosity coefficient $b_{2}$ was determined. The $b_{2}$ coefficient is an indicator that has the strongest correlation with the Green-Vermillion index. Microbiological studies included detection and identification of microorganisms from a biofilm using aerobic and anaerobic cultivation techniques by seeding clinical material from a transport swab into special nutritional environment. The results of the quantitative study of the microflora - the level of insemination - were expressed in colony-forming units per $1 \mathrm{ml}$ of clinical material $(\mathrm{CFU} / \mathrm{ml})$. To evaluate the state of local oral immunity and periodontium tissue, the content of immunoglobulin SIgA in the oral fluid was studied. Detection was performed using Manchini Radial Immunodiffusion.

Depending on further maintenance therapy, patients were divided into two study groups: the main (62 persons) - recieved the proposed differentiated maintenance therapy, the volume and multiplicity of which were determined by the initial hygienic state of the oral cavity; control (62 persons) - received traditional maintenance therapy. Since the medicamental therapy post implantation surgery was not indicated for patients with a healthy periodontium (25 people), they comprised a comparison group. The groups were randomized by sex, age, the nature of concomitant pathology, the state of periodontal tissues, and the type of dental defect. Reducing the amount of probiotic bacteria in a biofilm in patients with chronic catarrhal gingivitis with "unsatisfactory" hygienic conditions makes it advisable to use local probiotics - drugs containing "good" microflora. The presence of aerobic-anaerobic-fungal associations with predominance of parodontopatho- gens and yeast fungi as part of a biofilm in patients with generalized periodontitis defines the tactics of rational antimicrobial therapy - local application of antifungal and antibacterial remedies of a wide spectrum of action. Given the wider range of parodonotopathogens in biofilm and higher values of CFU in $1 \mathrm{ml}$ of clinical material in patients with GP with the progression of the pathological process: at the first degree of severity, antimicrobial therapy after implantation was performed for two weeks, with the second degree of severity - during three weeks. The revealed heterogeneous nature of the differences in the studied parameters of local immunity - the expressed intensity of the parameters studied in patients with generalized periodontitis of the I degree and a decrease in a number of indicators (lysozyme, $\beta$-lysine and immunoglobulin A) with GP II degree - indicate the expediency of using drugs with immunomodulatory action.

\section{RESULTS AND DISCUSSION}

The results of the dynamics of the level of oral hygiene by Green-Vermillion HI showed that in patients of main groups with a different state of periodontal tissues (CCG and GP of the I, II degree of severity) after dental implantation, there is a probable decrease in this indicator compared with the control $(p<0,05)$. In this case, the Green-Vermillion HI in the main groups was, respectively, in CCG patients 1,32 times lower, GP of the I degree - 1,58 times lower, GP II-degree - 1,53 times lower compared with control. This dynamic was stable during the entire term of observation up to 3 months. It should be noted that the level of oral hygiene in patients who received the proposed drug therapy in the postoperative period was comparable to such in healthy periodontium.

The evaluation of changes in the surfactant properties of the oral liquid in patients with chronic catarrhal gingivitis after dental implantation was carried out according to the dynamics of the viscosity coefficient $\left(b_{2}\right)$, which, according to the previous data, has the strongest correlation with Green-Vermillion HI. As can be seen from Table I, the use of a probiotic drug according to the proposed scheme in the postoperative period leads to a significant increase in the viscosity $\left(b_{2}\right)$ at all observation periods, on average 1,71 times compared with the control $(\mathrm{p}<0,05)$.

Table I. Dynamics of the viscosity coefficient (b2) of the oral liquid in patients with chronic catarrhal gingivitis in the immediate observation period(M $\pm \mathrm{SE}, \mathrm{mN} / \mathrm{m}$ )

\begin{tabular}{cccccc}
\hline Research groups & $\begin{array}{c}\mathbf{1 s t} \\
\text { week }\end{array}$ & $\begin{array}{c}\mathbf{2 n d} \\
\text { week }\end{array}$ & $\begin{array}{c}\mathbf{3 d} \\
\text { week }\end{array}$ & $\begin{array}{c}\text { After } \\
\mathbf{2} \text { months }\end{array}$ & $\begin{array}{c}\text { After } \\
\mathbf{3} \text { months }\end{array}$ \\
\hline $\begin{array}{c}\text { Main group } \\
(\mathrm{n}=18)\end{array}$ & $-2,38 \pm 0,32^{*}$ & $-2,32 \pm 0,30^{*}$ & $-2,29 \pm 0.27^{*}$ & $-2,28 \pm 0,29^{*}$ & $-2,32 \pm 0,30^{*}$ \\
\hline $\begin{array}{c}\text { Control } \\
(\mathrm{n}=17)\end{array}$ & $-4,18 \pm 0,30 \wedge$ & $-3,92 \pm 0,29 \wedge$ & $-3,96 \pm 0,32 \wedge$ & $-3,89 \pm 0,33 \wedge$ & $-3,90 \pm 0,28 \wedge$ \\
\hline $\begin{array}{c}\text { Comparison } \\
(n=25)\end{array}$ & $-2,26 \pm 0,24$ & $-2,20 \pm 0,21$ & $-2,23 \pm 0,20$ & $-2,21 \pm 0,21$ & $-2,22 \pm 0,23$ \\
\hline
\end{tabular}

Note: ${ }^{*}-p<0,05$ compared with control; $\wedge-p<0,05$ - compared with the comparison group 
Table II. Dynamics of the detection frequency and the level of insemination of the biofilm in patients with chronic catarrhal gingivitis after the removal of seams in the immediate obsevation terms (abs.units/CFU/ml)

\begin{tabular}{|c|c|c|c|c|c|c|}
\hline \multicolumn{2}{|c|}{ Genus of isolated microorganisms } & $\begin{array}{c}1 \text { st } \\
\text { Week }\end{array}$ & $\begin{array}{c}\text { 2nd } \\
\text { week }\end{array}$ & $\begin{array}{c}\text { 3d } \\
\text { week }\end{array}$ & $\begin{array}{c}\text { After } \\
2 \text { months }\end{array}$ & $\begin{array}{c}\text { After } \\
3 \text { months }\end{array}$ \\
\hline \multirow{6}{*}{ 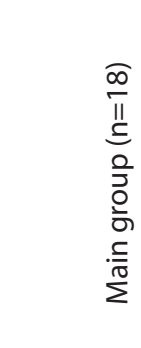 } & Staph. & $16 / 10^{4}-10^{8}$ & $16 / 10^{4}-10^{8}$ & $16 / 10^{4}-10^{8}$ & $16 / 10^{4}-10^{8}$ & $16 / 10^{4}-10^{8}$ \\
\hline & Strept. & $18 / 10^{4}-10^{8}$ & $18 / 10^{4}-10^{8}$ & $18 / 10^{4}-10^{8}$ & $18 / 10^{4}-10^{8}$ & $18 / 10^{4}-10^{8}$ \\
\hline & Lactobac. & $18 / 10^{7}$ & $18 / 10^{7}$ & $18 / 10^{7}$ & $18 / 10^{7}$ & $18 / 10^{7}$ \\
\hline & Entero-bacter & $1 / 10^{4}$ & $2 / 10^{4}, 10^{8}$ & $2 / 10^{4}, 10^{8}$ & $1 / 10^{4}$ & $1 / 10^{4}$ \\
\hline & Fuso-bacter. & $2 / 10^{6}, 10^{8}$ & $2 / 10^{6}, 10^{8}$ & $2 / 10^{6}, 10^{8}$ & $2 / 10^{6}, 10^{8}$ & $2 / 10^{6}, 10^{8}$ \\
\hline & Candida & $4 / 10^{6}-10^{8}$ & $4 / 10^{6}-10^{8}$ & $4 / 10^{6}-10^{8}$ & $4 / 10^{6}-10^{8}$ & $4 / 10^{6}-10^{8}$ \\
\hline \multirow{6}{*}{ 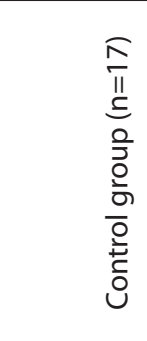 } & Staph. & $14 / 10^{4}-10^{8}$ & $13 / 10^{4}-10^{8}$ & $13 / 10^{4}-10^{8}$ & $13 / 10^{4}-10^{8}$ & $13 / 10^{4}-10^{8}$ \\
\hline & Strept. & $15 / 10^{4}-10^{8}$ & $15 / 10^{4}-10^{8}$ & $15 / 10^{4}-10^{8}$ & $15 / 10^{4}-10^{8}$ & $15 / 10^{4}-10^{8}$ \\
\hline & Lactobac. & $17 / 10^{6}$ & $17 / 10^{6}$ & $17 / 10^{6}$ & $17 / 10^{6}$ & $17 / 10^{6}$ \\
\hline & $\begin{array}{l}\text { Entero } \\
\text { bacter }\end{array}$ & $1 / 10^{4}$ & $2 / 10^{4}, 10^{8}$ & $2 / 10^{4}, 10^{8}$ & $1 / 10^{4}$ & $1 / 10^{4}$ \\
\hline & Fusobac. & $2 / 10^{6}, 10^{8}$ & $2 / 10^{6}, 10^{8}$ & $2 / 10^{6}, 10^{8}$ & $2 / 10^{6}, 10^{8}$ & $2 / 10^{6}, 10^{8}$ \\
\hline & Candida & $4 / 10^{6}-10^{8}$ & $5 / 10^{6}-10^{8}$ & $5 / 10^{6}-10^{8}$ & $4 / 10^{6}-10^{8}$ & $4 / 10^{6}-10^{8}$ \\
\hline \multirow{6}{*}{ 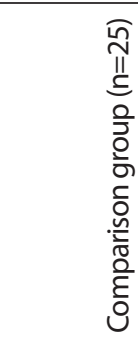 } & Staph. & $23 / 10^{4}-10^{7}$ & $23 / 10^{4}-10^{7}$ & $23 / 10^{4}-10^{7}$ & $24 / 10^{4}-10^{7}$ & $24 / 10^{4}-10^{7}$ \\
\hline & Strept. & $25 / 10^{4}-10^{7}$ & $25 / 10^{4}-10^{7}$ & $25 / 10^{4}-10^{7}$ & $25 / 10^{4}-10^{7}$ & $25 / 10^{4}-10^{7}$ \\
\hline & Lactobac. & $25 / 10^{7}$ & $25 / 10^{7}$ & $25 / 10^{7}$ & $25 / 10^{7}$ & $25 / 10^{7}$ \\
\hline & $\begin{array}{l}\text { Entero } \\
\text { bacter }\end{array}$ & $3 / 10^{3}-10^{5}$ & $3 / 10^{3}-10^{5}$ & $3 / 10^{3}-10^{5}$ & $2 / 10^{3}, 10^{5}$ & $3 / 10^{3}-10^{5}$ \\
\hline & Fusobac. & $2 / 10^{6}, 10^{8}$ & $2 / 10^{6}, 10^{8}$ & $2 / 10^{6}, 10^{8}$ & $3 / 10^{6}-10^{8}$ & $2 / 10^{6}, 10^{8}$ \\
\hline & Candida & $4 / 10^{6}-10^{7}$ & $4 / 10^{6}-10^{7}$ & $4 / 10^{6}-10^{7}$ & $4 / 10^{6}-10^{7}$ & $4 / 10^{6}-10^{7}$ \\
\hline
\end{tabular}

Table III. Dynamics of secretory IgA level in the oral liquid in patients with chronic catarrhal gingivitis after the removal of seams in the immediate observation period $(\mathrm{M} \pm \mathrm{SE}, \mathrm{g} / \mathrm{l})$

\begin{tabular}{cccccc}
\hline Research groups & $\begin{array}{c}\text { 1st } \\
\text { week }\end{array}$ & $\begin{array}{c}\text { 2nd } \\
\text { week }\end{array}$ & $\begin{array}{c}\text { 3d } \\
\text { week }\end{array}$ & $\begin{array}{c}\text { After } \\
\text { 2 months }\end{array}$ & $\begin{array}{c}\text { After } \\
\mathbf{3} \text { months }\end{array}$ \\
\hline \multirow{2}{*}{ Main group $(\mathrm{n}=18)$} & $0,338 \pm$ & $0,332 \pm$ & $0,329 \pm$ & $0,328 \pm$ & $0,332 \pm$ \\
& $0,027^{*}$ & $0,024^{*}$ & $0,022^{*}$ & $0,020^{*}$ & $0,023^{*}$ \\
\hline \multirow{2}{*}{ Control $(\mathrm{n}=17)$} & $0,398 \pm$ & $0,392 \pm$ & $0,386 \pm$ & $0,378 \pm$ & $0,379 \pm$ \\
& $0,030 \wedge$ & $0,029 \wedge$ & $0,026 \wedge$ & $0,027 \wedge$ & $0,028 \wedge$ \\
\hline \multirow{2}{*}{ Comparison $(\mathrm{n}=25)$} & $0,324 \pm$ & $0,320 \pm$ & $0,323 \pm$ & $0,308 \pm$ & $0,302 \pm$ \\
& 0,022 & 0,021 & 0,020 & 0,018 & 0,020 \\
\hline
\end{tabular}

Note: ${ }^{*}-p<0,05$ compared with control; $\wedge-p<0,05$ - compared with the comparison group

The revealed dynamics of the $b_{2}$ indicate the sensitivity of the viscous component of the complex viscoelastic module to the proposed drug treatment. This effect can be explained by the normalization of the amount of lactobacilli that produce lactic acid, which, by increasing salivation, change the viscosity of the oral fluid. The values of this coefficient in the main group were proportional to those with healthy periodontium (comparison group) and were in the range from $-2,20 \pm 0,21$ to $-2,38 \pm 0,32 \mathrm{mN} / \mathrm{m}(\mathrm{p}>0,05)$.

Results of evaluation of the frequency of detection and the level of insemination of the biofilm in patients with chronic catarrhal gingivitis after dental implantation are presented in Table II.
As can be seen from this table, in main group's patients with CCG we can observe a resumption of species dominance of the probiotic microflora in the biofilm, proportional to the frequency of detection and the level of insemination with such in a healthy periodontium. At the same time, in the control, the number of lactobacilli in the clinical material was reduced compared with the main group by 10 times. Periodontal pathogenic anaerobic bacteria in the biofilm were not detected in any patient. Based on the findings of the microbiological study, it can be concluded that the proposed maintenance drug therapy has a normalizing effect on the microbial association of biofilm in patients with chronic catarrhal gingivitis after dental implantation. 
Table IV. Dynamics of the viscosity coefficient (b2) of the oral liquid in patients with generalized periodontitis of the I degree of severity after the removal of seams in the immediate observation period ( $\mathrm{M} \pm \mathrm{SE}, \mathrm{mN} / \mathrm{m})$

\begin{tabular}{|c|c|c|c|c|c|}
\hline Research groups & $\begin{array}{c}\text { 1st } \\
\text { week }\end{array}$ & $\begin{array}{c}\text { 2nd } \\
\text { week }\end{array}$ & $\begin{array}{c}\text { 3d } \\
\text { week }\end{array}$ & $\begin{array}{c}\text { After } \\
2 \text { months }\end{array}$ & $\begin{array}{c}\text { After } \\
3 \text { months }\end{array}$ \\
\hline Main group $(n=15)$ & $\begin{array}{c}-2,42 \pm \\
0,28^{*}\end{array}$ & $\begin{array}{c}-2,38 \pm \\
0,30^{*}\end{array}$ & $\begin{array}{c}-2,30 \pm \\
0,28^{*}\end{array}$ & $\begin{array}{c}-2,32 \pm \\
0,32^{*}\end{array}$ & $\begin{array}{c}-2,34 \pm \\
0,26^{*}\end{array}$ \\
\hline Control $(n=15)$ & $\begin{array}{c}-5,08 \pm \\
0,32 \wedge\end{array}$ & $\begin{array}{c}-4,92 \pm \\
0,30 \wedge\end{array}$ & $\begin{array}{c}-4,95 \pm \\
0,32 \wedge\end{array}$ & $\begin{array}{c}-4.76 \pm \\
0,30 \wedge\end{array}$ & $\begin{array}{c}-4,80 \pm \\
0,29 \wedge\end{array}$ \\
\hline Comparison $(n=25)$ & $\begin{array}{c}-2,26 \pm \\
0,24\end{array}$ & $\begin{array}{c}-2,20 \pm \\
0,21\end{array}$ & $\begin{array}{c}-2,23 \pm \\
0,20\end{array}$ & $\begin{array}{c}-2,21 \pm \\
0,21\end{array}$ & $\begin{array}{c}-2,22 \pm \\
0,23\end{array}$ \\
\hline
\end{tabular}

Note: ${ }^{*}-p<0,05$ compared with control; $\wedge-p<0,05$ - compared with the comparison group

Table V. Dynamics of the detection frequency and the level of insemination of the biofilm in patients with generalized periodontitis of the I degree of severity after the removal of seams in the immediate observation period (abs.units/CFU/ml)

\begin{tabular}{|c|c|c|c|c|c|c|}
\hline \multicolumn{2}{|c|}{$\begin{array}{l}\text { Genus of isolated } \\
\text { microorganisms }\end{array}$} & \multirow{2}{*}{$\begin{array}{c}\begin{array}{c}\text { 1st } \\
\text { week }\end{array} \\
12 / 10^{4}-10^{8}\end{array}$} & \multirow{2}{*}{$\begin{array}{c}\begin{array}{c}\text { 2nd } \\
\text { week }\end{array} \\
12 / 10^{4}-10^{8}\end{array}$} & \multirow{2}{*}{$\begin{array}{c}\begin{array}{c}\text { 3d } \\
\text { week }\end{array} \\
12 / 10^{4}-10^{8}\end{array}$} & \multirow{2}{*}{$\begin{array}{c}\begin{array}{c}\text { After } \\
\mathbf{2} \text { months }\end{array} \\
12 / 10^{4}-10^{8}\end{array}$} & \multirow{2}{*}{$\begin{array}{c}\begin{array}{c}\text { After } \\
3 \text { months }\end{array} \\
12 / 10^{4}-10^{8}\end{array}$} \\
\hline 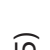 & Staph. & & & & & \\
\hline II & Strept. & $15 / 10^{4}-10^{8}$ & $15 / 10^{4}-10^{8}$ & $15 / 10^{4}-10^{8}$ & $15 / 10^{4}-10^{8}$ & $15 / 10^{4}-10^{8}$ \\
\hline \multirow{4}{*}{ 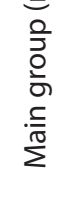 } & Lactobac. & $15 / 10^{7}$ & $15 / 10^{7}$ & $15 / 10^{7}$ & $15 / 10^{7}$ & $15 / 10^{7}$ \\
\hline & Entero-bacter & $2 / 10^{4}, 10^{8}$ & $2 / 10^{4}, 10^{8}$ & $2 / 10^{4}, 10^{8}$ & $2 / 10^{4}, 10^{8}$ & $2 / 10^{4}, 10^{8}$ \\
\hline & Fuso-bacter. & $3 / 10^{6}-10^{8}$ & $3 / 10^{6}-10^{8}$ & $3 / 10^{6}-10^{8}$ & $2 / 10^{6}, 10^{8}$ & $2 / 10^{6}, 10^{8}$ \\
\hline & Candida & $4 / 10^{6}-10^{8}$ & $4 / 10^{6}-10^{8}$ & $4 / 10^{6}-10^{8}$ & $4 / 10^{6}-10^{8}$ & $4 / 10^{6}-10^{8}$ \\
\hline \multirow{9}{*}{$\begin{array}{l}\frac{\pi n}{11} \\
\text { In } \\
0 \\
0 \\
0 \\
0 \\
0 \\
0 \\
0 \\
0 \\
0\end{array}$} & Staph. & $7 / 10^{4}-10^{8}$ & $7 / 10^{4}-10^{8}$ & $7 / 10^{4}-10^{8}$ & $8 / 10^{4}-10^{8}$ & $8 / 10^{4}-10^{8}$ \\
\hline & Strept. & $8 / 10^{4}-10^{8}$ & $8 / 10^{4}-10^{8}$ & $8 / 10^{4}-10^{8}$ & $8 / 10^{4}-10^{8}$ & $8 / 10^{4}-10^{8}$ \\
\hline & Lactobac. & $15 / 10^{5}$ & $15 / 10^{5}$ & $15 / 10^{5}$ & $15 / 10^{5}$ & $15 / 10^{5}$ \\
\hline & $\begin{array}{l}\text { Entero } \\
\text { bacter }\end{array}$ & $1 / 10^{4}$ & $2 / 10^{4}, 10^{8}$ & $2 / 10^{4}, 10^{8}$ & $1 / 10^{4}$ & $1 / 10^{4}$ \\
\hline & Fusobac. & $6 / 10^{6}-10^{8}$ & $6 / 10^{6}-10^{8}$ & $6 / 10^{6}-10^{8}$ & $6 / 10^{6}-10^{8}$ & $6 / 10^{6}-10^{8}$ \\
\hline & Candida & $7 / 10^{6}-10^{8}$ & $7 / 10^{6}-10^{8}$ & $7 / 10^{6}-10^{8}$ & $7 / 10^{6}-10^{8}$ & $7 / 10^{6}-10^{8}$ \\
\hline & Peptostr. & $2 / 10^{2}, 10^{7}$ & $2 / 10^{2}, 10^{7}$ & $2 / 10^{2}, 10^{7}$ & $3 / 10^{2}-10^{7}$ & $3 / 10^{2}-10^{7}$ \\
\hline & Prevotella & $2 / 10^{2}, 10^{8}$ & $2 / 10^{2}, 10^{8}$ & $2 / 10^{2}, 10^{8}$ & $3 / 10^{2}-10^{8}$ & $3 / 10^{2}-10^{8}$ \\
\hline & Porphyr. & $1 / 10^{6}$ & $1 / 10^{6}$ & $1 / 10^{6}$ & $1 / 10^{6}$ & $1 / 10^{6}$ \\
\hline \multirow{6}{*}{ 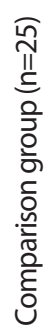 } & Staph. & $23 / 10^{4}-10^{7}$ & $23 / 10^{4}-10^{7}$ & $23 / 10^{4}-10^{7}$ & $24 / 10^{4}-10^{7}$ & $24 / 10^{4}-10^{7}$ \\
\hline & Strept. & $25 / 10^{4}-10^{7}$ & $25 / 10^{4}-10^{7}$ & $25 / 10^{4}-10^{7}$ & $25 / 10^{4}-10^{7}$ & $25 / 10^{4}-10^{7}$ \\
\hline & Lactobac. & $25 / 10^{7}$ & $25 / 10^{7}$ & $25 / 10^{7}$ & $25 / 10^{7}$ & $25 / 10^{7}$ \\
\hline & $\begin{array}{l}\text { Entero } \\
\text { bacter }\end{array}$ & $3 / 10^{3}-10^{5}$ & $3 / 10^{3}-10^{5}$ & $3 / 10^{3}-10^{5}$ & $2 / 10^{3}, 10^{5}$ & $3 / 10^{3}-10^{5}$ \\
\hline & Fusobac. & $2 / 10^{6}, 10^{8}$ & $2 / 10^{6}, 10^{8}$ & $2 / 10^{6}, 10^{8}$ & $3 / 10^{6}-10^{8}$ & $2 / 10^{6}, 10^{8}$ \\
\hline & Candida & $4 / 10^{6}-10^{7}$ & $4 / 10^{6}-10^{7}$ & $4 / 10^{6}-10^{7}$ & $4 / 10^{6}-10^{7}$ & $4 / 10^{6}-10^{7}$ \\
\hline
\end{tabular}

The nature of changes in the state of local oral immunity in patients with chronic catarrhal gingivitis after dental implantation is judged by the dynamics of secretory IgA level in the oral liquid (Table III).

As can be seen from this table, the level of secretory IgA in patients with CCG in the postoperative period during the entire observation period (from 1 week after removal of seams to 3 months) in the control was on average 1,16 times higher than in the main group $(p<0,05)$. The revealed differences in the investigated index in the mouth fluid towards its increase indicates the tension of local immunity of the oral cavity in patients in the control group. At the same time, the level of secretory IgA in patients who, additionally after the operation of dental implantation received the proposed treatment, was proportional to such in a healthy periodontium and was in range from $0,302 \pm 0,020$ to $0,338 \pm 0,027 \mathrm{~g} / \mathrm{l}(\mathrm{p}>0,05)$. This means that the prescribed probiotic, increasing the number of probiotic bacteria, has a stimulating effect on the indicators of local immunity of the oral cavity- leading them to normal values. Changes in the surfactant properties of oral fluid in patients with GP of the I degree in the immediate period after dental implantation were studied via the observation of dynamics of the viscosity coefficient $\left(b_{2}\right)$. 
Table VI. Dynamics of secretory IgA level in the oral liquid in patients with generalized periodontitis of the I degree of severity after the removal of seams in the immediate observation period $(\mathrm{M} \pm \mathrm{SE}, \mathrm{g} / \mathrm{l})$

\begin{tabular}{cccccc}
\hline \multirow{2}{*}{ Research groups } & $\begin{array}{c}\text { 1st } \\
\text { week }\end{array}$ & $\begin{array}{c}\text { 2nd } \\
\text { week }\end{array}$ & $\begin{array}{c}\text { 3d } \\
\text { week }\end{array}$ & $\begin{array}{c}\text { After } \\
\text { 2 months }\end{array}$ & $\begin{array}{c}\text { After } \\
\text { 3 months }\end{array}$ \\
& $0,342 \pm$ & $0,338 \pm$ & $0,334 \pm$ & $0,327 \pm$ & $0,334 \pm$ \\
\multirow{2}{*}{ Main group $(\mathrm{n}=15)$} & $0,026^{*}$ & $0,028^{*}$ & $0,025^{*}$ & $0,022^{*}$ & $0,025^{*}$ \\
\hline \multirow{2}{*}{ Control $(\mathrm{n}=15)$} & $0,438 \pm$ & $0,432 \pm$ & $0,436 \pm$ & $0,437 \pm$ & $0,439 \pm$ \\
& $0,024 \wedge$ & $0,026 \wedge$ & $0,022^{\wedge}$ & $0,025^{\wedge}$ & $0,026 \wedge$ \\
\hline \multirow{2}{*}{ Comparison $(\mathrm{n}=25)$} & $0,324 \pm$ & $0,320 \pm$ & $0,323 \pm$ & $0,308 \pm$ & $0,302 \pm$ \\
& 0,022 & 0,021 & 0,020 & 0,018 & 0,020 \\
\hline
\end{tabular}

Note: ${ }^{*}-p<0,05$ compared with control; $\wedge-p<0,05$ - compared with the comparison group

Table VII. Dynamics of the viscosity coefficient (b2) of the oral liquid in patients with generalized periodontitis of the II degree of severity after the removal of seams in the immediate observation period $(\mathrm{M} \pm \mathrm{SE}, \mathrm{mN} / \mathrm{m})$

\begin{tabular}{|c|c|c|c|c|c|}
\hline Research groups & $\begin{array}{c}\text { 1st } \\
\text { week }\end{array}$ & $\begin{array}{c}\text { 2nd } \\
\text { week }\end{array}$ & $\begin{array}{c}\text { 3d } \\
\text { week }\end{array}$ & $\begin{array}{c}\text { After } \\
2 \text { months }\end{array}$ & $\begin{array}{c}\text { After } \\
3 \text { months }\end{array}$ \\
\hline Main group $(n=17)$ & $\begin{array}{c}-2,58 \pm \\
0,31^{*}\end{array}$ & $\begin{array}{c}-2,46 \pm \\
0,30^{*}\end{array}$ & $\begin{array}{c}-2,41 \pm \\
0,29^{*}\end{array}$ & $\begin{array}{c}-2,42 \pm \\
0,30^{*}\end{array}$ & $\begin{array}{c}-2,39 \pm \\
0,28^{*}\end{array}$ \\
\hline Control $(n=17)$ & $\begin{array}{c}-6,12 \pm \\
0,30^{\wedge} \\
\end{array}$ & $\begin{array}{c}-5,97 \pm \\
0,28 \wedge \\
\end{array}$ & $\begin{array}{c}-5,94 \pm \\
0,27 \wedge \\
\end{array}$ & $\begin{array}{c}-5,96 \pm \\
0,31 \wedge \\
\end{array}$ & $\begin{array}{c}-6,08 \pm \\
0,31 \wedge \\
\end{array}$ \\
\hline Comparison $(n=25)$ & $\begin{array}{c}-2,26 \pm \\
0,24\end{array}$ & $\begin{array}{c}-2,20 \pm \\
0,21\end{array}$ & $\begin{array}{c}-2,23 \pm \\
0,20\end{array}$ & $\begin{array}{c}-2,21 \pm \\
0,21\end{array}$ & $\begin{array}{c}-2,22 \pm \\
0,23\end{array}$ \\
\hline
\end{tabular}

Note: ${ }^{*}-p<0,05$ compared with control; $\wedge-p<0,05$ - compared with the comparison group

As can be seen from Table IV, the use of the proposed drug therapy in addition to the traditional scheme of postoperative management of patients, changes the rheological properties of the oral fluid, resulting in a probable increase in the viscosity coefficient $\left(b_{2}\right)$ in all terms of observation, on average, 2,08 times higher compared with control $(\mathrm{p}<0.05)$. At the same time, the value of the investigated parameter in the main group was in the range from $-2,42 \pm 0,28$ to $-2,30 \pm 0,28 \mathrm{mN} / \mathrm{m}$, in control: from $-5,08 \pm 0,32$ to $-4,76 \pm 0,30 \mathrm{mN} / \mathrm{m}$. The revealed differences in the $b_{2}$ indicate a significant sensitivity of the viscous component of the complex viscoelastic module to the proposed drug combination. It should be noted that the values of this coefficient in the main group were comparable with those in healthy periodontium $(p>0,05)$.

Results of microbiological research in patients with generalized periodontitis of the I degree of severity after dental implantation are presented in Table V.

As can be seen from this table, in the main group there is a species dominance of lactobacilli and optional aerobes is proportional to the frequency of detection, and the level of insemination with such in a healthy periodontium throughout the monitoring period. At the same time, in patients of the control group the presence of aerobic-anaerobic-fungal associations was observed due to the expansion of the spectrum of identified gram-positive and gram-negative anaerobic periodontal pathogens, namely: Peptostreptcoccus, Prevotella, Porphyromonas. Based on the data obtained from microbiological studies it can be concluded that, in addition to the traditional therapy, the proposed combination of drugs provides the evident antifungal and antimicrobial activity in relation to the pathogenic microflora of a biofilm in patients with generalized periodontitis of the I degree of severity after dental implantation by reducing the frequency of detection and the level of insemination of periodontal tissues by parodontopathogens and fungi. The established antimicrobial efficacy of the proposed combination is related to both direct damage of lipid membranes of microorganisms and fungi under the action of antimicrobial drug, and with an indirect antimicrobial effect of an immunomodulatory drug.

The nature of changes in local oral immunity in patients with generalized periodontitis of the I degree of severity after dental implantation was judged by the dynamics of secretory IgA level in the oral liquid as the parameter most correlated with the level of hygiene by Green-Vermillion HI.

As shown in Table VI, the level of secretory IgA in the oral liquid of the GP of the I degree of severity patients in the postoperative period during the observation period from the 1 st week after removal of seams to 3 months in the control were significantly higher than in the main group and were in the range from $0,432 \pm 0,026$ to $0,438 \pm 0,024 \mathrm{~g} / \mathrm{l}(\mathrm{p}<0,05)$. The determined differences of the investigated index in the direction of increase indicate the pronounced tension of local oral immunity in patients of the control group. At the same time, the level of secretory IgA in patients who, after the operation, according to the proposed scheme, received appropriate drug therapy, were comparable with those with healthy periodontium and were observed in the range from $0,327 \pm 0,022$ to $0,342 \pm 0,028 \mathrm{~g} / \mathrm{l}(\mathrm{p}>0,05)$, which is, on average, 1,30 times less than in the control. The determined differences in the values of the investigated index indicate the expressed immunomodulatory properties of the proposed medical treatment that can stimulate local protective mechanisms by increasing the production of the antimicrobial fac- 
Table VIII. Dynamics of the detection frequency and the level of insemination of the biofilm in patients with generalized periodontitis of the II degree of severity after the removal of seams in the immediate observation period (abs.units/CFU/ml)

\begin{tabular}{|c|c|c|c|c|c|c|}
\hline \multicolumn{2}{|c|}{ Genus of isolated microorganisms } & $\begin{array}{c}\text { 1st } \\
\text { week }\end{array}$ & $\begin{array}{c}\text { 2nd } \\
\text { week }\end{array}$ & $\begin{array}{c}\text { 3d } \\
\text { week }\end{array}$ & $\begin{array}{c}\text { After } \\
2 \text { months }\end{array}$ & $\begin{array}{c}\text { After } \\
3 \text { months }\end{array}$ \\
\hline \multirow{6}{*}{ 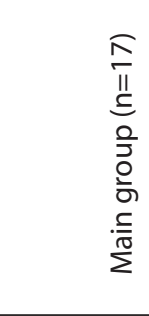 } & Staph. & $14 / 10^{4}-10^{8}$ & $14 / 10^{4}-10^{8}$ & $14 / 10^{4}-10^{8}$ & $14 / 10^{4}-10^{8}$ & $14 / 10^{4}-10^{8}$ \\
\hline & Strept. & $17 / 10^{4}-10^{8}$ & $17 / 10^{4}-10^{8}$ & $17 / 10^{4}-10^{8}$ & $17 / 10^{4}-10^{8}$ & $17 / 10^{4}-10^{8}$ \\
\hline & Lactobac. & $17 / 10^{7}$ & $17 / 10^{7}$ & $17 / 10^{7}$ & $17 / 10^{7}$ & $17 / 10^{7}$ \\
\hline & Entero-bacter & $3 / 10^{4}-10^{8}$ & $3 / 10^{4}-10^{8}$ & $3 / 10^{4}-10^{8}$ & $3 / 10^{4}-10^{8}$ & $3 / 10^{4}-10^{8}$ \\
\hline & Fuso-bacter. & $1 / 10^{6}$ & $1 / 10^{6}$ & $1 / 10^{6}$ & $1 / 10^{6}$ & $1 / 10^{6}$ \\
\hline & Candida & $3 / 10^{6}-10^{8}$ & $3 / 10^{6}-10^{8}$ & $3 / 10^{6}-10^{8}$ & $3 / 10^{6}-10^{8}$ & $3 / 10^{6}-10^{8}$ \\
\hline \multirow{14}{*}{ 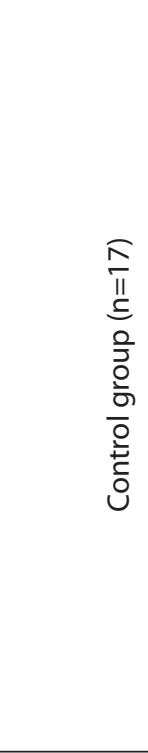 } & Staph. & $8 / 10^{4}-10^{8}$ & $8 / 10^{4}-10^{8}$ & $8 / 10^{4}-10^{8}$ & $8 / 10^{4}-10^{8}$ & $8 / 10^{4}-10^{8}$ \\
\hline & Strept. & $3 / 10^{4}-10^{8}$ & $3 / 10^{4}-10^{8}$ & $3 / 10^{4}-10^{8}$ & $3 / 10^{4}-10^{8}$ & $3 / 10^{4}-10^{8}$ \\
\hline & Lactobac. & $17 / 10^{4}$ & $17 / 10^{4}$ & $17 / 10^{4}$ & $17 / 10^{4}$ & $17 / 10^{4}$ \\
\hline & $\begin{array}{l}\text { Entero } \\
\text { bacter }\end{array}$ & $2 / 10^{4}, 10^{8}$ & $2 / 10^{4}, 10^{8}$ & $2 / 10^{4}, 10^{8}$ & $2 / 10^{4}, 10^{8}$ & $2 / 10^{4}, 10^{8}$ \\
\hline & Fusobac. & $9 / 10^{6}-10^{8}$ & $9 / 10^{6}-10^{8}$ & $9 / 10^{6}-10^{8}$ & $9 / 10^{6}-10^{8}$ & $9 / 10^{6}-10^{8}$ \\
\hline & Candida & $8 / 10^{6}-10^{8}$ & $8 / 10^{6}-10^{8}$ & $8 / 10^{6}-10^{8}$ & $8 / 10^{6}-10^{8}$ & $8 / 10^{6}-10^{8}$ \\
\hline & Peptostr. & $3 / 10^{2}-10^{7}$ & $3 / 10^{2}-10^{7}$ & $3 / 10^{2}-10^{7}$ & $3 / 10^{2}-10^{7}$ & $3 / 10^{2}-10^{7}$ \\
\hline & Prevotella & $4 / 10^{2}-10^{8}$ & $4 / 10^{2}-10^{8}$ & $4 / 10^{2}-10^{8}$ & $4 / 10^{2}-10^{8}$ & $4 / 10^{2}-10^{8}$ \\
\hline & Porphyr. & $3 / 10^{6}-10^{8}$ & $3 / 10^{6}-10^{8}$ & $3 / 10^{6}-10^{8}$ & $3 / 10^{6}-10^{8}$ & $3 / 10^{6}-10^{8}$ \\
\hline & Actinom. & $1 / 10^{7}$ & $1 / 10^{7}$ & $1 / 10^{7}$ & $1 / 10^{7}$ & $1 / 10^{7}$ \\
\hline & Pseudom. & $2 / 10^{5}, 10^{7}$ & $2 / 10^{5}, 10^{7}$ & $2 / 10^{5}, 10^{7}$ & $2 / 10^{5}, 10^{7}$ & $2 / 10^{5}, 10^{7}$ \\
\hline & Klebsiell. & $2 / 10^{4}, 10^{7}$ & $2 / 10^{4}, 10^{7}$ & $2 / 10^{4}, 10^{7}$ & $2 / 10^{4}, 10^{7}$ & $2 / 10^{4}, 10^{7}$ \\
\hline & Capnocyt. & $7 / 10^{7}-10^{8}$ & $7 / 10^{7}-10^{8}$ & $7 / 10^{7}-10^{8}$ & $7 / 10^{7}-10^{8}$ & $7 / 10^{7}-10^{8}$ \\
\hline & Bacteroid & $1 / 10^{6}$ & $1 / 10^{6}$ & $1 / 10^{6}$ & $1 / 10^{6}$ & $1 / 10^{6}$ \\
\hline \multirow{6}{*}{ 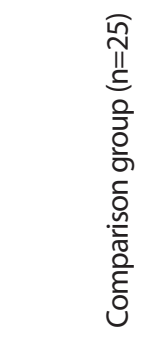 } & Staph. & $23 / 10^{4}-10^{7}$ & $23 / 10^{4}-10^{7}$ & $23 / 10^{4}-10^{7}$ & $24 / 10^{4}-10^{7}$ & $24 / 10^{4}-10^{7}$ \\
\hline & Strept. & $25 / 10^{4}-10^{7}$ & $25 / 10^{4}-10^{7}$ & $25 / 10^{4}-10^{7}$ & $25 / 10^{4}-10^{7}$ & $25 / 10^{4}-10^{7}$ \\
\hline & Lactobac. & $25 / 10^{7}$ & $25 / 10^{7}$ & $25 / 10^{7}$ & $25 / 10^{7}$ & $25 / 10^{7}$ \\
\hline & $\begin{array}{l}\text { Entero } \\
\text { bacter }\end{array}$ & $3 / 10^{3}-10^{5}$ & $3 / 10^{3}-10^{5}$ & $3 / 10^{3}-10^{5}$ & $2 / 10^{3}, 10^{5}$ & $3 / 10^{3}-10^{5}$ \\
\hline & Fusobac. & $2 / 10^{6}, 10^{8}$ & $2 / 10^{6}, 10^{8}$ & $2 / 10^{6}, 10^{8}$ & $3 / 10^{6}-10^{8}$ & $2 / 10^{6}, 10^{8}$ \\
\hline & Candida & $4 / 10^{6}-10^{7}$ & $4 / 10^{6}-10^{7}$ & $4 / 10^{6}-10^{7}$ & $4 / 10^{6}-10^{7}$ & $4 / 10^{6}-10^{7}$ \\
\hline
\end{tabular}

tor - secretory IgA, which provides an indirect antimicrobial action in relation to parodontopathogens of the oral cavity.

The dynamics of the viscosity coefficient in the oral liquid in patients with generalized periodontitis of the II degree of severity after dental implantation is presented in Table VII.

As can be seen from the table, the use of antimicrobial, antifungal and immunomodulatory drugs according to the proposed scheme in the postoperative period changes the rheological properties of the oral fluid, which leads to a probable increase in the viscosity $\left(b_{2}\right)$ value, starting from the 1st week after the seams are removed and in all further observation time up to 3 months, on average, 2,45 times higher compared with control $(\mathrm{p}<0,05)$. In this case, the value of the studied parameter in the main group was in the range from $-2,58 \pm 0,31$ to $-2,39 \pm 0,28 \mathrm{mN} / \mathrm{m}$, in: from $-6,12 \pm 0,30$ to $-5,94 \pm 0,27 \mathrm{mN} / \mathrm{m}$. The revealed differences of the $b_{2}$ coefficient indicate an even more significant sensitivity of the viscous component of the complex vis- coelastic module to the proposed drug combination as the periodontal tissue pathology progresses. It should be noted that the values of this coefficient in the main group were proportional to those in healthy periodontium $(\mathrm{p}>0,05)$.

The results of microbiological research in patients with generalized periodontitis of the II degree of severity in the immediate period of observation after dental implantation are presented in Table VIII.

As can be seen from this table, patients of the main group have a predominant probiotic microflora and optional aerobes, which by the frequency of detection and the level of insemination is comparable with such in a healthy periodontium throughout the observation period, starting from the 1 st week after withdrawal seams and for all subsequent terms up to 3 months. In control, the presence of aerobic-anaerobic-fungal associations with dominance of optional and obligate anaerobes and yeast fungi was noted. This is due, firstly, to the further expansion of the spectrum 
Table IX. Dynamics of secretory IgA level in the oral liquid in patients with generalized periodontitis of the II degree of severity after the removal of seams in the immediate observation period $(\mathrm{M} \pm \mathrm{SE}, \mathrm{g} / \mathrm{l})$

\begin{tabular}{cccccc}
\hline Research groups & $\begin{array}{c}\text { 1st } \\
\text { week }\end{array}$ & $\begin{array}{c}\text { 2nd } \\
\text { week }\end{array}$ & $\begin{array}{c}\text { 3d } \\
\text { week }\end{array}$ & $\begin{array}{c}\text { After } \\
\text { 2 months }\end{array}$ & $\begin{array}{c}\text { After } \\
\mathbf{3} \text { months }\end{array}$ \\
\hline \multirow{2}{*}{ Main group $(\mathrm{n}=17)$} & $0,354 \pm$ & $0,348 \pm$ & $0,344 \pm$ & $0,337 \pm$ & $0,338 \pm$ \\
& $0,028^{*}$ & $0,030^{*}$ & $0,027^{*}$ & $0,026^{*}$ & $0,025^{*}$ \\
\hline Control & $0,452 \pm$ & $0,448 \pm$ & $0,452 \pm$ & $0,449 \pm$ & $0,446 \pm$ \\
$(\mathrm{n}=17)$ & $0,023 \wedge$ & $0,022 \wedge$ & $0,024 \wedge$ & $0,025 \wedge$ & $0,024 \wedge$ \\
\hline Comparison & $0,324 \pm$ & $0,320 \pm$ & $0,323 \pm$ & $0,308 \pm$ & $0,302 \pm$ \\
$(\mathrm{n}=25)$ & 0,022 & 0,021 & 0,020 & 0,018 & 0,020 \\
\hline
\end{tabular}

Note: ${ }^{*}-p<0,05$ compared with control; $\wedge-p<0,05$ - compared with the comparison group

of identified periodontal pathogens, namely Actinomyces, Klebsiella, Capnocytophaga, Bacteroidas, and secondly, due to an increase in the frequency of detection and level of insemination with anaerobes and fungi. Based on the findings of the microbiological study, it can be concluded that the proposed maintenance therapy with the combination of antimicrobial and immunomodulatory drugs, has a pronounced antimicrobial action in relation to the pathogenic microflora of biofilm in patients with generalized periodontitis of the II degree of severity in the immediate period after dental implantation. This is due to a decrease in the frequency of detection and level of insemination of periodontal tissues with parodontopathogens and fungi.

The character of changes in the state of local oral immunity in patients with generalized periodontitis of the II degree of severity after dental implantation was judged by the dynamics of secretory IgA level in the oral liquid, as the parameter that most closely correlates with the level of hygiene by the Green-Vermillion index.

As can be seen from Table IX, the level of secretory IgA in this category of patients in the postoperative period during the observation period from the 1st week after removal of seams to 3 months in the control were significantly higher than in the main group, on average, by 1,31 times (ranged from 0,446 $\pm 0,024$ to $0,452 \pm 0,023 \mathrm{~g} / \mathrm{l}(\mathrm{p}<0,05)$. The differences of the investigated index in the oral liquid in the direction of an even greater increase compared to that of the GP of the 1st degree testify to the more pronounced tension of local immunity of the oral cavity with the GP of the II degree (control group). In this case, the level of secretory IgA in patients who received additional therapy after the surgery according to the proposed scheme, were proportional to those in healthy periodontium and were in the range of $0,337 \pm 0,026$ to $0,354 \pm 0,028 \mathrm{~g} / \mathrm{l}$ $(\mathrm{p}>0,05)$. The determined differences in the values of the investigated index indicate the expressed immunomodulatory properties of the proposed drug treatment, which stimulates local protective mechanisms by increasing the detection of an antimicrobial factor - secretory IgA, which has a pronounced mediated antimicrobial action in relation to the parodontopagic microflora of the oral cavity.

Our research confirms the fact that, firstly, the hygienic state of the oral cavity is determined by the quantitative and qualitative composition of the biofilm, the state of local immunity and the rheological properties of the oral fluid, and, secondly, the use of the proposed maintenance treatment after dental implantation leads to the normalization of surfactant properties of the oral fluid, the ratio of microbial associations of biofilms and indices of local immunity. We have proved that the indicated dynamics of the investigated parameters leads to a probable decrease in Green-Vermillion $\mathrm{HI}(\mathrm{p}<0,05)$. A number of researchers have proven the role of oral hygiene in the postoperative period [12]. However, we propose a differential approach to the prescription of drugs depending on the initial level of hygiene and, accordingly, the state of periodontal tissues.

\section{CONCLUSION}

An analysis of the dynamics of rheological, immunological and microbiological parameters in patients with a different state of periodontal tissues (chronic catarrhal gingivitis, generalized periodontitis of the I and II degrees of severity) after dental implantation testifies to the effectiveness of the proposed maintenance therapy in the immediate follow-up periods of the $1^{\text {st }}$ week after the seams are removed for up to 3 months. The application of the proposed drugs according to the scheme leads to optimization of the terms of postoperative wound healing, a probable improvement of the hygienic state of the oral cavity by Green-Vermillion $\mathrm{HI}$ due to the normalization of the surfactant properties of the oral fluid, the normalization of the ratio of microbial associations of the biofilm and indices of local immunity of the oral cavity.

\section{REFERENCES}

1. Timofeev A. A, Beda V, Yarifa M. Gigiena polosti rta posle provedeniya hirurgicheskogo etapa dentalnoy implantatsii [0ral hygiene after the surgical stage of dental implantation]. Sovremennaya stomatologiya. 2009;2 (46):106 - 114. (In Ukranian).

2. Yarov Yu.Yu, Silenko Yu. DvornikV, Kuts P. Podderzhivayucchee lechenie posle dentalnoy implantatsii [Supportive treatment after dental implantation]. Ukrainskii stomatologichnii almanax. 2014;5-6:71-74. (In Ukranian).

3. Novitskiy V. B. Efektivnist ratsionalnoyi gigieni porozhnini rota ta zastosuvannya osteotropnih zasobiv v period osteointegratsiyi dentalnih implantativ [Effectiveness of rational and hygienic empty company and osteotropic zasosuvannya during the period of osseointegration of dental implants] Visnik stomatologiyi. 2006;3:59 - 62. (In Ukranian) 
4. Gemmel E, Marshal R, Seymour G. Cytokines and prostaglandins in immune homeostasis and tissue destruction in periodontal disease. Periodontol. 2000. 2007; Vol. 14:112 - 143.

5. Maschenko I. S, Gudaryan A, Shirinkin S. Kompleksnaya otsenka faktorov riska razvitiya retsidivov dentalnyih periimplantitov v ramkah vtorichnoy profilaktiki [Comprehensive assessment of risk factors for recurrence of dental periimplantitis as part of secondary prevention]. Visnik stomatologiyi. 2013;1:66 - 73. (In Ukranian)

6. Borisenko A. V, Smolyar V. Zmini mikroflori porozhnini rota na etapah implantatsiyi [changes in the microflora of the empty company during the implantation stages]. Visnik stomatologiyi. 2013;4:50-53. (In Ukranian)

7. Sidelnikov P.V. Gigiena polosti rta na etapah implantatsii [Oral hygiene at the stages of implantation]. Sovremennaya stomatologiya. 2002;1:81 - 83. (In Russian)

8. Labunets V.A. Rasprostranennost, intensivnost, struktura, tendentsii razvitiya malyih vklyuchennyih defektov zubnyih ryadov u lits molodogo vozrasta i ih oslozhneniy [Prevalence, intensity, structure, development trends of small included dentition defects in young people and their complications]. Visnik stomatologiyi. 2013;1:93 100. (In Russian)

9. Paraskevich V. L. Dentalnaya implantologiya: Osnovyi teorii i praktiki [ Dental Implantology: Fundamentals of Theory and Practice]. 000 »Yunipress», 2002:368 s. (In Russian)
10. Shvarts F., Beker Yu. Periimplantit: etiologiya, diagnostika i lechenie. [Periimplantitis: etiology, diagnosis and treatment]. M.:GalDent, 2014:282s. (In Russian)

11. Borisenko A. V, Tivonenko L, Ahrameeva N. Zavisimost mezhdu sostavom mikrofloryi parodontalnyih karmanov i harakterom techeniya generalizovannogo parodontita [The relationship between the composition of themicroflora of periodontal pockets and the nature of the flow of generalized periodontitis]. Sovremennayastomatologiya.2005;3 (31):50-52. (In Russian)

12. Ugrin M. M, Bronska Yu, Ugrin 0 . Rol profesiynoyi gigieni u pidtrimuyuchiy terapiyi na riznih etapah implantoproteznoyi reabilitatsiyi patsientiv ta osnovni vimogi do spetsialista. [The role of professional hygiene and pediatric therapy in the early stages of implant prosthesis and patient rehabilitation is basic to specialist]. Implantologlya. Parodontologlya. Osteologlya. 2008;2 (10):13 -20. (In Ukranian)

The work is a fragment of the research initiative of the Department of Stomatology №2, Donetsk National Medical University «To develop supportive treatment of patients after dental implantation, depending on the level of oral hygiene». State registration number $0116 U 004191$.

Source of funding: own funds.

\section{Conflict of interest:}

The Author declare no conflict of interest.

\section{CORRESPONDING AUTHOR} Yuriy Yu. Yarov

Donetsk National Medical University

Mashonobudivnikov Boulevard, 39,

84404 Kramatorsk, Ukraine

tel: +380506204307

e-mail: Kaf.stomatologii2@ukr.net

Received: 02.10.2018

Accepted: 27.01.2019 
PRACA ORYGINALNA

ORIGINAL ARTICLE

\title{
MORPHOLOGICAL AND PHYSIOLOGICAL, BIOLOGICAL AND EPIDEMIOLOGICAL FEATURES OF ACARIANA OF THE GENUS IXODES (LATREILLE, 1795) - HUMAN ECTOPARASITES IN BIOGEOCENOSES OF TERNOPIL REGION
}

\author{
MORFOLOGICZNE, FIZJOLOGICZNE, BIOLOGICZNE \\ ORAZ EPIDEMIOLOGICZNE CECHY ROZTOCZY Z RZĘDU \\ KLESZCZY (LATREILLE, 1795) - LUDZKICH EKTOPASOŻYTÓW \\ W BIOGEOCENOZIE W OBWODZIE TARNOPOLSKIM
}

\author{
Larysa Ya. Fedoniuk', Stepan S. Podobivskyi', Alexandr M. Kamyshnyi' ${ }^{2}$, Anna S. Saturska', Vira 0. Khavtur', \\ Olga M. Marchuk', Oksana M. Zahrychuk', Olga B. Furka', Valentyna M. Cherniashova' \\ 'STATE HIGHER EDUCATIONAL ESTABLISHMENT IVAN HORBACHEVSKY TERNOPIL STATE MEDICAL UNIVERSITY OF MINISTRY OF PUBLIC HEALTH OF UKRAINE, \\ TERNOPIL, UKRAINE \\ 2ZAPORIZHZHIA STATE MEDICAL UNIVERSITY, ZAPORIZHZHIA, UKRAINE
}

\begin{abstract}
Introduction: Ixodine are an integral part of many biotopes, in particular rarefied deciduous and mixed forests, gardens, parks, squares, semi-steppe and steppe areas, etc. Over the past decade, the role of ticks has increased in the transfer of pathogens of many diseases of animals and humans. In particular, these are tick borelliosis, anaplasmosis, erlichiosis, babesiosis, and etc. An important element of the study of ticks is the study of their morphology, physiology, biology, medical and sanitary significance. The aim: Investigation of morphological and physiological features of various life stages of ticks during the feeding period, studying the epidemiological state of acariana in different seasons.

Materials and methods: The main materials and tools used to catch, keep and identify the ticks were tweezers, lenses, microscopic needles, white cloth for the «flag», alcohol $70 \%$, test tubes. The study was carried out using optical and electronic system SEO-IMAGLAB. Investigation of epidemiological state was carried out using the polymerase chain reaction (PCR) using amplifier method "ROTOR Gene -6000 " in real time.

Results: As a result of the analysis of morphological parameters, certain regularities in the ratio of total body length to the width of the abdomen were found at different stages of saturation. From the investigated acariana in 2017 to detect infectious pathogens, 46 females (39\%), 56 nymphs (32\%), 1 larvae (33.3\%) were investigated. 2 undetected acariana were carriers of 3 types of pathogens infectious diseases: Borrelia Burgdorferi senso lato (66 cases), Anaplasma phagocytophilum (30 cases) and Borrelia Miyamotoi (6 cases). According to the results of 2018, the number of carriers of the infectious agents was $158(33.2 \%)$, which of them were females $58(33.7 \%)$, males 2 (40\%), nymphs 86 (32.5\%), larvae $2(10.5 \%)$.

Conclusions: Proceeding from the analysis of the infection frequency of $I x$ odes ricinus carriers of infectious diseases, it was found out the increase in the number of females and nymphs of borrels carriers, from May to July with an average temperature increase of $18-23^{\circ} \mathrm{C}$ to $25-27^{\circ} \mathrm{C}$ and subsequently a decrease in the frequency of their infection from August to October when the temperature drops to $20-15^{\circ} \mathrm{C}$.
\end{abstract}

KEY WORDS: Ixodes, Ixodes Latr., Dermacentor Fabr., Ixodes ricinus, Dermacentor reticulatus, Borelli, Anaplasm

Wiad Lek 2019, 72, 2, 114-228

\section{INTRODUCTION}

Among the large variety of arthropods of invertebrates, a large number of them have a sanitarian and medical significance for humans $[1,2]$. One of these groups is a subclass of ticks (Acarina), which includes more than 1600 species in the world's fauna $[3,4,5]$. On the territory of Ukraine among the acarina, which have sanitarian and medical significance, the most representative family (Ixodidae), found in various natural and artificial habitats, including urban areas, is the most represented. [6,7] Their number, population density, sex ratio and even contamination with various pathogens of infectious diseases depends on the circulation of pathogens in the range of potential ticks at seasonal conditions of the environment [8].

In general, ticks are highly specialized hematophages and carriers of many transmissible diseases of humans and animals $[9,10]$. Y. S. Balashov and Y. M. Yemchuk $[11,12]$ in their theses indicate that ticks of Ixodes, Dermacentor, 
Ripiciphalus, Hyalomma are capable to transfer more than 10 transmissive diseases to animals and humans: boreliosis, pyroplasmosis, anaplasmosis, babesiosis, listeriosis , brucellosis and others.

During the last 15 years, the number of infection cases of people with various Borelians caused Lyme disease and granulocytic anaplasmosis has considerably increased.

The deterioration of the acarological situation in Ukraine, the increase of contact between man and domestic animals with ticks, the existence of natural cells of tick infections, cause increased interest in the study of tick-borne monofilaments and the ways of their prevention, which is relevant today.

\section{THE AIM}

To study the ecological, biological, morphological and physiological features of the most common types of Ixodes - carriers of transmissible diseases in Western Ukraine and to establish patterns of correlation of morphological indices during feeding. To set a list of pathogens and the degree of infection of them, acarina that were on people and were taken off from children in a traumatology center in Ternopil.

\section{MATERIALS AND METHODS}

The main morphometric parameters studied in ticks of Ixodes ricinus were: total body length, abdominal width, length gnatosome and scutum (shield).

798 ticks of Ixodes ricinus were investigated. All ticks of the first type were found mainly in the city of Ternopil and Ternopil region, as well as some ticks were brought from Lviv, Ivano-Frankivsk and Rivne regions. The main materials and tools used to catch, keep and identify the ticks tweezers, lenses, microscopic needles, white cloth for the «flag», alcohol $70 \%$, test tubes, optoelectronic system SEO - IMAGLAB.

To identify ticks, we used the definition tables given in the monographs of domestic and foreign scientists $[13,14]$.

The determination of the pathogens that the extracted ticks transmitted were performed using the polymerase chain reaction (PCR) method in real time by preparing a mash suspension, isolating the DNA itself and carrying out further amplification using the "ROTORGene -6000" amplifier in real time.

Ticks were taken off from people with tweezers or threads by screwing head, neck, limbs, and abdomen from the skin.

\section{RESULTS AND DISCUSSION}

Morphological examination of ticks was carried out in the direction of setting morphological indices of individual parts of the body (total body length, length of gnatosome and skutum, abdominal width) and identification of possible patterns in changing these parameters depending on the stages of saturation at different stages of life of ticks.

The morphology peculiarities of 124 females and 198 nymphs of Ixodes ricinus were studied.

We have accepted the conditional blood stages of various life forms of ticks, which is reflected on the lower axis of the diagrams: 1 - unsaturated; 2 - partially saturated; 3 saturated; 4 - strongly saturated; 5 - the most saturated.

As a result of the analysis of morphological indices of individuals of Ixodes ricinus, we found that females total length of their body and the width of the abdomen is greatest in the stage of maximum saturation and is $8.7 \mathrm{~mm}$ and $6.16 \mathrm{~mm}$ respectively, and the smallest - in the first stage, where the total length the body of the female is $3.01 \mathrm{~mm}$, and the width of the abdomen - $1.69 \mathrm{~mm}$ (Fig. 1). When conducting a correlation analysis of blood saturation of life forms of female ticks, the following correlation is observed: $1: 0.56 ; 1: 0.59 ; 1: 0.53 ; 1: 0.6 ; 1: 0.7$. Consequently, in females with an increase in the degree of saturation increases not only the length of the abdomen, but also its width.

As a result of the study, it was found that there are separate patterns in the ratio of total body length to the width of the abdomen at different stages of saturation in the nymph (Fig. 2).

Based on the obtained results, we see that the width of the abdomen in the nymph increases during the five stages of saturation very slowly (from $0.7 \mathrm{~mm}$ to $1.61 \mathrm{~mm}$ ), but the body length increases (from $1.24 \mathrm{~mm}$ to $2.76 \mathrm{~mm}$ ). The correlation is as follows: $1: 0.56 ; 1: 0.56 ; 1: 0.58 ; 1$ : $0.6 ; 1: 0.58$.

Indicators on the length of the gnatosoma and the length of the shield both, females and nymphs of Ixodes ricinus, do not have significant oscillations in the parameters and is an average of $0.92 \pm 0.7 \mathrm{~mm}$ (gnatosome length of females), $0.39 \pm 0,3 \mathrm{~mm}$ (shield length of females), 0.50 $\pm 0.4 \mathrm{~mm}$ (gnatosome length of nymph), $1.13 \pm 0.9 \mathrm{~mm}$ (shield length of nymph).

From April to October 2018 morphological indices of the body of larvae were investigated depending on their saturation with human blood. The results are presented in Fig. 3.

As it can be seen from the diagram, the increase in the blood volume of the larvae is mainly due to an increase in the length of the abdomen (increase in 2 times) but not in width (increase only in 1,3 times).

During the period from May to October 2017, 118 females, 174 nymphs and 3 larvae of Ixodes ricinus were tested in Ivan Horbachevsky Ternopil State Medical University of Ministry of Public Health of Ukraine, in order to detect pathogens of infectious diseases $[7,11]$.

From 08.05.17 to 07.07.17, 179 ticks were examined, 117 nymphs (infected with borrels 36 or $31 \%$ ), 51 females (17 or $33 \%$ infected with borrels) and 11 specimens were not identified, as there were only their individual fragments. As victims, predominantly ( $89 \%$ ) were children. The studies were conducted to detect DNA of the pathogens of boreliosis and anaplasmosis. According to the results of amplification, borelles and anaplasms were found in different life stages of the species Ixodes ricinus. In particular, Borrelia Burgdorferi senso lato was detected in 37 cases, including in adult ticks - 11, in nymphs - 25, the stage is not defined but only in one case. Anaplasma phagocytophilum was detected in 15 cases, including adult ticks - 5, in nymphs 9 , undefined stages -1 . Borrelia Miyamotoi was identified 


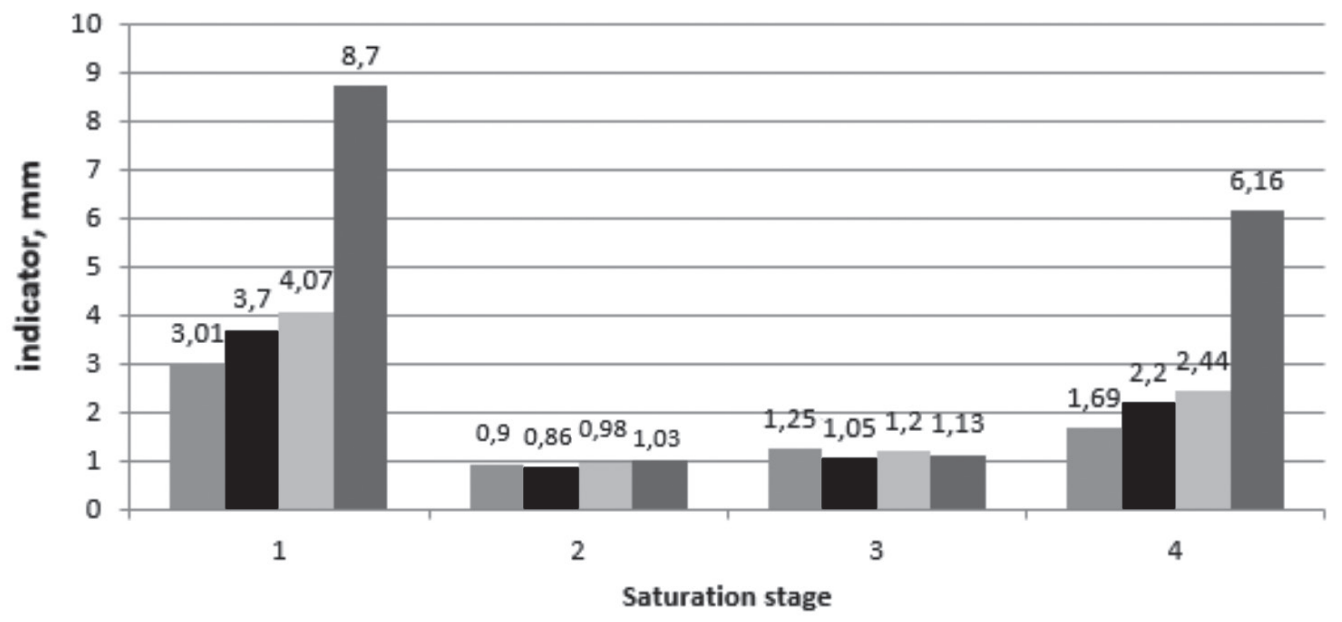

- to tal body length

- length gnatosome

wength of the shield

width of the abdomen

Fig. 1. Indices of the body structure of females acarina Ixodes ricinus

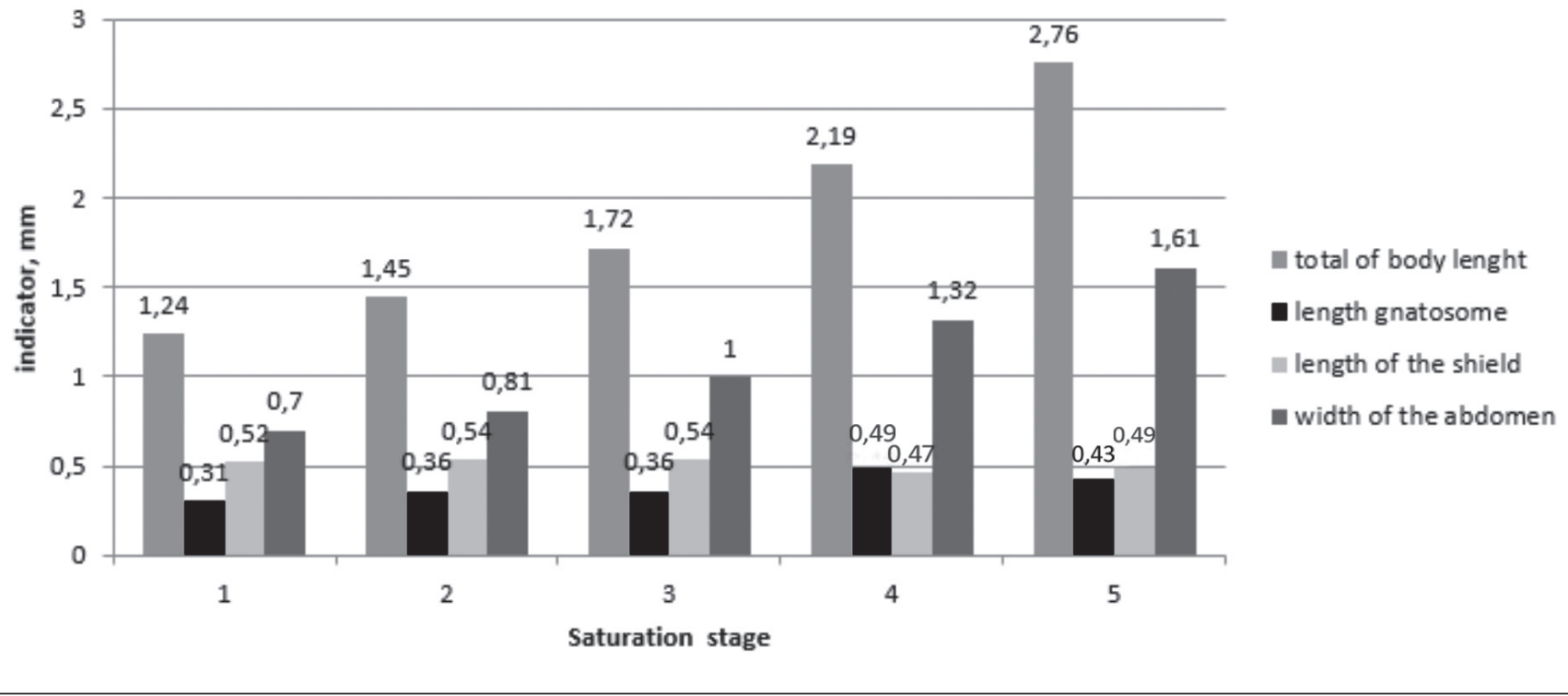

Fig. 2. Morphological indices of nymph of Ixodes ricinus

in 5 cases, including 1 adult ticks and 4 cases of nymphs. The last one was first detected in Ukraine in 2002 amonth Ixod mites [12].

From 10.07 to $18.07 .2017,18$ female ticks of the species Ixodes ricinus were examined, the carriers of pathogens were 13, which is equal to $72 \%$ (Borrelia Burgdorferi - 9, Anaplasma phagocytophilum-4). From infected females, three were both carriers of Borrelia Burgdorferi and Anaplasma phagocytophilum. During this period, 27 nymphs were also examined, 10 were carriers of pathogens (37\%), (1 - Borrelia Burgdorferi and 9 - Anaplasma phagocytophilum). The detected larva was not a carrier of Borelli.

From 11.09 to $18.10 .2017,81$ ticks of Ixodes ricinus (50 females, 1 larva, 30 nymphs) were examined. All ticks of Dermacentor reticulatus were not carriers of any of the pathogens. Of all the female acarina of Ixodes ricinus, the carriers of the pathogens were only 16 , which is equal to 32\% (14 - Borrelia Burgdorferi, 1 - Anaplasma phagocytophilum, 1 - Borrelia Miyamotoi). Of the 30 nymphs of ticks, carriers were 8 (27\%), 3 - Borrelia Burgdorferi, 3 - Anaplasma phagocytophilum, 1 - Borrelia Miyamotoi. It should be noted that in the period from 2.10 to 18.10.2017, out of 22 examined female ticks of Ixodes ricinus, only 5 were carriers of Borrelia Burgdorferi (22\%), and only 1 was infected with Borrelia Burgdorferi (14\%) of 7 nymphs. Two larvae were taken off from the body of children infected with ticks and only one of them was the carrier of Anaplasma phagocytophilum.

During the period from April to October 2018 a polymerase chain reaction was conducted to detect pathogens of the three above-mentioned infectious diseases among Ixodes ricinus species in females, males, nymphs and larvae 


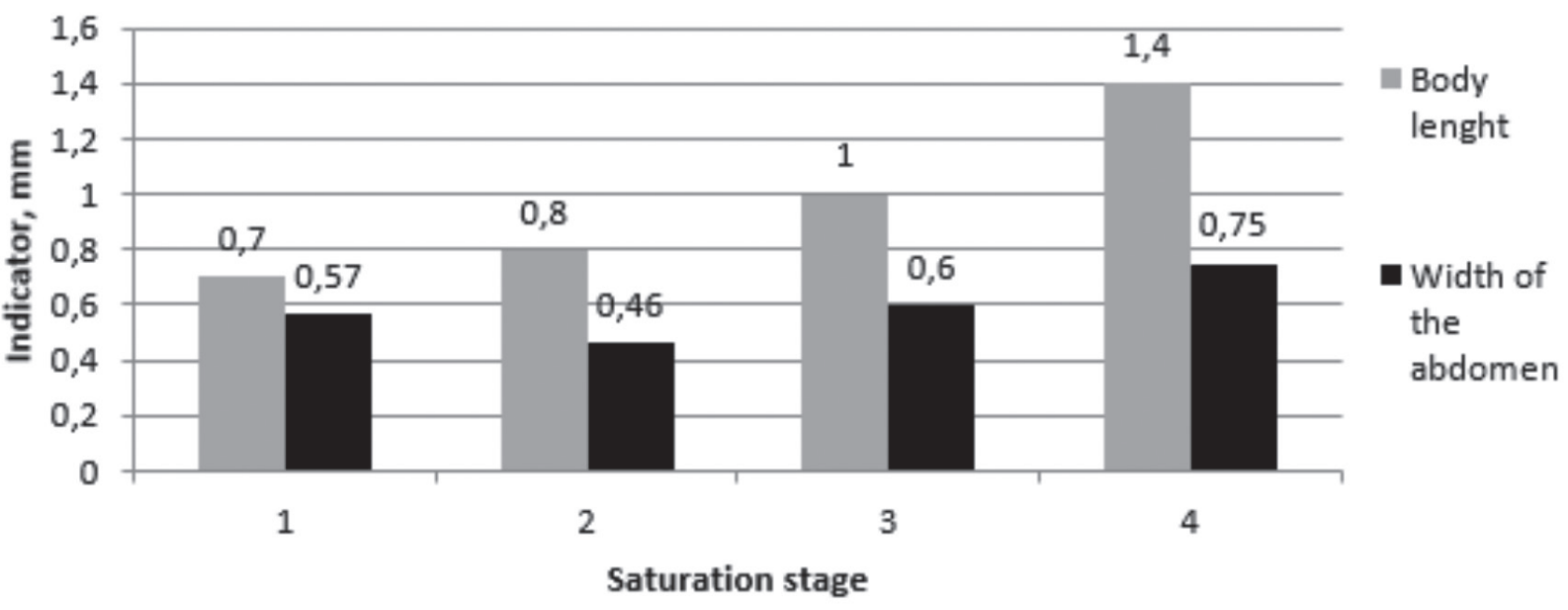

Fig. 3. Dependence of the morphological indices of the larvae body and their blood saturation

was carried out. Based on these studies, we see that of 68 infected female carriers with Borrelia Burgdorferi were 39 (57.4\%), Anaplasma phagocytophilum - 22 (32.3\%), together with Borrelia Burgdorferi and Anaplasma phagocytophilum, 7 (10.2\%) females.

Among 5 infected males, there were only $2(40 \%)$ carriers of Borrelia Burgdorferi.

Among 85 infected nymphs there were 35 (41.1\%) carriers with Borrelia Burgdorferi, Anaplasma phagocytophilum 43 (50.5\%), Borrelia Burgdorferi and Anaplasma phagocytophilum had 7 (8.2\%) and Borrelia Burgdorferi and Borrelia Miyamotoi at the same time (1 $(1.1 \%)$.

Among 19 examined larvae, there were two carriers of pathogens (10\%), one of them had Borrelia Burgdorferi and Anaplasma phagocytophilum (50\%), and another carried Borrelia Burgdorferi and Borrelia Miyamotoi (50\%) at the same time.

As we see from the general results of females, nymphs and larvae of Ixodes ricinus take an active part in the transfer of all three pathogens of infectious diseases. Including a complex carrying, that is the simultaneous transfer of pathogens of two diseases.

Taking into consideration the dynamics of the frequency of infection with ticks of Ixodes ricinus, we observed an increase the number of females and nymphs that are carriers of pathogens in the period of May-July, and then, decrease the frequency of their infection in August-October. Obviously, the main cause of these fluctuations is the temperature regime, which changes in the spring-summer-autumn periods. Thus, the average temperature in May-June was $18-23^{\circ} \mathrm{C}$, in July-August $-25-27^{\circ} \mathrm{C}$, in September-October $-20-15^{\circ} \mathrm{C}$. At a temperature of $10-$ $12^{\circ} \mathrm{C}$, the number of patients affected by ticks decreased. As a result of studies on the influence of seasonal changes on the degree of infection with ticks of Ixodes ricinus by pathogens of infectious diseases, it's direct dependence on the temperature regime: at a temperature of about 18- $15^{\circ} \mathrm{C}$, the degree of infection in the nymph is $14 \%$, and in females $-22 \%$, while at $25-28^{\circ} \mathrm{C}$ in the nymph this figure is $37 \%$, and in females $-72 \%$.

\section{CONCLUSIONS}

1. Between the total length of the body and the width of the abdomen, at different stages of saturation, a correlation ratio of 1: 0.5 - 1: 0.6 is observed, in contrast to the lengths of the gnatosome and the length of the skutum (shield), where there is no correlation corresponding to the norms of the disruptive selection.

2. In ticks of Ixodes ricinus, human ectoparasites are not only adult ticks, but also nymphs and even larvae (the ratio of taken off nymphs and adult females from children is 2: 1).

3. Females of ticks are more carriers of Borrelia Burgdorferi, and the nymphs are carriers of Anaplasma phagocytophilum and Borrelia Miyamotoi. Larvae can be human ectoparasites and tolerate all three pathogens of infectious diseases. Including a complex carrying, that is the simultaneous transfer of pathogens of the two diseases.

4. Among the males, the carriers were found of Borrelia Burgdorferi senso lato spirochete. At the present moment, carriers of other pathogens have not been investigated by us.

\section{REFERENCES}

1. Akimov A, Nebogatkin I. Iksodovyie kleschi (Ixodidae, Acarina) i bolezni Layma v Ukraine [Ixodes (Ixodidae, Acarina) and Lyme disease in Ukraine]. Zoology Journal. 1995;1:76-78. (In Ukraine).

2. Glinskih N. Kleschevoy entsefalit: epidemiologiya, klinika, diagnostika, profilaktika [lxodes Encephalitis: epidemiology, clinic, diagnostics, prevention]. In: Glinskih N, Kokorev V, Patsuk N. AMB Publishing House. Yekaterinburg: 2006, p. 94-120. (In Russia).

3. Kolonin G. Mirovoe rasprostranenie iksodovyih kleschey [World distribution of Ixodes]. Science. Moscow: 1983, p. 89-114. (In Russia). 
4. Stegnij V, Mashkej A. Krovosy'sni chleny `stonogi - perenosny 'ky` transmisy 'vny 'x infekcij [Bloody arthropods - carriers of transmissive infections]. Veterinary medicine. 2012;3(56):198-199. (In Ukraine).

5. Randolph S. E. The shifting landscape of tick-borne zoonoses: tick-borne encephalitis and Lyme borreliosis in Europe. Philos. Trans. Royal Society London Biological Sciences. 2001;356(1411):1045-1056.

6. Bertrand M. R. Microclimate-dependent survival of unfed adult Ixodes scapularis (Acari: Ixodidae) in nature: life cycle and study design implications. / M. R Bertrand, M. L Wilson. //Journal of Medical Entomology. 1996;12(33):619-627.

7. Smiianov V, Vygovskaya L. Intrauterine infections - challenges in the perinatal period (literature review). Wiad Lek. 2017;70,3(1):512-515.

8. Akimov I, Nebogatkin I. Seasonal Changes in Activity, Sex Composition and Areal of the Tick Ixodes ricinus (Acari, Ixodida) in the Landscape-Geographical Regions of Ukraine. Zoology Journal., 2010;3(44):245-251.

9. Buruhina E. G. Rezultatyi nablyudeniy za chislennostyu, vidovyim sostavom i virusoformnostyu iksodovyih kleschey na teritorii Primorskogo kraya [Results of observations on the number, species composition and viral form of Ixodes in the Primorsky Territory]. Problems of Infectology. 2007;4(37):181-187. (In Russia).
10. Pry`xod’ko 0, Nikiforova 0, Ponomar S. Iksodovi klishhi, yak perenosny 'ky` zbudny ka Lajm-boreliozu. Vetery narna medy`cy’na [lxodes as vectors of the causative agent of Lime borreliosis]. Veterinary medicine. 2014;4(99):154-156. (In Ukraine).

11. Nikitina I, Boychuk A, Babar T, Dunaeva M. Prediction of threats to multiple pregnancy interruption depending on the cause of its occurrence. Research Journal of Pharmaceutical, Biological and Chemical Sciences. 2016;7:764-771.

12. Balashov Zh. Iksodovyie kleschi - parazityi i perenoschiki infektsiy [lxodes as a parasites and carriers of infections]. St. Petersburg: Science; 1998, p. 126-200. (In Russia).

13. YemchukYe.FaunaUkrayiny'.lksodoviklishhi[Fauna ofUkraine.Ixodes].Academy of Sciences of the Ukrainian SSR. Kyiv: 1960, p. 28-43, 113-127. (In Ukraine).

14. Akimov A, Nebogatkin I. Iksodovyie kleschi gorodskih landshaftov $g$. Kieva [lxodes of Kiev city landscapes]. Kiev. 2016, p. 156. (In Ukraine).

\section{Authors' contributions:}

According to the order of the Authorship.

\section{Conflict of interest:}

The Authors declare no conflict of interest.

\section{CORRESPONDING AUTHOR Larysa Fedoniuk}

Department

Medical Biology of the I. Horbachevsky State Medical University

Valova street 9, 46000, Ternopil, Ukraine

tel: +380673999143

e-mail:Fedonyuk22Larisa@gmail.com

Received: 10.11 .2018

Accepted: 31.01 .2019 
PRACA ORYGINALNA

ORIGINAL ARTICLE

\title{
MORPHOFUNCTIONAL STATUS OF CARDIO-VASCULAR SYSTEM OF RATS WITH CONGENITAL HYPOTHYREOSIS
}

\section{STATUS MORFOLOGICZNO-CZYNNOŚCIOWY UKŁADU SERCOWO- NACZYNIOWEGO SZCZURÓW Z WRODZONĄ NIEDOCZYNNOŚCIĄ TARCZYCY}

\author{
Svitlana M. Chuhray' ${ }^{1}$ Viktoria E. Lavrynenko ${ }^{3}$, Rostyslav F. Kaminsky ${ }^{2}$, Iryna V. Dzevulska ${ }^{2}$, Olexandr V. Malikov ${ }^{2}$ \\ Olexandr I. Kovalchuk ${ }^{2,3}$, Liudmyla M. Sokurenko ${ }^{1,3}$ \\ 'DEPARTMENT OF HISTOLOGY AND EMBRYOLOGY, BOGOMOLETS NATIONAL MEDICAL UNIVERSITY, KYIV, UKRAINE \\ 2DEPARTMENT OF HUMAN ANATOMY, BOGOMOLETS NATIONAL MEDICAL UNIVERSITY, KYIV, UKRAINE \\ ${ }^{3}$ DEPARTMENT OF FUNDAMENTAL MEDICINE, TARAS SHEVCHENKO NATIONAL UNIVERSITY OF KYIV, KYIV, UKRAINE
}

\begin{abstract}
Introduction: There is an increasing number of cases of congenital hypothyroidism. One of the most common complications of hypothyroidism is damage to the cardiovascular system, which in 30-50\% of patients leads to the development of arterial hypertension.

The aim: studying the features of the ultrastructure of myocardial capillaries in mature rats with hypothyroidism.

Materials and methods: Experiments were conducted on 40Wistar line rats with congenital hypothyroidism: juvenile young (45-day) and sexually mature (100-day) rats, as well as intact animals of the corresponding age. While extracted from the experiment rats of all experimental groups had their arterial pressure measured using a plethysmograph while the development of hypothyroidism was controlled by the immune-enzymatic method. Electron microscopic examination of the left ventricular myocardium and morphometric study of volumetric and quantitative densities, cross-section area, and form factor of micropinocytotic vesicles were conducted.

Results: In the sexually mature rats with congenital hypothyroidism the quantitative density of the capillaries in the myocardium decreases. Activation of transcytosis is accompanied by significant violations of vesiculation. Some of the endothelial cells of experimental animals contain a moderate amount of transport vesicles, while others are overfilled with these structures and desquamate into the lumen. In older rats with congenital hypothyroidism there is a further dilution of capillaries, the development of hypoxic state in them, mucinous edema of interstitial space, decrease of biosynthetic and transport processes activity.

Conclusions: In young (45-day) rats with congenital hypothyroidism the direction and expressiveness of compensatory processes is to enhance the transcytosis processes. Dystrophicdestructive changes are manifested by apoptosis in some endothelial cells, decrease in the number of biosynthetic organelles, lysis and edema of their cytoplasm. In sexually mature (100-day) rats with congenital hypothyroidism destructively-dystrophic processes in the blood capillaries of the myocardium are approximately balanced with compensatory-adaptive.
\end{abstract}

KEY WORDS: myocardium, blood capillaries, rat, congenital hypothyroidism, electron microscopy

Wiad Lek 2019, 72, 2, 229-233

\section{INTRODUCTION}

In recent decades more and more attention of researchers is being attracted by prevalence of hypothyroidism - a disease caused by decrease in the biological effect of thyroid hormones on the tissue level or their deficiency in the body. The number of cases of congenital hypothyroidism (CHT) is increasing. One of the most common complications of hypothyroidism is a violation of the cardiovascular system, which in $30-50 \%$ of patients leads to the development of arterial hypertension [1-3]. However, although in people of different ages clinical manifestations and the course of hypothyroidism differ significantly $[4,5]$, data on morphofunctional changes in organs and tissues in the age aspect has not been identified in the literature.

\section{THE AIM}

In this regard, the purpose of the research was to study the features of the ultrastructure of myocardial blood capillaries in mature rats with hypothyroidism, that is, structures where metabolism occurs and which are largely responsible for tissue damage in the heart.

\section{MATERIALS AND METHODS}

Experiments were performed on 40 white rats of the Wistar line, which were under standard vivarium conditions of the Bogomolets National Medical University. The juvenile (45day) and sexually-grown (100-day) Wistar rats with CHT were studied. Control was provided by intact rats of the Wistar line of the same age. Congenital hypothyroidism was modeled by inhibition of thyroid gland by thyreo- 
static - Mercazolil. Starting from the $14^{\text {th }}$ day of perinatal development pregnant females were administered with the drug. After birth, the animal received it with the mother's milk, and in the future - while self-feeding. The drug was administered throughout the experiment daily at a dose of $20 \mathrm{mg} / \mathrm{kg}$ of body weight. The solvent was water. The development of hypothyroidism was controlled by the immune-enzymatic method on the Sunrise RC device, TEKAN in both control and hypothyroidic rats when they were removed from the experiment. Experiments with animals were carried out in accordance with the Law of Ukraine "On protection of animals from cruelty" (2006), "General ethical principles of animal experiments", adopted by the First National Congress on Bioethics (Kiev, 2001).

While extracted from the experiment rats of all experimental groups had their AP (arterial pressure) measured using a plethysmograph, while the development of hypothyroidism was controlled by the immune-enzymatic method on the Sunrise RC device, TEKAN.

Electron microscopic examination of the left ventricular myocardium of experimental rats was conducted. The material was processed in accordance with the generally accepted techniques of electron microscopic examination [6]. Ultra-thin sections were made with ultratome Reihart (Austria) and examined using an electron microscope PEM-125K.

Morphometric studies were carried out on a semi-automatic device for graphic research processing using the program "Organelle". Volumetric and quantitative densities, cross-section area, form factor of micropinocytotic vesicles (MPV) were studied. Statistical processing was carried out using the Student parametric criterion and the nonparametric Kolmogorov-Smirnov criterion according to the principle of variation statistics.

\section{RESULTS}

\section{CHANGES IN FUNCTIONAL PARAMETERS IN EXPERIMENTAL RATS}

At 45-day rats with CHT AP does not reach meaningful quantities yet. At 100 days after birth AP increases compared with control animals. In this case, about half of animals with CHT showed increase of this parameter (Table I).

The existence of persistent hypothyroidism is confirmed by a significant decrease in the concentration of free thyroxine in blood plasma during the whole experiment, starting with the early stages of the disease and becoming the most pronounced in the final stages (Table I), compared with control.

Ultrastructure of blood capillaries of myocardium in rats In the myocardium of 45-day rats with congenital hypothyroidism, capillaries with both narrowed and enlarged lumen (Fig.1A, B) as well as flattened microvessels can be observed. This may indicate, on one hand, the decrease in the intensity of the capillaries formation, and, on the other, the involvement of a greater number of capillaries in the microcirculation, which leads to the decrease in the number of reserve, non-functioning microvessels. Most capillaries have a flattened lumen surface, which contains single microvilli and invaginations (Fig. 1B).

However, there are capillaries with different magnitude of cervical protrusions at different stages of separation from the cell. Such microclazmatosis outgrowths can further lose connection with endothelial cells and get into the bloodstream.

Endothelial cells of moderate electron density with well-preserved cytoplasm are prevalent. They contain large nuclei of oval or somewhat irregular shape. Mitochondria in a small number are located mainly in the near-nuclear zone. They are usually oval, with an unevenly enlightened matrix and irregularly located crystae (Fig.1.A). The channels of the endoplasmic reticulum are mainly short, contain ribosomes on their membranes. The latter, in the form of discrete units and polyribosomal complexes unevenly fill the nuclear-containing and peripheral regions of the endothelial cells. Lysosomes, multivesicular corpuscles, secretory vesicles of the Golgi complex, secretory granules are not expressed. There are also rare elements of the cytoskeleton - microfilaments and microtubules.

In 100-day rats with congenital hypothyroidism ultrastructural changes become more expressed and more prevalent in the blood capillaries of the myocardium. Part of the capillaries have dilated lumen and thinned nuclear-containing and peripheral areas. Endothelial cells that form these capillaries have a preserved ultrastructure, but they also show damage to organelles. Some cells have only isolated tubules and ribosomes even within the nuclear-containing regions. Channels of the granular endoplasmic reticulum are often fragmented, degranulated, dilated. Dictiosomes of the Golgi complex are flattened and have blurred membranes that give them a look of a homogeneous mass of moderate electron density.

The number of mitochondria is negligible. They show electron-dense matrix, destruction of external mitochondrial membranes, fragmented crystae. In some mitochondria, the outer membrane is spirally twisted, thus resembling myelin sheaths. That is, the formation of myelin-like structures, which is a sign of a violation of lipid peroxide oxidation.

Attention is drawn to increasing electron density of inter-endothelial junctions, enlargement of the obliteration spots and storage of finely dispersed material, which may worsen the paracellular route of substances transport. Basal lamina is sometimes thinned, destructured, sometimes thickened, and loose.

Another feature that further increases in 100-day rats with congenital hypothyroidism is the prevalence of blood capillaries at different stages of destruction. Endothelial cells with increased electron density of the cytoplasm, picnotically altered nuclei, a large number of microclazmatosis outgrowths on the luminal and in some cases on basal surfaces are observed. In the myocardium, areas of perivascular edema are common. 
Table I. Changes in the content of free thyroxine in blood plasma and AT figures

\begin{tabular}{ccccc}
\hline & \multicolumn{2}{c}{45 days } & \multicolumn{2}{c}{$\mathbf{1 0 0}$ days } \\
\cline { 2 - 5 } & Control & CHT & Control & CHT \\
\hline Arterial pressure, $\mathrm{mm} \mathrm{Hg}$ & $98,7 \pm 6,1$ & $112,7 \pm 7,3$ & $109,4 \pm 5,3$ & $131,6 \pm 5,2^{* * * *}$ \\
\hline Thyroxine, $\mathrm{pmol} / \mathrm{I}$ & $7,63 \pm 0,99$ & $3,96 \pm 0,46^{*}$ & $8,58 \pm 0,72$ & $2,77 \pm 0,76^{*}$ \\
\hline
\end{tabular}

Note: ${ }^{*}-p<0,05$ in comparison with the data of the Control; ${ }^{* *}-p<0,05$ in comparison with the data of the other term group.

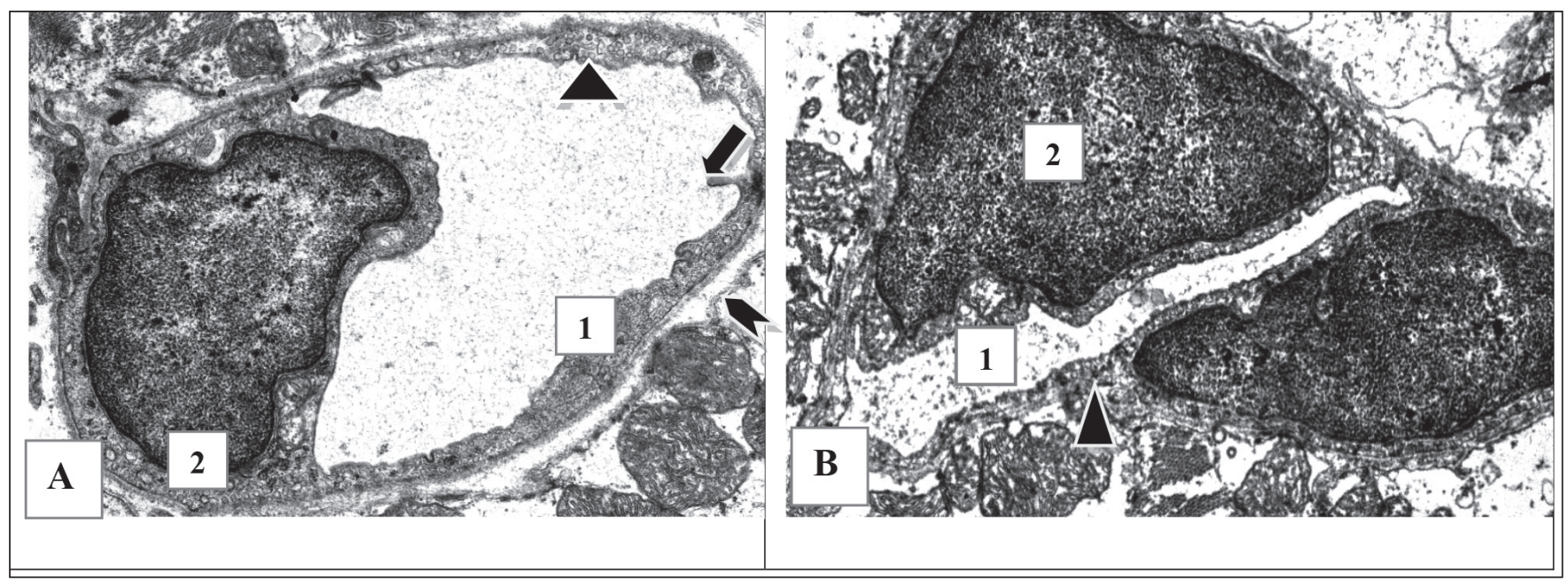

Fig. 1. Blood capillaries of the left ventricular myocardium in 45-day rat with CHT. Electron microscopic photo. Magnification: A-22000; B -19000: Lumen (1) of the capillary. Nucleus (2), micropinocytotic vesicles $(\boldsymbol{\Delta})$, interendothelial junctions $(\measuredangle)$ in endothelial cells. Basal lamina $(<)$.
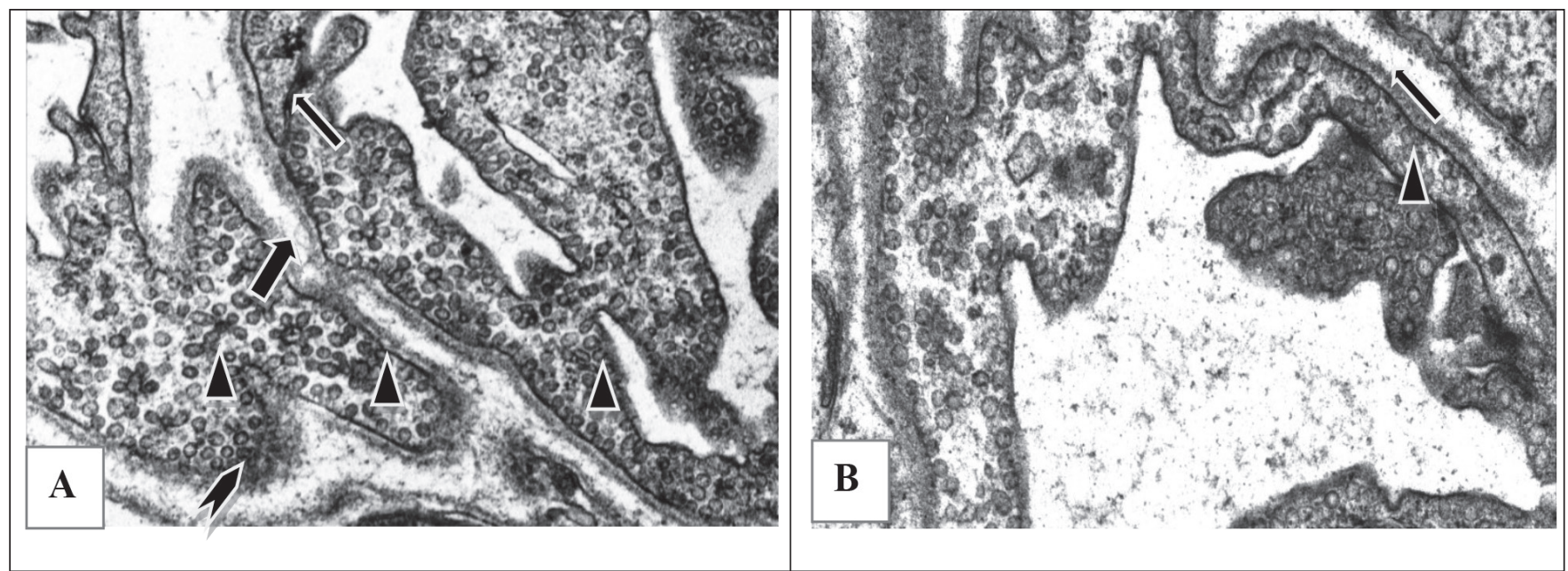

Fig. 2. Blood capillaries of the left ventricle myocardium of 100-day rats with CHT. Electron microscopic photo. Magnification: A-40000; B-60000. Interendothelial junctions $(\measuredangle)$, micropinocytotic vesicles $(\boldsymbol{\Delta})$ in endothelial cells. Basal lamina $(\boldsymbol{c})$.

\section{MICROPINOCYTOTIC VESICLES IN \\ ENDOTHELIAL CELLS OF MYOCARDIAL BLOOD CAPILLARIES}

Micropinocytotic vesicles in endothelial cells of myocardial circulatory capillaries in 45-day rats with congenital hypothyroidism may be attached to the basal or lumen surfaces of the cells or have free forms unequally, even within one endothelial cell locating in the cytoplasm (Fig.1.A). Morphometric analysis has shown that in this period of study in $1 \mu \mathrm{m}^{3}$ of the cytoplasm of endothelial cells of the myocardium of hypothyroid rats there are $400,7 \pm 28.9$ micropinocytotic vesicles, which significantly differs from this index in control (Table II).

In 100-day rats with congenital hypothyroidism, the micropinocytotic vesicles undergo major qualitative and quantitative changes. Cells without vesicles are observed. But most endothelial cells are filled with these structures. They are located along the basal or luminal surface densely one next to another, forming complexes of various shapes. In some cases, when too many vesicles are gathered, their 
Table II. The morphometric indexes of MPV in endothelial cells of myocardial circulatory capillaries

\begin{tabular}{cccccc}
\hline $\begin{array}{c}\text { Age of } \\
\text { animals }\end{array}$ & Groups & Volumetric density, \% & $\begin{array}{c}\text { Quantitative density, } \\
\mathbf{1 / \boldsymbol { \mu m } ^ { \mathbf { 3 } }}\end{array}$ & $\begin{array}{c}\text { Average area, } \\
\mathbf{1 0}^{-\mathbf{2}} \boldsymbol{\mu m}^{\mathbf{2}}\end{array}$ & Form factor \\
\hline \multirow{2}{*}{45 days } & Control & $18,09 \pm 1,04$ & $282,7 \pm 15,9$ & $0,57 \pm 0,01$ & $0,84 \pm 0,05$ \\
\cline { 2 - 6 } & CHT & $17,15 \pm 0,83$ & $400,7 \pm 28,^{*}$ & $0,46 \pm 0,01^{*}$ & $0,86 \pm 0,04$ \\
\hline \multirow{2}{*}{100 days } & Control & $21,95 \pm 0,85$ & $332,5 \pm 18,6$ & $0,57 \pm 0,01$ & $0,85 \pm 0,07$ \\
\cline { 2 - 6 } & CHT & $23,00 \pm 1,49$ & $443,7 \pm 25,9^{*}$ & $0,55 \pm 0,01$ & $0,84 \pm 0,06$ \\
\hline
\end{tabular}

Note: ${ }^{*}-p<0,05$ in comparison with the data of the Control;

excess is isolated in the form of microclazmatosis outgrowths and excreted out of endothelial cells.

As for morphometric analysis, it has shown that the vesicle density in 100-day hypothyroid rats is $443.7+25.9$ $/ \mu \mathrm{m}^{3}$, which is significantly higher than the control index (Table II). In intact animals the number of endothelial cells with a small amount of micropinocytotic vesicles decreases with age, but they still prevail in the population.

\section{DISCUSSION}

So, in 45-day rats with CHT, the ultrastructure of the myocardium capillaries is heteromorphic. This heterogeneity of the structure is due to changes that, on one hand, are compensatory, and on the other destructively-dystrophic. The processes of edema of endothelial cells in animals with CHT are widespread and expressive. Swollen endothelial cells commonly form sequestrums of the cytoplasm with fluid of edema, which are separated and observed both in the capillary lumen and perivascularly. This may be due to the fact that persistent deficiency of thyroid hormones observed in 45-day rats leads to violations in the synthesis of $\mathrm{Na}+/ \mathrm{K}+$-ATPase and ion channel proteins [7, 8]. Changes in the $\mathrm{Na}+/ \mathrm{K}+$ exchange function, free $\mathrm{Na}+$ and $\mathrm{K}+$ channels of plasmalemma lead to an increase in its permeability for $\mathrm{Na}+$ ions, and as a result, development of significant edema in the endothelial cells.

In rats with $\mathrm{CHT}$, there is a decrease in the number of biosynthetic organelles. It should be noted that hypoplastic processes are typical for hypothyroidism, as thyroid hormones are necessary for the metabolism of all cells. Due to their deficiency, synthesis and neogenesis of both organelles and their compounds are violated.

At the same time, in the capillaries of 45-day rats with $\mathrm{CHT}$, processes of transendothelial transfer of substances are intensified, as evidenced by an increase in the quantitative density of MPV. Intensification of the processes of substances transfer is a manifestation of adaptive processes that develop in response to the influence of the pathological factor. Another symptom of these processes in the capillaries is the local thinning of peripheral parts of the endothelial cells to the size of MPV. All these changes are due to changes in the physical and chemical composition of the plasma membranes. Thyroid hormones, regulating $\mathrm{Na}+/ \mathrm{Ca} 2+$ metabolism through the expression and phosphorylation of ion channels, affect the content of membrane-connected $\mathrm{Ca} 2+[9,10]$ That is, the cause of increased transcytosis may be, on one hand, increased fluidity of the plasma membrane, and on the other hand, destabilization and changes in its conformation, that lead to increase in the processes associated with the formation of invaginations and vesicles.

Another feature of the ultrastructure of myocardium capillaries in young rats with $\mathrm{CHT}$ is the presence of electron-dense endothelial cells. This condition is characteristic for apoptotic cells, and the receptor pathway plays a primary role in triggering of endothelial cell apoptosis with the participation of the nuclear and cytoplasmic receptors of thyroid hormones.

With increasing of age of rats with CHT up to 100 days both compensatory-adaptive and destructively-dystrophic changes become more expressive. The prevalence of endothelial cells with signs of edema is negligible compared with the previous observation period. Perhaps this is a consequence of the death of edematous endothelial cells, on one hand, and on the other, capillaries of the myocardium in both groups of observations undergo changes in the rigidity of the plasma membrane, which do not allow the development of expressed edema. The prevalence of capillaries with well-preserved ultrastructure can be explained by the manifestations of compensatory processes, while the decrease in the number of organelles taking part in biosynthesis - to destructive ones. The largest changes refer to the number of MPV. The activation of substances transfer is aimed, obviously, at the compensation of lowered transcytosis in myocardium due to destruction of the part of the capillaries accompanied by their insufficient formation due to the lack of hormones of thyroid gland. However, endothelial cells are overfilled with MPV forming conglomerates, which, as a rule, desquamate into the lumen of the capillaries as microclazmatosis outgrowths. Such ultrastructural changes can be dystrophic manifestations, which are the result of significant destabilization and conformation of the plasma membranes in the endothelial cells. In places where inter-endothelial junctions were disconnected "windows" were formed. Active transcytosis through them contributes to increase of perivascular edema, worsening the trophism of cardiomyocytes and is a manifestation of dystrophic processes.

\section{CONCLUSIONS}

1. In young (45-day) rats with CHT the direction and expressiveness of compensatory processes, is to enhance the tran- 
scytosis. Dystrophic-destructive changes are manifested by apoptosis of some endothelial cells, a decrease in the number of biosynthetic organelles, lysis and edema of their cytoplasm.

2. In blood capillaries of the myocardium in sexually mature (100-day) rats with CHT destructive-dystrophic processes are approximately balanced with compensatory and adaptive ones. In the myocardium, the quantitative density of the capillaries decreases. Activation of transcytosis occurs against significant violations of vesiculation. Some of the endothelial cells of experimental animals contain a moderate amount of transport vesicles, while others are overfilled with these structures and desquamate into the lumen.

\section{REFERENCES}

1. Pertsova, T.0., Kulikova, OM Stan Renin-Angiotensin-Aldosterone system in patients with hypothyroidism and arterial hypertension. Endocrinology. 2004; 9 (1): 97-100.

2. Katerhenchuk VI, Beregova 0.P. Cardiovascular hypothyroidism masks. Internal medicine. 2007; 3 (3): 50-55.

3. Fletcher AK., Weetman AH. Hypertension and hypothyroidism. J. Hum Hypertens. 1998; 12: 79-82.

4. Selivanova GB Cardiovascular manifestations of hypothyroidism: the role and place of hypertension. Cardiologist. 2006; 4: 64-69.
5. Anderson G., Biakeman N., Streeten D. The effect of age on prevalence of secondary form of hypertension in 4429 consecutively referred patients. J. Hypertens. 1994; 12(5): 609-615.

6. Karupu V.Ya. Electron microscopy. K.: Vishcha School, 1984: 208 p.

7. Strukov Al, Serov V.V. Pathological Anatomy. M .: Medicine, 1995:688p.

8. Kahaly G.J., Dillmann W.H. Thyroid hormone action in the heart. Endocrine Rev. 2005; 26: 704-728.

9. Gick G.G., Melikian J., Ismail-Beigi F. Thyroidal enhancement of rat myocardial Na,K-ATPase: preferential expression of alpha 2 activity and mRNA abundance. J.Membr. Biol. 1990; 115: 273-282.

10. Ojamaa K., Sabet A., Kenessey A., Shenoy R., I. Klein Regulation of rat cardiac Kv1.5 gene expression by thyroid hormone is rapid and chamber specific. Endocrinology. 1999; 140: 3170 - 76.

Acknowledgements: The authors would like to thank the employees of the Institute of Pathologists Problems Bogomolets National Medical University prof. L.O. Stechenko and T. P. Kuftyreva.

Authors' contributions:

According to the order of the Authorship.

\section{Conflict of interest:}

The Authors declare no conflict of interest.

\author{
CORRESPONDING AUTHOR \\ Liudmyla Sokurenko \\ Department Histology and Embryology \\ of National 0.0. Bogomolets Medical University \\ tel: +380675010815 \\ e-mail: I-sokurenko@i.ua
}

Received: 03.10 .2018

Accepted: 18.01.2019 
PRACA ORYGINALNA

ORIGINAL ARTICLE

\title{
PECULIAIRITIES OF THE FUNCTIONING CIRCADIAN ORGANIZATION THE ION-REGULATING FUNCTION OF KIDNEY UNDER THE CONDITION OF PINEAL GLAND HYPERFUNCTION OF THE INFLUENCE NITROGEN MONOXIDE SYNTHESIS BLOCKADE
}

\author{
CHARAKTERYSTYKA OKOŁODOBOWEJ FUNKCJI REGULACJ\| \\ WODNO-ELEKTROLITOWEJ NEREK W WARUNKACH \\ NADCZYNNOŚCI SZYSZYNKI I ZAHAMOWANIA SYNTEZY TLENKU \\ AZOTU
}

\author{
Svitlana B. Semenenko, Svitlana Y. Karatieieva, Oksana V. Bakun, Ksenia V. Slobodian, Oksana I. Yurkiv \\ HIGHER STATE EDUCATIONAL INSTITUTION OF UKRAINE“"BUKOVINIAN STATE MEDICAL UNIVERSITY", CHERNIVTSI, UKRAINE
}

\begin{abstract}
The aim of our work was to investigate the peculiarities of the functioning circadian organization the ion-regulating function of pineal gland hyperfunction of the influence nitrogen monoxide synthesis blockade.

Materials and methods: The experiments were conducted on 72 mature non-linear albino male rats with their body mass $0,15-0,18 \mathrm{~kg}$. The control group included animals $(\mathrm{n}=36)$ kept under conditions of usual light regimen (12.00L:12.00D) during 7 days. The experimental group included animals $(\mathrm{n}=36)$ injected with N-nitro-L-arginine ( $\mathrm{L}-\mathrm{NNA})$ in the dose of $20 \mathrm{mg} / \mathrm{kg}$ during 7 days under conditions of continuous absolute darkness (12.00D:12.00D). On the $8^{\text {th }}$ day the animals were exposed to $5 \%$ water load with heated to room temperature water supplied and the parameters of the kidney ion-regulating function under conditions of forced diuresis were investigated.

Results and conclusions: The obtained results of the performed blockade nitrogen monoxide (NO) synthesis in conditions of hyperfunction of the brain epiphysis allow to conclude that the daily mean of the rate of excretion of sodium ions decreases in comparison with the animals that were kept under pineal gland (PG) hyperfunction of the filtration fraction and reabsorption of sodium ions are reduced compared to the control animals and rats which were kept under conditions of $P G$ hyperfunction and accompanied by stable indicators of the concentration the specified cation in the blood plasma during the observation period. The action of the blockade N0 synthesis in conditions of PG hyperfunction leads to a decrease in the distal transport bridge of sodium ions with a maximum in the day and night intervals of the day the position of the acro-and batiphase of the rhythm changes as compared with the control animals.
\end{abstract}

KEY WORDS: circadian rhythm, nitrogen monoxide, hyperfunction, melatonin, kidney

Wiad Lek 2019, 72, 2, 234-238

\section{INTRODUCTION}

About the rhythmic organization of individual functions of the body scientists have long been known $[5,10]$. In healthy people the rhythms of physiological processes are synchronized both with each other, and with the rhythms of the environment while the synchronization of biorhythms, the preservation of their phase relations provides optimal conditions for the functioning of the organism and is a sign of health [1,9]. It was established that the most important regulator of the activity of the suprachiasmatic nuclei of the hypothalamus is neurohormon melatonin which is synthesized most often in the PG in the dark period of the day [2], and acts as the main signal that coordinates the rhythms of the organism's functions with the illumination fluctuations and the ambient temperature [6].

For any biological system including for the kidneys a spatial-temporal organization of functioning is characteristic
$[3,8]$. Renal effects of the epiphysis of the brain are due to the secretion of the indole melatonin [5]. Intracellular messengers NO and PG hormones in particular, were found to play an important role in the regulation of the main kidney functions and their circadian organization $[4,7]$.

\section{THE AIM}

Aim of our work was to investigate the peculiarities of the functioning circadian organization the ion-regulating function of pineal gland hyperfunction of the influence nitrogen monoxide synthesis blockade.

\section{MATERIALS AND METHODS}

The experiments were conducted on 72 mature non-linear albino male rats with their body mass $0,15-0,18 \mathrm{~kg}$. The 
animals were kept under vivarium conditions at a stable temperature and air humidity fed on a standard dietary intake. The control group included animals $(n=36)$ kept under conditions of usual light regimen (12.00L:12.00D) during 7 days. The experimental group included animals $(\mathrm{n}=36)$ injected with $\mathrm{N}$-nitro-L-arginine (L-NNA) in the dose of $20 \mathrm{mg} / \mathrm{kg}$ during 7 days under conditions of continuous absolute darkness (12.00D:12.00D). On the $8^{\text {th }}$ day the animals were exposed to $5 \%$ water load with heated to room temperature water supplied and the parameters of the kidney ion-regulating function under conditions of forced diuresis were investigated.

The experiments were conducted with 4 hour interval during the day. The level of were the concentration of sodium ions in the urine, excretion and concentration of sodium ions, sodium/potassium ratio, filtration fraction of sodium ions, absolute and relative reabsorption of sodium ions, clearance of sodium ions and sodium-free water, proximal and distal transport of sodium ions, concentration index of sodium ions studied. The results were statistically processed by means of "Cosinor-analysis" method and parametric methods of variation statistics. The diagnostics of functional peculiarities was based on the analysis of changes of the following characteristics: daily mean, amplitude, acrophase, and circadian rhythm curve shape. Individual chronograms for every animal obtained were distributed by the principle of maximal acrophase identity and intersecting for every group of chronograms daily mean, amplitude and phase structure (by the interval of time between acro- and bathyphase) were calculated by "Cosinor-analysis" method. All the stages of the experiment were carried out keeping to the major requirements of the European Convention on Human Attitude to Animals.

The experimental data obtained were processed on personal computers with the program package EXCE-2003 (Microsoft Corp., USA). The values of arithmetic mean sampling $(\mathrm{x})$, its dispersion and mean error (Sx) were calculated. To detect probable differences of the results in the experimental and control groups of animals Student (t) coefficient was determined, after that probability of sampling differences (p) and mean confidence interval by the tables of Student distribution were detected. The values were considered reliable with $\mathrm{p}<0,05$.

\section{RESULTS AND DISCUSSION}

Kidney functions in the control animals are subordinated to accurate circadian organization. Daily rhythms of the parameters of kidney ion-regulating function reflect similar changes of the renal processes [10]

The investigations of the ion-regulating function of the kidneys showed that both the blockade of the NO synthesis, and the dysfunction of the PG, lead to sharp violations of the structure of the chronorhythms of renal transport of sodium ions.

The injection of L-NNA against the background of PG hyperfunction resulted in a sharp increase in sodium urez. The daily mean significantly exceeded the average daily values in the control animals and rats who underwent a blockade of NO synthesis under normal light conditions but was 5 times lower than that of animals kept in conditions of constant darkness (Table I).

The amplitude of the rhythm was likely to decrease and was $24.5 \pm 0.52 \%$ (Table I). The maximum concentration of sodium ions in the urine was observed at 8.00 a.m., the second increase is about $16.00 \mathrm{a}$ a.m. The batiphase of rhythm was at $4.00 \mathrm{a} . \mathrm{m}$. The excretion of sodium ions and their concentration in the urine had a symmetrical character (Fig. 1, Table I).

Despite the high level of sodium urez when L-NNA was administered under hyperfunctional conditions the concentration of cation in plasma was significantly different from that of control animals as well as on the rates of animals that received L-NNA against the background of the normal light regime ((Fig. 2). Instead under conditions of PG hyperfunction an increase in the concentration of sodium ions in the blood plasma was observed (Table I).

Compared with the control values the average daily level of relative reabsorption of sodium ions in animals that was administered L-NNA under the background of PG hyperfunction significantly decreased and amounted to $99.1 \%$ ( Table I).

Increasing sodium thinning in conditions of inhibition of NO synthesis blockade resulted in a disturbance of sodium/ potassium urine (Table 1). The average daily level of the indicator significantly increased compared to the animals that were administered L-NNA under normal light conditions, and control rats. The maximum level of sodium/ potassium rhythm was at 16.00 a.m. and decreased from 8.00 a.m. to 12.00 a.m.

Observations on changes in the chronorhythm of the concentration index of sodium ions during the day showed that the administration of L-NNA resulted in an increase in the concentration index of sodium ions in animals that were under conditions of modeling PG hyperfunction (Table I).

Regarding the distal reabsorption of the cation in the conditions of PG hyperfunction the minimum value of distal reabsorption was recorded at about 12.00 a.m., and at the introduction of L-NNA at the background of PG hyperfunction of the batiphase were noted at 24.00 a.m. (Fig. 3, Table I).

The average daily mean of the indicator was significantly lower compared to other observation groups although the structure of the rhythm was in complete inversion relative to the studied groups.

\section{CONCLUSIONS}

The obtained results of the performed blockade NO synthesis in conditions of hyperfunction of the brain epiphysis allow to conclude that the daily mean of the rate of excretion of sodium ions decreases in comparison with the animals that were kept under hyperfunction of the brain epiphysis the filtration fraction and reabsorption of sodium ions are reduced 


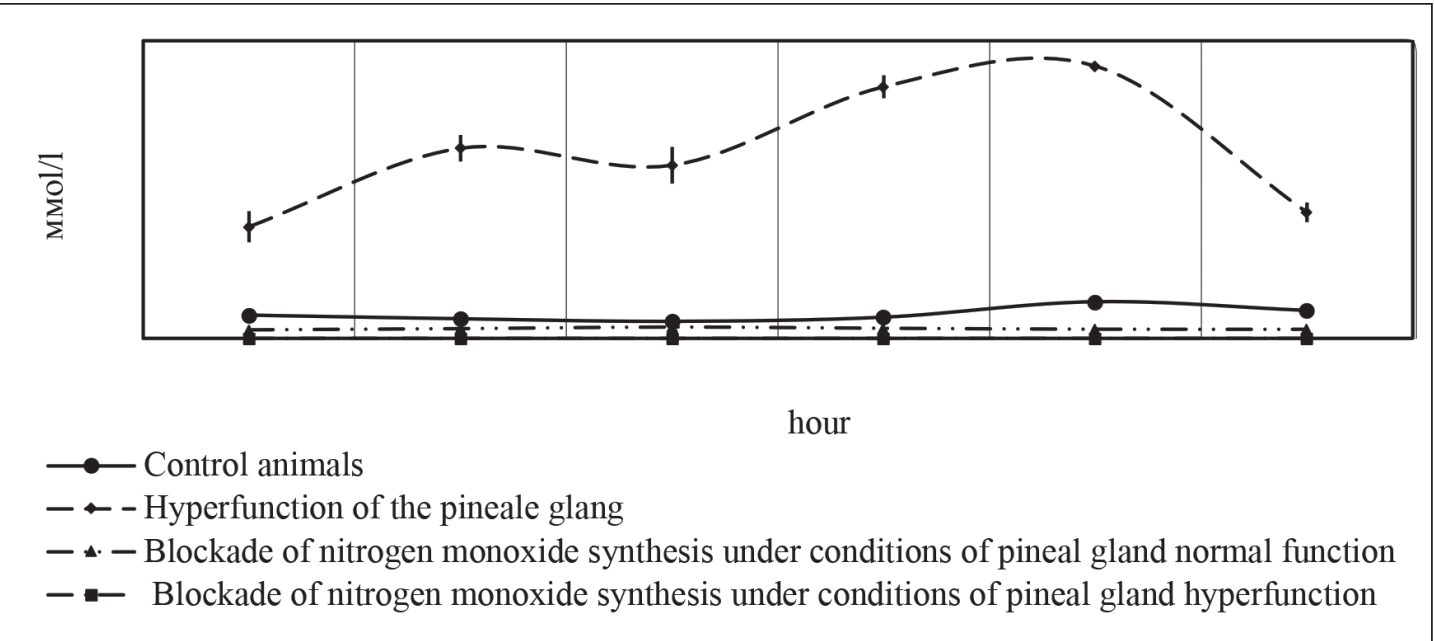

Fig. 1. Chronorhythms of concentration of sodium ions in urine $(\mathrm{mmol} / \mathrm{l})$ in rats exposed to the blockade of NO synthesis under conditions of pineal gland hyperfunction

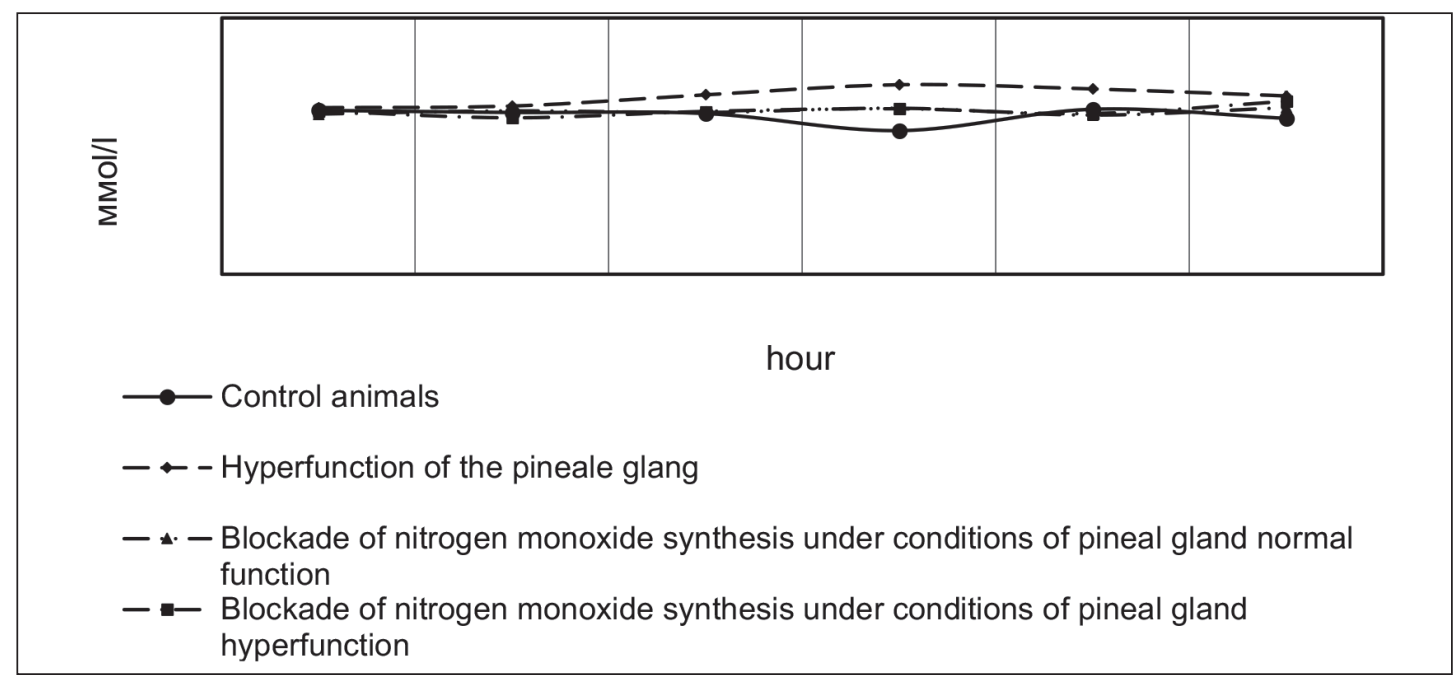

Fig. 2. Chronorhythms of concentration of sodium ions in the plasma ( $\mathrm{mmol} / \mathrm{l}$ ) in rats exposed to the blockade of NO synthesis under conditions of pineal gland hyperfunction

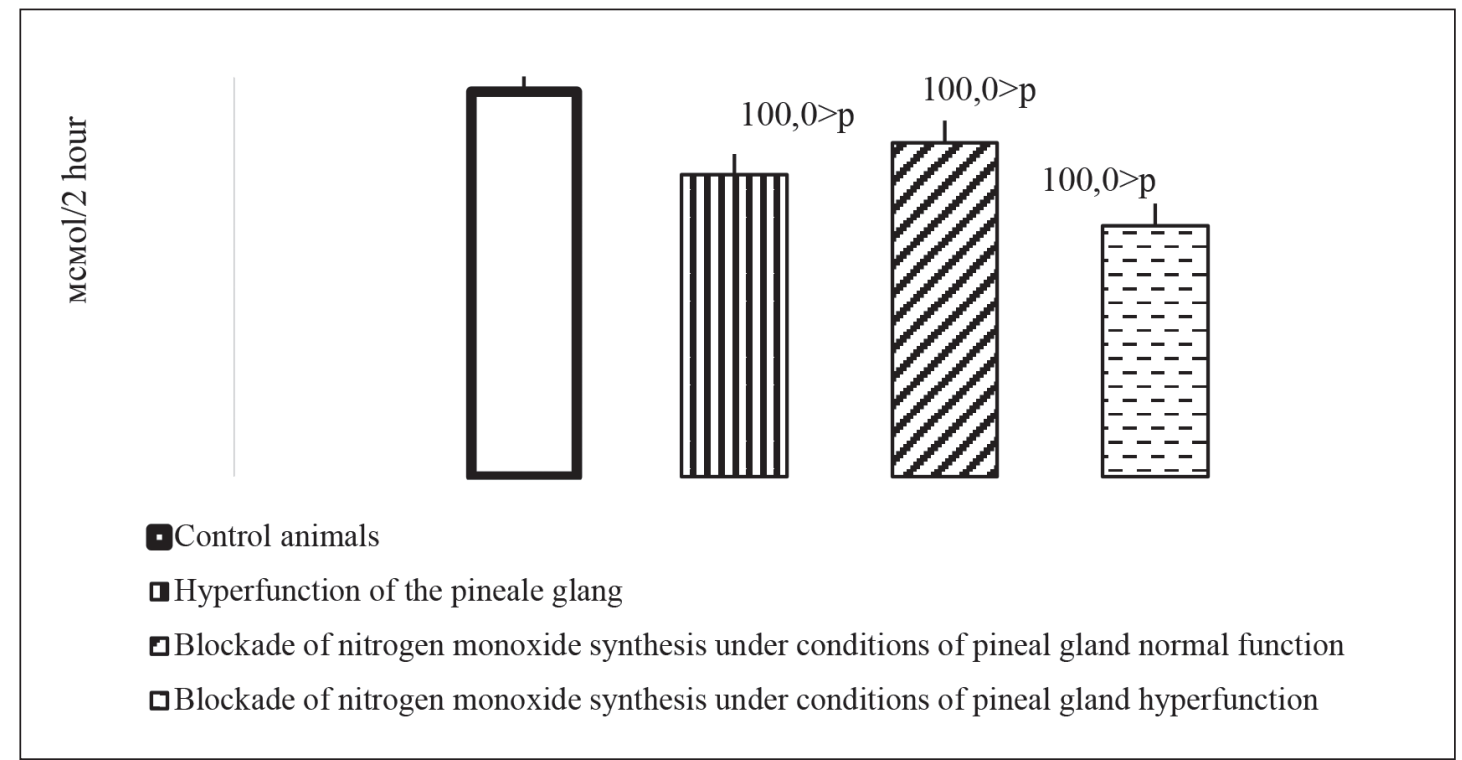

Fig. 3. Daily mean levels of distal transport of sodium ions ( $\mathrm{mcmol} / 2$ hour) in rats exposed to the blockade of NO synthesis under conditions of pineal gland hyperfunction 
Table I. Influence of nitrogen monoxide synthesis blockade under conditions of pituitary gland hyperfunction on mesor (daily mean) and amplitude of the rhythms of the kidney ion-regulating functions in albino rats $\left(\bar{x} \pm S_{-}\right)$

\begin{tabular}{|c|c|c|c|c|}
\hline \multirow[t]{2}{*}{ Parameters } & \multicolumn{2}{|c|}{$\begin{array}{l}\text { Control animals } \\
\qquad(n=36)\end{array}$} & \multicolumn{2}{|c|}{$\begin{array}{l}\text { Blockade of nitrogen monoxide } \\
\text { synthesis under conditions of } \\
\text { pineal gland hyperfunction }(n=36)\end{array}$} \\
\hline & $\begin{array}{c}\text { Mesor } \\
\text { (daily mean) }\end{array}$ & $\begin{array}{l}\text { Amplitude } \\
\text { (\%) }\end{array}$ & $\begin{array}{c}\text { Mesor } \\
\text { (daily mean) }\end{array}$ & $\begin{array}{c}\text { Amplitude } \\
\text { (\%) }\end{array}$ \\
\hline Concentration of sodium ions in the urine, $\mathrm{mmol} / \mathrm{l}$ & $3,9 \pm 0,19$ & $29,2 \pm 1,61$ & $\begin{array}{l}6,4 \pm 0,26 \\
p<0,001\end{array}$ & $\begin{array}{c}24,5 \pm 0,52 \\
p<0,01\end{array}$ \\
\hline Excretion of sodium ions, $\mathrm{MCMOl} / 2$ hours & $12,2 \pm 1,62$ & $32,5 \pm 2,61$ & $12,7 \pm 3,77$ & $\begin{array}{c}45,7 \pm 2,33 \\
p<0,005\end{array}$ \\
\hline Excretion of sodium ions, $\mathrm{MCMOl} / 100 \mathrm{Mcl}$ GF & $2,2 \pm 0,14$ & $26,9 \pm 1,91$ & $\begin{array}{l}4,5 \pm 0,41 \\
p<0,001\end{array}$ & $33,4 \pm 2,43$ \\
\hline Concentration of sodium ions in the plasma, $\mathrm{Mmol} / \mathrm{I}$ & $123,7 \pm 3,82$ & $5,0 \pm 1,21$ & $\begin{array}{c}127,7 \pm 1,37 \\
p<0,05\end{array}$ & $3,4 \pm 0,43$ \\
\hline Sodium/potassium ratio, un & $0,3 \pm 0,05$ & $41,7 \pm 1,51$ & $\begin{array}{l}0,9 \pm 0,02 \\
p<0,001\end{array}$ & $\begin{array}{c}11,3 \pm 0,51 \\
p<0,001\end{array}$ \\
\hline Filtration fraction of sodium ions,, $\mathrm{MCMO} / \mathrm{min}$ & $77,1 \pm 3,18$ & $19,1 \pm 1,02$ & $\begin{array}{c}39,4 \pm 1,54 \\
p<0,001\end{array}$ & $\begin{array}{c}9,09 \pm 0,83 \\
p<0,001\end{array}$ \\
\hline Absolute reabsorption of sodium ions, $\mathrm{MCMol} / \mathrm{min}$ & $76,9 \pm 2,35$ & $9,0 \pm 0,82$ & $\begin{array}{c}39,3 \pm 2,86 \\
p<0,001\end{array}$ & $\begin{array}{c}42,4 \pm 1,51 \\
p<0,001\end{array}$ \\
\hline Relative reabsorption of sodium ions, $\%$ & $99,9 \pm 0,02$ & $0,1 \pm 0,01$ & $\begin{array}{c}99,1 \pm 0,07 \\
\mathrm{p}<0,001\end{array}$ & $\begin{array}{l}1,5 \pm 0,01 \\
p<0,001\end{array}$ \\
\hline Clearance of sodium ions, $\mathrm{ml} / 2$ hours & $0,1 \pm 0,01$ & $28,3 \pm 2,41$ & $0,1 \pm 0,02$ & $\begin{array}{c}48,2 \pm 2,11 \\
p<0,001\end{array}$ \\
\hline Clearance of sodium-free water, $\mathrm{ml} / 2$ hours & $3,1 \pm 0,09$ & $18,8 \pm 0,42$ & $\begin{array}{c}1,9 \pm 0,05 \\
p<0,01\end{array}$ & $\begin{array}{c}47,9 \pm 1,81 \\
p<0,001\end{array}$ \\
\hline Proximal of sodium ions, $\mathrm{Mmol} / 2$ hours & $8,9 \pm 0,17$ & $20,2 \pm 0,41$ & $\begin{array}{l}4,5 \pm 0,19 \\
p<0,001\end{array}$ & $\begin{array}{c}42,4 \pm 2,11 \\
p<0,001\end{array}$ \\
\hline Distal transport of sodium ions, $\mathrm{MCMol} / 2$ hours & $385,4 \pm 13,46$ & $21,1 \pm 0,41$ & $\begin{array}{c}251,1 \pm 8,45 \\
p<0,001\end{array}$ & $\begin{array}{c}47,1 \pm 2,21 \\
p<0,001\end{array}$ \\
\hline Proximal of sodium ions, $\mathrm{MCMOl} / 100 \mathrm{MCl}$ GF & $11,8 \pm 0,29$ & $4,2 \pm 0,41$ & $12,1 \pm 0,13$ & $3,8 \pm 0,09$ \\
\hline Distal transport of sodium ions, $\mathrm{MCMOl} / 100 \mathrm{Mcl}$ GF & $0,6 \pm 0,07$ & $32,4 \pm 0,41$ & $0,7 \pm 0,06$ & $\begin{array}{c}19,5 \pm 0,81 \\
\mathrm{p}<0,001\end{array}$ \\
\hline Concentration index of sodium ions, un & $0,1 \pm 0,01$ & $34,4 \pm 0,41$ & $0,1 \pm 0,11$ & $\begin{array}{c}25,3 \pm 0,11 \\
p<0,001\end{array}$ \\
\hline
\end{tabular}

Notes:

$\mathrm{p}$ - reliable difference between the parameters of the experimental and control animals;

$n$ - number of animals

compared to the control animals and rats which were kept under conditions of PG hyperfunction and accompanied by stable indicators of the concentration the specified cation in the blood plasma during the observation period. The action of the blockade NO synthesis in conditions of hyperfunction of the brain's epiphysis leads to a decrease in the distal transport bridge of sodium ions with a maximum in the day and night intervals of the day the position of the acro- and batiphase of the rhythm changes as compared with the control animals.

\section{REFERENCES}

1. Bondarenko 0.V. Osoblyvosti porushen snu ta yikh korektsiia melatoninom pry likuvanni khvorykh litnoho viku z hipertonichnoiu khvoroboiu. 0. V. Bondarenko. Problemb starenyia y dolholetyia. 2012; 21, (2): 171-180.
2. Эpyfyzarnui hormon melatonyn y khronycheskaia bolezn pochek. N. N. Kaladze, E. Y. Slobodian, A. L. Hovdaniuk. Zdorovia dytyny. 2015; 2 (61):183 - 184.

3. Natochyn Yu. V. Vodno-solevoi homeostaz - rol refleksov, hormonov, ynkretynov, autakoydov. Yu. V. Natochyn. Fyzyol.zh. 2011; 57 (5): 13-15.

4. NO - zavysymbe mekhanyzmы rasstroistv okyslytelnoho obmena pry эksperymentalnom metabolycheskom syndrome. N. Elynskaia, L. Y. Leshenko, V. V. Tanash, Y. V. Soloveva. Funktsyonalnaia nauka y klynycheskaia medytsyna - chelovek y eho zdorove: Tezysы 17 Vserossyiskoi medyko-byolohycheskoi konferentsyy molodbkh yssledovatelei s mezhdunarodnum uchastyem. Sankt-Peterburh, 19 aprelia. 2014;149-150.

5. Orlova N. Y. Tsyrkadyannыe rytmb u detei pubertatnoho vozrasta: podkhodы y faktы. N. Y. Orlova, T. S. Pronyna. Alm. «Nov. yssled. 2014; (1): 40-47. 
6. Age-related effect of melatonin on permeability transition pore opening in rat brain. Krestinina 0. V., Odinokova S. V. Baburina Y. I., Azarashvili T. S. Biochem Sup Ser A Memb Cell Biol. 2013; 3 (4): 286-23.

7. Alteration of is chemia modified albumin and nitric oxide levels in hypothyroidish. Daniya K., Verma M., Dhankhan R. [et al.]. Clin. lab. 2014; 60 (6): 969-972.

8. Bryukhanov V. M. The kidney role in regulation of circade rithms of the organism. V. M. Bryukhanov, A. J.Zvereva. Nephrology. 2010; 14(3):17-31.

9. Jom L. 0. Hour does light affect melatonin. Jom L. 0., Jonsson A. Med. Hypotheses. 2008;71 (3): 458.

10. Peguliairities of melatonin effect on chronorhytmic organization of kidney acid-regulating function influenced by nitrogen monoxide synthesis blockade under conditions of pineal gland hypofunction. Semenenko S., Tymofiychuk I., Boreyko L. [et al.]. Georgian medical news. 2017; 10 (271): 117-122.

\section{Authors' contributions:}

According to the order of the Authorship.

\section{Conflict of interest:}

The Authors declare no conflict of interest.

\section{CORRESPONDING AUTHOR} Svitlana B. Semenenko

Higher State Educational Institution of Ukraine

"Bukovinian State Medical University"

2, Theatralna sq., 58002 Chernivtsi, Ukraine

tel: +380505277151

e-mail: semenenko.svitlana@bsmu.edu.ua

Received: 10.11 .2018

Accepted: 29.01.2019 
PRACA ORYGINALNA

ORIGINAL ARTICLE

\title{
PRÓBA OCENY WIEDZY KOBIET NA TEMAT CIĘCIA CESARSKIEGO W BADANIU ANKIETOWYM
}

\section{AN ATTEMPT TO ASSESS WOMEN'S KNOWLEDGE ABOUT CAESAREAN SECTION IN THE QUESTIONNAIRE SURVEY}

\author{
Patrycja Zielińska, Inga Janik, Martyna Maciejewska, Olimpia Sipak \\ ZAKŁAD POŁOŻNICTWA I PATOLOGII CIAZŻYY POMORSKIEGO UNIWERSYTETU MEDYCZNEGO W SZCZECINIE, WYDZIAŁ NAUK O ZDROWIU, SZCZECIN, POLSKA
}

\section{STRESZCZENIE}

Wstęp: W ostatnich latach odsetek cięć cesarskich stale rośnie.

Cel pracy: Próba oceny wiedzy kobiet na temat cięcia cesarskiego w badaniu ankietowym.

Materiał i metody: Badaniu poddano 1462 kobiety w wieku 18-57 lat, metodą sondażu diagnostycznego. Narzędziem badawczym była własna ankieta złożona z 26 pytań. Wyniki: Spośród 1462 ankietowanych kobiet 79,6\% uznało niepokój za główny czynnik skłaniający do wykonania cięcia cesarskiego. Najczęściej wymienianym schorzeniem w 93,6\%, które może wystąpić u kobiet po operacji były zrosty, natomiast opóźnienie laktacji - 59,36\% - miało negatywny wpływ na noworodka.

Wnioski: 1. Wzrost odsetka elektywnych cięć cesarskich ma związek z rozszerzeniem procedur związanych ze wskazaniami psychiatrycznymi .Większość kobiet jednak nadal preferuje poród drogami natury ze względu na bezpieczeństwo dla matki i dziecka.

2. Świadomość kobiet z wyżzzym wykształceniem wiąze się z większym niepokojem o własny stan zdrowia, noworodka oraz bezpieczeństwo porodu drogami natury, co powoduje wyższy odsetek cięć cesarskich.

3. Kobiety w wieku rozrodczym powinny mieć możliwość cyklu spotkań psychoedukacyjnych oraz szzzegółowe omówienie kwestii medycznych na ten temat związanych z obiema formami porodu oraz łatwość dostępu do literatury i szkół rodzenia.

4. Wzrastająca świadomość i znajomość prawa przez społeczeństwo powoduje wzrastającą liczbę roszzzeń pacjentek, co przyczynia się do wzrostu odsetka cięć cesarskich, ponieważ personel medyczny chce uniknąć odpowiedzialności karnej, cywilnej i zawodowej.

SŁOWA KLUCZOWE: cięcie cesarskie, wiedza, bezpieczeństwo, kobiety, noworodki

\begin{abstract}
Introduction: In last year the proportion of caesarean sections constantly growing.

The aim: To evaluate the knowledge in the questionnaire survey of women about the Caesarean section.

Materials and methods: 1462 women in age 18-57 were tested by the method of diagnostic survey. The tool of research was own survey composed of 26 question. Results: Among 1462 of women, which was poll, 79,6\% described anxiety as the main factor to make a decision to have a caesarean section. The most frequently mentioned disease in $93,6 \%$, which may appear among women after surgery were adhesions, while a delay of lactation in 59,36\% has a negative influence on newborn children.

Conclusions: 1. The percentage increase of elective caesarean sections is related to the extension of procedures related to psychiatric indications. However, most women, still prefer a natural birth because of safety for the mother and the child.

2. The awareness of women with higher education causes a higher percentage of cesarian sections, because of the greater anxiety about their own health, health of the newborn and safety of a natural birth.

3. Women in a reproductive age should have access to literature and antenatal schools, but also to psychoeducational meetings and a detailed discussion on this subject of both forms of delivery.

4. Increasing the number of cesarean sections to avoid criminal, civil and professional liability contributes to the increase of awareness and claims and by the knowledge of the law by the society.
\end{abstract}

KEY WORDS: caesarean section, knowledge, safety, women, newborns

Wiad Lek 2019, 72, 2, 239-245

\section{WSTĘP}

Ciążajest jednym z najpiękniejszych, a zarazem najważniejszych etapów życia kobiety. Sposób jej ukończenia jest uzależniony od wielu czynników m.in. od stanu rodzącej, od stanu płodu, wskazań do wykonania cięcia cesarskiego oraz od doświadcze- nia personelu medycznego. W wielu szpitalach w Polsce i na świecie można zauważyć rosnącą tendencję wykonywanych cięć cesarskich [1,2]. W Polsce w 2008 roku około $30 \%$ ciąż było zakończonych w ten sposób. W 2010 roku wskaźnik cięć cesarskich wyniósł 33,2\%, w 2011 roku przekroczył 35\%, a w latach 


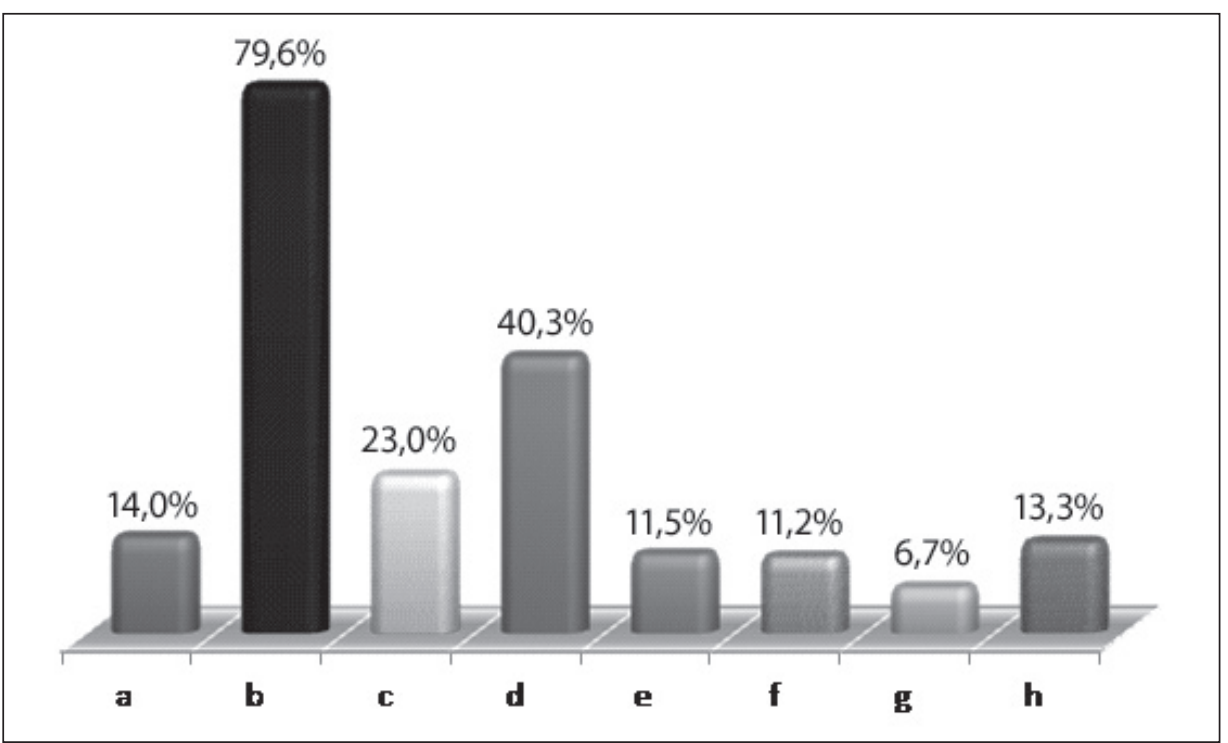

Ryc. 1. Które z wymienionych czynników skłoniłyby Panią do wykonania cięcia cesarskiego „na życzenie”?

Legenda:

a) strach przed porodem i bólem porodowym;

b) niepokój o stan zdrowia własny oraz dziecka;

c) negatywne doświadczenia związane z poprzednim porodem;

d) chęć uniknięcia komplikacji u siebie i dziecka będących skutkiem porodu siłami natury;

e) przekonanie, że cięcie cesarskie jest bezpieczniejsze dla dziecka, a także dla zdrowia kobiety;

f) strach przed uszkodzeniem tkanek pochwy i krocza, co wiąże się z obniżeniem atrakcyjności seksualnej;

g) prawo do podejmowania decyzji dotyczących własnego stanu zdrowia;

h) inne

2016-2017 wyniósł 43\% [3]. Według danych Organisation for Economic Co-operation and Development (OECD) z 2009 roku zanotowano, że najniższy odsetek cięć cesarskich był w Holandii (14,3\%), natomiast najwyższy w Brazylii (47,4\%). Odsetek cięć cesarskich na 100 żywych urodzeń w Wielkiej Brytanii wyniósł 23,7\%, w Hiszpanii 24,9\%, a w Irlandii 26\% [4]. Według szacunków OECD w krajach członkowskich w latach 2000-2011 liczba wykonanych cięć cesarskich wzrosła o 4,3\% [5].

W ostatnich latach zaobserwowano zwiększenie się wskazań medycznych oraz pozamedycznych do tego typu operacji. Wzrastająca liczba wykonywanych cięć cesarskich powinna nakłonić kobiety do głębszego zapoznania się z zagrożeniami, możliwymi powikłaniami i następstwami z nimi związanymi. Dotyczy to szczególnie sytuacji, gdy cięcie cesarskie wykonywane jest „na życzenie” pacjentki.

Wiedza na temat cięcia cesarskiego jest bardzo rozległa, a zdobywanie jej wymaga dużego zaangażowania i uporu ze strony kobiet, par, które starają się o pierwsze lub kolejne dziecko. Często kobiety nie zdają sobie sprawy z powikłań i konsekwencji przeprowadzonej operacji, dlatego ważne jest odpowiednie przygotowanie i przekazanie najistotniejszych informacji. Ważną rolę odgrywa tu personel medyczny, który przekazuje rzetelną wiedzę oraz przygotowuje przyszłych rodziców fizycznie oraz psychicznie do zabiegu chirurgicznego.

Wielu położników-ginekologów uważa, że wzrost liczby wykonywanych cięć cesarskich to zjawisko o charakterze „epidemii”. Próbując ograniczyć tak powszechny trend lekarze przedstawiają ciężarnym powikłania medyczne oraz argumenty etyczne, eko- nomiczne i prawne. Na decyzję o wykonaniu cięcia cesarskiego wpływają różne czynniki, takie jak: uwarunkowania medyczne, ekonomiczne czy społeczne, kulturowe postawy kobiet, a także cechy osobnicze rodzących [6]. Doskonalenie techniki operacyjnej przyczyniło się także do wzrostu liczby wykonywanych operacji.

Do głównych powikłań medycznych po cięciu cesarskim zalicza się: żylną chorobę zakrzepowo-zatorową, zakażenia (miejsca operowanego, układu moczowego), powikłania znieczulenia, zapalenia (błony śluzowej macicy, otrzewnej), zrosty pooperacyjne, jatrogenne uszkodzenie sąsiadujących narządów, martwicze zapalenie powięzi oraz utratę krwi powyżej $1000 \mathrm{ml}[7,8]$.

Odsetek ciężkich powikłań w odniesieniu do noworodka wzrasta. Noworodki po cięciu cesarskim pozbawione są kontaktu skóra do skóry, może być opóźnione pierwsze karmienie piersią. Częściej zauważany jest u nich zespół zaburzeń oddychania, nadciśnienia płucnego i mokrych płuc [9]. Czasami pobyt w szpitalu jest przedłużony i konieczne jest leczenie antybiotykami, co zaburza biofilm bakteryjny jelit dziecka. Głównie zmniejsza się liczba bakterii: Lactobacillus i Bifidobacterium [10].

\section{CEL PRACY}

Celem pracy była próba oceny poziomu wiedzy kobiet na temat cięcia cesarskiego w badaniu ankietowym w poszczególnych grupach społecznych, wiedzy kobiet dotycząca wskazań i powikłań związanych z cięciem cesarskim oraz próba oceny wiedzy na temat bezpieczeństwa wykonywanej operacji dla matki i dziecka. Ocena czynników, które kobieta wybrałaby jako wskazanie do 
Tabela I. Analiza zależności pomiędzy statusem materialnym, a pytaniem: Czy według Pani cięcie cesarskie jest bezpieczniejsze dla dziecka niż poród siłami natury?

\begin{tabular}{|c|c|c|c|c|}
\hline & $\begin{array}{c}\text { A1 } \\
\text { N (\%) }\end{array}$ & $\begin{array}{c}\text { B1 } \\
\text { N (\%) }\end{array}$ & $\begin{array}{c}\text { C1 } \\
\text { N (\%) }\end{array}$ & $\begin{array}{c}\text { SUMA } \\
\mathbf{N}\end{array}$ \\
\hline$A$ & $\begin{array}{c}59 \\
(34,50)\end{array}$ & $\begin{array}{c}92 \\
(53,80)\end{array}$ & $\begin{array}{c}20 \\
(11,70)\end{array}$ & 171 \\
\hline$B$ & $\begin{array}{c}182 \\
(25,49)\end{array}$ & $\begin{array}{c}378 \\
(52,94)\end{array}$ & $\begin{array}{c}154 \\
(21,57)\end{array}$ & 714 \\
\hline$C$ & $\begin{array}{c}142 \\
(25,54)\end{array}$ & $\begin{array}{c}266 \\
(47,84)\end{array}$ & $\begin{array}{c}148 \\
(26,62)\end{array}$ & 556 \\
\hline D & $\begin{array}{c}7 \\
(25,93)\end{array}$ & $\begin{array}{c}8 \\
(29,63)\end{array}$ & $\begin{array}{c}12 \\
(44,44)\end{array}$ & 27 \\
\hline$E$ & $\begin{array}{c}1 \\
(50,00)\end{array}$ & $\begin{array}{c}1 \\
(50,00)\end{array}$ & $\begin{array}{c}0 \\
(0,00)\end{array}$ & 2 \\
\hline SUMA & $\begin{array}{c}391 \\
(26,60)\end{array}$ & $\begin{array}{c}745 \\
(50,68)\end{array}$ & $\begin{array}{c}334 \\
(22,72)\end{array}$ & 1470 \\
\hline
\end{tabular}

\section{Legenda:}

Status materialny: $\quad$ Odpowiedzi:

A- bardzo dobry $\quad$ A1-tak

B- dobry B1- nie

C-zadowalający C1-nie wiem

D- zły

E - bardzo zły

Tabela II. Analiza zależności pomiędzy wykształceniem kobiet a negatywnym wpływem cięcia cesarskiego na stan noworodka.

\begin{tabular}{|c|c|c|c|c|c|c|c|}
\hline & $\begin{array}{c}\text { A1 } \\
\text { N (\%) }\end{array}$ & $\begin{array}{c}\text { B1 } \\
\text { N (\%) } \\
\end{array}$ & $\begin{array}{c}\text { C1 } \\
\text { N (\%) } \\
\end{array}$ & $\begin{array}{c}\text { D1 } \\
\text { N (\%) } \\
\end{array}$ & $\begin{array}{c}\text { E1 } \\
\text { N (\%) } \\
\end{array}$ & $\begin{array}{c}\text { F1 } \\
\text { N (\%) } \\
\end{array}$ & $\begin{array}{c}\text { SUMA } \\
\mathbf{N}\end{array}$ \\
\hline$A$ & $\begin{array}{c}4 \\
(36,36) \\
\end{array}$ & $\begin{array}{c}2 \\
(18,18)\end{array}$ & $\begin{array}{c}2 \\
(18,18)\end{array}$ & $\begin{array}{c}4 \\
(36,36)\end{array}$ & $\begin{array}{c}6 \\
(54,55)\end{array}$ & $\begin{array}{c}7 \\
(63,64)\end{array}$ & 25 \\
\hline B & $\begin{array}{c}7 \\
(16,28) \\
\end{array}$ & $\begin{array}{c}13 \\
(30,23)\end{array}$ & $\begin{array}{c}2 \\
(4,65)\end{array}$ & $\begin{array}{c}5 \\
(11,63) \\
\end{array}$ & $\begin{array}{c}30 \\
(69,77) \\
\end{array}$ & $\begin{array}{c}25 \\
(58,14)\end{array}$ & 82 \\
\hline$C$ & $\begin{array}{c}23 \\
(23,47) \\
\end{array}$ & $\begin{array}{c}39 \\
(39,80)\end{array}$ & $\begin{array}{c}3 \\
(3,06) \\
\end{array}$ & $\begin{array}{c}6 \\
(6,12) \\
\end{array}$ & $\begin{array}{c}70 \\
71,43 \% \\
\end{array}$ & $\begin{array}{c}58 \\
59,18 \% \\
\end{array}$ & 199 \\
\hline$D$ & $\begin{array}{c}137 \\
(22,39)\end{array}$ & $\begin{array}{c}272 \\
(44,44)\end{array}$ & $\begin{array}{c}36 \\
(5,88)\end{array}$ & $\begin{array}{c}79 \\
(12,91)\end{array}$ & $\begin{array}{c}381 \\
(62,25)\end{array}$ & $\begin{array}{c}358 \\
(58,50)\end{array}$ & 1263 \\
\hline $\mathrm{E}$ & $\begin{array}{c}209 \\
(29,65) \\
\end{array}$ & $\begin{array}{c}441 \\
(62,55) \\
\end{array}$ & $\begin{array}{c}24 \\
(3,40) \\
\end{array}$ & $\begin{array}{c}75 \\
(10,64) \\
\end{array}$ & $\begin{array}{c}380 \\
(53,90) \\
\end{array}$ & $\begin{array}{c}424 \\
(60,14) \\
\end{array}$ & 1553 \\
\hline SUMA & $\begin{array}{c}380 \\
(25,87)\end{array}$ & $\begin{array}{c}767 \\
(52,21)\end{array}$ & $\begin{array}{c}67 \\
(4,56)\end{array}$ & $\begin{array}{c}169 \\
(11,50)\end{array}$ & $\begin{array}{c}867 \\
(59,02)\end{array}$ & $\begin{array}{c}872 \\
(59,36)\end{array}$ & 3122 \\
\hline
\end{tabular}

\section{Legenda:}

A1 - zaburzenia oddychania;

B1 - nie dochodzi do fizjologicznej kolonizacji przewodu pokarmowego bakteriami: Lactobacillus i Bifidobacter;

C1 - krwiak główki;

D1 - wychłodzenie organizmu;

E1 - utrudniony kontakt miedzy matką a noworodkiem;

F1 - opóźnienie laktacji

cięcia „na życzenie”, wpływu cięcia cesarskiego na stan noworodka oraz negatywnych powikłań mogących wystąpić po operacji.

\section{MATERIA I METODY}

Badania przeprowadzono w Samodzielnym Publicznym Wielospecjalistycznym Zakładzie OpiekiZdrowotnej w Stargardzie oraz poprzez stronę internetową. Adres URL kwestionariusza https://www.survio.com/survey/d/X9W0M9I1T6G2N2P7I. Obejmowały one okres od 14.07.2017 r. do 04.09.2017 r.

Ankiety przeprowadzono na Bloku Porodowym i Oddziale Położniczo-Neonatologicznym, a także na stronie internetowej. Respondentkom przygotowano autorski sondaż diagnostyczny. Badaniem objęto 1462 kobiety 


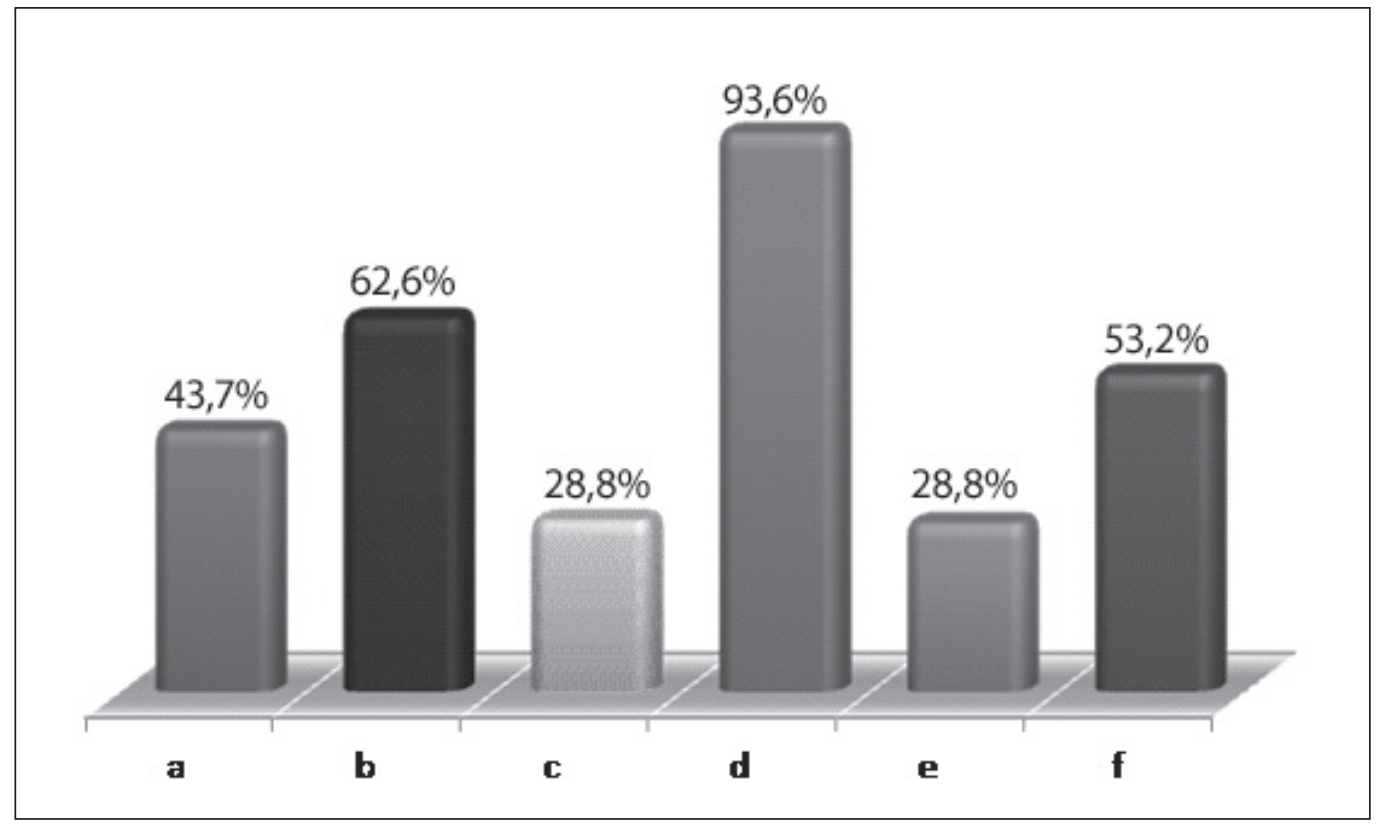

Ryc. 2. Które z wymienionych schorzeń mogą wystąpić jako powikłania po cięciu cesarskim?

Legenda:

a) ból głowy; b) krwotoki; c) infekcje dróg rodnych, moczowych;

d) zrosty pooperacyjne;

e) spadek ciśnienia tętniczego;

f) jatrogenne uszkodzenie sąsiadujących narządów podczas cięcia cesarskiego

w wieku od 18 do 57 r.ż. Sondaż diagnostyczny składał się z 26 pytań jednokrotnego i wielokrotnego wyboru, części socjodemograficznej dotyczącej wieku, stanu cywilnego, wykształcenia, miejsca zamieszkania, statusu materialnego. Obliczenia wykonano przy pomocy oprogramowania Statistica v 10.0 firmy Statsoft, przyjmując 5\% prawdopodobieństwo błędu. Opracowanie wyników przedstawiono korzystając z oprogramowania firmy Microsoft: Word 2013 i Excel 2013. Do oceny zależności w badaniach ankietowych wykorzystano test chi kwadrat Pearsona ( $\mathrm{s} \leq 0,05)$.

\section{WYNIKI}

Wśród badanych największą grupę stanowiły kobiety, które posiadały wykształcenie wyższe (48\%), średnie (41,6\%), a najmniejszą - podstawowe $(0,8 \%)$. Mieszkankami miast liczących >100 tys. mieszkańców było 43,4\% kobiet. Najmniejszą grupę - 7,6\% stanowiły kobiety mieszkające $\mathrm{w}$ mieście $<10$ tys. mieszkańców.

Swój status materialny większość $(48,6 \%)$ kobiet określała jako dobry. Status zadowalający posiadało 37,8\%, bardzo dobry $11,6 \%$, zły 1,8\%, a bardzo zły $0,1 \%$. Kobiety, które urodziły dziecko przez cięcie cesarskie stanowiły 78,4\% ankietowanych, kobiety po porodzie drogami natury 14,6\%. 10,5\% ankietowanych rodziła zarówno drogami natury, jak i drogą cięcia cesarskiego. Najmniejszą grupę $1,5 \%$ stanowiły respondentki rodzące dziecko siłami natury z zastosowaniem kleszczy położniczych lub próżnociągu.

Badane kobiety zapytano, które z wymienionych czynników skłoniłyby do wykonania cięcia cesarskiego „na życzenie”.
Spośród wymienionych czynników 79,6\% ankietowanych wybrało niepokój o stan zdrowia własny oraz dziecka. Mniej niż połowa 40,3\% kobiet chciałaby uniknąć komplikacji u siebie i dziecka będących skutkiem porodu siłami natury. 23\% przeżyło negatywne doświadczenie podczas poprzedniego porodu. Niewielka różnica występowała między strachem przed porodem i bólem - 14\%, a innymi czynnikami 13,3\%. Część ankietowanych - 11,5\% - przekonana była, że cięcie cesarskie jest bezpieczniejsze dla zdrowia kobiety i dziecka, 11,2\% bała się uszkodzenia tkanek pochwy i krocza, co wiąże się z obniżeniem atrakcyjności seksualnej, a 6,7\% pań miała świadomość prawa do podejmowania samodzielnych decyzji dotyczących swojego stanu zdrowia (Ryc. 1).

Ważnym aspektem było poznanie opinii kobiet $\mathrm{z}$ różnym statusem materialnym na temat bezpieczeństwa lub jego braku wykonanego cięcia cesarskiego w porównaniu do porodu siłami natury dla dziecka (Tab. I).

Analizując tabelę I stwierdzono istotny związek ( $p=0,000367)$ pomiędzy statusem materialnym a odpowiedzią na pytanie: Czy cięcie cesarskie jest bezpieczniejsze dla dziecka niż poród siłami natury? Ankietowane o statusach materialnych: bardzo dobry 53,8\%, dobry 52,94\%, zadowalający 47,84\% i bardzo zły $50 \%$ uważały, że cięcie cesarskie nie jest bezpieczniejsze dla dziecka niż poród siłami natury. Ponad połowa kobiet 50,68\% we wszystkich grupach podzielało to zdanie.

Tabela II. przedstawia istotną zależność statystyczną ( $\mathrm{p}=0,000003$ ) pomiędzy wykształceniem a wyborem negatywnych czynników, które wpływają na stan noworodka po cięciu cesarskim. Najwyższy wskaźnik (36,36\%) we wszystkich grupach stanowiły zaburzenia oddychania u noworodka ma- 
Tabela III. Analiza zależności pomiędzy statusem materialnym a pytaniem: Czy według Pani cięcie cesarskie jest bezpieczniejsze dla matki niż poród siłami natury?

\begin{tabular}{|c|c|c|c|c|}
\hline & $\begin{array}{c}\text { A1 } \\
\text { N (\%) }\end{array}$ & $\begin{array}{c}\text { B1 } \\
\text { N (\%) }\end{array}$ & $\begin{array}{c}\text { C1 } \\
\text { N (\%) }\end{array}$ & $\begin{array}{c}\text { SUMA } \\
\mathbf{N}\end{array}$ \\
\hline$A$ & $\begin{array}{c}40 \\
(23,39) \\
\end{array}$ & $\begin{array}{c}108 \\
(63,16)\end{array}$ & $\begin{array}{c}23 \\
(13,45) \\
\end{array}$ & 171 \\
\hline B & $\begin{array}{c}128 \\
(17,93)\end{array}$ & $\begin{array}{c}450 \\
(63,03)\end{array}$ & $\begin{array}{c}136 \\
(19,05)\end{array}$ & 714 \\
\hline C & $\begin{array}{c}87 \\
(15,65)\end{array}$ & $\begin{array}{c}353 \\
(63,49)\end{array}$ & $\begin{array}{c}116 \\
(20,86)\end{array}$ & 556 \\
\hline $\mathrm{D}$ & $\begin{array}{c}5 \\
(18,52)\end{array}$ & $\begin{array}{c}16 \\
(59,26)\end{array}$ & $\begin{array}{c}6 \\
(22,22)\end{array}$ & 27 \\
\hline$E$ & $\begin{array}{c}2 \\
(100,00)\end{array}$ & $\begin{array}{c}0 \\
(0,00)\end{array}$ & $\begin{array}{c}0 \\
(0,00)\end{array}$ & 2 \\
\hline SUMA & $\begin{array}{c}262 \\
(17,82)\end{array}$ & $\begin{array}{c}927 \\
(63,06)\end{array}$ & $\begin{array}{c}281 \\
(19,12)\end{array}$ & 1470 \\
\hline
\end{tabular}

\begin{tabular}{ll}
\hline Legenda: & \\
Status materialny: & 0dpowiedzi: \\
A- bardzo dobry & A1- tak \\
B- dobry & B1- nie \\
C-zadowalający & C1- nie wiem \\
D- zły & \\
E- bardzo zły &
\end{tabular}

Tabela IV. Analiza zależności pomiędzy wiekiem a źródłem wiedzy na temat cięcia cesarskiego.

\begin{tabular}{|c|c|c|c|c|c|c|c|c|}
\hline & $\begin{array}{c}\text { A } \\
\text { N (\%) }\end{array}$ & $\begin{array}{c}\text { B } \\
\text { N (\%) }\end{array}$ & $\begin{array}{c}\text { C } \\
\text { N (\%) }\end{array}$ & $\begin{array}{c}\text { D } \\
\text { N (\%) }\end{array}$ & $\begin{array}{c}E \\
N(\%)\end{array}$ & $\begin{array}{c}F \\
\text { N (\%) }\end{array}$ & $\begin{array}{c}\text { G } \\
\text { N (\%) }\end{array}$ & $\begin{array}{c}\text { SUMA } \\
\mathbf{N}\end{array}$ \\
\hline $18-28$ lat & $\begin{array}{c}518 \\
(54,24)\end{array}$ & $\begin{array}{c}259 \\
(27,12)\end{array}$ & $\begin{array}{c}125 \\
(13,09)\end{array}$ & $\begin{array}{c}294 \\
(30,79)\end{array}$ & $\begin{array}{c}584 \\
(61,15)\end{array}$ & $\begin{array}{c}587 \\
(61,47)\end{array}$ & $\begin{array}{c}142 \\
(14,87)\end{array}$ & 2509 \\
\hline 29-39 lat & $\begin{array}{c}284 \\
(63,11) \\
\end{array}$ & $\begin{array}{c}131 \\
(29,11) \\
\end{array}$ & $\begin{array}{c}102 \\
(22,67)\end{array}$ & $\begin{array}{c}155 \\
(34,44) \\
\end{array}$ & $\begin{array}{c}267 \\
(59,33) \\
\end{array}$ & $\begin{array}{c}229 \\
(50,89) \\
\end{array}$ & $\begin{array}{c}87 \\
(19,33) \\
\end{array}$ & 1255 \\
\hline $40-50$ lat & $\begin{array}{c}30 \\
(51,72)\end{array}$ & $\begin{array}{c}9 \\
(15,52)\end{array}$ & $\begin{array}{c}3 \\
(5,17)\end{array}$ & $\begin{array}{c}24 \\
(41,38)\end{array}$ & $\begin{array}{c}20 \\
(34,48)\end{array}$ & $\begin{array}{c}21 \\
(36,21)\end{array}$ & $\begin{array}{c}14 \\
(24,14)\end{array}$ & 121 \\
\hline$>50$ lat & $\begin{array}{c}3 \\
(50,00)\end{array}$ & $\begin{array}{c}0 \\
0,00 \%\end{array}$ & $\begin{array}{c}0 \\
0,00 \%\end{array}$ & $\begin{array}{c}4 \\
66,67 \%\end{array}$ & $\begin{array}{c}2 \\
33,33 \%\end{array}$ & $\begin{array}{c}1 \\
16,67 \%\end{array}$ & $\begin{array}{c}1 \\
16,67 \%\end{array}$ & 11 \\
\hline SUMA & $\begin{array}{c}835 \\
(56,84)\end{array}$ & $\begin{array}{c}399 \\
(27,16)\end{array}$ & $\begin{array}{c}230 \\
(15,66)\end{array}$ & $\begin{array}{c}477 \\
(32,47)\end{array}$ & $\begin{array}{c}873 \\
(59,43)\end{array}$ & $\begin{array}{c}838 \\
(57,05)\end{array}$ & $\begin{array}{c}244 \\
(16,61)\end{array}$ & 3896 \\
\hline
\end{tabular}

Legenda:

Źródła wiedzy na temat cięcia cesarskiego:

A - lekarz ginekolog /położnik;

B - położna;

C - szkoła rodzenia;

D - literatura medyczna;

E - Internet;

F - doświadczenie innych kobiet;

G - inne;

tek $\mathrm{z}$ wykształceniem podstawowym. 62,55\% respondentek z wyższym wykształceniem stwierdziło, że nie dochodzi do fizjologicznej kolonizacji przewodu pokarmowego bakteriami: Lactobacillus i Bifidobacter. Wśród badanych grup 4,56\% kobiet uważało, że dziecko po cięciu cesarskim będzie miało krwiaka główki, natomiast powyżej 59\% respondentek twierdziło, że po tej operacji będzie krótszy kontakt między matką a noworodkiem oraz laktacja będzie opóźniona (Tab. II).
Dokonując oceny zależności pomiędzy statusem materialnym, a pytaniem: Czy według Pani cięcie cesarskie jest bezpieczniejsze niż poród siłami natury dla matki? Stwierdzono, że wszystkie osoby z bardzo złym statusem materialnym uważały, że cięcie cesarskie jest bezpieczniejszą formą porodu od porodu siłami natury dla matki. 63,06\% wśród wszystkich ankietowanych twierdziło, że cięcie cesarskie nie jest lepszą formą rozwiązania ciąży (Tab. III). 
Analizując rycinę 2., dostrzegamy, że najczęściej (93,6\%) wymienianym powikłaniem, które może wystąpić po operacji były zrosty pooperacyjne. Na drugim miejscu $(62,6 \%)$ były krwotoki, jatrogenne uszkodzenie sąsiadujących narządów przy cięciu cesarskim (53,2\%), ból głowy (43,7\%). Podobny odsetek respondentek zaznaczyło infekcje dróg rodnych $(28,8 \%)$, moczowych oraz spadek ciśnienia tętniczego krwi (28,3\%) (Ryc. 2.).

$\mathrm{Z}$ tabeli IV wynika, że wiek miał istotny statystycznie $(\mathrm{p}=0,000007)$ wpływ na źródło wiedzy na temat cięcia cesarskiego. Kobiety powyżej 50 r. ż. najczęściej (66,67\%) korzystały z wiedzy na ten temat z literatury medycznej, natomiast nie otrzymywały wiadomości odnośnie cięcia cesarskiego od położnej ani ze szkoły rodzenia. Niski poziom 5,17\% zdobywania wiedzy ze szkoły rodzenia zaobserwowano u respondentek pomiędzy 40 a 50 r. ż. 59,43\% wśród wszystkich badanych grup (najwyższy procent) jako źródło wskazywało internet (Tab. IV).

\section{DYSKUSJA}

W ostatnich latach odsetek cięć cesarskim stale rośnie. Światowa Organizacja Zdrowia (WHO) wykazuje, że ma on się zwiększać co kolejne 2-3 lata o 1-2\% [11]. Może to być spowodowane coraz większym zainteresowaniem kobiet tematem operacyjnego ukończenia ciąży.

Przeprowadzone badania własne wykazują, że w 79,6\% niepokój o stan zdrowia własny kobiety oraz dziecka był najczęstszym czynnikiem, który skłoniłby do wykonania cięcia cesarskiego. Bezwzględnym wskazaniem w 90,8\% do wykonania cięcia cesarskiego były zaburzenia czynności serca płodu. Na drugim miejscu 82,5\% znajdowało się nieprawidłowe położenie płodu. Przedwczesne oddzielenie łożyska stanowiło 81,4\%, wypadnięcie pępowiny - 55,7\%, ciąża bliźniacza (33,3\%), tokofobia (lęk przed porodem) $30,2 \%$, stan po cięciu cesarskim $29,1 \%$, najmniej liczebna grupa $6,9 \%$ to prośba pacjentki bez wskazań medycznych.

Według innych autorów $[4,12,13]$ brak zgody rodzącej na podjęcie próby porodu naturalnego to najczęstsze wskazanie do cięcia cesarskiego.

Odmienne wyniki przedstawili Michałowska i wsp. [14], którzy zaobserwowali, iż najczęstszą grupą wskazań były wskazania pozapołożnicze: okulistyczne i ortopedyczne.

W szystkie kobiety z bardzo złym statusem materialnym uważały, że cięcie cesarskie jest bezpieczniejszą dla matki formą porodu od porodu siłami natury. 63,06\% wszystkich ankietowanych twierdziło, że cięcie cesarskie nie jest lepszą forma rozwiązania ciąży. Również Głuszak i wsp. [12] zaobserwowali, że cięcie cesarskie stanowi większe zagrożenie dla życia rodzącej w porównaniu z porodem fizjologicznym.

Odmienne wyniki niż w badaniach własnych autorów pracy zaobserwowali Mieczkowska i wsp. [15], twierdząc, że cięcie cesarskie jest korzystniejszą formą porodu dla kobiet i noworodków. 67,8\% pacjentek uważało, że cięcie cesarskie jest bezpieczniejszą formą porodu dla matki, a 55,4\%, że cięcie cesarskie jest korzystniejsze dla noworodka. Podobnie Wardak i wsp. [16] zaobserwowali u 79\% młodych kobiet, że operacja chirurgiczna jest korzystniejsza również dla dziecka, a w 78,4\% dla matki [16]. Analogicznie Piwnica i wsp. $[17,18]$ stwierdzili, że cięcie cesarskie jest bezpieczniejsze dla dziecka.

Podobne wyniki do badań autorów pracy uzyskali Sendecka i wsp. [19]. Zaobserwowali oni wśród położnic po cięciu cesarskim trudności w karmieniu piersią spowodowane utrudnionym kontaktem między matką a noworodkiem oraz opóźnioną laktacją. W przeprowadzonych badaniach stwierdzono, że kobiety nie otrzymywały informacji na temat cięcia cesarskiego od położnej ani ze szkoły rodzenia.

Odmienne rezultaty uzyskali natomiast Kaźmierczaki wsp. [20]. Wykazali oni, że 65\% należących do grupy pierwiastek pozyskuje wiedzę od rodziny/znajomych oraz położnej (75\%). Natomiast u wieloródek, podobnie do badań własnych (59,43\%), głównym źródłem wiedzy był internet (85\%).

Dzięki większej wiedzy kobiet na temat cięcia cesarskiego i większej ich świadomości w przyszłości zmniejszy się liczba tych operacji.

\section{WNIOSKI}

Przeprowadzone wyniki badań wykazały, że:

1. Wzrost odsetka elektywnych cięć cesarskich ma związek $\mathrm{z}$ rozszerzeniem procedur związanych ze wskazaniami psychiatrycznymi. Większość kobiet jednak nadal preferuje poród drogami natury ze względu na bezpieczeństwo dla matki i dziecka.

2. Świadomość kobiet $\mathrm{z}$ wyższym wykształceniem wiąże się z większym niepokojem o własny stan zdrowia, noworodka oraz bezpieczeństwo porodu drogami natury co powoduje wyższy odsetek cięć cesarskich.

3. Kobiety w wieku rozrodczym powinny mieć możliwość cyklu spotkań psychoedukacyjnych oraz szczegółowe omówienie kwestii medycznych na ten temat związanych $\mathrm{z}$ obiema formami porodu oraz łatwość dostępu do literatury związanej z tym tematem i szkół rodzenia.

4. Wzrastająca świadomość i znajomość prawa przez społeczeństwo powoduje wzrastającą liczbę roszczeń pacjentek, co przyczynia się do wzrostu odsetka cięć cesarskich, ponieważ personel medyczny chce uniknąć odpowiedzialności karnej, cywilnej i zawodowej.

\section{PIŚMIENNICTWO}

1. Simm A, Mathew D. Caesarean section: techniques and complicaions. Obstrectics, gynaecology and reproductive medicine. 2008;6:448-455.

2. Nowacki R. Od mitologii do współczesności - z historii cięcia cesarskiego. Perinatol Neonatol Ginekol. 2008;5-7.

3. Cunningham FG, Grant NF, Lerumo KJ et al. Abnormal labour: Williams' Obstetrics 21 st edition. New York: Mc Graw Hill, 2001:425-451.

4. Stasiełuk A, Langiewicz I, Kosińska-Kaczyńska K et al. Czy epidemia cięć cesarskich jest wykładnikiem liberalizacji wskazań? Ginekol Pol. 2012;83:604-608.

5. OECD Indicators. Health at a Glance, OECD Publishing; 2013. http:// dx.doi.org/10.1787/health_glance-2013-39-en [dostęp: 27.01.2016]

6. Marx GF, Luyks WM, Cohert S. Fetal neonatal status following ceasarean section for fetal distress. Brit J Anaesth. 1984;56:1009-1012. 
7. Poręba R, Jędrzejko M, Poręba i wsp. Wskazania do cięcia cesarskiego. Perinatol Neonatol Ginekol. 2008(1);1:11-18.

8. Poręba R. Rekomendacje Polskiego Towarzystwa Ginekologicznego. Cięcie cesarskie. Ginekol Pol. 2008;79:378-384.

9. Rabiej M, Dmoch-Gajzlerska E. Opieka położnej nad kobietą i jej dzieckiem po cięciu cesarskim. Poloz Nauka Prakt. 2014(26);2:50-53

10. ProstM,WilczyńskiJ. Konsensus okulistyczno-położniczy wsprawiewskazań do rozwiązania porodu drogą cięci cesarskiego zpowodu zmian w narządzie wzroku. Wytyczne Polskiego Towarzystwa Okulistycznego. 10.06.2014.

11. NiemiecT. Raport:Zdrowie kobiet w wieku prokreacyjnym 15-49 lat. 2006

12. Głuszak M, Frącki S, Wielgoś M et al. Metody oceny postępu porodu we współczesnym położnictwie. Ginekol Pol. 2013;84:709-713.

13. Kostrzewa T, Walczak J, Wieckowska K. Porod drogą pochwową po cięciu cesarskim. Ginekol Pol. 2010;81:287-291.

14. Michałowska S, Zaleski M, Heimrath J et al. Analiza sposobów ukończenia ciąży na podstawie preferencji ciężarnych oraz danych statystycznych z lat 2006-2010. Nowa Med. 2012;4:67-75.
15. Mieczkowska K, Szymoniak K, Fryc D et al. Opinia pacjentek na temat Cięcia cesarskiego na życzenie. Piel Pol. 2017;6 (64), 2: 240-245.

16. Wardak K, Nagórska M, Łoziński T. Preferowana droga ukończenia ciąży wśród młodych kobiet. Prz Med Uniw Rzesz NIL Warsz. 2011;2:239-248.

17. Piwnica M. Cięcie cesarskie jako ucieczka przed bólem porodowym. Piel Poloz. 2014;10.

18. Piec $P$, Suchocki $S$, Obst M et al. Ocena stanu noworodka urodzonego cięciem cesarskim w porównaniu z porodem drogą pochwową. Perinatol Neonatol Ginekol. 2008;1(2):94-97.

19. Sendecka M et al. Jakość w opiece pielęgniarskiej. Ogólna konferencja Szkoleniowo-Naukowa. 1996:191-196.

20. Kaźmierczak M, Skoczylas E, Gebuza G et al. Ocena poziomu wiedzy kobiet na temat karmienia naturalnego. Piel Pol. 2016;3(61):308-316.

\section{Konflikt interesów:}

Wszyscy autorzy deklarują brak konfliktów interesów.

\section{AUTOR KORESPONDUJĄCY \\ Patrycja Zielińska \\ Skalin 36, 73-102 Stargard \\ tel. 725671877 \\ e-mail: patrycjaz1@poczta.onet.pl}

Nadesłano: 16.12.2018

Zaakceptowano: 11.02 .2019 
PRACA ORYGINALNA

ORIGINAL ARTICLE

\title{
QUANTITATIVE ASSESSMENTS OF THE QUALITY OF MEDICAL CARE FOR PATIENTS IN CONDITIONS OF PRIVATE-STATE PARTNERSHIP
}

\author{
ILOŚCIOWA OCENA JAKOŚCI OPIEKI MEDYCZNEJ PACJENTÓW \\ LECZONYCH W PLACÓWKACH FUNKCJONUJĄCYCH W RAMACH \\ PARTNERSTWA PUBLICZNO-PRYWATNEGO
}

\author{
Petro P. Hanynets, Natalia A. Sinienko, Ozar P. Mintser \\ SHUPYK NATIONAL MEDICAL ACADEMY OF POSTGRADUATE EDUCATION, KYIV, UKRAINE
}

\begin{abstract}
Introduction: The article discusses the problems of joint activities of public and private sectors to ensure the proper quality of medical services and jointly overcome financial and production risks. It is emphasized that if the financial and administrative issues of such interaction have been studied to a certain extent, then a quantitative assessment of the quality of medical care provided in a public-private partnership has so far raised questions

The aim: Identify ways to use industrial quality criteria for providing medical care to patients in public-private partnership conditions.

Materials and methods: The results of rehabilitation of 300 patients with gastrointestinal pathology who underwent rehabilitation in the resort "Kvitka Poloniny" of the TOV "Suzirya" were studied. 160 patients underwent rehabilitation in the private part of the resort, 140 - in the state.

Results and conclusions: The theoretical approaches to the use of scientific and technological tools for the implementation of public-private partnership in medical institutions, in particular in a rehabilitation center, are discussed. They are based on instrumental approaches to assessing the quality of medical care. The use of Pareto assessment techniques and the Taguchi loss function allows us to quantitatively characterize the improvement in the quality of care provided with the help of public-private partnership.
\end{abstract}

KEY WORDS: quality of medical care, quantitative assessments of medical care, industrial assessments of the quality of medical care, risk of adverse outcome, publicprivate partnership, Pareto efficiency theory, Taguchi loss function

Wiad Lek 2019, 72, 2, 246-249

\section{INTRODUCTION}

Public-private partnership (PPP) - an effective formula for increasing the efficacy of the national economy through the formation of cooperation between private partners and the state has become widespread recently. Despite significant progress in solution the issue of creating a legislative field of PPP, Ukraine is only at the beginning of a complex and lengthy process of institutional transformation of relations between the state and business. Difficulties in this process are associated with the necessity to prepare the "ground" for PPP, namely the creation of an institutional and organizational alliance of state power and business. Such an alliance should provide the definition, development and implementation of large-scale socially significant projects that can cover a wide range of activities in various sectors of the economy and operate within the framework of both the state and individual territories. The active development of various PPP forms, which takes place in almost all regions of the world, and their widespread use in the health care system of countries with different economies, makes it possible to consider this form of relationship as a characteristic feature of the modern mixed economy. It should be borne in mind that PPP in the health care sector, in contrast to traditional administrative relations, creates special models of property, financing and management methods relations [1-4].

It is worth to be emphasized that although today a legal framework that provides opportunities for developing the state concept of PPP in health care has been created in Ukraine, the criteria for the effectiveness of the quality of medical care have not been approved yet. At the same time, such criteria are crucial for the integral evaluation of the PPP's utility.

\section{THE AIM}

Identify ways to use industrial quality criteria for providing medical care to patients in PPP conditions.

\section{MATERIALS AND METHODS}

The results of rehabilitation of 300 patients with gastrointestinal pathology who underwent rehabilitation in the re- 
sort "Kvitka Poloniny" of the TOV "Suzirya” were studied. 160 patients underwent rehabilitation in the private part of the resort, 140 - in the state. In fact, the studies were conducted in the same conditions by the same medical workers according to state standards. The use of mineral waters ("Luzhanskaya-4", "Luzhanskaya-7", "Polyana Kvasova") and medical supplies was equal. However, the living conditions in the private part were better, patients could use advanced diagnostic and therapeutic options.

A special technique to assess and compare the effectiveness of rehabilitation was proposed.

\section{RESULTS AND DISCUSSION}

A set of questions related to the redistribution of property rights is fundamental in the process of development of PPP, since the institutional partnership is re-generating relations in the health sector, which traditionally belonged to state authority. In practice, this involves the development of mechanisms for the transfer to private partners of a certain part of the functions of the material and technical services of health care institutions at various levels (both public and municipal property), in particular, diagnostic studies, nutritional management of patients, disinfection, transport, household services, communications and the other. In the simplest cases (catering, laboratory tests) it really works. In more complex situations, the assessment of the usefulness of the association may be debatable. A typical example is the creation of parallel structures for the diagnosis and treatment of patients, where the logic of utility does not give a definite answer.

It is believed that the benchmarking procedure should be recognized as effective. It is proposed to compare the quality of medical care in its own health care facility with the quality on the market, primarily the one offered by competitors. Based on this information, it is recommended to make decisions concerning various aspects of the resort's activities, including the feasibility of using various techniques and the possibility of rehabilitation technologies improving. But in reality it is not. An exceptional multi-factoriality due to the fundamental inconsistency of the rehabilitation conditions in various resort facilities, the incompatibility of the patients' condition makes the task of the benchmarking infeasible.

Under the quality of medical care we will understand a set of characteristics confirming the compliance of the provided medical care with the patient's (population's) needs, expectations, the current level of medical science and technology, and under the continuity of medical care the degree of coordination throughout the entire period of medical care for the patient (medical intervention) between practitioners, organizations. Finally, the coordination of medical care is understood as medical care in which the likelihood of an adverse outcome (or undesirable complications) at least does not increase.

In assessing the quality of medical care, the number of medical errors was taken into account. At the same time, the medical error was considered as the wrong action or inaction of the doctor, which made it difficult or could make it difficult to perform medical technologies, contributed to or could help to increase or stabilize the risk of the patient's disease progression, the appearance of a new pathological process, and non-optimal use of medical resources. The significance of the medical error was also assessed by the magnitude of the likelihood of an adverse outcome and the degree of patient dissatisfaction.

An essential significance in assessing the results of medical care should also be attributed to the key characteristics that determine patient satisfaction (comfort, care, confidence, convenience, communication and cost). The integral characteristic of the patient's subjective sensations made it possible to evaluate additional specific indicators of the rehabilitation process [5].

Thus, in assessing the quality of medical care, all recommendations of the World Health Organization were implemented. Namely, the following components of the medical care quality : 1) professional functions (or the realization of the therapeutic and diagnostic process), qualification of a doctor; 2 ) the risk to the patient due to medical intervention; 3 ) optimal use of resources; 4 ) patient satisfaction with provided medical care [6].

However, many different situations that we face every day, when it is quite difficult to determine the quality of medical care may be highlighted. In some cases, only one side is informed about the scope and compliance of the performed diagnostic and therapeutic actions - medical workers. In other words, the patient does not know what exactly he received, and the quality of medical care becomes clear much later. Potential patients, and sometimes potential expert groups, often hide the true goals of their behavior and use almost all methods for obtaining one-sided benefits. Patients with outpatient medical care often do not give all the information to the doctor that is important for determining the correct diagnosis. This situation, called information asymmetry, is of great importance in assessing the usefulness, optimality of medical care, and evaluating preferences when choosing a treatment strategy.

Accordingly, although the requirements for completeness, validity and accuracy of medical information have been postulated for more than the last two centuries, in fact they are not fully met.

Accordingly, in a conceptual strategy for assessing the quality of medical care, it is important to evaluate not only the optimality (utility), but also the loss function. We have selected the Pareto efficiency indicators (W. F. Pareto) and the loss function of Taguchi (G. Taguchi) for the integral industrial quality assessment of medical care.

However, the obtained estimate is too general. Detailing the approach associated with the use of industrial quality indicators of medical care.

A criterion approach was used associated with the logic of Pareto optimality determining [7-9]. The system state was considered as optimal when the value of each particular criterion describing the patient's condition could not be improved with the deterioration of the values of other indicators. The set of Pareto optimal system states was called the set of optimal alternatives. The situation when Pareto efficiency is achieved is a situation when all approaches to achieving a more favorable result have been exhausted. 
In this way, a narrowing of the acceptable solutions set to a set of effective solutions was ensured. It can be partially provided based on a preference analysis. We will consider a solution of course effective if there is no more preferred therapeutic approach.

If it is necessary to determine the effectiveness of rehabilitation for a group of patients, another Pareto's rule can be used, considering that the state $\mathrm{A}$ is preferable to state $\mathrm{G}$ if at least for one individual state $\mathrm{A}$ brings a greater level of utility than state $\mathrm{G}$ without reducing the level of utility of any of the other individuals.

A multi-criteria assessment of rehabilitation for a particular patient can also be performed on the basis of the wellknown Pareto selection rule: rehabilitation is considered preferable when there is no other option better than that given by at least one indicator and no worse than all others.

Accordingly, the choice of the best alternative was previously carried out in terms of achieving the goals set, resource costs, and meeting the specific conditions for the implementation of alternatives.

When deciding on the usefulness (feasibility) of one of the methods of restoring the patient's ability to work, for example, after a stroke or other fairly complex clinical cases, it was often difficult to work out unambiguous recommendations on the preference of one alternative to all others based on the proposed quantitative calculations. Therefore, groups of preferred (effective) alternatives, also derived from Pareto optimization approaches, were identified.

The quality assessment of the diagnostic and therapeutic processes was obtained using the Taguchi toolkit, which, as is well known, boils down to the following postulates: a) it is impossible to reduce costs without degrading quality; b) quality improvement without increasing costs is also impossible; c) reducing the variability of the performance of the resort contributes to improving the quality and efficiency $[10,11]$.

The Taguchi method is based on a quadratic loss function. The value of the quality indicator is plotted on the horizontal axis, and the vertical axis shows the magnitude of the "loss" or "harm". These losses are assumed to be zero when the quality characteristic reaches its nominal value.

The general algorithm is illustrated on Fig. 1.

Of course, consumers of services (patients, patients) want the quality level of medical care to be at point $\mathrm{C}$, because they are trying to get the maximum recovery effect from efforts and money invested or to get the best result for the lowest price. However, from the point of view of service providers, point $\mathrm{C}$ is more consistent with optimal quality, since it reflects the most economical use of available resources and ensures a sufficiently high quality of medical care. In fact, the interval $\{\mathrm{C}, \mathrm{A}\}$ may be a quantitative assessment of the medical institution work. In reality, with the quality work of a medical institution, we get point $B$, and the distance $\mathrm{BA}$ is a reflection of the medical team efforts to improve the quality of medical care.

They carried out a comparison of the resort performance before and after the creation of a complex on the basis of PPP, both in relation to clinical work, infrastructure, human resources, and specific results.

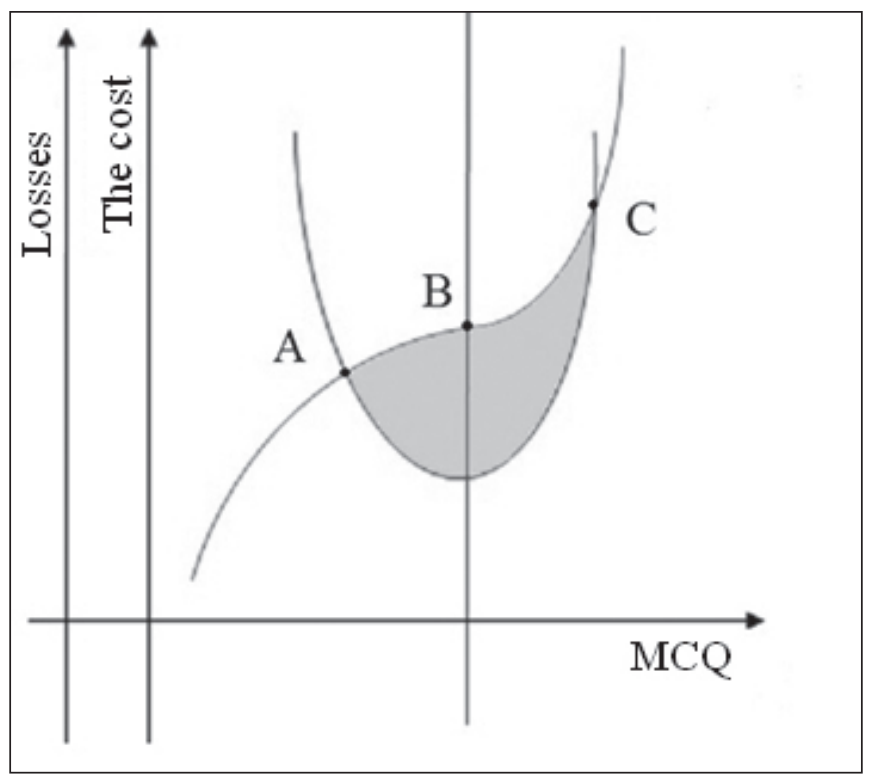

Fig. 1. The algorithm of the medical care quality evaluation.

Clinical performance and average rehabilitation results were close, but in all cases requiring close attention and the use of expensive diagnostic and treatment technologies for PPP. It is important to note that the repeatability of the results was significantly higher. The number of medical errors decreased by $42 \% \pm 3 \%$. The integral evaluation by the Pareto and Taguchi methods turned out to be shifted towards PPP. The distance BA was 1.7 conventional units, which can be considered a quantitative proof of the effectiveness of the new format of the resort's activities.

\section{CONCLUSIONS}

1. The theoretical approaches to the use of scientific and technological tools for the implementation of PPP in medical institutions, in particular in a rehabilitation center, are discussed. They are based on instrumental approaches to assessing the quality of medical care.

2. The use of Pareto assessment techniques and the Taguchi loss function allows us to quantitatively characterize the improvement in the quality of care provided with the help of PPP.

\section{REFERENCES}

1. Saragiotis $P$, editor. Public-private partnerships in infrastructure days 2008 [Internet]. Proceedings of the 3rd "Public-Private Partnerships in Infrastructure (PPPI) days"; 2008 Dec 15-18; Washington, D.C. Washington, D.C.: The International Bank for Reconstruction and Development/The World Bank; 2009 [cited 2018 Oct 13]. 124 p. Available from: http://documents.worldbank.org/ curated/en/301771468337169167/Public-private-partnerships-ininfrastructure-days-2008

2. Harding A, Preker A, editors, Private participation in health services. Health, nutrition and population [Internet]. Washington, DC: The World Bank; 2003 [cited 20180ct 13]. Taylor R J, Contracting for health services; p. 195-204. Available from: http://documents.worldbank.org/curated/ en/665011468741360137/Private-participation-in-health-services 
3. Delmon J J, Understanding options for public-private partnerships in infrastructure: sorting out the forest from the trees: BOT, DBFO, DCMF, concession, lease... [Internet]. Policy Research working paper; No. WPS 5173. Washington, DC: The World Bank; 2010 Jan [cited 2018 0ct 13].75 p. Available from:http://documents.worldbank.org/curated/ en/999661468323693635/Understanding-options-for-public-privatepartnerships-in-infrastructure-sorting-out-the-forest-from-the-treesBOT-DBFO-DCMF-concession-lease

4. Hammami M, Ruhashyankiko J F, Yehoue E B. Determinants of public-private partnership in infrastructure [Internet]. IMF working paper. Washington, DC: World Bank; 2006 [cited 2018 0ct 13]. 37 p. Available from: http://documents.worldbank.org/ curated/en/936961468338942251/Determinants-of-public-privatepartnerships-in-infrastructure

5. Baliga B S, Ravikiran S R, Rao S S, Coutinho A, Jain A. Public-private partnership in health care: a comparative cross-sectional study of perceived quality of care among parents of children admitted in two government district-hospitals, Southern India. J Clin Diagn Res. 2016 Feb;10(2):SC05-SC09. D0I: 10.7860/JCDR/2016/17124.7250

6. Hanefeld J, Powell-Jackson T, Balabanova D. Understanding and measuring quality of care: dealing with complexity. Bull World Health Organ. [Internet]. 2017 May 1;95(5):368-74. D0I: 10.2471/ BLT.16.179309 Available from: https://www.ncbi.nlm.nih.gov/pmc/ articles/PMC5418826/

7. Blaug M. The methodology of economics: or how economists explain. 2nd ed. Cambridge: Cambridge University Press; 1992. 286 p.

8. Ehrgott M. Vilfredo Pareto and multi-objective optimization. In Grötschel M, editor, Optimization stories: 21st International Symposium on Mathematical Programming, Berlin, Aug 19-24, 2012. Bielefeld. 2012. p. 447-453. (Documenta mathematica).
9. Reinhardt UE. Can efficiency in healthcare be left to the market? J Health Polit Policy Law. 2001 Nov;26(5):967-92. D0I: 10.1215/03616878-265-967

10. Kumar R, Chandrakar R, Kumar A, Ram Chandrakar H. Taguchi loss function as optimised model for supplier selection and evaluation. Int. J. Adv. Sci. Eng Inf Technol. 2012 Jan-Mar;/II(I):268-70

11. Taner T, Antony J. Applying Taguchi methods to health care. Int J Health Care Qual Assur Inc Leadersh Health Serv. 2006;19(1):xxvi-xxxv.

\section{Authors' contributions:}

According to the order of the Authorship.

\section{Conflict of interest:}

The Authors declare no conflict of interest.

\section{CORRESPONDING AUTHOR Petro P. Hanynets}

Shupyk National Medical Academy

of Postgraduate Education

Dorohozhytska St., 9, 04112 Kyiv, Ukraine

e-mail:t.duxowi41992@gmail.com

Received: 09.11.2018

Accepted: 29.01.2019 
PRACA ORYGINALNA

ORIGINAL ARTICLE

\title{
LATERAL INSTABILITY OF THE KNEE JOINT AND DISORDER OF THE ANKLE JOINT EXTENSION DISORDER IN MEN
}

\section{NIESTABILNOŚĆ BOCZNA STAWU KOLANOWEGO A ZABURZENIE WYPROSTU STAWU SKOKOWEGO U MĘŻCZYZN}

\author{
Tomasz Tittinger ${ }^{1}$, Rafał Słoniak 1, 2, Damian Szczepański3 ${ }^{3}$, Tadeusz Szymon Gaździk ${ }^{4}$, \\ Małgorzata Kulesa-Mrowiecka ${ }^{4}$, tukasz Kikowski ${ }^{5}$ \\ 'REHABILITATION CENTRE, RZESZOW, POLAND \\ ${ }^{2}$ THE HOLY FAMILY SPECIALIST HOSPITAL NTM, RUDNA MALA, POLAND \\ ${ }^{3}$ RZESZÓW UNIVERSITY OF TECHNOLOGY, CHAIR OF COMPUTER SCIENCE AND AUTOMATION, RZESZOW, POLAND \\ ${ }^{4}$ JAGIELLONIAN UNIVERSITY, INSTITUTE OF PHYSIOTHERAPY, KRAKOW, POLAND \\ ${ }^{5}$ CENTER FOR PREVENTION AND REHABILITATION CREATOR, LODZ, POLAND
}

\begin{abstract}
Introducion: The flexion of the knee joints in the movement of the squat may be accompanied by physiological varus deformity that increases smoothly with the lowering of the center of gravity, followed by a return to the starting position. Observing the disturbances of the physiological movement of the knee joints in the frontal plane, the authors correlated them with the mobility of the ankles in the sagittal plane.

The aim: To show the relationship of knee joint motion disorders in the frontal plane with the movement of the ankle joints in the sagittal plane in the movement of the squat. The authors asked themselves about the number of subjects with the physiological mobility of both joints in the given planes and in what part of the subjects there are disorders and whether they relate to the ipsi or the contralateral part of the body. There was also the question of whether and in which group there are deviations not meeting the above criteria. Materials and methods: 20 healthy right-handed men aged 25-35 were examined with physiological mobility of lower limb joints, confirmed in a physiotherapeutic study. Exclusion criteria included: polyarticular laxity, systemic diseases, rheumatoid arthritis, osteoarthritis. The subjects performed a three-time squat after putting in the Biomech measuring system inertial sensors on the lower limbs and the pelvis. Assessment was related to the movement of the knee joint in the frontal plane with the movement of the ankle joint in the sagittal plane.

Results: Alternating deformity with right knee valgus occurred in 16 people in the right knee joint ( $80 \%$ of subjects) and in 6 men in the left knee joint ( $30 \%$ of subjects). Three subjects (15\%) had a degenerative disorder in both knee joints. The others presented physiological mobility or single (not correlating) disturbances in the mobility of selected joints. Conclusions: The tests confirmed that the ankle joint is functionally connected to the dysfunctional knee joint on the opposite side, despite various surfaces of mutual movement. Dysfunction of the knee joint is about $10^{\circ}$ reduction of varus deformity during squat during maximum flexion of the knee joint and again varus deformation when lifting the center of gravity, which ends in distortion until the starting position. These deflections are accompanied by a decrease in the opposite ankle extension at the time of knee valgus deformity in the maximum flexion. The above dysfunctions occurred in $100 \%$ instability of the non-dominant knee joint, and on the dominant side in $63 \%$.
\end{abstract}

KEY WORDS: lateral instability, knee, ankle, MVN Biomech

\section{STRESZCZENIE}

Wstęp: Zgięciu stawów kolanowych w ruchu przysiadu może towarzyszyć fizjologiczne szpotawienie narastające płynnie wraz z obniżaniem środka ciężkości, po którym następuje powrót do pozycji wyjściowej. Obserwując zaburzenia fizjologicznego ruchu stawów kolanowych w płaszzzyźnie czołowej, autorzy skorelowali je z ruchomością stawów skokowych w płaszczyźnie strzałkowej.

Cel pracy: Wykazanie związku zaburzeń ruchomości stawów kolanowych w płaszczyźnie czołowejz ruchem stawów skokowych w płaszzzyźnie strzałkowej w ruchu przysiadu. Autorzy zadali sobie pytania o ilość badanych z fizjologiczną ruchomością obu stawów w podanych płaszzzyznach oraz w jakiej części badanych występują zaburzenia i czy dotyczą one ipsi-, czy kontrlateralnej części ciała. Pojawiło się również pytanie czy i w jakiej grupie występują odchylenia nie spełniające powyższych kryteriów.

Materiał i metody: Zbadano 20 zdrowych, praworęcznych mężczyzn w wieku 25 - 35 lat z fizjologiczną ruchomością stawów kończyn dolnych, potwierdzoną w badaniu fizjoterapeutycznym. Kryteria wyłączenia obejmowały: wiotkość wielostawową, choroby układowe, RZS, chorobę zwyrodnieniową stawów. Badani wykonali trzykrotny przysiad po założeniu czujników inercyjnych MVN Biomech na kończyny dolne i miednicę. Ocenie podlegały powiązania ruchu stawu kolanowego w płaszczyźnie czołowej z ruchem stawu skokowego w płaszzzyźnie strzałkowej.

Wyniki: Naprzemienne szpotawienie z koślawieniem prawego stawu kolanowego wystąpiło u 16 osób w prawym stawie kolanowym (80\% badanych), a u 6 mężczyzn w lewym stawie kolanowym (30\% badanych). 3 badanych (15\%) miało zaburzenie szpotawienia w obu stawach kolanowych. Pozostali prezentowali ruchomość fizjologiczną lub pojedyncze (nie korelujące ze sobą) zaburzenia ruchomości wybranych stawów.

Wnioski: Badania potwierdziły, że staw skokowy związany jest funkcjonalnie z dysfunkcyjnym stawem kolanowym po przeciwnej stronie, mimo różnych płaszzzyzn wzajemnego ruchu. Dysfunkcja stawu kolanowego polega na około $10^{\circ}$ zmniejszeniu szpotawienia podczas przysiadu podczas maksymalnego zgięcia stawu kolanowego i ponownym 
szpotawieniu podczas podnoszenia środka ciężkości, które kończy się koślawieniem do momentu uzyskania pozycji wyjściowej. Wychyleniom tym towarzyszy zmniejszenie wyprostu przeciwnego stawu skokowego w momencie koślawienia stawu kolanowego w maksymalnym jego zgięciu. Powyższe dysfunkcje wystąpiły w 100\% niestabilności niedominującego stawu kolanowego, a po stronie dominującej w $63 \%$.

SŁOWA KLUCZOWE: niestabilność boczna, staw kolanowy, staw skokowy, MVN Biomech

Wiad Lek 2019, 72, 2, 250-254

\section{INTRODUCTION}

The aim of this study was seizing non-physiological mobility within the knee joint in the frontal plane and an attempt to find the relationship of the dysfunction with the ankle joint.

Instability of the knee joint in the frontal plane enforces a compensatory disorder of the maximal extension movement in the opposite ankle joint.

\section{MATERIALS AND METHODS}

20 healthy right-handed men aged from 25 to 35 with physiological mobility of joints of the lower limbs have been examined, without signs of instability in the physiotherapeutic examination. The exclusion criteria included: polyarticular laxity, systemic diseases, rheumatoid arthritis (RA), osteoarthritis. The subjects performed a threefold squat after placing MVN Biomech inertial sensors on the lower limbs and the pelvis.

Relationship between the movement of the knee joint in the frontal plane with the movement of the ankle joint in the sagittal plane was subject to assessment. Three electronic measuring devices. i.e. an accelerometer, a gyroscope and a magnetometer in one case constitute an
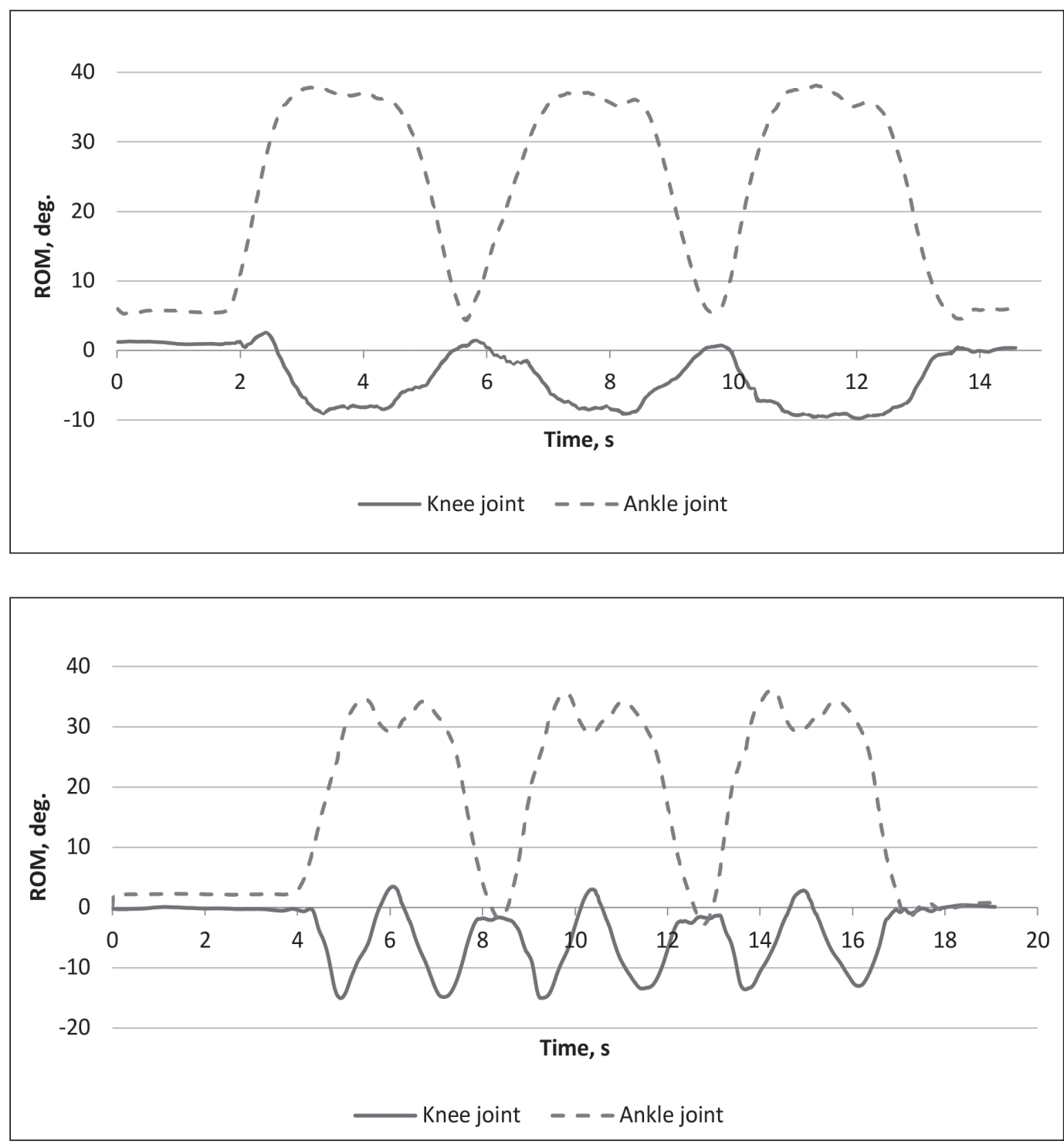

Fig. 1. Variant A. 3 squats. Normal movement of the knee joint in the frontal plane and ankle joint in the sagittal plane.
Fig 2. Variant B. 3 squats. Double abnormal movement of the knee joint in the frontal plane, with accompanying ankle joint disorder in the sagittal plane. 

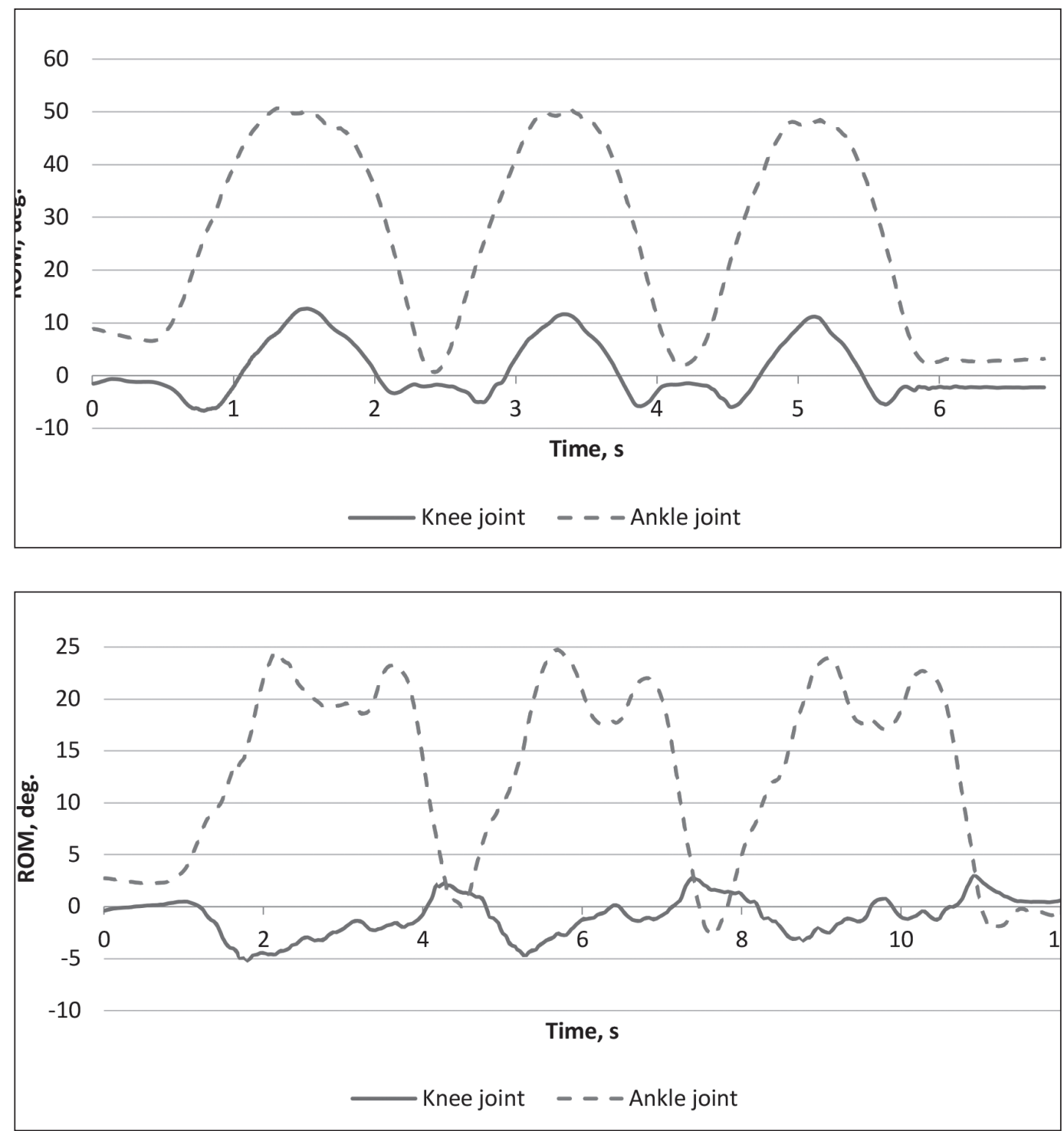

Fig 3. Variant C. 3 squats. The knee joint in the frontal plane, ankle joint in the sagittal joint. Medial instability of the knee joint (distortion), normal movement of the ankle joint.
Fig 4. Variant D. 3 squats. Normal movement of the knee joint despite the disorder of the maximum extension of the opposite ankle joint. inertial measure unit (IMU). The current orientation of the IMU is calculated based on the temporary indication of the accelerometer and gyroscope. The magnetometer is used to become independent of the rotation of the IMU with respect to the axis of rotation parallel to the gravity vector. Additionally, as a result of double counting of the acceleration signa value in time, the displacement value in relation to each axis of the coordinate system is calculated. The sensors were placed on the so-called segments, i.e. the tendons and bellies of the extensor muscles of the ankle joint, the belly of the quadriceps femoris muscles and the sacrum, using special Velcro bands. At the intersection points of the segments (joints), a three-dimensional motion reading the current mobility of a particular joint was determined, providing the information about the range of motion (ROM) as well. In addition, knee and ankle joint stability tests were carried out, which did not detect hypermobility in the subjects.

The analysis of collected data has confirmed the correlation of the time of occurrence of the knee joint motion disorders in the frontal plane with the sagittal plane of the opposite ankle joint. The graphical variants of mutual dependencies between the knee joint and the opposite ankle joint are presented below.

Variant A. Negative values in the graph for the left knee joint confirm bendiness of this joint which - while lowering the centre of gravity - moves laterally (physiology) and - while raising the centre of gravity - returns to the starting position. The maximum flexion of the knee joint is accompanied by a smooth transition from the extension to bending of the opposite ankle joint. The described, normal movement has occurred in 2 people between the right knee joint and the left ankle joint (10\% of the subjects) and in 4 people with the dependence of the left knee and right ankle joint (20\% of the subjects).

Variant B. Flexion of the ankle joint correlates with distortion of the opposite knee joint. Negative, growing values on the knee joint chart confirm bendiness whereas decreasing numbers are evidence of the distortion. The knee joint of the examined person moves laterally (physiology) while lowering the centre of gravity to perform adduction (pathology) at the moment of maximal flexion and 

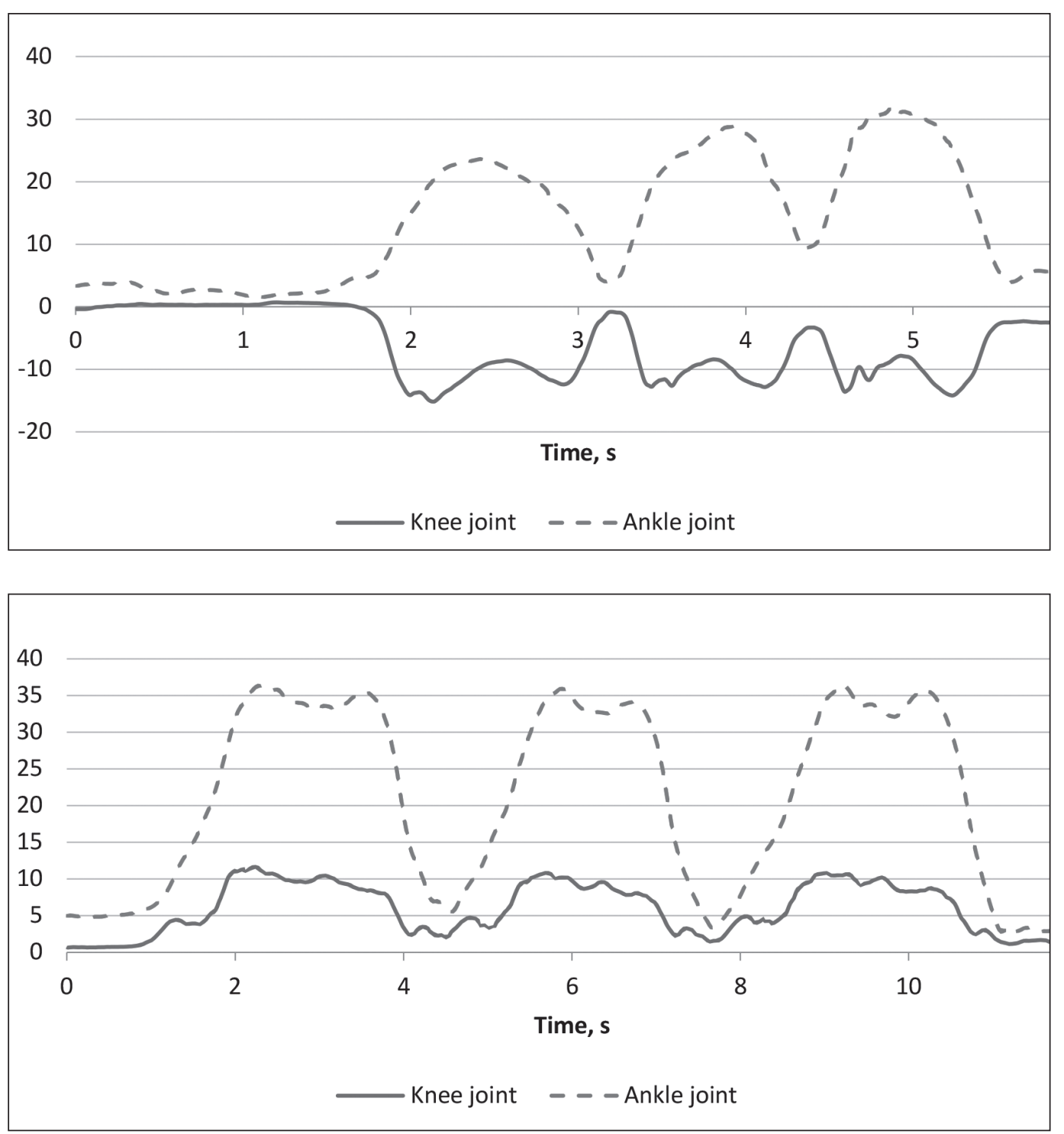

Fig 5. Variant E. 3 squats. Normal movement of the ankle joint despite the change of bandiness for distortion of the knee joint of small amplitude.
Fig 6. Variant F. 3 squats. Abnormal distortion of the knee joint with ankle joint extension disorder. Medial instability of the knee joint is accompanied by the ankle joint disorder characteristic of variant $B$. repeats the movement while raising the centre of gravity. Characteristically, the medial movement is accompanied by a disturbance of the maximal extension of the ankle joint as if the ankle joint retracted to flexion, which may indicate its instability. Comparing the right knee joint with the opposite ankle joint, 10 subjects (50\%) have presented the described disorder and the relationship between the left knee joint with the right ankle joint affected 6 people (30\% of the subjects).

Variant C. The left knee joint is marked with significant over $10^{\circ}$ distortion (pathology), which is not accompanied by a considerable decrease in the opposite ankle extension at the peak of the movement (physiology). In the knee joint there is no characteristic double refraction of the abduction movement characteristic of variant B (which may force the ankle to deflect in the maximum extension range). This dependence has occurred only between the left knee joint and the right ankle joint in $30 \%$ of the subjects (6 people).

Variant D. The knee joint is subject to $5^{\circ}$ bendiness and distortion occurs only in the rest position. Abnormal change in the maximum extension of the ankle joint for flexion does not disturb, in this variant of movement of the knee joint in the frontal plane. This has applied to 4 people (20\% of the subjects) - 2 subjects with the right knee joint and left ankle joint and the same number with the left knee joint with the opposite ankle joint.

Variant E. Bendiness of the right knee joint changes to adduction, which is not accompanied by reduction of the opposite ankle extension in the maximum range of motion (physiology). Abnormal movement of the knee joint in the frontal plane did not cause disturbances of the opposite ankle joint extension. This variant has occurred only between the right knee joint and the left ankle joint in 6 people (30\% of the subjects).

The knee joint is subject to significant, over $10^{\circ}$ distortion (pathology), accompanied by a decrease in the opposite ankle joint extension in the maximum range of motion (pathology). Despite the lack of bendiness change to distortion in the knee joint characteristic of variant $\mathrm{B}$, there is ankle joint flexion on the opposite side and this has concerned only 2 men (10\% of the subjects) between the left knee joint and the right ankle joint. 


\section{RESULTS}

In the majority of men, bendiness change to distortion of the knee joint was reported while lowering of the centre of gravity, followed by another bendiness ended in distortion after reaching the initial position. This phenomenon has occurred in 16 people in the right knee joint ( $80 \%$ of the subjects) and in 6 men in the left knee joint (30\% of the subjects). Three subjects (15\%) had a bendiness disorder in both knee joints. Correlation of the right knee joint disorders in the frontal plane with the opposite ankle joint in the sagittal plane has occurred in 10 people (50\% of the subjects). Two subjects (10\%) have had physiological bendiness of the right knee joint with a smooth transition from flexion to the opposite extension of the ankle joint - variant B physiology. In 2 men ( $10 \%$ of the subjects) there has been a disorder in the sagittal plane of the mobility of the ankle joint at the physiological bendiness of the knee joint - variant $\mathrm{D}$.

In the system of the left knee joint and the right ankle joint in 6 subjects (30\%), there has been a double change in mobility in the knee joint in the frontal plane and all have met the criteria of variant A (pathology). In 4 people ( $20 \%$ of the subjects) there has been a variant B physiology, and in $6(30 \%)$ variant C, i.e. medial instability of the knee joint that was not accompanied by disorders of the ankle extension. In 2 men (10\% of the subjects) there has been a disorder in the sagittal plane of the ankle joint mobility at the physiological knee joint abduction - variant D. The same number has been accompanied by medial instability of the knee joint with an abnormal extension of the opposite ankle joint (2 people - 10\% of the subjects).

\section{DISCUSSION}

Isolated lateral instability of the knee joint constitutes a rare phenomenon because it occurs most frequently with instability in the sagittal plane [1]. Lateral stability of the knee, apart from the ligaments and articular capsule, is secondarily influenced by the ischiocrural muscles and tensor fascia lata [2]. In addition to ligament stabilization, other important structures are responsible for active stabilization, such as: hip belt, long and short heads of the biceps femoris, lateral tendon of the gastrocnemius muscle [3]. The dynamic stability of the knee joint can be influenced by the appearance of metabolic fatigue during sports activity, which may increase the risk of knee injury [4]. Dynamic control of knee joint work depends primarily on the eccentric ability to suppress overloads in the muscles of the lower limb and especially the quadriceps femoris [5]. The fatigue of the quadriceps femoris increases the mobility of the dorsal flexion of the foot during landing after the jump. The ankle joint shows increased compensations during landing in the event of exercise fatigue in the quadriceps femoris [6]. Functional training and strengthening the quadriceps femoris muscles affects reduction of bendiness of the lower limbs in the knee joints during the landing test from height [7].

\section{CONCLUSIONS}

The function of the ankle joint depends on the function of the knee joint on the opposite side. The ankle joint is functionally connected to the dysfunctional knee joint on the opposite side despite different surfaces of mutual movement. Dysfunction of the knee joint consists in about $10^{\circ}$ reduction of bendiness during the squat at the maximum flexion of the knee joint and another bendiness while raising the centre of gravity, which ends in distortion until the initial position is reached. These deflections are accompanied by a decrease in the opposite ankle extension at the time of the knee joint distortion deformity in its the maximum flexion.

The above-mentioned dysfunctions have occurred in $100 \%$ of instability of the non-dominant knee joint and on the dominant side in $63 \%$.

Therefore, knee joint disorders can occur in the absence of an opposite ankle impairment in $30 \%$ of the subjects (on the dominating side), where the amplitude of bendiness changes was about $5^{\circ}$ in all subjects.

In $30 \%$ of the respondents, there has been an ankle disorder without characteristic bendiness deformity of the knee joint on the opposite side.

\section{REFERENCES}

1. Baker CL Jr., Norwood LA, Hughston JC. Acute combined posterior cruciate and posterolateral instability of the knee. Am J Sports Med 1984;12:204-208.

2. Kakarlapudi TK, Bickerstaff DR. Knee instability. West J Med. 2001;174(4):266-272.

3. James EW, LaPrade ChM, LaPrade RF. Anatomy and Biomechanics of the Lateral Side of the Knee and Surgical Implications. Sports Med Arthrosc Rev 2015;23:2-9

4. Ortiz A. Fatigue Effects on Knee Joint Stability During Two Jump Tasks in Women. J Strength Condition Res. 2010;04(01)

5. Coventry E, O'Connor KM, Hart BA, Earl JE, Ebersole KT. The effect of lower extremity fatigue on shock attenuation during single-leg landing. Clin Biomech. 2006;21:1090-1097.

6. Orishimo KF, Kremenic IJ. Effect of fatigue on single-leg hop landing biomechanics. J Appl Biomech. 2006;22 (4):245-54.

7. Noyes FR, Barber-Westin S, Flekenstein CM. Difference in Lower Limb Control by Gender and Effect of Neuromuscular Training in Female Athletes. Am J Sports Med. 2005;33(2):197-207.

\section{Conflict of interest:}

There is no conflict of interest

\section{CORRESPONDING AUTHOR}

Tomasz Tittinger

ul. Miłocińska 95/1

35-506 Rzeszów

e-mail: biuro@fizjokursy.pl

Received: 10.01.2019

Accepted: 04.02.2019 
PRACA POGLADDOWA

REVIEW ARTICLE

\title{
VACCINATION COVERAGE RATES AND THE INCIDENCE OF VACCINE PREVENTABLE DISEASES AMONG CHILDREN IN SUMY REGION OF UKRAINE
}

\author{
ODSETEK WYSZCZEPIENIA POPULACJI A WYSTĘPOWANIE \\ CHORÓB ZAKAŹNYCH, KTÓRYM MOŻNA ZAPOBIEC DZIĘKI \\ SZCZEPIENIOM U DZIECI W OBWODZIE SUMSKIM NA UKRAINIE
}

\author{
Vladyslav A. Smiianov ${ }^{1}$, Halyna S. Zaitseva ${ }^{2}$, Victorya A. Kurganskaya ${ }^{1}$, Anatoly G. Dyachenko ${ }^{1}$, \\ Volodymyr P. Zbarazhskyi ${ }^{2}$, Yevhen V. Smiianov', Olha A. Pilipec' \\ 'SUMY STATE UNIVERSITY, SUMY, UKRAINE \\ 2STATE INSTITUTION «SUMY OBLAST LABORATORY CENTRE OF MINISTRY OF HEALTH OF UKRAINE», SUMY, UKRAINE
}

\begin{abstract}
Introduction: Routine immunization contributes immensely to decline the incidence of vaccine preventable diseases among children. Statistical data shown the sharply decrease the vaccination coverage rates in Sumy region of Ukraine.

The aim: Assess routine immunization uptake and its effect on the incidence of vaccine preventable diseases among children in Sumy region of Ukraine.

Review: During some years, only 50-60\% of Sumy region children had received all recommended vaccines, which is far below World Health Organization target of $80 \%$. This has led to an increase of morbidity associated with some infectious diseases. Outbreaks of measles were registered in 2006 and 2012, when were ill 9346 and 7931 children respectively. Massive measles outbreak ongoing nowadays. Total number infected have already exceeded 35,000 cases.

Conclusions: Rl uptake in Ukraine is still below World Health Organization target. The main reason for the ongoing measles outbreak was low vaccination coverage for routine immunization antigens as a result of which collective immunity decreased to a critical level. Strict monitoring of the implementation of the immunization schedule by medical institutions at all levels are recommended to improve vaccination status of Ukrainian children.
\end{abstract}

KEY WORDS: vaccine preventable diseases, vaccination coverage, children

Wiad Lek 2019, 72, 2, 255-260

\section{INTRODUCTION}

Routine childhood vaccination remains the most cost-effective public health strategies to reduce morbidity and mortality associated with vaccine preventable diseases. The World Health Organization (WHO) established the expanded program on immunization (EPI) in 1974, with the goal of ensuring full accessibility of routine vaccinations to all children. According to the EPI, a child should receive Bacillus Calmette Guerin (BCG), three doses of oral polio vaccine (OPV) and Diptheria Pertusis Tetanus (DPT), measles vaccines by 12 months of age, and some other antigens to ensure maximum protection against vaccine preventable diseases (VPDs). Receipt of these vaccines at the recommended ages and intervals will provide the children adequate protection from VPDs [1].

At the end of the 20th century, a series of WHO documents identified key aspects of modern immunization policies, one of which states that epidemic safety can be achieved due to high population coverage of preventive vaccines (at least
95\%) and an adequate immune response (90\% of vaccinated ones). Within the framework of this program, the end of the last century managed to get impressive results on the prevention of infectious diseases [1]. A number of countries have been certified as free of poliomyelitis, dramatically reduced tetanus, diphtheria and some other infections. Globally, vaccination has evolved from a situational campaigns aimed at preventing a specific epidemic into a permanent planned action, and vaccination in many countries, such as EU, have become an indispensable condition of health insurance.

In May 2012194 members of World Health Assembly accepted a Global Vaccine Action Plan (GVAP) 2011-2020, aimed to improve plan vaccination, based on Decade of Vaccines concept, by providing all humanity with immunization access during 2011-2020 [2, 5]. Ukrainian vaccination schedule is familiar to the European immunization scheme and includes vaccination antigens of 10 infections (in the USA, France, the UK and Italy against 12 infections, in Germany - 13, in Poland - against 11). 
Table I. Vaccination schedule, Ukraine

\begin{tabular}{|c|c|c|c|c|c|c|c|c|c|c|c|}
\hline & \multicolumn{7}{|c|}{ During first 18 months after birth } & \multicolumn{3}{|c|}{ 2-16 years } & \multirow{2}{*}{$\begin{array}{c}\text { Adults } \\
\text { every } 10 \\
\text { years }\end{array}$} \\
\hline & $\begin{array}{c}1 \\
\text { day }\end{array}$ & $\begin{array}{l}3-5 \\
\text { day }\end{array}$ & $\begin{array}{c}2 \\
\text { months }\end{array}$ & $\begin{array}{c}4 \\
\text { months }\end{array}$ & $\begin{array}{c}6 \\
\text { months }\end{array}$ & $\begin{array}{c}12 \\
\text { months }\end{array}$ & $\begin{array}{c}18 \\
\text { months }\end{array}$ & $\begin{array}{c}6 \\
\text { years }\end{array}$ & $\begin{array}{c}14 \\
\text { years }\end{array}$ & $\begin{array}{c}16 \\
\text { years }\end{array}$ & \\
\hline Hepatitis B & $\checkmark$ & & $\checkmark$ & & $\checkmark$ & & & & & & \\
\hline Tuberculosis & & $\sqrt{ }$ & & & & & & & & & \\
\hline $\begin{array}{l}\text { Measles, Mumps, } \\
\text { Rubella }\end{array}$ & & & & & & $\checkmark$ & & $\checkmark$ & & & \\
\hline Diphtheria, Tetanus & & & $\checkmark$ & $\checkmark$ & $\checkmark$ & & $\sqrt{ }$ & $\checkmark$ & & $\checkmark$ & \\
\hline Pertussis & & & $\checkmark$ & $\checkmark$ & $\checkmark$ & & $\sqrt{ }$ & & & & \\
\hline Poliomyelitis & & & $\sqrt{ }$ & $\sqrt{ }$ & $\sqrt{ }$ & & $\sqrt{ }$ & $\sqrt{ }$ & $\sqrt{ }$ & & \\
\hline $\mathrm{HiB}$ & & & $\sqrt{ }$ & $\sqrt{ }$ & & $\sqrt{ }$ & & & & & \\
\hline
\end{tabular}

However, during last quarter-century Ukraine and other European countries are facing outbreaks of well-known and emergency infections. Particularly alarming is the increase in the incidence of VPDs, which may be the result of a sharp decline in RI that leads to the accumulation of susceptible individuals in the population.

Despite significant gains with childhood routine vaccination coverage over the many years, sometimes ago coverage rates for routine immunization antigens in Ukraine decreased significantly and as a result multitude children have remained incomplete vaccinated, exposing them to disabilities or premature death [3, 7]. Even though vaccines provided free of charge by the government, routine immunization (RI) coverage in Sumy region of Ukraine fall below 50-60\% [7]. World experience suggests that uptake of vaccination services depends a little on the level of socioeconomic development of the state, since the insignificant cost of vaccines makes them accessible to the poorest countries, besides, international organizations, if necessary, help them. It depends not only on provision of these services but other factors related to maternal knowledge, geographical accessibility and many other socio-demographic characteristics. Sumy region of Ukraine represents highly developed area in terms of distribution and access to health care interventions including vaccination services $[7,9]$. Thus, we conducted a study to assess immunization coverage rates and the incidence of VPDs in this area.

\section{THE AIM}

Aim is to assess the incidence of vaccine preventable infections and the vaccination coverage for routine immunization antigens during last 10 years among children of Sumy region of Ukraine.

\section{MATERIALS AND METHODS}

Routine immunization provides according to Ministry of health care of Ukraine order No. 595 from 16.09.2011 (the last edition - 03.07.2018) which defines the nomenclature, age, and intervals between doses of antigens administered (table.I).
State Statistical Reporting Form No. 2 "Report on Certain Infections and Parasitic Diseases", and No. 6 "Report concerning Persons of Selected Age Groups Immunized to Infectious Diseases" were used as main data sources.

\section{REVIEW AND DISCUSSION}

\section{HEPATITIS B VIRUS}

The incidence of hepatitis B infection in Ukraine and Sumy region, particularly, started decrease after 2001 (1.88 per 100,000 of Sumy region population). Thus, during 20132015, and during 2017 no case of hepatitis B infection among children was registered.

Beginning from 2000 all newborn have to be vaccinated against hepatitis B virus, as well as some risk groups, like medical workers. Starting from the 2002 a planned vaccination according the epidemical data was provided. According to the rates from 01.12.2017 in Ukraine more than 180,608 children of first life year were vaccinated by primary vaccine complex against hepatitis B ( 3 doses - during first day of life, 1 month, 6 months), that makes out $50.8 \%$ of planned amount. The lowest vaccination coverage rates are in Transcarpathian (15.6\%), Khmelnitski $(23.4 \%)$ and Ternopil regions (30\%). The highest rates are in Chernihiv (73.9\%), Dnipro (69.8\%) and Kropivnitsky (69.3\%) regions. The rate of general vaccination against hepatitis $B$ virus during first life year showed $12.7 \%$ in November 2017 [10].

According to the information of Sumy region, the vaccination coverage rate began to decrease starting from 2009 year: in 2011-2012 years it made out only $45 \%$, and in 2015 and 201639 i 44 \% correspondently. During 2017 this index was to be improved, however it still reveals in quite low level (60\%) (fig. 2). One also should mention that in Sumy the vaccination coverage during last years was dangerously low: $2014-25.8 \%, 2015-25.5 \%, 2016-24.8$ $\%$. In 2017 it was still far below WHO target.

\section{TETANUS, DIPHTHERIA, PERTUSSIS (WHOOPING COUGH)}

No cases of diphtheria or tetanus were registered in Sumy region, beginning from 2001. Although, there is rather 

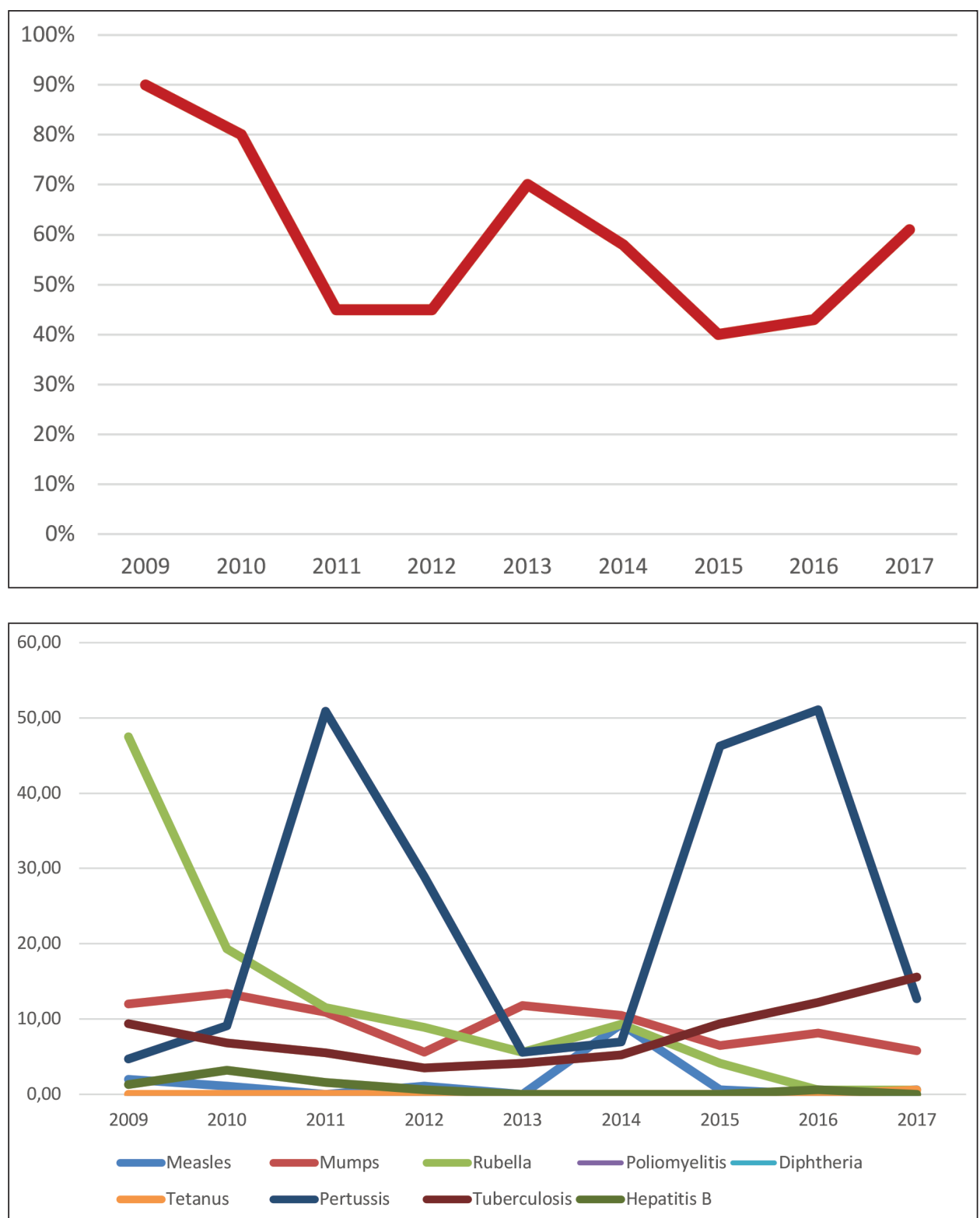

Figure 1. Vaccination coverage for Hepatitis B antigens in Sumy Region
Figure 2. The incidence of vaccine preventable diseases among the children in Sumy region (per 100,000 population). inconsolable statistics about whooping cough case rate, that during this period was measured from 4.7 till 51.09 cased per 100,000 children. The highest indexes were registered during 2007, 2011, and 2016. The whooping cough is mostly spread among children at the age before 1 year, and often has such complications as pneumonia, nervous system diseases and respiratory standstill. Lethal outputs were not observed. Ukrainian Ministry of health care has quite strict opinion about epidemical situation of diphtheria, pertussis, tetanus taking into account low children immunization coverage. [7, 9] Average RI coverage along last 5 years was varying from 27 to $64 \%$ (fig. 2). In 2017 only $47.5 \%$ of all Ukrainian children aged 2, 4 and 6 months got initial vaccination against tetanus, diphtheria, whooping cough by 3 corresponding doses of DPT vaccine [10]. Lowest coverage rates of this vaccination were registered in Rivno (22.1\%), Volynska (24.9\%) and Ternopil $(27.9 \%)$ regions. The highest coverage index was shown by Kiev city (91.7 \%), Donetsk (65.2\%), and Kropivnitsky
$(61.5 \%)$ regions. First dose of the DPT vaccine received $60.9 \%$ of all children aged before 1 year, that was rather higher than during last 3 years (in $2014-40.9 \%$, in 2015 $-31 \%$, in $2016-9 \%$ ).

\section{MEASLES}

Global WHO strategy against measles (total vaccination) caused sharply reduce mortality after measles during 20002014 period on $79 \%$ that means almost in five times. The plan against measles mortality included its decreasing on $95 \%$ until 2015 in comparison to the 2000 index, and fully elimination of measles and scarlet fever at least in five regions. Unfortunately, this plan was doomed to failure, as the biggest outbreak of this infection started in Europe at the end of 2017.20 August 2018 WHO informed about one of the highest level of disease rate in European region: then infected people number at first 6 months of 2018 counted more 41,000, 37 lethal outputs $[3,4,6]$. 

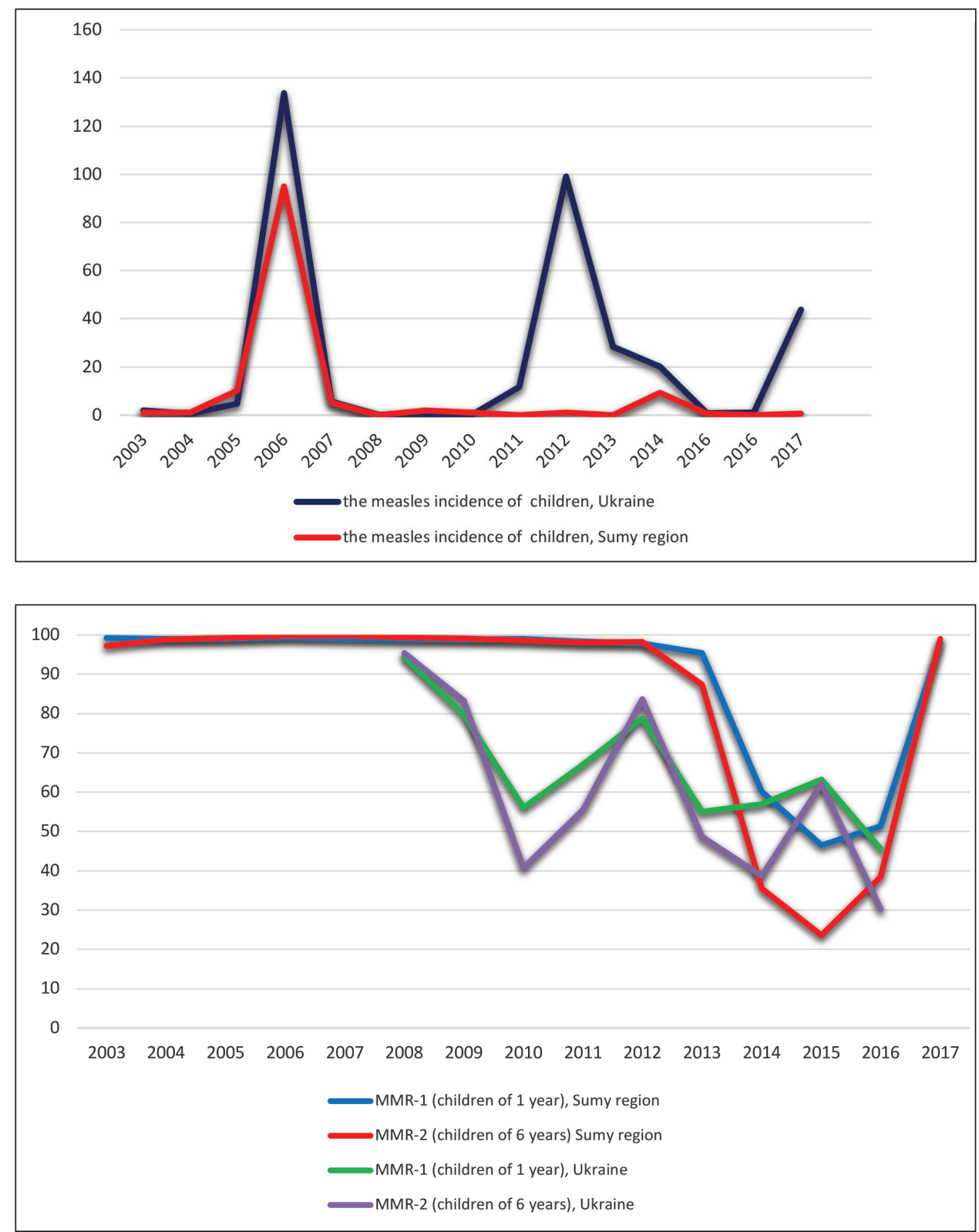

Figure 3. The incidence of children's measles in Ukraine and Sumy Region (per 100,000 population)
Figure 4. Vaccination coverage by MMR-1 and MMR-2 of children in Ukraine and Sumy region (\%).
It was said that it is the highest index of case rate after 2010. Thus, Ukraine found itself among leading countries that spread measles around the region [7]. According to the latest data from Public health center of Ukrainnian Ministry of health care dated 10 November 2018 year Ukraine suffered measles infection with about 38,108 ill people, among them 14,609 adults and 23,499 children. Further complications caused 15 deaths ( 4 adults and 11 children). Case rate of measles in Ukraine continues increase: during eighteenth week, 1,682 people were reported to be sick, that is $35 \%$ higher, than previous week. Disease rate during 9 months 2018 was in 17 times more, then in previous year. The peaks of disease appeared at the middle of May (1,610 infected) and middle of November (1,682 infected). The disease rate in Ukraine is embarrassing. The highest indexes of morbidity and mortality are fixed in the regions with the lowest vaccination coverage rate. Among those: Lviv (7,845 people: 2,276 adults, and
5,569 children), Ivano-Frankivsk (3,816 people: 1,020 adults, and 2,796 children), Zacarpathian (3,582 people: 695 adults and 2,887 children), Odessa (2,567 people: 1,279 adults and 1,288 children) regions, Kiev city (2,445 people: 1,505 adults and 940 children) and Ternopil region (2,265 people: 810 adults and 1,455 children). Previous outbreaks of measles in Ukraine were registered in 2006 and 2012 (fig. 3).

The only method of specific preventions of measles is live antivirus vaccine that is often used in complex with mumps, measles, and rubella vaccines (as components of multiple vaccines MMR and MMRV) [8]. Anti-measles vaccination is rather effective in use. After initial dose a stable antivirus immunity develops among $95 \%$ of children aged by 1 year. If vaccination coverage occurs to be more than $93 \%$ of all children population, measles outbreaks will be hardly possible. Still, they may occur after decreasing of immunization coverage [8]. 
Several problems with measles, and parotitis vaccination coverage happened in Ukraine after 2008, and, particularly in Sumy region, after 2013 (fig. 4). Generally, during 2017 about $87,8 \%$ of all children aged by 1 year were vaccinated. The lowest rate of vaccine coverage against measles, and parotitis were registred in Zacarpathian (67.7 \%), Rivne (69.5\%) and Lviv (79.3\%) regions. The highest are in Kiev (97.5\%) and Chernihiv (95.9\%) regions and in Kiev city $(94.5 \%)$.

Analysis of vaccination status of the last measles outbreak suffers has shown, that about 22,995 people were not vaccinated. Measles are mostly spread among children at the age of 5-9 years (32\% among all children measles cases); they are the children, who did not get their booster doses of MMR in time, thus, their immunity was not complete.

\section{TUBERCULOSIS}

The incidence of tuberculosis among children in Sumy region grows up extremely fast. For example, in 2013 it counted 4.6 per 100,000 children, in 2014 - 2.2; in 2015 - 9.09, in 2016 this index was increased to 26.9 per 100,000. Tuberculosis case rates among children in recent years were about 7.8 - 8.0 per 100, 000. Their part among all first diagnosed patients was only $1,6-1,8 \%$, that is much lower than in some other countries (according to the WHO data this index may vary from 3 till 25 and more). Case rate of tuberculosis among teens is more higher than among children before 14 years, and now it counts 28-30 cases per 100,000.

The state of specific tuberculosis prophylaxis is still dangerously unstable. Initial vaccination has to be done to all healthy full-term newborns in first 3-5 days of the life. According to the statistics, in Sumy anti-tuberculosis vaccination coverage was: in 2013 year $-81.5 \%$ of children were vaccinated, in $2014-82.9 \%$, in $2015-63.2 \%$, in $2016-60.7 \%$. In 2017 this index became quite higher and counted $90.2 \%$ (fig. ). Generally, about $75.5 \%$ of children were vaccinated in Ukraine. The lowest immunization coverage with tuberculosis antigens was in Zhytomyr (52.6 $\%)$, Ivano-Frankivsk (66.0 \%), Chernihiv regions (67.0 $\%)$. The highest was in Sumy (88.4 \%), Kiev (87.6\%), and Chernivtsi ( $87.3 \%)$ region.

\section{POLIOMYELITIS}

WHO announced Ukraine to be a country with high risk of poliomyelitis outbreak. Despite the fully absence of the disease both in region and in Ukraine generally, total vaccination coverage is not in an appropriate state. During last 5 years 3 -doses vaccine coverage children by 1 year $(2$, 4 and 6 months) was: 2013 year - $99.0 \%, 2014-48.6 \%$, $2015-75.6 \%, 2016-45.7 \%, 2017-90.2 \%$ (fig. ). Till 01.12.2017 all regions provided an initial doses of vaccine against poliovirus to 170,832 children aged by 1 year, that makes only $47.4 \%$ of all number. The lowest coverage rates was in Rivno (22.4 \%), Volyn (27.9 \%), Kherson (30.1 \%) regions; the highest correspondently was in Kiev city (93.6 $\%)$, Donetsk (63.3\%), Poltava (62.0\%) regions.
Thus, RI coverage was temporary reduced that soon led to increase incidence of some VPD. The epidemic situation regarding the incidence of vaccine-dependent infections among the child population of Sumy region and Ukraine in general. Sporadic cases can cause infection outbreaks. During 10-15 years, several large-scale outbreaks took place, the most powerful of which is still ongoing. Undoubtedly, the reason for the latest epidemic of measles in Ukraine is to reduce the coverage of children vaccinations, which led to a catastrophic decline in collective immunity. Against the background of high contagiousness, this provides a rapid spread of infection, especially in children's collectives, which leads to the introduction of quarantine measures. The peculiarities of the epidemic are a large proportion of adult patients, and the large number of fully vaccinated children. There are also cases of the disease of children under 1 year old and even congenital measles. We consider it expedient to make the obligatory revaccination of adults (to make it into the vaccination plan). To decrease the incidence of VPDs and to keep epidemic welfare RI coverage should be not less than $95 \%$ as it was established by WHO and General state immune-prophylaxis program. Encouraging mothers to attend antenatal care and educational interventions targeted at mothers are recommended to improve vaccination status of children in Ukraine. All these aspects can be done after total vaccine coverage for all medical establishments for further regular regional supplying by specific medicines [8]. It is clear, that progress in vaccine-prophylaxis works would be impossible without strict state control over immune medicaments safety and quality, and providing an appropriate social and medical protection for patients with post-vaccine complications.

\section{CONCLUSIONS}

RI uptake in Ukraine is still below WHO target. The main reason for the ongoing measles outbreak was low vaccination coverage for routine immunization antigens as a result of which collective immunity decreased to a critical level. Strict monitoring of the implementation of the immunization schedule by medical institutions at all levels are recommended to improve vaccination status of Ukrainian children.

\section{REFERENCES}

1. National Primary Health Care Development Agency. National Immunisation Policy 2009. Available at http://www.jhsph.edu/ research/

2. World Health Organization (WHO). United Nations Children's Fund (UNICEF). Global immunization data. Geneva:WHO; 2014. Jul. Available from: http://www. who.int/immunization/monitoring_surveillance/ global_immunization.

3. World Health Organization. The Global Vaccine Action Plan 2011-2020. Introduction and Immunization Landscape Today. Available from: http://www.who.int/immunization/global_vaccine_action_plan/ GVAP_Introduction_and_Immunization_Landscape_Today. 
4. Strategic Advisory Group of Experts on Immunization. 2016 midterm review of the Global Vaccine Action Plan. WHO; 2016. 26p. Available from: http://www.who.int/immunization/global_vaccine_action_ plan/SAGE_GVAP_Assessment_Report_2016

5. I. Abdulraheem, A. Onajole, A. Jimoh. Reasons for incomplete vaccination and factors for missed opportunities among rural Nigerian children. Public Health Epidemiology. 2011;3(4):194-203.

6. World Health Organization. «Measles vaccines: WHO position paper». Weekly epidemiological record. 2017;84 (35):349-360.

7. Ministry of Health of Ukraine. Order № 551: On the improvement of preventive vaccination in Ukraine. Available from: http:// www.moz. gov.ua/ua/portal/dn_20140811_0551. Accessed: August 11, 2014. (in Ukrainian).

8. V. A. Smeyanov, S. V. Tarasenko, 0. I. Smeyanova. Development and implementation of the internal audit mechanisms to be used in the health care facilities. Georgian Medical News. 2013;6 (219):58-60.

9. Ministry of Health of Ukraine. Information on the state of implementation of the National program of immunoprophylaxis and rotection of population against infectious diseases 2009-2015 for 2014. Available from:http://www.moz.gov.ua/ua/portal/pgrep_imun_2014.html. (in Ukrainian)
10. World Health Organization. Immunization coverage. Fact sheet. Available from: http://www.who.int/mediacentre/factsheets/ fs378/ en/. Accessed: July 2017.

\section{Authors' contributions:}

According to the order of the Authorship.

\section{Conflict of interest:}

The Authors declare no conflict of interest.

\section{CORRESPONDING AUTHOR} Vladyslav A. Smiianov

Sumy State University

Rymskoho-Korsakova St., 2, 40007 Sumy, Ukraine

e-mail:v.smiyanov@med.sumdu.edu.ua

Received: 24.11.2018

Accepted: 31.01 .2019 
PRACA POGLADDOWA

REVIEW ARTICLE

\title{
NATURAL ENVIRONMENT AS COMPONENT OF PUBLIC HEALTH: SOME ASPECTS OF ITS LEGAL REGULATION
}

\section{ŚRODOWISKO NATURALNE JAKO ELEMENT ZDROWIA PUBLICZNEGO: WYBRANE ASPEKTY REGULACJI PRAWNYCH}

\author{
Vitalii M. Pashkov, Maryna V. Trotska \\ DEPARTMENT OF CIVIL, COMMERCIAL AND ENVIRONMENTAL LAW OF POLTAVA LAW INSTITUTE OF YAROSLAV THE WISE NATIONAL LAW UNIVERSITY, \\ POLTAVA, UKRAINE
}

\begin{abstract}
Introduction: Human health depends on various factors that have a different physical origin, degree of influence on the human body, methods of manifestation and other characteristics. Within public health, their research is carried out implementing an integrated approach and understanding the causation of the factors that influence each other as well as their effects on the human body. The natural environment, namely its state in general and individual natural objects, in particular, is one of the elements having both direct and indirect effects on human health.

The aim: To analyze the legal basis for the regulation of the impact of the natural environment as a component of public health.

Materials and methods: The study examines provisions of international documents and scientists' attitudes. The article analyzes generalized information from scientific journals by means of scientific methods from a medical and legal point of view. This article is based on dialectical, comparative, analytic, synthetic and comprehensive research methods. Within the framework of the system approach, as well as analysis and synthesis, the concepts of public health, health and influence of the natural environment on them are researched.

Review: As a result of the study of a particular range of problems, it may be noted that human health depends on a number of factors that allow it to be adequately addressed. The environmental component, namely, the state of the natural environment affecting the human body both directly and indirectly, is not the least of them. Proper legal settlement of the above-mentioned range of problems will allow a comprehensive approach to understanding the causation of human health and the natural environment. Conclusions: when researching the impact of the natural environment within public health, it can be noted that the legal basis for the multidimensional regulation of the notion of health in general, as well as its individual components, in particular, has been formed and reflected in a number of regulatory legal acts. In turn, inadequate implementation of the systematic approach with an in-depth understanding of the real and potential factors that affect human condition in one way or another does not allow the fullest possible determination of their causation both on the positive and negative sides.
\end{abstract}

KEY WORDS: public health, health, physical health, mental health, social well-being, diseases, physical defects, natural environment

\section{INTRODUCTION}

Human health is the value that, on the one hand, is laid out by nature due to parents' genetic and physiological characteristics, their social and economic conditions and, on the other hand, is determined by the degree of awareness of the meaning of this category for a person, which manifests itself in their thoughts, actions that are directly or indirectly reflected in their condition.

Communication from the Commission to the Council, the European Parliament, the Economic and Social Committee and the Committee of the Regions On the sixth environment action programme of the European Community 'Environment 2010: Our future, Our choice' - The Sixth Environment Action Programme [1] provides that in recent decades, there has been a growing realisation that the quality of our air, water, soil and food affect the quality of our health and of our lives. This ranges from increased allergies, respiratory disease, and cancers to the disruption of the body's hormone and fertility systems and premature death. The causes of our various environment-health problems are numerous and include pollution from transport, agricultural activities, industrial processes, domestic effluent and waste management. Thus tackling environment-health issues requires actions and initiatives on many different fronts (para. 5.1). In other words, the proper environment in general and its natural component, in particular, are closely related to and directly effect human health.

Determinants of health are those factors that can enhance or threaten an individual's or a community's health status. These can be matters of individual choice, such as whether to smoke tobacco or not, or can relate to social, economic, and environmental characteristics beyond the control of individuals [2, p. 16]. WHO Public Health \& Environment 
Global Strategy [3] makes provisions that human health should be seen in a physical, social behavioural and ecological context. Moreover, for instance, according to Art. 29 Law of Health Act Bulgaria passed Prom. SG. 70/10 Aug 2004 [4], the state bodies and institutions shall plan, develop and conduct policy, directed to preservation of the health of citizens by ensuring healthy living environment, education in healthy way of life and health prophylactics.

According to the Preamble of the International Charter of Physical Education and Sport [5], one of the essential conditions for the effective exercise of human rights is that everyone should be free to develop and preserve his or her physical, intellectual and moral powers. According to Art. 25 of the Universal Declaration of Human Rights [6], everyone has the right to a standard of living adequate for the health and well-being of himself and of his family, including food, clothing, housing and medical care and necessary social services, and the right to security in the event of unemployment, sickness, disability, widowhood, old age or other lack of livelihood in circumstances beyond his control.

In other words, human health depends on a number of factors that help to ensure its proper level. In particular, According to the Preamble of Decision № 1600/2002/EC of the European Parliament and of the Council of 22 July 2002 laying down the Sixth Community Environment Action Programme (hereinafter - Decision № 1600/2002/ EC) [7], a clean and healthy environment is essential for the well-being and prosperity of society, yet continued growth at a global level will lead to continuing pressures on the environment (part 1). Despite improvements in environmental standards, there is increased likelihood of a link between environmental degradation and certain human illnesses. Therefore the potential risks arising, for example, from emissions and hazardous chemicals, pesticides, and from noise should be addressed (part 23). Accordingly, in the context of the specific article, it should be noted that the safe natural environment is also a prerequisite for the proper ensuring of human health. According to part 4 of Art. 1 of Decision № 1600/2002/EC, environment and health and quality of life are among the areas at which the Community should pay attention first of all.

In turn, health, in humans, is defined as the extent of an individual's continuing physical, emotional, mental, and social ability to cope with his or her environment [8]. Furthermore, health is understood as a state of dynamic equilibrium between an organism and its environment in which all functions of mind and body are normal [9]. According to provisions of the Constitution of the World Health Organization, health is understood as "a state of complete physical, mental and social well-being and not merely the absence of disease or infirmity". Nearly the same wording of health is fixed at the level of statutory regulation, in particular, in section 2 of para. 2. of Chapter 1 of the General Provisions Public Health Act Estonia passed 14 June 1995 [10]. This definition includes mental and social dimensions and moves the focus beyond individual physical abilities or dysfunction [11, p. 1].

Moreover, public health is defined as the discipline in health science that, at the level of the community or the public, aims at promoting prevention of disease, sanitary living, laws, practices and a healthier environment [12]. According to section 1 of para. 2 of Chapter 1 of the General Provisions Public Health Act Estonia passed 14 June 1995, "public health" means the science and art of disease prevention, extending life expectancy, promoting and improving mental and physical health through the organized efforts of society.

So, health is connected with the corresponding human condition characterized by a set of such components as 1) physical condition; 2) state of mind; 3) social well-being; 4) absence of diseases and physical defects. Each of these elements of the concept in question is of importance in shaping a person's general sense and their attitude to their health. A person is healthy when the specified elements interact with each other at a certain equilibrium complementing each other. Accordingly, public health focuses on the study of the concept of health from various aspects, among which the state of the environment is not the least significant. Various authors have studied certain factors influencing human health from different positions [13-16]. Let us pay attention to the ecological component, namely, the state of the natural environment and its impact on other elements through which the concept of health, as well as its significance within the particular discipline, is defined.

\section{THE AIM}

To analyze the legal basis for the regulation of the impact of the natural environment as a component of public health.

\section{MATERIALS AND METHODS}

The study examines provisions of international documents and scientists' attitudes. The article analyzes generalized information from scientific journals by means of scientific methods from a medical and legal point of view. This article is based on dialectical, comparative, analytic, synthetic and comprehensive research methods. Within the framework of the system approach, as well as analysis and synthesis, the concepts of public health, health and influence of the natural environment on them are researched.

\section{REVIEW AND DISCUSSION}

Before proceeding to the above-mentioned study, let us note that the natural environment is a complex of atmospheric, geological and biological characteristics found in an area in the absence of artifacts or influences of a well developed technological, human culture [17]. That is, in this notion, special attention is paid to the state of the natural environment without any human influence and activity. In accordance, the environment is defined as a combination of elements whose complex interrelationships make up the settings, the surroundings and the conditions of life of the individual and of society, as they are or as they are felt. The environment thus includes the built environ- 
ment, the natural environment and all natural resources, including air, land and water. It also includes the surroundings of the workplace [18]. Hence, in the spectrum of the above-mentioned range of problems, it is a natural aspect of the environment directly or indirectly affecting human health which will be examined. Specifically, the natural environment can be positively and negatively affected by human intervention and impact. It, in turn, can positively and negatively affect people and their physical and mental health $[19$, p. 1]. It is clear that the well being and integrity of natural ecosystems and the biophysical environment are integral to human health and well being [20, p. 5].

In particular, one of the components of the category of health, which is taken into account when describing it, is a physical one. Moreover, physical condition and health are not synonymous terms. A person may have good physical characteristics but poor health [8]. Regular physical activity is a well-established protective factor for the prevention and treatment of the leading noncommunicable diseases (NCD), namely heart disease, stroke, diabetes and breast and colon cancer [21]. It also contributes to the prevention of other important NCD risk factors such as hypertension, overweight and obesity, and is associated with improved mental health [22-23], delay in the onset of dementia [24] and improved quality of life and well-being [25]. Physical health relates to the functioning of the physical body [26, p. 8]. We can particularly talk about its static and dynamic components.

The static one is expressed in the physical characteristics of the human body, which are defined as traits or features of the body [27]. They include weight, height, and size, including skinfold thicknesses, circumferences, lengths, and breadths. Each of the specified elements plays an important role in the human body functioning as a coherent mechanism and can undergo changes in the process of its life. They occur precisely due to the dynamic side, namely, the ability of the body to physical activity in the process of life. The WHO defines physical activity as any bodily movement produced by skeletal muscles that requires energy expenditure - including activities undertaken while working, playing, carrying out household chores, travelling, and engaging in recreational pursuits [28]. Accordingly, such activity is associated with actions resulting in the release of energy, which, in turn, positively affects the state of the body as a whole.

It must be of a constructive nature, that is, in the first place, the human body must receive a positive effect from it, which is achieved when various factors that determine it, namely, intensity level, degree of loading, physical characteristics, age, gender, etc., are considered. Differences in levels of physical activity are also explained by significant inequities in the opportunities for physical activity by gender and social position, as well as between countries [29]. Taking into account each of these components will allow achieving the most positive result in ensuring the proper level of both physical health and health in general. All forms of physical activity can provide health benefits if undertaken regularly and of sufficient duration and intensity [30]. Accordingly, such a body condition is one of the elements of a complex concept determining its level only in combination with other components.

Furthermore, Global Action Plan on Physical Activity 2018-2030 [30] defines the following principles which should underpin implementation of actions at every level as Member States, partners and WHO work towards achieving the shared vision of a more active world. In particular, they include human rights approach; equity across the life course; evidence-based practice; proportional universality; policy coherence and health in all policies; engagement and empowerment of policymakers, peoples, families and communities; multisectoral partnerships. Each of them is defined through the essential components of ensuring physical activity in its maximum manifestation according to various indicators.

In turn, the natural environment influences the physical component in its static and dynamic manifestations both directly and indirectly. Specifically, the degree of its safety in general and its individual natural objects, in particular, are of importance. For example, as noted at the scientific level, the natural environments affect human health and well-being both directly and indirectly. Urban green and blue areas provide opportunities for stress recovery and physical activity. Chronic stress, physical inactivity, and lack of social cohesion are three major risk factors for noncommunicable diseases, and therefore abundant urban greenery is an important asset for health promotion [31].

Neither physical nor mental health can exist alone. Mental, physical, and social functioning are interdependent [2, p. 12]. Physical health and mental health are closely associated through various mechanisms, as studies of links between depression and heart and vascular disease are demonstrating. The importance of mental health in the maintenance of good physical health and in recovery from physical illness is now well substantiated, as is the converse. Mental health status is a key consideration in changing the health status of a community [2, p. 15]. According to para. 42 of the European Parliament resolution on improving the mental health of the population. Towards a strategy on mental health for the European Union [32], mental and physical aspects of health are interlinked, mental disorders can have a biological, social, emotional or historical basis. There is no doubt that all the studied components of the concept of health are interconnected and, first of all, it manifests itself in the harmonious interdependence of the physical and mental components along with others properly influenced by the natural environment.

Accordingly, a person's state of mind is the following component of the concept of health which is determined by their mental health. According to para. 9 of the Council conclusions on the European Pact for Mental Health and Well-being results and future action [33], it recognizes that mental well-being is an essential constituent of health and quality of life, and a prerequisite for the ability to learn, work and contribute to social life. In positive sense, mental health is the foundation for well-being and effective functioning for an individual and for a community. It is more than the 
absence of mental illness, for the states and capacities noted in the definition have value in themselves. Neither mental nor physical health can exist alone. Mental, physical, and social functioning are interdependent. Furthermore, health and illness may co-exist. They are mutually exclusive only if health is defined in a restrictive way as the absence of disease [34]. Recognizing health as a state of balance including the self, others, and the environment helps communities and individuals understand how to seek its improvement [2, p. 12].

According to informed estimates, $27 \%$ of adult Europeans are estimated to experience at least one form of mental ill health during any one year, of which $6.3 \%$ are somatoform disorders, $6.1 \%$ major depressions and $6.1 \%$ phobias (para. 3.1.1 of Opinion of the European Economic and Social Committee on the Green Paper Improving the mental health of the population - Towards a strategy on mental health for the European Union [35]). According to para. 4 of the European Parliament resolution on improving the mental health of the population. Towards a strategy on mental health for the European Union, it believes that good mental health is a prerequisite for the overall health and well-being of European citizens and for a healthy economic performance in the EU.

The WHO declaration about mental health is also clear: it is "a state of well-being in which the individual realizes his or her own abilities, can cope with the normal stresses of life, can work productively and fruitfully, and is able to make a contribution to his or her community" [2, p. 12]. Mental health has been defined as social and emotional wellbeing, and spiritual, environmental (such as land and place), physical, social (including community and culture), and emotional factors [2, p. 31]. Mental health can itself be defined variously. Some say that a person is mentally healthy if he or she is able to function reasonably well and is emotionally and behaviorally stable. Others define it as the absence of mental disorder [8]. Mental health is a positive concept related to the social and emotional wellbeing of individuals and communities [26, p. 8].

In other words, its mental component is determined by certain characteristics whose essence is manifested through a person's ability to respond adequately under certain circumstances, to analyze the results of their behaviour, to be stable in stressful situations, to achieve their capacity in the absence of mental disorders. Mental health is the foundation for well-being and effective functioning for an individual and for a community [2, p. 12]. Its state is associated with behaviour at all stages of life [2, p. 14]; any factors affecting a person, regardless of their origin, affect it either directly or indirectly.

The degree of such impact will depend both on its internal state and on the external environment, and the natural environment exists along with other environments. For example, as a result of relevant studies, it has been noted that nature improves emotional well-being by increasing positive affect and, to a lesser extent, decreasing negative affect [36, p. 24]. A person's emotional state definitely affects their mental state, and, accordingly, taking into account a positive or negative impact of the natural environment, it is a direct factor of influence. It is clear that the well being and integrity of natural ecosystems and the biophysical environment are integral to human health and well being. The implications for humans are not limited to physical health and well being, and available and uncontaminated air, water, food, but include psychological need and benefit considerations relating to a spectrum of developmental, competence fostering and care-eliciting experiences in natural environments, such as identity formation, restoration, recreation, connection, and inspiration. Equally, the perception and/or direct experience of environmental degradation and loss can lead to concern, anxiety, guilt, anger, helplessness, dread, and pessimism [3738]. One of the most researched yet often overlooked benefits of the availability of natural environments for humans is stress reduction, restoration, and experienced personal connection with a coherent and meaningful world [39-40].

Along with the highlighted components of the concept of health, formulation of social well-being requires special attention. Several dimensions of health can be identified in the social domain, including people's capacity to fulfill their potential and obligations, the ability to manage their life with some degree of independence despite a medical condition, and the ability to participate in social activities including work. Health in this domain can be regarded as a dynamic balance between opportunities and limitations, shifting through life and affected by external conditions such as social and environmental challenges [41]. In recent years there has been an increased understanding of the importance of the social determinants of health: a term that encompasses not only social, but economic, political, cultural and environmental determinants. Essentially, these are the conditions into which people are born, grow, live, work and age [42]. According to this view, a person's occupation, education, material resources, social support networks and social status can affect their health and contribute to broader health inequalities within the population $[11$, p. 4]. Social well-being is an end state in which basic human needs are met and people are able to coexist peacefully in communities with opportunities for advancement. This end state is characterized by equal access to and delivery of basic needs services (water, food, shelter, and health services), the provision of primary and secondary education, the return or resettlement of those displaced by violent conflict, and the restoration of social fabric and community life [43].

There are many influencing factors that will determine a person's quality of life and health outcomes which have been categorised as the "social determinants of health". For example, the kind of housing and environments they live in, the health or education services which they have access to, the incomes generated and the type of work they do, all influence the health and lifestyle decisions made [44]. The specified social determinants influence the formation of human health from birth to death. In other words, social well-being is characterized by the level of social development reflected in presence of appropriate opportunities and ability to implement them, which, in turn, can affect human health both positively and negatively.

In identifying the relationship between social well-being and the natural environment, it can be noted that it is not possible to achieve social well-being in the natural environment that does not meet the proper requirements for its safety. Implementation of opportunities through which social well-being is 
manifested is carried out only in the environment which does not constitute a threat for personal physical well-being and mental condition. For example, section 6 of the Preamble of Directive 2003/35/EC of the European Parliament and of the Council of 26 May 2003 providing for public participation in respect of the drawing up of certain plans and programmes relating to the environment and amending with regard to public participation and access to justice [45] stipulates that among the objectives of the Arhus Convention is the desire to guarantee rights of public participation in decision-making in environmental matters in order to contribute to the protection of the right to live in an environment which is adequate for personal health and well-being.

Absence of diseases and physical defects is the last component emphasized while formulating the concept of health. A disease is a physical or mental disturbance involving symptoms, dysfunction or tissue damage, while illness (or sickness) is a more subjective concept related to personal experience of a disease [46]. The 2 main categories of disease that may lead to ill health are infectious and chronic diseases: - infectious diseases are caused by pathogens and can be spread from person to person by air, food, water, inanimate objects, insects or by direct or indirect contact with an infected person. Examples of infectious diseases include influenza, malaria i т.д.; - chronic diseases are caused by multiple factors, including a person's genetic make-up lifestyle and environment. They are long-term conditions and cannot be directly spread from one person to another. Examples of chronic diseases include diabetes, asthma and heart disease [11, p. 4].

Accordingly, a disease is determined as a person's condition reflected on their physical or psychological component which are directly or indirectly influenced by their social well-being, which in some sources is revealed not only through social, but economic, political, cultural and environmental determinants. Essentially, these are the conditions into which people are born, grow, live, work and age [42]. In addition, diseases may have different nature of occurrence and, respectively, different classification criteria that reflect their specificity and peculiarities in relation to others. As for infirmity, for example, in vocabularies, it is assumed that infirmity is physical or mental weakness [47], a physical, mental, or moral weakness or flaw [48]. Accordingly, there are certain defects related to both physical and mental condition in the presence of which it can be argued that there are certain limitations of the functioning of a human body at one level or another compared to a person who does not have them.

When analyzing the definition of health, along with others, absence of a disease or physical defects is one of the indicators of a healthy person, and vice versa, when they are present, one cannot say that a person is healthy. Their presence is reflected on a person's condition in one way or another.

\section{CONCLUSIONS}

In other words, when researching the impact of the natural environment within public health, it can be noted that the legal basis for the multidimensional regulation of the notion of health in general, as well as its individual components, in particular, has been formed and reflected in a number of regulatory legal acts. In turn, inadequate implementation of the systematic approach with an in-depth understanding of the real and potential factors that affect human condition in one way or another does not allow the fullest possible determination of their causation both on the positive and negative sides.

\section{REFERENCES}

1. Communication from the Commission to the Council,theEuropean Parliament, the Economic and Social Committee and the Committee of the Regions On the sixth environment action programme of the European Community 'Environment 2010: Our future, Our choice' - The Sixth Environment Action Programmе від24.01.2001//https://eur-lex.europa.eu/legal-content/EN/ TXT/?qid=1547494556524\&uri=CELEX:52001DC0031.

2. Promoting mental health: concepts, emerging evidence, practice: summary report/a report from the World Health Organization, Department of Mental Health and Substance Abuse in collaboration with the Victorian Health Promotion Foundation (VicHealth) and the University of Melbourne. (2004)..

3. WHO Public Health \& Environment Global Strategy, World Health Organization, Geneva, 1993 See at: http://apps.who.int/iris/bitstream/ handle/10665/59479/WHO_EHE_93.2.pdf?sequence=1\&isAllowed=y.

4. Law of Health Act Bulgaria passed Prom. SG. 70/10 Aug 2004 // https:// www.ecolex.org/details/legislation/law-of-health-lex-faoc061743/?q= physical+health\&type=legislation\&xkeywords=public + health\&xregion $=$ Europe $\&$ xdate_min $=\& x$ date_max $=$.

5. International charter of physical education and sport (Adopted by the General Conference at its twentieth session, Paris, 21 November 1978) See at: http:// www.unesco.org/education/pdf/SPORT_E.PDF.

6. Universal Declaration of Human Rights, 1948 See at: http://www.un.org/ en/universal-declaration-human-rights/

7. Decision № 1600/2002/EC of the European Parliament and of the Council of 22 July 2002 laying down the Sixth Community Environment Action Programme // https://eur-lex.europa.eu/legal-content/EN/ TXT/?uri=CELEX\%3A32002D1600.

8. Health, //https://www.britannica.com/topic/health.

9. Health//https://www.eea.europa.eu/help/glossary/gemet-environmentalthesaurus/health

10. Public Health Act Estonia passed 14 June 1995 // https://www.ecolex.org/ details/legislation/public-health-act-lex-faoc037194/?q

11. 1.1 Health and illness (Chapter 1 - Understanding health and illness; Australia's health 2014) (AlHW) Seeat:https://www.aihw.gov.au/getmedia/ fc2c053f-7707-437e-90b3-227818bba0a5/1_1-health-illness.pdf.aspx.

12. Public health // https://www.eea.europa.eu/help/glossary/gemetenvironmental-thesaurus/public-health.

13. Vitalii Pashkov, Olena Batyhina, Maryna Trotska Legal Restraints of Pesticide Effect on Human Organism and Environment under International Legislation Wiadomości Lekarskie 2017, tom LXX, nr 2, cz II - C. 366-372.

14. Vitalii Pashkov, Olena Batyhina, Maryna Trotska Concept of Waste and Its Impact on Human Health Wiadomości Lekarskie 2017, tom 70, nr 5 - C. 964-969.

15. Vitalii Pashkov, Olena Batyhina, Maryna Trotska International Legal Regulation of Impact of Occupational Injuries and Diseases on Agricultural Workers'Health Wiadomości Lekarskie 2017, tom 70, nr 5 - C. 953-958.

16. Gutorova N, Batyhina 0, Trotska M Legal protection of public health through control over genetically modified food Wiadomości Lekarskie 2018, tom 71, nr 2 pt 2 - C. 366-370.

17. Natural environment//https://www.eea.europa.eu/help/glossary/gemetenvironmental-thesaurus/natural-environment. 
18. Environment // https://www.eea.europa.eu/help/glossary/gemetenvironmental-thesaurus/environment.

19. Impacts of the natural environment on health (Chapter4). Australian Institute of Health andWelfare 2018. Australia's health 2018. Australia's health series no. 16. AUS 221. Canberra: AlHW.

20. Psychology and the Natural Environment. A Position Statement prepared for The Australian Psychological Society by Joseph P. Reser with input from Joan Bentrupperbäumer, Elizabeth Bragg, Rob Hall, Helen Ross, Geoff Syme (Australia); Deborah Winter, Wes Schultz (U.S.A.); David Uzzell (UK) September 2007.

21. World Health Organization. Global Recommendations on Physical Activity for Health. 2010.)

22. Schuch F, Vancampfort D, Richards J, Rosenbaum S, Ward PB, Stubbs B. Exercise as a treatment for depression: A meta-analysis adjusting for publication bias. Journal of Psychiatric Research; 2016: 77, 42-51.

23. Mammen G, Faulkner G. Physical Activity and the Prevention of Depression: A Systematic Review of Prospective Studies. American Journal of Preventive Medicine: 201345 (5), 649-657.

24. Livingston G, Sommerlad A, Orgeta V, Costafreda SG, Huntley J, Ames D, et al, Dementia prevention, intervention, and care. The Lancet Commission. 2017.

25. Das Pand Horton R, Rethinking our approach to physical activity. The Lancet. 2012; 380(9838): 189-190.

26. Physical health and mental wellbeing: evidence guide. Sydney. Mental Health Commission of NSW. 2016. See at: https://nswmentalhealthcommission. com.au/sites/default/files/publication-documents/Physical\%20health\%20 and\%20wellbeing\%20-\%20final\%208\%20Apr\%202016\%20WEB.pdf.

27. Physical characteristics // https://examples.yourdictionary.com/examplesof-physical-characteristics.html.

28. Physical activity // https://www.who.int/news-room/fact-sheets/detail/ physical-activity.

29. World Health Organization. Global Status Report on Noncommunicable Diseases 2014.

30. Physical activity for health. More active people for a healthier world: draft global action plan on physical activity 2018-2030 See at:https://www.who. int/ncds/governance/who-discussion-paper-gappa-9april2018.pdf?ua=1.

31. Matilda van den Bosch Natural Environments, Health, and Well-Being See at: http://oxfordre.com/environmentalscience/view/10.1093/ acrefore/9780199389414.001.0001/acrefore-9780199389414-e-333.

32. European Parliament resolution on improving the mental health of the population. Towards a strategy on mental health for the European Union (2006/2058(INI)) // https://eur-lex.europa.eu/legal-content/EN/ TXT/?qid=1546891431367\&uri=CELEX:52006IP0341.

33. Council conclusions on the European Pactfor Mental Health and Well-being: results and future action // https://eur-lex.europa.eu/legal-content/EN/ TXT/?qid=1547334382007\&uri=CELEX:52011XG0708(01).

34. Sartorius N (1990). Preface. In: Goldberg D, Tantam D, eds. The public health impact of mental disorders. Toronto, Hogrefe and Huber.

35. Opinion of the European Economic and Social Committee on the Green Paper Improving the mental health of the population - Towards a strategy on mental health for the European Union (COM(2005) 484 final) (2006/C 195/11) // https://eur-lex.europa.eu/legal-content/EN/ TXT/?qid=1546891431367\&uri=CELEX:52006AE0739.

36. Ethan A. McMahana and David Estes The effect of contact with natural environments on positive and negative affect: A meta-analysis See at: file:///C:/Documents\%20and\%20Settings/Admin/Мои\%20документы/ PDF_A\%20The\%20Effect\%20of\%20Contact\%20With\%20Natural\%20 Environments\%20on\%20Positive\%20and\%20N.pdf.
37. Bohm, G. (2003) Emotional reactions to environmental risks: Consequentialist versus ethical evaluation. Journal of Environmental Psychology, 23, 199-212.

38. Edelstein, M.R. (2002) Contamination: The invisible built environment. In R.B. Bechtel \& A. Churchman (Eds) Handbook of environmental psychology (pp 559-588). New York: Wiley.

39. Hartig, T. \& Staats, H. (2003) (Eds) Restorative environments: Part special issue. Journal of Environmental Psychology, 23, 103-170.

40. Uzzell, D.L. \& Moser, G. (2006) Environment and quality of life. European Review of Applied Psychology, 56, 1-4.

41. Machteld Huber senior researcher, J André Knottnerus president, Scientific Council for Government Policy, Lawrence Green editor in chief, Oxford Bibliographies Online - public health, Henriëtte van der Horst head, Alejandro R Jadad professor, Daan Kromhout vice president, Health Council of the Netherlands, Brian Leonard professor, Kate Lorig professor, Maria Isabel Loureiro coordinator for health promotion and protection9, Jos W M van der Meer professor, Paul Schnabel director, Richard Smith director, Chris van Weel head, Henk Smid director How should we define health? See at:https:// www.researchgate.net/publication/51523299_How_should_we_define_ health.

42. WHO 2013. What are social determinants of health? Geneva:WHO. Viewed 6 December 2013.

43. Section 10. Social Well-Being See at: https://www.usip.org/sites/default/ files/GP_170-203_Social_Well-Being.pdf.

44. Health\&SocialWellbeing Seeat:http://healthallianceni.com/health-socialwellbeing/.

45. Directive 2003/35/EC of the European Parliament and of the Council of 26 May 2003 providing for public participation in respect of the drawing up of certain plans and programmes relating to the environment and amending with regard to public participation and access to justice // https://eur-lex. europa.eu/legal-content/EN/TXT/?uri=celex\%3A32003L0035.

46. AlHW (Australian Institute of Health and Welfare) 2010. Australia's health 2010. Cat no. AUS 122. Canberra: AlHW.

47. Infirmity // https://dictionary.cambridge.org/dictionary/english/infirmity

48. Infirmity // http://www.whatdoesthatmean.com/dictionary//infirmity. html

\section{Authors' contributions:}

According to the order of the Authorship.

\section{Conflict of interest:}

The Authors declare no conflict of interest.

\section{CORRESPONDING AUTHOR} Vitalii M. Pashkov

Department of Civil, Commercial and Environmental Law, Poltava Law Institute of Yaroslav the Wise National Law University 6 Monastyrska str., 36000, Poltava, Ukraine

tel: +380666931651

e-mail:v.pashkov26.06@ukr.net

Received: 01.12.2018

Accepted: 29.01.2019 
PRACA POGLADDOWA

REVIEW ARTICLE

\title{
HYGIENIC ASSESSMENT OF THE EFFECTS OF PESTICIDES APPLICATION ON CHILDREN POPULATION MORBIDITY WITH THYROID GLAND DISEASES
}

\section{SANITARNA OCENA WPŁYWU EKSPOZYCJI NA PESTYCYDY NA CHOROBOWOŚĆ W POPULACJI DZIECI Z CHOROBAMI TARCZYCY}

\author{
Anna M. Antonenko, Olena P. Vavrinevych, Maria M. Korshun, Sergii T. Omelchuk \\ HYGIENE AND ECOLOGY INSTITUTE OF BOGOMOLETS NATIONAL MEDICAL UNIVERSITY, KYIV, UKRAINE
}

\begin{abstract}
Introduction: It is proved that some groups of fungicides and herbicides are capable of affecting the thyroid gland, provoking its growth, leading to a compensatory change in the activity of the hormones synthesis. Therefore, the presence of their residual amounts in plant may affect the level of thyroid gland pathology.

The aim of the work was to analyze the influence of pesticide application on the Ukrainian child population morbidity with thyroid diseases in the period from 2001 to 2014.

Materials and methods: The methods of empirical and theoretical research of scientific information, namely analysis, synthesis, induction, deduction and systematization, epidemiological, cartographic and statistical methods were used.

Review: The maximum level of thyroid pathology was found in the northern, western and northwestern regions, where the diffuse goiter dominates in the morbidity and prevalence of thyroid diseases; minimal - in the southern, eastern and south-eastern regions. It was established that the highest volumes of application of chemical plant protection products in the period 2001-2013 took place in the southern and central regions of Ukraine, namely in Poltava, Vinnitsa, Kharkiv, Dnipropetrovsk, Khmelnytsky regions. Sufficiently high levels of pesticide application were in the Kyiv, Kherson regions, Zaporizhia, Kirovograd and Cherkasy regions.

Conclusions: The probability of the active chemical plant protection products application effect on the level of thyroid cancer, various types of goiter, hypothyroidism, thyrotoxicosis and thyroiditis in the central and southern regions was determined. These are regions with well-developed agricultural production.
\end{abstract}

KEY WORDS: children, thyroid gland, morbidity, pesticides

Wiad Lek 2019, 72, 2, 267-270

\section{INTRODUCTION}

In the structure of children and adolescents endocrine pathology thyroid disease according to frequency occupy the 2 nd place after diabetes mellitus. Diffuse euthyroid goiter - the most common pathology of the thyroid gland among children from 0 to 14 years old $[1,2]$. A similar situation with the level of this pathology and among the children's population of Poland. The high percentage of follicular carcinoma and follicular adenoma indicates that the long-term iodine deficiency in Poland may be significant in the pathogenesis of malignant transformation $[3,4]$.

In addition, in recent years after the Chernobyl nuclear power plant accident, a significant increase in primary incidence of thyroid cancer among the population of Ukraine and Poland under 18 years old was found $[4,5]$.

Reducing the prevalence of thyroid diseases, including among the children of the world, is one of the priorities of WHO specialists [6].

\section{THE AIM}

The purpose of the work was to analyze the influence of pesticide application on the Ukrainian children population morbidity with thyroid diseases in the period from 2001 to 2014 .

\section{MATERIALS AND METHODS}

The object of our research was the level of morbidity of the thyroid gland diseases of Ukrainian children population during the period from 2001 to 2014, and the application volume of various pesticides groups in the specified regions during the same period.

The methods of empirical and theoretical research of scientific information, namely analysis, synthesis, induction, deduction and systematization, epidemiological, cartographic and statistical methods were used.

Reports of Endocrinology Service of Ukraine "Key Indicators of the Endocrinology Service of Ukraine ..." for 2000-2014 [10] and Attachments to the letters from the Ministry of Agrarian Policy and Food [9] were used as the sources of information.

The research was conducted in three stages. At the first stage, ranking of studied regions according to the levels of primary and general morbidity of the children population 
in the period of 2001-2014 for thyroid cancer, nodular goiter, diffuse nontoxic goiter of the I degree and II-II degrees, hypothyroidism, thyrotoxicosis and thyroiditis was made. At the next - we have ranking of studied regions by application volume of whole chemical plant protection products, as well as separately herbicides, fungicides and insecticides. At finally, correlation analysis of the relationship between the levels of thyroid diseases and the volume of pesticides application with the calculation of the Spirman ranks correlation coefficient was conducted.

Statistical processing of the results was performed using the statistical suite of statistical software IBM SPSS StatisticsBase v.22.

\section{REVIEW AND DISCUSSION}

The analysis of morbidity in different regions showed the following pattern: the maximum level of thyroid pathology was found in the northern, western and northwestern regions, where the diffuse goiter dominates in the morbidity and prevalence of thyroid diseases; minimal - in the southern, eastern and south-eastern regions. In addition, significant regional differences in levels of prevalence and morbidity on individual nosologies have been established.

The prevalence of endocrine diseases among children (0-14 years old) has a general tendency to decrease in the investigated period (2000-2014). In most regions (15 out of 24 ) growth rates ranged from -18.7 to $-59.9 \%$. Similarly, in the majority of regions ( 14 out of 24 ) a reliable correlation between the level of morbidity and death was determined $(\mathrm{r}>0.7060)$.

With regard to the prevalence of diffuse goiter of various degrees, it has, in most of cases, a significant $(\mathrm{p} \leq 0.05)$, tendency to decrease in 18 regions for diffuse goiter of I degree and in 20 regions for diffuse goiter of II-III degrees.

The maximum incidence of diffuse goiter is observed predominantly in western (Zakarpattia, Rivne, Volyn, Chernivtsi, Ternopil, Lviv, Ivano-Frankivsk) and northern (Rovne, Kyiv, Chernihiv, Zhytomyr) regions, where there is an unsatisfactory microelement composition of the environmental objects $[8,9]$. The same situation with iodine deficiency was observed in some Poland regions, for example Lower Silesia [4]. Significant levels of this pathology have also been registered in the Vinnytsia, Khmelnytsky regions, which do not belong to the iodine-endemic regions.

There was no clear tendency to change the prevalence of nodular goiter during the study period. In part of regions (15), there was a significant decrease in the general incidence of nodular goiter, in other regions - its growth.

Thus, the highest incidence of thyroid nodular goiter was found in Kyiv, Vinnytsya, Cherkasy, Volyn, Chernihiv and Sumy regions. A rather high level was observed in the Luhansk, Poltava, Khmelnytskyi and Zhytomyr regions. Analyzing the possible causes of this situation, we can assume that high rates of thyroid nodular goiter in the northern region (Kyiv, Chernihiv, Sumy, Zhytomyr) are related to the impact of ionizing radiation on the population as a result of the Chernobyl accident; in the Luhansk region - with significant pollution of the environment by industrial emissions, including heavy metals, which play an essential role in the development of thyroid gland pathology [11]. But both of these factors are not leading in the formation of pollution in the Vinnytsia, Poltava and Cherkasy regions.

The prevalence of hypothyroidism has a distinctly tendency $(p \leq 0.05)$ to increase the level with a clear correlation of changes with the year of observation $(r>0.7060)$. It should be noted that in most cases the rate of growth of this pathology was higher than $100 \%$.

In the majority of Ukraine regions, a general tendency to decrease in the prevalence of thyrotoxicosis was noted, although a strong correlation and significant differences were practically not detected (only in 9 regions). This may be due to a low overall prevalence of thyrotoxicosis among children (0.9-10.7 cases per 100 thousand children in 2000 and 0.7-5.4 - in 2013).

Thyroiditis is a much more common pathology among the child population than nodular goiter, hypothyroidism and thyrotoxicosis, but less common than diffuse goiter of various degrees. In the majority of regions (15) there was a decrease in the overall incidence of thyroiditis, but a strong correlation was found in only 8 cases.

High levels of thyroiditis are recorded in industrially developed Kropyvnytskii, Zaporizhzhya regions; in the northern region, affected by the Chernobyl accident (Kiev, Sumy, Chernihiv regions), as well as in Kherson, Vinnytsia regions, where the impact on the human body of the environment with radionuclides, heavy metals and other industrial toxicants is not too powerful.

Thyroid cancer is also one of the not common pathologies for childhood. The level of primary morbidity varies from 0.33 to 1.83 cases per 100 thousand children. The highest incidence of thyroid cancer was found in Kyiv, Vinnytsya, Cherkasy, Volyn, Chernihiv, Chernivtsi and Sumy regions. A rather high level was observed in the Donetsk, Dnipropetrovsk, Poltava, Rivne and Zhytomyr regions. Analyzing the possible causes of this situation, we can assume that high rates of thyroid nodular goiter in the northern region (Kyiv, Chernihiv, Sumy, Zhytomyr) are related to the impact of ionizing radiation on the population as a result of the Chernobyl accident; in the Donetsk, Dnipropetrovsk regions - with significant pollution of the environment by industrial emissions, including heavy metals, which play an essential role in the development of thyroid gland pathology [11]. But both of these factors are not leading in the formation of pollution in the Vinnytsia, Chernivtsi, Poltava and Cherkasy regions.

A significant increase in primary morbidity among the children was observed immediately after the accident at the Chernobyl Nuclear Power Plant, due to the significant release of short-lived radioactive iodine isotopes that settled on grass pastures for cattle and from there into cow's milk. The use of such milk by children on the background of general iodine deficiency, characteristic for the western regions of Ukraine, has led to a significant increase in the level of primary thyroid cancer [5]. 
Taking into account intensive application of agricultural chemicals in recent years, it could be assumed that the development of diffuse and nodule goiters, thyroiditis, etc. in the Vinnitsa, Chernivtsi, Poltava, Cherkasy regions with a developed agricultural sector of the economy is associated with the introduction into the human body of pesticides that affect the function of the thyroid gland [12-16].

To test this hypothesis, we examined the application volumes of pesticides in the studied regions and compared them with the levels of thyroid pathology.

It was established that the highest volumes of application of chemical plant protection products in the period 2001-2013 took place in the southern and central regions of Ukraine, namely in Poltava, Vinnitsa, Kharkiv, Dnipropetrovsk, Khmelnytsky, Odesa and Mykolaiv regions. Sufficiently high levels of pesticide application were in the Kyiv, Kherson regions, Crimea, Zaporizhia, Kirovograd and Cherkasy regions. In addition, the Vinnytsia region fell into the top five in application volumes of all three groups of pesticides - herbicides, fungicides and insecticides.

It can be assumed that high rates of application volumes both pesticides in general and their individual groups are associated with high children morbidity rates for thyroid cancer and nodular goiter in the Vinnytsia, Chernivtsi and Cherkassy regions; on diffuse goiter - in the Vinnytsia, Khmelnytsky regions, thyroiditis - in Vinnitsa, Khmelnytsky regions.

In addition to comparing the incidence of thyroid disease and pesticides application volumes, we have conducted a correlation analysis between the values of these indices by regions. There was a significant correlation $(p<0.05)$ between the levels of thyroid cancer, diffuse goiter of various degrees and thyroiditis, and the all pesticides application volumes in general, herbicides and insecticides.

It should be noted that the exposure of child's body with pesticides is not likely to be related to the consumption of agricultural products, as the level of residues of their active substances in plants is strictly regulated and controlled. However, pesticides are well penetrated to milk of breastfeeding mothers. In addition, children living in rural areas may come into contact with components of pesticide formulations crawling around the land near treated areas $[17,18]$.

In view of this, the connections we discovered need further detailed study.

\section{CONCLUSIONS}

1. It has been established that in the majority of cases $(62.5 \%)$ the overall endocrine morbidity among the children's population of Ukraine in the period from 2000 to 2014 has a significant $(\mathrm{p}<0.05)$ tendency to decrease. The disease of the thyroid gland in the structure of the general endocrinological morbidity of the child population, as well as the adult, occupy one of the leading places. Diffuse goiter is the most common pathology among the child population of Ukraine in the study period.

2. In recent years, there has been a tendency towards a significant decrease in the level of both general and pri- mary thyroid cancer incidence among 0-14 year olds, as opposed to the incidence rates of this pathology for 10 years after the Chernobyl nuclear power plant accident.

3. The existence of a reliable $(\mathrm{p}<0.05)$ correlation between the levels of morbidity of Ukrainian child population on thyroid gland cancer, diffuse goiter of various degrees, thyroiditis and volumes of pesticides application has been shown.

4. The probability of the active chemical plant protection products usage effect on the level of thyroid cancer, various types of goiter, hypothyroidism, thyrotoxicosis and thyroiditis in the central and southern regions (for example, Vinnytsia, Cherkassy, Poltava, Chernivtsi, Khmelnytsky) was determined. Are regions with well-developed agricultural production.

\section{REFERENCES}

1. Larin 0.S., Zelins'ka N.B., Berezhnyy V.V. Diagnosis and treatment of diffuse cirrhosis of children. Guidlines. Kyiv, 2005.

2. Kravchenko V.I., Postol S.V. The dynamics of morbidity in pathology of thyroid gland in Ukraine. International Endocrinology Journal. 2011; 3 (35): $12-16$.

3. Niedziela M., Korman E., Breborowicz D., Trejster E., Harasymczuk J., Warzywoda M., Rolski M., Breborowicz J. A prospective study of thyroid nodular disease in children and adolescents in western Poland from 1996 to 2000 and the incidence of thyroid carcinoma relative to iodine deficiency and the Chernobyl disaster. Pediatric Blood and Cancer. 2004; Volume 42, Issue 1: 84-92.

4. Zak T., Noczynska A., Wasikowa R., Zaleska-Dorobisz U., Golenko A. Chronic autoimmune thyroid disease in children and adolescents in the years 1999-2004 in Lower Silesia, Poland. Hormones. 2005; 4 (1): 45-48.

5. WHO Information Bulletin No. 303: Medical consequences of the Chernobyl accident: review, April 2006.

6. WHO, UNISEF, ICCIDD. Global Database on lodine Deficiency - lodine status worldwide. - Geneva, 2004. 48 p.

7. [Use of plant protection products by agricultural producers in Ukraine in ... years]. - Letter of the Ministry of Agrarian Policy of Ukraine dated February 24, 2005 №. 156-05-02 / 56, supplemented by 15.02 .2011 № 37-156-10/2217, 22.03.2012 № 37-156-10/451322, 14.03.2013 № $37-156-10 / 4513$.

8. [Report of the Endocrinology Service of Ukraine «Key Indicators of the Endocrinology Service of Ukraine for ... Year»]. Academy of Medical Sciences of Ukraine and the Ministry of Health of Ukraine, DU «Institute of Endocrinology and Metabolism named after them. VP Commissioner of NAMS of Ukraine «. 2000, 2004, 2006, 2007, 2010, 2011, 2012, 2013, 2014. $31 p$.

9. Pyrohova V.H., Kravchenko V.I. [Dynamics of diseases of the thyroid gland caused by iodine deficiency in the population of the Transcarpathian region]. Naukovyy visnyk Uzhhorods'koho universytetu. 2011; 3 (42); 132-139.

10. Karachentsev Yu.I., Tymchenko A.M., Kozakov 0.V. [Modern tendencies of endocrine morbidity of the population and prospects of development of endocrinology service]. Zdorov»ya Ukrayiny [Content last modified 2016]. http://health-ua.com/article/110.html. (Assessed 21.12.2017).

11. Antonenko A.M., Korshun M.M. [Environmental factors as risk factors for thyroid gland pathology (first report)]. Dovkillya i zdorov»ya. 2016; 3 (79): 74-79. 
12. Sarne D. Effects of the environment, chemicals and drugs on thyroid function, Thyroid disease manager. 2010.54.

13. Antonenko A.M., Korshun M.M., Milokhov D.S. [Features of the mechanism of action of inhibitors of succinate dehydrogenase on the body of warm-blooded animals and humans]. Suchasni problemy toksykolohiyi, kharchovoyi ta khimichnoyi bezpeky. 2015; 4 (72): 23-29.

14. Antonenko A.M., Blagaia A.V., Vavrinevych 0.P. Mechanism of action of 4-hydroxyphenylpyruvate dioxygenase inhibitor herbicide on homoterm animals and humans. Journal of Pre-Clinical and Clinical Research. 2015; 9 (2): 148-153.

15. Stavnichenko P.V., Antonenko A.M., Bardov V.H. [Hygienic estimation of assortment changes and volumes of use of fungicides in agriculture of Ukraine]. Ukrayins'kyy zhurnal z problem medytsyny pratsi. 2016; 4 (49): 32-36.
16. Antonenko A.M., Vavrinevych O.P., Korshun M.M. et al. Hygienic assessment of the effects of pesticides application on adult population morbidity with thyroid gland diseases. Wiad. Lek. 2018; 2 (71):353-357.

17. Ogg C.L., Hygnstrom J.R., Bauer E.C., Hansen P.J. Managing the risk of pesticide poisoning and understanding the signs and symptoms. University of Nebraska-Lincoln and United States Department of Agriculture. 2012.

18. Fishel F.M. Pesticides: Routes of Exposure. US Department of Agriculture, UF/IFAS Extension service. 2015.

\section{Authors' contributions:}

According to the order of the Authorship.

\section{Conflict of interest:}

The Authors declare no conflict of interest.

\section{CORRESPONDING AUTHOR}

Anna Antonenko

Ivana Franka str, 6, ap. 257,

v. Sofiivska Borshchahivks, 08131, Kyiv, Ukraine

tel: +380991466331

e-mail:antonenk01985@ukr.net

Received: 10.07 .2018

Accepted: 08.12.2018 
PRACA POGLADDOWA

REVIEW ARTICLE

\title{
POSTNATAL PERIOD PSYCHOLOGICAL ASPECTS
}

\section{PSYCHOLOGICZNE ASPEKTY OKRESU POKOGU}

\author{
Larysa 0. Herasymenko \\ UKRAINIAN MEDICAL STOMATOLOGICAL ACADEMY, POLTAVA, UKRAINE
}

\begin{abstract}
The result of labour is not only the birth of a child but also the formation of a mother, woman who has got to know motherhood. Moreover there is a radical change in the social status of the couple as a whole. It turns into a mother and father. The consequence of this is a change in attitude towards yourself and others, that is, the transformation of the personality. This explains why during pregnancy and delivery the risk of family problems worsening rises sharply and somatic and neuropsychic disorders emerge. The aim of the work is to describe and systematically outline the main psychological and psychiatric aspects of the postnatal period in the life of a woman and a child. Changes occur in the life of a woman, and the possible to diagnose the manifestations of disharmonious development in a timely manner, to prevent and help to solve them constructively. The information is presented taking into account both historical aspects and the state of the issue in modern society.
\end{abstract}

KEY WORDS: postnatal period, woman, baby

Wiad Lek 2019, 72, 2, 271-274

\section{INTRODUCTION}

The result of labour is not only the birth of a child but also the formation of a mother, woman who has got to know motherhood. Moreover there is a radical change in the social status of the couple as a whole. It turns into a mother and father. The consequence of this is a change in attitude towards yourself and others, that is, the transformation of the personality. This explains why during pregnancy and delivery the risk of family problems worsening rises sharply and somatic and neuropsychic disorders emerge [1].

\section{THE AIM}

The aim of the work is to describe and systematically outline the main psychological and psychiatric aspects of the postnatal period in the life of a woman and a child.

\section{REVIEW AND DISCUSSION}

\section{WOMAN DURING POSTNATAL PERIOD}

The situation is ideal when realizing the instinct of procreation the woman gets married and later becomes a happy mother. But there are many obstacles along this way. Therefore at the end of pregnancy the future mother has a state of primary maternal anxiety, which is an unconscious regressive mechanism that encourages her to identify herself with her own parents, to find out how they acted in similar situations. An additional catalyst of this process is the dominant holding (engl. holding - to take care of) formed in the mother central nervous system immediately after delivery and exercises a regulatory influence on the "mother-child" system for the next three years [2].
The result of the process of finding yourself in a new role is the transformation of the unconscious imago images (latin. imago - adult sexually mature stages of development of insects) to ideal parental images serving as a guide, imitating which helps to cope with new role functions, acquire maternal competence [3].

This is a psychologically complex process that can fail under the influence of a variety of reasons.

Negative experience gained in childhood from their parents sometimes causes difficulties in mastering the maternal role. Poor care at an early age is transferred as a feeling of "maternal incompetence" to an adult woman [4].

In other cases, the infantile inability to part with children's behavior patterns can lead to a conflict between ideal parental images and a really existing ego in the parental status. The contradiction between the instinctual desire to protect the infant as effectively as possible and the individual lack of experience and competence becomes a powerful source of anxiety. Excessive fear of doing something irreparably wrong enslaves a woman, turns her natural caution to paranoid and creates an unfavorable emotional atmosphere for the development of strong-willed and creative qualities of the infant. A wise mother's love is always beautiful and harmonious, but such "blind" feelings acquire ugly destructive forms and tend to stop cultivation of the child talents, his individual natural abilities [5].

Early and sufficiently long postpartum skin contact with the newborn by placing it onto the bare breast is an extremely important factor in the formation of maternal competence. This contributes to both mother's lactation and mental and somatic state harmonization of the new- 
born, calms it, warms it, and promotes switching from the dominant during delivery sympathetic tone of the vegetative nervous system to the parasympathetic one [6].

Due to the mechanisms of imprinting bonding (engl. bonding unity, reproduction) forms at this time. It is the intuitive invisible connection between the mother and the baby which arises immediately after delivery and allows woman to understand her child's nonverbal signals at a subconscious level in order to satisfy his needs.

Manifestations of bonding are various particularly women who spent at least an hour after birth with their newborn children are able to recognize them by smell, tactilely and by screaming. Mutual regulation within the dyad provides a high quality of further dialogue: the child acquires the confidence that his signals for help will be heard and his mother gets the ability to understand them.

Therefore the practice of divorcing mother and child right after delivery which was quite common in Western Europe until the 1970s and was practiced in the Soviet Union even in the nineties is now recognized as profoundly mistaken [7].

For the parturient woman the early separation from the infant results in increased level of anxiety and often to the formation on this background the ideas of the possibility of substitution of the child. Anxious feelings are one of the factors that negatively affect the formation of lactation.

Somatoendocrine-conditioned lability of mental processes in the postpartum period is an additional factor that prevents women from successfully coping with challenges on the way to motherhood and adapting to their new socio-psychological status. In many peoples, a kind of "quarantine", which lasted about 40 days, was applied to women recently confined on the basis of empirical experience. Such measures, to a certain extent, seem justified because during this period a woman is considered to be the most vulnerable to the development of postpartum psychosis, depression, or vice versa, euphoric safety with disregard for physical fatigue and disregard for rest. Depressive conditions which are fed by conflicts of the past and actualized during pregnancy appear more often.

Three models of the interaction of depressed women with their children are described:

- sad, slow, silent and submerged mothers who languidly show their feelings;

- mothers of the choleric type with a feeling of inner tension, which is often manifested by the twitching of the face muscles;

- unceremonious and rude.

For the prevention and prompt assistance in the case of postpartum complications, patronage of the obstetric-gynecological service plays an important role. It is the control over the involution of the uterus and the dynamic observation of the condition of the woman and psychotherapeutic help with an explanation of the essence of the problems that arise. The pediatrician visits the mother at home, additionally monitoring the condition of the child and teaching her how to care for him properly [8].

\section{BABY DURING POSTNATAL PERIOD}

Loss of the umbilical cord and the transition from the primary ecological niche of the uterus to the world around is only the beginning of the child's organism path for independent existence. At first physiological independence is purely formal and autonomy exists just in the narrow sense of the physical division of two bodies. Functionally the baby remains a part of the mother's body from which it receives food, care and a sense of security. Therefore the harmonious development of the infant in the postnatal period largely depends on the relationship within the dyad "mother-child".

Critical for the formation of this relationship is the early postnatal period, when the main stress of delivery is already behind, but the content of catecholamines in the mother's and baby's blood is still many times higher than the norm. The unique hormonal status of these moments serves as a physiological basis for the psychological phenomena of imprinting and bonding which further determine the quality of the proto-dialogue within the dyadic relationship [9].

It is especially important at this time to place the baby onto the mother's breast. In addition to the actual function of satiation of the child breastfeeding is of particular importance for communication carried out with the help of non-verbal, expressive-emotional communications, which subsequently exert a decisive influence on the formation of the type of family upbringing. When the mother and baby unite in the breastfeeding the initiation of human relationships takes place, and the model of the child's relationship to the objects of the environment and to the world as a whole is formed.

This early skin to skin breast contact promotes babies ability to react positively to the mother's smell and under the conditions of choice infants reliably determine exactly the mother's milk. They distinguish the mother's voice from others during the first minutes of life. In addition due to the phenomenon of bonding the ability to determine a distance to the mother which provides a sense of relative safety is formed. The criterion of security is the ability to signal your needs effectively with whimpering and receive care promptly [10].

If the mother is outside a certain distance and becomes real or imaginary inaccessible the kid acts according to reflex behavioral scenarios aimed at rapid recovery of intimacy. Fear of losing a mother can cause panic. If the need for intimacy is frustrated too often child anxiety remains at a high level even after restoring it gradually evolving from a situational reaction to a personal trait.

The easiest way to calm a baby is to take it in the arms and clasp it to breast. Even the tiniest children are sensitive to how they are held in the arms. In some cases they cry while in others they quiet down enough. This reflects the quality of bonding. Sometimes babies stop crying even when they hear recording sounds of the working heart, because during antenatal development baby constantly hears blood flow noise in the abdominal aorta and the mother's heart beat. The appearance of positive emotions on the faces of children who during the experiment were 
given the opportunity only to listen to records of sounds most similar to intrauterine ones was described [11].

It should be noted that in the case of separating of the baby with the mother in the first hours after the labour, the phenomena of bonding and imprinting do not arise or manifest partially. Resumption of joint residence after a two-hour separation, under certain conditions, can compensate for the mechanisms of lactation, but violations of the child's self-regulation in this case are irreversible which subsequently affects his mental development. In addition to the neurotic effect on the personality of the newborn, deprivation of contact with the mother during this critical period leads to a deterioration of the visual analyzer, a violation of the process of formation of orientation in space and thermoregulation, and makes the baby more vulnerable. Therefore, a joint declaration of $\mathrm{WHO}$ and the United Nations Children's Fund (UNICEF) was adopted in 1989 which recommends encouraging and supporting the early placing of the baby onto the breast [12].

Babies are very sensitive to the psychological state of their mothers. The development of their mental and motor functions is directly related to a sense of closeness to her. Therefore, in the first months of life the child must necessarily be surrounded by care, even if he is born full-term, somatically healthy and successfully overcame the stress of delivery.

Empirically and as a result of observations M. Ainsworth (1981) distinguished three types of children behavior formed under the influence of communication with the mother.

Type A. Avoid attachment " $A$ " the child continues the game and does not pay attention to either the mother's exit from the room or to her return. The child does not seek contact with her and does not support communication even when the mother starts to make advances to him. Children with this behavior are called indifferent [13].

Type B. Secure attachment "B" the child feels comfortable in the presence of the mother but reacts with anxiety and stops the research activity if it goes. When the mother returns the child looks for contact with her and setting it quickly calms down, continuing the game again.

Type C. Resistant-ambivalent attachment " $C$ " the child worries and cries when mother leaves and reacts positively when she returns but resists attempts to take him in her arms.

Type D. Disorganized attachment " $D$ " child's reaction to the mother appearance with "frozen fright" or flight which is regarded as pathological [14].

If the experiment is impossible since the child is closely watching the mother and does not allow her the slightest attempt to leave the room this is considered a symbiotic type of attachment.

S. Freud believed that the basis of the child's relationship to the mother is the pleasure principle. It is the desire to have pleasantness by satisfying the hunger with mother's milk.

Without rejecting these theoretical postulates, J. Bowlby (1951) came to the conclusion that the dyadic connection is based on the child's need for intimacy with the person who cares for him. This need is a basic one for the devel- opment of the ego, since proximity provides security which allows engaging in research, learning and adapting to new situations [15].

Expressive mothers are able to respond sensitively to signals from the child's body and have a positive effect on babies. They effectively suppress their basal anxiety which is caused by the need for comfort and safety. Feeling confident in their abilities, the child begins carelessly engaged in exploring the world around him, learning, adapting to new realities. Based on a sense of his own safety, the baby gradually increases the distance to which his mother quietly lets go. He begins to act more independently, not afraid to experiment. In later life, this becomes the basis for the development of such personal traits as self-confidence, openness to the new, courage and self-sufficiency.

Incorrect organization of care at the early postpartum period can create a chronic psychotraumatic situation. It prevents the overcoming of separation anxiety. The sense of insecurity makes it necessary to direct the main activity to attempts to restore affinity. The result can be a violation of the process of adaptation, deviation and delay of psychomotor development.

Communication with rigid mothers who reluctantly take children in their arms and hide their emotions ("mothers with wooden faces") interferes with the development of the child's mental functions. Secure attachment "B" is not formed in such babies. This does not allow them to explore the surrounding world to the full extent and learn it. They look sad, lethargic or, on the contrary, excessively excitable. Not reaching the age of one year such children differ because they show less positive, vivid emotions, look too immersed in themselves, have difficulty concentrating and low level of general activity.

Neurotic due to lack of emotional contact from the mother they form patterns of behavior that can additionally negatively affect the depressive symptoms of the mother herself. A system of mutual negative impact is formed [16].

The findings on the impact of emotional contact with mom on the mental development of infants have questioned the validity of the once popular behavioral approach to upbringing. Based on the principles of the theory of operant conditioning behaviorists called for ignoring the importance of non-verbal forms of communication between infants and adults for the development of cognitive functions. These views have a great influence on pedagogy and many mothers have implemented the recommendations "not to teach the children to the hands", because this kind of slows down the research activity of the child. The results of this approach, unfortunately, were the opposite of desired.

Dyad "mother-child" continues to exist until the child has self-consciousness. The realization that mom exists separately occurs within the process of self-consciousness development, called E.S. Fromm (1961) individualization. It comes gradually, in part, because of the experiences of prohibitions in the process of upbringing. Collision with frustration helps transform the assessment of the role of the mother. The child comes to realize that his desires do 
not always coincide with his own aspirations. And sometimes the mother even turns into a hostile and dangerous force. This antagonism becomes an important factor in understanding the difference between "I" and "You" as a stage in the formation of independence, independence from the mother.

The situation of the parents negative attitude to children is dangerous for their mental development. Unwanted children are born prematurely about eight times more often than desirable. But even in the case of prematurity, half of them have signs of morphofunctional immaturity, which often causes the need for intensive care of somatic and neurological complications [17].

Difficulties of dialogue with the child arise if he does not justify the hopes pinned on him by the parents. Upbringing in this case, as a rule, is carried out by the type of hypoprotection, against the background of emotional coldness in the relationship.

Many signs indicate a relationship with a child in the family. Even the choice of a name is sometimes very informative. It can reflect the ambitions of parents, for example, their discontent with the sex of the child.

The most critical is the combination of undesirability of the child in general and undesirability by gender. This is especially true of the second child in the family. Emotionally rejected babies cry a lot, sleep poorly and need a dummy or a nipple for calming, they have a painful tendency to suck their fingers, later they have a habit of nibbling nails, hair, manipulating their own genitals. Inadequate parenting makes them disturbing, asexual, and rejected by peers of infantile-dependent neurotics [18].

Gained psychotrauma spreads its influence far beyond the perinatal period and determines scenarios of social adaptation throughout life. Growing up such children differ in suspicion, pessimism, paranoia, ironic sarcastic, a tendency to envy and ill-will, have an underestimated self-esteem, experience great difficulties in establishing interpersonal relationships. They find it difficult to choose a profession and create a family, and in sexual life they are prone to painful masturbation and other sexual perversions. In relation to their own children they are distinguished by the same stiffness and coldness that their parents gave them at the time [19].

\section{CONCLUSIONS}

The main task of the perinatal psychologist is to identify possible scenarios of disharmonious development in proper time, to prevent them and help to solve them constructively.

\section{REFERENCES}

1. Abramchenko V.V., Kovalenko N.P. Perinatalnaya psihologiya: Teoriya, metodologiya, opyit. Kyiv: Svichado; 2004. 349p.
2. Abramchenko V.V. Psihosomaticheskoe akusherstvo. Saint Petersburg: Sotis; 2001. 320p.

3. Avdeeva N.N., Meshherjakova S.J., RazhnikovaV.G. Psykholohiia vashoho nemovliaty. Kyiv: Osnova; 2006. 384p.

4. Argajl M. Psykholohiia shchastia. Kyiv: Ranok; 2010. 272p.

5. Batuev A.S. Psihofiziologicheskaya priroda dominantyi materinstva. Psihologija segodnja. 1996; 4: 69-70.

6. Brutman V.I., Radionova M.S. Formirovanie privyazannosti materi k rebenku v period beremennosti. Voprosy psihologii. 1997; 6: 38-47.

7. Jejdemiller J., Justickis V., Gorodnova M., Kulakov S., Aleksandrova N., Nikol'skaja I., Dobrjakov I., Makarova 0., Chaeva S. Sistemnaya semeynaya psihoterapiya. Saint Petersburg: Piter; 2002. 368p.

8. Herasymenko L.O. Psykholohichni aspekty zachattia. Praktikujuchij likar. 2017; 3: 45-51.

9. Luk'janova 0.M., Kachalina T.S., VolovikV.M. Perinatalnaya psihologiya: Hrestomatiya. Saint Petersburg: Piter; 2002. 476p.

10. Ovcharova R.V. Psihologicheskoe soprovozhdenie roditelstva. Moscow: Izdatelstvo Instituta Psihoterapii; 2003. 211p.

11. Sokolova 0.A. Mozhlyvist vplyvu emotsiinykh podii u zhytti materi pid chas vahitnosti na formuvannia dominuiuchykh staniv dytyny. Perinatal'na psihologija ta psihologija bat'kivstva. 1996; 5: 49-55.

12. Skrypnikov A.M., Herasymenko L.0., Isakov R.I. Perynatalna psykholohiia. Kyiv: Vidavnichij dim Medkniga; 2017. 168p.

13. Skrypnikov A.M., Herasymenko L.0., Isakov R.I. Zhinka i perynatalna vtrata. Praktikujuchij likar. 2017; 4: 33-38.

14. Tsaregradskaja Z.V. Rebenok ot zachatiya do goda. Moscow: Astrel'; 2005. 281p.

15. Chopra D., Sajmon D., Abrams V. Beremennost i rodyi. Volshebnoe nachalo novoy zhizni. Moscow: Sofija; 2008. 304p.

16. Bibring G. Some Considerations of the Psycological Processes in Pregnancy. Psychoanalytic Study of the child. 1959; 14: 113-121.

17. Bowlby J. Child care and the grouth of love. London: Pelican Original. 1987. 254p.

18. Deutsch H. The psychology of women. New York: Grune \& Stratton. 1995. $413 p$.

19. Douglas E.M., Straus M.A. Assault and injury of dating partners by university students in 19 countries and its relation to corporal punishment experienced as a child. European Journal of Criminology. 2006; 3: 293-318.

Conflict of interest:

The Author declare no conflict of interest

\section{CORRESPONDING AUTHOR Larysa 0. Herasymenko \\ Ukrainian Medical Stomatological Academy \\ 1 Medychna Str., Poltava 36013, Ukraine \\ e-mail: larysaherasymenko@gmail.com}

Received: 17.10 .2018

Accepted: 05.01.2019 
PRACA POGLADDOWA

REVIEW ARTICLE

\title{
ENSURING THE CONTINUITY OF MEDICAL CARE AT THE STAGE OF PATIENTS REHABILITATION
}

\section{ZAPEWNIENIE CIĄGŁOŚCI OPIEK\| MEDYCZNEJ U CHORYCH PODDAWANYCH REHABILITACJI}

\author{
Oleksandr Sarkanich, Olena Shevtsova, Ozar Mintser \\ SHUPYK NATIONAL MEDICAL ACADEMY OF POSTGRADUATE EDUCATION, KYIV, UKRAINE
}

\begin{abstract}
The problems of ensuring continuity of medical care are considered. Information and cybernetic issues of continuity, in particular information standards, resource management systems of a medical institution, are analyzed. It emphasizes the need to develop standards for the continuity of care. It is concluded that long-term continuity of medical measures in rehabilitation is one of the main components of the effectiveness of medical care. Further qualitative research is needed, including some types of rehabilitation services (e. $\mathrm{g}$. specialized medical care). At the same time the most important factors for ensuring continuity at the current stage of medicine development are the use of ontologies, representing the most general conceptual concepts of the modeled field of medicine, completely abstracted from specific models of knowledge representation and practical implementation. It is also shown that the specification of the patient management model in the rehabilitation period of treatment is provided by a wide application of telemedicine consultations. The index of continuity of medical aid is also proposed. It represents a simple additive function that reflects the change in the probability of an unfavorable outcome.
\end{abstract}

KEY WORDS: continuity of medical care, accessibility of medical care, quality of medical care, information standards of continuity of medical care, quantitative characteristics in the evaluation of continuity of care, knowledge ontology, telemedicine

Wiad Lek 2019, 72, 2, 275-278

\section{INTRODUCTION}

According to the today's point of view on the providing of medical care, physical rehabilitation plays a significant role. Its particular importance lies in the maintenance and restoration of body function, the prevention of possible recurrences of the pathological process and the avoidance of complications.

At the same time, due to a certain fragmentation of the treatment (especially in case of sudden exacerbations of the disease), rehabilitation is usually carried out individually according to individual clinical disciplines without substantial or even formal coordination. It is important to underline that most international studies emphasize a rather high level of problems associated with the coordination of medical care in real conditions when many specialists involved in the treatment of one patient. The growing interest among rehabilitation specialists in the development of policies conducive to continuity and succession of rehabilitation assistance is consistent with international efforts to maintain and strengthen continuity in the health care system in general. However, despite the growing interest, research on the continuity of rehabilitation assistance is extremely insufficient $[13,14]$.

\section{THE AIM}

The aim of this study is to formalize the definitions, procedures and conclusions in the problem of medical care continuity.

\section{REVIEW AND DISCUSSION}

Let's discuss the conceptual basis of the medical care continuity first. Usually, under these terms coordination of activities in the process of providing the patient with medical care at different times by various specialists and medical institutions is understood. A simplified approach largely links the continuity in the providing of medical care with standard requirements for medical documentation, technical equipment, process and personnel. It is assumed that such coordination of the health workers activities guarantees the stability of the treatment process and its result $[19,5]$.

However, in reality, the continuity of medical activity, as a rule, is not ensured by this. Note that the concept of "coordination" is poorly defined. It does not contain quantitative parameters and is understood by different authors and the majority of physicians in different ways.

In addition, continuity is strongly influenced by accompanied factors, such as the medical care availability, medical errors in diagnostic and therapeutic procedures, etc.

Under the continuity we will understand such a sequence of actions of doctors in which the probability of an adverse outcome of the pathological process or possible complications does not increase at least. We have previously discussed a similar approach in clinical medicine $[2,6]$. 
It is quite obvious that in order to achieve continuity of medical care it is necessary to fulfill many other conditions.

The first factor that affects the continuity is the availability of medical care. It is the most important condition for the medical care providing to the population in all countries of the world, reflecting both the economic capabilities of the state as a whole and the capabilities of a particular person. Unfortunately, universal and equal access to all types of medical services is not ensured anywhere. This kind of approach to the use of limited resources is called rationing and is practiced to varying degrees in all countries of the world.

Defects in the quality of medical care have a strong effect on the medical care continuity. According to the international statistics, the most significant causes of defects in the work of doctors are insufficient qualifications of medical workers, inadequate examination of patients, inattention to the patient, limitations in the medical process organization, underestimation of the patient's condition severity $[4,5]$. Note that, according to some data, defects in the medical care organization make up at least $15 \%$ of all defects in medical care [15].

Another factor in ensuring continuity is the medical care continuity. The most important role in its control play the information mechanisms. Therefore, to ensure continuity in international practice, a corresponding standard was created, which was called the CCR (Continuity of Care Record) [19]. In general, the CCR has data that includes two large clusters: a patient's health summary (e.g., diagnosis, medications, allergies) and basic insurance information. In addition, identification data and the target of the CCR are included. More detailed information about the standard is as follows. The standard has six sections and the following obligatory elements. These are 6 sections: heading; patient's identification (demographic and administrative data); patient's financial and insurance information; the patient's health condition (providing as a snapshot that contains the relevant clinical data); care documentation; service plan recommendations. At the same time, this standard may present some difficulties in the implementation of interdisciplinary and transdisciplinary approaches $[8,10,16]$.

CCR can be obtained on paper or electronically. XML coding used in electronic transmission provides some flexibility by allowing users to prepare, transmit and view CCR in several ways, for example in a browser, as a Health Level 7 (HL7) element; message as a PDF file, either as an HTML file, or as a document for text processing. Naturally, data protection is provided.

It is worth to note that the formalization of the patient's condition data and recommendations for its further management is clearly insufficient. As a result, it was noted that the transfer of information between doctors who provide continuous and successive medical care, has a number of problems. It is revealed that therapists and resuscitators in the majority note the insufficiency or even absence of patient's data regarding previous health problems $[7,18]$.

For example, research in the field of primary health care refers to "accumulated knowledge" and "flexibility" as corresponding factors of both information continuity and continuity of management, but it is impossible to recreate a complete clinical picture. The concept of "flexibility" of the data presented is particularly confusing. It is worth to emphasize the absence of the concept of clinical information "completeness".

It can be argued that the existing (or planned) informatization of health care system will let to provide complete information for the actual implementation of the medical care continuity in a real life. Never the less, this is true only to a certain extent. As part of the "E-Health" strategy, it is really possible to obtain a lot of information regarding the previous periods of the diagnostic and therapeutic process in this patient. However, it is extremely difficult to ensure individualization of actions (as a rule, non-directional reaction of the patient's body), to guarantee a personalized sequence of procedures, especially during the rehabilitation period when exposed to a new set of factors.

We have proposed to use ontologies of knowledge in ensuring the continuity of medical care. As is known, ontologies are a way of knowledge representation. The most common model for the representation of ontologies and complexly structured data are semantic networks $[1,11,12]$. As a rule, the ontology of knowledge allows you to collect and systematize data about patients, make recommendations for additional examinations, draw conclusions about the possible causes of the disease, make recommendations about the methods and means of treating, monitor the patient's state and evaluate the efficacy of received therapy. It is important that by creating an "individual" ontology, it is possible to provide a rehabilitation specialist with reference information about the features of the pathological process, about food products and drugs used in its treatment. Moreover, on the basis of data about a particular person (anthropometric data, a list of diseases and problems related to his health and well-being, his goals), it is possible to rationale the most appropriate types of physical activity, diet, restorative or preventive procedures. In addition, the giving of directional reference information on rehabilitation complexes, their indications and contraindications is provided.

A number of studies emphasize the idea that successful rehabilitation is associated not only with such factors as trust and comfort, but also with the need to establish communication with attending physician directly during the rehabilitation period. The presence of established relationships between the attending physician and the patient increased the feeling of comfort among the participants and ensured an effective connection between past and current interventions.

Regarding this, we consider it extremely important to achieve the use of telemedicine consultations in the process of rehabilitation of patients. The innovative goal of this process is the correction of information modeling processes of the pathological process based on ontological models. The technological basis for telemedicine counseling can be the Internet. We emphasize that the favorable conditions for communication between the attending 
physician and the rehabilitation specialist are ensured by the fact that the connection does not require a long time, and the intellectual basis of the interaction is the standard of medical knowledge HL7 [3].

Let us also dwell on the quantitative characteristics of the continuity of medical care. Continuity is one of the main factors determining the administrative, demographic and clinical aspects of health care.

Regarding this, numerous indices reflecting this factor have been proposed $[16,17]$. Among them, we call only the traditional patient care (TPC) (the original equivalent of the usual provider of care (UPC)), representing the ratio of the frequency of visits by the patient to the attending (family) doctor to the total number of visits. According to the literature, the TPC median is $56(\mathrm{SD}=9.5$, range $43-75)$.

An interesting is the index that determines the ratio of prescriptions of the attending physician and other medical specialists - PPM (the original equivalent is continuity for physician $(\mathrm{PHY}))$. The PPM median is $55(\mathrm{SD}=8.6$, range 37-63).

The index of continuity of care by narrow specialists (CCNS) (the original equivalent is the continuity of care index (COCI)) is also proposed. Of course, it is lower than the TPC. Moreover, the results fall with an increase in the number of narrow specialists and, as a rule, is below other indicators of continuity. The median according to the literature is $30(\mathrm{SD}=17$, range 11-56).

Modified modified continuity index (MMCI)) assesses the ratio of the total number of doctors visited by the patient and the total number of visits. Of course, its value is slightly higher than the TPC. According to the literature, the MMCI median is 59 ( $\mathrm{SD}=12.9$, range $43-76)$. It is worth to emphasize that all the listed indices do not have a direct relationship to either continuity or succession. Regarding this, we have proposed the index of medical care continuity. It is a simple additive function, reflecting a change in the likelihood of an adverse outcome.

A preliminary study of the effectiveness of this approach was performed. The value of probability was made on the basis of Wald sequential statistical analysis.

It turned out that in most cases the index retains at least a small but negative value (the median is $-15, \mathrm{SD}=8.7$, the range is $(-10)-(-21)$, which indicates that the problems of continuity of medical care are not leading for the doctors.

\section{CONCLUSIONS}

1. The long-term continuity of treatment measures in rehabilitation is one of the main components of the of medical care efficacy. Further qualitative research is needed, including some types of rehabilitation services (for example, specialized medical care).

2. The most important factor in ensuring continuity at the present stage of medicine development is the use of ontologies, that represents the most common conceptual concepts of the modeled field of medicine, completely abstracted from specific models of knowledge representation and practical implementation.
3. Specification of the patient management model in the rehabilitation period of treatment is provided by the wide use of telemedicine consultations.

4. The index of continuity of medical care is proposed. It is a simple additive function, reflecting a change in the likelihood of an adverse outcome.

\section{REFERENCES}

1. Gavrilova T. A., Horoshevskij V. F. Bazy znanij intellektual'nyh system [Intelligent systems knowledge base]. St. Petersburg: Piter. 2001.[In Russian].

2. Mintser 0. P., Kharyk N. V., Yarmenchuk I. A. Do pitannja kil'kisnogo ocinjuvannja nastupnosti medichnoi dopomogi [To the question of quantitative estimation of succession of medical care]. Medichna informatika ta inzhenerija (Medical Informatics and Engineering), 2011; 4: 8-11. [In Ukrainian].

3. Mintser 0. P., Matjuha L. F., Carenko A. V. et al. Model' pokrashhennja dostupnosti ta jakosti medichnoi dopomogi sil's'komu naselennju z zastosuvannjam telemedichnih tehnologij [Model improving the accessibility and quality of medical care to rural populations using telemedicine technologies]: guidelines. Kyiv; Ivano-Frankivs'k: Vasyl Stefanyk Precarpathian National University Publ. House. 2012. [In Ukrainian].

4. Ocenka zarubezhnyh sistem zdravoohranenija: chastnye mnenija i indeks potrebitelej medicinskih uslug [Assessment of foreign health systems: private opinions and the index of consumers of health services]. Voprosy jekonomiki i upravlenija dlja rukovoditelej zdravoohranenija (Issues of economics and management for health managers), 2008; 2(77): 23-26. [In Russian].

5. Ocenka kachestva zdravoohranenija SShA [US Health Quality Assessment]. Voprosy jekspertizy i kachestva med. pomoshhi (Questions of expertise and quality of care), 2008; 2(26), 61-64. [In Russian].

6. Kharyk N. V., Banchuk M. V. Informacijni problemi zabezpechennja nastupnosti medichnoi dopomogi [Information security problems of succession of medical care]. Medichna informatika ta inzhenerija (Medical Informatics and Engineering), 2012; 1:49-51. [In Ukrainian].

7. Medina-Mirapeix F., Oliveira-Sousa, S. L., Escolar-Reina P. et al. Continuity of care in hospital rehabilitation services: a qualitative insight from inpatients' experience. Braz J. Phys. Ther., 2017; 21(2):85-91. doi: 10.1016/j.bjpt.2017.03.002

8. Haggerty J. L., Reid R. J., Freeman G. K. et al. Continuity of care: a multidisciplinary review. BMJ, 2003); 327(7425): 1219-1221. doi: 10.1136/bmj.327.7425.1219.

9. Walker J., Payne B., Clemans-Taylor B. L. et al. Continuity of care in resident outpatient clinics: a scoping review of the literature. J. Grad. Med. Educ., 2018;10(1):16-25. doi: 10.4300/JGME-D-17-00256.1.

10. Cowie L., Morgan M., White P. et al. Experience of continuity of care of patients with multiple long-term conditions in England. J. Health Serv. Res. Policy, 2009;14(2): 82-87. doi: 10.1258/jhsrp.2009.008111.

11. Gruber T. Toward principles for the design of ontologies used for knowledge sharing. International Journal of Human-Computer Studies, 1995; 43(5-6): 907-928.

12. Guarino N. Formal ontology in information systems. In Guarino N. (Ed.). Formal ontology in information systems. Proceedings of F0IS'98, Trento, Italy, June 6-8, 1998: p. 3-15. Amsterdam: IOS Press.

13. Gutenbrunner C., Chamberlain A. C., Ward T. B. White book on physical and rehabilitation medicine in Europe. J. Rehabil. Med., 2007; 39(45 Suppl.): 1-48. 
14. Beattie P., Dowda M., Turner C. et al. Longitudinal continuity of care is associated with high patient satisfaction with physical therapy. Phys. Ther., 2005; 85(10):1046-1052.

15. WHO. (2018, July 5). Low quality healthcare is increasing the burden of illness and health costs globally. News Release: Geneva. Retrieved from: http://www.who.int/news-room/detail/05-07-2018-low-qualityhealthcare-is-increasing-the-burden-of-illness-and-health-costsglobally

16. Magill M. K., Senf, J. A new method for measuring continuity of care in family practice residencies. J. Fam. Pract., 1987; 24(2): 165-168.

17. Rogers, J., Curtis, P. The concept and measurement of continuity in primary care. Am. J. Public Health., 1980; 70(2): 122-127.

18. Saultz J. W. Continuity of care. In Saultz J. W. (Ed.). Textbook of Family Medicine. New York, NY: McGraw-Hill. 2000: p. 52-77.

19. Ferranti J. M., Musser R. C., Kawamoto K. The clinical document architecture and the continuity of care record: a critical analysis. J. Am. Med. Inform. Assoc., 2006; 13(3):245-252. doi:10.1197/jamia.M1963.

\section{Authors' contributions:}

According to the order of the Authorship.

\section{Conflict of interest:}

The Authors declare no conflict of interest.

\section{CORRESPONDING AUTHOR} Oleksandr Sarkanich

Shupyk National Medical Academy

of Postgraduate Education

Dorohozhytska St., 9, 04112 Kyiv, Ukraine

e-mail: t.duxowi41992@gmail.com

Received: 02.11 .2018

Accepted: 30.01 .2019 
PRACA POGLADDOWA

REVIEW ARTICLE

\title{
THE RIGHTS OF SURGEONS WHILE WORKING WITH HIV-INFECTED PATIENTS IN UKRAINE
}

\section{PRAWA LEKARZY CHIRURGÓW LECZĄCYCH PACJENTÓW Z WIRUSEM HIV NA UKRAINIE}

\author{
Anatolii T. Komziuk ${ }^{1}$, Dmytro M. Velichko ${ }^{1}$, Volodymyr S. Goshovskyi ${ }^{3}$, Valentyna A. Goshovska ${ }^{4}$, Olena V. Klymenko ${ }^{2}$ \\ 1 KHARKIV NATIONAL UNIVERSITY OF INTERNAL AFFAIRS, KHARKIV, UKRAINE \\ ${ }^{2}$ KRYVYI RIH NATIONAL UNIVERSITY, KRIVYI RIH, UKRAINE \\ ${ }^{3}$ OLES HONCHAR DNIPRO NATIONAL UNIVERSITY, DNIPRO, UKRAINE \\ ${ }^{4}$ NATIONAL ACADEMY FOR PUBLIC ADMINISTRATION UNDER THE PRESIDENT OF UKRAINE, KYIV, UKRAINE \\ ${ }^{5}$ TAVRIDA NATIONAL V.I. VERNADSKY UNIVERSITY, KYIV, UKRAINE
}

\begin{abstract}
Introduction: Surgeons that are working with HIV-infected patients in Ukraine are in a vulnerable state due to the lack of special regulation of this issue in labor, medical law and labor contract, as well as the spread of HIV among the population of the country.

The aim of this article is to determine and uncover the content of the rights of surgeons while working with HIV-infected patients in Ukraine.

Materials and Methods: The research materials of the rights of the surgeons that are working with HIV-infected patients consist of national legislation, official explanations of the Social Insurance Fund of Ukraine, statistics on HIV infection. The research methods that have been used are cross-sectoral, complex statistical, analysis and synthesis. In order to obtain the results of the research the norms of medical, labor and civil law have been analyzed.

Review: The authors of the article have emphasized and described the rights of surgeons that are working with HIV-infected patients.

Conclusions: It has been proved that the current system of surgeons' rights needs to be improved. It has been offered: to establish, at the legislative level, the responsibility of the patient with HIV infection to warn a medical employee about his infection in case of surgery or other medical manipulation that leads to contact with blood or other biological materials; to revise and significantly increase the payment of obligatory insurance of surgeons, if they are infected by a patient with HIV infection.
\end{abstract}

KEY WORDS: rights of surgeons, HIV infected patients, performance of professional duties, work-related disease, obligatory insurance

\section{INTRODUCTION}

The rights of surgeons, while working with HIV-Infected patients, is an element of the hygiene system and labor provision. The purpose of this article is to find out the specifics of the protection of the rights of surgeons in working with HIV-infected patients in Ukraine. The research of this problem is caused by the actual HIV prevalence among the Ukrainian population. Thus, in the four months of 2018, according to the data of the Center of Public Health of the Ministry of Health of Ukraine, 5,764 new cases of HIV infection were registered (783 of them are children to 14 years old). Since 1987, 321,382 new cases of HIV infection have been officially registered in Ukraine, 46,024 people died from AIDS in Ukraine [1]. In the world as of 201719.5 million people with HIV were registered [2]. Every year, about $1 \%$ of people with confirmed positive results are among those who surveyed for HIV in Ukraine [3] Meanwhile in Ukraine the surgeon is not entitled in refusing treatment or surgical intervention for such persons, as this is prohibited by Art. 16 of the Law of Ukraine "On prevention of diseases caused by Human Immunodeficiency Virus (HIV), and legal and social security of people living with HIV" [4]. In addition, there is no obligation for the patient to report his or her positive status. Therefore, the surgeon during the medical manipulations and operations is constantly in a state of risk, in particular, HIV infecting. The evidence of this is the following facts: in the world there were 350 cases of professional HIV infections registered. In Ukraine, from 1987 to 2013, three cases of medical workers HIV infections were officially registered (1 case before 1997, 1 in 2004, 1 in 2005), which is 2.1 per 100 thousand of the corresponding professional group [5]. So, the risk of surgeons' infection is constant, since the risk of infection after the wound contact with HIV-infected blood is approximately $0.3 \%$ ( $95 \%$ confidence interval (CI): $0.2-0.5 \%$ ). The risk of infection after HIV-infected blood contact with intact mucous membranes is approximately 0.09\% (95\% CI: $0.006-0.5 \%$ ) [6]. Additional negative factor of the surgeon's work in Ukraine is the low salary, which sometimes does not justify all the risks of the profession. Although, the average salary level has been recently increased significantly. For example, according to statistics in May 2018, the average salary 
was $12,500 \mathrm{UAH}$ [7], which is approximately $450 \$$. The average salary of a surgeon in the United States as of October 31, 2018 is $380,736 \$$, but the average range is usually from $321,978 \$$ to $451,875 \$$. Salaries can vary widely, depending on many important factors, including education, certificates, extra skills and the work experience [11]. The salary of a surgeon, when considering the legal relationship with the participation of a surgeon and an infected patient, acts as one of the safety factors of the surgeon, since the material support of the medical worker is a possibility factor of further personal treatment in case of HIV infection from the patient. Thus, surgeons in Ukraine when working with HIV-infected patients are in a vulnerable state. To overcome it, it is necessary to clearly define at the legislative level the system of the rights of surgeons in working with $\mathrm{HIV}$-infected patients.

\section{THE AIM}

The objective of this article is to define and reveal the content of the rights of surgeons while working with HIV-infected patients in Ukraine, taking into account the provisions of the current medical, civil, labor legislation, as well as statistical data on occupational diseases of Ukrainian surgeons, when dealing with this category of patients. The tasks of the article are to characterize the rights of surgeons while working with HIV-infected patients, to find out the perspectives for their further study and to suggest the ways to improve legislation in this area.

\section{MATERIALS AND METHODS}

The research materials of the rights of the surgeons that are working with HIV-infected patients consist of national legislation, official explanations of the Social Insurance Fund of Ukraine, statistics on HIV infection. The research methods that were used are cross-sectoral, complex statistical, analysis and synthesis. In order to obtain the results of the research the norms of medical, labor and civil law have been analyzed.

\section{REVIEW AND DISCUSSION}

In modern medical law, surgeons in Ukraine are no different in rights compared to other medical workers, which declared in the Art. 77 of the Law of Ukraine "Fundamentals of Health Care Legislation" [9]. Analyzing the rehabilitation rights of surgeons that are working with HIV-infected patients, following should be mentioned: 1) the right to proper conditions of professional activity; 2) the right to free choice of tested forms, methods and means of activity, introduction, in accordance with the established procedure, of modern advances in medical and pharmaceutical science and practice; 3 ) the right to free use of social, environmental and special medical information that is necessary for the performance of professional duties; 4) the right to receive payments in case of HIV infection while performing professional duties; 5 ) the right to protect their personal non-property rights (honor, dignity) and property rights (right to compensation, etc.).
The right to provide individual protection while working with HIV-infected patients is defined in the Typical instruction on the use of personal protective equipment by workers who carry out diagnostic tests for HIV infection, provide medical care and social services to people living with HIV or who are in contact with blood either other human biological materials, contaminated tools, equipment or objects [10]. In particular, chiefs of health facilities should provide medical staff and other staff with personal protective equipment such as bathrobes, gloves, safety glasses, etc. In this case surgeons are obliged to use them. The right to provide individual protection is based on the fact that the life and health of a person, as well as a surgeon while performing his professional duties, is protected by thelaw in accordance with the Art. 3 of the Constitution of Ukraine, which determines that a person, his life and health, honor and dignity, inviolability and security are recognized in Ukraine as the highest social value [11].

The right of a surgeon to choose methods and means of action is implemented in accordance with the established order of modern advances in medical and pharmaceutical science and practice. This right has certain limitations in the form of rights and interests of patients, in particular the treatment may be appointed after its agreement with the patient. Surgeons in nowadays are facing more ethical dilemmas than before, due to the growth of scientific knowledge, increased availability and effectiveness of medical technologies, more equal relationships between patients and surgeons. The growth of scientific knowledge and technologies has provided surgeons with new and better diagnostic equipment and treatment options [12]. The choice of treatment for an HIV-infected patient should be based on the patient's interests, and only then on his own safety.

The right to receive medical information in the treatment of a patient with HIV is based on the fact that a medical worker has the right to receive information about the results of a person's testing for the detection of HIV in connection with the treatment of this person (Part 4 of Article 13 of the Law of Ukraine "On prevention of diseases caused by Human Immunodeficiency Virus (HIV), and legal and social security of people living with HIV" [4]). The patient has the right not to warn the doctor about his condition, as in accordance with Part 1 of Art. 12 of this Law, but people living with HIV are obliged: 1) to take measures to prevent the spread of HIV infection, proposed by health authorities; 2) to inform the persons who were their partners before the fact of infection about the possibility of their infection; 3 ) to refuse donations of blood, its components, other biological fluids, cells, organs and tissues for their use in medical practice [4]. Thus there is no direct obligation for a person living with HIV to warn about his health condition. It may be reasonable to expand the list of these responsibilities. For example, Part 1 of the Art. 12 should be added with the fourth paragraph, for example: "To warn of about the possibility of infection of a health worker in case of surgery or other medical manipulations leading to blood or biological materials contact".

There is also the right to receive payments in case of surgeon's infection with HIV while performing their professional duties. The Article 22 of the Law of Ukraine "On prevention of diseases caused by Human Immunodeficiency Virus (HIV), and legal 
and social security of people living with HIV" [4] determines that the HIV infection by a surgeon while performing his professional duties belongs to work-related diseases. According to the List of Work-related Diseases, approved by the Cabinet of Ministers of Ukraine on November 8, 2000, No. 1662, the AIDS disease is classified as a disease caused by the action of biological factors in the case of contact with infectious patients, infected materials or carriers of diseases in medical institutions [13].

Work-related disease is a disease that arose as a result of the professional activity of the insured and is determined exclusively or mainly by the influence of harmful substances and certain types of work and other factors related to the work (paragraph 7, Part lof the Art. 1 of the Law of Ukraine "On Mandatory state social insurance") [14]. Cases of work-related infectious diseases and other chronic professional intoxications are being investigated as chronic work-related diseases (Part 3, paragraph 63 of the Procedure for the Investigation and Accountability of Accidents, Work-related Diseases and Accidents at Work) [15]. Each case of a work-related infectious disease of a surgeon requires an investigation that is specifically created by a employer commission, which includes a representative of the sanitary and epidemiological service. Before the beginning of the investigation, it is necessary to establish the final diagnosis and connection of the disease with the influence of harmful factors of the production environment and labor process. This is done by the occupational therapist of the region. In addition, the level of sustainable loss of professional ability is established on the basis of the conclusion of the medical and social expert commission. A medical report of a medical-expert commission of a specialized occupational pathology treatment-preventing institution about the presence (absence) of a work related disease (paragraph 72 of the Procedure for the Investigation and Accountability of Accidents, Work-related Diseases and Accidents at Work) is issued to the employee on a receipt. [15]. As a result of the investigation an act of investigation of a chronic occupational disease is compiled, also the employer makes an act about the causes of work-related infectious disease. On the basis of these acts, the employer is obliged to give a five-day period an order to take measures to prevent the occurrence of work-related diseases and to bring to the responsibility the offenders of violations of sanitary norms and rules that led to the emergence of a work-related disease.

While investigating the infection of a surgeon with HIV while performing his professional duties, it must be established that there is a link between the infection of the surgeon with HIV and the fulfillment of his professional duties, in accordance with the Procedure of confirming the connection of the infection with the HIV with the performance of the worker's professional duties approved by the order of the Ministry of Health of Ukraine dated March 17, 2015, No. 148 [16]. This Order applies to health care providers who provide medical care and are subjects of mandatory state social insurance in accordance with the Law of Ukraine "On Mandatory state social insurance" [14] and mandatory insurance against infection with HIV while performing their official duties in accordance with the Resolution of the Cabinet of Ministers of Ukraine of 16 October 1998 No. 1642 "On Approval of the Procedure and Conditions for Mandatory Medical Insurance of medical workers and other persons in case of HIV infections while performing their professional duties, as well as in case of occurrence of disability or death due to diseases caused by the development of HIV infection, and the list of categories of medical workers and other persons, which are subjects of mandatory insurance in case of HIV infection while performing their professional duties, as well as in case of the onset of disability or death from illnesses caused by the development of HIV infection" [17]. From the above, it follows that establishing of a connection between the infection of a surgeon with HIV while performing his professional duties is possible only if the following conditions exist: 1) the surgeon must work in a health care institution; 2) the surgeon has a mandatory state social insurance; 3 ) the case of infection occurred during the performance of work-related duties. Establishment of the relation of infection with HIV is carried out by the commission of the institution of health care, scientific institutions, enterprises, which concludes on this fact. A decision to confirm the connection of HIV infection with the employee's performance of his professional duties is taken by the regime committee in three, six and twelve months, in the presence of a certificate of positive results of confirmatory researches for the presence of antibodies of HIV [16].

Confirmation of the fact of this connection provides an opportunity to assert the existence of a work-related infectious disease, which is the basis for receiving compensation. In this case, the Art. 9 of the Law of Ukraine "On Labor Protection" will be used for a compensation for damage in the event of damage to the health of workers or in the event of their death [18]. Compensation for damage in case of establishing the fact of work-related disease is carried out by the expense of social insurance payments made by the Social Insurance Fund of Ukraine. Insurance payments consists of: 1) insurance payment of lost earnings (or the corresponding part), depending on the degree of loss of victims of professional disability; 2) the insurance payment in the established cases of one-time assistance to the victim (his family members and those who were dependent on the deceased); 3) insurance payments to a child born as a disabled person as a result of a professional illness of her mother during pregnancy; 4 ) insurance costs for medical and social assistance [19]. Another form of payments to an infected surgeon is the payments of an employer at the expense of the legal entity's own funds in accordance with a collective or employment contract (Part 2 of the Art. 9 of the Law of Ukraine "On Labor Protection" [18].) This method is exclusively discretionary, thus it is implemented on voluntary basis by the employer and may be considered as additional. In accordance with paragraph 2, Part 1 of the Art. 7 of the Law of Ukraine "On Insurance", personal insurance of medical workers (except for those who work in institutions and organizations financed from the State Budget of Ukraine) in case of infection with HIV during performing their official duties is mandatory [20]. Insurers are paying insured sums: a) in case of death of the employee from diseases caused by the development of HIV infection due to infection with HIV during the performance of his professional duties - in the amount of ten-year salary of the deceased for his last position held; $b$ ) in the case of recognition of an employee with a disabled person as a result of the infection with the human immunodeficiency 
virus during his professional duties: I group - in the amount of 100 non-taxable minimum incomes of citizens; Group II - in the amount of 75 non-taxable minimum incomes of citizens; Group III - in the amount of 50 non-taxable minimum incomes of citizens; c) in case of temporary disability of the employee as a result of the infection with the human immunodeficiency virus during the performance of his duties - for every day 0,3 non-taxable minimum incomes of citizens, but not more than 50 non-taxable minimum incomes of citizens for all time of temporary disability during the course of action of the mandatory insurance agreement; $d$ ) in the case of a person infected with a human immunodeficiency virus during performance of his professional duties - in the amount of 50 tax-free minimum incomes of citizens (paragraph 10 of the Procedure and Conditions of Mandatory Medical Insurance of medical workers and other persons in case of HIV infections while performing their professional duties, as well as in case of occurrence of disability or death due to diseases caused by the development of HIV infection, and the list of categories of medical workers and other persons, which are subjects of mandatory insurance in case of HIV infection while performing their professional duties, as well as in case of the onset of disability or death from illnesses caused by the development of HIV infection ) [17]. If we analyze the mandatory insurance payments, then we understand that their size is too low, since the cost of a surgeon's harm in case of HIV infection from a patient is significant. Therefore, the size of the payment of mandatory insurance of surgeons needs to be reviewed and significantly increased.

The right of a surgeon to protect his personal non-property and property rights arises in the case of their violation. In accordance with Part 1 of the Art. 15 of the Civil Code of Ukraine: Every person has the right to defend his civil rights in case of violation, non-recognition or their disputes [21]. This rule also applies to the rights of surgeons. The surgeon has the right to sue for the protection of honor and dignity in case of distribution of false or offensive information about his professional activity, moral qualities, etc. The property rights of a surgeon can be protected by appealing to a court with a claim for compensation for property damage, in particular if the HIV-infected patient intentionally infects a surgeon. The protection of civil rights and interests of surgeons (the right to health care) can also be enforced through self-defense. The self-defense of surgeons against HIV infection can be manifested in all actions aimed at protecting themselves while performing the treatment of patients, in particular the use of safety glasses, bathrobes, etc. In this case, subjectively the surgeon has the right to consider each patient as a potential carrier of HIV / AIDS, especially during an urgent surgical intervention.

\section{CONCLUSIONS}

The rights of surgeons while working with HIV-infected patients in Ukraine have been determined in the article. In particular, the authors distinguish the following types of the rights: 1) the right to proper conditions of professional activity; 2) the right to free choice of tested forms, methods and means of activity, introduction, in accordance with the established procedure, of modern advances in medical and pharmaceutical science and practice; 3 ) the right to free use of social, environmental and special medical information that is necessary for the performance of professional duties; 4) the right to receive payments in case of HIV infection while performing professional duties; 5) the right to protect their personal non-property rights (honor, dignity) and property rights (right to compensation, etc.).

The scholars did not address the topics in modern scientific papers on medical law concerning the rights of surgeons while working with HIV-infected patients. This problem was addressed in the context of protecting the labor rights of medical workers without taking into account the specifics of the protection of the rights of surgeons working with HIV-infected patients.

The rights of surgeons' topic is the perspective area of scientific research, since unlike other medical workers, they are constantly at risk of direct contact with blood and / or biological materials of patients.

Surgeons in Ukraine while working with HIV-infected patients are in a vulnerable state, and to overcome it, it is necessary to clearly define at the legislative level the system of the rights of surgeons that are working with this group of patients. The existing system of the rights of surgeons needs to be improved, in particular: 1) Part 1 of the Art. 12 of the Law of Ukraine "On prevention of diseases caused by Human Immunodeficiency Virus (HIV), and legal and social security of people living with HIV" should be complemented by the fourth paragraph of the following sentence: "A patient with HIV infection is obligated to warn of about the possibility of infection of a health worker in case of surgery or other medical manipulations leading to blood or biological materials contact"; 2) the payment of mandatory insurance of surgeons, if they are infected by a patient with HIV, need to be reviewed and significantly increased.

\section{REFERENCES}

1. Elena Pinchuk Foundation. Statistics on HIV/AIDS in Ukraine on 01.05.2018. Available from: http://www.antiaids.org/eng/news/ aids_stat/statistics-on-hivaids-in-ukraine-on-01012018-11253.html (In Ukrainian).

2. AVERT. History of HIV and AIDS overview. United Kingdom; 2017. Available from: https://www.avert.org/professionals/history-hiv-aids/ overview. (In USA).

3. Ministerstvo okhorony zdorovia Ukrainy. Epidemichna sytuatsiia z VILinfektsii v Ukraini [The epidemic situation with HIV in Ukraine]. Kyiv: MOZ Ukraini; 2018. Available from: http://moz.gov.ua/article/news/ epidemichna-situacija-z-vil-infekcii-v-ukraini- (In Ukrainian).

4. Pro protydiiu poshyrenniu khvorob, zumovlenykh virusom imunodefitsytu liudyny (VIL), ta pravovyi i sotsialnyi zakhyst liudei, yaki zhyvut z VIL [On combating the spread of diseases caused by the human immunodeficiency virus (HIV) and legal and social protection of people which have HIV]: Zakon Ukrainy 12.12.1991 № 1972-XII. Available from: http://zakon1.rada.gov.ua/laws/show/1972-12. (In Ukrainian).

5. Nahorna AM, Sokolova MP, Kononova IH. Profesiina zakhvoriuvanist medychnykh pratsivnykiv v Ukraini yak medyko-sotsialna problema [Professional incidence of medical workers in Ukraine as a medical and social problem]. Ukrainskyi zhurnal z problem medytsyny pratsi. 2016 April 18; 2(47):3-16. (In Ukrainian). 
6. Kostiuk OK. Zakhyst medychnykh pratsivnykiv: profilaktyka VIL/SNIDu na robochomu mistsi [Protection of healthcare workers: prevention of HIV / AIDS in the workplace]. Posibnyk. Kyiv: LHSI, 2008. 23 c. (In Ukrainian).

7. Trud.com. Obzor statystyky zarplat professyy Khyrurh v Ukrayne [Statistics overview of salaries of surgeons in Ukraine]. Kyiv: Ua.trud. com; 2018. from: https://ua.trud.com/salary/2/3905.html. (In Ukrainian).

8. Salary.com. Salary for Surgeon in the United States. United States. 2018. Available from: https://www1.salary.com/Surgeon-Salary.html. (In USA).

9. Osnovy zakonodavstva Ukrainy pro okhoronu zdorovia [Fundamentals of the Legislation of Ukraine on Health Care]: Zakon Ukrainy vid 19.11.1992 №2801-XII. Available from: http://zakon.rada.gov.ua/laws/show/280112 (In Ukrainian).

10. Typova instruktsiia shchodo poriadku vykorystannia zasobiv indyvidualnoho zakhystu pratsivnykamy, yaki provodiat diahnostychni doslidzhennia na VIL-infektsiiu, nadaiut medychnu dopomohu ta sotsialni posluhy liudiam, yaki zhyvut z VIL, abo kontaktuiut z kroviu chy biolohichnymy materialamy liudyny, zabrudnenymy nymy instrumentariiem, obladnanniam chy predmetamy [Standard Operating Procedure on using personal protective equipment by employees who carry out diagnostic tests for HIV infection, provide medical care and social services to people living with HIV or who are in contact with human blood or biological materials, impured tools, equipment or objects]: Nakaz Ministerstva okhorony zdorovia Ukrainy vid 05.11.2013 № 955. Available from: http://zakon.rada.gov.ua/laws/show/z1979-13 (In Ukrainian).

11. Konstytutsiia Ukrainy [The Constitution of Ukraine]: Zakon Ukrainy vid 28.06.1996 № 254K/96-BP. Available from: http://zakon2.rada.gov.ua/ laws/show/254\%D0\%BA/96-\%D0\%B2\%D1\%80?find=1\&text=\%E6\% E8\%F2\%EB\%EE\#w11. (In Ukrainian).

12. Torjuul K, Nordam A, Sørlie V. Action ethical dilemmas in surgery: an interview study of practicing surgeons. BMC Medical Ethics. 2005. July; 6:7. Available from: https://www.ncbi.nlm.nih.gov/pmc/articles/ PMC1182373/. doi: 10.1186/1472-6939-6-7. (In USA).

13. Perelik profesiinykh zakhvoriuvan [A list of occupational diseases]: Postanova Kabinetu ministriv Ukrainy. 08.11.2000 № 1662. Available from: http://zakon.rada.gov.ua/laws/show/1662-2000-\%D0\%BF?find $=1 \&$ text=\%B3\%ED\%F4\%E5\%EA\#w11 (In Ukrainian).

14. Pro zahalnooboviazkove derzhavne sotsialne strakhuvannia [0n compulsory state social insurance]: Zakon Ukrainy vid 23.09.1999 № 1105-XIV. Available from: http://zakon.rada.gov.ua/laws/ show/1105-14 (In Ukrainian).

15. Poriadok provedennia rozsliduvannia ta vedennia obliku neshchasnykh vypadkiv, profesiinykh zakhvoriuvan i avarii na vyrobnytstvi [The procedure of investigation and record keeping of accidents, occupational diseases and accidents at work]: Postanova Kabinetu Ministriv Ukrainy vid 30.11.2011 № 1232. Available from: http://zakon.rada.gov.ua/laws/ show/1232-2011-\%D0\%BF?find=1\&text=\%EF\%F0\%EE\%F4\#w11 (In Ukrainian).

16. Poriadok ta umovy oboviazkovoho strakhuvannia medychnykh pratsivnykiv ta inshykh osib na vypadok infikuvannia virusom imunodefitsytu liudyny pid chas vykonannia nymy profesiinykh oboviazkiv, a takozh na vypadok nastannia u zviazku z tsym invalidnosti abo smerti vid zakhvoriuvan, zumovlenykh rozvytkom VIL-infektsii, i pereliku katehorii medychnykh pratsivnykiv ta inshykh osib, yaki pidliahaiut oboviazkovomu strakhuvanniu na vypadok infikuvannia virusom imunodefitsytu liudyny pid chas vykonannia nymy profesiinykh oboviazkiv, a takozh na vypadok nastannia u zviazku z tsym invalidnosti abo smerti vid zakhvoriuvan, zumovlenykh rozvytkom VIL-infektsii [The procedure and conditions for compulsory insurance of medical personnel and other persons in case of human immunodeficiency virus infection during their professional duties, as well as in case of the occurrence of disability or death due to illness caused by the development of HIV infection, and a list of categories of medical employees and other persons who are subject to compulsory insurance in case of human immunodeficiency virus infections while performing their professional duties, and also in case of the occurrence of disability or death from the disease due to the development of HIV infection]. Postanova Kabinetu Ministriv Ukrainy vid 16.10.1998 № 1642. Available from: http://zakon. rada.gov.ua/laws/show/1642-98-\%D0\%BF?lang=ru (In Ukrainian).

18. Pro okhoronu pratsi [On Labor Protection]. Zakon Ukrainy vid 14.10 .1992 № 2694-XII. Available from: http://zakon.rada.gov.ua/laws/show/269412 (In Ukrainian).

19. Roziasnennia shchodo pryznachennia ta zdiisnennia strakhovykh vyplat u razi nastannia neshchasnoho vypadku na vyrobnytstvi abo profesiinoho zakhvoriuvannia [Clarifications on the appointment and implementation of insurance payments in the event of an accident at work or occupational disease]: ofitsiinyi sait Fondu sotsialnoho strakhuvannia Ukrainy. Available from: http://www.fssu.gov.ua/fse/ control/main/uk/publish/article/954974 (In Ukrainian).

20. Pro strakhuvannia [On Insurance]: Zakon Ukrainy vid 07.03.1996 № 85/96-BP. Available from: http://zakon.rada.gov.ua/laws/ show/85/96-\%D0\%B2\%D1\%80?find=1\&text=100 (In Ukrainian).

21. Tsyvilnyi kodeks Ukrainy [Civil Code of Ukraine] Zakon Ukrainy vid 16.01.2003 № 435-IV. Available from: http://zakon.rada.gov.ua/laws/ show/435-15 (In Ukrainian).

\section{Author Contributions:}

Conceptualization, Anatoliy Komziuk and Dmitro Velichko; Formal analysis, Dmitro Velichko and Valentyna Goshovska; Methodology, Volodymyr Goshovskyi and Olena Klymenko; Validation, Dmitro Velichko, Anatoliy Komziuk and Valentyna Goshovska;

Visualization, Anatoliy Komziuk and Olena Klymenko; Writing - original draft, Anatoliy Komziuk, Dmitro Velichko and Volodymyr Goshovskyi;

Writing - review \& editing, Volodymyr Goshovskyi, Valentyna Goshovska and Olena Klymenko.

\section{Conflicts of Interest:}

The authors declare no conflict of interest.

\section{CORRESPONDING AUTHOR Dmytro Velichko}

Kharkiv National University of Internal Affairs

L. Landau avenue, 21, 61080, Kharkiv, Ukraine

tel: +380661882892

e-mail: velichkodm29_@ukr.net

Received: 10.12 .2018

Accepted: 31.01.2019 
PRACA POGLADOWA

REVIEW ARTICLE

\title{
NIEWYDOLNOŚĆ SERCA - PROBLEM MEDYCZNY, EKONOMICZNY I SPOŁECZNY
}

\section{HEART FAILURE - MEDICAL, ECONOMIC AND SOCIAL PROBLEM}

\author{
Piotr Feusette ${ }^{1}$, Joanna Płonka', Jarosław Bugajski' ${ }^{1}$ Agata Duszańska ${ }^{1}$, Beata Łabuz-Roszak ${ }^{2,3}$, Marek Gierlotka' \\ 'KLINIKA KARDIOLOGII, UNIWERSYTECKI SZPITAL KLINICZNY, INSTYTUT MEDYCYNY, UNIWERSYTET OPOLSKI, OPOLE, POLSKA \\ 20DDZIAL NEUROLOGII, WOJEWÓDZKI SZPITAL SPECJALISTYCZNY IM. ŚW. JADWIGI, OPOLE, POLSKA \\ 3KATEDRA IZAKKAD PODSTAWOWYCH NAUK MEDYCZNYCH, WYDZIAŁZDROWIA PUBLICZNEGOW BYTOMIU, ŚLASKI UNIWERSYTET MEDYCZNYW KATOWICACH, \\ BYTOM, POLSKA
}

\begin{abstract}
STRESZCZENIE
Pierwsze wzmianki o chorobie, którą dzisiaj określamy jako niewydolność serca, pochodzą z czasów antycznych. Epidemiologia objawowej niewydolności serca jest dobrze poznana, szczególnie w Europie. Na naszym kontynencie niewydolność serca występuje u około 2\% dorosłej populacji. W artykule przedstawiono: definicję, epidemiologię i rokowanie chorych z niewydolnością serca. Opracowanie charakteryzuje aktualne metody farmakoterapii i leczenia interwencyjnego. Ważnym elementem postępowania u chorych z niewydolnością serca jest rehabilitacja medyczna i przestrzeganie zasad profilaktyki chorób sercowo-naczyniowych zalecanych przez Europejskie Towarzystwo Kardiologiczne. Artykuł porusza również temat analizy kosztów społeczno-ekonomicznych. W podsumowaniu pracy podkreślono, że: niewydolność serca jest istotnym problemem medycznym, ponieważ pomimo wprowadzenia nowych metod leczenia nie udało się uzyskać znaczącej poprawy rokowania; stanowi też problem ekonomiczny, ponieważ jej leczenie jest kosztowne i pochłania około 2\% wszystkich wydatków przeznaczonych na ochronę zdrowia; oraz problem społeczny, ponieważ jest schorzeniem dotykającym głównie osób w wieku podeszłym, prowadząc do istotnego ograniczenia ich zdolności do samodzielnej egzystencji, co skutkuje wykluczeniem z życia społecznego.
\end{abstract}

SŁOWA KLUCZOWE: niewydolnośćserca, epidemiologia, leczenie i prewencja niewydolności serca

\begin{abstract}
Heart failure has accompanied mankind since the dawn of time. The first mentions of the disease, which today we describe as heart failure, come from ancient times. Epidemiology of symptomatic heart failure is well known, especially in Europe. Heart failure affects approximately $2 \%$ of the adult population in Europe. The article presents: definition, epidemiology and prognosis of patients with heart failure. The article presents current methods of pharmacotherapy and treatment of heart failure. An important element in the management of patients with heart failure is medical rehabilitation and the prevention of cardiovascular diseases, according to the ESC guidelines. The topic also discussed in the article is the analysis of socio-economic costs of heart failure. The article concludes that: heart failure is a medical problem, because despite the introduction of new treatment methods, it is a disease that is still characterized by poor prognosis; heart failure is an economic problem because its treatment is expensive and absorbs $2 \%$ of all costs of healthcare; heart failure is a social problem because it is a disorder affecting mainly elderly people, leading to a significant reduction in their ability to live independently, which results in their exclusion from social life.
\end{abstract}

KEY WORDS: heart failure, epidemiology, heart failure treatment and prevention

Wiad Lek 2019, 72, 2, 284-290

\section{WSTĘP}

\section{KRÓTKI RYS HISTORYCZNY}

Niewydolność serca towarzyszy ludzkości od zarania dziejów. Pierwsze wzmianki o chorobie, którą dzisiaj określamy jako niewydolność serca, pochodzą z czasów antycznych. W egipskich papirusach, w dziełach Hipokratesa, w pismach Rzymian spotykamy opisy dolegliwości, które dzisiaj określilibyśmy dusznościami czy też obrzękami. Ewangelia św. Łukasza, w rozdziale 14, opisuje jak w szabat Jezus uzdrowił człowieka cierpiącego na puchlinę wodną. Dzisiaj raczej nie ma wątpliwości, że był to chory cierpiący z powodu nie- wydolności serca. Okres średniowiecza i renesansu to czas, w którym nie doszło do przełomu w zrozumieniu chorób serca. Dopiero opublikowane w 1628 r. fundamentalne dzieło angielskiego uczonego Williama Harveya o krążeniu krwi, pozwoliło na powiązanie rozlicznych dolegliwości człowieka z niedomogą serca. W 1794 r. nadworny lekarz króla Francji Ludwika XV - Jean Battista Senac - opublikował książkę o chorobach serca, w której po raz pierwszy powiązał obrzęki kończyn dolnych i duszności z poważnymi chorobami serca. Przez wielu historyków Senac uważany jest za ojca nowo tworzącej się dziedziny wiedzy medycznej - kardiologii. Pod koniec XVIII wieku angielski lekarz William Withering roz- 
począł stosowanie naparstnicy jako leku przeciwobrzękowego o działaniu moczopędnym. W 1867r. William Murrell - farmakolog angielski - wprowadza do leczenia nitraty. Koniec XIX wieku i pierwsza połowa XX to czas rozwoju technik diagnostycznych - elektrokardiogram, pomiar ciśnienia tętniczego krwi, zdjęcia rentgenowskie - są do dzisiaj trwałym elementem diagnostyki niewydolności serca. Prawdziwy przełom w leczeniu tej dolegliwości przyniosła II połowa XX wieku. W 1959 r. do terapii wprowadzono nowe środki moczopędne - tiazydy, w 1972 r. Leon Goldberg zapoczątkował stosowanie dopaminy. Kolejny przełom to wprowadzenie do terapii chorób układu krążenia inhibitorów konwertazy angiotensyny w $1980 \mathrm{r}$. i blokerów kanału wapniowego w 1982 r. Ogromne wkład do leczenia niewydolności serca wniosła kardiochirurgia. W 1960 r. Albert Starr po raz pierwszy wszczepił człowiekowi sztuczną zastawkę serca. W roku 1967 r. rozpoczęła się era chirurgii wieńcowej. W Leningradzie Vasilij Kolesov, jako pierwszy na świecie, użył tętnicy piersiowej wewnętrznej lewej jako pomostu wieńcowego, wszywając ją do gałęzi okalającej lewej tętnicy wieńcowej. W tym samym czasie, w Clevelend, Rene Favaloro po raz pierwszy użył żyły jako pomostu aortalno-wieńcowego. Do dzisiaj wielonaczyniowa choroba wieńcowa z upośledzoną funkcją skurczową lewej komory pozostaje klasycznym wskazaniem do zabiegu chirurgicznej rewaskularyzacji mięśnia sercowego. W dniu 3 grudnia 1967 r. w Kapsztadzie Christian Barnard przeprowadził pierwszą udaną transplantację serca, dając tym samym wielu pacjentom $z$ niewydolnością serca szansę na dłuższe życie. W latach sześćdziesiątych, w Bostonie i Buffalo, Paul M. Zoll, William Chardack i Wilson Greatbatch skonstruowali i po raz pierwszy wszczepili pacjentowi kardiostymulator, rozpoczynając erę elektroterapii serca. Dzisiaj bez kardiostymulatora, kardiowertera / defibrylatora, terapii resynchronizującej, trudno jest sobie wyobrazić nowoczesne leczenie chorego $\mathrm{z}$ niewydolnością serca [1].

Także Polacy wnieśli swój wkład w zrozumienie chorób układu krążenia. W XIV wieku biskup Tomasz z Wrocławia jeden $\mathrm{z}$ rozdziałów swojego medycznego dzieła poświęcił „ułomnościom serca”. W XVI wieku Piotr Czachowski - położnik, opisuje bicie serca i omdlenia u brzemiennych. W 1833 r., w Krakowie, Jan Klecki publikuje rozprawę o obrzękach i wodobrzuszu, wiążąc je z niedomogą serca. Za twórcę kardiologii w Polsce uważany jest Józef Pawiński. Żyjący na przełomie XIX i XX wieku uczony uważał, że choroba serca prowadzi do zaburzeń funkcji całego organizmu chorego. Liczne swoje prace naukowe poświęcił Pawiński właśnie problematyce niewydolności serca. Niewydolności serca, określana często jako jego niedomoga, znalazła także swoje miejsce w polskim podręczniku chorób wewnętrznych, wydanym na przełomie XIX i XX wieku, pod redakcją Walerego Jaworskiego - rozdział napisany przez Antoniego Gluzińskiego czy też w pierwszym polskim podręczniku kardiologii napisanym przez lwowskiego lekarza Oskara Widmanna. Niezwykle ważnymi badaniami na temat patofizjologii układu krążenia stały się prace krakowskiego uczonego Tadeusza Tempki, który w okresie międzywojennym zajmował się problematyką wpływu jonów wapniowych na mięsień sercowy. Za jednego z twórców echokardiografii można z całą pewnością uznać Tomasza Cieszyńskiego. W 1956 r., we
Wrocławiu, po badaniach nad wykorzystaniem ultradźwięków w obrazowaniu struktur serca, Cieszyński opatentował echosondę sercową. Trudno jest sobie wyobrazić współczesną kardiologię bez echokardiografii. W 1953 r., w Warszawie, Leon Manteuffel przeprowadził pierwszą w Polsce udaną komisurotomię mitralną, rozpoczynając w naszym kraju kardiochirurgiczne leczenie wad serca. W $1958 \mathrm{r}$. Wiktor Bross, w dawnej klinice Jana Mikulicza-Radeckiego we Wrocławiu, przeprowadzil pierwszą w Polsce operację na otwartym sercu, używając do tego krążenia pozaustrojowego. Pierwszą udaną transplantacjęserca, przeprowadził w Polsce w 1985 r.wZabrzu, profesor Zbigniew Religa. [1].

\section{PRZEGLĄD I DYSKUSJA}

\section{DEFINICJA}

Definicje niewydolności serca ulegały z czasem zmianom. Było to spowodowane rozwojem wiedzy na temat patofizjologii układu krążenia, która uwzględniała odkrywane co raz to nowe mechanizmy prowadzące do rozwoju niewydolności serca. Philip Poole-Wilson określa niewydolność serca jako zespół kliniczny spowodowany nieprawidłowością serca o charakterystycznym obrazie hemodynamicznym, któremu towarzyszy upośledzenie czynności nerek oraz odpowiedź układu nerwowego i hormonalnego. Tym samym tropem idzie Milton Packer, który proponuje uznać niewydolność serca za zespół kliniczny, na który składają się nieprawidłowości w funkcji lewej komory serca i zaburzenia regulacji neurohormonalnej, którego konsekwencjami są upośledzenie wydolności wysiłkowej, nadmierna retencja płynów i skrócenie długości życia. Zespół Narodowego Instytutu Zdrowia Stanów Zjednoczonych, pod przewodnictwem Eugena Braunwalda, zdefiniował w 1994 r. niewydolność serca jako stan organizmu, który ma miejsce w dwóch sytuacjach: kiedy zaburzona czynność serca powoduje niedostateczność przepływu krwi w stosunku do potrzeb metabolicznych tkanek organizmu i kiedy przepływ krwi odpowiada zapotrzebowaniu organizmu, jednak odbywa się to kosztem podwyższonego ciśnienia napełniania komór serca. Autorzy tej definicji podkreślają, że u źródeł niewydolności serca może leżeć każda choroba serca zaburzająca wyrzut krwi z komór serca lub ich napełnianie [2-4].

Według aktualnie obowiązujących wytycznych dotyczących rozpoznania oraz leczenia ostrej i przewlekłej niewydolności serca, opublikowanych w 2016 r, przez Europejskie Towarzystwo Kardiologiczne, niewydolność serca można zdefiniować jako zespół typowych objawów podmiotowych, tj.: duszności, obrzęków kończyn dolnych, obniżenia tolerancji wysiłku, którym mogą towarzyszyć odchylenia w badaniu przedmiotowym, takie jak: poszerzenie żył szyjnych, trzeszczenia nad płucami, obrzęki obwodowe, spowodowane zaburzeniami w budowie i/lub czynności serca, które powodują zmniejszony rzut serca i/ lub zwiększone ciśnienia wewnątrzsercowe w spoczynku lub w trakcie wysiłku. Nieprawidłowości budowy i/lub czynności serca prowadzą do upośledzenia dostarczania 
Tabela I. Aktualnie obowiązująca definicja niewydolności serca z podziałem na HFrEF, HFmrEF i HFpEF.

\begin{tabular}{|c|c|c|c|}
\hline \multirow{2}{*}{ KRYTERIA } & \multicolumn{3}{|c|}{ TYP NIEWYDOLNOŚCI SERCA } \\
\hline & HFrEF & HFmEF & HFpEF \\
\hline 1. & $\begin{array}{c}\text { Objawy podmiotowe } \\
\pm \text { przedmiotowe }\end{array}$ & $\begin{array}{c}\text { Objawy podmiotowe } \\
\pm \text { przedmiotowe }\end{array}$ & $\begin{array}{c}\text { Objawy podmiotowe } \\
\pm \text { przedmiotowe }\end{array}$ \\
\hline 2. & LVEF $<40 \%$ & LVEF $40-49 \%$ & LVEF $\geq 50 \%$ \\
\hline 3. & - & $\begin{array}{c}\text { 1. Zwiększenie stężenia peptydów } \\
\text { natriuretycznych } \\
\text { 2. Przynajmniej jedno dodatkowe } \\
\text { kryterium: } \\
\text { a. obecna strukturalna choroba serca } \\
\text { (przerost lewej komory i/lub powiększenie } \\
\text { lewego przedsionka) } \\
\text { b. dysfunkcja rozkurczowa }\end{array}$ & $\begin{array}{c}\text { 1. Zwiększenie stężenia peptydów } \\
\text { natriuretycznych } \\
\text { 2. Przynajmniej jedno dodatkowe kryterium: } \\
\text { a. obecna strukturalna choroba serca } \\
\text { (przerost lewej komory i/lub powiększenie } \\
\text { lewego przedsionka) } \\
\text { b. dysfunkcja rozkurczowa }\end{array}$ \\
\hline
\end{tabular}

tlenu do tkanek organizmu proporcjonalnie do ich zapotrzebowania metabolicznego, mimo prawidłowych ciśnień napełniania lub kosztem zwiększonego napełniania Podstawowa terminologia stosowana w opisie HF jest historyczna i opiera się na pomiarze frakcji wyrzutowej lewej komory serca - LVEF, najczęściej za pomocą badania echokardiograficznego. Niewydolność serca obejmuje szeroką grupę chorych, poczynając od pacjentów z prawidłową frakcją wyrzutową (typowo LVEF $\geq 50 \%$ ), określanych jako niewydolność serca z zachowaną frakcją wyrzutową lewej komory - HFpEF), kończąc na pacjentach z obniżoną frakcją wyrzutową (typowo LVEF <40\%), określanych jako niewydolność serca $\mathrm{z}$ obniżoną frakcją wyrzutową lewej komory - HFrEF. Pacjenci z LVEF między 40 a 49\% reprezentują „szarą strefę”, którą obecnie zdefiniowano jako niewydolność serca $\mathrm{z}$ pośrednią frakcją wyrzutową lewej komory - HFmrEF. Różnicowanie pacjentów z HF na podstawie wartości LVEF jest ważne z powodu innych etiologii leżących u jej podłoża, różnic demograficznych, chorób współistniejących, a także z uwagi na odpowiedź na zastosowane leczenie $[1,3,5]$. Aktualnie obowiązującą definicję niewydolności serca z podziałem na HFrEF, HFmrEF i HFpEF przedstawiono w tabeli I [5].

\section{EPIDEMIOLOGIA}

Epidemiologia objawowej niewydolności serca jest dobrze poznana, szczególnie w Europie. Niewydolność serca występuje u około $2 \%$ dorosłej populacji naszego kontynentu. U jednej na pięć osób w wieku 40 lat podczas dalszego życia dojdzie do rozwoju niewydolności serca. Dane brytyjskie wskazują, że niewydolność serca występuje u 2-3\% populacji osób powyżej 45. roku życia. Liczba chorujących na niewydolność serca znacząco wzrasta wraz z wiekiem. W holenderskim badaniu „Rotterdam” stwierdzono, że wskaźnik chorobowości na niewydolność serca wynosi 0,9\% dla osób w wieku 55-64 lat, zaś dla osób powyżej 84 . roku życia wynosi $17,4 \%$. U osób powyżej 65 . roku życia niewydolność serca występuje u około 6-10\% populacji. Według danych amerykańskich 20 na 1000 osób w przedziale wiekowym 65-69 lat ma objawy niewydolności serca. Liczba ta wzrasta do 80 na 1000 dla osób powyżej 85 . roku życia. Opierając się na danych z badania Framingham, można przyjąć, że liczba chorych z niewydolnością serca podwaja się z każdą dekadą. Według prognoz American College of Cardiology i American Heart Association, w 2050 r. jeden na pięciu Amerykanów przekroczy 65. rok życia. Według tych samych prognoz liczba pacjentów z niewydolnością serca do 2030 r. wzrośnie o około 50\% w stosunku do 2012 r. Największe zmiany będą dotyczyć osób powyżej 65. roku życia, gdzie należy spodziewać się wzrostu nawet o ponad $60 \%[1,4-6$, $]$

W epidemiologii niewydolności serca Polska nie odbiega od innych krajów europejskich. Uważa się, że niewydolność serca występuje w u $2-4 \%$ populacji. Oznacza to, że liczbę chorych na niewydolność serca należy w Polsce określić na od 700000 do 1000000 osób [7].

\section{ETIOLOGIA}

Dane epidemiologiczne sprzed 40 lat wskazywały na nadciśnienie tętnicze i chorobę niedokrwienną serca (IHD - ischemic heart disease) jako główne przyczyny rozwoju skurczowej niewydolności serca. Aktualnie nieco mniejsze znaczenie w rozwoju niewydolności serca mają nadciśnienie tętnicze i wady serca. Wynika to prawdopodobnie z coraz lepszej diagnostyki i leczenia wad serca i znaczącej poprawy kontroli ciśnienia tętniczego krwi. Parametrem, który pozwala określić wpływ poszczególnych czynników ryzyka na wystąpienie danej choroby jest tzw. ryzyko przypisane populacji (PAR - population attributable risk). PAR informuje, za jaką część zachorowań w badanej populacji odpowiada oceniany czynnik ryzyka. W amerykańskim badaniu epidemiologicznym NHANES I (First National Health and Nutrition Examination Survey) opublikowanym w 2001 r. wykazano, że największy wpływ na rozwój niewydolności serca ma IHD PAR=62\%, a w dalszej kolejności, palenie tytoniu $\mathrm{PAR}=17 \%$, nadciśnienie tętnicze PAR $=10 \%$, mała aktywność fizyczna PAR=9,2\%, płeć męska PAR $=8,9 \%$, nadwaga i otyłość $\mathrm{PAR}=8 \%$, cukrzyca $\mathrm{PAR}=3,1 \%$ i wady zastawkowe $\mathrm{PAR}=2,2 \%$. W populacji polskiej za rozwój niewydolności serca w około $70 \%$ odpowiada IHD. Do innych przyczyn leżących u rozwoju skurczowej niewydolności serca zaliczyć można infekcje 
wirusowe, nadużywanie alkoholu, chemioterapię oraz idiopatyczną kardiomiopatię rozstrzeniową, chorobę o podłożu prawdopodobnie genetycznym $[1,4,5]$.

Niewydolność serca z zachowaną LVEF ma odmienną etiologię i epidemiologię od niewydolności z istotnie obniżoną LVEF. Pacjenci z niewydolnością serca i zachowaną LVEF są starsi, jest wśród nich więcej kobiet, jest też więcej osób otyłych. Rzadziej w tej grupie chorych występuje IHD, częściej natomiast nadciśnienie tętnicze i migotanie przedsionków. Pacjenci z niewydolnością serca i zachowaną LVEF charakteryzują się lepszym rokowaniem od tych $\mathrm{z}$ istotnie obniżoną $\operatorname{LVEF}[1,5]$.

Niewydolność serca ma charakter postępujący. Do progresji choroby przyczyniają się dwa mechanizmy. Pierwszy to powtarzające się incydenty niedokrwienne, prowadzące do śmierci kolejnych komórek mięśnia sercowego, co skutkuje postępująca utratą siły skurczu mięśnia lewej komory. Drugim mechanizmem jest ogólnoustrojowa odpowiedź, przede wszystkim aktywacja neurohumoralna. U chorego $\mathrm{z}$ niewydolnością serca uaktywnieniu ulegają dwa kluczowe układy neurohumoralne - układ renina-angiotensyna-aldosteron oraz współczulna część autonomicznego układu nerwowego. Poza postępującym uszkodzeniem mięśnia sercowego, aktywacja obu układów wywiera niekorzystny wpływ na wiele narządów, przede wszystkim na naczynia krwionośne i nerki. Prowadzi to do powstania patofizjologicznego błędnego koła, które odpowiada za wiele klinicznych objawów niewydolności serca i niestabilność elektryczną mięśnia sercowego. Przerwanie obu mechanizmów jednocześnie stanowi podstawę skutecznego leczenia pacjenta $\mathrm{z}$ niewydolnością serca $[1,4,5]$.

\section{ROKOWANIE}

Niewydolność serca jest chorobą, która w istotny sposób pogarsza jakość życia. Analizy porównawcze wskazują, że stopień pogorszenia jakości życia u chorych z niewydolnością serca jest większy niż w innych chorobach przewlekłych - chorobach przewodu pokarmowego, chorobach płuc czy też cukrzycy. Podobne obserwacje dotyczą także populacji polskiej. Prace Rywika i Grodzickego wskazują, że niewydolność serca jest tym zespołem chorobowym, który w największym stopniu obniża komfort życia chorych, szczególnie tych w wiek podeszłym, znacznie, utrudniając codzienne funkcjonowanie $[6,7]$.

Niewydolność serca jest chorobą o bardzo złym rokowaniu. Dane kliniczne, zarówno europejskie, jak i amerykańskie, wskazują, że pięcioletnie przeżycie chorych z niewydolnością serca jest gorsze niż chorych na chorobę nowotworową i wynosi jedynie 50\%. Pięcioletnie przeżycie chorych na chorobę nowotworową wynosi średnio 25-28\%. Rokowanie pacjentów $z$ niewydolnością serca jest związane ze stopniem zaawansowania choroby. U pacjentów z umiarkowanym nasileniem choroby śmiertelność roczna wynosi około 10-15\%, u chorych ze znacznym nasileniem objawów wynieść może nawet okołó 50\% w skali roku. Różne są przyczyny zgonów chorych z niewydolnością serca. Według badaczy MERIT-HF w klasie umiarko- wanej i średniociężkiej czynnościowej niewydolności serca - klasa II i III według NYHA - przyczyną zgonów chorych z niewydolnością serca jest nagły zgon sercowy. Podłożem nagłego zgonu sercowego są złożone komorowe zaburzenia rytmu serca. U pacjentów z najbardziej zaawansowaną niewydolnością serca - klasa czynnościowa NYHA IV przyczyna zgonów leży w postępie niewydolności serca. Czynnikiem świadczącym o niekorzystnym rokowaniu $\mathrm{u}$ chorych z niewydolnością serca jest niedokrwienna etiologia uszkodzenia serca. Rokowanie pogarszają także współistniejące choroby: cukrzyca, niewydolność nerek i niedokrwistość. O niekorzystnym rokowaniu świadczą także kolejne hospitalizacje. Dane z rejestrów klinicznych wskazują, że każda kolejna hospitalizacja pacjenta $\mathrm{z}$ niewydolnością serca jest niezależnym czynnikiem pogarszającym rokowanie $[1,4,5]$.

Mimo że w ciągu ostatnich 30 lat dokonano postępu w zakresie metod leczenia i ich dostępności, co poprawiło przeżywalność oraz ograniczyło liczbę hospitalizacji pacjentów z HFrEF, wyniki leczenia wciąż pozostawiają wiele do życzenia. Dane z ostatnich badań europejskich (ESC-HF pilot study) wskazują, że 12-miesięczna śmiertelność całkowita wśród pacjentów hospitalizowanych lub stabilnych/leczonych ambulatoryjnie $\mathrm{z}$ powodu $\mathrm{HF}$ wynosiła odpowiednio 17 i 7\%, a 12-miesięczna częstość hospitalizacji odpowiednio 44 i $32 \%$ w obu grupach. W grupie pacjentów z HF zarówno hospitalizowanych, jak i leczonych ambulatoryjnie większość zgonów ma charakter sercowo-naczyniowy; dominują zgony nagłe i zgony w przebiegu pogorszenia HF. Śmiertelność całkowita jest zasadniczo wyższa w HFrEF niż w HFpEF. Pacjenci są często hospitalizowani z powodów pozasercowo-naczyniowych, szczególnie w przypadku HFpEF. Liczba hospitalizacji z przyczyn sercowo-naczyniowych nie uległa zmianie między 2000 a 2010 rokiem, podczas gdy liczba hospitalizacji z powodów pozasercowo-naczyniowych w tym samym czasie wzrosła [5].

Pomimo nadal złego rokowania, należy podkreślić, że w leczeniu niewydolności serca dokonał się w ostatnich latach znaczący postęp. Wprowadzenie do leczenia niewydolności serca inhibitorów enzymu konwertującego, beta-blokerów, antagonistów receptora mineralokortykoidowego spowodowało znaczącą poprawę rokowania chorych. Przełomowe w prewencji nagłych zgonów sercowych u chorych z niewydolnością serca okazało się zastosowanie implantowanych kardiowerterów-defibrylatorów (ICD) i terapii resynchronizującej [5].

Dane z rejestrów klinicznych wskazują, że na początku XXI stulecia nastąpiła poprawa rokowania chorych $\mathrm{z}$ niewydolnością serca. Analiza amerykańskiego badania Framingham pokazuje, że 5-letnia śmiertelność chorych z niewydolnością serca w ciągu 40 lat obserwacji zmniejszyła się o około 10\%. Dane europejskie, po uwzględnieniu wieku, wskazują, że śmiertelność roczna chorych z niewydolnością serca wynosiła 11\%, a 5-letnia $41 \%$. W tym samym czasie śmiertelność populacji ogólnej wynosiła rocznie 3\%, a śmiertelność 5-letnia 15\%. Zbiorcze dane pochodzące z różnych krajów europejskich wskazują, 
że trend spadku śmiertelność chorych z niewydolnością serca uległ po 2005 r. zahamowaniu, a nawet zaznaczyła się pewna tendencja wzrostowa. Obserwacje te, niestety, dotyczą także populacji polskiej, na co wskazują prace zespołu kierowanego przez prof. Rywika [7].

W porównaniu do innych krajów europejskich, pacjenci z pierwszym rozpoznaniem niewydolności serca w Polsce są młodsi, mniej samodzielni, a przebieg zespołu chorobowego jest u nich cięższy ze względu na częstsze hospitalizacje. Niewydolność serca jest trzecią po chorobach naczyń mózgowych i chorobie niedokrwiennej serca, a przed chorobami nowotworowymi przyczyną utraty oczekiwanych lat życia u polskich kobiet. Niewydolność serca u polskich mężczyzn jest na szóstym miejscu jako przyczyna utraty oczekiwanych lat życia, przed wszystkimi nowotworami, z wyjątkiem raka płuca $[8,9]$.

\section{LECZENIE AMBULATORYJNE}

Przeważająca liczba chorych $\mathrm{z}$ niewydolnością serca jest leczonych w poradniach podstawowej opieki medycznej przez lekarza pierwszego kontaktu. Według analiz przeprowadzonych przez zespół badaczy pod kierunkiem prof. Rywika, co drugi pacjent, powyżej 65. roku życia, który zgłasza się po poradę do lekarza pierwszego kontaktu to chory z niewydolnością serca. Do poradni podstawowej opieki medycznej zgłaszają się częściej kobiety z niewydolnością serca i wieloletnim nadciśnieniem tętniczym. Natomiast do poradni kardiologicznych częściej zgłaszają się mężczyźni, zazwyczaj młodsi, u których przyczyną niewydolności serca jest przebycie zawału serca [7].

Leczenie ambulatoryjne chorych z niewydolnością serca wymaga szczególnej uwagi. Celem poprawy rokowania tej grupy chorych konieczne jest stosowanie aktualnych standardów postępowania zalecanych przez Europejskiego Towarzystwo Kardiologiczne. Do leków, których stosowanie poprawia rokowanie chorych z niewydolnością serca zalicza się: inhibitory enzymu konwertującego (ACE-I), beta-blokery i antagonistów aldosteronu (MRA). Oprócz tych stosuje się także terapię objawową, która nie wpływa na rokowanie chorych, ale prawie zawsze w istotny sposób podwyższa komfort życia. Do tej grupy zalicza się przede wszystkim diuretyki. ACE- I powinno stosować się u wszystkich chorych z rozpoznaną niewydolnością serca niezależnie od obecności objawów. Dane obserwacyjne z lecznictwa ambulatoryjnego wskazują, że ACE-I stosowane są jedynie u $60 \%$ chorych z niewydolnością serca w Europie i u 65\% chorych w Polsce. W ostatnich latach zanotowano wyraźną poprawę w stosowaniu tej grupy leków, zarówno w Europie, jak i w Polsce. Niestety, w większości przypadków nie stosuje optymalnych dawek ACE-I. Sartany, grupa leków o podobnym mechanizmie działania i zbliżonym efekcie klinicznym do ACE-I, znalazła zastosowanie u 3\% populacji chorych z niewydolnością serca. Drugą grupą leków o udowodnionej skuteczności w poprawie rokowania chorych z niewydolnością serca są beta-blokery. Leki z tej grupy należy stosować u wszystkich objawowych chorych z niewydolnością serca. Są one niezbędne u wszystkich chorych, niezależnie od obecności objawów klinicznych, z niedokrwiennym uszko- dzeniem serca. W codziennej praktyce lekarskiej w Europie i w Polsce beta-blokery stosuje się jedynie u 34\% chorych z niewydolnością serca. Wiele do życzenia pozostawia także optymalizacja dawki stosowanych preparatów. MRA należy stosować u wszystkich chorych z zaawansowanymi postaciami niewydolności serca. Podstawowy preparat $z$ tej grupy spironolakton znalazł zastosowanie u jedynie $20 \%$ chorych z niewydolnością serca w populacji europejskiej. Znacznie częściej lek ten stosuje się w Polsce, gdzie u chorych leczonych ambulatoryjnie zastosowano go w około $50 \%$ przypadków. Należy podkreślić, że w ostatnich latach zanotowano istotny postęp w farmakoterapii niewydolności serca. Ostatnio do leczenia wprowdzono iwabradynę i inhibitor neprilizyny - sakubitril. Iwabradyna jest lekiem, który zmniejsza akcję serca poprzez hamowanie kanałów If w węźle zatokowym i z tego powodu powinna być stosowana jedynie u pacjentów z rytmem zatokowym. European Medicines Agency (EMA) zarejestrowała iwabradynę w Europie u pacjentów z HFrEF, LVEF $\leq 35 \%$, rytmem zatokowym i spoczynkową $\mathrm{HR} \geq 75$ uderzeń na minutę, ponieważ dla tej podgrupy chorych wykazano poprawę. Wielkie zainteresowanie, podczas kongresu Europejskiego Towarzystwa Kardiologicznego w 2014 wzbudziły wyniki badania PARADIGM-HF. Badany w tym programie klinicznym lek inhibitor neprilizyny - sakubitril wykazał swoją skuteczność w terapii niewydolności serca zmniejszając ryzyko zgonu i częstość rehospitalizacji. Lek ten szybko znalazł swoje zastosowanie w aktualnie zalecanej farmakoterapii niewydolności serca $[5,10,11]$. Nadal jednak wiele do życzenia pozostawia częstość zastosowania i dawkowanie podstawowych leków, które istotnie mogą poprawić rokowanie [5].

Stale wzrastająca liczba przypadków niewydolności serca powoduje konieczność zwiększania środków przeznaczonych na leczenie tej grupy chorych. Jak podają dane, zarówno amerykańskie, jak i europejskie, koszty leczenia chorych z niewydolnością serca pochłaniają około $2 \%$ wszystkich wydatków przeznaczonych na opiekę zdrowotną. Około $35 \%$ tej kwoty przypada na ambulatoryjne leczenie chorych, zaś 65\% to koszty leczenia szpitalnego [7].

Bardzo dokładną analizę ekonomiczną leczenia chorych na niewydolność serca przedstawił w opracowaniu „Niewydolność serca - analiza kosztów ekonomicznych i społecznych" opublikowanym w 2013 r. Instytut Zarządzania w Ochronie Zdrowia Uczelni Łazarskiego w Warszawie. Zgodnie z tym opracowaniem, koszty leczenia chorych $\mathrm{z}$ niewydolnością serca tylko $\mathrm{w}$ ambulatoryjnej opiece specjalistycznej stanowiły w 2012 roku, według danych Narodowego Funduszu Zdrowia, 0,2\% wszystkich kosztów przeznaczonych na opiekę specjalistyczną. Koszt świadczeń opieki zdrowotnej opłaconych przez NFZ na leczenie w ambulatoryjnej opiece specjalistycznej ponad 93000 pacjentów z niewydolnością serca wyniósł $10 \mathrm{mln}$ PLN [12].

\section{LECZENIE SZPITALNE}

Wzrost liczby zachorowań na niewydolność serca powoduje stały znaczny wzrost liczby hospitalizacji. Około $75 \%$ chorych, którzy są leczeni ambulatoryjnie z powodu 
niewydolności serca będzie wymagało w ciągu 2 lat hospitalizacji. Amerykańskie dane epidemiologiczne wskazują, że około $83 \%$ pacjentów z niewydolnością serca było lub będzie, w ciągu 4 lat hospitalizowanych co najmniej raz, a $43 \%$ nawet cztery razy. Najczęstszą przyczyną prowadzącą do hospitalizacji chorych $\mathrm{z}$ niewydolnością serca jest zła współpraca pacjentów z lekarzem i personelem medycznym. Nieprzestrzeganie przez pacjentów zaleconych zasad farmakoterapii i postępowania profilaktycznego może odpowiadać nawet za $60 \%$ hospitalizacji chorych z niewydolnością serca. W dalszej kolejności za hospitalizacje chorych z niewydolnością serca odpowiadają: zła kontrola ciśnienia tętniczego krwi, zaburzenia rytmu serca i niedokrwienie. Jak już wspomniano w niniejszym artykule, każda kolejna rehospitalizacja chorych z niewydolnością serca, jest niezależnym czynnikiem pogarszającym ich rokowanie. Niewydolność serca jest najczęstszą przyczyną hospitalizacji pacjentów powyżej 65. roku życia. W tej grupie wiekowej niewydolność serca odpowiada za około 7,2\% wszystkich hospitalizacji u kobiet i 6,8\% u mężczyzn. Średni czas pobytu chorych w szpitalu wynosi 6 dni. Pod względem płci notuje się nieco więcej hospitalizacji kobiet, które stanowią 55,68\% wszystkich hospitalizacji chorych z niewydolnością serca.

W Polsce większość chorych z niewydolnością serca jest leczonych na oddziałach internistycznych. Hospitalizacje na oddziałach kardiologicznych chorych z niewydolnością serca stanowią jedynie od 11 do $31 \%$ wszystkich hospitalizacji na tych oddziałach.

Podczas corocznych Kongresów Europejskiego Towarzystwa Kardiologicznego zawsze wiele sesji poświęca się problematyce niewydolności serca. Według zgodnej opinii wszystkich ekspertów uniknięcie kolejnych hospitalizacji, które każdorazowo pogarszają rokowanie, wymaga uzyskania w warunkach szpitalnych optymalnego wyrównania klinicznego chorego. Niestety zdarza się, że chorzy opuszczają szpital nie będąc w stanie optymalnego leczenia.

Jak już wspomniano koszty leczenia pacjentów hospitalizowanych $\mathrm{z}$ rozpoznaniem niewydolności serca to około 65\% wszystkich wydatków na leczenie tej jednostki chorobowej. Jak podaje w swoim opracowaniu dotyczącym problematyki niewydolności serca Instytut Zarządzania w Ochronie Zdrowia Uczelni Łazarskiego, koszt świadczeń opieki zdrowotnej opłaconych przez Narodowy Fundusz Zdrowia w 2012 r., związanych z hospitalizacją ponad 187000 pacjentów z niewydolnością serca wyniósł ponad 635 mln PLN. Podstawową grupą rozliczeniową dla pacjentów z niewydolnością serca w ramach Jednorodnych Grup Pacjentów (JGP) jest grupa E53 - niewydolność serca powyżej 69. roku życia lub z powikłaniami i chorobami współistniejącymi. W ramach tej grupy chorych w 2012 r. rozliczono 158760 procedur hospitalizacji o wartości 358 mln PLN. Koszt jednej hospitalizacji wyniósł 2465 PLN. W tej grupie JGP wartość rozliczonych hospitalizacji w województwie opolskim wyniósł 10,6 mln PLN. [12].

Dane Narodowego Funduszu Zdrowia z 2016 r. wskazują, że roczne wydatki związane z leczeniem niewydolności serca wynoszą $900 \mathrm{mln}$ PLN. Z tej sumy blisko $90 \%$ to koszty hospitalizacji. Duże rozpowszechnienie niewydolności serca generuje także koszty pośrednie pod postacią zmniejszenia się potencjalnych dochodów publicznych [13].

\section{REHABILITACJA W NIEWYDOLNOŚCI SERCA}

Według Europejskiego Towarzystwa Kardiologicznego, rehabilitacja kardiologiczna jest skoordynowanym, wielowymiarowym działaniem podejmowanym w celu stabilizacji lub zwolnienia progresji choroby, złagodzenia jej objawów, poprawy tolerancji wysiłku oraz jakości życia, zmniejszając przez to zachorowalność i śmiertelność. Rehabilitacja kardiologiczna składa się z kilku elementów: wyjściowej oceny klinicznej chorego połączonej ze stratyfikacją ryzyka, optymalnej farmakoterapii i leczenia chorób towarzyszących. W skład rehabilitacji kardiologicznej wchodzą także metody niefarmakologiczne, do których zalicza się: programy edukacyjne, trening fizyczny i działania psychoterapeutyczne. Rehabilitacja ruchowa (ćwiczenia fizyczne) stanowią podstawę rehabilitacji chorych z niewydolnością serca. Przeprowadzone badania kliniczne udowodniły, że trening fizyczny, indywidualnie dobrany, prowadzony u chorych z wyrównaną przewlekłą niewydolnością serca prowadzi w tej grupie chorych do istotnej poprawy wydolności fizycznej, co przekłada się na wydłużenie życia i poprawę jego jakości [14].

W 2012 r. rehabilitację kardiologiczną prowadzono u jedynie około 8000 chorych leczonych z niewydolnością serca. Wydatki na rehabilitację leczniczą tych pacjentów wyniosły $26 \mathrm{mln}$. PLN. Oznacza to, że rehabilitacja kardiologiczna prowadzona była jedynie u co 22 pacjenta hospitalizowanego z rozpoznaniem niewydolności serca [14].

\section{PROFILAKTYKA}

Zalecenia dotyczące zasad profilaktyki chorób układu krążenia w codziennej praktyce klinicznej, opracowane przez ekspertów Europejskiego Towarzystwa Kardiologicznego, zostały opublikowane w 2012 r. Według tych zaleceń pacjenci z niewydolnością serca są grupą chorych, u których przestrzeganie zasad profilaktyki ma kluczowe znaczenie dla poprawy rokowania. Jako że przeważająca część niewydolności serca ma etiologię niedokrwienną, profilaktyka miażdżycy tętnic odgrywa pierwszoplanową rolę. Zarówno profilaktyka pierwotna, a więc to jak uniknąć choroby, jak i profilaktyka wtórna - co zrobić, aby ograniczyć postęp choroby są niezwykle ważne. Standardy postępowania w niewydolności serca opracowane w Syanach Zjednoczonych wspólnie przez American College of Cardiology i American Heart Association wyróżniają 4 stadia niewydolności serca: od A do D. W stadium A znajdują się wszyscy ludzie z czynnikami ryzyka chorób układu krążenia, bezobjawowi, bez uchwytnego w badaniach dodatkowych uszkodzenia serca. U tych chorych zaleca się intensywną modyfikację czynników ryzyka, aby nie doprowadzić do rozwoju niewydolności serca. Niestety kontrola czynników ryzyka chorób sercowo-naczyniowych pozostawia wiele do życzenia. Według wyników badania 
NATPOL opublikowanych w 2012 r. około 8 mln Polaków pali papierosy. Podwyższony poziom cholesterolu ma 18 mln Polaków, z tego $10 \mathrm{mln}$ nie wie, że ma hypercholesterolemię. Ponad $10 \mathrm{mln}$ Polaków ma nadciśnienie tętnicze. Z tej liczby $30 \%$ ma tę chorobę nierozpoznaną, a tylko $26 \%$ jest skutecznie leczonych hipotensyjnie. Około $2 \mathrm{mln}$ Polaków choruje na cukrzycę. Tylko niecała połowa Polaków ma prawidłową masę ciała. W ciągu ostatnich 10 lat liczba osób otyłych wzrosła w naszym kraju o 5\%. Wszyscy Polacy z czynnikami ryzyka są potencjalnym kandydatami do rozwoju w przyszłości niewydolności serca $[4,14]$.

Wytyczne Europejskiego Towarzystwa Kardiologicznego, opublikowane w 2016 r., dotyczące prewencji chorób układu sercowo-naczyniowego, mające na celu zminimalizowanie ryzyka rozwoju miażdżycowego zalecają:

- całkowite zaprzestanie palenia tytoniu;

- systematyczną aktywność fizyczną;

- wskaźnik masy ciała - BMI : od 20 do $25 \mathrm{~kg} / \mathrm{m}^{2}$;

- obwód pasa: u mężczyzn <94 cm i <80 cm u kobiet;

- ciśnienie tętnicze krwi < 140/90 mm Hg;

- cholesterol frakcji LDL: dla osób z grupy ryzyka niskiego i umiarkowanego $<115 \mathrm{mg} / \mathrm{dl}$, dla osób z grupy ryzyka wysokiego $<100 \mathrm{mg} / \mathrm{dl}$ i dla osób z grupy bardzo wysokiego ryzyka $<70 \mathrm{mg} / \mathrm{dl}$;

- U pacjentów z cukrzycą: hemoglobina glikowana$\mathrm{HbA} 1 \mathrm{c}<7,0 \%$.

Wytyczne zalecają, aby u osób z podwyższonym ryzykiem sercowo-naczyniowym, tj. $z$ rodzinnym wywiadem przedwczesnej śmierci sercowo-naczyniowej, rodzinnej hiperlipidemii, u chorych, u których występują główne czynniki ryzyka takie jak: palenie tytoniu, wysokie ciśnienie tętnicze krwi, cukrzyca lub podwyższone stężenie cholesterolu, dokonywać systematycznej oceny ryzyka sercowo-naczyniowego za pomocą kart SCORE [14].

\section{PODSUMOWANIE}

1. Niewydolność serca jest istotnym problemem medycznym, ponieważ pomimo wprowadzenia nowych metod leczenia nie udało się uzyskać znaczącej poprawy rokowania. Pięcioletnie przeżycie pacjenta $z$ niewydolnością serca wynosi jedynie 50\% i jest gorsze niż chorego $z$ rozpoznaniem choroby nowotworowej.

2. Niewydolność serca jest problemem ekonomicznym, ponieważ jej leczenie jest kosztowne i pochłania około $2 \%$ wszystkich wydatków przeznaczonych na ochronę zdrowia. W strukturze kosztów leczenia niewydolności serca większości krajów europejskich 65\% wydatków przypada na leczenie szpitalne, a 35\% na opiekę ambulatoryjną. W Polsce ponad 90\% kosztów leczenia niewydolności serca przypada na leczenie szpitalne, co pochłania 2,2\% wszystkich wydatków Narodowego Funduszu Zdrowia na lecznictwo szpitalne.

3. Niewydolność serca jest problemem społecznym, ponieważ jest schorzeniem dotykającym głównie osób w wieku podeszłym, prowadząc do istotnego ograniczenia ich zdolności do samodzielnej egzystencji, co skutkuje ich wykluczeniem z życia społecznego.

\section{PIŚMIENNICTWO}

1. Podolec P, Jankowska EA, Ponikowski P et al. Przewlekła niewydolność serca. Kraków: Medycyna Praktyczna, 2009.

2. Zipes DP, Libby P, Bonow RO et al. Braunwald's Heart Disease, A textbook of Cardiovascular Medicine. Filadelfia: Elsevier Saunders, 2005.

3. Camm AJ, LuscherTF, Serruys PW et al. The ESC Textbook of Cardiovascular Medicine. Oxford: Blackwell Publishing Ltd.,2006.

4. Yancy CW, Jessup M, Bozkurt B et al. 2013 ACCF / AHA Guideline for Management of Heart Failure. JACC 2013;62(16):e147-239

5. Ponikowski P, Voors AA, Anker SD et al. Wytyczne ESC dotyczące diagnostyki i leczenia ostrej i przewlekłej niewydolności serca w 2016 roku. Kardiol Pol 2016;74:1037-1147.

6. Grodzicki T, Gryglewska B, Dubiel JS et al. Kardiologia u osób w wieku podeszłym. Gdańsk: Medical Press, 2003.

7. Rywik TM. Niewydolność serca - problem społeczny w Polsce i na świecie. In: Wożakowska-Kapłon B, Mamcarz A, Filipiak KJ (eds). Iwabradyna w terapii niewydolności serca - od teorii do praktyki. Warszawa: Medical Education, 2014, 11-23.

8. Balsam P, Tymińska A, Kapłon-Cieślicka A et al. Predictors of one-year outcome in patients hospitalised for heart failure: results from the Polish part of the Heart Failure Pilot Survey of the European Society of Cardiology. Kardiol Pol 2016;74:9-17.

9. Sosnowska-Pasiarska B, Bartkowiak R, Wożakowska-Kapłon B et al. Population of Polish patients participating in the Heart Failure Pilot Survey (ESC - HF Pilot). Kardiol Pol 2013;71, 3:234-240.

10. Swedberg K, Komajda M, Böhm M et al. Ivabradine and outcomes in chronic heart failure (SHIFT): a randomised placebo-controlled study. Lancet 2010;376:875-885.

11. McMurray JJ, Packer M, Desai AS, et al., on behalf of the PARADIGM-HF Investigators and Committees. Angiotensin-Neprilysin Inhibition versus Enalapril in Heart Failure. N Engl J Med. 2014;371:993-1004.

12. Gierzyński J, Gryglewicz J, Karczewicz E et al. Niewydolność serca - analiza kosztów ekonomicznych i społecznych. Warszawa: Uczelnia Łazarskiego, 2013, 12, 48.

13. Łyszczarz B, Gierczyński J, Nojszewska E et al. Ocena kosztów niewydolności serca z perspektywy gospodarki państwa. Warszawa: Instytut Innowacyjna Gospodarka. 2017.

14. Piepoli F, Hoes AW, Agewall S et al. Wytyczne ESC dotyczące prewencji chorób układu sercowo-naczyniowego w praktyce klinicznej w 2016 roku. Kardiol Pol, 2016;74: 821-936.

Konflikt interesów:

Autorzy deklarują brak konfliktu interesów.

\author{
AUTOR KORESPONDUJAZCY \\ Piotr Feusette \\ Klinika Kardiologii \\ Uniwersytecki Szpital Kliniczny w Opolu \\ Al. W. Witosa 26, 45-401 0pole, Polska \\ Telefon: +48606380462 \\ e-mail: feusette@wp.pl
}

Nadesłano: 25.10.2018

Zaakceptowano: 31.01.2019 
OPIS PRZYPADKU

CASE REPORT

\title{
HIV/AIDS IN THE GUISE OF A DEMYELINATING DISEASE
}

\section{ZAKAŻENIE HIV/AIDS OBJAWIAJĄCE SIĘ POD POSTACIĄ CHOROBY DEMIELINIZACYJNEJ}

\author{
Pavel A. Dyachenko \\ CENTER OF INFECTIOUS DISORDERS OF THE NERVOUS SYSTEM, SI"L.V. GROMASHEVSKY INSTITUTE OF EPIDEMIOLOGY AND INFECTION DISEASES OF \\ NAMS OF UKRAINE", KYIV, UKRAINE
}

\begin{abstract}
Introduction: A significant part of patients with HIV / AIDS develops damage to the nervous system. There are also cases where opportunistic infections of the nervous system, especially herpes viral origin, can hide the underlying disease, making it difficult diagnosis.

The aim: To show the possibility of HIV infection mimicry a neurological pathology.

Clinical case: A 41-years-old female presented to The Center of Infectious disorders of the Nervous System (Kyiv, Ukraine) in August, 2018 after developing acute fever following by a left side hemiparesis, violation of coordination. Tuberculosis and HIV denied. Her physical examination showed tremor in her hands during a Barre-probe. She performed the coordination tests with intent, staggering in the Romberg pose. A small brain lesion was revealed at MRI. Antibodies to HSV1/2, CMV, Tox. gondii were found in the CSF and blood. Blood PCR was reported to be positive for EBV DNA, and HCV RNA. A rapid HIV test was negative. A repeated blood test performed 10 days after admission showed low level of CD4+T cells (36 cells $/ 1 \mu \mathrm{ll}$ ), and HIV RNA $(850,104 \mathrm{cp} / \mathrm{ml})$. HIV antibodies were also revealed. As a result, patient was transferred to a specialized department for further treatment.

Conclusion: Considering high clinical polymorphism of HIV/AIDS, physicians of all specialties should be alert for the possible neurologic manifestations of this disease to timely examine patients.
\end{abstract}

KEY WORDS: HIV / AIDS, neurological pathology, demyelinating disease

Wiad Lek 2019, 72, 2, 291-293

\section{INTRODUCTION}

The problem of HIV infection for more than 25 years remains relevant for the world community; the scale of the HIV spreading has become global in nature and poses a real threat to the socio-economic development of most countries. At present, the epidemic situation with HIV remains tense in Ukraine: HIV continues to disseminate among the population, and the cumulative number of HIV-infected people and AIDS patients is increasing. According to official data, at the beginning of 2018, there were 244,000 HIV-infected persons of all age groups in Ukraine [1]. In 2016, 14334 new cases of HIV infection were detected, with $57.7 \%$ of people diagnosed with clinical conditions at later stages (CD4 $<350$ cells / $\mathrm{mm}^{3}$ ), of which $30 \%$ had an immunosuppression below 200 cells / $\mathrm{mm} 3$ [1] . This testifies to the untimely diagnosis of HIV status, and as a consequence, the inadequate quality of medical care. The reason for this is the high clinical polymorphism of HIV / AIDS, the similarity with various diseases (masks), which often leads to erroneous diagnoses in such patients. Diagnostic and therapeutic errors contribute to the lack of orientation of doctors, whose specializing is outside the plane of infectious diseases and HIV-medicine, in the manifestations of this disease. Sometimes patients deliberately do not inform the medical staff about their HIV status or are themselves in the dark about it (especially those who are not in the categories of high risk of infection). In addition, existing regulations on compulsory HIV testing for certain clinical and epidemiological grounds in some cases inhibit or make it difficult to establish the correct diagnosis.

A significant part of patients with HIV / AIDS develop damage to the nervous system, which often leads to a lethal outcome. There are also cases where opportunistic infections of the nervous system, most often of herpes viral origin, can hide the underlying disease, making it difficult diagnosis $[2,3]$.

\section{THE AIM}

To show the possibility of HIV infection mimicry a neurological pathology.

Below we present a case when HIV / AIDS was concealed under the mask of demyelinating disease.

\section{CLINICAL CASE}

A 41-years-old female presented to the Center of infectious disorders of the nervous system (Kyiv, Ukraine) 


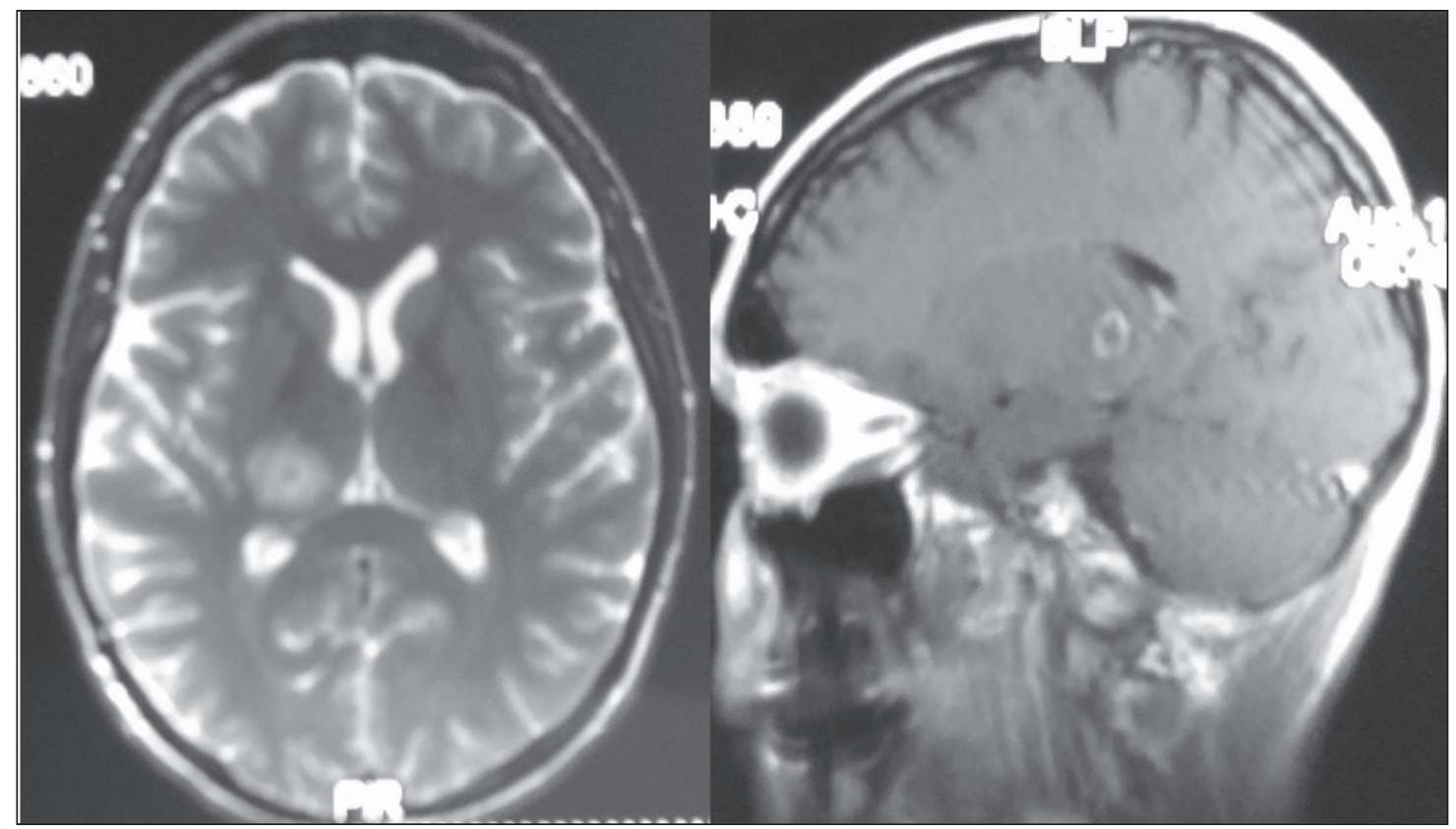

Figure 1. Focus of the brain demyelination on MR imaging a week before admission.

in August, 2018 with complaints of numbness in the left half of the body, left-side hemiparesis, impaired pelvic organ function by type of non-sustainability, violation of coordination. The patient was in good health until a month before admission to our clinic. Ill had acute onset when the left palm numbness was occurred, and quickly progressed. A left arm paresis appeared after a week, then the left leg was joined to the process. She turned to the neurologist of a local hospital, and was directed to the brain MRI. During the examination in the projection of the right visual hillock, a small irregular-shaped lesion, with unexpressed boundaries, was revealed. Intravenous contrast was accumulated along the periphery like a ring (Fig. 1). Screening for antibodies to HIV at the same time was negative. Debut of multiple sclerosis or toxoplasmosis of the central nervous system were supposed, and the patient was transferred to our clinic.

On admission, general condition was of moderate severity. Axillary temperature was normal. The patient was normotensive with pulse beats of 70 per minute. Her physical examination showed slow mentation along with generalized slowing of her responses to verbal commands and also generalized weakness. She was emotionally labile, good contact, well oriented, and answered the questions adequately. There was left-side partial loss of sensitivity. The abdominal reflexes were asymmetrical, sharply reduced. There was tremor in her hands during a Barre-probe. Meningeal symptoms were not detected. She performed the coordination tests with intent, staggering in the Romberg pose. Episodes of uncontrollable urination were recorded. According to the patient, she has one sexual partner during last year, and four years ago she was tested for HIV with negative result. In 2017, she underwent massive dental intervention. In the same year she was treated in the dermatology department for pemphigus.
A lumbar puncture was performed just on admission and CSF analysis revealed cytosis of $8 \mathrm{cell} / \mu \mathrm{l}$ (lymphocytes). The protein and glucose levels were $0.41 \mathrm{~g} / \mathrm{L}$ and $3.2 \mathrm{mmol} / \mathrm{L}$ respectively (the synchronous serum values were $6.1 \mathrm{umol} / \mathrm{L}$ and $4.9 \mathrm{mmol} / \mathrm{L}$ ). G class antibodies to HSV1/2, CMV, Tox.gondii were revealed.

General blood test showed leukopenia $\left(2.4^{\star} 10^{9} / 1\right)$ with relative lymphocytosis (77\%) and very low proportion of CD4+ (11\%). M class antibodies to VZV, and CMV; total antibodies in high titer to $\mathrm{HCV}$, and high titer IgG Tox. gondii were also detected. Blood PCR was reported to be positive for EBV DNA (2.4 lg), and HCV RNA $\left(2.6^{*} 10^{4}\right.$ $\mathrm{IU} / \mathrm{ml}$ ).

In view of the above, prescribed therapy included antitoxoplasmic, antiviral, neuroprotective and hepatoprotective medicines. At the same time, a rapid HIV test was conducted with the permission of the patient (the result was negative). The treatment has proven to be partially successful at least clinically: the patient's condition improved, volume of movements in the limbs increased, areas of sensitivity appeared on the palms, decreased vestibulo-atactic and cerebrostenic manifestations, uncontrolled urination stopped. A repeated blood test performed 10 days after admission showed very low level of CD4+ T cells (36 cells $/ 1 \mu \mathrm{l})$. RT-PCR blood test revealed HIV-1 RNA $(850,104 \mathrm{cp}$ $/ \mathrm{ml}$ ). As a result of the conversation with the patient, her informed agreement was reached on the re-examination of HIV antibodies. Test was carried out and was positive.

The patient with final diagnosis encephalitis with liquor-hypertensive, vestibulo-atactic, cerebrostenic syndromes, left-side hemiparesis, and hemianaestesia underlined with mixed infection (VZV, EBV, CMV, Tox.gondii in the activation phase), severe course; HIV infection, clinical stage IV; chronic Hepatitis C, was transferred to a specialized department for further treatment. 
The presented case reflects not only the diversity of the HIV infection itself, but also, to a certain extent, the in sufficient awareness of outpatient physicians and hospitals about the manifestations of the disease, including its late stages. In our observations, although the patient had one of the classic AIDS lab-indicator (deep depletion of CD4+ lymphocytes), which is the basis for an appropriate examination [4]. However, since antibodies to HIV were not firstly identified as a result of a weak immune response to HIV antigens in conditions of severe immunodeficiency, the assumption of HIV / AIDS in the outpatient stage did not occur. The clinical protocol of antiretroviral therapy of HIV infection in adults and adolescents, approved by order of the Ministry of Health of Ukraine, No. 551 dated $07 / 12 / 2010$, which regulates the basic principles of diagnosis and treatment of HIV-infected persons, recommends that the diagnosis of HIV infection should be based on the presence of antibodies to the virus. Since the "gold standard" for the diagnosis of HIV infection is currently PCR, we believe that this protocol needs to be modified accordingly.

\section{CONCLUSIONS}

The given clinical example testifies to the possibility of masking clinical manifestations of HIV / AIDS under the signs of demyelinating diseases of the central nervous system. A one-time negative test for HIV antibodies does not exclude the presence of the virus, especially with underlying leukopenia and $\mathrm{T}$ cells depletion.

\section{REFERENCES}

1. HIV-infection in Ukraine. Public Health Center. Inf.bull. № 49. Kyiv, 2018 (ukr).

2. Dyachenko P., Smiianova 0., Kurhanskaya V., Oleshko A., Dyachenko A. Epstein-Barr virus-associated encephalitis in a case-series of more than 40 patients. Wiad Lek 2018, 71, 6, 1224-1230.

3. Dyachenko P.A. and Dyachenko A.G. TheSpectrum of Herpesvirus Infections of the Nervous System in Adult Patients in Ukraine: A Prospective Single Center Study. Int Neuropsych Dis J (INDJ), 9(4): 1-10, 2017; Article no. INDJ.35179.

4. Shah D., Flanigan T., Lally E. Routine screening for HIV in rheu- matology practice. J Clin Rheumatol 2011; 17 (3): 154-156.

\section{Conflict of interest:}

The Author declare no conflict of interest.

\section{CORRESPONDING AUTHOR \\ Pavel A. Dyachenko}

Center of infectious disorders of the nervous system,

SI "L.V. Gromashevsky institute of epidemiology

and infection diseases of NAMS of Ukraine"

4 Galytska St., 04123, Kyiv, Ukraine

tel: +380444343288

e-mail: duieih@amnu.gov.ua

Received: 20.11.2018

Accepted: 25.01.2019 
OPIS PRZYPADKU

CASE REPORT

\title{
KASZEL U PACJENTA Z ZAPALENIEM DRÓG ŻÓŁCIOWYCH W PRZEBIEGU CHOROBY CAROLIEGO. OPIS PRZYPADKU
}

\section{A COUGH IN A PATIENT WITH CHOLANGITIS IN THE COURSE OF CAROLI'S DISEASE. CASE REPORT}

\author{
Aleksandra Kaszyńska' ${ }^{1}$, Tadeusz M. Zielonka ${ }^{1,2}{ }^{,}$Katarzyna Życińska ${ }^{1,2}$ \\ 'KLINIKA CHORÓB WEWNĘTRZNYCH I METABOLICZNYCH, SZPITAL CZERNIAKOWSKI W WARSZAWIE, WARSZAWA, POLSKA \\ 2KATEDRA I ZAKŁAD MEDYCYNY RODZINNEJ, WARSZAWSKI UNIWERSYTET MEDYCZNY, WARSZAWA, POLSKA
}

\section{STRESZCZENIE}

Kaszel może być objawem zarówno chorób płucnych, jak i pozapłucnych. Rzadko jednak podejrzewa się choroby wątroby jako przyczynę ostrego kaszlu. Opisano przypadek 34-letniego chorego z rozpoznaną chorobą Caroliego, u którego kaszel z towarzyszącą gorączką był główną manifestacją zapalenia dróg zółciowych w przebiegu choroby podstawowej. Choroba Caroliego to wrodzona patologia charakteryzująca się torbielowatym poszerzeniem wewnątrzwątrobowych dróg żółkiowych. Zwykle przebiega bezobjawowo, ale sprzyja infekcyjnym powikłaniom, takim jak ropnie wątroby i nawracające zapalenia dróg żółciowych. Pacjent został przyjęty na oddział z powodu wysokiej gorączki i kaszlu, bez objawów ze strony układu pokarmowego. Na podstawie badań laboratoryjnych, mikrobiologicznych oraz obrazowych wykluczono różne przyczyny kaszlu i postawiono rozpoznanie zapalenia dróg żółciowych. Po zastosowaniu odpowiedniej antybiotykoterapii uzyskano bardzo szybką poprawę stanu klinicznego i ustąpienie objawów.

SŁOWA KLUCZOWE: choroba Caroliego, diagnostyka różnicowa, kaszel, pozapłucne przyczyny kaszlu, torbiele dróg żółciowych, zapalenie dróg żółciowych

\begin{abstract}
Cough may be a manifestation of pulmonary and extra-pulmonary diseases. However, rarely liver disease is suspected as a cause of acute cough. A case of a 34-year-old patient with diagnosed Caroli's disease has been described, in which cough with fever was the main manifestation of cholangitis in the course of complications of the underlying disease. Caroli's disease is a congenital pathology of intrahepatic bile ducts, causing their cysts to widen. It usually has an asymptomatic course, however it promotes infectious complications such as liver abscesses and recurrent cholangitis. The patient was admitted to the ward because of high fever and cough, without any symptoms from the digestive system. On the basis of laboratory, microbiological and visual examinations, various causes of cough were excluded and a diagnosis of cholangitis was made. After appropriate antibiotic therapy, a rapid improvement in the clinical condition and resolution of symptoms was achieved.
\end{abstract}

KEY WORDS: biliary cysts, cough, Caroli's disease, cholangitis, differential diagnosis, extra-pulmonary causes of cough

Wiad Lek 2019, 72, 2, 294-297

\begin{abstract}
WSTĘP
Kaszel jest jednym z najczęstszych objawów klinicznych i stanowi ważną przyczynę porad lekarskich [1]. Jest on odruchem obronnym służącym oczyszczeniu dróg oddechowych, a także sygnalizującym uszkodzenie struktur (np. opłucnej, przepony lub oskrzeli) [2]. Wyróżniono kaszel ostry (do 3 tygodni), podostry (3-8 tygodni) oraz przewlekły (powyżej 8 tygodni) [3]. Kaszel przewlekły stanowi trudny problem diagnostyczny, a ustalenie jego przyczyny niejednokrotnie wymaga udziału różnych specjalistów (pulmonologów, laryngologów, kardiologów i gastroenterologów). U ponad 90\% chorych udaje się określić jego etiologię [4]. Może on być objawem wirusowych infekcji górnych dróg oddechowych, które są najczęstszą przyczyną ostrego kaszlu, ale zwykle nie wymagają diagnostyki [5]. Czasami jednak jest on objawem chorób zagrażających życiu, takich jak: zapalenie płuc, grypa, niewydolność serca, rak
\end{abstract}

płuca czy zatorowość płucna [1]. Kaszel może być objawem płucnych lub pozapłucnych schorzeń. Najważniejszymi płucnymi przyczynami kaszlu są: astma oskrzelowa, przewlekła obturacyjna choroba płuc, zapalenie płuc, nowotwory, zatorowość płucna, choroby śródmiąższowe płuc, choroby infekcyjne dróg oddechowych (szczególnie krztusiec i gruźlica), poinfekcyjna nadreaktywność oskrzeli, a także aspiracja ciała obcego i narażenie na substancje drażniące [6]. Do głównych pozapłucnych przyczyn kaszlu zalicza się: choroby górnych dróg oddechowych (zapalenie zatok, przewlekły nieżyt nosa, zapalenie krtani, dysfunkcję strun głosowych, zespół bezdechu podczas snu itp.), choroby serca (takie jak przewlekła niewydolność serca, obrzęk płuc, zapalenie osierdzia), choroby przewodu pokarmowego (refluks żołądkowo-przełykowy, przetoki oskrzelowo-przełykowe, zakażenia w jamie brzusznej szerzące się przez ciągłość do klatki piersiowej i.in.), choroby opłucnej (nowotwory, 

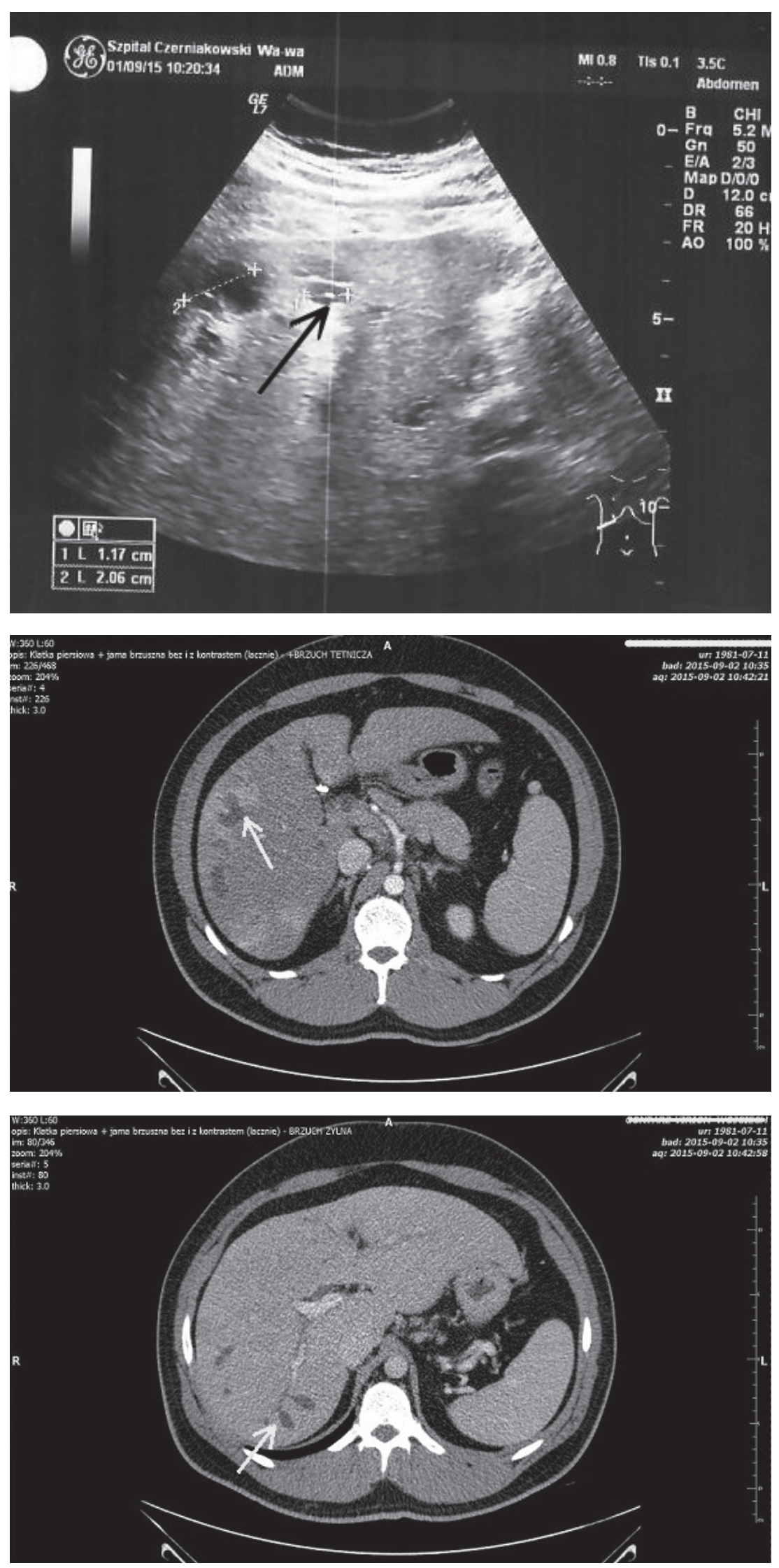

Ryc. 1. Obraz ultrasonograficzny jamy brzusznej. Zmiany hipoechogeniczne w wątrobie z charakterystycznymi hiperechogenicznymi odbiciami w środku (strzałka).

Ryc. 2. Obraz tomografii komputerowej jamy brzusznej. Zmiany hipodensyjne typowe dla choroby Caroliego ze strefami zaburzeń perfuzji silnie wzmacniające się w fazie tętniczej (strzałka).
Ryc. 3. Obraz TK jamy brzusznej. Wrzecionowate poszerzenie dróg żółciowych (strzałka). zapalenie lub wysięk), choroby układu nerwowego (np. kaszel psychogenny), stosowane leki (przede wszystkim ACE-inhibitory i $\beta$-blokery) $[6,7]$.
Kaszel i gorączka kojarzone są głównie z zakażeniami układu oddechowego. W pracy przedstawiono przypadek chorego na chorobę Caroliego powikłaną zapaleniem dróg 
żółciowych, u którego kaszel z gorączką były głównymi objawami choroby.

\section{OPIS PRZYPADKU}

Do kliniki został przyjęty 34-letni mężczyzna z podejrzeniem zapalenia płuc. Od 3 tygodni występował u niego suchy kaszel z towarzyszącymi dreszczami, gorączką do $40^{\circ} \mathrm{C}$ i z dużym osłabieniem. Zgłaszał także utratę apetytu, zmniejszenie ilości przyjmowanych pokarmów i schudł w tym czasie około 7 kg. Przed 7 laty miał wykonaną cholecystektomię oraz rozpoznaną chorobę Caroliego. Chory był przytomny, skóra była blada, spocona, czynność serca miarowa 110/min, RR 136/86 mm Hg, SaO $28 \%$, nad płucami szmer pęcherzykowy prawidłowy, a brzuch miękki i niebolesny. W badaniach laboratoryjnych stwierdzono znacznie podwyższone parametry stanu zapalnego (CRP $26,5 \mathrm{mg} / \mathrm{dL}$ przy normie $<0,5 \mathrm{mg} / \mathrm{dL}, \mathrm{WBC} 25,97 \mathrm{~K} / \mu \mathrm{L})$ i nieznacznie podwyższoną aktywność GGTP (106 U/L, przy normie 5-61 U/L), stężeniu bilirubiny i aktywność aminotransaminaz były prawidłowe. $\mathrm{W}$ radiogramie klatki piersiowej nie uwidoczniono zmian patologicznych. W badaniu ultrasonograficznym jamy brzusznej opisano poszerzenie dróg żółciowych z licznymi torbielowatymi zmianami zawierającymi hiperechogeniczne punktowe odbicia w ich wnętrzu (Ryc. 1). Obraz był charakterystyczny dla choroby Caroliego. Posiewy z krwi i plwociny były jałowe, a w surowicy nie stwierdzono przeciwciał przeciwkrztuścowych. Pomimo zastosowania klarytromycyny, utrzymywały się suchy i męczący kaszel oraz gorączka. W wykonanej tomografii komputerowej klatki piersiowej i jamy brzusznej uwidoczniono powiększoną wątrobę z licznymi, różnej wielkości zmianami hipodensyjnymi charakterystycznymi dla choroby Caroliego, w obu płatach opisano strefy zaburzeń perfuzji, a w segmencie 5 i 6 kilka obszarów silnie wzmacniających się w fazie tętniczej, sugerujących ropnie wątroby, tkanka tłuszczowa wokół więzadła wątrobowo-dwunastniczego oraz okołoaortalna była zmieniona i stwierdzono powiększone okoliczne węzły chłonne (Ryc. 2). Nie obserwowano nieprawidłowości w obrazie płuc i klatki piersiowej. Rozpoznano zapalenie dróg żółciowych i zastosowano ceftriakson $\mathrm{z}$ metronidazolem, uzyskując już po 2 dniach poprawę stanu ogólnego, ustąpienie kaszlu, gorączki oraz zmniejszenie parametrów stanu zapalnego. Po kilku dniach leczenia chory w dobrym stanie ogólnym wypisany został do domu.

\section{DYSKUSJA}

Odruch kaszlowy zapoczątkowany jest podrażnieniem receptorów kaszlowych zlokalizowanych w drogach oddechowych lub poza nimi (zewnętrzny przewód słuchowy, błona śluzowa zatok obocznych nosa, żołądek, opłucna, osierdzie i przepona) [8]. W związku z licznymi receptorami kaszlowymi poza drogami oddechowymi, w diagnostyce różnicowej kaszlu należy brać pod uwagę pozapłucne patologie. Choroby wątroby, takie jak ropnie wątroby lub pęcherzyka żółciowego i zapalenie dróg żółciowych mogą być również przyczyną kaszlu. Powstaje on wówczas w wyniku drażnienia receptorów kaszlowych znajdujących się w przeponie przez mediatory stanu zapalnego, takie jak prostaglandyna E, histamina i bradykinina. Uruchamia to łuk odruchowy i w efekcie powstaje nieproduktywny kaszel. W opisywanym przypadku kaszel związany był z zapaleniem dróg żółciowych w przebiegu choroby Caroliego. Jest to rzadka, wrodzona choroba wątroby, charakteryzująca się odcinkowym, torbielowatym lub wrzecionowatym poszerzeniem wewnątrzwątrobowych dróg żółciowych w całej wątrobie lub w jej fragmencie (Ryc. 3) [9]. Do najbardziej typowych jej objawów należy ból w prawym górnym kwadrancie brzucha. W analizie przypadków przedstawionej przez Wanga i wsp. występował on u $46 \%$ chorych [10]. Innymi częstymi objawami były: gorączka (36\%, a w przypadku zapalenia dróg żółciowych nawet u $72 \%$ ), jadłowstręt (26\%), zmęczenie (20\%), żółtaczka (20\%) i krwawienia z górnego odcinka przewodu pokarmowego (26\%) [10]. Dotychczas nie opisywano kaszlu jako objawu choroby Caroliego. Głównymi jej powikłaniami są nawracające zapalenia dróg żółciowych, ropnie wątroby lub rak dróg żółciowych.

W opisanym przypadku nie występowały typowe dla choroby Caroliego bóle brzucha, a gorączce towarzyszyło osłabienie i kaszel. Po wykluczeniu, na podstawie badań mikrobiologicznych, radiologicznych i serologicznych, płucnych infekcyjnych przyczyn gorączki i kaszlu, na podstawie obrazu TK rozpoznano zapalenie dróg żółciowych. Jest to najczęstsze i najbardziej charakterystyczne powikłanie choroby Caroliego, które występuje u około 64\% chorych [11]. Wdrożono odpowiednią do tego rozpoznania antybiotykoterapię uzyskując poprawę stanu ogólnego i ustąpienie objawów w ciągu dwóch dni.

Przedstawiony przypadek pokazuje, że kaszel może być trudnym problem diagnostycznym. W jego diagnostyce należy brać pod uwagę również rzadkie choroby i pozapłucne przyczyny. Choroby zlokalizowane pod przeponą, w tym infekcyjne choroby wątroby, mogą przebiegać pod „maską" zapalenia płuc lub uporczywego kaszlu, dlatego należy o nich pamiętać w diagnostyce różnicowej. W literaturze niewiele jest publikacji poruszających to zagadnienie.

\section{PIŚMIENNICTWO}

1. Dicpinigaitis PV, Colice GI, Goolsby MJ, Rogg GI, Sheldon LS, Winther B. Acute cough: a diagnostic and therapeutic challenge. Cough. 2009;5:11. doi:10.1186/1745-9974-5-11.

2. Polverio M, Polverino F, Fasolino M, Ando F, Alfieri A, De Blasio F. Anatomy and neuro-physiology of the cough reflex arc. Multidiscip Respir Med. 2012;7:5. doi:10.1186/2049-6958-7-5.

3. Irwin RS, French CL, Chang AB, Altman KW; CHEST Expert Cough Panel. Classification of cough as a symptom in adults and management algorithms: CHEST Guideline and Expert Panel Report. Chest. 2018;153(1):196-209. doi: 10.1016/j.chest.2017.10.016.

4. Morice AH, Fontana GA, Sovijarvi AR et al. The diagnosis and management of chronic cough. Eur Respir J. 2004;24:481-492.

5. Dicpinigaitis PV. Cough: an unmet clinical need. Br J Pharmacol. 2011;163:116-124. doi: 10.1111/j.1476-5381.2010.01198.x.

6. Kardos P. Management of cough in adults. Breathe. 2010;7(2):123-133. doi: $10.1183 / 20734735.019610$. 
7. Rao M. Diagnosis and management of chronic cough due to extrapulmonary etiologies. Indian J Clin Prac. 2014;25(5):437-442.

8. Nowak P. Kaszel - przyczyny, podział, zasady postępowania. Farmaceutyczny Przegl Nauk. 2007;1(2):33-37.

9. Yonem 0, Bayraktar Y. Clinical characteristics of Caroli's disease. World J Gastroentrol. 2007;13(13):1930-1933.

10. Wang ZX, LiYG, Wang RL, et al. Clinical classification of Caroli's disease: an analysis of 30 patient. HPB (0xford). 2015;17:278-283. doi: 10.1111/ hpb. 12330 .

11. Bakoyiannis A, Delis S, Triantopoulou C, Dervenis C. Rare cystic liver lesions: a diagnostic and managing challenge. World J Gastroentrol. 2013;19(43):7603-7619. doi: 10.3748/wjg.v19.i43.7603.

\section{Konflikt interesów}

Autorzy deklarują brak konfliktu interesów.

\author{
AUTOR KORESPONDENCYJNY \\ Tadeusz M Zielonka \\ Katedra iZakład Medycyny Rodzinnej, Warszawski Uniwersytet Medyczny \\ ul. Stępińska 19/25, 00-739 Warszawa \\ tel./fax: +48223186325 \\ e-mail: tadeusz.zielonka@wum.edu.pl
}

Nadesłano: 14.12 .2018
Zaakceptowano: 25.01 .2019

\section{„Życie ze stwardnieniem rozsianym (SM): perspektywa opiekuna" - Raport nt. emocjonalnego wpływu SM}

Raport „Życie ze stwardnieniem rozsianym: perspektywa opiekuna” (oryg. „Living with Multiple Sclerosis: The Carer's Perspective") ukazuje wpływ długotrwałej opieki nad osobami z SM na ich bliskich i jest to pierwszy taki dokument zawierający analizę sytuacji opiekunów osób chorych na SM. Raport powstał dzięki współpracy z wiodącymi organizacjami opiekunów IACO (ang. International Alliance of Carer Organizations) oraz Eurocarers.

Raport „Życie ze stwardnieniem rozsianym (SM) - perspektywa opiekuna” został przygotowany z myślą o porównaniu doświadczeń wśród 1050 opiekunów osób z SM, mających powyżej 18 lat, w siedmiu krajach: Stanach Zjednoczonych, Kanadzie, Wielkiej Brytanii, Francji, Niemczech, Włoszech i Hiszpanii. Dane w nim zawarte powstały w oparciu o przeprowadzone badanie ankietowe online. W ankiecie zadano 32 pytania koncentrujące się na trzech głównych zagadnieniach: informacjach na temat opiekunów i osób z SM, wpływie sprawowanej opieki na życie bliskich oraz rozwiązaniach odpowiadających na wyzwania wynikające z troski o osoby z SM.

Na podstawie wyników badania stwierdzono, że prawie połowa (48\%) respondentów została opiekunem osoby chorej na SM będąc w wieku poniżej 35. roku życia, a prawie jedna trzecia z nich opiekowała się taką osobą minimum 11 lat i dłużej. Inne, równie istotne wyniki badania ankietowego opiekunów są następujące:

- 43\% respondentów przyznało, że sprawowana opieka wywiera znaczny wpływ na ich zdrowie emocjonalne/psychiczne, a u 28\% ankietowanych rzutuje na zdrowie fizyczne;

- 34\% pytanych odpowiedziało, że opieka nad osobą z SM ma istotny wpływ na ich sytuację finansową, ponad jedna trzecia respondentów (36\%) z tego powodu zrezygnowała z pracy; w tej grupie $84 \%$ opiekunów stwierdziło, że opieka nad osobą z SM wpływa na ich pracę zawodową i karierę;

- jedynie 15\% opiekunów uczestniczących w badaniu skontaktowało się z innymi opiekunami lub organizacjami pacjentów, aby uzyskać pomoc w wykonywaniu codziennych obowiązków.

Raport dowodzi, że SM to choroba zarówno pacjentów, jak i ich opiekunów. SM znacząco zmienia sytuację życiową bliskich chorego, pokazując jednocześnie skalę niezaspokojonych potrzeb społeczno-zdrowotnych.

- SM może być wyniszczającą chorobą zarówno dla pacjentów, jak i ich opiekunów, którzy zajmując się chorymi latami, w miarę postępu choroby przejmuja coraz więcej obowiazków. Opieka nad osobą z SM może wywierać głęboki wplyw na zdrowie fizyczne i emocjonalne, sytuacje finansowa i zawodowa opiekuna - powiedziała Nadine Henningsen, prezes IACO. - Nie jest też zaskoczeniem potwierdzony przez wyniki tego badania fakt, że opiekunami zostaje duża liczba młodych ludzi -często wokresie kształtowania się własnej drogi życiowej.

W raporcie znajdują się również rekomendacje zmian, które mogłyby wpłynąć na poprawę sytuacji opiekunów osób z SM. Według twórców dokumentu, ma on stanowić punkt wyjścia do dyskusji nt. możliwości wsparcia opiekunów, których głos nie był dotychczas tak bardzo słyszalny. Ma także zachęcać środowisko SM do aktywnego poszukiwania rozwiązań zapewniających większą pomoc zarówno osobom ze stwardnieniem rozsianym, jak i ich opiekunom.

Globalna premiera prezentująca wyniki sponsorowanego przez firmę Merck badania ankietowego odbyła się w trakcie 34. Kongresu Europejskiego Komitetu ds. Leczenia i Badań nad Stwardnieniem Rozsianym (ECTRIMS, European Committee for Treatment and Research In Multiple Sclerosis) w Berlinie.

Więcej informacji: Weronika Kot | FleishmanHillard | ul. Ogrodowa 58 | 00-876 Warsaw | Poland | O +48 225201301 | M +48 603693353 


\title{
CLINICAL CASE OF SUCCESSFUL MANAGEMENT OF ACUTE MYOCARDIAL INFARCTION DURING PREGNANCY
}

\author{
SKUTECZNE LECZENIE OSTREGO ZAWAtU SERCA \\ U KOBIETY W CIĄŻY
}

\author{
Oleh A. Loskutov, Andrii 0. Zhezher, Yevhen M. Sulimenko \\ DEPARTMENT OF ANESTHESIOLOGY AND INTENSIVE CARE OF SHUPYK NATIONAL MEDICAL ACADEMY OF POSTGRADUATE EDUCATION, KYIV, UKRAINE
}

\begin{abstract}
Introduction: There have recently been increasingly frequent reports of myocardial infarction (MI) in pregnancy and in the postpartum period. Pertinent and timely treatment affect maternal and fetal morbidity and mortality.

Clinical case: We are reporting about a 42 years old woman at the 19th week of gestation, with complains of chest pain with irradiation into the left arm, and shortness of breath. It was known from the history of present illness, that at the time of the event ventricular fibrillation was recorded and resuscitation measures with cardioversion were performed. Subsequently, after an additional examination in the hospital, a diagnosis of MI has been determined. Coronary angiography with cardiac ventriculography (CVG) has been performed and stenosis of left anterior descending coronary artery (LAD) and right coronary artery (RCA) detected. A revascularization with the insertion of the bare-metal stent system has performed and double antiplatelet therapy prescribed. At 37 weeks of gestation, the patient gave birth to a healthy child by caesarean section. Conclusions: This clinical case illustrates the importance of minimizing the time to hospitalization of a pregnant woman with a MI to a specialized center for timely and complete diagnostic measures, which, in turn, allow to properly choose the tactics of patient management. Timely revascularization and properly selected anticoagulation are the key factors of the successful management in this category of patients.
\end{abstract}

KEY WORDS: pregnancy, acute myocardial infarction, coronary angiography with cardiac ventriculography, revascularization, antiplatelet therapy

Wiad Lek 2019, 72, 2, 298-301

\section{INTRODUCTION}

Cardiovascular pathology in pregnant occupies one of the first positions in the structure of maternal morbidity and mortality [1-3].

Nowadays there is a tendency for the childbirth by women in older age. This, along with other risk factors, raises coronary artery disease to higher positions in the structure of cardiovascular disease in pregnant [1,4 -7].

It has been reported that the incidence of $\mathrm{MI}$ in pregnant is 3 to 6 cases per 100,000 pregnancies $[1,4,8-10]$. The development of this pathology accounts for $11 \%$ of maternal mortality and $9 \%$ of fetal loss [5].

$\mathrm{MI}$ is more common in the third trimester of pregnancy (STEMI - 25\%, NSTEMI - 32\%) or in the postpartum period (STEMI - 45\%, NSTEMI - 55\%) [7]. If MI takes place during 2 weeks after delivery, then mortality may be as high as $37 \%-45 \%[5,6]$. The localization of the pathological process in $69 \%$ of cases is the front wall of the left ventricle, in $27 \%$ of cases - the lower wall, and the side wall in $4 \%$ of cases [7].

James A.H. et al, in their studies, noted that the MI in pregnant women was caused by coronary artery (CA) dissection in $16 \%$ of cases, in $21 \%$ of cases coronary thrombosis without atherosclerotic disease, atherosclerosis with or without an intracoronary thrombus in $43 \%$ of cases, and in $29 \%$ of cases, the MI was registered in pregnant women who did not have pathomorphological changes in CA [8].

Complications that arise in case of MI in pregnant are both specific (rapid decompensation, premature childbirth, antenatal death of the fetus) and general, as for all populations (which depend on the zone, area and depth of infarction).

We present a clinical case of pregnancy, which was accompanied by an acute MI and management variant according to modern recommendations.

\section{CLINICAL CASE}

A pregnant 42 years old woman, with third pregnancy, two of which ended with childbirth, has been hospitalized to "State Institution Heart Institute of the Ministry of Health of Ukraine" (Kyiv) with complaints of severe pain in the cardiac area with irradiation into the left arm of compressive character, with a feeling of heaviness in the chest.

It has been known from the history of present illness that the pain appeared at night at 2:00 am. An emergency team was called, an ECG study has been performed and acute MI recorded. Later, ventricular fibrillation was recorded 


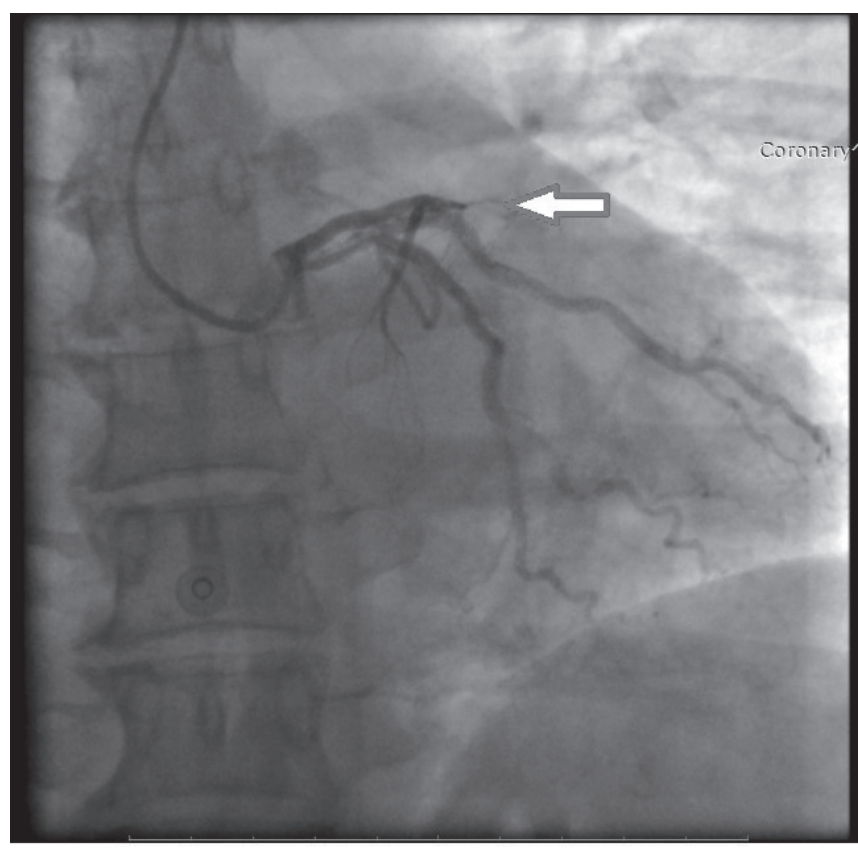

Fig. 1a. Initial CVG patient P. LAD occlusion.

and resuscitation measures with cardioversion performed Amiodarone and Esmolol have been chosen for pharmacological support. Therapy with IV unfractionated heparin and acetylsalicylic acid has been initiated.

It has been known from the history of present illness that the patient had stage II hypertension, which existed before pregnancy, that the woman was a smoker, and overweight (BMI 32). Before this case, she had no cardiac complaints.

The physical examination has shown that the patient suffered from shortness of breath at minimal physical activity, $\mathrm{SpO} 2=90 \%$, had moderate tachycardia ( $\mathrm{HR}=$ 90-110 beats/min). Blood pressure was 140/90 mm. Hg. on both hands. Auscultation: Heart tones muffled, rhythmic.

Concerning pregnancy and fetus state: pregnancy of 1920 weeks, with the signs of threatening miscarriage, fetal heartbeat rhythmic, 168-170 beats/min.

Results of ECG study has shown signs of acute MI of the anterior-membrane-apical region (pathological Q in V2V4 leads, ST elevation in V2-V4 leads). Echocardiography has shown hypokinesia of the apex of the LV, with slightly enlarged left atrium (LA), and preserved contractile ability $(\mathrm{EF}=58 \%)$.

The results of serum chemistry studies have shown a significant increase in Troponin I serum concentrations of up to $5.1 \mathrm{ng} / \mathrm{ml}$, and creatine phosphokinase-MB up to $120 \mathrm{IU} / \mathrm{L}$.

The results of the urgent coronary angiography (which has been performed with appropriate protection of the pregnant uterus - shielding the patient's abdomen) have shown LAD occlusion in its middle portion, and 40\% RCA stenosis in the proximal portion (Fig. 1a).

Considering the vital indications, the right side radial artery access was used for occluded LAD segment recanalization and subsequent angioplasty with a $2.0 \times 15$

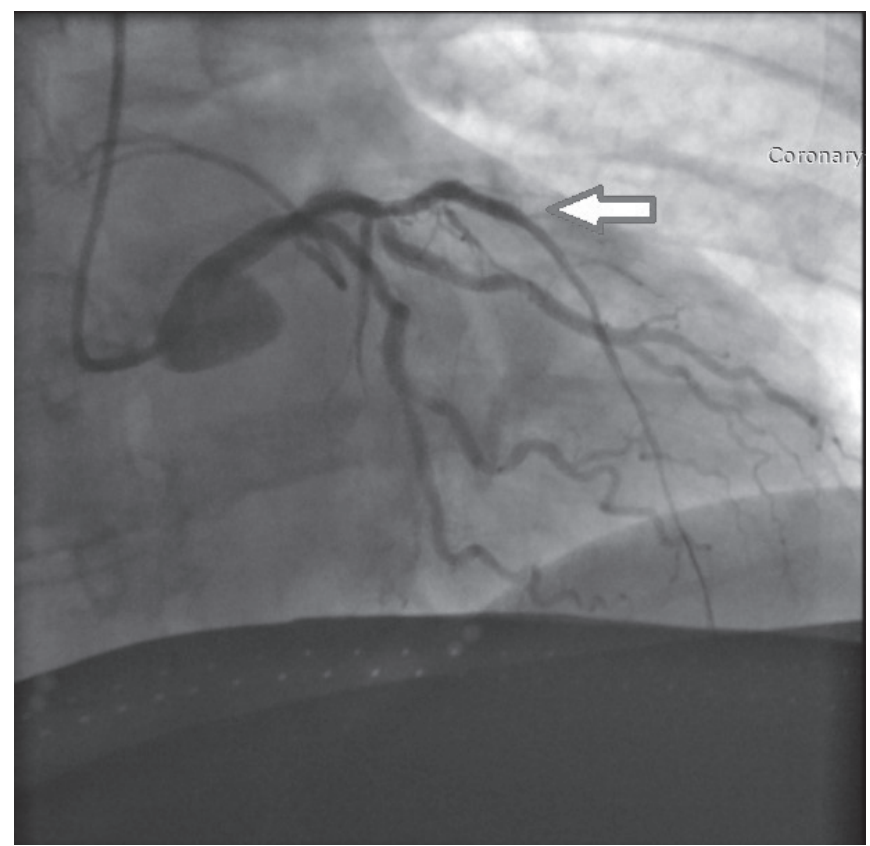

Fig. 1b. CVG of the patient P. after the LAD recanalization.

mm balloon was performed. The PRO-Kinetic Energy 3.0 $\times 18 \mathrm{~mm}$ cobalt-chrome coronary stent system has been implanted into the stenotic segment of the LAD (Fig.1b).

Clopidogrel has been added to anticoagulant therapy that had been administered at the pre-hospital stage.

The postoperative period proceeded without peculiarities. On the same day the pregnant woman, with appropriate recommendations, was transferred to the regional cardiology clinic for further treatment and rehabilitation. The pregnant woman received dual antiplatelet therapy clopidogrel, acetylsalicylic acid, as well as beta-blockers.

Pregnancy and fetus follow-up has been carried out collaboratively by obstetrician-gynecologist with cardiologists. However, this pregnancy was complicated by moderate severity pre-eclampsia due to arterial hypertension that existed before pregnancy.

At gestational age of 35 weeks the woman has been hospitalized to the obstetric clinic for supervision, and later, due to moderate severity pre-eclampsia, at gestational age of 37 weeks, the multidisciplinary team decided to perform elective cesarean section on the basis of the cardiac surgery clinic "State Institution Heart Institute of the Ministry of Health of Ukraine".

The patient has been re-hospitalized for elective caesarean section. At the time of arrival - there has been no complaints.

The preliminary diagnostics has not found any changes for the worse from the side of the heart functional state. At the time of re-hospitalization, before delivery, the patient had been taking the following therapy: acetylsalicylic acid, and beta-blockers. Clopidogrel had been canceled 5 days before delivery.

At 37 weeks of pregnancy, a planned delivery by cesarean section under epidural anesthesia, was performed. A girl 
with a weight of 3660 grams, a height of $51 \mathrm{~cm}$ and an estimate on the Apgar score of 8-9, was born. Blood loss during surgical delivery was $600 \mathrm{ml}$.

There have been no complications during anesthesia, the patient had stable hemodynamic parameter. The postpartum period proceeded without any peculiarities, the patient received therapy with beta-blockers and acetylsalicylic acid\$ clopidogrel therapy was restored and statins added. On the 6th day, the patient and her child, in satisfactory condition with recommendations were discharged home.

\section{DISCUSSION}

Pregnancy causes changes in the cardiovascular system in accordance with an increase in the metabolic needs of mother and fetus $[1,2,11,12]$. The physiological increase of blood volume and cardiac output during pregnancy, along with pregnancy-related hypertension, is an additional threat to CA dissection or thrombotic rupture [5]. An increase in heart rate in a woman during pregnancy can facilitate to the progression of acute coronary syndrome (ACS), by reducing the time of diastole phase and thereby reducing the effectiveness of coronary blood flow.

Changes in hemostasis, regulated by the hormonal background of the pregnant woman, cause a tendency to hypercoagulation and affect the vascular wall [1,2,11-14]. High levels of progesterone lead to degeneration of connective tissue in intima and middle layer of CA [5]. This may become a risk factor of thrombosis or spontaneous CA dissection $[13,14]$. Other risk factors include: pregnancy in older age, smoking, diabetes mellitus, hypertension, hyperlipidemia, family history of ACS, preeclampsia, and obesity - all become increasingly detected in modern society and drive the development of complications $[1,2,4,11,12,15,16]$.

In this case, the patient had the following risk factors: pregnancy in older age, smoking, obesity, and hypertension, which, in our opinion, together with the physiological changes in pregnancy, caused acute MI.

Concerning the management of $\mathrm{MI}$ in pregnant women, it's worth to note that it's identical to the principles of ACS management in non-pregnant population. However, certain physiological peculiarities of pregnancy require adaptation necessary for protection of life and health of both mother and fetus - shielding the abdomen of pregnant women and minimizing exposure to radiation during percutaneous coronary intervention (PCI) $[1,2,4,11,12,14]$

A patient with ACS should be transported immediately to a specialized center for PCI with subsequent revascularization in the shortest possible time [1,2].

In our opinion, in the described case, minimizing the time from the onset of symptoms to the PCI had prevented the further development of myocardial ischemia and subsequently, after rehabilitation and with adequate medical support, gave an opportunity for a woman to prolong pregnancy and give birth to a healthy, full-term child.

Certain authors note the superiority of bare-metal stent systems over drug-eluting stents $[1,2,11,12,16]$. The effects of these drugs on fetus haven't been properly studied.
Drug-eluting stent (DES) systems, require prolonged, up to one year, double antiplatelet therapy, whereas bare-metal stent systems require only four weeks long double antiplatelet therapy, thus reducing the risk of hemorrhagic complications $[1,2,11,12,16]$.

In our case, a bare-metal stent system has been implanted, which allowed to safely withdraw clopidogrel five days before the elective caesarean section, which had been performed under regional anesthesia and without significant blood loss.

It is important to note that women with ACS risk factors should receive pre-conceptional counseling from cardiologist and obstetrician-gynecologist and continue monitoring throughout pregnancy with a possible extension of the number of specialists, if needed $[12,16]$.

Thus, MI during pregnancy has its own characteristics associated with physiological changes in mother's body, and can be successfully treated if a PCI with a revascularization is timely performed.

\section{CONCLUSIONS}

1. This clinical case illustrates importance of minimizing time to hospitalization of a pregnant woman with MI to a specialized center for timely complete diagnostic measures, which allows to properly choose the tactics of patient management. Timely revascularization and properly selected anticoagulation therapy are the mainstay of the successful management in this category of patients.

2. An important thing that follows from this case is the right choice of stent system for revascularization. The bare-metal stent system, along with a proper anticoagulation allows to safely prolong pregnancy and perform delivery, with the possibility of using regional anesthetic techniques.

3. More and more women in modern society are planning pregnancy after 35 years. This poses new problems for obstetricians-gynecologists, cardiologists and anesthesiologists. Such pathology, which until now wasn't characteristic for pregnant women, increasingly poses a challenge for multidisciplinary team of physicians whose participation is required for the management of coronary heart disease during pregnancy and in the postpartum period.

Abbreviations:

$M I=$ myocardial infarction

$A C S=$ acute coronary syndrome,

$C V G=$ coronary angiography with cardiac ventriculography,

$C A=$ coronary artery,

$L A D=$ left anterior descending coronary artery,

$R C A=$ right coronary artery,

$P C I=$ percutaneous intervention.

\section{REFERENCES}

1. Regitz-ZagrosekV, Blomstrom LundqvistC, Borghi Cet al. ESC Guidelines on the management of cardiovascular diseases during pregnancy. The task force on the management of cardiovascular diseases during pregnancy of the european society of cardiology (ESC). European Heart Journal (2011) 32, Pages 3147-3197 
2. Adamyan L., Barabashkina A., Bichan N. et al. Diagnosis and treatment of cardiovascular disease in pregnancy. Russian recommendations, Russian Cardiology Journal 2013; 4 (102).

3. Kuriya A, PiedimonteS, Spence AR et al. Incidence and causes of maternal mortality in the USA. J Obstet Gynaecol Res. 2016;42: Pages 661-668.

4. Roth A, Elkayam U. Acute myocardial infarction associated with pregnancy. Journal of the American College of Cardiology Volume 52, Issue 3, 15 July 2008, Pages 171-180.

5. Ismail S, Wong C, Rajan P et al ST-elevation acute myocardial infarction in pregnancy: 2016 update. Clin Cardiol. 2017 Jun;40(6): Pages 399-406.

6. El-DeebM, El-Menyar A, Gehani A et al. Acute coronary syndrome in pregnant women. Expert Rev Cardiovasc Ther. 2011 Apr;9(4): Pages 505-515.

7. Elkayam U, Jalnapurkar S, Barakkat MN et al. Pregnancy-associated acute myocardial infarction: a review of contemporary experience in 150 cases between 2006 and 2011. Circulation. 2014 Apr 22;129(16): Pages 1695-1702.

8. James AH, Jamison MG, Biswas MS et al. Acute myocardial infarction in pregnancy: a United States population-based study. Circulation. 2006;113: Pages 1564-1571.

9. Ladner HE, Danielsen B, Gilbert WM. Acute myocardial infarction in pregnancy and the puerperium: a population-based study. Obstet Gynecol. 2005;105: Pages 480-484.

10. Sabiye Y, Salih S, Harun K et al. Acute Coronary Syndrome During Pregnancy: A Case Report and Literature Review Turkish Journal of Emergency Medicine Volume 14, Issue 3, September 2014, Pages 135-138
11. Rekha Wuntakal, Nanda Shetty, Elena Ioannou et al. Myocardial infarction and pregnancy. The Obstetrician \& Gynecologist Volume 15, Issue 4 0ctober 2013 Pages 247-255.

12. R Ashrafi, SL Curtis. Heart Disease and Pregnancy. Cardiology and Therapy 2017 Dec;6(2): Pages 157-173.

13. Júlio César Queiroz França, Márcio Antonio Santos, Moacir Fernandes Godoy. Unusual presentation of extensive spontaneous coronary dissection: Case report and literature review. ARYA Atheroscler 2017; Volume 13; Issue 1 Pages 46-49.

14. Andraž Cerar, Dunja Latifić Jasnič, Marko Gričar et al. Myocardial infarction in pregnancy - a review article with a case reportZdrav Vestn. 2016; 85: Pages 180-85.

15. Ibánez B, James S, Agewall S et al. 2017 ESC Guidelines for the management of acute myocardial infarction in patients presenting with ST-segment elevation. European Heart Journal, Volume 39, Issue 2, 7 January 2018, Pages 119-177

16. Kealey A. Coronary artery disease and myocardial infarction in pregnancy: a review of epidemiology, diagnosis, and medical and surgical management, Can J Cardiol , 2010, vol. 26 Pages 185-189.

Authors' contributions:

According to the order of the Authorship.

Conflict of interest:

The Authors declare no conflict of interest.

\section{CORRESPONDING AUTHOR \\ Yevhen M. Sulimenko}

Department of Anesthesiology and Intensive Care

Shupyk National Medical Academy of Postgraduate Education

9 Dorogozhytska St., 04112 Kyiv, Ukraine,

tel: +380966090404

e-mail: sulimenko.evgen@gmail.com

Received: 16.10 .2018

Accepted: 23.01.2019 


\title{
ZESPÓŁ OGILVIEGO - OPIS PRZYPADKU
}

\section{OGILVIE SYNDROME - CASE REPORT}

\author{
Dawid Gajda, Michał Dyaczyński \\ ODDZIAŁ CHIRURGII OGÓLNEJ, SZPITAL MIEJSKI W SIEMIANOWICACH ŚLASKICH, SIEMIANOWICE ŚLASKIE, POLSKA
}

\section{STRESZCZENIE}

Zespół Ogilviego jest stanem klinicznym, w którym dochodzi do rozdęcia jelita grubego przy braku mechanicznej przeszkody. Wczesne rozpoznanie i odpowiednie leczenia znacznie zmniejzzają śmiertelność. Częstość występowania zespołu nie jest znana. W pracy przedstawiono przebieg diagnostyki i leczenia, zarówno zachowawczego, jak i operacyjnego, 82-letniego pacjenta z zatorowością płucną, obciążonego chorobą wieńcową, nadciśnieniem tętniczym, niewydolnością krążenia i przewlekłą niewydolnością nerek, u którego podczas hospitalizacji rozpoznano zespół Ogilviego

SŁOWA KLUCZOWE: zespół Ogilviego, niemechaniczna niedrożność przewodu pokarmowego, pseudoniedrożność okrężnicy, zatorowość płucna

\begin{abstract}
Ogilvie syndrome is a clinical condition in which there is a colorectal distention in the absence of mechanical obstacles. Early diagnosis and appropriate therapy significantly reduce mortality. The incidence of this is not known. This paper presents the course of diagnosis and treatment, both conservative and operational, of an 82 year old patient with pulmonary embolism, burdened with coronary artery disease, hypertension, heart failure and chronic kidney failure, in which the hospital diagnosed Ogilvie syndrome.
\end{abstract}

KEY WORDS: Ogilvie syndrome, non-mechanical intestinal obstruction, colonic pseudo-obstruction, pulmonary thromboembolism

Wiad Lek 2019, 72, 2, 302-304

\section{WSTĘP}

Zespół Ogilviego, określany również jako ostra niedrożność okrężnicy bez cech obturacji, to stan kliniczny, w którym dochodzi do rozdęcia jelita grubego bez mechanicznej przeszkody powodującej jego niedrożność. Dotyczy on najczęściej osób starszych płci męskiej, hospitalizowanych lub przebywających w zakładach opiekuńczych. Jego patogeneza nie została dobrze poznana, jednak w niektórych przypadkach wykazano związek z zaburzeniami w autonomicznym układzie nerwowym jelita grubego [1]. Chorobę po raz pierwszy opisał William Heneage Ogilvie w 1948 roku [1-4]. Niemechaniczna niedrożność przewodu pokarmowego prawie nigdy nie występuje jako odrębne schorzenie, lecz towarzyszy innym ciężkim stanom, jak na przykład: uraz, zakażenia, niewydolność oddechowa, niewydolność serca, niewydolność nerek, zaburzenia elektrolitowe, choroby neurologiczne, choroby onkologiczne, zatrucia, po zabiegach operacyjnych w obrębie stawu biodrowego, po cięciu cesarskim [4-6]. Może również wystą̧ić po stosowaniu niektórych leków, jak: opioidy, benzodiazepiny, antagoniści kanału wapniowego, przeciwparkinsonowskie, leki stosowane w chemioterapii [2].

Do głównych objawów pseudoniedrożności okrężnicy należą: ból brzucha, nudności i wymioty, znaczne po- większenie obwodu brzucha, zatrzymanie gazów i stolca $[3,4,6,7]$.W diagnostyce różnicowej bierze się pod uwagę: niedrożność mechaniczną, ostre rozdęcie okrężnicy, zrosty otrzewnowe, zespół jelita drażliwego, zakażenia pasożytnicze [7].

Śmiertelność w zespole Ogilviego wynosi około 15\%, wzrasta ona do około $40 \%$ w przypadku wystąpienia niedokrwienia lub perforacji jelita. Śmiertelność okołooperacyjna kształtuje się na poziomie $30 \%[2,8]$.

\section{OPIS PRZYPADKU}

Pacjent, lat 82, przyjęty na Oddział Chorób Wewnętrznych $\mathrm{w}$ trybie pilnym, $\mathrm{w}$ ramach ostrego dyżuru, przekazany $\mathrm{z}$ oddziału ratunkowego, gdzie trafił $\mathrm{z}$ podejrzeniem neuroinfekcji. W dniu przyjęcia chory z objawami zaburzenia orientacji, splątany, z zawrotami głowy, gorączką. Od około 10 dni rodzina obserwowała pogorszenie stanu ogólnego, wymioty, bóle głowy, gorączkę prowadzącą do pogorszenia kontaktu, bełkotliwej mowy, niepokoju. W wywiadzie nadciśnienie tętnicze, choroba wieńcowa, przewlekła niewydolność krążenia, przewlekła niewydolność nerek, stan po laparotomii z cholecystojejunostomia (2001 r.). W badaniu fizykalnym bez istotnych odchyleń. W badaniach laboratoryjnych przy przyjęciu podwyższone parametry stanu zapalnego: leukocytoza 13,6 K/ul, OB $69 \mathrm{~mm} / \mathrm{h}$. 


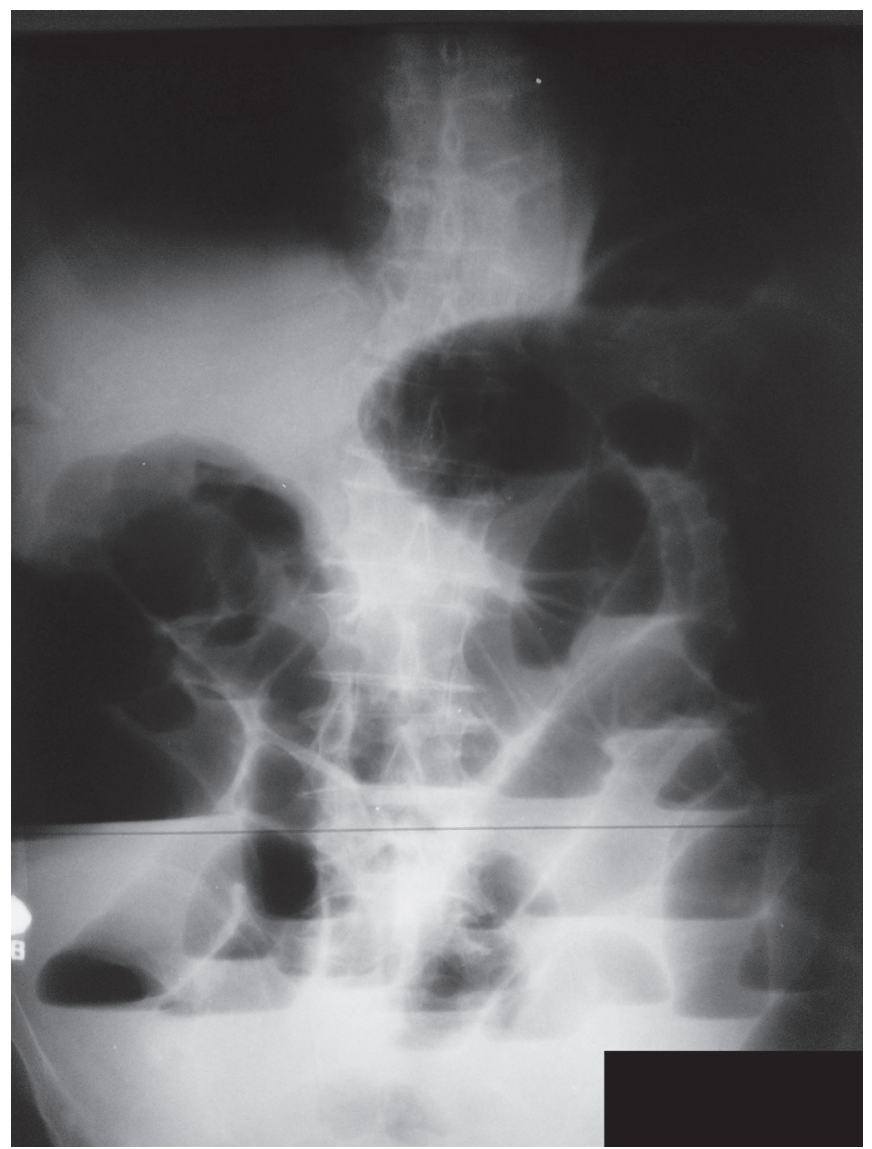

Ryc. 1. Zdjęcie przeglądaowe jamy brzusznej przedstawiające rozdęte pętle okrężnicy.
Dodatkowo D-dimery 21144,0 ng/ml, HGB 13 g/dl, PLT $101 \mathrm{~K} / \mathrm{ul}$, Bilirubina całkowita $1,46 \mathrm{mg} / \mathrm{dl}$, Glukoza 115 $\mathrm{mg} / \mathrm{dl}$, Kreatynina w surowicy $2,0 \mathrm{mg} / \mathrm{dl}(0,9-1,5)$, ALT $112 \mathrm{U} / \mathrm{l}$, AST $85 \mathrm{U} / \mathrm{l}$, APTT 73,30 s (27-40) INR 2,19 $(0,80-1,20)$. Wyniki badań elektrolitów, poza obniżoną wartością K do $3,3 \mathrm{mmol} / \mathrm{l}(3,5-5,5)$ bez odchyleń. $\mathrm{W}$ trakcie diagnostyki, $\mathrm{w}$ wykonanym badaniu TK głowy wykluczono zmiany w OUN, natomiast $w$ angio-TK klatki piersiowej zdiagnozowano zatorowość płucną.

Włączono do leczenia stały wlew heparyny niefrakcjonowanej 25000 j.m./dobę, płynoterapię, leki diuretyczne, uzyskując niewielką poprawę stanu klinicznego. W czwartej dobie pobytu stan chorego uległ pogorszeniu - wystąpiła gorączka, nasiliły się zaburzenia orientacji, niepokój. Po zintensyfikowaniu leczenia i włączeniu antybiotyku Amoskiklav 2x1.2g i.v. uzyskano ponowną poprawę. W kontrolnych badaniach leukocyty $10,3 \mathrm{~K} / \mathrm{ul}$, OB $78 \mathrm{~mm} / \mathrm{h}$, CRP 409,97 mg/l, D-dimer 13265,0 ng/ml, kreatynina w surowicy $1,2 \mathrm{mg} / \mathrm{dl}$. Zlecono badanie krwi na posiew (otrzymany w późniejszym czasie wynik posiewów krwi pozwolił na postawienie rozpoznania posocznicy). W szóstej dobie hospitalizacji pojawiły się u pacjenta nagłe dolegliwości bólowe brzucha $\mathrm{z}$ objawami bębnicy, perystaltyką żywą z tonami metalicznymi, z zatrzymaniem gazów i stolca. Wykonano kilka wlewek doodbytniczych oraz kolonoskopię, podczas której odessano duże ilości powietrza i płynnego stolca nie stwierdzając przeszkody mechanicznej. Uzyskano krótkotrwałą poprawę stanu klinicznego, po czym dolegliwości powróciły. Wykonano zdjęcie przeglądowe jamy brzusznej w pozycji stojącej,

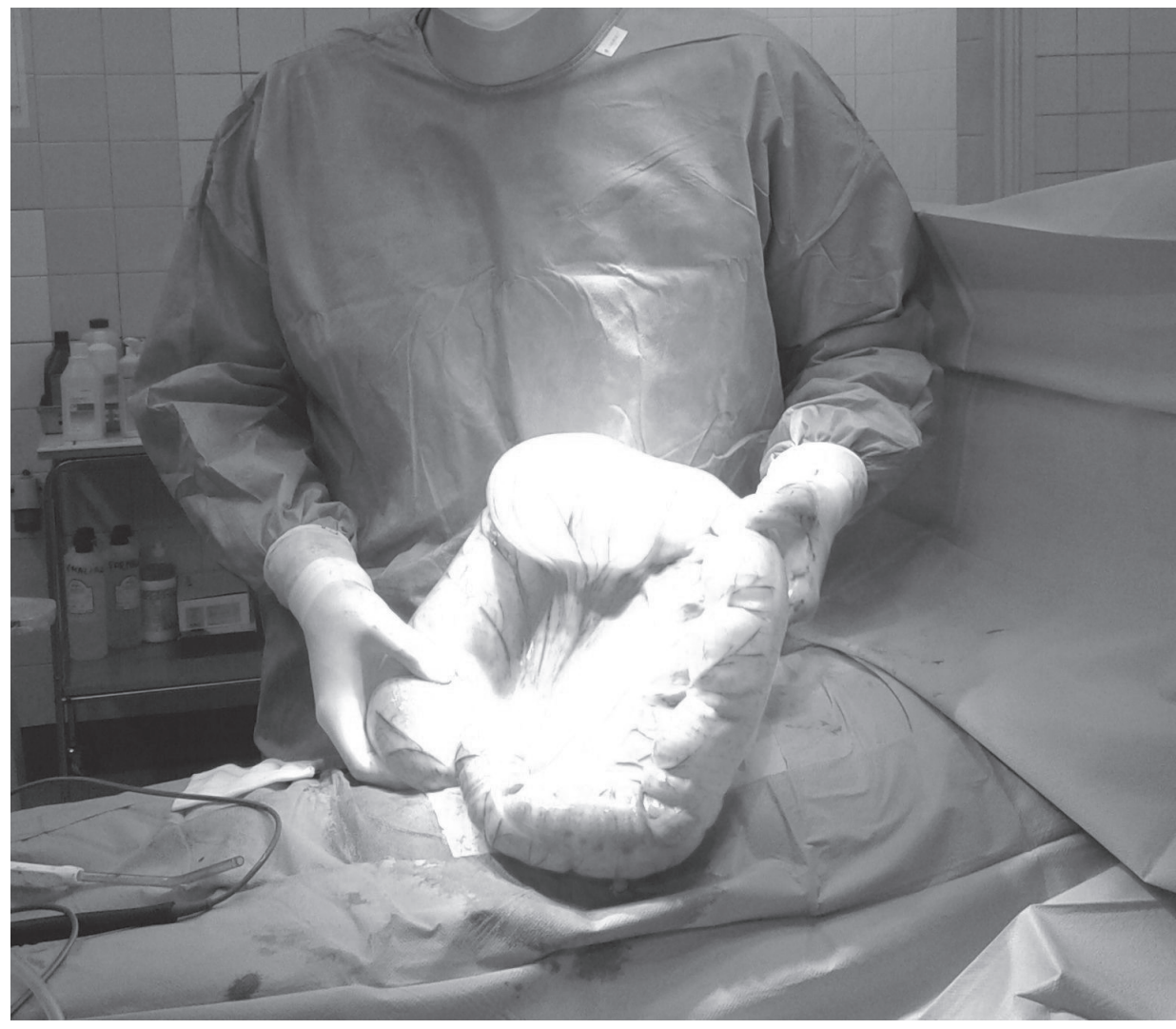

Ryc. 2. Okrężnica - obraz śródoperacyjny. 
w którym opisano znaczne rozdęcie okrężnicy oraz pojedyncze poziomy płynów (Ryc.1.). Po konsultacji chirurgicznej chorego przekazano na Oddział Chirurgii Ogólnej z rozpoznaniem niedrożności przewodu pokarmowego. Pacjenta zakwalifikowano do zabiegu operacyjnego. Wykonano laparotomię zwiadowczą, w której stwierdzono rozdętą kątnicę, wstępnicę, poprzecznicę oraz zstępnicę (Ryc. 2.). Kontrola jelita grubego nie wykazała przeszkody mechanicznej. Uwolniono zrosty otrzewnowe, usunięto wyrostek robaczkowy oraz podjęto decyzje o wykonaniu stomii odbarczającej. Bezpośrednio po zabiegu z powodu niewydolności krążeniowo-oddechowej chorego przekazano na Oddziału Intensywnej Terapii. Zastosowano respiratoroterapię, antybiotykoterapię początkowo empiryczną: Amoksiklav 2x1.2g i.v., a następnie celowaną: Meronem $3 x 1 g$ i.v oraz Cipronex 2x0,4g i.v. (z pobranej do badań bakteriologicznych krwi wyhodowano E. Coli), wysokie dawki heparyn drobnocząsteczkowych: Clexane $80 \mathrm{mg} / 0,8 \mathrm{ml}$ 2xs.c., ciągły wlew Levonoru w dawce $20 \mathrm{mg} /$ dobę. Wyrównano zaburzenia gospodarki wodno-elektrolitowej. W czwartej dobie pooperacyjnej zakończono wentylację mechaniczną i chorego ekstubowano. Następnego dnia pacjenta przytomnego, w prostym kontakcie logicznym, wydolnego krążeniowo-oddechowo przekazano ponownie na Oddział Chirurgii Ogólnej. Po 6-dniowej obserwacji i leczeniu zachowawczym chorego wypisano do domu w dobrym stanie ogólnym.

\section{DYSKUSJA}

Sposób leczenia i taktyka postępowania operacyjnego w przypadku zespołu Ogilviego zależy od stanu klinicznego pacjenta, etiologii, na podstawie której doszło do niedrożności, czasu trwania objawów, oraz odpowiedzi na leczenie zachowawcze. U chorych z ostrą pseudoniedrożnością okrężnicy postępowanie zachowawcze obejmuje zastosowanie sondy żołądkowej, drenu doodbytniczego, farmakoterapii neostygminą, odstawienie leków, które spowalniają motorykę okrężnicy (m.in. opioidy, leki anty-cholinergiczne, blokery kanału wapniowego), kontrolę poziomu elektrolitów, morfologii, kontrolne zdjęcia jamy brzusznej. [9]. Kolonoskopowe odbarczenie jelita grubego jest skuteczne w 80-90\% przypadków, należy jednak być ostrożnym, ograniczając insulfację powietrza by nie nasilać rozdęcia i nie doprowadzić do perforacji $[2,7,10]$. Decyzję o operacji należy podjąć, jeżeli po skutecznym leczeniu zachowawczym, nastąpi nawrót dolegliwości, dojdzie do rozdęcia kątnicy powyżej $12 \mathrm{~cm}$, pojawią się objawy perforacji przewodu pokarmowego lub niedokrwienia jelit oraz jeśli się ma oparte na doświadczeniu klinicznym przekonanie o zagrażającym ryzyku perforacji przewodu pokarmowego.

W przypadkach bez perforacji zaleca się wykonanie cekostomii, natomiast gdy doszło do przedziurawienia jelita wykonuje się hemikolektomię prawostronną lub resekcję kątnicy z wyłonieniem ileostomii i przetoki śluzowej na okrężnicy $[1,2,3,9,11]$.

\section{WNIOSKI}

Wśród przyczyn wystąpienia zespołu Ogilviego u opisanego w pracy chorego należy rozważyć: wiek, wystąpienie zatorowości płucnej, obciążenie układu krążenia, niewydolność nerek. Zastosowano u niego postępowanie chirurgiczne, zgodnie z powszechnie ustalonymi wskazaniami, które polegało na wykonaniu stomii odbarczającej, appendektomii, uwolnieniu zrostów otrzewnowych. Zminimalizowało to ryzyko wystąpienia potencjalnie poważnych rokowniczo powikłań.

\section{PIŚMIENICTWO}

1. Gedliczka 0, Szczerbań J, Wysocki A. Ostre choroby jamy brzusznej In: Szmidt J, Kużdzała J (eds). Podstawy chirurgii. vol 2. Kraków: Medycyna Praktyczna, 2010, 604

2. Saunders MD. Acute colonic pseudo - obstruction. Gastrointest Endosc Clin North Am. 2007;341-356

3. Jain A, Vargs D. Advances and Challenges in the Management of Acute Colonic Pseudo-Obstruction (Ogilvie Syndrome) Clin Colon Rectal Surg. 2012;37-45

4. De Giorgio R, Knowles CH. Acute colonic pseudo-obstruction. Br J Surg. 2009;229-239

5. DiMarino AJ, Benjamin SB. Gastrointestinal Disease. An Endoscopic Approach. 2002;900-904

6. Valle RL, Godoy FL. Neostigmine for acute colonic pseudo-obstruction: A meta-analysis Ann Med Surg (Lond). 2014;3(3):60-64.

7. Ertberg P, Vilandt J, Bødker B. Diagnosis and treatment of acute colonic Pseudoobstruction. Ugeskr Laeger 2013;1176-1180

8. Kulig J, Nowak W. Ostry Brzuch. Warszawa: Wydawnictwo Lekarskie PZWL, 2007, 372

9. Bielecki K, Pusty M. Zespół Ogilviego z pęknięciem kątnicy - powikłanie po nagłym zatrzymaniu krążenia. Chir Dypl 2017, 2, 13-16

10. Fink AS, Branum GD.: Zespół Ogilviego. Med Prakt Chir. 1998;4:103

11. Bernardi MP, Warrier S, Lynch AC et al. Acute and chronic pseudoobstruction: a current update. Anzj J Surg. 2015;85:709-714

Konflikt interesów:

Autorzy deklarują brak konfliktu interesów

\section{AUTOR KORESPONDUJĄCY Dawid Gajda}

ul. Brynowska 43/12, 40-585, Katowice, Polska

tel. 663323122

e-mail: dawidgajda87@gmail.com

Nadesłano: 15.01.2019

Zaakceptowano: 11.02.2019 